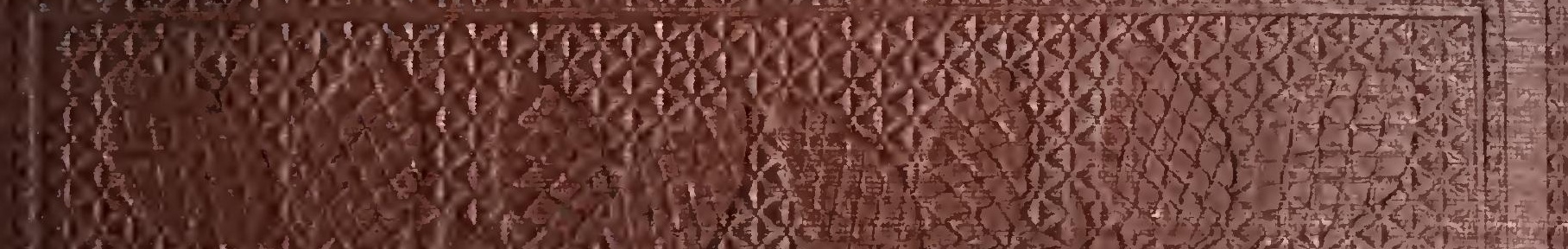

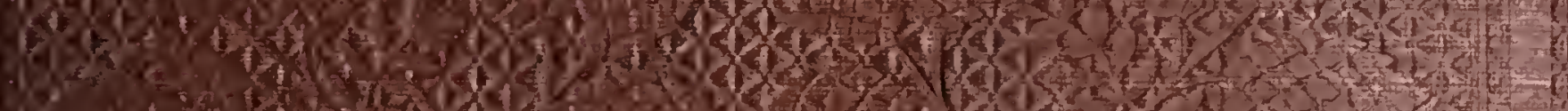

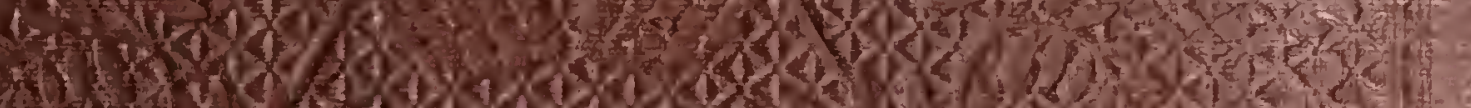

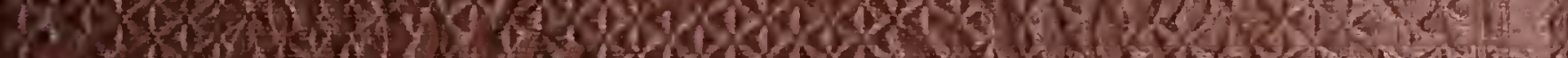

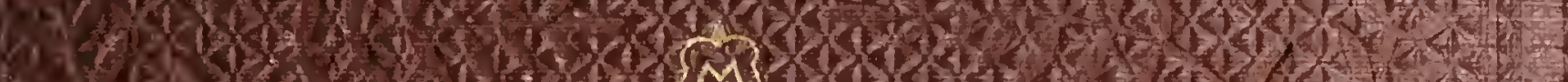

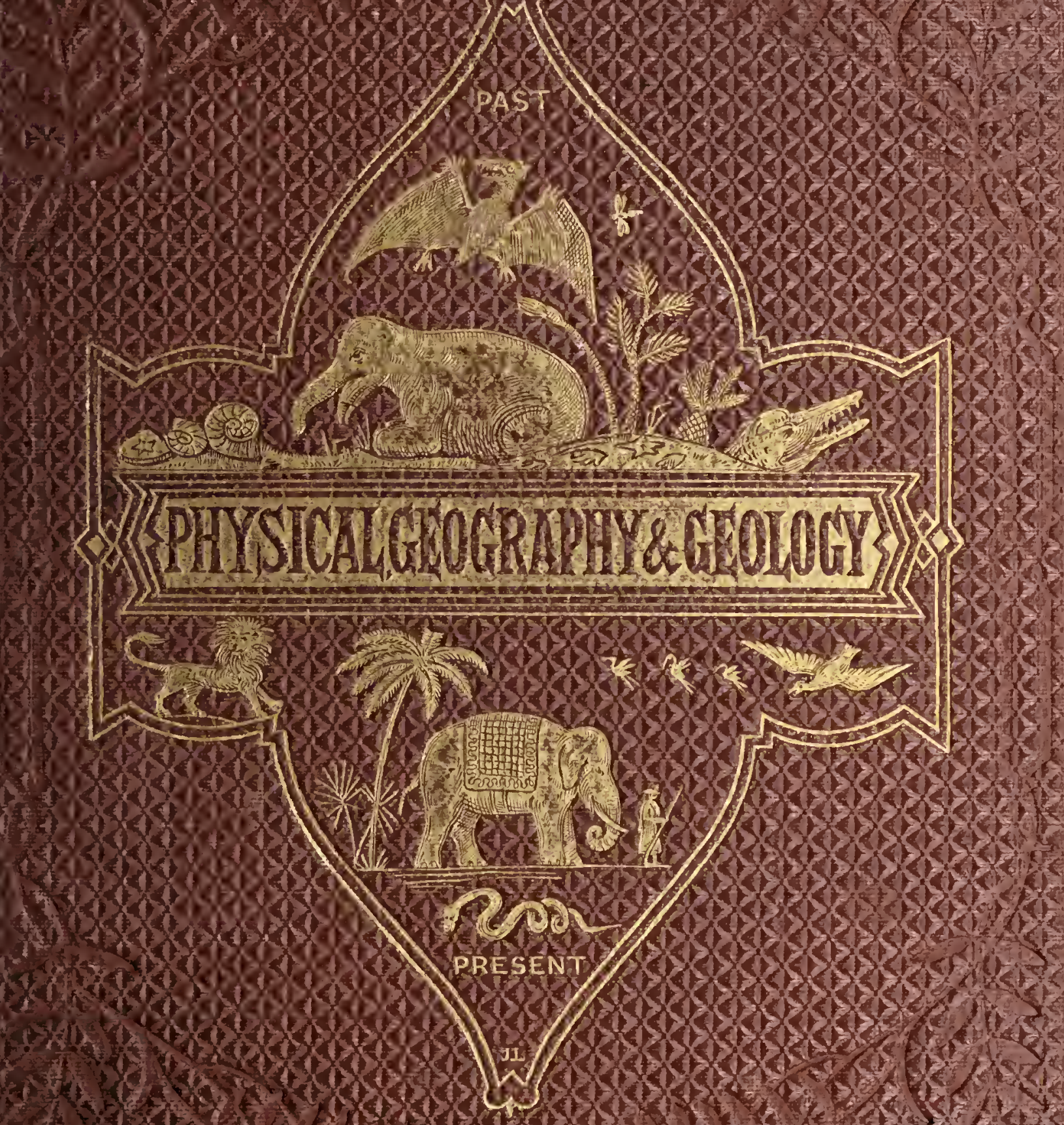

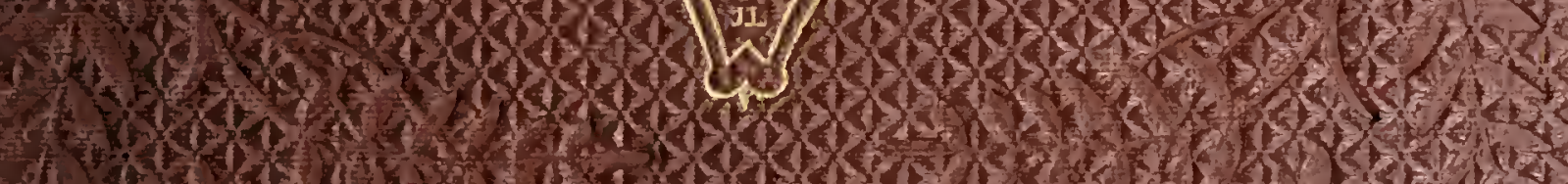

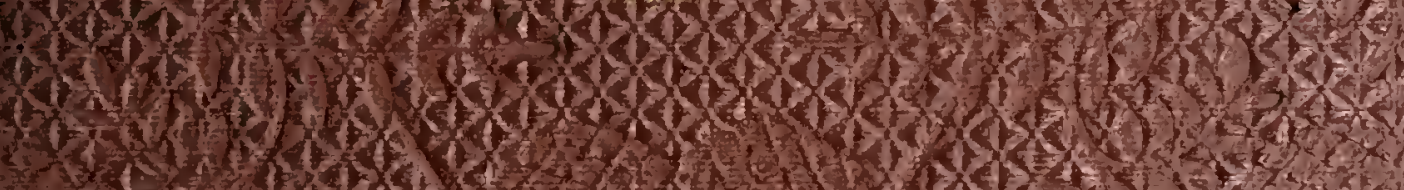

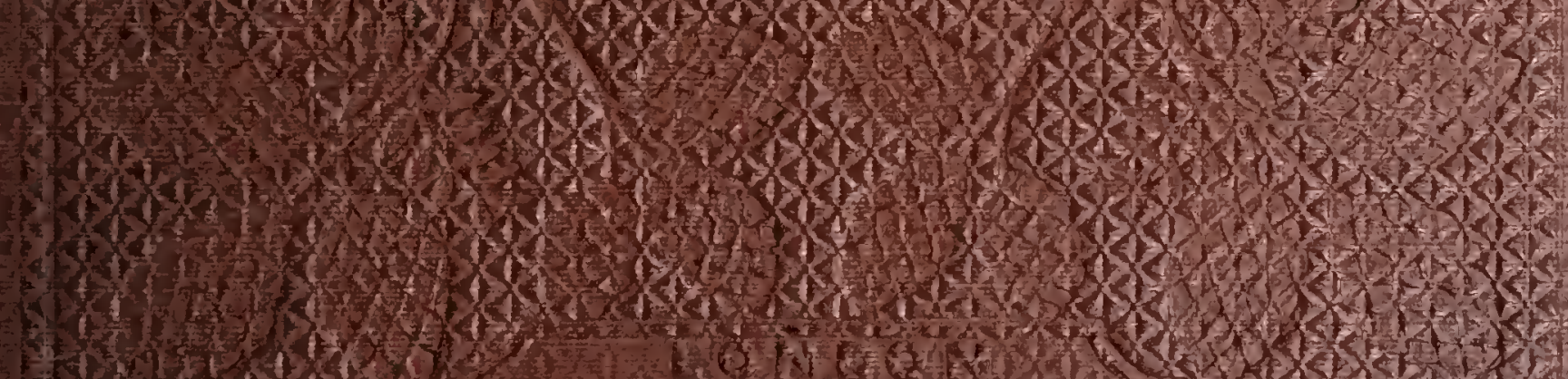




\section{6}

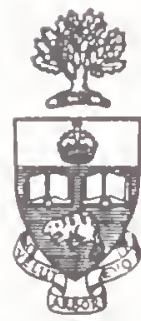

\section{Library}

of the

University of Toronto 

Digitized by the Internet Archive in 2018 with funding from University of Toronto 


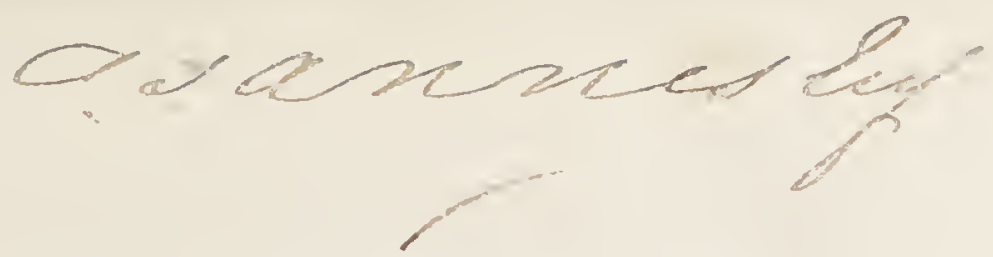

THE

\section{REASON WHY}

\section{PHY S I AL GE OGRAPHY AND \\ G E $0 \mathrm{~L} 0 \mathrm{G} \mathrm{Y}$}

CONTAINING UPWARDS OF ELEVEN HUNDRED REASONS EXPLANATORY OF THE PHYSICAL PHENOMENA OF 'TIE EARTI, ITS GEOLOGICAL HISTORY, AND THE

GEOGRAPHICAL DISTRIBUTION OF PLANTS, ANIMALS, AND THE IIUMAN FAMILIES.

\section{B Y T II E A UTIOR OF}

\footnotetext{
"THE REASON WHY, GENETAL SCIENCE;" "THE REAson Whi, NATURAL IISTORT;" "THE DENominational REASON WhY;" "THE histolical reason _WHY;" "THE HOUSEWIFE'S IREASON WHY," ETC.
}

Detith Rumcrous Enltustrations.

\section{LONDON}

H O UL T T N A N D W R I G H T

65, Paternoster Row

$$
\text { IDCCCLXIII }
$$

The right of translation is reserved. 



\title{
LIST OF AUTIORITIES
}

\author{
CONSULTED AND RUOTED.
}

Andersen's Sandhills of Jutlancl. Anstead's Principles of Geology. Anstcad's Geological Gossip.

Atkinson's Travels in Siberia.

Bartlett's Travels in Texas and Mexico.

Barkic's Explorations in Africa.

Belcher's Last of the Aretic Voyages.

Black's Physical Atlas.

Broigniart's History of Fossil Vegetables.

Brown's Account of Voyages in Search of

a Nortli-west Passage.

Broderip's Zoological Reactions.

Buckland's Geology-Bridgewater Treatise.

Burton's Travels in Central Africa.

Catlin's American Indians.

Chalmers on the Adaptation of External

Nature to the Moral and Intellectual

Constitution of MIan.

Chambers's Ancient Sea Margins.

Cook's Voyages Round the World.

Costello's Falls, Lakes, and IIountains of South Wales.

Darwin's Voyage round the World.

De La Beche's Geological Observer.

Edwards's Voyage up the Amazon.

Eley's Geology in the Garden.

Faraday's Lectures on the Forces of Matter.

Forbes's, Capt., Travels in Iceland.

Forbes's Norway, and its Glaciers.

Fitzroy's Weather Book.

Geikie's Story of a Boulder.

Hartwig's Sea, and its Living Wonders.

Harris's Pre-Adamite Earth.
Herschel's Physical Geomraphy.

Higgrins's lyook of Geolory.

Hlind's Exploring lixpedition in Canada.

IIooker's Himalaym Journal.

Humboldt's Cosmos.

IIumboldt's Aspects of Nature.

II unt's Poetry of Science.

Hursthouse's New Zetland.

IIutehinson's Wanderings amongst the Ethropians.

Jackison's What to Observe.

Jolnnston's Physical Atlas.

Kane's Arctic Explorations.

Kitto's Plyysical Geography of Palestine. Fidd's Adaptation of External Nature to the Condition of Min.

Kobell's Sketches of the Mineral Kingdom. Fohl's Wanderings round Lake Superior.

Latham's Man, and his Migrations.

Lityard's Ninereh, and its liemains.

Lewes's Sea-side Studies.

- Livingstone's Travels in Africa.

Lyell's Principles of Geology.

Wantell's Wonders of Geology.

JIantell's Petrifications and their 'Teachings. Maury's Plyysical Geograplyy of the Sea.

Jiedlock's Book of Nature.

Miller's Old Red Sandstone.

Miller's 'Testimony of the Rocks.

Milner's Baltic, and its Shores.

JIundy's Travels in Australia.

Nichol's Thoughts on the System of the

World.

Noble's After Icebergs with a Painter. 
Olipliant's Shores of the Black Sea.

Osborne's Career of Sir John Franklin.

Owen's Distribution of Mammalia.

Owen's Summary of Extinct Inimals.

l'eaks, Passes, and Glaciers, by Members of the Alpine Clut).

Phillips's Origin of Life on the Earth.

Pluillips's Treatise on Geology-

Pickering's liaces of Maur.

Reef Rovings in the Pacific.

lieills Australian Gold Ficlus.

richardson's Geology, Mincralogy, antl lalacontology.

Riehardson's, Sir J., Progress of Discovery in the Polar Jiegions.
Jussell's Polynesian Islands.

Ruxton's Rocky Mountains.

Schow's Eartl, Plants, and Min.

Searth's 'Iwelve Years in China.

Schomberg's Travels in India.

Smith's Natural llistory of Man.

Snith's (I'ye) Geology and Scripture.

Smytlis Memoir of the Mediterranean.

Somerville's, Jrs., Pliysical Geograplyy.

Swainson's Geograplyy, and Classification of Animals.

Taylor's Glance at the Globe.

Tomlin's Recreations in Physical Geogrophy.

IIiseman's Scionce and licrealcd licligion. 


\section{PREFA CE.}

WrTmin twenty years the sciences of GEoLoGr and Pirsical Geography have made unexampled ulvances, and now constitute essential branches of liberai education. The first has turned a flood of light upon the material history of the Earth; the second revealed physical laws and adaptations; so that the great plans of an Allwise Providence are brought home to the knowledge and understanding of even lowly members of the human family.

It must again be submitted here-as in the Prefaces to previous volumes of the "Reason Why" Series-that the Editor of the Series presents in the pages of these works the conclusions arrived at by distinguished masters of the Sciences upon those branches of enquiry that liave been objects of their especial study. Phenomena and Facts form the ground-work of all great scientific investigations, and Reasons are the essence of mental operations upon material and inductive evidences. These volumes, therefore, though of uupretending dimensions, contain a mass of useful instruction, fiom which much ambiguous and voluminous matter has been eliminated. Such being the case, they assist Scholars of the Old Schools in comprehending the 
results of new investigations, and conduct younger Students: to sound teachers, and the latest truths deduced from the most recent discoveries. What a Cabinet of specimens is to a Geologist or Mineralogist, such is a volume of "Reasons" to the Student of any course of science-each Reason being a nucleus around which listory, facts, and opinions group themselves in a natural order, enabling the Student to receire and retain a large amount of instruction, thus rendering the facility of teaching commensurate with the rapid accumulation of knowledge, arising from the multiplying labours of master-minds in every branch of science, and in every part of the world.

Even while we write a telegram has reached the President and Council of the Royal Geographical Society, aunouncing in effect that a great problem of ages has been solved, in the discovery of the source of the Nile-the telegram being couched in these pithy words, "The Nite is: settled." Within a short space of time great discoveries hare been made in Australia aud Arrica by Mr. Gregory and Dr. Livingstone, and the more recent information comes from the Eastern African expedition, under Messr's. Sperie and Grint. These facts, as communicated to the Royal Geographical Society by their President, Sir Roderick Murcmisos, are these:-Au expedition to Eastern Africa, under the direction of Messis. Spere and Graxt, and promoted by the Royal Geographical Society, lad been instituted with the view of solving the great geographical problem, the source of the Nile. Accounts from the explorers had made known their arrival at Kazel, far to the soutl of the Lake Victoria Nyanza, on the 30th September, 1861. They had then, after great delays, just emerged from countries occupied by tribes at variance with each other, and hal been deserted by many of their porters. 
Prior to this Consul Petherick had been despatched with fresh supplies to overtake and relieve the explorers, whose difficulties had been anticipated; but a subsequent telegram from Alexandria anmounced that Petherick had perished en route in passing to the west of the White Nile. After a long interval of suspense, a first telegram from: Alexandria announced that Spere and Grant's expedition had reached Khartum; and shortly a second telegram made known the actual discovery of the long-sought source of the great African river; this was followed by intelligence that Consul Pexherick was not only alive, but had joined Srene and Grant at Gondokoro, on the 20th of February, 1863. These telegraphic communications were followed by the journal of the travellers, and a map of the country they had explored, in pursuing which they had traversed a region never previously approached by any civilised person, and had solved the problem of ages by discorering that the great fresh-water Lake, Victoria Nyanza, whose southern water-shed extends to nearly 4 deg. south of the Equator, is the reservoir from which the sacred Bahr-al-Abiad, or White Nile, mainly descends to. Gondokoro, and thence by Khartum into Egypt.

The exploring party had, prior to Consul Petmenick's arrival from his ivory station, been relieved by Mr. S. BAKER, an enterprising explorer, who, having heard of certain disasters occurring to the travellers, fitted out an expedition at his own cost, was first to meet the long absent parties, and to supply them with money, provisions, and boats. Mr. BAKER, already celebrated for his travels in Ceylon, and in the districts north of Abyssinia, has since gone to the south-west of Africa, in the hope of tracing the extent of a lake on the west, laid down by Spene in his map as the Luta Nzigi, and will probably ere long 
contribute a solution to this collateral question, as to a great feeder of the White Nile in a higher latitude.

When the African and Australian explorations hare further progressed towards maturity, we may have some additional "Reasons" to offer respecting the hydrographical phenomena of the two vast Continents, the scenes of these recent discoveries.

Our part in these undertakings is confessedly a rery humble one. But the best explorer's are often rery imperfect writers, and, left to their own penmanship, would scarcely do justice to themselves, or the Sciences of which they are the promoters.

"I have spent," says Dr. Livixgstone, "the sixteen year's from 1840 to 1856 in medical and missionary labour's in Africa, and my life has not been farourable to literary pursuits. 'This has made composition irksome to me, and I think I would rather cross the African Continent again than compose another book." For ourselves, we would rather compose another book than cross the African Continent; and thus, "each to his mission," let the good work proceed, and success attend upon meritorious labours.

Lonilon, 1863. 


\section{N D E X.}

\section{The Numbers refer to the Paragraphs.}

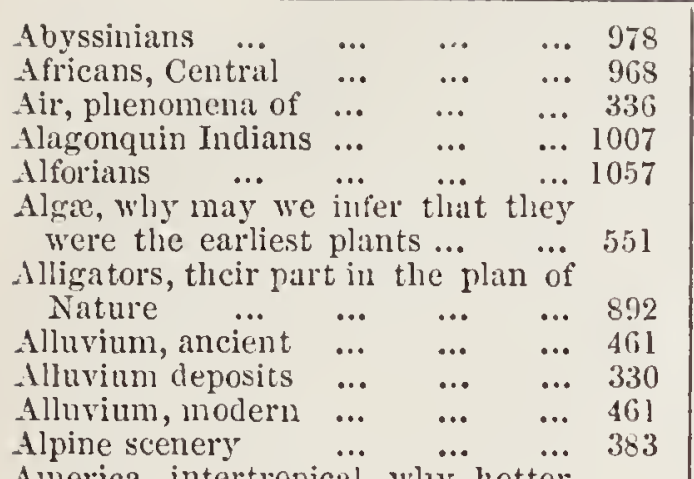

America, intertropical, why hotter and dryer than corresponding latitudes of Africa ... $\quad \ldots . \quad \ldots .84$ Imerican Indian ideas of God $\quad \ldots .1005$ American nations, why fallen fiom a ligher degree of culture $\quad$... 994

American races, white $\quad$... $\quad$... 1043

American type, why so called ... 991

Animals, estimated total numbcrs of 777

Animals, first appearance of various 634

Animals of the carboniferous era ... \$60

Animals, their geograplical distribution

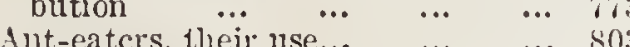

futisians

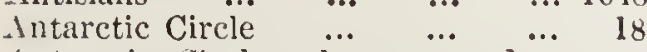

Antarctic Circle, wliy supposed to include large masses of land ... 511

Aqueous roclis $\quad \ldots \quad$... $\quad \ldots \quad 229$

Aqueous rocks, origin of $\quad \ldots \quad \ldots \quad \ldots \quad 25.5$

Aretic Circle $\quad . . \quad \quad \ldots \quad \quad \ldots \quad \ldots \quad \ldots \quad 18$

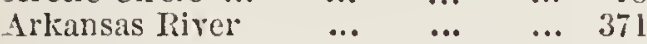

Armadilloes, their uses $\quad$... $\quad$... 809

Artesian welis $\quad \ldots \quad$... $\quad \ldots$ 4ll

Atacama Indians $\quad \ldots \quad$... $\quad \ldots 1046$

Atlantic, currents of tlıc $\quad \ldots \quad$... 94

Atlantic, what is the character of the bed of the North $\quad$... $\quad$.. 123

Atmosphere, the .... ... $\quad$... 158

A tmosplerc, cliemical effccts of upon rocks, buildings, \&c. ... $\quad . .3 \quad 347$

Atmosphere, circulation of the $\quad$... 158

Atmosphere, diagram of the circulation of

.. $\quad$...

Atmosphere, its effects upon stone $\begin{array}{lllll}\text { edifices } \quad \ldots & \ldots & \ldots & \ldots & 3.52\end{array}$

$\begin{array}{llll}\text { Atmospliere of the early ages } & \ldots & 588 \\ \text { Atolls have volcanic foundations } & \ldots & 153\end{array}$

$\begin{array}{lllll}\text { Atolls have volcanic foundations } & \ldots & 153 \\ \text { Aymaras Indians } & . . & . . & . . & 1046\end{array}$

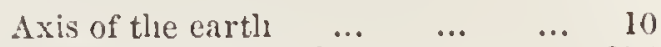

Aztecs, what were they $\quad \ldots \quad$... 996

Bangor formations $\quad . . \quad$... $\quad \ldots \quad$. 33 ;

Barbadoes, great hurricane at $\quad \ldots \quad 126$;

Barton brine springs $\quad$.. $\quad$.. 402

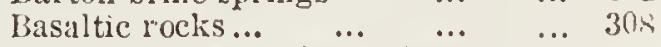

Bats, why widely distributed ... is is

Beacliy Hcal, enormous precipitit-

tion of rock $\quad . . \quad$... $\quad \ldots \quad 448$

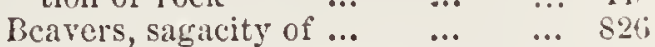

Bechunas $\quad \ldots \quad$... $\quad \ldots \quad$... 98 !

Bees, first appearance of $\quad \ldots .6306$

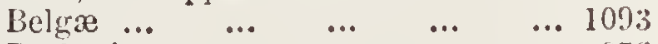

$\begin{array}{llllll}\text { Berberines } \quad \ldots & \ldots & \ldots & \ldots & 976 ;\end{array}$

Bircl-rocks $\quad \ldots \quad$... $\quad \ldots \quad$... 846

Birds, geograplical listribution of... 83!)

Birds of Paradise $\quad \ldots \quad$... $\quad \ldots \quad 840$

Black-feet Incians $\quad$... $\quad$... $\quad$... 1024

Iolnemian coal mines $\quad \ldots . \quad \ldots .503$

Bores, callses of $\quad \ldots \quad \quad \ldots \quad$... $1: 31$

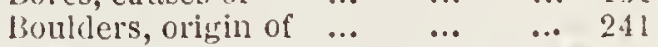

Brazil current... $\quad$... $\quad$... $\quad \ldots \quad 94$

Breczes, land and sea, why do they prevail more in some parts than in other's $\quad . . \quad \ldots . \quad \ldots \quad \ldots$ i 82

Bridlington coasts, cflects of the sea upon ... $\quad \ldots \quad \ldots \quad \ldots \quad \ldots \quad \ldots 43$

Briclis, effects of the atmosplierc

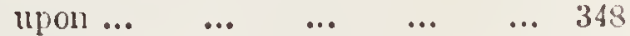

Brigantes $\quad \ldots \quad$... $\quad \ldots \quad$... 108 ?

Brigliton, encroachment of the sea upon its coasts $\quad \ldots \quad$... $\quad$... 449

Briue springs ... $\quad$... $\quad$... $\quad$... 409

Britain emerged from the sea $\quad$.. 435

British tribes ... $\quad \ldots \quad$... ... 1072

$\begin{array}{llllll}\text { Buslimen } & \ldots & \ldots & \ldots & \ldots & \ldots \\ & & & & & \end{array}$

Cainozoic strata $\quad \ldots \quad \ldots . \quad \ldots \quad$... 331

$\begin{array}{llllll}\text { Caledonians } & \ldots & \ldots & \ldots & \ldots & \ldots \\ \text { Callfornian } & \ldots & \ldots & \end{array}$

Californian Incians $\quad \ldots \quad \ldots \quad \ldots \quad \ldots 1032$

Calms, causes of tlie region of $\quad \ldots \quad 174$

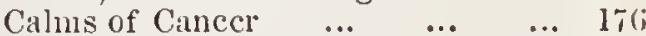

Calms of Capricom $\ldots . . \quad \ldots . \quad \ldots \quad 176$

Camel, adaptations of the $\quad . . \quad \quad \ldots \quad 815$

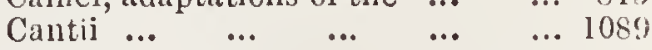

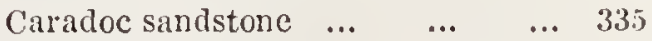

Carbonate of lime in sca witer $\quad \ldots \quad 45$

Carbonates $\quad \ldots \quad \quad \ldots \quad-\ldots \quad \ldots \quad \ldots \quad 342$

Carbonic acid, $\dddot{i t s}$ action upon rocks 358

Carbonic acid gas, its effect upon plants, \&c.... 
Carboniferous era, animals of the ... Carboniferous era, characteristic vegetation of the ... $\quad \ldots . \quad \ldots$

Carboniferous limestone $\quad \ldots . \quad \ldots \quad . .334$

Caribbean Sea, its effects upon ocean currents

Carnivorous animals, distribution of Cascades and eataraets, differences between them

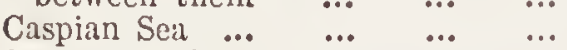

Cataracts, why is their noise greater by night than by day ... ...

Cathedrals, why do they decay unequally on their different sides

"Cat's-paris," causes of ... ...

Cancasians, moral eharacteristics of

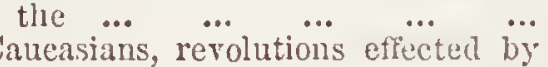

the $\ldots \quad \ldots \quad \ldots \quad$...

Calucasians, sublivisions of $\dddot{0}$ the $\quad \ldots$

Cuueasians, why so ealled ... $\quad .$.

$\begin{array}{llll}\text { Care of Ataruisse } & \ldots & \ldots & \ldots\end{array}$

Cave of Gaileureuth

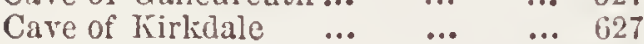

$\begin{array}{lllll}\text { Celtie nations ... } & \ldots & \ldots & \ldots & 1072\end{array}$

Clialk formation $\quad \ldots . \quad \ldots . \quad \ldots \quad$... 332

Chalk, origin and nature of $\quad \ldots . \quad .178$

Chalk, why does it contain flint $\ldots .480$

Chango Indians $\quad \ldots \quad \ldots \quad \ldots \quad \ldots 1046$

$\begin{array}{lllll}\text { Cheese grotto } & \ldots & \ldots & \ldots & 309\end{array}$

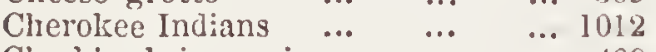

$\begin{array}{llll}\text { Cheshire brine springs } & \ldots & \ldots & 409\end{array}$

Cheshire, intrusion of the sea npon $\begin{array}{lllll}\text { the coasts of } & \ldots & \ldots & \ldots & 45\end{array}$

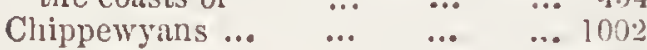

$\begin{array}{lllll}\text { Clay formation } & \ldots & \ldots & \ldots & 331\end{array}$

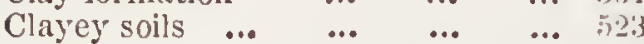

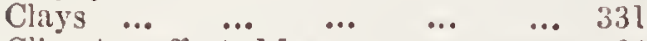

Climates affected by ocean currents 64

Climates, distinctions between insular and excessive

Climates of sea and land, diffierences $\begin{array}{lllll}\text { of } & \ldots & \ldots & \ldots & \ldots\end{array}$

Clonds condensed by mountains .... position of islands... Clouds, why do they render new islanls inliabitable $\quad \ldots \quad \ldots$

Coco-Juricopas ludiuns

Coal bets, canse of their geolerical positions $\quad \ldots \quad \ldots \quad \ldots \quad \ldots$

Coal bels, why do they orerlie each other... $\ldots$... ... ...

Coal deposit 8000 feet abore the sea

Coal formuations $\quad \ldots \quad \ldots \quad \ldots$

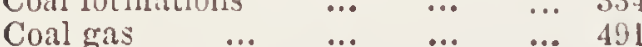

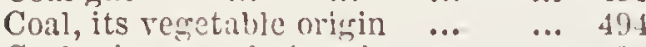

Coal mines, explosions in $\quad \ldots \quad$... 493

Coal mines of Ibohemia $\quad \ldots \quad \ldots \quad 503$

Coal, origin of... $\quad \ldots \quad \ldots \quad \ldots \quad 487$

Coal pits, annual yiele of throughout $\begin{array}{llllll}\text { the world } & \ldots & \ldots & \ldots & \ldots & 489\end{array}$

Coal pits, why do they ignite $\quad \ldots .492$

Coal, plants fossilized in $\quad \ldots \quad$... 495

Cold, effects upon atmo*llheric

Columbus observed the Gulẗ strum

Conception, town of, destroyed $\mathrm{by}: \mathrm{am}$ eartliqualie ...
Conflomerates $\quad \ldots$.
Continents, geological ageneies

affecting $\ldots$....

Copper, geological distribution of ...

Colial islands and rcefs $\ldots . \quad \ldots . \quad 148$

Cornwall, aetion of the sea upon its $\begin{array}{llllll}\text { coasts } & \ldots & \ldots & \ldots & \ldots & 45 j\end{array}$

$\begin{array}{llllll}\text { Crimoideans } & \ldots & \ldots & \ldots & \ldots & 575\end{array}$

Clomer, aneient town of, swept away $\begin{array}{llllll}\text { by the sea } & \ldots & \ldots & \ldots & \ldots & 445\end{array}$

Crystallization, what is it ... $\quad$... 530

$\begin{array}{lllll}\text { Cumanclie Indians } & \ldots & \ldots & \ldots & 1026\end{array}$

Current of air, remarliable example $\begin{array}{llllllll}\text { of } & \ldots & \ldots & \ldots & \ldots & \ldots & 213\end{array}$

Currents, benefits to narigation from $\begin{array}{llll}\text { a knowledge of them } \quad . . & \ldots & 108\end{array}$

Currents have counter-currents ... 96

Currents of the Atlantic $\quad . . \quad$...

Currents of the atmosphere $\quad \ldots \quad 100$

Currents of tle Indian Ocean $\quad \ldots .99$

Currents of the Preific $\quad \ldots \quad \ldots \quad \ldots \quad 104$

Currents of the sea, how caused $\quad . .5 \quad 54$

Currents, overlyins, and moving in $\begin{array}{llll}\text { opposite directions } & \ldots & \ldots & 10 \tau\end{array}$

Currents produced by different degrees of saltness in sea water

Currents produced by evaporation and rain $\quad \ldots \quad \ldots \quad \ldots \quad \ldots \quad \ldots e s 7$

Currents, why none at the bottom $\begin{array}{lllll}\text { of deep seas } & \ldots & \ldots & \ldots & 116\end{array}$

Damascus, eity of $\quad \ldots \quad \ldots \quad \ldots \quad \ldots 949$

Day and night, why do they alternately succeed cacli other $\quad$...

Dilys and nights, why does their duration change $\ldots \quad \ldots \quad \ldots \quad 16$

Dead Sea, why unfitted for the lrabi-

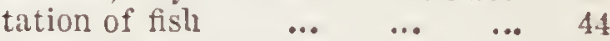

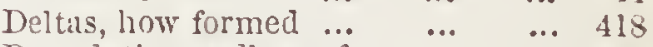

Denudation, ralleys of $\quad \ldots . \quad \ldots .426$

$\begin{array}{lllll}\text { Deserts of the sea } & \ldots & \ldots & \ldots & 130\end{array}$

Deserts, their effeet upon the cirenlation of the winds $\quad \ldots \quad \ldots \quad 178$

Devon, action of the sea upon its $\begin{array}{llllll}\text { consts } & \ldots & \ldots & \ldots & \ldots & 453\end{array}$

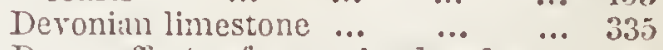

Dews, effeets of, upon land ind sea 44

$\begin{array}{lllll}\text { Dilurian deposits } & \text {... } & \text {... } & \text {... } & 330\end{array}$

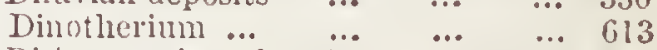

Disintegration of rocks $\quad \ldots . \quad \ldots .341$

Dislocation, ralleys of $\quad \ldots . \quad \ldots .431$

Dog-rib Indians $\quad \ldots \quad \ldots . \quad \ldots \quad 1004$

Dordrecht, inburst of the sea near 455

Dover clift's indermined by the sea 447

$\begin{array}{llll}\text { Droitwich brine springs } & \ldots & \ldots & 40 \text { ? }\end{array}$

D) ruils, account of the $\quad \ldots \quad \ldots .61095$

Dunwich, ancient town of, swept $\begin{array}{lllll}\text { away by the sea } & \ldots & \ldots & \ldots & 415\end{array}$

Durlam eoasts, effects of the sea Inpon ... $\quad \ldots \quad$...

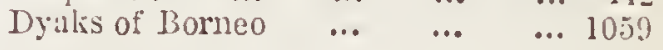

Eagres, cause of $\quad \ldots \quad \ldots \quad \quad \ldots \quad 131$

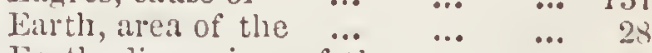

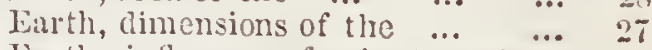

Lurth, influence of minnte animal

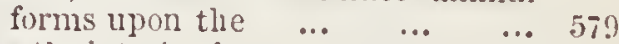

Earth, interior heat of the $\ldots . \quad \ldots .519$ 
Earth's temperature greater in the earlier ages

Earth, the, how do $\ddot{w c}$ know that $\ddot{~ i t ~}$ is globular ... ... ... ...

Eartl, the, how do we know that it turus on its axis towards the east

Earth, the various substances composing it $\quad \cdots$... ...

Earth, velocity of its rotatory motion $\quad . . . \quad \ldots . . . \quad \ldots$

Earth, why do geologists affirm tlaat it underwent changes preparatory for man

Earth, why is its globular form best adratcd to the creatures that inhalbit it $\quad . . \quad \ldots \quad \quad \ldots \quad \ldots$

Eartl, why is its rotatory motion imperceptible ... ... ...

$\begin{array}{lll}\text { Larth's axis and poles } & \ldots & \ldots \\ \text { Earth's subterlanean fires, canses of }\end{array}$

Earthquakc destroys tle town of Conception ... $\quad . . \quad \ldots . \quad \ldots$

Eartiquake of Lisbon $\ldots$... propagation ... $\quad . . \quad \ldots \quad$...

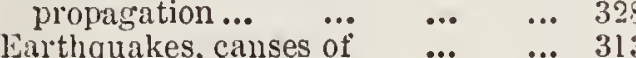

Earthquakes, circular $\quad \ldots . \quad \ldots \quad 319$

Earthquakes, effeets of $\quad \ldots \quad \ldots 315$

Eartliquakes, extent of tlicir influences $\quad . . \quad$... $\quad . . \quad \ldots$

Earthquakes harbingers of rain ...

Firthouakes, noises of $\ldots$...

Earthquakes, peculiar movements of 318

Earthquakes, what relation do they bear to volcanoes ... ... ...

Earthquakes, why do great waves of the sea attend them $\quad .$. ...

Earthquakes, why attended by a wave-like motion, both on sca and land $\ldots \quad \ldots \quad \ldots \quad \ldots \quad \ldots$

Eastern Hemispherc, map of the ...

Egypt, stupendous effects of sand-

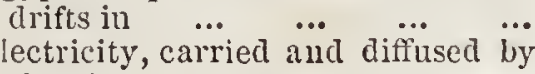

Electricity, carried and diffused by
the air

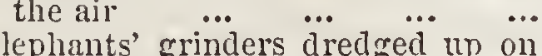
the Norfolk coast ... ... ...

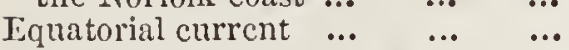

Equatoric

Erratic blocks or boulders $\ldots \quad$... 241

Erupted rocks... $\quad$... $\quad \ldots \quad$... 281

Esquimaux $\quad \ldots \quad \ldots \quad \ldots \quad \ldots \quad$... 1000

Estuaries, how formed $\quad \ldots . \quad \ldots \quad 424$

Ethiopians, their moral cliaracteristics $\quad . . \quad$... $\quad . . \quad \ldots \quad . .970$

Ethiopians, why so called $\quad . . \quad$... 967

Eraporation and rain, effects upon oceanic currents $\quad . . \quad \ldots \quad \ldots \quad$ si

Evaporation, effects of $\quad \ldots . \quad \ldots \quad 198$

Evaporation, its cffects upon sea all land... $\quad . . . . . . . . . . .$.

Evaporation, what is the principal

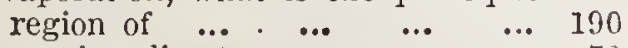

Excessive climatcs $\quad . . \quad \ldots \quad \ldots \quad \ldots \quad 78$

Extinct animals, why may their. habits when living be inferred from their fossilized remains

Falkland Islands, why is their cli-

mate mild in winter ... ... 113 $\begin{array}{llllll}\text { Fern tree } & \ldots & \ldots & \ldots & \ldots & 556\end{array}$

Festiniog formations ... $\quad$.. $\quad \ldots \quad 335$

Fire and water, why may they be remaled as antagonistic forces ... 515

Fishes, first appenliance of ... $\quad . .6031$

0 Fishes, geographical distribution of 854

Fishes, how first produced in lakes and ponds $\quad \ldots \quad \quad \ldots \quad$... $\quad \ldots \quad 862$

Fislies of the Carbonif rous era $\quad . .5599$.

Fishes of the Chalk formation ... 601

Fishes of the Old Red Sindstone ... 600

Fishes of the Tertiary formation ... $60 \%$

Fislies, the earliest... $\quad \ldots \quad$... $\quad 601$

Fishes, why do they migrate $\quad . . .6$ s 81

Fishes, why does the study of their. liabits promote a knowledge of plyysieal geomraphy ... ...

Fislies, wliy favoured by archipelagooes and islands ... $\quad \ldots \quad$... 867

Flint, wliy found in clualk ... ... 480-

Fogs, red, why encountered at sea... 211

Folkstone, land -falls on the coast ... 447

Forests affect the temperature and humidity of countries ... $\quad . . \quad 526$

Forests, origin of submarine $\quad \ldots .543$

Fossil ferns, what evidence do they aftord of the former temperature of the eartl

Fossil fishes important to tlie study of geology ... $\quad . . \quad$... $\quad$... 596

Fossil fishes of Monte Bolea... $\quad \ldots \quad 550$.

Fossil fishes of Torre d'Orlando

Fossil footprints, origin of $\ldots \quad$... 59 ?

Fossil rain-drops $\quad \ldots \quad$... $\quad \ldots \quad$... 592

Fossiliferous rocks, table of ... $\quad$... 273

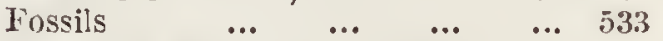

Fossils display Divine wisdom $\quad \ldots \quad 536$

Fossils of fresh and salt water animals, why found together $\quad$... 507

Fossils of Great Britain $\quad$... $\quad \ldots .330$.

Fossils, why do different strata contain distinct fossils $\quad$... ...

Fossils, why found cliefly in strati deposited by water $\quad$... $\quad . .553$

Fossils, why unequally ditrised in different formations $\quad$... $\quad . . .547$

Freezing of water $\quad$... $\quad$... $\quad$... 345

Feshwater marl $\quad \ldots \quad$... $\quad$... 331

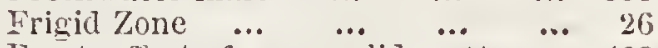

Frost, effect of upon solid matter ... 403

Fulahs ... $\quad \ldots \quad$... $\quad \ldots \quad$... 983

Fungi, their use in nature $\quad$... $\quad$... 695

Galla, the race of $\quad \ldots \quad$... $\quad \ldots \quad 979$

Ganges, matter transporter by the 419

Gases, what effects Jave they upon organic and inorganic substances

Geological deposits, reasons for clianging tlie names of ... ... 456

Geological deposits, why arranged

into three great divisions ...

Geological strata, order of arrangement ... ... ... ... $\quad$... 265

Gcological strata of Great Britain... 330 $\begin{array}{llllll}\text { Geology } \quad \ldots & \ldots & \ldots & \ldots & 227\end{array}$

Gcology, its comection with pliysical geography $\ldots \ldots \quad \ldots \quad \ldots \quad \ldots$

Geology, why indebted for many of its facts to shell-forming animals 
Geygers of Iceland ... ... ... Geysers of Jeelaud, mineral con$\begin{array}{lllll}\text { cretions of } \ldots & \ldots & \ldots & \ldots & 410 \\ & \ldots & \end{array}$

Giant's Canseway $\quad \ldots \quad$... $\quad \ldots \quad$... 308

Giraffe, adaptations of the ... $\quad . . . \quad 821$

Glaciers, effects of upon mountainous countries ... ...

Glacier fall, dreadful effect of $\quad \ldots$

Glaciers grind and wear down rocks

Glacier of Weissliorn $\quad . . \quad$...

Glaciers, observations upon the descent of ... ... ... ...

Glaciers transport stones and rocks

Glaciers, what are they $\quad . . \quad$...

Globe, description of the $\quad \ldots \quad \quad \ldots$

Gneiss, disintegrated... ... ...

God's goodness displayed in the gradual preparation of tlee eartl for $\operatorname{man} \quad \ldots \quad \ldots \quad \ldots \quad \ldots$

Gorl's goolness evidenced in the formation of Trilobutes ... ...

God's goodness exlihited in the laws of the atmospliere... ... ...

God's goodness testitied by fussils ...

Gold, geologrica! distribntion of ${ }^{\circ}$...

Goodwin Sands a submerged estate

Granite, disintegrated ... ...

Granite, what evidence have we of its iqneous formation $\quad . . \quad$...

Granitic formation $\quad \ldots \quad \ldots$...

Granite, immense block ot transported by ice $\quad \ldots . \quad \ldots . \quad \ldots \quad 402$

Grisses, their first appearance $\quad \ldots \quad 631$

Great Iritain, effests of the Gult stream upon $\quad \ldots \quad$... $\quad .$.

Great Britain, fossils of $\quad \ldots . \quad \ldots$

Great Britain, geological strata of ...

Grecn sand ... ... ... ...

Gronnd ice, wly formed $\quad \ldots \quad$...

Ground swells, causes of $\quad \ldots \quad$...

Fintclio Indians $\quad \ldots \quad$... $\quad \ldots .1033$

Gulf of Mexico, its effects upon ocean currents ... ... ...

Gulf stream, amount of lient diffirsed by the $\quad .$. ... ...

Gult strcam, cause of the $\ldots$...

Gulf stream, effects of mpun the climate of Europe... $\quad \ldots \quad \ldots$

Gulf stream, effeets of upon tlee climates of Mexieo, Central Aneriea, and the West Indies... ...

Gulf strcan furtler explained ...

Gulf strean, recent opinions respecting tlie $\quad \ldots \quad \ldots \quad \ldots \quad \ldots$

Gulf stream, why called the “ Storin Fing" $\quad \ldots \quad \ldots \quad \ldots \quad \ldots$

Gulf stream, why diel it promote the discovery of America by Columbus $\quad . . \quad \ldots \quad \quad \ldots \quad \quad \ldots$

Ileat of the early ages $\quad$.. $\quad$... $\quad 562$

Hare Indians, tlie $\quad . . \quad \ldots . \quad \ldots 1003$

Harwich, town of, threatened by encroachnents of tho sear

Heat, cause of atmosplieric eircillation

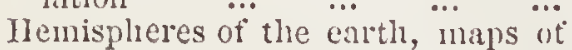
the $\ldots \quad \ldots \quad \ldots \quad \ldots \quad \ldots$
Ilills and valley's beneficial ..

202

Ilimalaya Momtains, peculiarities

of temperature on their different

sides ... $\quad . . . \quad \ldots \quad$... $\quad$... 220

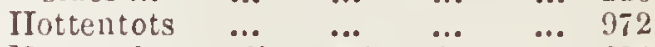

II unan bones, discoveries of $\quad \ldots .624$

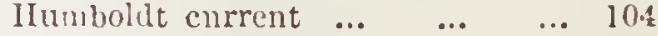

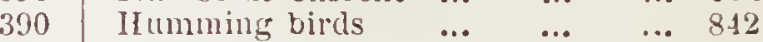

382 Ilmricane of Barbadoes $\ldots . \quad \ldots \quad 126$

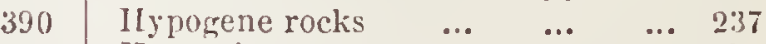

IIypozoic strata $\quad \ldots \quad \ldots . \quad \ldots \quad \ldots \quad 33$

391 Ice at the bottom of a stream, why

formed $\quad . . \quad \ldots \quad \ldots \quad \ldots 397$

Ice, immense block of granite trans$\begin{array}{llllll}\text { ported by } & . . & \ldots & \ldots & \ldots & 402\end{array}$

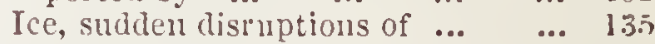

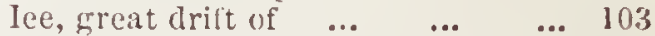

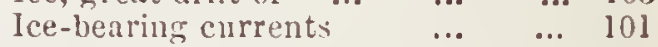

Iceberes, nearest approach to tlie

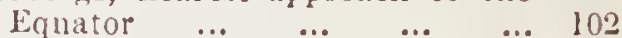

Icebergs, their effect upon climates 81

Icebergs, their effects upon winds 82

$\begin{array}{lllllll}\text { Iceni } & \ldots & \ldots & \ldots & \ldots & \ldots & 1085\end{array}$

Indian Ocean, currents of the $\quad . .698$

Inorganie and organic bodies $\quad \ldots .75$

Infusoria, whence derired ...

Inseets, geograplical distribution of 99.5

Insular climates $\quad \ldots \quad$... $\quad \ldots . \quad 77$

Inundations frequent where lakes are absent ... $\quad . \quad \ldots . \quad \ldots \quad 376$

Iron, geological distribntion of $\quad \ldots \quad 254$

Iroquois Indians $\quad \ldots \quad \ldots \quad \ldots 1007$

Istaml destroyed by the sea $\quad \ldots 455$

Islands, description of uninlabited $\$ 17$

Islands, formation of new

Island, geological agencies attectins 274

Islands, how fil'st supplied with

reretation $\quad . . \quad \ldots \quad \ldots \quad \ldots \quad \ldots$ 6ss

Islands, what effect have they upon $\begin{array}{llllll}\text { winds } & \ldots & \ldots & \ldots & \ldots & 205\end{array}$

Isle of Sheppy, new land formed near 447

Isle of Wiglit, encronelnuent of the sea upon $\quad \ldots \quad \ldots \quad \ldots \quad \ldots \quad \ldots \quad 451$

Japanese, account of the $\quad \ldots \quad$... 962

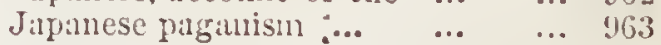

Kaffirs ... $\quad \ldots \quad \ldots \quad \ldots \quad \ldots \quad \ldots 70$

Kinguroo, alaptations of the $\quad \ldots \quad 797$

kent. eftects of the sea upon its $\begin{array}{llllll}\text { consts... } & \ldots & \ldots & \ldots & \ldots & 447\end{array}$

Kimitzi lndians $\quad \ldots \quad$... $\quad \ldots 1040$

Kiawas Indians $\quad \ldots \quad \ldots . \quad \ldots \quad \ldots 1026$

Koluski Indians $\quad \ldots \quad$... $\quad \ldots \quad 1040$

121 Iarmllas current $\ldots . \quad \ldots \quad$...

Lakes, inundations o.eur ï the alsence $\quad \ldots \quad \ldots \quad \ldots \quad \ldots \quad 370$

Lakes, reproductive arency of $\quad \ldots \quad 4 \quad 416$

Lakes, why to they equalise the flow of waters to rivers ... $\quad \ldots \quad$... 375

Lancashire brine springs $\quad \ldots \quad$... 409

I and urcezes, canses of $\quad \ldots \quad$... 180

Land, its proportion to sea ... $\quad \ldots \quad 28$

Land surfices have all been suojeet

to the action of water $\quad \ldots \quad \ldots \quad \ldots 437$

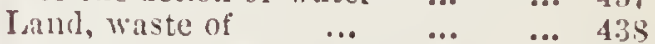

59 Land-slips, what is the cumse of $\quad \ldots \quad 357$ 
Lenape Indians $\quad \ldots \quad \ldots \quad \ldots \quad \ldots 1007$

Lead, geological distribution of $\quad \ldots \quad 248$

Lias formation $\quad \ldots \quad$... $\quad$... 333

Light of the early ages $\quad$... $\quad$... 589

Lightning, what are the effects of upon the eartlis surface ... $\quad$... 514

Limestonc, origin of $\quad \ldots . \quad \ldots \quad 476$

Lincolnshire, coasts of, encroached upon by the sea $\quad \ldots \quad$... $\quad \ldots \quad 443$

Lisbon, great earthquakc of $\quad \ldots . .316$

Llandilo rocks... $\quad \ldots \quad$... $\quad \ldots \quad 335$

$\begin{array}{llllll}\text { London clay } & \ldots & \ldots & \ldots & \ldots & 331\end{array}$

Lower mesozoic strata $\quad \ldots \quad$... 333

Lowel, or Batl oolite $\quad$... $\quad \ldots \quad$... 333

Lower palæozoic strata $\quad \ldots \quad \ldots \quad \ldots 335$

Ludlow rocks... $\quad \ldots \quad$... $\quad \ldots \quad 335$

Lybian Desert, drift of sands from

the $\quad . . \quad$... $\quad \ldots \quad$... $\quad \ldots \quad 464$

Lyme, great land-s!ip near ${ }^{\cdots} \quad \ldots \quad$ \$52

Malaria, causes of $\quad \ldots \quad$... $\quad \ldots \quad 695$

Malay, why is the fifth human type so called $\quad \ldots \quad$... $\quad .$. ...

Man, causes of different complexions

Man, comparatively recent origin of

Man, distinctions between men and animals

Man, gengraphical distribution of, and rarieties $\quad . . \quad \ldots . \quad .$.

Man influcuced by the pliysical condition of the earth ... $\quad . . \quad \ldots$

Man, of all the races, sprung from one origin $\quad \ldots \quad \ldots \quad \ldots . \quad \ldots$

Man, origin of his varicus labits ...

Man, remarlkable examples of lis influence upon animals and plints

Man, why more widely distributed than other animals $\quad$... ...

$\begin{array}{llll}\text { Mandan Indians } & . . & \ldots & \ldots \\ \text { Manlind, principal types ind va- }\end{array}$

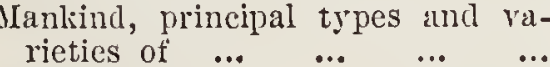

$\begin{array}{ccccc}\text { rieties of } & \ldots & \ldots & \ldots & \ldots \\ \text { Mrarbles... } & \ldots & \ldots & \ldots & \ldots\end{array}$

Darine mammalia, adaptations to geographical distributions ...

Maury's, Lieut., opinion of atmosplieric circulation... ... ...

Meduse of the sea $\ldots$... ...

Mediterranean Sea, why of a higher temperature than the deep water of other scas

... 510

Megatherium, the $\quad \ldots \quad \ldots \quad \ldots 33,618$

Mercury, geological distribution of 253

$\begin{array}{lllll}\text { Mesozoic strata } & \ldots & \ldots & \ldots & 332\end{array}$

Metalliferous mineral reins, origin of 244

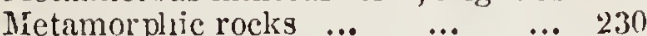

Metamorphic rocks, wlyy so ca!led... 260

MIexican listorical monuments ... 995

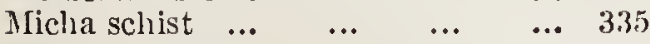

Middle oolite $\quad \ldots . \quad \ldots . \quad \ldots . \quad \ldots \quad \ldots 333$

Middle palreozoic strati $\quad \ldots . \quad \ldots \quad$... 335

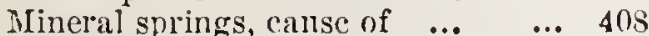

Mississippi, allurial plain of $\quad \ldots \quad 414$

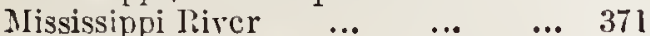

Mists, wlyy frequent orer slioals $\ldots . \quad 210$

Mollusca, their influence upon tiı sea

Yongolians, subdivisions of the $\quad \ldots \quad 954$

Mongolians, why so caller ... $\quad \ldots .952$

Mongols, moral characteristies of the
MIongols, religion of the $\quad \ldots \quad$... 959

Monkeys, wliy confined to certain limits $\quad \ldots \quad \ldots . \quad \ldots \quad \ldots \quad 788$

Monsoons, causes of ... $\quad \ldots . \quad \ldots . \quad 169$

Momnt Roa, cruption of $\quad$... $\quad$.. 291

Mountain limestone ... $\quad \ldots \quad \ldots \quad$... 331

Mountains bencficial to comtries ... 201

Mountains compared with the earth 203

Momntains, probable formation of

new ... ... ... ... ... 306

Mountains, why have they dry and rainy sides ... $\quad . . \quad$... $\quad$... 204

Mozambique current... $\quad . . \quad \ldots \quad \ldots$ 98

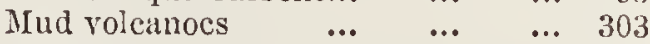

Navigation improved by a linowledge of ocean currents ... $\quad$... $\quad$... 108

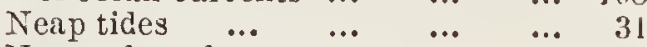

New red sandstone system ... $\quad$... 333

Niagara, Falls of $\quad \ldots \quad \quad \ldots \quad \ldots \quad \ldots 337$

Niagara Falls, descent of $\quad . . \quad 3 \quad \ldots \quad 350$

Niagara, recession of the bed of the fill ... ... ...

Night and day, why do they alternately succeed ench otlier $\quad . . . \quad 13$

Nights and days, why does their duration cliange $\quad \ldots \quad$... $\quad \ldots \quad$ 16

Nile, delta of the $\quad . . \quad \ldots \quad \ldots \quad \ldots 415$

Nile, source of the, see Prefucc.

Nomadic races, the five $\quad$... $\quad$... 965

Nootka Columbians ... $\quad$... $\quad$... 1042

Norfolk coasts destroyed by the sea 444

Northumbrian coasts, effects of the sea upon $\quad$.. $\quad$... $\quad \ldots . \quad \ldots \quad 442$

$\begin{array}{llllll}\text { Nubians } & \ldots & \ldots & \ldots & \ldots & 975\end{array}$

Ocean, sce also Sea $\quad$... $\quad$... $\quad$... 29

Occall currents, their direction and efrects $\quad \ldots$... ...

Ocean currents, their cffects upoir $\begin{array}{llllll}\text { climates } \quad \ldots & \ldots & \ldots & \ldots & 59\end{array}$

Ojibway Indians $\quad \ldots \quad \ldots . \quad \ldots \quad 1010$

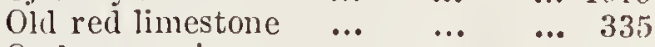

Ombay warriors $\quad \ldots . \quad \ldots . \quad \ldots 1063$

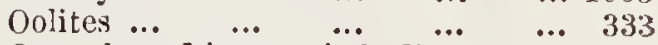

Organic and inorganie borlies $\quad \ldots \quad 758$

Orinoco, current of, observed by Columbus $\quad . . \quad$... $\quad \ldots \quad \ldots$

Orliney Islands, cffects of the sea upon ... $\quad$... $\quad \ldots \quad$... $\quad \ldots \quad 441$

Oxygen, its abundance in rarious $\begin{array}{llllll}\text { stiles } & \ldots & \ldots & \ldots & \ldots & 350\end{array}$

Oxymen, its action upon metals $\quad \ldots .630$

Oxygren, its action upon rocks $\quad$... 333

Paclyydermata, distribution of $\quad \ldots \quad 810$

Pachydermata, their uses ... $\quad \ldots .811$

Pacific, principal currents of the $\quad . . . \quad 104$

Paluca Indians $\quad \ldots \quad$... $\quad \ldots \quad 1026$

Palæozoic strata $\quad \ldots \quad$... $\quad \ldots \quad 334$

Palagian negroes $\quad \ldots . \quad \ldots . \quad \ldots \quad 1057$

Patagonia, climate of, why mild in $\begin{array}{llllll}\text { winter } & \ldots & \ldots & \ldots & \ldots & 113\end{array}$

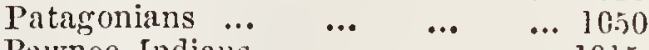

Pawnee Indians $\quad \ldots . \quad \ldots . \quad \ldots 1050$

Peat marshes, origin of $\quad \ldots \quad$... 504

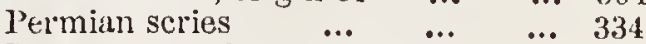

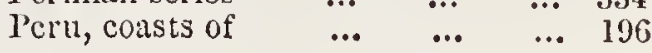


Peru, why are the coats of tempe-

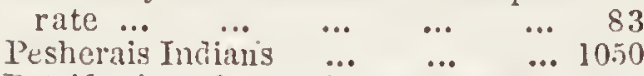

Petrifaction of organic substances... $\quad 5.37$

Petrifaetion, what is it $\quad \ldots \quad \ldots .531$

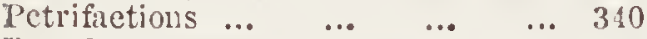

Petrolcum springs $\quad \ldots . \quad \ldots . \quad \ldots \quad \ldots \quad 50$

Pliosphorescenee of the sea... ... 50

Physical geograpliy, elianges affecting the distribntion of animals ...

Physical reograply, its connection witl geology

Pliysical geograplsy. practical benefits of the study of $\quad .$. ...

Physieal geograpliy, why should it be studied ... $\quad . . \quad \quad \ldots \quad \quad \ldots$

Piets and Caledonians $\quad \ldots . \quad \ldots 1086$

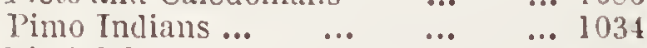

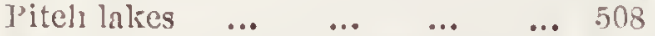

l'lants, ageneies in their ristribution 669

Plants, distribution of by the Caucasian races ... ... ...

Plants, distribution of, exhibited by belts on mountrius $\quad . . . \quad$...

Plants, effects of lieat upon ...

Plants, effeets of light upon ...

Plants, facts in connection witl the distribution $\quad \ldots \quad \ldots . \quad \ldots$

Plants, first appearance of various

Plants found in the secondary series

Plants found in the tertiary serie's

Plants found in the transition series $\quad \ldots \quad \ldots \quad \ldots \quad \ldots$

Plants, low do they first beenme established upon barron surfices

Plants, how first conveyed to islands

P'lants, leadiner clumateristics of ...

l'lants possess a lighli degree of vitality $\quad \ldots \quad \ldots . \quad \ldots \quad \ldots$

Plants, Proviclential designs in tleir distribution $\quad \ldots \quad \ldots . \quad \ldots$

Plants, their effect upon the atmosphere

Plants, uses of many not at first apparent $\quad . . \quad \ldots \quad \ldots . \quad \ldots$

Plants, why absent fiom certain distriets $\quad . . \quad$... $\quad \ldots$...

Plants, wly are eertain linds more fertile than others ... ... ...

Plants, why are sone molo scarce than others ... ... ... ...

Plants, wlyy do ecrtain tribes flower best in particular situations ...

Plants, why very widely diffiused ...

I'lastic clay ... $\ldots$... ... $\ldots$

Plesiosinurus ... $\quad$... $\quad$... $\quad \ldots .605$

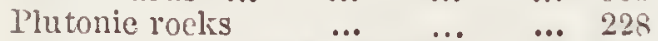

Plutonic rocks, why so called $\quad \ldots . \quad 233$

Poles of the eartl $\quad \ldots \quad$... $\quad \ldots \quad 17$

Polynesian races $\quad \ldots . \quad \ldots . \quad \ldots \quad 1062$

Polypes, what function do they fulfil in the sea $\ldots$... $\quad . . \quad \ldots$

Portland, eneronelnnents of the sea upon ... $\quad . . \quad \ldots \quad \ldots \quad \ldots$

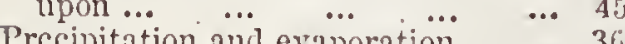

$\begin{array}{lllll}\text { Primary rocks } & \ldots & . . & \ldots & 268 \\ & & & \end{array}$

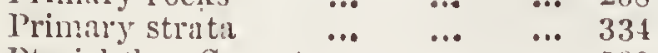

$\begin{array}{llll}\text { Ptericlitliys Cornutus } & \ldots & \ldots & \\ & & & \end{array}$ $\begin{array}{lllll}\text { Pterodactyles ... } & \ldots & \ldots & \ldots & 608\end{array}$

Purbeck, cueroachments of the sea

upon ... $\quad \ldots . \quad \ldots \quad \quad \ldots \quad \ldots 451$

Quieha Indians $\quad \ldots \quad \ldots \quad \ldots 1044$

Quicksilver, geologieal distribution of 253

Quarries in whiel footprints arc

found, why destitute of remains

of the animals ... .. $\quad$... 594

liain, amount dai!y over the eartl $\quad 89$

Rain, effects of $\quad$... $\quad$... $\quad$... 198

Iain, total annual fill upon the $\begin{array}{llllll}\text { entl } & \ldots & \ldots & \ldots & \ldots & 87\end{array}$

Rain, its cffcets upon tle sea $\quad$... $\quad 34$

Rains, distriets denuded by ... $\quad \ldots \quad 355$

liains, effects of upon the carth's $\begin{array}{llllll}\text { surface } \quad \ldots & \ldots & \ldots & \ldots & 355\end{array}$

Rains, cffects of upon the sear $\quad$... 44

Rains, why are they heary in the Equatorial calm regions ... $\quad \ldots \quad 189$

Rainy seasons, how caused $\quad . . . \quad \ldots . \quad 187$

Rainless regions enumerated $\quad \ldots \quad 197$

liainless regions, how caused $\quad \ldots .6195$

liavenspurn, aneient town of, swcpt away by the sca $\quad \ldots \quad \quad \ldots . \quad \ldots \quad 443$

$\begin{array}{llllll}\text { Tavines } & \ldots & \ldots & \ldots & \ldots & 433\end{array}$

lied fogs explained $\quad \ldots \quad$... $\quad$... 212

licd Sea, why so called $\quad$.. $\quad$... 52

liegni ... $\quad \ldots \quad \ldots \quad \ldots \quad \ldots 1100$

leptiles, geograplieal distribution

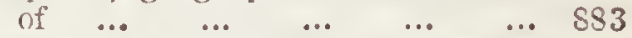

Reptiles, why confined to narrow reographical limits $\quad$... $\quad$... $\quad 851$

Resolute exploring slip $\quad \ldots . \quad \ldots \quad 103$

Reuss, Falls of the $\quad$.. $\quad$... $\quad$... 382

River basins explained $\quad$... $\quad \ldots .361$

Rivers, meehanical foree of ... ... 421

Rircrs of Amerien, effects of upon $\begin{array}{llllll}\text { climate } \quad \ldots & \ldots & \ldots & \ldots & 8 j\end{array}$

Rivers of the northern"liemisphere, how supplied $\quad \ldots \quad \quad \ldots \quad \quad \ldots \quad 192$

Rivers, origin of $\quad \ldots \quad$... $\quad \ldots \quad 360$

livers, reproductire ageney of $\quad \ldots \quad 413$

livers, their effeet upon tlie sea ... 34

livers, why are thc waters less rapid at their sicles than in their centres $\quad \ldots . \quad \ldots \quad \ldots . \quad \ldots \quad 421$

Rivers, wly do they drain lands into

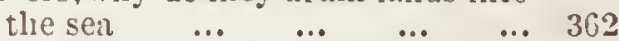

Rivers, why sometimes charaeterised by black waters $\quad$.. $\quad$... $\quad$.. 369

Roek salt, origin of $\quad . . \quad \ldots \quad \ldots \quad \ldots \quad 480$

liocks, componcnts of $\quad$... $\quad$... 48.5

lioek elystal ... $\quad \ldots \quad$... $\quad \ldots .484$

liocks, how disintegrated by water 336

Irocks, how formed ... $\quad$.. $\quad \ldots \quad 232$

liocks now being formed $\quad . . \quad$... 285

liocks of all kinds $\quad \ldots \quad \ldots \quad \ldots \quad \ldots \quad 227$

liodentia, distribution of $\quad \ldots \quad$... $\quad \$ 25$

liosaccre, first appearance of $\quad$ :... $\quad 630$

Rumiuantia, distribution of... $\quad$... 829

Saabian races ... $\quad \ldots \quad$... $\quad \ldots \quad \ldots \quad 984$

Salt, proportion of in sca water $\quad . . . \quad 33$

Salt works in France... $\quad$.. $\quad$... 49

Salts of the sea, estimated amount of 42

Salts of the sea, what becomes of them ... ... ... ... ... 
Sand, changes through the drifting of $\ldots$... $\ldots$... $\ldots$... $\ldots$ covered by the temperaturc of the waters over them ... ... $\ldots$

Sand-drif:s arrested by a solution of iron $\ldots \begin{array}{lllll}\ldots & \ldots & \ldots & \ldots & \ldots\end{array}$

Sand-dritts arrested by the growt of sand-reed

Sand-drifts in Scotland

$\begin{array}{llll}\text { Sandstone, origrin of } & \ldots & \ldots & 471\end{array}$

$\begin{array}{llllll}\text { Sandy soils } & \ldots & \ldots & \ldots & \ldots & 522\end{array}$

Saragossa Sea, what causcs the $\quad . . \quad 127$

$\begin{array}{lllll}\text { Sea }(\text { see also Oeean) } & \ldots & \ldots & \ldots & 29\end{array}$

Sea breezes, eanses of $\quad \ldots \quad \ldots \quad$ I $>0$

Sea, ehanges produeed by its action 440

Sca, currents of, how cansed $\quad$.. $\quad 54$

Sea deserts and wildernesses $\quad \ldots \quad 130$

Sea, effeets of dews, rains, ank rivers upon the $\ldots . \quad \ldots \quad \ldots$

Sea, its proportion to land ... ...

Sea, salt from the beginning $\quad$...

Sea shells, why found upon mountains ... $\quad$... $\quad \ldots$. $\quad \ldots \quad \quad \ldots$

Sea, suddenly bursts in mon and destroys seventy-two villages ...

Sea water, why frozen around coasts

Sea water, why not liable to be frozen $\quad \ldots \quad \ldots \quad \ldots \ldots$

Sea waters, why do different degrees of saltness produce currents ...

Sea waters, why do they differ in their degrees of saltness...

Sca waters, why of different enlours

Sea, why does it emit a phosphorescent light

Sca, why has $\dddot{i t}$ been found impossible to sound its grcatest deptl...

Seas, why is it believed that at the hottom of deep seas therc are no

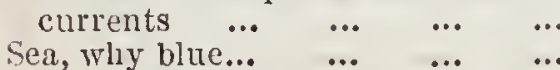

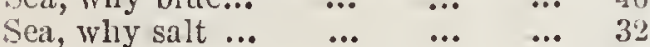

$\begin{array}{lllllll}\text { Seals } & \ldots & \ldots & \ldots & \ldots & \ldots & \\ & \ldots & \ldots & \\ & & & \end{array}$

Seasons, phenomena of the ... $\quad \ldots \quad 18$

Seasons, why do they change $\quad \ldots .23$

$\begin{array}{lllll}\text { Seeondary rocks } & \ldots & \ldots & \ldots & 267\end{array}$

Secondary serics, plants found in the $\begin{array}{llllll}\ldots & \ldots & \ldots & \ldots & \ldots & 564\end{array}$

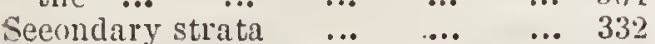

$\begin{array}{lllll}\text { Sedimentary roeks } & \ldots & \ldots & \ldots & 282\end{array}$

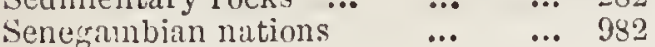

Serpents, why confined to very narrow distriets $\quad \ldots \quad \ldots \quad \ldots$

Shell-forming animals, how to they assist the eirculation of the ocean

Shell-forming animals, their effects upon the water's of the sea $\quad .$.

Shell-forming animals, why inportant in relation to geolory ...

Shells of the various formations ...

Shetland Islands, effeets of the sea ilpon

Shoals in the sea, wly made known by the temperature of the water

$\begin{array}{llllr}\text { Shosonces Indians } & \ldots & \ldots & \ldots & 1026 \\ \text { Silex, or siliea, wluat is it } & \ldots & & \ldots & 483\end{array}$

$\begin{array}{llllll}\text { Silieates } & \ldots & \ldots & \ldots & \ldots & 342\end{array}$

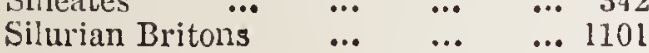

Silver, geologieal distribution of $\ldots 251$

Simoon, effects of $\quad \ldots . \quad \ldots . \quad \ldots .466$

Sionx Indians ... $\quad \ldots \quad \ldots \quad \ldots \quad \ldots 1015$

Sluths, thcir uses in turcsts... $\quad . .806$

Snake Indians ... $\quad \ldots \quad \ldots \quad \ldots \quad \ldots 1026$

Snow-line, phenomena of $\quad \ldots . \quad \ldots \quad 217$

Snow-line, table of elevation $\quad \ldots .216$

Snow-line, what is mcunt by the ... 214

Snow-line, why higlest at twenty degrees from the Equator... $\quad . . \quad 215$

Snow-line, why raised by adjacent

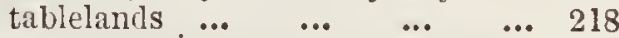

Soils equalise the discharge of watcr

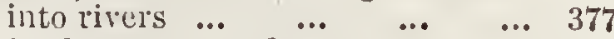

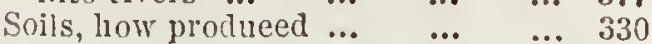

Soils, why do they affect the tempe. lature of comintries $\quad \ldots \quad \ldots \quad$... 521

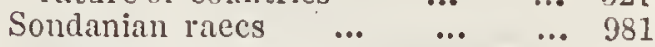

Soundings of the sea, diffieultics in $\begin{array}{llllll}\text { making } & \ldots & \ldots & \ldots & \ldots & 119\end{array}$

Specifie gravities of waters, why produetive of currents $\quad . . \quad$... 71

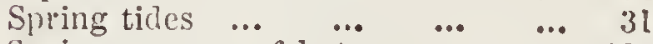

Springs, ciluses of hot $\quad \ldots . \quad \ldots .6297$

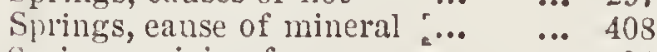

Springs, origin of $\quad$... $\quad \ldots \quad \ldots \quad \ldots 404$

$\begin{array}{lllll}\text { Stalac tite grotto } & \ldots & \ldots & \ldots & 339\end{array}$

$\begin{array}{llllll}\text { Stillarmite } & \ldots & \ldots & \ldots & \ldots & 341\end{array}$

Stone buildings, why do they decay 352

Stome lilies, why so eallcd $\ldots . \quad \ldots .575$

Stonehenge, probable origin of $\quad \ldots \quad 1094$

Storms frequent near voleanocs $\quad \ldots \quad 301$

Strata, seetion of regular $\quad$... $\quad$... 270

Streams, meehanieal foree of $\quad \ldots \quad 421$

Suffolk coasts dcstroyed by the sea 444

Sun and stars, why do thcy appear

to move round the eartli... $\quad \ldots \quad 9$

Sim, effeets of upon the sca... $\quad \ldots \quad 54$

Supcrficial accumulations on the earth... $\quad \ldots \quad \ldots \quad \ldots \quad \ldots \quad 330$

Sussex coast, eneroachments of the $\begin{array}{llllllll}\text { sea } & \ldots & \ldots & \ldots & \ldots & \ldots & 501\end{array}$

Swampy frounds $\quad \ldots .6 \quad \ldots \quad \ldots \quad 524$

Tertiary scries, plants found in the 56.5

Temperate Zone $\quad . . . \quad \ldots \quad$... 26

Temperature, cffects of mon the

$\begin{array}{lllllll}\text { sea } & \ldots & \ldots & \ldots & \ldots & \ldots & 54\end{array}$

Temperature of the earth greater

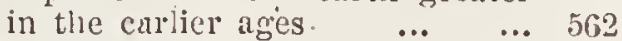

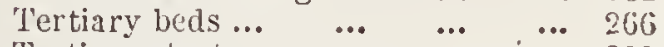

Tertiary strata $\quad \ldots . \quad \ldots \quad, \ldots .331$

Thunderstorms, why cio they accompany the changing monsoons $\quad . . . \quad 172$

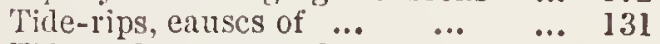

Ticles, what camses them $\quad \ldots \quad$... $\quad 29$

Tierra del Fuego, inhabitants of the 1050

Tin, geological distribution of $\quad \ldots \quad 247$

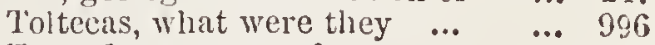

Tornadocs, eauses of $\quad \ldots \quad \quad \ldots \quad 173$

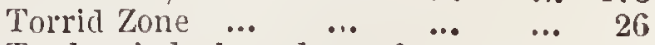

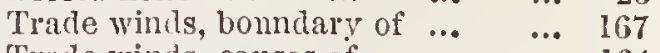

Trade winds, causes of $\quad \ldots . \quad \ldots . \quad 164$

Trade wincis, why aceompanied by

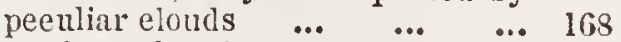

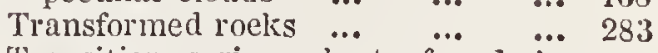

Transition series, plants found in

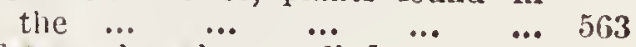

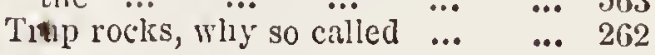


Trilobites, eycs of $\quad \ldots \quad \ldots \quad \ldots \quad \ldots 8.5$

Trilobites important tu the stndy of

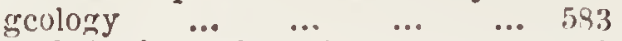

Trinilad, pitcl lakes ot $\quad \ldots \quad$... 509

Trinobantes $\quad . . \quad \ldots \quad \ldots \quad \ldots 1091$

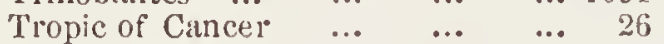

Tropic of Capricorn $\quad . . \quad$... $\quad \ldots \quad 26$

$\begin{array}{llllll}\text { Turulites } & \ldots & \ldots & \ldots & \ldots & \ldots 72\end{array}$

Turtles, migrations of $\quad \ldots \quad$... 85.3

Typhoons, causes of ... $\quad \ldots \quad \ldots \quad \ldots 173$

Upper mesozoic stratil $\quad \ldots \quad$... 332

Upper oolite ... $\quad \ldots \quad$... $\quad \ldots \quad 333$

Uncivilized tribes, why do they frequently become morc barbarons upon their first intercourse with civilized races $\quad \ldots \quad$... $\quad$... 931

Undulation, valleys of $\quad \ldots \quad$... 432

Uprer palacozoic stratil $\quad \ldots . \quad \ldots .334$

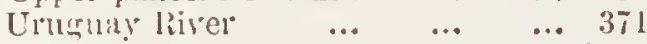

Utall Indians ... $\quad \ldots . \quad \ldots . \quad \ldots 1026$

Valleys of denudation $\quad \ldots \quad \ldots \quad \ldots 426$

Valleys of dislocation $\quad \ldots . \quad \ldots \quad 431$

Valleys of undulation $\quad \ldots \quad \ldots \quad 432$

Vegctation, first appcarance of upon

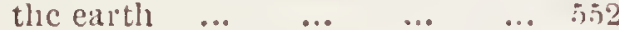

$\begin{array}{lllll}\text { Vegetation, marine } & \ldots & \ldots & \ldots & 5.54\end{array}$

Vegetation of the carboniferous era 5.57

Vibrations in solid masses ... $\quad \ldots \quad 32 \vec{i}$

$\begin{array}{lllll}\text { Volcunic triets } & \ldots & \ldots & \ldots & 3 \% 3\end{array}$

Volcanocs have existed in all parts of the cartl ... $\quad . . . \quad \ldots \quad \quad \ldots \quad 30$ t

Volcumoes, physical cffects of $\quad \ldots . \quad 278$

Volcanocs, quantity of matter cjecter by $\quad . .6 \quad \ldots \quad \ldots . \quad \ldots \quad \ldots .296$

Volcanoes throwing mud $\quad \ldots \quad$... 304

Volcanocs, what is it that burns in tliein ... $\quad \ldots \quad \ldots \quad \ldots \quad \ldots$

Tolemocs, whnt rclation do they bear to eartliquakes $\quad . . \quad \ldots$

Volcanoes, why are fislies sometimes thrown out by them $\quad \ldots \quad$...

Volcanocs, why are storms frequent around their summits $\quad$... ...

Volcanocs, why do springs of water frequently issue from their sides...

Volcamoes, why frequent on the borders of the sea... ... ...

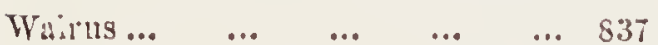

Water and fire, why may they be regarded as antagonistic forces ... 51:

Water, effect of its movements upon the carth's erust ... $\quad . . \quad$... 25?

Watcr, its action upon rocks $\quad . . \quad 336$

Water, mechanical force of while

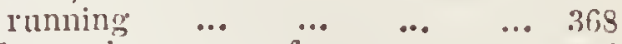
Water, plienomena of $\quad$... $\quad$... 346

Wiltcr, why does it freeze ... $\quad$... 39.5

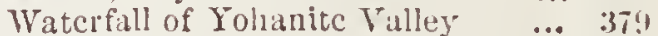

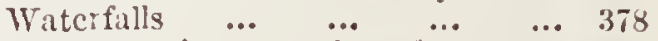

Water-parting, meaning of ... $\quad \ldots .36$ l

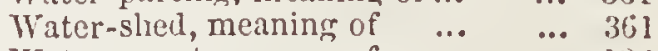

Water-spouts, callses of $\quad \ldots \quad \ldots \quad 136$

Watcr-spouts frequent during mon-

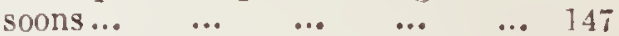

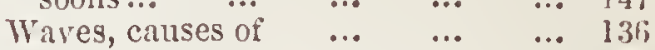

Waves, force of $\quad \ldots \quad$... $\quad \ldots \quad 141$

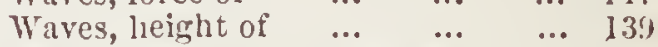

Waves indicate the apploach and direction of storms ... $\quad \ldots \quad$... 143

Wraves of the sea accompanying $\begin{array}{lllll}\text { carthquakes... } & \ldots & \ldots & \ldots & 325\end{array}$

Wares, progress of $\quad \ldots \quad$... $\quad \ldots \quad 142$

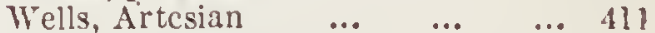

Wenlock formations ... $\quad . . \quad \ldots \quad$.. 33 ;

Western liemispherc, thass of the ... 5.9

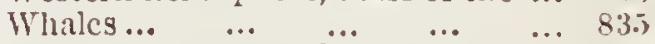

Whirlpools, cainscs of... $\quad \ldots . \quad \ldots \quad \ldots \quad 144$

$\begin{array}{llll}\text { Whirlwinds, eauses of } \quad \ldots & \ldots & 173\end{array}$

Winds, liow are they affected by $\begin{array}{llllll}\text { islands } & \ldots & \ldots & \ldots & \ldots & 20 \text {; }\end{array}$

Winds, sources and names of $\quad . . .97$

Winds, what gives character to the ditterent $\quad \ldots \quad \ldots \quad \ldots \quad \ldots \quad \ldots \quad$ 185

Winds, why do gusty accompany hail-storms ... $\quad \ldots \quad$... $\quad \ldots \quad 186$

Winds, why is it supposed that they cross at the calm-belts $\quad . . \quad \ldots \quad \ldots l 6 l$

Winter, why none between the $\begin{array}{llllll}\text { Tropics } & \ldots & \ldots & \ldots & \ldots & 24\end{array}$

Wood, why does it acquirc increased specific gravity by being immersed in water $\quad . . \quad \ldots . \quad \ldots \quad$... 540

Yorkshire consts, effects of the sea upon ... $\quad . . \quad \ldots \quad \ldots \quad \ldots \quad \ldots \quad+42$

Zoncs of the eartl cxplained $\quad . . \quad 26$ Zuỵcler Sea formerly an inland lake 455 


\section{THE}

\section{R E A S O N W H}

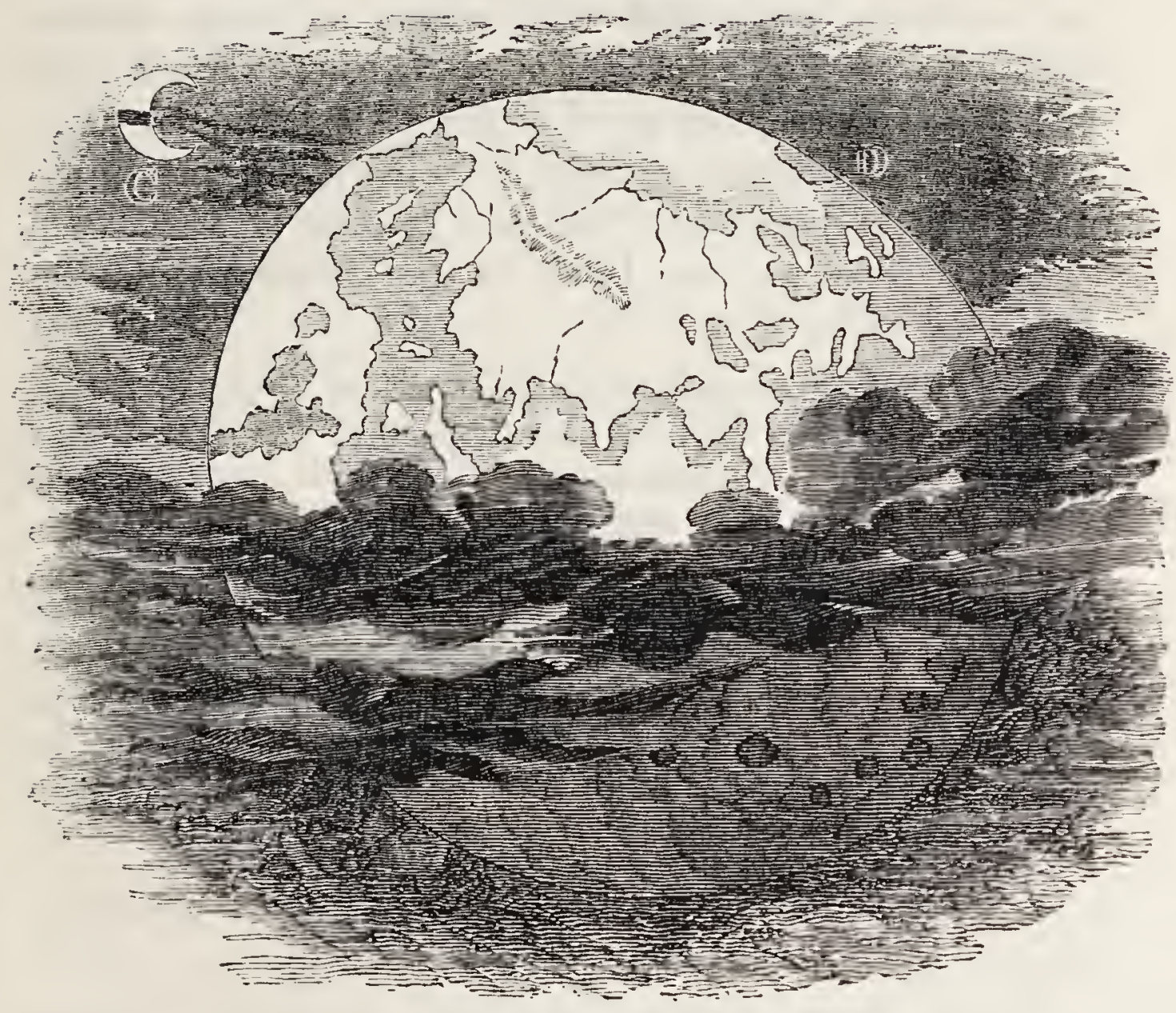

\section{PHYSICAL GEOGRAPHY, AND GEOLOGY.}

1. Why should Physical Geography be generally Studied?

Because it is a subject of leading importance and interest to mankind. It directs attention to the structure of the earth which we inhabit; and affords explanations relating not only to distant lands, but to the hills and dales upon which we daily tread; to alterations in the temperature and 
"For as the heaven is high abore the earth, so great is His mercy tomards them that fear Him."-Psalus ciil.

humidity of the air which affect our health; to the flow of waters in our rivers, and the ever-varying features of the majestic ocean; makes known laws affecting ourselves as a race of people; and our brethren of various hues and habits in extreme parts of the wide world; it treats also of the distribution of animals on the earth, and in the seas; and of vegetation, fiom the tropics to the frozen regions; from the sea level, to the mountain line of perpetual snow.

2. The study of Physical Geography is one of surpassing interest -illnstrated in every part by natural pictures. It is, to a great extent, a science of demonstration, of things seen and proved, not merely conjectured. 'The liill, the valley; the river', the mountain, the volcano, the earthquake, the desert, the cataract, the calm ocean, the storm, the snow-fall, the drenching shower, the blue and oper: sky, - these, in all their varying aspects, are pictures that illustrate this interesting study; we see some of them every day, and most of them in the course of our lives. Every natural object that ree look upon will be enriched to our vien, by a knowledge of Physical Gcography.

3. What is the conirection between Physical Geography and Geology?

Geology afforels to us a scientific history of many things. which Physical Geography describes. Geology tells us how a given rock or mineral was formed; Physical Geography tells us where the rock is found, how it appears, and what influence it exerts upon surrounding objects.

4. Many facts termed geological belong to physical geography, and these will be found included in the following "Reasons." The term geology is derived from two Greek words, ge signifying the earth, and logos a discourse, which together mean reasoning about the structure of the earth, or simply the science of the earth. The oljects of Geology are to produce a true history of the origin and structure of the globe; of the changes which it has undergone; of 
"Fe hath made the earth by His power, He hath established the world by IIs wisdom, and hath stretched out the heavens by His discretion."-Jeresina $x$.

the various tribes of plants and animals which have at different periods occupied its surface; and in some measure to reason from the known state of things in the past, to the probable state of things in the future. Geology, therefore, is connected with Physical Geography in some of its parts, and only in such connection will it be embraced in the present volume.

5. What are the practical benefits of an Acquaintance with Physical Geography?

Many of the advantages that arise from this department of knowledge will appenr in the following reasons. 'They may, howerer', be briefly summarised here:- $\Lambda^{T}$ arigation has been, and still may be, greatly simplified and improved; travelling by land and sea rendered in all parts of the world more speedy and less dangerous; the earth's produce in all parts increased, and applied to useful purposes; the people of various countries brought into friendly relations with each other; and all mantind taught to regard the wisclom of God as displayed in His works.

\section{DESCRIPTION OF THE GLOBE.}

6. How do we know that the earth is a Globular body?

The best proof we have presents itself to our view luring an eclipse of the moon, when the shadou of the earth (which must present a true outline) falls upon the moon's surface. The form of the shadow is always circular, never oval, or plane-like.

7. We have another proof in the fact that when a ship at sea, or a tall tree on a plain, comes first into view, we see the top of it first; as we approach nearer, 
"Truly the light is sweet, and a pleasant thing it is for the cyes to bchold the suin."-Ecclesiastes xi.

we gain a view of the midlle parts, and at last the base of the tree or hull of the ship becomes visible.

8. Navigators, by steering in a given direction, have gone round the globe, and returned to the place whence they sailed.

9. Why do the Sun and Stars appear to Move Round the Earth?

Because the rotation of the earth upon its own centre, gives this apparent motion to the heavenly bodies towards which we look. Just as, when travelling in a railway train, the hedges and houses appear to be moring in an opposite direction.

10. How do we know that the Earth Tums on its Axis tourarls the east?

Because the sun and the stars appear to rise in the east, and to sink in the west.

11. If we turn our faces towards the east, or the point where the sun rises, the west will be behind us, the north on our left, and the south on our right hand.

12. Why is the globular form of the earth best adapted to the creatures that inhabit it?

The earth, in any other shape, would liave been uninhabitable, at least to animals as now constituted, and subject to the law of gravitation, which draws everything towards the centre. Suppose the earth had been square, like a cube, which has six flat sides. It would have been impossible for us to stand upright, on any one of those sides, except in the very middle of each, and from that centre it would have been up-hill every way. The corners of the cube would have been like so many immense pyramids, or mountains, which, if any one had 
"While the sun, or the light, or the moon, or the stars, be not darkened, nor the clouds return after the rain."-Ecchesiastes xii.

ascended, he would then have looked on these rast sloping plains, down any one of which he might, if his foot had slipped, have rolled thousands of miles without stopping.*

13. Why do Day and Night alternately succeed each other?

Because of the turning of the earth; the sun sheds forth perpetual day, and the earth, turning round once in each period of twenty-four hours, enjoys the warmth and light of day, and the darkness and repose of night, alternately on its principal parts.

14. In consequence of this motion of the earth, any point on the earth's surface at the Equator has a rotary motion, imperceptible to living things, of more than one thousand miles per hour. This velocity gradually diminishes towards the Poles, until it nearly ceases, on account of the lessening diameter of the earth. The velocity of this turning motion in the parallel of London is about six hundred and fifty miles in the hour.

15. Why is the Rotatory Motion of the Earth unperceived by living creatures?

Because they all move with the earth at precisely the same rate of velocity. A traveller on board ship, in a still sea, is quite unconscious of lis motion with the vessel if he avoids looking out upon any object that may indicate his progress.

16. Why does the duration of Days and Nights change?

Because the earth, as well as turning towards the sun upon its own centre, has a grand orbit around the sun, through which it passes annually, the natural year being determined by this revolution of the earth.

* Jefferys Taylor's "Glance at the Globe." 
"He that gathereth in summer is a wise son, but he that slecpeth in liarvest is a son that causetin shame."-Provelibs $x$.

17. 'The earth rotating upon its centre may be said to turn round an imaginary line, to which the name of axis is given. The places where this axis may be supposed to pass out from the opposite

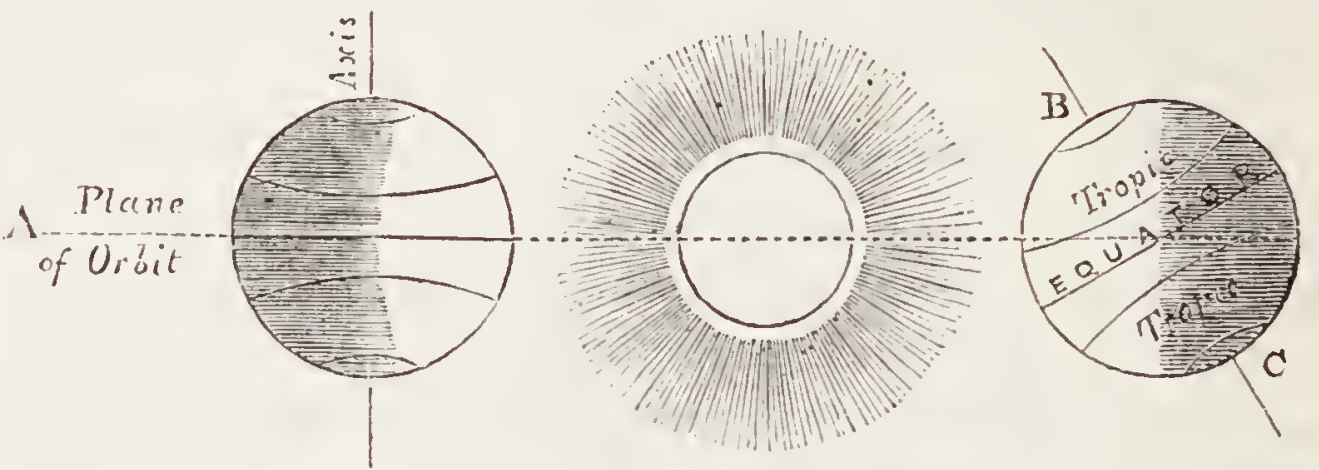

ends of the carth are called Poles, one the Forth Polc, and the other the South Pole, and northerly and southerly situations and movements are spoken of in reference to these Poles. The axis of the earth is always directed tourals the same spot, and points uniformly in the same direction tourds the heavens. In whatever position the earth may be with respect to the sun, onc-half of the carth's surface must aluays be in the light, and one-half in alarkness. It will be evident, also, that if the axis of the earth were perpendienlar to the direction in which the earth mores round the sun, or, A, then, as the earth turned round, each part of its surface would be turning half the time in light and half the time in rlarkness. But the axis is inclined to the plane of the earth's orbit about $23 \frac{1}{2}$ degrees, as from $\mathrm{B}$ to $\mathrm{C}$, so that one Pole is aluays at some distance from the edge of the light on the illuminated side, and the opposite Pole an equal distance from the light on the dark side, $\mathrm{as}$ at $\mathrm{B}$ and $\mathrm{C}$.

18. The nearly circular course in which the eartl moves around the sun is called its orbit, D. The following figure shows the earth in four positions relative to the sun, as it may be understood to be on June 21st, September 22nd, December 21st, and March 20th. In position $\mathrm{F}$ the North Pole is constantly illuminated, while the South Pole is as constantly in darkness; so that it is constant day at the north, and constant night at the sonth. The circle about the North Pole, which at this time is constantly illuminated, is called the Arctic Cirele; and the circle now in darkness at the Sonth Pole is called the Antaretic Cirele; and these circles are also spoken of as Polar Circles and Regions. 
"I have made the earth, and created man upon it; I, even my hands, have stretched out the heavens, and all their host have I commanded."-IsalaII xlv.

19. At the edge of the Arctic Circle the sun only disappears at midnight for a few minutes on the 21st of June; but as we proceed towards the south, we shall have more shade, and the

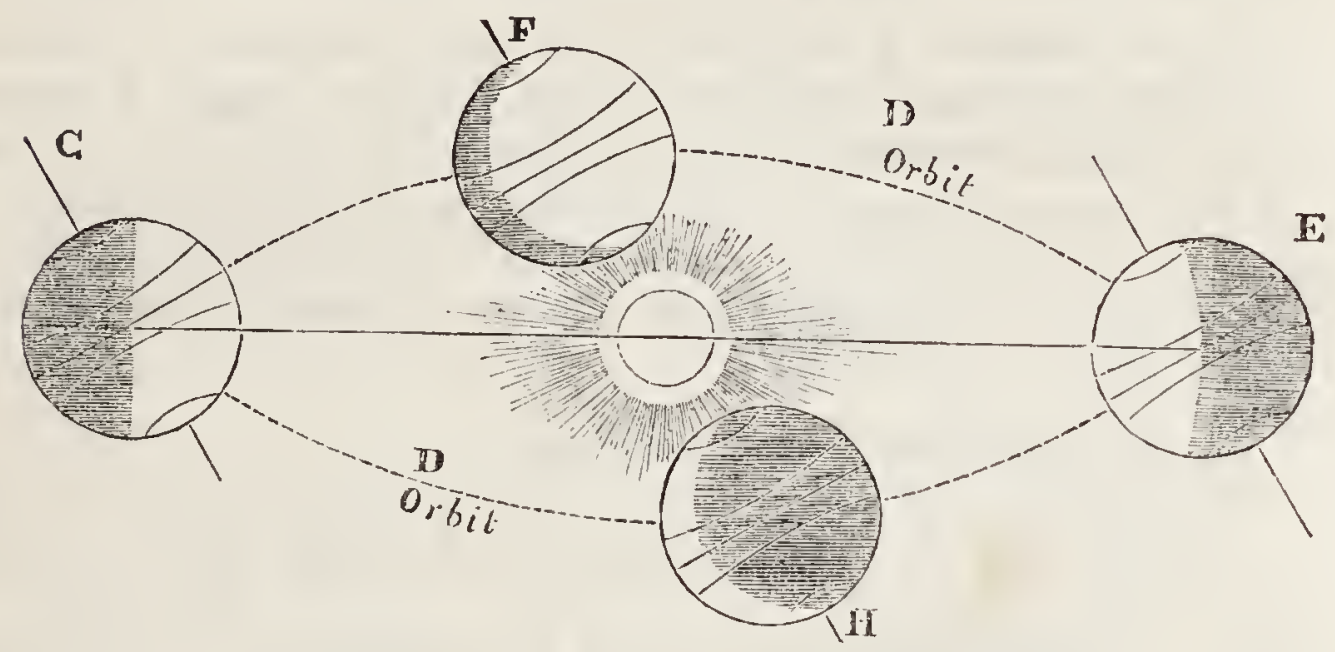

nights will continually lengthen until midway between the polesor the Equator as it is called. Here the light and darkness are equal. From this Equatorial Line the halves of the earth which lie respectively north and south are called the Northern and Sonthern Henispheres. Going on from this point to the sonth the nights continually lengthen, till, in the Antarctic Circle, we lose the sun entirely, and continue in darkness at the South Pole.

20. When the earth has moved through its orbit to the position F, September 22nd, all parts of the surface will be, during each diurnal rotation, in light and darkness for equal times. The days and nights will then be of exactly twelve hours each at all parts of the globe. Hence this period of the year is called the Autumnal Equinox, and the opposite position, Ir, the Spring Equinox. The days and nights are thus twice in a year of equal length over the whole earth.

21. On the 21st of December the earth is in the position G; and now, over the whole of the Arctic Circle, it is constant night; the days lengthen southward, and to the parts within the Antarctic Circle it is constant day. Therefore, at the Equator the days and nights are always of twelve hours duration each; but as we approach either of the Poles the days during onc-half of the year are longer than the nights, and during the other half the nights are longer than the days. In England the longest 
"To crerything there is a season, and a time to cvery purpose under the heavens." $\rightarrow$ Ecclesiastes iii.

day, June 21st, is sixteen hours, and the night following only eight hours; whilst on the 21 st of December the night is sixteen hour's, and the day only eight hours.

22. The rotation of the earth on its axis produces no alteration of light or darkness round the Poles, the only change in those regions being produced by the revolution of the earth through its orbit around the sun. As the earth passes from the positions $\mathrm{E}$ to $\mathrm{G}$ in six months, it follows that at the Poles there are six months of continuous light and six months of continuous slarkness.*

\section{Why do the Scasons change?}

The changes of the seasons proceed from the rariations in the duration of nights and days at various parts of the globe. When the days exceed the nights in the fullest degree at any part, the earth at that part is more heated during the day than it is cooled by night; and this period constitutes Summer. At the Spring and Autummal Equinoxes the heating and cooling of the earth occur during equal times; this produces the moderate warmth of Spring and Autumn. When the nights are longer than the days the earth is more cooled than leated, and hence the cold season of Winter.

24. Why is there no Winter between the Tropics?

Because, although the changes in the position of the earth and its relation to the sun are sufficient to cause variations of weather, yet they are never sufficient to produce winter.

25. At the Equator the heat is nearly the same all the year round; but, owing to the inclination of the earth's axis, the sum does not always shine directly down upon the Equator. Above and below the Equator are two lines representing imaginary circles Arawn round the globe called Tropics. On June 2lst the sun is

* The student should master these explanations, as they supply a key to mung pats of Physical Goography. 
"The fowers appear on the earth; the time of the singing of birds is come. and the roice of the turtle is heard in our land."-Soloyon's Song ii.

directly over the Northern Tropic, and on December 21 st he is directly over the Southern Tropic. The Northern Tropic is caliet the Tropis of Cancer, the Sonthern the Tropic of Capricorn.

26. What are the characteristics of the different Zones?

The surface of the earth is marked by geographers into five zones or belts, and the characters of the earth's divisions thus marked mainly depend on the proportions of heat and light which they receive. The middle zone, between the tropics, is hot and burning. It is called the Tomid Zone, from the Latin torreo, to parch or dry. The spaces between the tropics and the two Arctic Circles are the Temperate Zones; and the Polar Circles are the Frigid Zones.
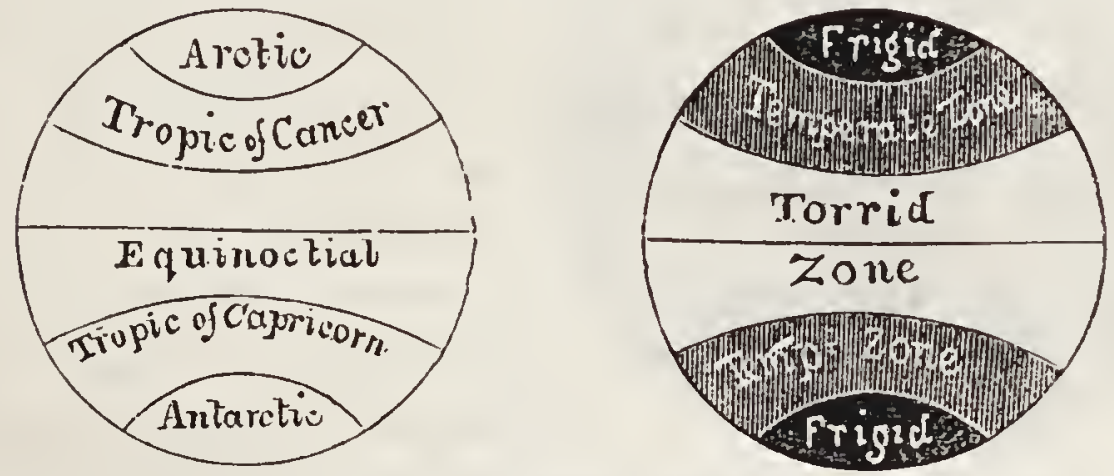

27. The earth has hitherto been described as a globe; but it is not strictly so, being slightly flattcned on two sides, like an orange. This flattening is at the Poles: hence the earth, measured from Fole to Pole, is 7898 miles in diameter, while at the Equator it is 7924 miles. The earth is thus twenty-six miles shorter from Pole to Pole than along the Equatorial Line. This depression is considerably less in proportion than the usual flattening of an orange.

28. The circumference of the eartl at the Equator is about 24,900 miles. The whole superficial area of the globe is equal to $197,000,000$ square miles; of this the LAND does not occupy more than 52,000,000 square miles, or little above one-fourth part; whilst the OCEAN covers an area of more than $144,000,000$ square miles. 
"They that go down to the sea in ships, that do business in Ereat waters; these see the works of the Lord, and Ifis wonders in the decp." - 'saLM crii.

\section{THE OCEAN.}

29. What causes the Tides of the occan?

They arise chicfly from the attraction of the moon, drawing the waters into a great and steady wave, at that point of

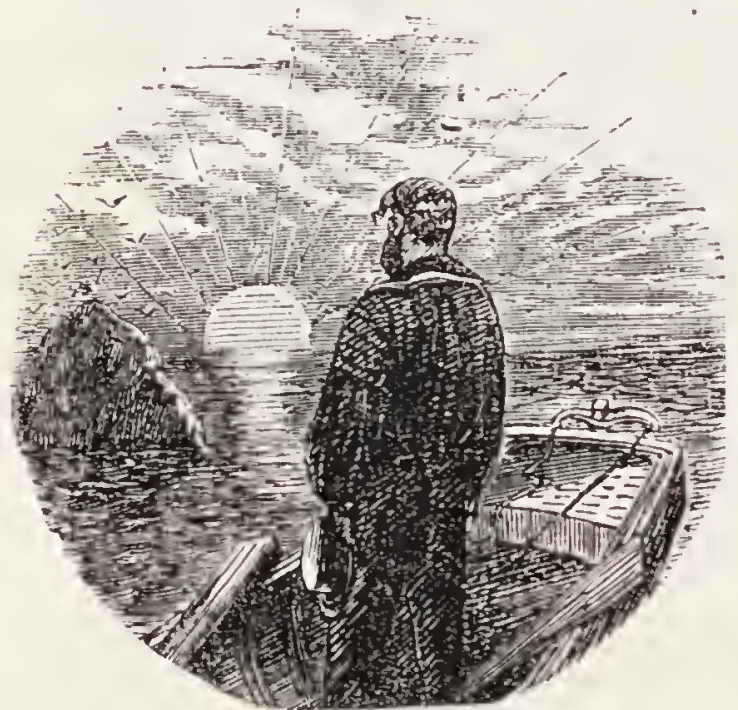
the earth's surface which is at the time turned towards the moon. The waters thus drawn do not come from the parts of the earth that are turned from the moon, but from those which lie intermediate between the two extremes. Hence there is low water at those intermediate points, and high water at the two opposite parts of the earth at the same time.

30. As the eartl turns, and presents one part of her surface after another towards the moon, these tidal wares, or heapings of the waters, travel gradually round the earth. Thus, as the earth revolves upon its axis once in twentyfour hours, there result high water and low water alter- nately on cach part of the coast, these changes occurring at intervals of about six hours and a quarter.

31. The sun exerts a similar action upon the earth, though, from his far greater distance, it is much less poucerful than the action of the moon. At ncw moon (that is, when the moon and sun are both on the same side of the earth) they both act in the same dirction, 
"And Amaziah strengthened himself, and led forth his people, and went to tine valley of salt, and smote of the children of Levi ten thousand."-II CHroNICLES XXY.

and the wave caused by their united forces is the greater. This produces the spring tides. As the moon moves round the globe once in about twenty-eight days, she will in seven days, or at her first quarter, have come to a point at right angles to her first position. In this place the moon tends to form a tide wave on the side of the earth under her; but the sun, on another side, at right angles to the moon, exerts a counteracting infuence. The depth of the moon's wave is then only that due to the difference of these actions. It is then that neap tides oeeur. The moon in seven days more comes to the side of the earth opposite to the sum, in the position which produces full moon. Now the sun again assists the moon, for he tends to draw the earth away from the water on the moon's side, whilst on the side towards himself he draws the water nearest to him away from the earth. Thus he increases the clirect ware of the moon on one side, and also the wave on the side nearest to himself. This igain produees spring tides. In the moon's third quarter neap tides again occur. Thus the spring tides occur at now and full moon, and neap tides at the first and third quarters.

\section{Why is the Sea Salt?}

The sea holds in solution common salt, from which arises the popular idea of the "saltness of the sea." But this characteristic of the ocean must not be regarded in so limited a sense, since the sea holds in solution not merely" common salt, but other substances known as "salts" in chemistry. Common salt imparts to sea-water its sarour; chloride of magnesium imparts the damp sticky feeling to clothes that have been wetted by salt water.

33. The solid constituents of sea-water amount to about $3 \frac{1}{2}$ per cent. of its weight, or nearly half an ounce to the pound.

34. River's which are constantly flowing into the ocean contain salts, varying from ten to one hundred grains per gallon. 'They are chiefly common salt, sulphate and carbonate of lime, magnesia, soda, potash, and irou; and these 
"Therefore will not we fear, though the earth be removed, and though the mountains be earried into the midst of the sea." - Psaly xlvi.

are found to constitute the distinguishing substances in sen-water.

35. 'The water which evaporates from the sea is nearly pure, containing but very minute traces of salts. Falling as rain upon the land, it washes the soil, percolates through the rocky layers, and becomes charged with saline substances, which are borne seaward by the returning currents.

36. 'The ocean, therefore, is the great depository of everything that water can dissolve and carry down from the surface of the continents; and, as there is no channel for their escape, they consequently accumulate.

37. We have reason to bclieve that the sea was salt from the beginning, and that it las not become so through subsequent ages from the washings of the land or the scourings of the ocean bed. Go back as far as we may in the dim records which Nature has left inscribed upon the geological pages of her history, and there we find the fossil shell, and the remains of many inarine organisms, to inform us that when the foundations of the mountains were laid with granite the sca was salt as it is now. Had not the sea been salt, conld those creatures have obtained solid matter for thicir edifices and structures. "Creeping things" are doing now precisely what they wcre set about when the dry land appeared, namely, preserving the purity of the occan, and regulating it in the due performance of its offices.*

38. Why do the waters of the ocean Differ in their degree of Saltness?

Because there are agents at work in different parts of the ocean, the tendency of which is to make the water's in one part salter and heavier, and in another part lighter and less salt. Among these agents are animals that form sea-shells for their dwellings, by secreting solid matter from the water; and also heat and radiation, evaporation and precipitation.

"Lieut. Maury's "Plysical Geography of the Sea." 
"Thy way is in the sea, and Thy path in the great waters, and Thy footsteps are not known." - Psaly Ixxvii.

39. In the trade-wind regions at sea, evaporation is generally in excess of precipitation, while in the extra-tropical regions the reverse is the case: the clouds let down more water than the winds take up again. In the process of evaporation from the sea, fresh water only is taken up, the salts are left behind.

40. Why do the Different Degrees of Saltness in water tend to produce Currents?

Because salt water is heavier than fresh, as is evidenced by the greater buoyancy by which a swimmer floats upon salt than upon fresh water. The trade winds, by their constant force, assist to skim the Atlantic of water in the form of saltless vapour; this they deliver as fresh water over vast areas of land and sea.

41. Here we lave, on one side, the Caribbean Sea and Gulf of Mexico, with their waters of brine; on the other, the great Polar basin, the Baltic and the North Sea, the two latter with waters that are but little more than brackish. In one set of these sea-basing the water is heary, in the other it is light. Between them the ocean intervenes; but water is bound to seek and to maintain its level; and here we recognise one of the forces concerned in producing the great Gulf Stream.

42. If all the salts of the sea were crystallised, and spread out over an area of seven millions of square miles, it would cover the ground one mile deep. What force could move such a mass of matter on the diy land! Yet the machinery of the ocean, of which it forms a part, is so wisely and wonderfully compensated, that the most gentle breeze that plays on its bosom, the tiniest insect that secretes solid matter for is sea-shell, is capable of putting it instantly in motion. Still, when solidified and placed in a heap, all the mechanical contrivances of man, aided by the tremendous forces of all the stean and water power of the world, could not lemove this mass 
"The waters wear the stones: Thou washest among the things which grow out. of the dust of the earth; and 'Thou destroyest the hope of man."-Jors xir.

an inch in centuries of time, though, in its present adaptation, the sun-beam, the zepliyr, and the infusorial inscet, keep it in perpetual motion.**

43. What becomes of the Salts that are constantly bcing "ashed into the sea?

Shell-forming animals are the conservators of the ocean. As the salts are emptied into the leep, these creatures separate the solid matters held in solution, converting them into more enduring solid forms; these in comrse of time are piled in solid masses to serve as the bases of new islands and continents.

44. 'The dews, recins, and rivers are continually dissolriug certain minerals of the earth, and carrying them off to the sea. This is an accumulative process; and if it were not compensated by the labours of marine animals, the sea would finally become as the Dead Sea is, saturated with salt, and therefore unsuitable for the habitation of many fish of the sea.

45. If we examine the class of animals called Mollusca, to which various forms of lane sliells and shell fishes belong, we shall find that nearly the whole of their shell is composed of carbonate of lime. This substance is soluble in water containing carbonic acid gas; and thus we find it in solution in scas, livers, and springs, and the Molluscous creatmes inhabiting these water's are able to separate it from its dissolving acid, and to form for themselves an insolnble tenement to dwell in. In this simple agency, the formation of solid carbonate of lime from the carbonic acid of water, there are changes of greater magnitude brouglit about than the mind of man can conceive.

46. Thly is the sea blue?

The cause is not clearly understood, though by some persons it is explained that the blueness of the sea is, 
"Let the sea roar, and the fullness thereof; let the fields rejoice, and all tinat is therein." -I Chroniches xivi.

like that of the sky, an absorptive colour proper to either element.

47. By "an absorptive colour" is meant, that the sea absorbs all the prismatic colour's except that of ultremarine, which, being reflected in every direction, imparts a hue resembling the azure of the sky.

48. The sea is only purcly blue in the open ocean, or in very deep water, away from the influence of rirers, the washing of the coasts, or such currents as drift along sand and impurities. When free from all such causes of discolouration, a white object thrown overboard is seen to become bluer as it sinks. It can hardly be contended that the colour is owing either to salt, or to the presence of copper, as has been suggested; because the vater of the Rhone, where it issues from the Lake of Geneva, far surpasses the deepest blue of the sea.*

49. Yet, at the salt-works in France, and along the shores of the Adriatic, where salt is produced by the craporation of sea water, the salt-makers judge of the richness of sea water, in respect of sall, by its blueness. The presence of salt in greater or smaller quantity may affect the arrangement of the atoms of water, so as to render it absorptive of the other qualities of light, and reflective of the blue; and the blueness of the sky may arise from a similar arrangement of the atoms of air, but with which salt has nothing to do.

50. Why does the sea emit a Phosphorescent Light

The phosphorescent light of the sea-so called from its resembling the glow emitted by phosphorous-is caused by the presence of myriads of Medusce, marine organisms, some soft and gelatinous, some minute crustacea, and others. They mostly shine when excited by agitation of the water, as when an oar dashes into it, or the water

" Tierschel's "Physical Geography." 
"For the earth shall be filled with the knowledge of the glory of the Lord, as the waters cover the sea.-WABAKntK ii.

closes in the track of a ship. Most of these creatures are inconceivably small; but there are others of more than an inch in length, which appear, when excited, like lumps of white họt-iron.

51. Why are patches of the sea fiequently observed to be of Difjerent Colours?

Independently of those differences of colour which arise from the varying nature of the sea bottom in shallow waters, from the discharge of rivers, the reflections of the clouds, the passage of shoals of fish, \&c., there are other discolourations, which for some time were the subject of special investigation.

52. These latter discolourations are caused by the organisms of the sea, but whether wholly animal or regetable, or whether sometimes the one and sometimes the other, has not been satisfactorily ascertained. They sometimes swarm so thickly in the Pacific and Indian Oceans, that they change the colour of the sea, making it crimson, brown, black, or white, according to their hues.

53. The tints which have given to the Red sea its name may, perhaps, be in some measure due to agencies similar to those which in the salt-maker's ponds give a reddish cast to the brine, just before it reaches that point of concentration when crystallization is about to commence. Some consider that this tinge is imparted by the shells and other remains of infusoria which have perished in the growing saltiess of the water. Quantities of slimy red colouring matter aro at certain seasons of the year washed up along the shores of the Red Sea, which Dr. Ehrenberg, after microscopic examination, pronounces to be a very delicate kind of sea-weed. So, also, the Yellow Sea.

54. What causes the occan Currents?

The chicf cause is the heat of the sun. The high degree of temperature at the Equator expands the water and makes it lighter. It therefore flows over the surface of the colder ocean in the temperate zones towards the Poles, while a 
"Then the channels of waters were seen, and the foundations of the world were discovered at 'llyy rebuke, $O$ Lord, at the blast of the breath of Thy nostrils.Psalur xviii.

flow of the cold water fiom the Poles takes place beneath the surface towards the Equator. These natural tendencies of the suriace water to flow from the Equator to the Poles, and of the under water to form a current firom the Poles to the Equator, are similar to the motions of the atmosphere, and are modified by the rotation of the earth in the same way.

55. Hence a current results, to the extent of $30^{\circ}$ on each side of the Equator. 'This current, striking against the eastern coasts of Asia, Africa, and America, is thrown off north and south; the heated water flows over to the Poles, there cools, sinks, and sweeps again into the Equator along the western coasts of the land. Two general currents thus revolve on each side of the Equator.

56. As a rule, on all eastern coasts of the great oceans, the current is from the Equator to the Poles, and on all western coasts from the Poles to the Equator. 'The Gulf Stream, which flows powerfully from south-west to northeast, along the easterin coast of North America, is a remarkable branch of this general current.

57. If we except the ticles, and those partial currents that may be created by the wind, we may lay it down as a rule that all the currents of the ocean owe their origin to difference of specific gravity between sea water at one place and sea water at another; for, wherever there is such a difference, whether it be owing to difference of temperature or to difference of saltness, or to these two causes combined, it is a difference that disturbs equilibrium, and currents are the consequence.

58. How do ocean currents tend to Diffuse and Equalize T'emperature?

The hot water of the equatorial currents, in all the seas, 
"As fal as the east is from the west, so far hath He remored our trangrressions from us."-PSiLI ciii.

is dashed against the eastern coasts of southern lands, while the cold supplying currents from the southern ocean sweep along the west side of those masses. In its northern

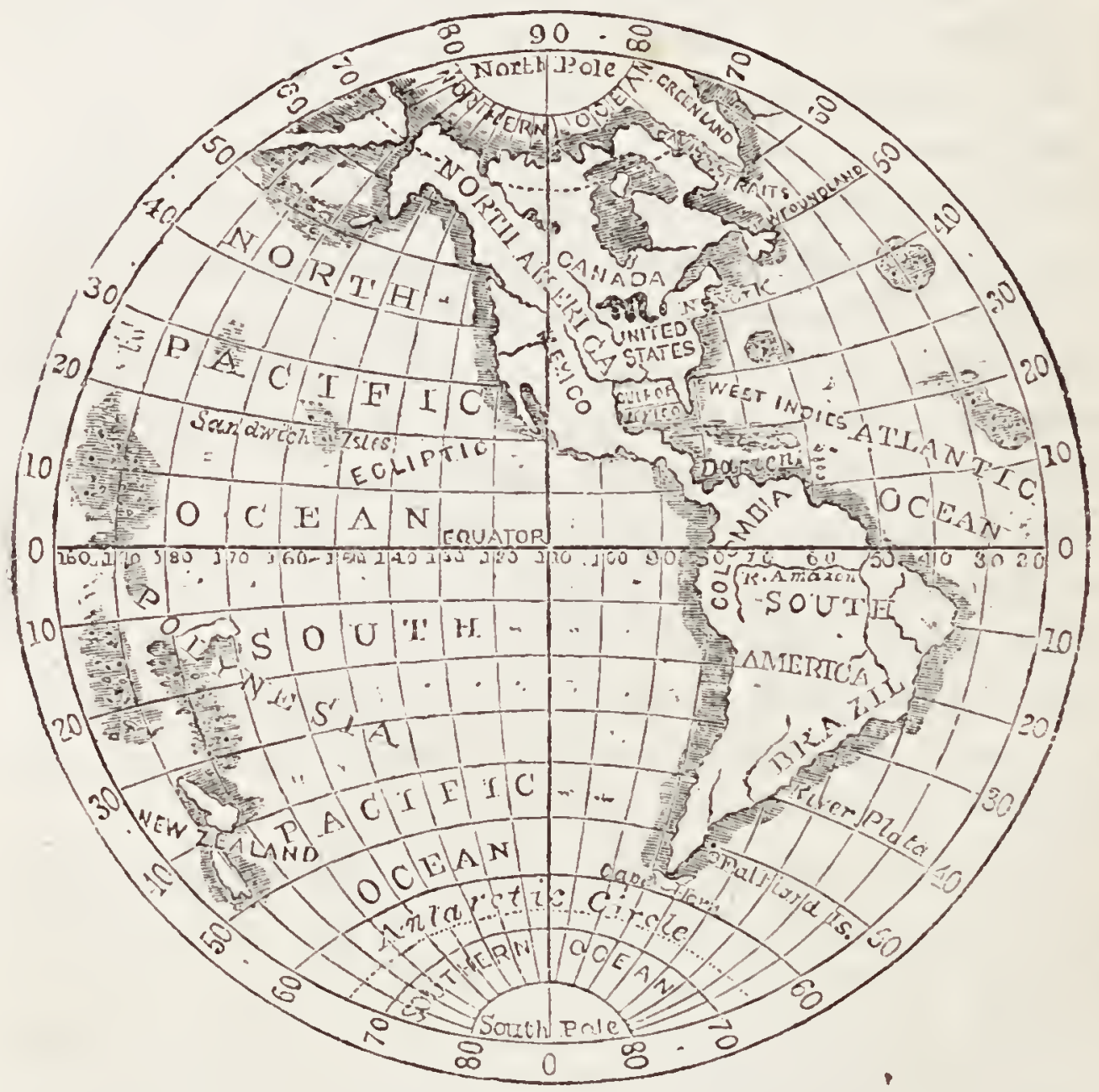

THE WLSTERN IIEMISPIERE.

airculation, the hot water is carried across the great oceans north-eastward, to strike on the west sides of the northern lands, while cold return currents flow down their east sides; and, in its southern circulation, the hot water is 
"The north and the south Thou hast created them: Tabor and Ilermon shall rejoice in 'Thy name."-Psalit lxixix.

thrown off southwards by the eastern coasts of the southern masses.*

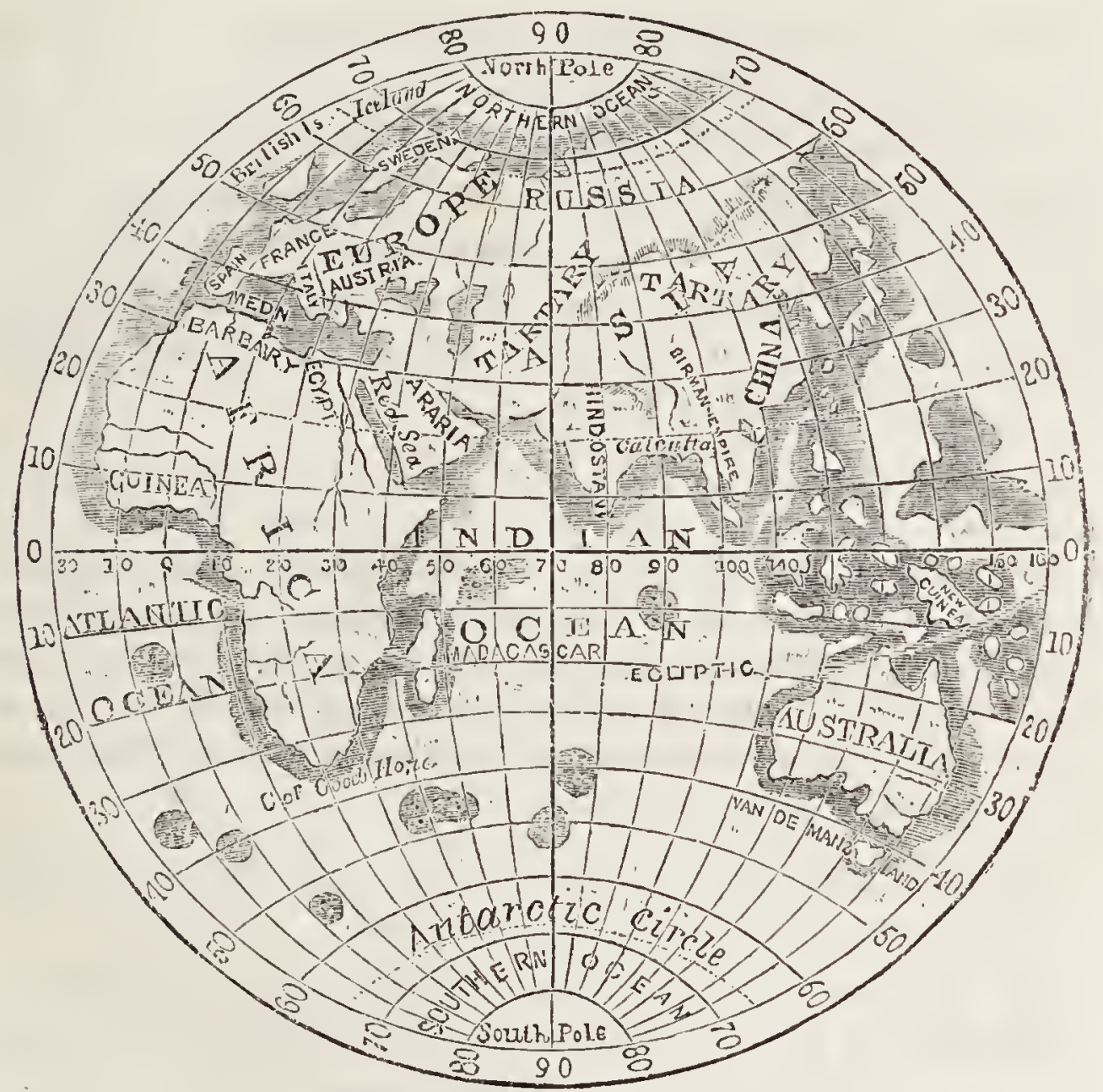

TIIE EASTERN IEMISFHERE.

59. What is the canse of the Gulf Stream?

Modern investigations are beginning to throw light upon this subject; though all is not now clear. 'The generally received opinion is that which was held by $\mathrm{Dl}^{\text {. }}$. Franklin, that the Gulf Stream is the escaping of the waters that have been forced into the Cariblean Sea by the trade winds, and that it is the messure of those winds upon

* Herschel. 
"Iie gave to the sea His decree, that the waters should not pass His commandment: when He appointed the foundations of the earth."-Provelibs viii.

the water, which forces up into this sea a head or reservcir of water for this great stream.

60. But more recent opinions appear to indicate that, though the pressure of the trade winds may assist to give the Gulf Stream its initial velocity, this cause is not in itself adequate to the whole effect. The other causes that assist this wonderful movement of waters, are the differences of temperature at rarious parts of the earth, and differing degrees of saltness in rarious parts of the ocean, altering the specifie gravity of the waters.

61. The Gulf Strcam is one of the most wonderful things in nature. It constitutes a grand river in the occan. In the severest drougints it never fails, and in the mightiest floods it never overflons. Its banks and bottom are of cold water, while its current is of rarm. The Gulf of Mexico is its fountain, and its mouth is in the Arctic Seas. There is no other such majestic flow of waters. Its current is more rapid than the Mississippi or the Amazon, and its volume more than a thousand times greater.*

62. Why did the existence of the Gulf Stream promote the Discovery of America by Columbus?

By washing to the islands of the Azores bamboos, artificially cut pieces of wood, trunks of trees, and bodies of men of unknown race. These, among other evidences, led Columbus to believe in the existence of lands westward of Asiatic countries.

63. The current produced by the Orinoco, between the mainland and the island of Trinidad, also prompted Columbus in his diseovery. He inferred that so immense a body of fresh water as there flowed into the sea could only be collected in a long course, and "that the land which supplied it must be a continent, not an island." 
"There is a river, the streams whereof shall make glad the city of God, the hoiy place of the tabernacles of the Most High.,"-PsAly xlvi.

64. What effect has the Gulf Stream upon the Temperature of Europe?

The maximum temperature of the Gulf Stream is $86^{\circ}$ or about $9^{\circ}$ above the ocean temperature due to the latitude. Increasing its latitude $10^{\circ}$, the water of the Stream loses but $2^{\circ}$ of temperature; and, after having run three thousand miles towards the north, it still preserves, even in winter, the heat of summer. With this temperature it crosses the 40 th degree of north latitude, and there, overflowing its liquid banks, spreads itself out for thousands of square leagues over the cold waters around, and covers the ocean with a mantle of warmth that serves to mitigate in Europe the rigours of winter.

65. The warm waters which are contained in the Gulf of Mexico resemble a heating apparatus employed to give heat to a conservatory, or to a dwelling in the winter, the furnace and the cauldron being placed at a distance from the apartment to be warmed. The furnace is the torrid zone; the Mexican Gulf and the Cariblean Sea are the cauldrons; and the Guif stream is the conducting pipe. The warmth thus conveyed is taken up by genial west winds, and diffused in the most benign manner throughout Europe.

66. What is the effect of the Gulf Stream upon Great Britain?

Every volume of west wind that blows crosses the warm Gulf Stream on its way to Europe. The warm winds, and waters meet, and diffuse their influences through and around the British Islands-influences not only of warmth but of moisture. These genial influences make Ireland the "Emerald Isle of the Sea," and clothe the shores of England in ever-green robes, while, in the same latitude on the opposite shores of the Atlantic, the coasts of Labrador are fast bound in ice.

67. In 1831 the harbour of St. John's, Newfoundland, was closed 
"He maketh the deep to boil like a pot; Ile maketh the sea like a pot of ointment."-Jors xli.

so late as the month of $J$ une; yet the port of Liverpool, though $2^{\circ}$ further north, is never seriously affected by ice even in winter. Sir Walter Scott has witten that the ponds in the Orkneys (latitude nearly $60^{\circ}$ ) are not frozen in winter, a soft climate prevailing owing to this grand heating apparatus.

68. Why does the Gulf Stream influence furourably the Climates of Mexico, Central America, and the West Indies?

The West Indies are encompassed on one side by a chain of islands, and on the other by the Cordilleras of the Andes, contracting with the Isthmus of Darien, and stretehing themselves out over the plains of Central America and Mexico. Beginning on the summit of this mountain range, we leave the regions of perpetual snort, and descend into the temperate level, and then wC reach the burning land. Descending still lower, we arrire at the surface of the Mexican scas, and here, were it not for the cooler returning currents through the Curibbean Sea, there would prevail the hottest, and mobably the most pestilential climate in the world.

69. As the waters in these two great caulirons (the Mexican Gulf and the Cirribbean Sea) become heated, they are borne off by the Gulf Stream, and are replaced by cooler currents returning from the North Atlantic through the Caribbean Sea.

70. Tho difference in temperature between the escaping and the retiring waters shows that the quantity of heat daily carried off by the Gulf Stream and diffused over the Atlantic is sufficient to raise mountains of iron from soro to the melting point, and to kecp in flow from them a molten strecam of metal greater in volume than the waters daily discharged from the Mississippi River!

71. Why do the different specific gravities of $\Pi$ torm and Cold Waters produce Ocean Currents?

Hot water, being the lightest, expands and rises to 
"Let the heavens rejoice, and let the earth be blad; let the sea roar, and the fulness thereof."-Psaly xcvi.

the top; and there, parting with its heat, descends, and gives piace to volumes of warmer water rising from below.

72. Thus, in a winter's day, the waters at the surface of the Gulf Stream off Cape Hatteras may be at $80^{\circ}$, and at the depth of three thousand feet the thermometer will stand at $57^{\circ}$. Following the stream thence off the Capes of Virginia, one hundred and twenty miles, it will be found that it now stands a degree or two less at the surface, while all below is cooler. In other words, the stratum of water at $55^{\circ}$ which was three thousand feet below the surface off Hatteras, has, in the course of one hundred and thirty miles in a horizontal direction, ascended vertically six hundred feet-has actually mu up hill with an ascent of five or six feet to the mile.

73. There is reason to believe that the warm waters of the Gulf Stream are nowhere permitted to touch the bottom. There is evcrywhere a cushion of cool water between them and the earth. This arrangement is strikingly beautiful. One of the benign influences of the Gulf Stream is to convey heat from the Gulf of Mexico, where otherwise it would become excessive, and to disperse it in regions beyond the Atlantic for the amelioration of the climates of Europe. Now, cold water is one of the best non-conductor's of lieat, and if the warm Gulf Stream were sent across the Atlantic in actual contact with the earth - comparatively a good conductor of heat-instead of being sent across, as it is, with a cold nonconducting cushion to separate it from the bottom, all its heat would be lost in the first parts of the way, and the soft climates of France and England would be cold in the extreme.

74. What marlied difjerence exists between the Climates of Sea and Land?

Althugh they both change with latitude, that of the land. varies with elevation above, and of the sea 
"Who layeth the beans of His clambers in the waters; who maketh the clouds His chariot; who walketh upon the willgs of the wind."-Psaly cir.

with depression below the sea level. The higher we ascend a mountain the colder it becomes; descending again we find increasing warmth until we reach the plain. But were it possible for us to descend into very deep waters, we should quit the warmth of the surface and find increasing degrees of cold the deeper we sank.

75. Why may the presence of Sand Banlis, Shoals, \&.c., be recognised by the low temperature of the water covering them?

Because when, in the general movement of the water forming a current, the deeper situated and colder particles strike upon a bank, their motion is inclined upwards, and they mingle with and chill the upper stratum of water.

76. The fact was first discovered by Dr. Franklin, who may be said thereby to have transformed the thermometer into a sounding line. Sir Humphry Dary attributed the fact rather to the descent of the surface particles, cooled by nocturnal radiation, and to their being prevented from sinking deeper by the shoal, which thus retained them in closer proximity to the surface.

77. What are the distinctions between Insular and Excessive Climates?

We find that the climate of islands, and of countries bordering on the sea, differs considerably from that of the interior of continents, the former being usually characterised by milder winters and more temperate summers. Such countries are said to possess an insular climate.

78. When, on the other hand, any region experiences great sererity of eold in winter, and at the same time a considerable degree of heat in summer, it is said to possess an excessive climate.

79. The slowness with which the great mass of water in the oeean 
"The sea is His, and He made it, and His hands formed the dry land."-Psaly xcr.

follows the variations of temperature in the atmosphere, and the consequent influence of the sea in equalising temperatures, gives rise to an important contrast between insular or littoral climates (enjoyed also in more degree by countries whose outline is broken by peninsulas and bays) and the climate of great masses of solid land. These insular climates exert peculiar effects upon vegetation and agriculture, on the transparency of the atmosphere, and the serenity of the sky, on radiation from the surface, and on the height of the limit of perpetual snow.

80. The mean temperature of the month of August in Hungary is $69^{\circ} 8^{\prime}$ Fah.; in Dublin, which is situated on the same isothermal line (i.e.) the line of equal mean annual temperature) of $49^{\circ} 2^{\prime}$, it is barely $60^{\circ} 8^{\prime}$ the mean winter temperature of the two stations being $27^{\circ} 7^{\prime}$ at Buda, and $39^{\circ} 8^{\prime}$ at Dublin. The winter temperature of Dublin is $3^{\circ} 6^{\prime}$ ligher than that of Milan, Pavia, Padua, and of the whole of Lo:nbardy, although they enjoy, on the mean of the whole year, a temperature of at least $5^{\circ} 8^{\prime}$. Stromness, in the Orkneys, not half a degree south of Stockholm, has a winter temperature of $39^{\circ} 2^{\prime}$, being nearly as mild as London, and milder than Paris; even in the Faroe Islands, in lat. $62^{\circ}$, under the favouring influence of the sea and of westerly winds, the island waters never freeze. On the lovely coast of Devonshire, where Salcombe Bay has been called, on account of its mild climate, the Montpellier of the North, the agave Mexicana has been seen to blossom in the open air, and orange trees trained against espaliers, and only slightly protected by mats, liave borne fiuit. There and at Penzance and Gosport, as well as Cherbourg in Normandy, the mean winter temperature is above $41^{\circ} 8^{\prime}$, only $2^{\circ} 4^{\prime}$ lower than that of Montpellier and Florence. Hence we perceive in what a variety of ways the same mean annual temperature may be distribnted in the different seasons of the year, and the important influence of this distribution, whether considered in reference to vegetation to agriculture, to the ripening of fruits, or to the comfort and well being of man.*

81. In what manner do Ice-bergs assist in the Moderation of Climates?

Noi merely by cooling the intertropical seas, but in 
"The sea is come up upon babylon: she is corered with the multitude of the wares thereof."-Jeresian li.

withdrawing heat from the atmosphere as they melt and return to a state of fluidity. Nor is this all : while they are in process of congelation, the heat of fluidity is set free and this assists to give activity and energy to the Polar systems of atmospheric circulation, by warming and cxpanding the air at its places of ascent.

82. Thus it is that ice-bergs are employed to push forward the winds in the Polar regions, and to hold them. back in the Equatorial. In contemplating these facts, we perceive how ice-bergs are "coupled on," and made to perform the work of a regulator, with adjustments the most beautiful and compensations the most exquisite, in the grand machinery of the atmosphere.

83. Why does great Coolness prevail for a considerable period of the year within the tropics on the coast of Peru?

This is accounted for by the prevailing fogs, which veil the sun, and a cold sea current, which, commencing in the Aretic regions and coming from the sonth-rest, strikes the coast of Chili near Valdavia and Conception, and thence streams rapidly along the coast to the northward, as far as Cape Pariña.

84. Why are the Heat and Dryness of intertropical America less cxtrome than in corresponding latitudes of Africa?

Amongst various causes may be mentioned the narrowness and deep indentation of the American land in the northern part of the torricl zone, where the atmosphere, having the ocean for its base, does not present so heated an ascending current; the extension of the continent towards the Poles, the expanse of ocean orer which the trade winds sweep, acquiring thereby a cooler temperature; the fiatness of the eastern consts; currents of cold 
"For He maketh small the drops of water; they pour down rain aceording to the rapour thereof."-JoB Xxxvi.

sea water from the Antarctic regions; the numerous lofty mountain chains rich in springs, and whose snow-clad summits, rising high above the clouds, cause descending currents of air to roll down their declivities.

85. The abundance of rivers of enormous breadth which, after many windings, seek the most distant coast; -steppes which, not being sandy, become less heated than the African deserts;-impenetrable forests, protecting with their shade the soil beneath from the direct influence of the sun, and extracting vast quantities of moisture;-all these circumstances afford to the flat part of America a climate which, by its humidity and coolness, contrasts wonderfully with that of Africa.

86. These explanatious, however, relate to the state of the atmosphere and the temperature of the New Contiment as a whole. Single districts, such as the island of Margarita, and the coasts of Cumana and Coro, are as hot and dry as any part of Africa.

87. In what manner do alternate Evaporation and Rainfall cause oceanic Currents?

The total annual fall of rain on the earth's surface is estimated at one hundred and eighty-six thousand two hundred and forty cubic miles. The Pacific and Indian Oceans covel an area quite equal in extent to one-half of the whole surface of the earth.

88. Three-fourths of the vapour which makes the total amnual amount of rain is taken up from the waters of these two great oceans.

89. But supposing that only half of this quantity, i.e. nivety-three thousand one hundred and twenty cubic miles 
"Thou, O God, didst send a plentiful rain, whereby thou didst confire thire inheritance when it was weary."-l'satar lxviii.

of rain, falls upon these seas, and that an equal quantity is taken therefrom again as vapours, this would give two hundred and fifty-five cubic miles as the quantity of water which is DAILY lifted up and poured back again into this expanse.

90. The better to appreciate the operation of such agencies in producing currents in the sea, now here, now there, first this way, and then that, let us, by way of illustration, imagine a district of two hundred and fifty-five square miles in extent to be set apart in the midst of the Pacific Ocean as the scene of operations for one day. We must now conceive a machine capable of pumping up, in the twenty-four hours, all the water to the depth of one mile in this district. The machine must not only pump up and bear of this immense quantity of water, but must discharge it again into the sea on the same day, but at some other place. Here is a force for creating currents that is eqnivalent in its results to the effects that would be produced by baling up, in twenty-four hours, two hundred and fifty-five cubic miles of water from one part of the ocean, and emptying it out ngain upon another part.

31. The currents that would be created by such an operation wonld overwhelm navigation and desolate the sea; and, happily for the human race, the great atmospherical machine which actually does perform every day, on the average, all this lifting up, transporting, and lettiug down of water upon the face of the grand ocean does not confine itself to an area of two hnndred and fifty-five square miles, but to an area three hundred thonsand times as great.

92. Yet the samo quantity of water is kept in motion, and the : currents, in the aggregate, trausport as much water to restore the equilibrium as they would have to do were all the disturbance to take place upon the imagined area of one mile deep over the space of two hundred and fifty-five square miles.

93. When we consider that evaporation is lifting up, that the winds are propelling, and that the clouds are transporting and letting down EVERY DAY actually snch a body of water, we see existing in nature a force perhaps quite sufficient to give rise to just such a system of 
"All the rivers run into the sea; yet the sea is not full; unto the place from whence tine rivers come, thither they return again."-Ecchesiastes $i$.

currents as that which mariners find in the Pacific-currents which appear to rise in mid-ocean, run at unequal rates, sometimes east, sometimes west, and finally lose themselves in the great body of the waters.

\section{What are the principal Currents of the Atlantic?}

The chief Atlantic current is the Great Gulf Stream, already described. Besides this, there are the Equatorial current, and the Brazil current. 'Their fountain-head is the same. It arises in the warm waters about the Equator, between Africa and America. The former, receiving the Amazon and Orinoco as tributaries by the way, flows into the Caribbean Sea, and becomes, with the waters in which the vapours of the trade winds leave their salts, the feeder of the Gulf Stream.

95. The Brazil current, coming from the same fountain, is supposed to be divided by Cape St. Roque, one branch going to the south under this name, the other to the westward. There is also a large periodical flow of Arctic waters into the Atlantic, which bears, no doubt, an important part in the system of oceanic circulation.

96. We may lay it down as a law in the system of oceanic circulation that every current in the sea has its counter-current; in other words, that the currents of the sea are, like the arteries and veins of the human system, arranged in pairs or sets; for, wherevcr one current is found carrying off water from this or that part of the sea, to the same part must some other current convey an equal volnme of water, or else the first would, in the course of time, cease for the want of water to supply it.

97. Winds are named from the points whence they blow, currents exactly the reverse. An easterly wind comes from the east, but an easterly current comes from the west and flows towards the east. 
"The waters saw thee, $O$ God, the waters saw thee: they were afraid: the rieptis also were trouvied.-Psan lxxii."

98. What are the principal Currents of the Indian Ocean?

'They are the Mozambique current or Lagullas current; and another great current, which makes it escape through the Straits of Malacea, and, being joined by the warm streams, from the Java and Chinese Scas, flows out into the Pacific between the Phillippines and the shores of Asia. Thence it pursues a circle route for the Aleutian Islands, tempering climates, and losing itsclf in the sca on its route toward the north-west const of America.

99. Besides these, there is a surface-current flowing north through Behring's Straits into the Arctic Sea. There are also Ice-bearing currents, but they are insignificant as compared with those of the North Atlantic.

100. Betwcen the physieal features of this current and the Gulf stream of the $A$ tlantic there are several points of resemblanee. sumatra and Malacea eorrespond to Florida and Cuba; Borneo to the Bahamas, with the Old Providenee Channel to the south, and the Florida Pass to the west. The eoasts of China answer to those of the United states, the Phillippines to the Bermudas, and the Japan Islands to Newfoundland. As with the Gulf Stream, so also here with the China current, there is also a eountcr-eurrent of eold water between it and the shore. The climates of the Asiatic coust correspond with those of America along the Atlantie, and those of Columbia, Washington, and Vancouver, are duplicates of those of western liurope and the British Islunds; the elimatc of California (Statc) resembling that of spain; the sandy plains and rainless regions of California reminding one of Africa, with its deserts, between the same parallels.* Moreover, the North Pacific, like the North Atlantie, is enveloped, where these war'm waters go, with mists and fogs, streaked with lightning. The Atlantie Islands are almost as renowned for fogs and mists as are the banks of Newfoundland.

101. What is meant by Ice-bearing Currents?

Ice-bearing currents are those which are from the Arctic

* Lieut. Maury. 
"The waters were gathered together, the floods stood upright as a heap, and" the deptlis were congealed in the heart of the sea."-Exod's $\mathrm{xv}$.

and Antaretic Seas, bearing with them mountains and fields. of ice, which become graciually dissolved as they approach warmer latitudes. Mid-way between Africa and Australia,

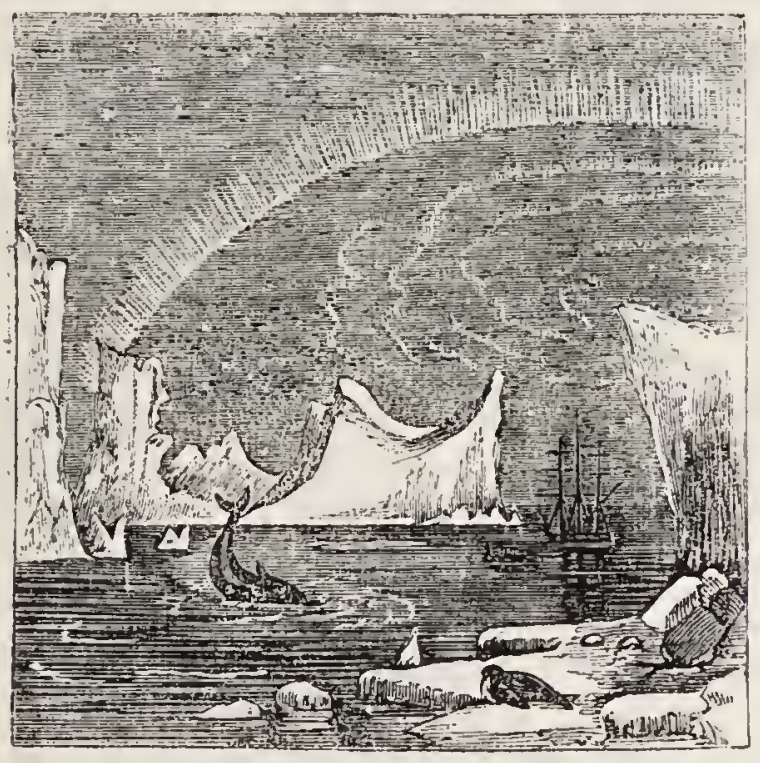

bearings occasionally interfere with ressels bound to Australia. The Gulf Stream seldom permits them to get so near to the Equator as that in the North Atlantic. But an ice-bearing current which passes east of Cape Horn into the South Atlantic has been known to convey its bergs as far as the parallel of $37^{\circ}$ south latitude. This is the nearest approach of icebergs to the Equator.

103. The Resolute exploring ship, having been abandoned on account of getting locked in a vast field of ice in Melville's Straits, was found afterwards in Baffin's Bay, liwving been carried 1000 miles from its former position by the drift of an ice-field 300,000 square miles in extent, and seven feet thick. A field of ice covering to the depth of seren feet an area of 300,000 square miles would weigh not less than 18,000,000,000 tons !

104. What are the principal Currents of the Pacific?

The currents of the Pacific are but little understood: 
"He made hearen and earth, the sea, and all that therein is."-Psacy cxlvi.

the best known is the Humboldt current of Peru. 'This current is felt as far as the Equator, mitigating the rainless climate of Peru as it goes, and making it delightful. 'The Andes, with their snow caps, on one side of the narrow Pacific slopes of this intertropical republic, and the current fiom the Antarctic regions on the other, make its climate one of the most remarkable in the world; for, torrid as to latitude, its temperature is such that cloth clothes are seldom felt oppressive.

105. There is, along the coast of California and Mexico, a southwardly morement of waters, as there is along the west coast of Africa, towards the Cape de Verd Islands. 'To the west from California lies the Pool into which the drift-wood and sea-weed of the North Pacific are generally gathered.

106. There is also a warm current from the intertropical regions of the Pacific, midway between the American coast and the slore-lines of Australia. There are also about the Equator in this ocean some curious currents, which are not yet sufficiently understood; some of them run with great force. On a royage from the Society to the Sandwich Islands, Lieutenant Maury encountered one ruming at the rate of ninety-six miles a-day.

107. A curious illustration of the existence of orcr-lying strata of watcr moving in opposite directions is afforded by the following circumstance, which occurred in the Baltic Sound, and which was narrated to Lieutcnant Maury by an able seaman who was present at the making of the trial. He said that, being in one of the King's frigatcs, some of the crew went with their pinnace into the mid stream, and were carried away violently by the current; that obscrving this, they sunk a bucket with a heary cannon ball to a ccrtain depth of watcr, and found that it gave a check to the boat's motion; and, sinking it still lower, the boat was driven 
"He shall have dominion also from sea to sea, and from the river unto the ends of the earth."-PsAL, lxxii.

ahead to the windward against the upper current, and that the lower the bucket was sunk the stronger the under-current was found to be. The boat was thus towed, by the bucket and ball sunk to the under-current, in an opposite direction to the upper current.

108. What benefits have resulted to Navigation and Commerce from a more perfect inowledge of the Oceanic Currents?

It would be impossible briefly to enumerate them all. One of the most marked examples is that afforded by the Gulf Stream, which intersects the tract of the world's greatest commerce. Though navigators had been in the habit of crossing and re-crossing the stream almost daily for three centuries, it never occurred to them to make use of it as a means of giving them their longitudes, and of warning them of their approach to the American shores. Vessels from Europe to Boston frequently found themselves at New York, and thought the landfall by no means bad. Instances are numerous of vessels navigating the Atlantic in those times being $6^{\circ}, 8^{\circ}$, and even $10^{\circ}$ of longitude out of their reckoning in as many days from port.

109. Colonel Sabine, a ferw years ago, in his passage from Sierra Leone to New York, was drifted one thousand six hundred miles of his way by force of currents alone; but, since the Gulf Stream has been better understood, the average sailing passage from England to America has been reduced from upwards of eight weeks to a little more than four.

110. Between England and Australia the average time going was formerly 124 days, and returning about the same, making the round voyage about 250 days on the average. The outward passage has lately been reduced to 97 days on the average, and the homeward passage has been made in 
"By the breath of God frost is given: and the breadth of the waters is straitened."-Јов xxxvii.

63. The average voyage fiom New York to California was 183 days, but the duration of the sailing has been reduced to 135 days.

111. No part of the world affords a more difficult or dangerous navigation than the approaches to the northern coast of America in winter. Before the warmth of the Gulf stream was known, a winter voyage from Europe to New York, and eren to the Capes of the Delaware or Chesapeake, was many times more trying, difficult, and dangerous than it now is. In making this part of the coast, ressels are frequently met by snow-storms and gales, which mock the seaman's strength and sct at nought his skill. In a little while lis bark becomes a mass of ice; with her crew frosted and helpless, she remains obedient only to her helm, and is kept hway from the Gulf Stream. After a few hour's' r'un she reaches its edge, and almost at the next bound passes from the midst of winter into a sea at sumner leat. Now the ice disappears from her apparel; the sailor bathes his stiffened limbs in tepid waters. He rises up, and attempts to make lis port arain, and is again, perliaps, as rudely met and beaten back from the north-west; but each time that he is driven off from the contest, he comes forth from this stream, like the ancient son of Neptune, stronger and stronger, until, after many days, his freshened strength prevails, and he at last triumplss, and enters a haren in safety.

112. Before the course and the warmth of the Gulf Stream were known, vessels distressed upon the Atlantic Sea firont knew of no place of refuge short of the West Indies, and it was no uncommon occurrence for ressels bound for the Capes of Delaware in winter to be blown off and go to the West Indies, and there wait for the return of spring before they would attempt another approach to this part of the coast.*

113. Why is the Climate of Patagonia and the Falkland Islands remarliably Mild in winter?

Because the heated waters of the Gulf of Guinea diffuse warmth to the extra-tropical regions of South America, as do the water's of the Gulf of Mexico to the Continent and Islands of Europe. The water in the Equatorial cauldron 
"Fea, thou shalt be as he that lieth down in the midst of the sea, or as ho that lieth upon the top of a mast."-Provenus xxiii.

of Guinea cannot escape north; the shore-line will not permit it. It must, therefore, overflow to the south, carrying to Patagonia and the Falkland Islands a climate mild as that prevailing in Ireland in winter.

114. On the Falkland Islands (latitude $51-2^{\circ}$ south) thousands of bullocks, sheep, and horses run wild over the country, gathering a living all through the winter.

115. We cannot now tell the reason, though explanations founded upon mere conjecture have becn offered, why there should be a jutting in and ont of the shore-lines, as at Cape St. Roque and the Gulf of Guinea, on opposite sides of the Atlantic; but one of the purposes, at least, which this peculiar coast formation was intended to subserve is no doubt revealed to us in the fact that it gives direction to the waters of the two great hot cisterns found in this ocean, causing them to distribute warmth to Western Europe and to Eastern Patagonia.

116. Why is it believed that at the bottom of Deep Seas there are No Currents?

Because, since comparatively deep sea soundings hare been effected, the objects brought up by the deep-sea plummet have been such as must have been swept away from the bottom had any active current existed.

117. These objects have been found to consist of the remains of microscopic creatures, in some cases the sliells having the flesh still in them. Now, these feculences of the sea, as the remains of its microscopic inhabitants may be called, are relatively as light in the water as dust in the air, and, if the bottom of the sea were scoured by currents, those light bodies would be swept away into drifts like snow or sand; they would be scratched, their sharp corners and edges would be broken off and rounded. Moreover, were they dirifted about, then sand and other scourings of the ocean would be found mixed with them.

118. But the specimens brought up from the deep show no such mixture, and the infusoria thence benr no marks of abrasicn upon even their most delicate parts. 
"In His hands are the deep places of the earth: the strength of the hills is IIis also."-PSALII xer.

119. Why has it hitherto been found impossible to Sound the Depths of the Sea in its deeper parts?

Because the porrerful under-currents of the sea continue

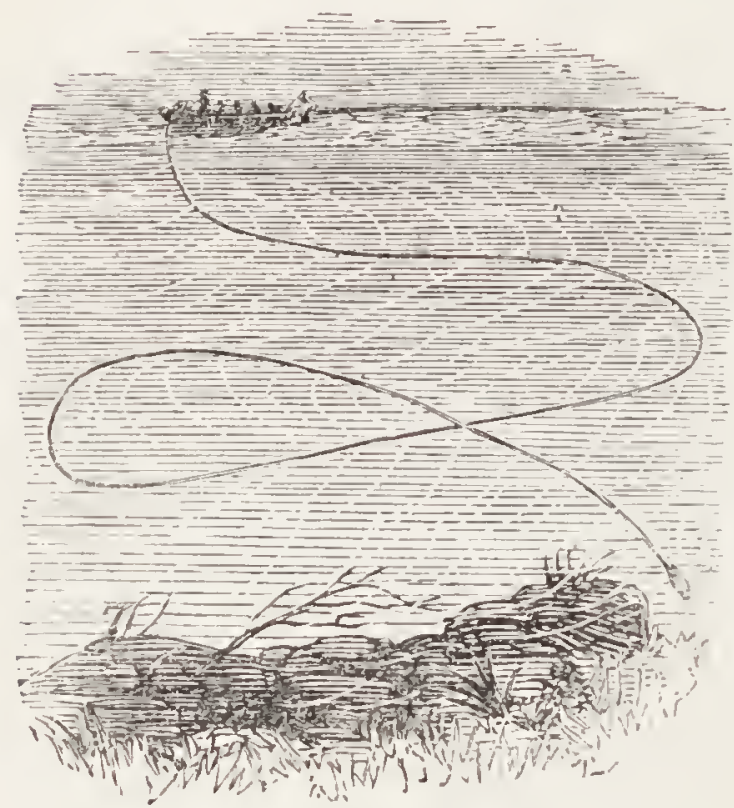

to run out the sounding line after the plummet has reached the bottom, with such rapidity as to render it impossible to judge whether the bottom has been reached or not; and because erery mechanical invention designed to register its lescent is rendered ineffective at considerable depths by the enormous pressure of the water's.

1:20. The depths of the ocean, it is known, are liable to great rariations. Soundings taken in the Atlantic hive shown a depth of 18,000 feet, or about three miles and a half; soundings in the Southern Atlantic, to the west of the Cape of Good Hope, showed a depth of 27,000 feet, or more than fire miles, and the bottom had not been reached. It a point 300 miles from the Bcrinuclas, 5700 fathoms of line rere paid out, nerrly six and a half miles, and no bottom found. Near the same parallel, bottom was found at less than half the aborc depth. Midway between the islands of Tristan d'Acunha and the mouth of the Rio de la Plata, the bottom was reached at a depth of 7706 fathoms, or cight miles and three-quarters. The time occupied in running out the line was nearly three hours. But these deep soundings are of rery doubtful character, on account of the cffects of the current.

121. 'The areragc depth of the sca on the coast of England is about 120 feet; on the coast of Scotland, 360 fect; on the Wcstern coast of Ireland, 2000 fect. From the summit of Chimborazo to the bottom of the Atlantic, at the deepest place yet reached by the plummet, and affording a reliable sounding, is nine miles in a vertical line.

12:. Could the waters of the Atlantic be drawn off, so as to expose to 
"There go the ships; there is that leviathan whom Thou hast made to play therein."-Psalm cir.

view this great sea gaash, whieh separates great eontinents, and extends from the Aretic to the Atlantic, it would present a seene the most rugged, grand, and imposing. The very ribs of the solid earth, with the foundations of the sea, would be brought to light, and we should have presented to us at one view in the cradle of the oeean a thousand fearful wrecks, with that dreadful array of dead men's skulls, great anchors, heaps of pearl, and inestimable stores, whieh, in the dreamer's eye, lie scattered on the bottom of the sea, making it sad with sights of death.

123. What is the leading characteristic of the Bed of the North Atlantic?

It has been satisfactorily ascertained that there exists at the bottom of this sea, between Cape Race, in Newfoundland, and Cape Clear, in Ireland, a remarlable steppe, which has become known as the telegraphic plateau. It was upon this that the trans-Atlantic telegraph cable was laid down in 1858 ; and although the first attempt proved a failure, and a great disappointment to the people of both the Old and the New World, there can be little doubt that the establishment of submarine telegraphic communication between England and America will ere long be numbered among the great achievements of science.

124. Why is the Gulf Stream called the "Storm King" of the North Atlantic?

Because the heat, warmth, and moisture naturally prevailing orer and around the current produce frequent atmospheric disturbances, by coming as it were suddenly into contact with cold air on either side of it, which air is frequently at the freezing point.

125. The most terrific storms that rage on the ocean have been known to occur within or near the borders of the Gulf Stream. The fogs of Newfoundland, which so 
"The burden of the desert of the sea. As whilwinds in the south pass. through, so it cometh frum the desert, from a terrible land."-Isalai xai.

much endanger narigation in winter, doubtless owe their origin to it.

126. The great liurricane of 1780 commenced at Barbadoes. Then the bark was blown from trees, and the fruits of the earth destroyed; the very bottom and deptlis of the sea were uprooted, and the wares rose to such a height that forts and eastles were washed away, and their great guns carried about in the air'; houses were razed, ships wreeked, and the bodies of men and beasts lifted up in the air, and dashed to pieces in the storm. At the different islands, not less than twenty thousand per'sons lost their lives on shore, while, further to the north, the Stirling Castle and the Dover Castle went down at sca, and fifty: sail were driven on shore at the Bermudas.

\section{What is the cause of the Saragossa Sea?}

It is caused by the circular morements of the waters of the Gulf Stream. 'The sea lies midway in the Atlantic, in the triangular space between the Azores, Canaries, and the Cape de Verd Islands.

128. The Saragossa Sea corers an area equal in extent to the Mississippi Valley, and is so thickly matted over with Gulf weeds that the speed of ressels passing through it is often much retarded. When the companions of Columbus saw it they thought they had reached the boundaries of navigation, and became alarmed. 'To the eye, from a little distance, it looks substantial enough to walk upon. Patches of the weed are always to be seen floating along the outer elge of the Gulf Stream.

1ミ9. If bits of eork, or chaff, or any floating substanee be put into a basin, and a cireular motion be given to the water, all the light substances will be found erowding together near the centre of the pool, where there is the least motion. Just such "basin is the Atlantic Occan to the Gulf Stream; and the Saragossa Sea is the eentre of the whirl. Columbus first discovered this weedy sea in one of his royages; there it has remained to this day, moving up and down, and ehanging its position aceording to the seasons, storms, and winds. 
"The wickea are like the troubled sea. When it cannot rest, whose waters cast up mire and dirt."-isaIAIr lvii.

Exact observations as to its limits and thcir range, extcnding back for fifty years, assure us that its mean position has not been altercl since that time.

130. The sea has its deserts and wildernesses, and these are as untravelled and as unknown as the great Amazonian wildernesses of Brazil or the inland basins of Central Africa. 'To the south of a linc extending from Cape Hor'n to the Cape of Good Hope, is an inmense waste of raters. None of the commcreial thoroughfares of the ocean lead through it; only the adventurous whalcman finds his way there now and then in pursuit of his game; but, for all the purposes of science and navigation, it is a vast unknown region.

131. What is the cause of "Tide-rips", "Bores," and "Eagres?"

These are examples of commotion of the seas not casily accounted for. They occur at uncertain interrals, and are not inaptly likened to "spasms," or throbbings.

132. Tide-rips are usually found in the neighbourhood of the equatorial calms-that region of constant rain to which they have been attributed. They are described as sometimes starting up in a calm, and then approaching the vessel, with great waves and noise.

133. The bores or eagres of India, the I'sien-Tang River, the Bay of Fundy, and the Amazon, are the most celebrated. "They are a tremendous tidal wave, which, at stated periods, comes rolling in from the sea, apparently threatening to engulph ererything that moves on the beach.

134. In the Bay of Fundy these tidal waves rise many feet high, and are said to overtake deer, swine, and other wild beasts that feed on the beach, and to swallow them up before the swiftest of foot among them have timc to escapc. Swine, which feed on mussels at low water are said to "snuff" the bore, eithcr by sound or smell, and sometincs to dash off to the cliffs before it rolls in.

135. Besides tide-rips, bores, and eagres, there are the sudden dis suptions of ice which Arctic voyagers tell of-the immense berg's 
"For He commandeth, and raiseth the stormy wind, which lifteth up the wares thereof."'-l sALM crii.

which occasionally appear in groups near certain latitudes; the variable character of all the currents of the sea-now fast, now slow-now running this way, now that-all of which may be taken as so many signs of the tremendous throes which occur in the bosom of the ocean. Sometimes the sea recedes from the shore, as if to gather strength for a great rush against its barriers, as it did when it fled back to join with the earthquake and overwhelm Callao in 1746 . and again Lisbon nine year's afterwards. The tide-rips in mid-ocean, the waves dashing against the shore, the ebb and flow of the tides, may be regarded, in some sense, as the throbbings of the great sea pulse.*

\section{What is the canse of Waves?}

Wares that are not tidal are produced by the friction of the wind, agitating the surface of the ocean. If the motion

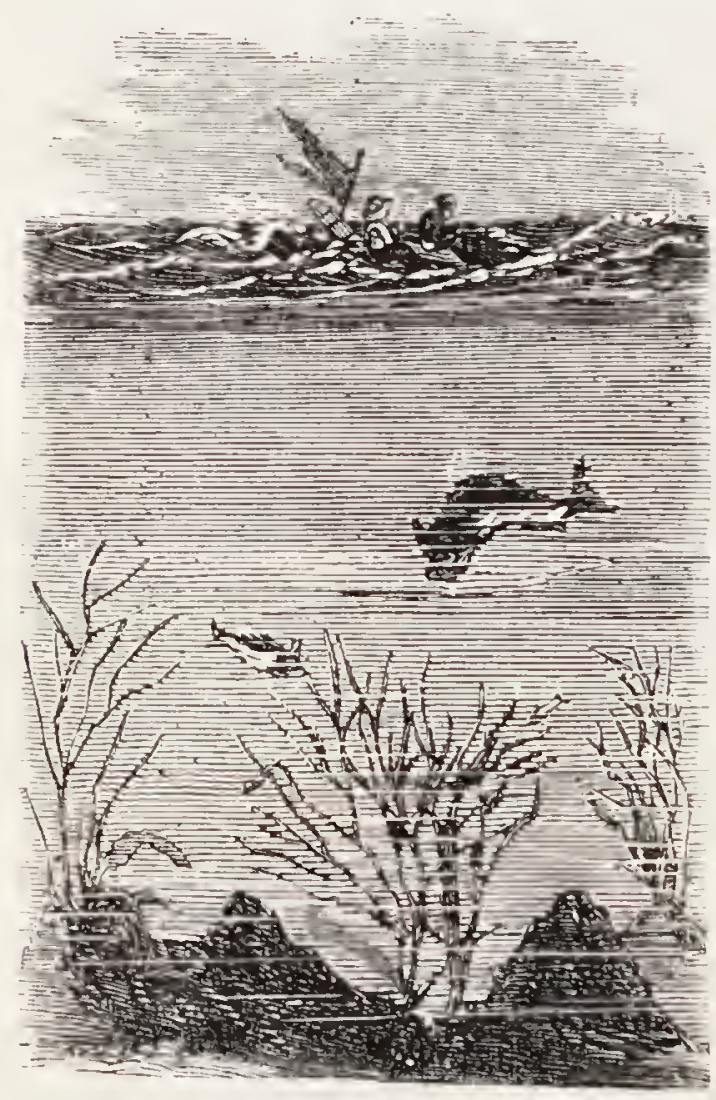
of the wind be exactly parallel to the surface, there will be friction, yet the water will be smooth; but if the motion of the wind be inclined, in howerer small a degree, a ripple will appear. The friction raises a minute ware, whose elevation protects the water beyond it from the wind, which consequently impinges on the surface at a small distance beyond; thus, each impulse combining with the other, produces an undula-

tion which continually adrances.

137. Those beautiful silvery streaks on the surface of a 
"Thou didst blow with thy wind, the sea covered them; they sank as lead in the mighty waters."-Exoves xv.

tranquil sea, called "cat's paws" by sailors, are orving to a partial deviation of the wind from a horizontal direction. The agitation at first extends a little below the surface; but in long continued gales, even deep water is troubled, the billows rise higher, and, as the surface of the sea is driven before the wind, curling waves, impelled beyond the perpendicular, fall in wreaths of foam.

138. Sometimes several waves overtake one another, and form a sublime and awful sea. The lighest waves known are those which occur during a north-west galc off the Cape of Good Hope, aptly ealled by the ancient Portuguese navigators, thc Cape of Storms. Cape Horn also seems to be the abode of tempests.

139. The sublimity of sea-storns, united to the threatencd danger, leads to an over-estimate of the magnitude of the waves, which appear. to rise "mountain-high," as they are said to do. There is, however, reason to believe that the highest waves off the Capc of Good Hope do not exceed the height of forty feet from the trough of the wavc to its erown.

140. Waves are short and abrupt in shallow scas, and arc regarded as more dangcrous than the long rolling billows of the wide ocean.*

141. The force of waves, when breaking against an obstacle, is enormous. Their pressure during violent storms has bcen cstimated as high as 6000lbs. per square foot. The waves breaking against the base of the Eddystone Light-housc have been known to dash above its top to $\mathbf{1 5 0}$ feet above the sca level, and deseend like a cataract on its summit. In the Barbadoes hurricane of 1780 , cannon which had been long sunk, were washed far up on shorc, and found high and dry on the subsidence of the storm.

\section{What are "Ground Swells?"}

This name has been given by mariner's to a peculiar and heavily rolling motion of the sea. It arises generally from undulations, transmitted along the upper stratum of 
"Deep calleth unto deep at the noise of Thy waterspouts; ail Thy waves and Tly billuws are gone over me."-l'sabs xlii.

waters that are the immediate seene of a prevailing storm, to firr distant waters, and which are continued, even in the seat of the storm, after the winds and wind-waves have subsided. In the South Pacific, billows which must have travelled 1000 miles against the trade-winds, expend their fury on the lee side of the many eoral islands of that sea.

143. These swells are heralds that point out to the mariner the distant region where the tempest has howled, and not unfrequently they foretell the approach of a storm. At the margin of the Polar ice, in addition to other dangers, there is generally a swell which would be rery formidable to the mariner in thick weather, did not the loud grinding noise of the ice warn him of his near approach thereto.

\section{1-1-1. What is the cause of Whirlpools?}

They are produced by opposing currents, and by contram? wints and tides. The whirlpool of Maclstrüm: on the coast of Norway, is occasioned by the meeting of tidal eurrents round the islands of Lofoden and Moskëe; it is a mile and a half in dianeter, and its rouring is heard at the distance of several miles.

145. Into the whinl of waters which here prevails, whales and large fishes have been drawn, and have been unable to extricate themselves, and boats and ships have been lost in the rortex of its waters. For six hours this whirlpool draws into its gulf everything that comes within its influence, and the next six hours easts up the fragments of the wrecks it has made.

146. What is the cause of Water-spouts?

They are created by whirlwinds, which are themselves 
"They came upon me as a wide breaking in of waters; in the desolation they rolled themselves upon me."-Jor xix.

produced by two violent currents of wind striking each other obliquely. Sometimes those water-spouts are as much as two hundred feet in diameter; but such large ones are very rare.

147. These spouts frequently oceur during the changing of the monsoons. At these seasons there are thunder-storms day and night. "The elourls are in eontinual movement, and the darkened air, laden with vapour, flies in all directions through the skies. The eombat which the elouds seem to eourt and to dread appears to make them more thirsty than ever. They resort to extraordinary means to refresh themselves: in tunnel form, when time and opportunity fail to allow them to queneh their thirst from the surrounding atmosphere in the usual manner, they deseend near the surface of the sea, and appear to lap the water direetly up with their blaek mouths. Water-spouts thus ereated are often seen, especially among small groups of islands, which appear to fieilitate their formation. Water-spouts are not always aceompanied by strong winds; frequently more than one are seen at a time, whereupon the elouds whenee they proceed disperse in various direetions, and, the ends of the water-spouts bending orer, finally eauses them to break in the middle, although the water, whie! is now seen foaming around their base, has suffered little ol no movement. The height of the spouts is usually somewhat less than 200 yards, and their diameter not more than twenty feet, yet they are often taller and thicker. They seldom last longer than five minutes. As they are going away the bulbous tube, which is as palpable as that of a thermometer, beeomes broader at the base, and little clouds, liko steam from the pipe of a loeomotive, are continually thrown off from the circumferenee of the spout; gradually the water is released, an't the eloud whenee the spout eane again eloses its mouth.*

\section{What are Coral Islands and Reefs?}

'They are produced by singular organisms which secrete from the sea water the stony matter with which they form their dwellings, in continuous rocliy masses, perforated according to regular patterus and known by the name of coral. In appearance the animals are like oblong

* Licut. Jansen. 
"So is this great and wide sea, wherein are things creeping innumerable, both small and great veasts." - P'sans cir.

bags of jelly, closed at one end, but having the other open, and surrounded by thread-like mouths or suckers

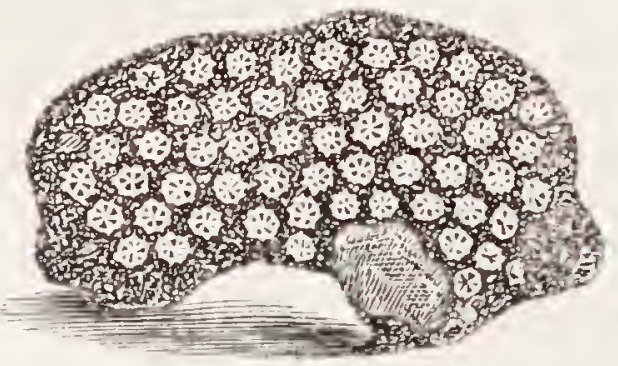
(tentacles), usually six or eight, bordering the central body, like the rays of a star.

140. As soon as a reef has reaehed sueh a height that it remains almost dry at low water, the eorals leave off building higher. Sea-shell, fragments of eoral, and the various washings of the sea, are united by the burning sun, eemented by the ealcareous sand, whieh aecumulates from the pulverisation of the shells, into one mass, which, strengthened by the eontinual throwing up of new materials, gradually inereases in thiekness, till at last it beeomes so ligh that it is eovered only during some seasons of the year by the spring tides.

1jo. The leat of the sun so penetrates the mass of stone when it is dry, that it splits in many places, and breaks off in flakes. These flakes are raised one upon another by the wares at the time of high water. The surf throws up large bloeks of eoral, and shells of marine animals, between and upon the foundation of the stones. After this the sand lies undistnibed, and offer's to the seeds of trees and plants east upon it by the wares a soil upon whieh they rapidly grow.

151. Trunks of trees, whieh are borne by rivers from other eountries, find here at length a resting-place after their long wanderings; with these eone some small animals, sueh as lizards and inseets, as the first inhabitants. Even before the trees form a wood, sea birds nestle there, and strayed land birds take refuge in the seanty shrubs.

15. Thus are new istands formed. Man finds his way to them, tempted cither by a love of diseovery, or driven upon their shores by tempestrous storms. The eoral formations are ehiefly eonfined to the Indian and Paeific Oeeans, between the parallels of $30^{\circ}$ north and south. The Arabian and Persian Gulfs, and the Red Sea, are full of them, and between the eoasts of Madagasear and Malabar the whole ocean may be considered as a great eoral sea. 
"Counsel in the heart of man is like deep water; but a man of understanding will draw it out."-Proveris $\mathrm{xx}$.

153. Why is it believed that many of the Atolls in the Inctian and Pacific Oceans have Submarine Toícanoes for their Foundations?

Because the coral-forming animals live and work only within very moderate limits of depth, not exceeding ninety fathoms. Their tendency is to found their habitations upon every summit rising from deep water, and to form, upon sunken rocks, circular basins or lagunes, called atolis. On the outside of each circle or atoll the reefs of coral extend to a distance of two or three miles, beyond which there are immense depths of water, which cannot be sounded.

154. How do Shell-forming Animals assist the Circulation of the Ocean?

The better to comprehend how such creatures may influence currents of the sea, let us suppose that every part of the ocean is perfectly at rest. In this state of things -the waters being in a state of perfect equilibrium-we will suppose that a single molluse or coralline commences his secretions, and abstracts from the water solid matter for his cell. In that act this animal has destroyed the pre-existing equilibrium, for the specific gravity of that portion of water from which this solid matter has been abstracted is altered.

155. Having lost a portion of its solid constituents, and become lighter than it was before, it gives place to the pressure which the heavier water exerts to push it aside, and to occupy its place, and it must, consequently, travel about and mingle with the waters of the other parts of the ocean until its proportion of solid matter is returned to it, and until it attains the exact degree of specific gravity due to sea water generally. 
"They shall not hurt nor lestroy in all my holy mountains; for the earth shall be full of the knowledge of the Lord, as the waters cover the sea."-IsalaII xi.

156. The sea breeze plays upon the surface; it eonverts only fresh water into vapour, and leaves the solid matter behind. The surface water becomes specifically heavier and sinks. On the other hand the molluseous animal at the bottom as he rorks upon his bi-valve shell, abstracts from the water there a portion of its solid contents; it therefore becomes specifieally lighter, and up it goes, ascending to the top with inereased velocity, to take the place of the descending column, which by the aetion of the winds has been sent down loaded with fresh food, and materials for the busy little mason in the depths below. These movements are also assisted by the respiration and movements of fishes, and the organic fumetions of marine plants.

157. We dive into the liquid erystal of the Indian Ocean, and it opens to us the most wondrous enchantments of the fairy tales of our childhood's dreams. The strangely-branching thickets bearing flowers; dense masses of Mecondrincs and Astreces contrast with the leafy eup-shaped expansions of the Explanarias, the rariouslyramified Madreprores, which are now spread out like fingers, now rise in trunk-like limbs, and now display the most elegant array of interlacing branelies. The colouring surpasses everything: virid green alternates with brown and yellow; rich tints of purple, from pale red to deepest blue. Brilliant rosy, yellow, or peach-coloured Nullipores over-grow the decaying masses, and are themselves interworen with the pearl-coloured plates of the Retipores, resembling the most delicate ivory earvings. Close by wave the yellow and lilac fans, perforated like trellis-work, of the Gorgonias. The elear sand of the bottom is covered with the thousand strange forms and tents of sea-urchins and star-fishes. The leaf-like Hustras and Escharas adhere like mosses and lichens to the branches of the corals; the yellow, green, and purple-striped Limpets eling like monstrous cochineal insects to their trunks. Like gigantic cactus blossoms sparkling in the most ardent colours, the Sea anemones expand their crowns of tentacles upon the broken rocks, or more modestly embellish the flat bottom, looking like beds of rariegated ranunculuses. Around the blossoms of the coral shrubs play the humming-birds of the ocean, little fish sparkling with red or blue metallic glitter, or gleaming in golden green, or in the brightest silvery lustre.* 
"The clonds poured out water: the skies sent out a sound: thine arrows also went abroad."-Psacar lxxvii.

\section{THE ATMOSPERE.}

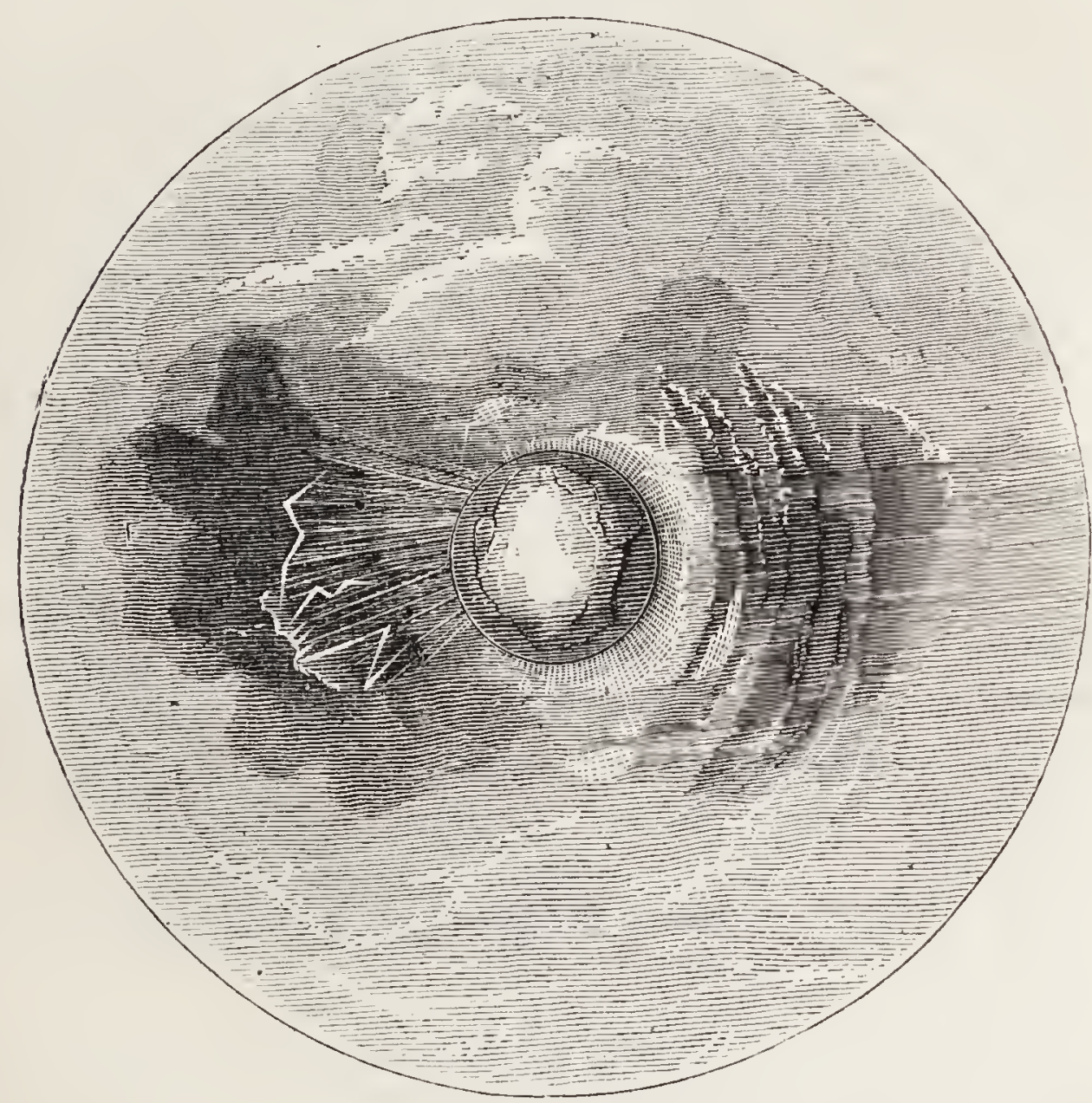

Imaginary view of the Earth, surrounded by Atmospherc, and Clouds of the rarious formations. But the Earth is here reduced to a very small size, to give better effect to the surrounding Atmosphere.

158. What is meant by the "Circulation of the Atmosphere?"

It is this-that in the atmosphere which surrounds and enrelopes the earth, as in the ocean which lies upon its 

PSALM Cvii.

"He maketh the storm a calm, so that the wares thereof are still."-

surface, there are regular currents, fulfilling an appointed plan of circulation.

159. From the parallel of about $30^{\circ}$ north and south, nearly to the equator, there extend entirely around the eartl two zones of perpetual winds, viz., the zones of tle north-east and the south-east trades. With slight interruptions they blow perpetually, and are steady and constant, always moving in the same direction, except when they are turned aside by a desert here and there, to blow as monsoons, or as land and sea breezes. As these two main currents of air are constantly moving from the Poles towards the Equator, we are safe in assuming that the air which they keep in motion must return by some channel to the place toward the Poles, whence it comes in order to supply the trades. If this were not so, these winds would soon exhaust the Polar regions of atmospliere and then cease to blow.

160. Why is it believed that the Return Currents pass through the Upper Regions of the Atmosphere?

Because the trade winds are continually blowing on the surface. The return current must necessarily move in a direction opposite to that wind the place of which it is intended to supply; and it is naturally concluded that the return takes place through the upper regions.

161. Why is it supposed that there is a Crossing of the Winds at the Calm-belts?

Because of the uniformity of the constituents of the atmosphere in all parts of the world; and because, also, of the great amount of rain which is thrown down upon the lands of the north, which it seems clearly proved must, to a great extent, be derived from the seas of the south.

162. Lieutenant Maury contends for an actual circulation of the winds from the Arctic to the Antarctic Circles-tinat the same wind which at one time sets out from the Polar 
"Terrors are turned upon me: they pursue my soul as the wind: and $m y$ wifare passeth away as a cloud." -Jon $\mathrm{xxx}$.

regions of the north, at some time or other reaches the Polar rejions of the south.

163. That such a grand operation is within the scheme of the Creative Power there can be no question; but an equally great conception, with a more probable reality; is to be derived from regarding the great calm-belts as grand troughs into which the atmospheric streams from north and south are poured and intermixed. Or as three great hostelries, where the vapour and electric carriers of the air, meet, rest, and exchange their burdens, thus equalizing the atmospheric constituents, and keeping up a circulation through exchange and intermixture.

164. What causes the Trade Winds?

The heat of the torrid zone, by rarefying the air over that region, causes it to rise, when the colder air of the temperate zones rushes towards the Equator to supply its place; but as the colder currents of air come from regions where the rotatory motion of the earth's surface is much slower than it is at the Equator, and as they do not at once acquire the greater velocity peculiar to the Equatorial region, their direction is relatively modified, and they become north-east and south-east winds.

165. The earth, we know, moves on its axis from west to east. Now, if we imagine a particle of atmosphere at the North Polc, where it was once at rest, to be put in motion in a straiglit line towards the Equator, we can imagine that this particle of air, coming from the very axis of diurnal rotation, where it did not partake of the diurnal motion of the earth, would, in consequence of its vis inertice, find, as it travels south, the earth slipping under it, as it were, and thus it would appear to be coming from the north-east, and going toward the south-west; in other words, it would be a north-east wind.

166. On the other hand, we can perceive how a like particle of 
"Thy mercy, O Lorl, is in the hearens, and thy faithfulness reacheth unto the clouds."-Psucir xxiri.

atmosphere, that starts from the Equator to take the place of the other at the Pole, would, as it travels north, be going toward the east faster than the earth. It would, therefore, appear to be blowing from the south-west, and going toward the north-east, and exatly in the opposite direction to the other.

167. Why is the Boundary of the Trade Winds acout three or four clegrees to the North of the Equator?

Because, owing to the greater proportion of land in the northern hemisphere, it is warmer than the southern, and hence the limit or boundary between the two winds, proeceding from the nortl and south, is situated to the north of the equator.

168. Why are the Trade Winds accompanied by peculiar Clouds?

Because the rapour of the upper current of air becomes condensed, and again evaporates as it descends into the lower and dry current from the Poles, - the eonstancy and rapidity of this action, giving a peculiar appearance to the vapour.

169. What is the cause of "Monsoons?"

Monsoons are a modification of the trade winds, occasioned by the interposition of the Asiatic eontiment to the north, the rarefied atmosphere of Africa on the west, the partial openings among the islands which separate the Indian Ocean from the Pacific, and the position of the sun in the different seasons. The south-west monsoon is violent and accompanied by rain; the nortl-east is gentle and dry.

170. The monsoons blow for about fire months from the north-east and north-west, and five months from the southeast and south-west. 'The ehange from one period to the other is marked by violent stoms and hurricanes. 
"Bchold, a whirlwind of the Lord is gone forth in fury, even a grievons whirlwind; it shall fall grievously upon the leat of the wicked."-JERsisin xxiii.

171. When, at stated periods of the year, a trade wind is deflected, or turned aside from its regular course, being drawn in by over-heated distriets, or otherwise, it is regarded as a monsoon. 'Thus, the African monsoons of the Gulf of Mexieo, and the Central Ameriean monsoons of the Paeific, are, for the most part formed of the trade winds, which are turned back to restore the equilibrium which the over-lieated plains of Africa, Utah, Texas, and New Mexicu have disturbed. The influence of these heated plains upon the winds is felt at sea for a thousand miles or more. The deserts of Arabia affect the winds of Europe.

172. Why clo Thunderstorms Accompany the Changing of the Monsoons?

Because in every great atmospheric change the cquilibrium of electricity is disturbed.* 'This wonderful and mysterious agent, driven out of its natural chamnels, in which it has been performing silently and unobserved the mysterious task appointed to it, now displays itself with the most dazzling majesty.

173. What causes Whirlwinds, Tornadoes, Typhoons, s.c.?

'They arise from the meeting of powerful and opposing currents of air, producing a circular motion. Whirlwinds cause waterspouts, and tornadoes or typloons give rise to circular storms of greater breadth than whirlwinds. They occur principally in the regions of the Antilles, or the West Indies, in the Indian Ocean, between Australia and Africa, and in the Pacific, along the coasts of China and Siam.

174. What is the cause of the "Pegions of Calms?"

On approaching the Equator the winds become gradually heated, and acquire an ascending direction, so that their horizontal movement is no longer felt. The upward cur- 
"IIc found him in a desert land, and in the wnste howling wilderness; he led him about, he instrueted him, he kept him as the apple of his eye."-Detr. xxxii.

rent of air occurs for a space of about $6^{\circ}$ wide, and this is called the "region of calms."

175. But there are other calm regions besides that of the Equator. A calm region prevails at each of the Poles; the air, setting off from the Polar regions (for some reason which does not appear to have been very satisfactorily explained), instead of travelling on the surface all the way, travels in the upper regions until it gets near the parallel of $30^{\circ}$. Here it meets, also in the lofty regions, atmosphere that is coming from the Equator and going north. These two bodies of air, pressing together with the whole amount of their motive power, produce a calm. From this latitude of calms (called the Calms of Cancer) two surface currents of wind are ejected, one towards the Equator, or the north-eust trades, the other towards the Pole, or the south-uest passage winds.

176. At the Equatorial place of meeting there is another conflict of winds, and another calm region (called the Equatorial Calms). Here, warmed by the heat of the sun, and presser on each side by the force of the north-east and soutli-east trades, the air ascends, a portion of it returning towards the Calms of C(uncer, while another portion moves towards the South Pole, in a line counter to the south-east trades, until it meets near the parallel $30^{\circ}$ south, the atmosphere moving from the South Pole; and here again results a state of calm (called the Catme of Capricorn).

177. What is the difierence between the Atmospheric action in the Equatorial Calm-belt and the Calms of Cancer and Capricorn?

In the Equatorial region, the air which is brought to the calm-belt by the north-east and south-east trades ascends; the two currents flow in at the bottom, and occasion two currents to flow out at the top. But in the currents of Cancer and Capricorn the currents flow in at the top and out at the bottom.

178. What effect have Deserts upon the Circulation of the Winds?

By becoming heated centres, and giving a high degree 
"The wind gocth towards the south, and turneth about unto the north; it whirleth about continualy, and the wind returnetl again according to his circuits."ECCLESLASTES i.

of rarefaction to large volumes of atmosphere, they cause the air to rush towards them, deflect the trade winds, and

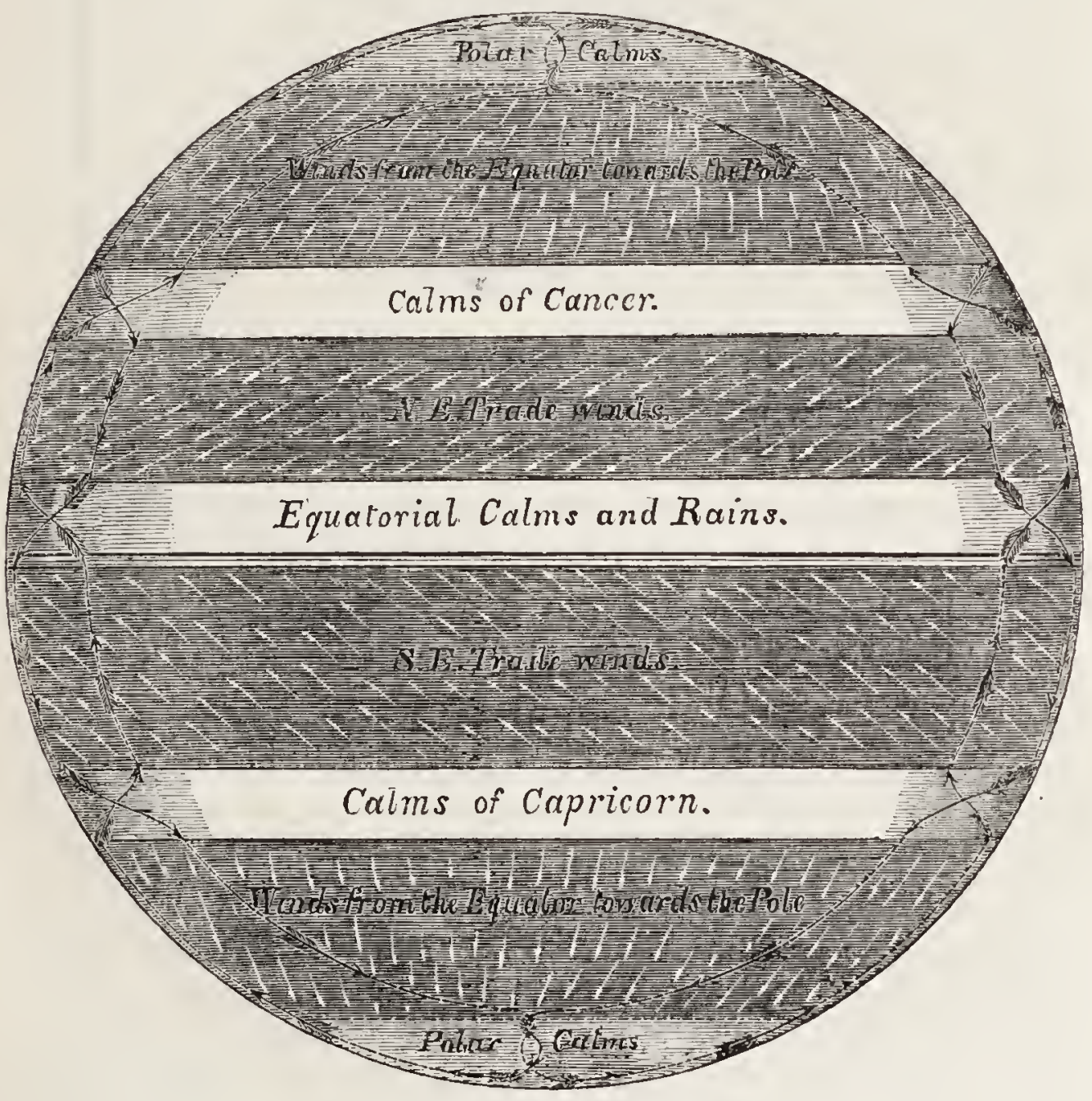

Diagram of the Circulation of the Atmosphere. indicating the Five Calm licgions, and the direction of the Surface Currents. The arrows across the Calm liegions are designed to illustrate the Crossing or singling of Currents throughout those Ielts.

give rise to monsoons. 'The Desert of Cobi, and the arid wastcs of Asia, cause the south-west monsoons of the Indian Ocean.

179. When the sun is north of the Equator, the force of his rays upon these wide and thirsty plains is such as to cause the vast superincumbent body of air to expand and ascend. Consequently, there is an 
"O come, Iet us sins unto the Lord, let us make a joyful noise to tlie rock of our salvatius."-I'salis der.

indratight of air from the surrolinding regions to supply the ascending columns. The air that is going to feed the north-east trades is thus arrested, drawn in, heated, and caused to ascend; and thus the northeast trade winds are first weakened, then "lilled," and afterwards drawi into the rortex of ascending air over the burning sands of the deserts. On the other hand, the sonth-east trade winds are drawn over into the northern hemisphere. Going now from the Equator towards the Poles, their tendency is to obey the forces of diumal rotation, as well as the indraught for the heated plains; and thus the south-cast trades become eouth-west monsoons.

\section{What is the cause of Land and Sea Breczes?}

'They arise from difference in the density of the air over the land, by the alternate presence and absence of the sun. Generally, the biecze from the sea begins to be felt a few hours after the sun has risen; and, afier sunset the air of the land, condensed by the diminution of temperature, rushes towards the sea.

181. When a fire is first kindled on a liearth, we may, if we observe the priticles of dust floating in the rom, see that those nearest the chimiey are the first to feel the dranght and to obey it - they are drawn into the blaze. The circle of in-flowing air is gradually enlarged, until it is scarcely perceived in the remote parts of the room. Tor, the innd is the hearth, the rays of the sun the fire, and the sea, with its cool and calm air, the room, and the air moring towards the fire is the sea-breeze. When the sun goes down the fire ceases; then the land begins to cool, until it falls below the temperature of the air over the sea. The atmosphere on the land thus becomes hearier than that on the sea, and consequently there is a brisk seawind, winch is called the Land-brecze.

182. Why do Land and Sea Breezes merail more in some parts than in others?

Because it is casier to obstruct and turn back the current in a sluggish than in a rapid stream. So, also, in turning a current of air first upon the land, and then upon the sea. Very slight alterations of temperature would 
"The north wirul driveth away rain; so dotl an angry countenance a backbiting tongue."-PlioverBs $\mathrm{xxy}$.

suffice for this on the west coast of Africa, in and about the Equatorial calms; there the air is in a state of rest, and will obey the slightest call in any direction-not so in regions where the trade winds blow over the land, and are strong.

183. What other sources of IIcat and Cold are there which promote movements in the Air and Ocean?

Wherever the condensation of vapour into water, or the congelation of water into ice, takes place, latent heat ${ }^{*}$ is set free. Thus, the heat which is liberated by the condensation of vapour in the regions of calm, and that which is set fres: by the production of ice in the Arctic and Antrietic Sers, exerts a force upon the winds that proceed from thosi regions.

184. And when rains or frosts are local, winds which affect the adjacent districts are produced. Every rain-drop that falls evolves heat enough, in the process of its condensation, to raise by one degree the temperature of one thousand and thirty rain-drops.

\section{What gives Charactor to the various Wincls?}

They generally derive their characteristics from the surfaces over which they blow. Winds blowing across snow-crowned mountains, like the Alps, are cold, while those blowing over dry and arid plains are hot and dry. In England a south-west or west wind, which has crossed the Atlantic Ocean from warmer regions, is generally mild, with frequent rains; while an easterly wind, which has crossed the continent of Europe, is dry; and if from the north-east is cold and piercing, from coming over the frozen regions of Lapland and Northern Russia. 
"Ile watereth the hills from Iis chambers; the earth is satisfied with the fruit of Thy works."-Psalar cir.

186. Why do Gusty Winds usually accompany IIail-storms?

Because congelation takes place so immediately after condensation that the degree of heat evolved is greater and more suddenly produced than by a slower process. The change is at once from vapour to frost, causing the whole measure of latent heat of rapour and water to be suddenly thrown out. The surrounding air therefore has its temperature suddenly raised, and winds arise, not in steady currents, but in unequal gusts.

187. How are the "Rainy Seasons" caused.

The calm and trade-wind regions or belts move across the earth annually in latitude nearly a thousand miles. In July and August the zone of Equatorial calms is found betreen $7^{\circ}$ and $12^{\circ}$ north, sometimes higher; in March and April, between latitude $5^{\circ}$ south and $2^{\circ}$ north.

188. It is thus easy to perecive why it is that there prevail a rainy season in Oregon, a rainy and a dry season in California, another at Panama, \&c.

189. Why do Heavy Rains prevail in the Equatorial Calm Regions?

Because, where the north-east and south-east trades meet, they are heavily laden with moisture from having travelled over a large space of the ocean. Here the winds ascend and become cooler, and the vapours which they contain, becoming condensed, are precipitated as rain.

190. What is the mrincipal Region of Evaporation?

Evaporation occurs on every part of the earth's surface where water in large or small bodies may be found ; and such is the force of this all important law of nature that even snow and blocks of ice will eraporate without melting, 
"Behold He withholdeth the waters, and they dry up; also He sendeth them out, and they overturn the earth."-Jos xii.

and disappear. But the chief amount of atmospheric vapour is taken up at the torrid zone.

191. To evaporate water enough annually to cover the earth on an average five feet deep with rain; to transport this moisture from one zone to another, and to precipitate it in the right places, at suitable times, and in the proportions due, is one of the offices of the grand atmospherical machine. Supposing all the rain-vapour were derived from the torrid zone, we should have, encircling the earth, a belt of ocean three miles in breadth, from which the superincumbent atmosphere evaporates a layer of water annually sixteen feet in depth. And to hoist up as high as the elouds, and to lower down again, all the water in a lake sixteen feet deep, three thousand miles broad, and twentyfour thousand long, is the work of invisible machinery!

192. Whence comes the Vapour that feeds the Rivers of the Northern Hemisphere?

In the northern hemisphere the land and water are nearly equally divided. In the southern there is several times more water than land. All the great rivers of the world are in the northern hemisphere, where there is less ocean to supply them, yet the total amount of rain which falls in the northern hemisphere is much greater than that which falls in the southern.

193. Late in the autumn of the north, throughout its winter, and in early spring, the sun is pouring his rays with the greatest intensity down upon the seas of the southern hemisphere, and this powerful engine raises waters there for our river's with the greatest activity.

194. The heat which this heavy evaporation absorbs becomes latent, and, with the moisture, is carried through the upper regions of the atmosphere until it reaches our climates. Here the vapour is formed into clouds, condensed, and precipitated. The heat which held this water in the state of vapour is set free; it becomes sensible heat, and it is that which contributes so much to temper our winter climate. It clouds in winter, turns warm, and we say we are going to have falling 
"The fountains also of the deep and the windows of heaven were stopped, and the rain from heaven was restrained."-Genesis viii.

weather. That is because the process of eondensation has already commenced, though no rain or snow may have fallen: thus we feel this southern heat, that has becn collected from the rays of the sun by the sea, been bottled away by the winds in the elouds of a southern summcr, and set frec in the process of condensation in ollr northern winter.

\section{Why are there "Rainless Regions?"}

Because heated columns of air, everywhere ascending, dissolve vapours, and disperse every approaching cloud. Because, also, in some countries mountain ranges condense the clouds, and deprive them of their moisture, before they reach the arid districts.*

196. The coast of Peru is within the region of perpetual south-east trade winds. Though the Peruvian shores are on the verge of the great South Sea bordcr, yet it never rains there. The reason is, that thcse winds in the Atlantic Ocern first strike the water on the eoast of Africa. Travelling to the north-west, thcy blow obliquely across the ocean until they reach the coast of Brazil. By this time they are heavily laden with vapour, which they eontinue to bear along aeross the continent, depositing it as they go, and supplying with it the sources of the Rio de la Plata, and the southern tributaries of the Amazon. Finally, they reach the snow-eapped Andes, and here is wrung from them the last particle of moisturc which the very low temperature can extract. Reaehing the summit of that range, they now tumble down as cool and dry winds on the Paeific slopes beyond. They reach the ocean before they again become cliarged with fresh vapour, and bcfore, therefore, thcy have any which the Fcruvian climate can extraet.

197. The other rainless, or almost rainless regions, are the western consts of Mexico, the deserts of Africa, Asia, Nortli America, and Australia. A rainless region prevails about the Red Sea, because it for the most part lies within the nortli-east trade-wind region, and these winds, when they reacl that region, arc dry winds, for they have as yet, in their course, crossed no widc slieets of water from which they could take up a supply of vapour.

* Humboldt. 
"They are wet with the showers of the mountains, and embrace tile rock for want of shelter."-Jols xxiv.

198. What are the visible effects of Suffuient or Deficient Evaporation and Rain?

In the sheets of water, which are distributed orer erery inhabitable inland basin, we see reservoirs and evaporating surfaces sufficient for the supply of that degree of moisture which is best adapted to the well-being of the plants and animals that people such basins.

199. In other parts of the earth we find places, as the Desert of Sahara, in which neither evaporation nor precipitation takes place, and in which is to be found neither man nor animal.

200. And in others, where the humidity would otherwise be in excess, it is drained off by magnificent river cisterns, which vary and beantify the landscape, allowing as much moisture to remain as is suitable to the wants of the animals and plants that occupy the area of country drained by the river basin.

\section{Why are Mountains Beneficial to countries?}

They intercept the clouds, and canse then to clistit and pour down refieshing showers; they detain snow and ice until the approach of warmth, and therefore, they form the reservoirs of the chief rivers in the world. They protect many valleys fiom cold and tempestuous winds, and form natural boundaries and fortifications to nations.

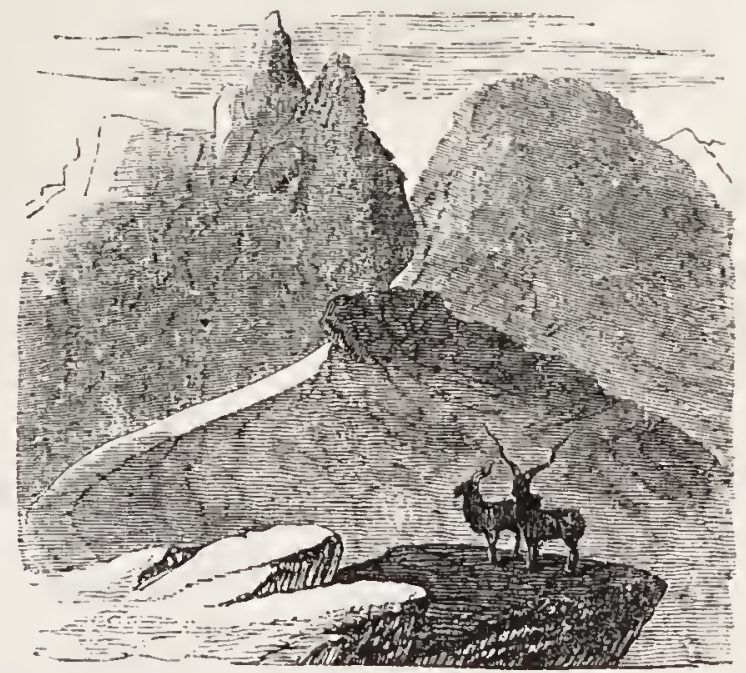


"The mountains saw Thee, and they trembled; the overflowing of the water passed by ; the deep uttered his voiee, and lifted up his hands on high."-IIAB.LKLI ii.

202. But the little hills, the gentle slopes, the smiling ralleys so beautifully noticed in the Psalms, and which abound in our own country, may be said to ornament the landscape; they give a character and an interest to every scene; and from their gushing sides issue many a little rill and sparkling fountain which the plains very seldom supply. And it is owing to this constant inequality of the surface, tilting often insensibly this way or that, that we are enabled to get our lands aud dwellings drained and purified. Without this arrangement, every shower would incommode us, and we should have stagnant water ererywere.

203. The Inftiest mountains in the world arc very inconsiderable compared to the size of the globe-scarcely observable indeed. Fet, if it were possible to transport the highest of the Himalaya Mountains hither, we should tremble lest it might depress our island below the level of the occan. The summit of such a mountain, standing in the middle of our island, would be visible from sea to sea. The loftiest mountains are no more than the roughnesacs on the coat of an orange, compared to the size of the globe.*

201. Why has every considerable Mountain a Dry and a Rainy Side?

All considerable mountains which lie athwart the course of winds lare a dry and a rainy side, according to the latitudes from which the winds blow. But in some instances each side of a mountain is made alternately the wet and the dry side, by changes in the prevailing direction of the wind.

\section{What effects have Islands upon Winds?}

Islands which stand away from any large extent of land have a rery singular but marked effect upon the wind. They frequently interfere with the trade winds, and turn them back, or draw off broad streams of air from them. This arises from the difference in the temperature between the surfaces of the land and the sea. 
"When He established the clouds above: when He strengthened the fountains of the deep."-Proveris, viii.

206. Why do Clouds serve to Indicate the Position of Islands?

Bccause the hills attract and condense clouds, and thus, long before the islands themselves become visible, navigators in the Pacific are made aware of their proximity to islands, and may take their bearings by the compass, precisely as those of a high mountain or a soliatry peak.

207. Erery navigator who has cruised in those parts of

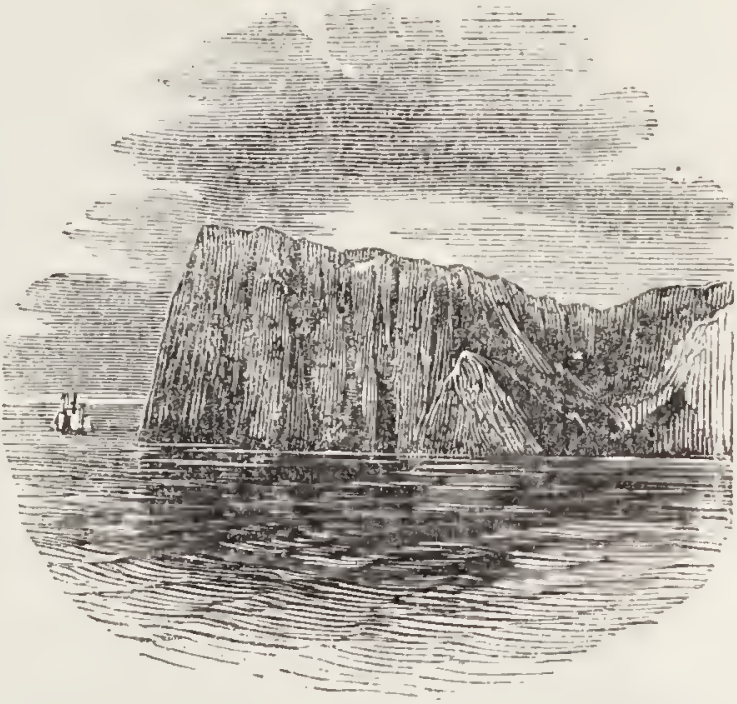
the ocean has often turned with wonder and delight to admire the gorgeous piles of cumulous clouds, * heaped in the most delicate and exquisitely beautiful masses that it is possible for fieecy matter to assume Not only are these piles found capping the hills among the islands, but they are often seen to overhang the lowest islet of the tropies, and even to stand above coral patches and hidden reefs, "a cloud by day" to serve as a beacon to the lonely mariner out at sea, and to warn him of shoals and dangers which no lead nor seaman's cye has ever seen or sounded.

208. Why do the Clouds which gather over Newly-formed Islands tend to render them Inhabitable?

Because, by screening the new carth from the too powerful action of the sun, and by frequent showers of fresh water, they prepare these new centres of life for regetation and animal existences.

209. Clouds may be likened to a sponge of the most exquisite and delicate texture, which at intervals becomes saturated with moisture, and the cooler temperature of elevated currents to the 
"With clouds He covereth the light; and commandeth it not to shine by the cloud that cometh betwixt."-Joв xxxvi.

hand that squeezes the sponge, causing the clouds to "drop their fatness."

210. Why are Mists frequently met with over Shoals?

From the influence of the couled water in condensing the vapour of the atmosphere. Iumboldt observed such mists to the south of Jamaica and in the Pacific, showing the outline of the shoals beneath them so well defined as to be distinctly recognised from a distance; thus forming to the eye aërial images reflecting the form of the bottom of the ocean.

211. Why are "Red Fogs" frequently encountered at sea, especially in the vicinity of the Cape de Verd Islands?

'These "fogs" are, in fact, dust showers. What they precipitate in the Mediterranean is called "sirocco dust," and in other parts "African dust," because the winds which accompany them were supposed to come from the Sirocco Desert, or some other parched land of the continent of Africa.

212. But the dust, upon being subjected to microscopic examination, las been found to consist of infusoria, and organisms found not in Africa, but in South America, and in the South-cast trade-wind region. It is of a brick-red or cimmamon colour, and sometimes comes down in such quantities as to corer the sails and rigging, though the vessel may be hundreds of miles from the land.

213. Professor Elnenberg has examined specimens of "sea dust" from the Cape de Verds, and the regions thereabouts, from Maita, Genon, Lyous, and the Tyrol; and he has found a similarity among them as striking as it would have been had these specimens been all taken from the same pile. South American forms are the prevailing ones in every specimen he has cxamined. It may from these facts be regarded as established, that there is a perpetual upper current of air 
"For" He saith to the snow, Be thou on the earth; likewise to the small rain, and to the great rain of His strength.-JoB xxxvii.

from South America to North Africa. In the present state of our information we cannot tell why this "rain-dust" should not be gradually precipitated from this upper current, and descend into the stratum of trade-winds, as it passes from the Equator to higher norther'n latitudes; neither can we tell why the vapour which the same winds carry along should not in like manner be precipitated on the way. But we establish a most material point-that the currents in the xpper regions of the atmosphere are remarkable for their force, extent, and regularity.

\section{What is meant by the "Snow-line?"}

The height at which snow lies is the snow-line of any latitude. Temperature varies not only with the latitudes of places, but more or less with their elevation above the surface of the sea. Thus, an elevation of thirty fathoms causes the same variation as a removal of one degree from the Equator towards the Poles. In the ascent from the plain we experience the influence of every

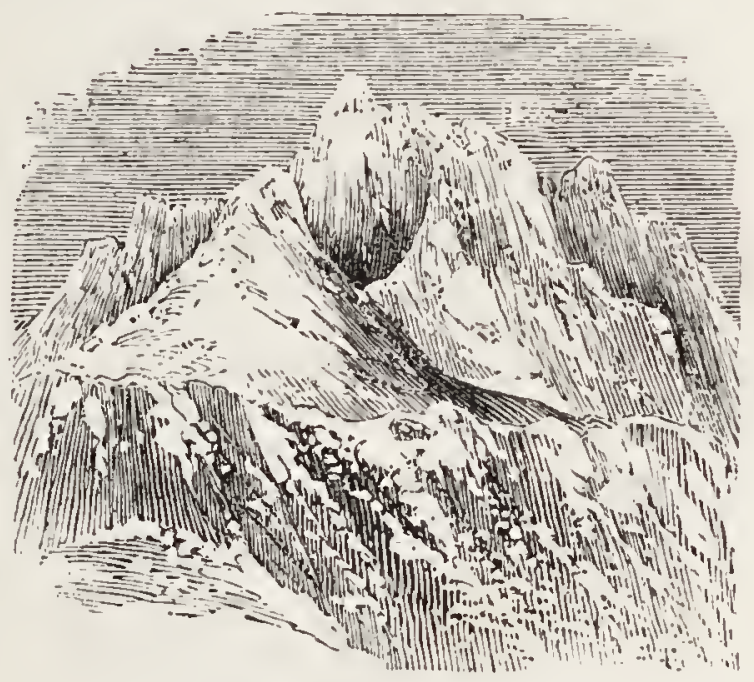
variety of climaie aud pass through every degree of vegetation, that would, occur in our progress towards either Pole.

215. Why is the Snow-line Highest at twenty degrees from the Equator?

Because at the Equator the sun is never more than twelve hours above the horizon; whereas near the tropics the longest days are thirteen hours and a half in duration, and the summer heat is greater than at the Equator. 
"As snow in summer, and as rain in harvest, so honour is not seemly for a fool." -Provenhs xxvi.

216 TABLE OF THE "SNOW-LINE."

Latitude. Mountain Elevation.

$\begin{array}{rrrrrrrrrr}0^{\circ} & \ldots & \ldots & \ldots & \ldots & \ldots & \ldots & \ldots & 16,000 & \text { feet } \\ 10 & \ldots & \ldots & \ldots & \ldots & \ldots & \ldots & \ldots & 16,500 & , \\ 20 & \ldots & \ldots & \ldots & \ldots & \ldots & \ldots & \ldots & 17,000 & , \\ 30 & \ldots & \ldots & \ldots & \ldots & \ldots & \ldots & \ldots & 14,000 & , \\ 40 & \ldots & \ldots & \ldots & \ldots & \ldots & \ldots & \ldots & 10,000 & , \\ 50 & \ldots & \ldots & \ldots & \ldots & \ldots & \ldots & \ldots & 6,000 & , \\ 60 & \ldots & \ldots & \ldots & \ldots & \ldots & \ldots & \ldots & 5,000 & , \\ 70 & \ldots & \ldots & \ldots & \ldots & \ldots & \ldots & \ldots & 1,000 & , \\ 80 & \ldots & \ldots & \ldots & \ldots & \ldots & \ldots & \ldots & 0 & ,\end{array}$

297. We know only the lower and not the upper limit of perpetual snow, for the highest mountains of the earth are far from attaining to those strata of highly rarefied and excessively dry air, concerning which we may suppose that they no longer contain vapour capable of being converted into crystals of snow, and of thus becoming risible. The phenomenon of the snow-line is a very complicated one, depending generally on relations of temperature and moisture, and on the peculiar shape of the mountains, the direction of the prevailing winds, and whether they have blown over sea or land, \&c.

218. Why does an Elevated Table Land, adjacent to a Mountain, Raise the Snow-line?

Because the table land receires heat from the sum, and: radiates it into the atmosphere. The mountain participates in this increase of temperature at a considerable eleration, and hence the snow-line of the mountain is raised.

219. An effect very similar to this may be observed in our dwellings. If the windows of our apartments are situated near to the ground, we may, in sunny weather, perceire that the temperature of our rooms is increased by the reflection of the sun's rays from the ground, especially if they fall on a stone parement. If we ascend 
"Upon a lofty and high mountain hast thou set Thy bed: even thither wentest thou up to offer sacriflce."-Isaran lvii.

into our upper apartments, we shall find the reflection from the stone pavement-partly owing to the greater distance, and partly to the different angle or direction from the ground to the upper windowwill be far less intense, and will communicate little or no heat to the upper rooms. Should, however, a balcony extend in front of the upper windows, this will form no bad representation of a table land adjoining a mountain, and will, by reflecting the sun's rays directly into the rooms, elevate their temperature.*

220. Why do the Himalaya Mountains exhibit Diversities of Temperature on their Opposite Sides?

Because they are affected on one side by an elevated table land. On the southern side of this great mountain range, in latitude $30^{\circ}$, the snow-line commences at the elevation of about 12,500 or 13,000 feet above the level of the sea; whilst on the northern side, where from the aspect a greater degree of cold might be anticipated, the snow-line in some parts attains the extreme height of nearly 20,000 feet above the sea.

221. This is because the northern declivity of the mountain mass terminates in the rast and elevated plains of Thibet, the surface of which is about 15,000 feet above the lerel of the sea; whilst on the southern side the mountains rise directly to a great elevation, from a flat country, scarcely 1000 feet above the sea.

222. In considering the general laws which govern the physical agents of the universe, and regulate them in the due performance of their offices, we are everywhere met with evidences of the completeness of the system of natural adaptation. If the earth, air, and water had not been in exact counterpoise, the whole arrangement of the animal and vegetable kingdoms must havo varied from their present state.

- Zornlin's "Recreations in Physical Geography." 
"And of Joseph he said, hiessed of the Lord be his land, for the preciour things of heaven, for the dew, and for the deep that coucheth beneath."DEUTERONOMY XXXiii.

223. God, for reasons which man may never comprehend, chose to make those kingdoms what they are; for this purpose it was necessary, in his judgment, to cstablish proportions between the land and water, and the descent, just as they are, and to make the capacity of the air to circulate heat and moisture just what it is, and make it do all its work in obedience to law, and in subservience to order.

224. If this were not so, why was power given to the winds to lift $11 p$ and transport moisture, and to feed the plants with nourishment? or why was the property giren to the sea, by which its waters may become first rapour, and then fruitful showers or gentle dews?

225. Or why was it ordained that, in taking up vapour from tho sca, the atmosphere should leave every particle of salt and other solid matter belind, and transport orcr the land a purely fresh fluid to liquefy the juices of plants and animals, and cleanse and invigorate the whole face of nature? Imagine that only for a short season this single law should be suspended. In a few weeks every regetablo would become covered with crystals of salts, their pores would be stopped up, their juices would be absorbed, and nothing but their dried woody fibres would remain, and these be covered with crystals, just as we see the face of nature on the morning of a hoar frost. Man and animals of all kinds would die, and the whole face of nature bear the aspect of petrifaction!

226. If the proportions and propertics of land, sea, air, and vaponr were not adjusted according to the reciprocal capacities of all to perform the functions required by each, why should we be told that the Almighty "measured the watcrs in the hollow of his hand, and comprchended the dust. in a measure, and weighed the mountains in scales, and the hills in a balance?" Why did he "span the licavens," but that he might mete out the atmosphere in exact proportion to all the rest, and impart to it those properties and powers which was necessary for it to liave, in order that it might perforre all those offices for which $\mathrm{He}$ had designed it?*

- Lieut. Maury. 
"The mountains shall bring peace to the people, and the little hilis, by righteousness."-PsaLsI lxxii.

\section{G E O L G Y.}

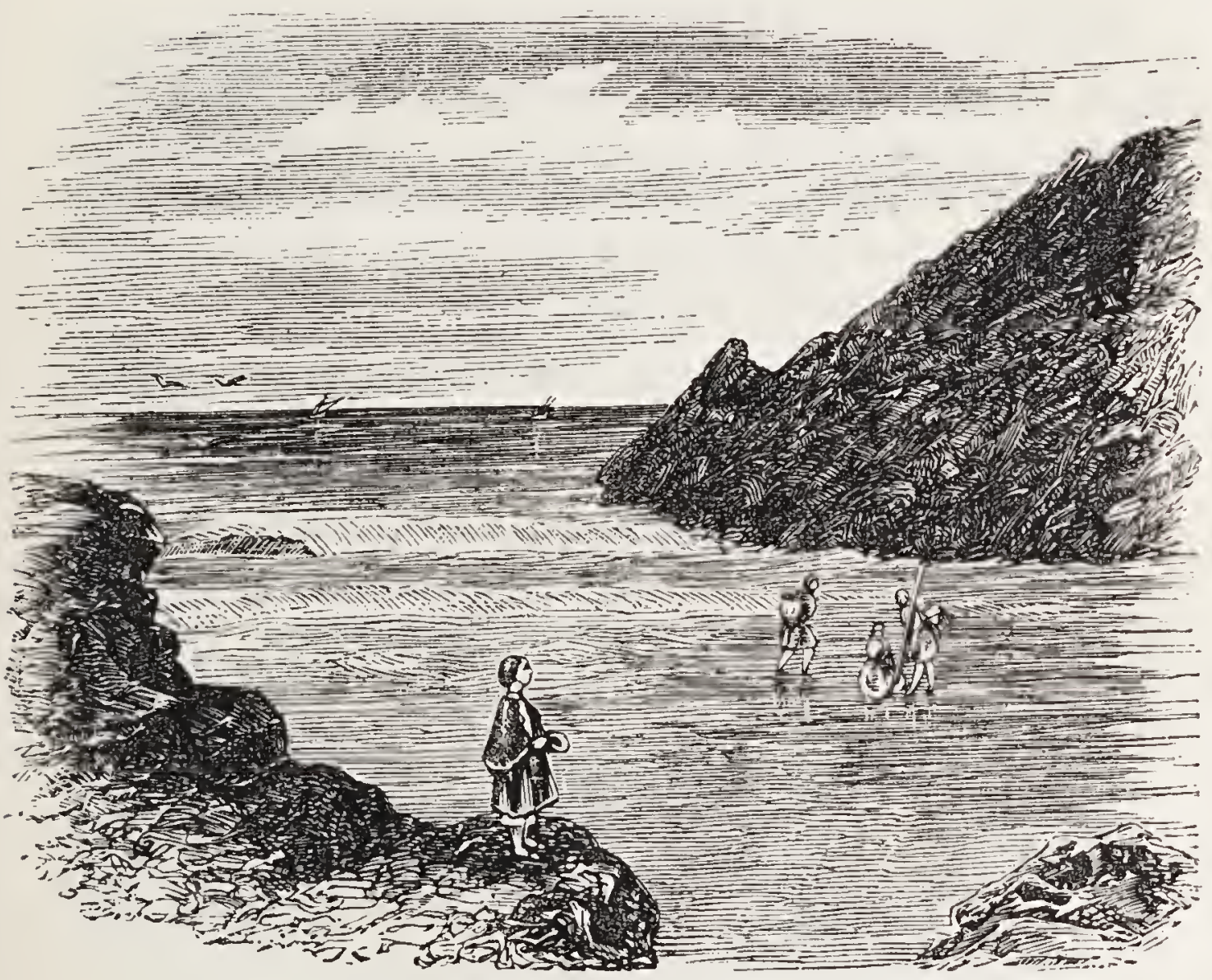

227. Of what do the Various Substances composing the Earth consist?

Speaking in a geological sense, all the substances of which we have any knowledge are divided into four classes, distinguished by the manner in which they have been formed:-

228. Plutonic and volcanic rocks, both of fiery origin, though produced under different circumstances. 
"He only is my rock and my salvation; he is my defence; I shall not be moved."-Psalur Ixii.

229. Aqueous or stratified rocks, entirely due to the action of water; and

230. Metamorphic rocks, deposited by water, and consequently stratified, but subsequently aitered and crystallized by heat.

231. All mineral substances are termed rocks, whether they are soft or stony. The reason for this is, that often there is so insensible a passage from a soft and incoherent state to that of stone, that it has been found necessary to include all the component strata of the earth under one ter'm, however much they may differ.

232. The aqueous and volcanic rocks were and still are formed at or near the earth's surface; the Plutonic and metamorphic at great depths; but all of them have been formed simultaneously through every geological period, and are now in a state of slow and constant progress. The antagonist principles of fire and water liare ever been and continue to be the cause of the perpetual changes to which the earth's crust is liable.

233. Why are Plutonic rocks so called?

The name (derived from Pluto, the fabled god of the fiery regions) implies that the rocks of this class were formed by the action of fire, at great depths in the earth.

234. It has been ascertained by observation that the Plutonic rocks, consisting of the granites, and some of the porphyries, were formed, in the deep and fiery caverns of the earth, of melted matter, which crystallized as it slowly cooled under enormous pressure, and was then upheaved in unstratified masses, by the elastic force of the internal heat, even to tops of the highest mountains, or forced in a semi-fluid state into fissures of the superincumbent strata, sometimes 
"Ie putteth forth his hand upon the rock; He overturneth the mountains by the roots."-JoB Xxviii.

into the cracks of the previously-formed granite; that rock, which constitutes the base of so large a portion of the earth's crust, has not been all formed at once; some portions had been solid, while others were yet in a limpid state.*

235. Many conjectures have been formed, and many theories propounded, as to the nature and condition of the internal parts of our globe. Some have supposed that there is an outer solid film or crust, ten or twenty miles thick, enveloping a vast ball of intensely heated matter. Others have attempted to show that the interior must be nearly solid throughout, with, however, great lakes, or vesicles of gas and melted rock, somewhat after the fashion, we may suppose, of the oil-holes in a Gruyère cheese. But whether the heated material occupy the whole or only parts of the internal area, is not a matter of much importance to the practical geologist; he is content to believe that it exists, and in sufficient quantity, too, to produce the most momentous clianges on the surface of the earth.

236. We see the effects of this subterraneous agent in earthquakes and volcanoes; and the geologist can tell us of similar, as well as of other changes, effected by it during past ages. Granite hills, and mountainons districts of mica-slate, bear evidence of what is termed

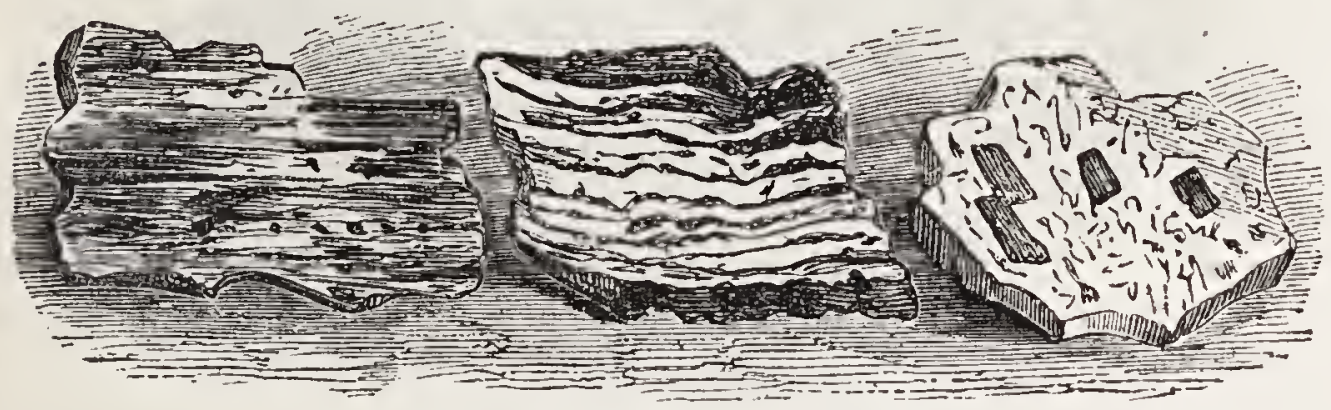

GRANITE, GNEISS, AND MICA.

metcunorphism-a change in the mineral structure of rocks, believed to have taken place through the agency of heat deep in the interior of the earth; for no analogous appearances have been detected in process at the surface.

237. Such rocks known as metamorphic, or hypogene, form a problem, not likely to be satisfactorily solved until the chemist

* Irs. Somerville. 
"Say unto God, low terrible art Thon in Thy works! through the greatness of Thy power shall Thine enemies submit themselves unto Thee."-P'sacur lxvi.

shall have thoroughly investigated the subject; for it seems likely to be found that long-continued chemical action, without a very alarming degree of heat, may hare produced even the most intense metamorphism.*

238. What evidence have we of the Igneous Formation of Granite?

Blocks of granite are frequently found, in which occur irregular fissures or cracks, that have been filled with the same minerals, exactly adapted to their shape, and exhibiting all the appearances of having flowed into the fissures in as stcute of fusion.

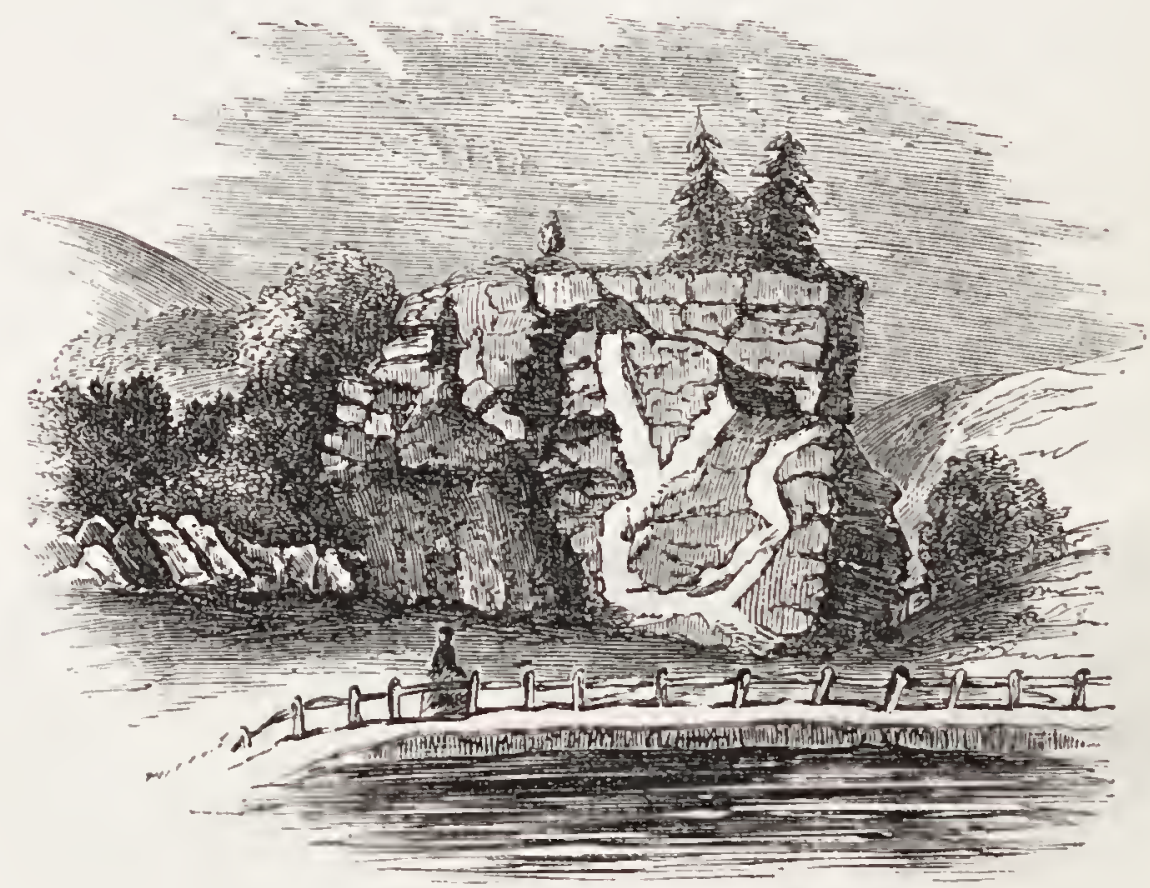

GRANITIC VEINS IN GRANITE.

239. Granite rises to the highest elevations, and forms the lighest pimuacles on our globe, and constitutes, at the same time, the skeleton or framework on which most of the other deposits repose. It likewise occurs in the state of beds of irregular shape, among strata of gneiss and other ancient stratified deposits. It is also met with in veins, intruding into rocks of all ages, from those granitic injections which are

- Geikic's "Story of a Boulder." 
"They go up by the mountains; they go down by the valleys unto the place which Thou hast founded for them."-PsaLM civ.

found to penctrate masses of granite older than themselves, up to similar intrusions into the Secondary and Tertiary strata. Granite veins are often found intersected by veins of granite still newer than themselves; and this rock occasionally occurs as dykes, which are, in fact, similar ramifications on a larger scale, the essential difference being that the dykes continue for a longer distance, while the vcins thin out into filaments. Indeed, cvery mass of granite which forms the central peak of a mountain-chain, is no otlicr than a dyke on an enormons scale, which has burst through the superincumbent strata and bornc them upwards in its elevation.

240. While granite is supposed to lave generally been erupted in a fuid condition, instances occur in which it has evidently been protruded in a solid state. The proofs of this circumstance are afforded by the absence of any dykes, or filaments ramifying into the surrounding rocks, as well as by the presence of conglomerates and breccias resulting from the grinding and attrition of such rocks by the elevation of the granitic mass. The localities of granite in England, are Cumberland, Cornwall, and Devon ; in Scotland, the Highlands and the Isle of Arran ; and in Ireland, the Morne Mountains.*

241. What was the origin of "Erratic Bloclis," or "Boulders?"

These are large blocks of stone, of various kinds, which are found scattered over the northern parts of Europe and North America, detached from the system of rocks to which they originally belonged, and evidently conveyed to their present beds by some enormous force.

242. It appear's evident that their transport is due to monstrous ice-bergs, drifted by currents of water, at a time when the land upon which the blocks now lie was covered by the ocean.

243. The transportation of huge blocks of stone which become imprisoned in ice-bergs is still in progress in the cold and temperate latitudes, both of the northern and southern liemispheres; as, for example, on the coasts of Canada and Gulf of St. Lawrence, and also in 
"Remove not the old landmark; and enter not into the fields of the fatherkss." -Proverns xxiii.

Chili, Patagonia, and the Island of South Georgia. In those regions, the uneven bed of the ocean is becoming strewed over with ice-drifted fragments, which have either stranded on shoals, or been dropped in deep water by melting bergs. The entanglement of boulders in drift

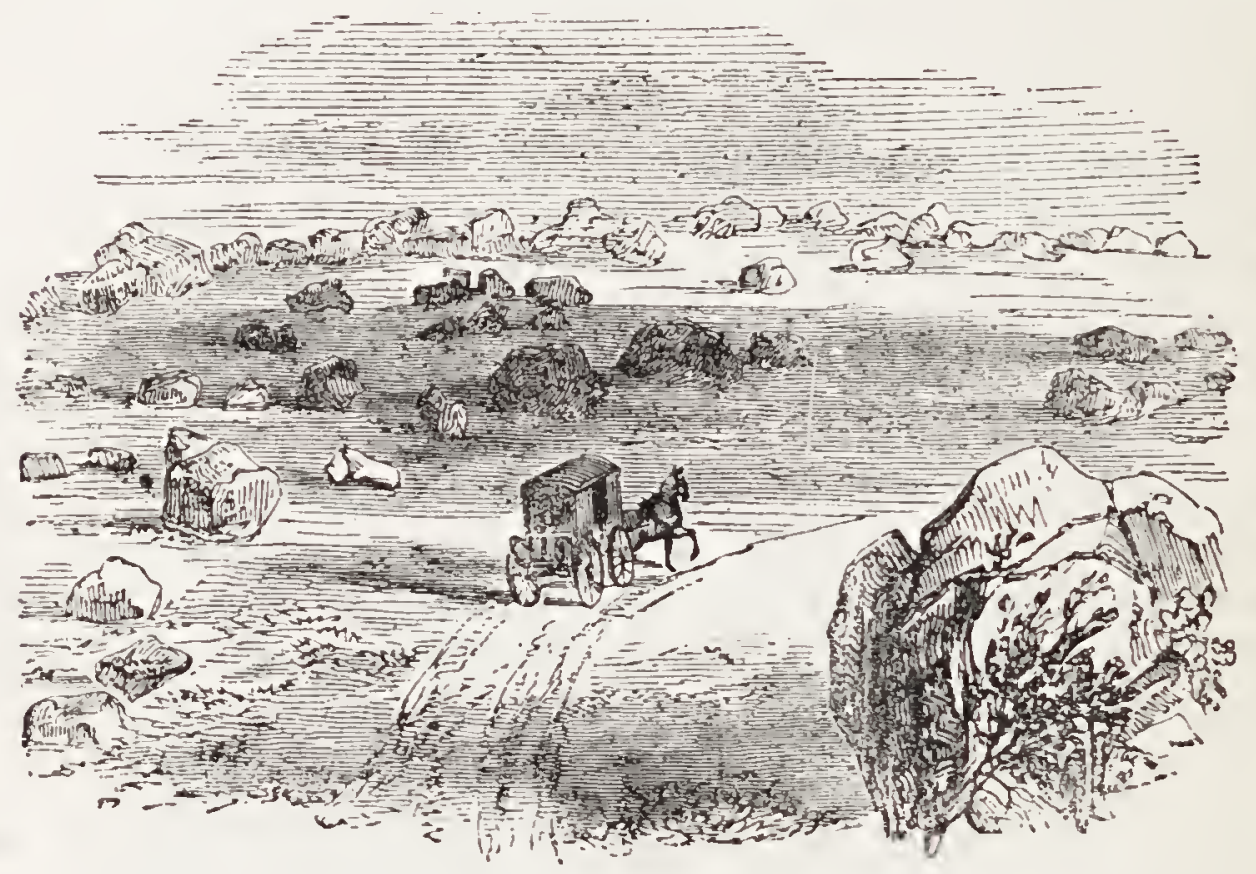

ERHATIC BLOCKS, OR BOULDERS.

jce also occurs annually in North America; and these stones, when firmly frozen into ice, wander year after year from Labrador to the St. Lawrence, and reach points of the western hemisphere further south than any part of Great Britain.*

244. What was the Origin of Metalliferous Mineral Veins?

Mineral veins yielding metals, exist throughout the primary, lower secondary, and in some cases in the tertiary deposits, but they are far more frequent in the first two classes. They exhibit various peculiarities, many of which the present state of our knowledge does not enable us to explain ; but it is assumed that the difference in substances found in veins, and their comparative richness and poorness, 
"Moreover the profit of the earth is for all; the king himself is served by the fleld."-Ecclesiastes v.

have been the consequence of different electric states in the rocks in which they are deposited.

245. Metalliferous veins are usually poor near the surfacc, but become richer at certain depths, and poor again in lower situations. They also change their metal at different distanees from the surfaee; the sume vein, in Cornwall, having been known to eontain zinc above and copper below; while there are mines in the south of France which contain iron above, next silver, and lastly eopper.

246. They are divided into two kinds; 1 . Those which are contemporaneous with the roek itself, and are supposed to have been formed by the separation of the metallie particles from the surrounding mass into one point, and are therefore tcrmed veins of segregation; 2. The metalliferous lodes are considered to have been fissures, causcd during the elevation of the rocks, whieh have subsequently been filled by metallic substances.*

The following list shows the geological distribution of a few of the chief metals :-

247. Tin generally oecurs in quartz veins travcrsing granite and selist. It has not been diseovered in a native state, but is eommonly found as an oxide, and rarely as a sulphurct. The orcs of this metal are of great hardness and speeific gravity, and are termed tin-stone. Wood-tin, so-called from its fibrous strueture, and stream-tin, are found in the beds of streams and rivulets: they are the alluvial detritus of tin-veins that existed in roeks now destroyed. The stanniferous gravel of Cornwall is the débris of pre-existing roeks traversed by tin veins, and lias been formed in the same manner as the auriferous alluvia of Russia. The mines of Cornwall are the most produetive in Europe, and have been worked from the remotest historical period. The Syrians, as early as the time of Moses, imported tin from that distriet.

248. Lead.-The ores of this metal are very numerous; and the sulphuret of lead, or galena, occurs in primary and secondary roeks. In Derbyshire, the prineiple veins of lead are in the carboniferous limestone.

249. Copper is found in primary and secondary rocks, and in modern

* Hichardson. 
"Behold, the heaven and the heaven of heavens is the Lord's thy God, the. earth also, with all that therein is." -DECTERoNoury $\mathrm{x}$.

deposits; it often oeeurs native, that is, in a pure metallic state, in blocks many tons in weight: its ores, or eombinations with other metals and minerals, are very numerous. Cornwall is the principal European repository for this metal.

250. Gold exists in granite and quartz roeks. The gold found in the mud and sands of rivers has been derived from reins of that metal which existed in rocks, subsequently broken up and disintegrated; sueh is the origin of the auriferous sands and alluvia of Russia.

251. Silver.-This metal is found in transition and primary rocks, often native, but generally in ores associated with arsenie, cobalt, \&e. Sulpliuret of silver (a eombination of metallie silver and sulphur) is the most eommon one of this metal. Masses of pure silver, 200lbs. in weight, have been found in Norway. The rieh Mexican silver and gold mines are in porphyritic rocks.

252. Platinum oecurs in the Ural Mountains. This metal combines the lustre of gold and silver with incomparable hardness. A vein has reeently been discovered in metamorphie rocks, in the valley of Drae, in the department of Isère.

253. Mercury or Quicksilver is found always liquid when in a metallic state; it is generally obtained from cinnabar, which is a sulphuret of mereury, and forms beds and reins in gneiss and sehist; and in strata of the earboniferous epoch. The mines of Idria in Carnioia are the most productive in Europe.

254. Iron.-The almost universal presence of the ores of iron, and the infinite variety of its combinations, are too well linown to require deseription. Native iron is sometimes found in the rocks; but, from the rapid oxidation of this metal when exposed to air or moisture, it is seldom met with.**

255. What is the Origin of "Aqueous" Rocks?

Aqueous rocks include all those that extend upward from the underlying granite, or igneous rocks; and are so called because they have evidently all been cleposited as sediment from water, mostly in the shape of sand, clay, \&c., and became subsequently hardened, and in various other

* Jfantell's "Wonders of Geology." 
"He is the rock, His work is perfect: for all His ways are judgment: a God of truth and without iniquity, just and right is. He."-Deutenonosy xxxii.

ways affected, by subterranean heat, and also by the superincumbent pressure of other rocks that were gradually laid upon them.

256. The aqueous rocks deposited in seas can be distinguished from those deposited by the waters of lakes and estuaries, by the fossils contained in them; some obviously being inhabitants of salt, others only of fresh water.

257. We can also learn much of the climate that prevailed during any particular formation, by studying the character of the fossil vegetation.

258. Aqueous rocks still continue to originate in the wear of the land by winds, rain, streams, or the ocean. "The débris caused by rumning water is deposited at the bottom of seas and lakes, where it is consolidated, and then raised up by subterraneous forces, again to undergo the same process after a lapse of time.

259. The decay and removal of the carth's crust by the tide, and by meteorological changes, and its deposit elsewhere, with the change affected by time on the accumulation, is a study of great interest. The cause of decay in apparently impenetrable rock is the action of air and wates upon minerals - an action which is not merely mechanical but chemical; the oxygen of the air, and also of the water, in certain instances, converting thc exposed surface into a state of corrosion. Of the rapidity with which this wcar and tear goes

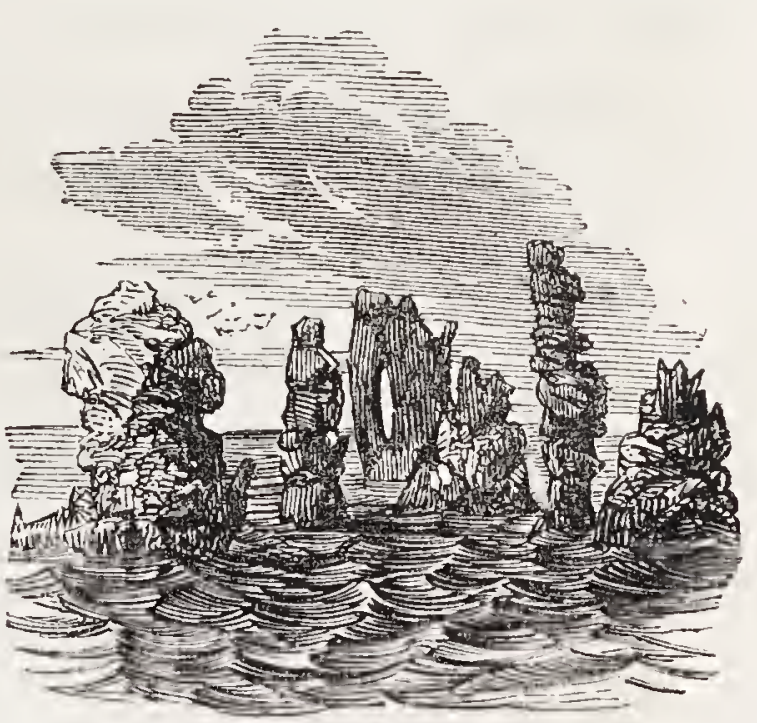
on we have no accurate means of judging. The cffect of storm and water on rocks is remarkably exemplified both in the Orkney and Shetland Islands, where the 
"The earth is utterly broken down, the earth is clean dissolved, the earth is moved exceedingly."-Isaiau xxiv.

Pentland Firth rushes through its channel at the speed of thirteen. miles an hour, scooping out the sides of the rocks into caverns, cells, and hollows. The storms, so frequent upon this part of the coast, have so battered and excavated the adjacent rocks, that in a calm they look like some ruined city rising from the placid face of the deep.

260. Why are "Metamorphic" Rocks so called?

Because, having been formed of the sediment of water in regular layers, differing in kind and colour, and deposited near the place where plutonic rocks were generated, they have been changed by the heat transmitted from the fused matter; and, in cooling under heavy pressure, and at great lepths, they have become as highly crystallized as granite without losing the stratified form.

261. An earthy stratum has sometimes been changed into a highly crystallized rock to the distance of a quarter of a mile from the point of contact, by transmitted heat; and there are instances of dark-coloured limestone, full of fossil shells, that have been changed into statuary marble from that cause.

262. Why are Trap Rocks so called?

Basalt, lava, pumice, scoriae, and ashes are the rarious matters ejected from volcanoes. When these materials are

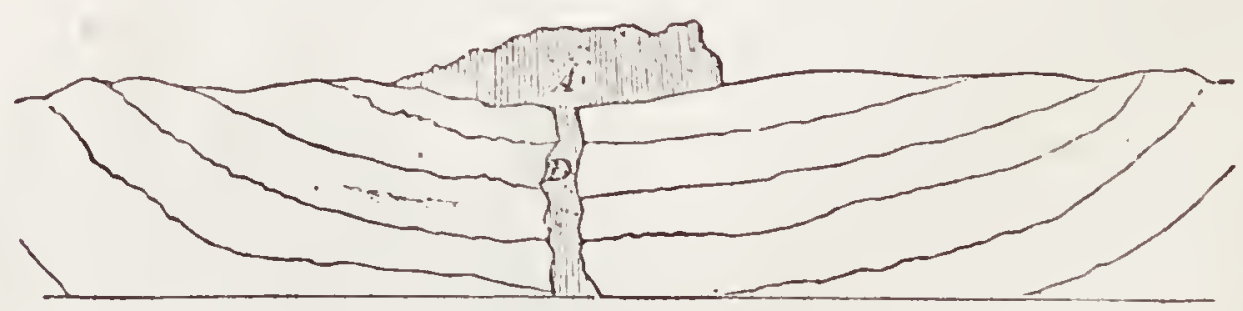

TRAP HOCK, OVERIJING REGULAR STRATA.

found interstratiffed among the various geological formations, they are termed trap rocks-a name derived from the 
"The heaven for height, and the earth for depth, and the heart of kings is unsearchable." - Proveris $\mathrm{xx \nabla}$.

Swedish trappa, a stair, in allusion to the step-like or terraced appearance which they often present.

263. In the accompanying diagram, $\mathrm{A}$ is a block of trap, thrown up through an intrusive vein, $\mathrm{D}$. These intrusive traps occur in the form of walls and veins; sometimes in that of flat parallel beds, and often as huge amorphous masses, to which no definite name can be given. The rocks through which they pass are more or less liardened, often contorted, and sometimes traversed by innumerable cracks and rents, in to some of which the trap has penetrated in the form of veins.

264. A trap-dyke is a long wall of igneous matter, cutting more or less perpendicularly through the surrounding rocks. Sometimes these dykes attain a breadth of many yards, and may not unfrequently be traced for miles, running in nearly a straight line over hill and valley, easily recognisable by a long smooth ridge, with the rock protruding here and there from below where the soil is thin. It is interesting to follow out one of these long ramparts from its beginning to the close, and mark how undeviatingly it cuts through the rocks, no matter what may be the nature of the stone encountered. Of course, this trap must have been formed after all the rocks through which it passed. The sandstones and shales must have settled down long previously on some estuary bed or sea bottom. Trap-dykes are, therefore, appropriately termed intrusive. They have been intruded among, and must always be later than, the rocks in which they occur.**

\section{In what Order are the Geological Strata Arranged?}

The upper surface of our earth in level tracts, generally speaking, does not consist of such rocks as constitute the regular strata of the crust of the earth; but, chiefly of a covering formed of the débris or ruin of those rocks. From this springs the vegetation which adorns our world.

266. Below the superficial covering lie the Tertiany beds, or formations. By this term, the series of subterranean beds down to the chalk rocks is denoted. 
"And surely the mountain falling cometh to nought, and the rock is remored out of Mis place."-JoB xiv.

267. Underneath these beds lies another series of formations, which, like the former, are of a stratified and sedimentary nature. These are called SEcondary rocks.

268. Lastly, we find a series of crystalline and other masses situated below the secondary rocks, and beyond which the researches of man have never penetrated. These are the granite, gneiss, and mica-slate rocks. All these are formed of the same materials-quartz, felspar, and mica in different proportions and modifications, and these constitute the Primary Series.

269. As regards the position of rocks in respect to the surface of the earth, it appears that all but the primary preserve generally a uniform thickness, or else vary in this respect by imperceptible and regular. gradations. It is found that the strata extend over large surfaces in nearly, but not quite, a horizontal direction. They incline, in fact, a little below the horizon, pass under the surface, and disappear under other strata, which, in their turn, also dip in the same direction. Thus, the surface of the globe, in countries where secondary and subsequent formations occur, is formed of the edges of strata which gently dip down into the earth.

270. In the annexed diagram is represented the section of a country

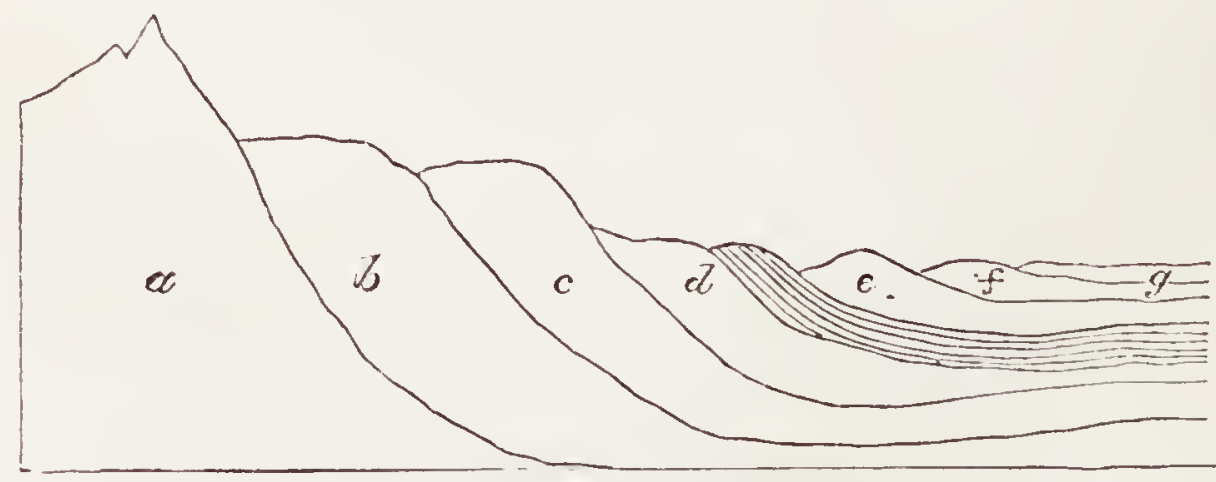

SECTION OF REGUIJAR STRATA.

in which granite is towering into a mountain at $A$, gneiss lying upon it at $\mathrm{B}$, mica slate at $\mathrm{C}$, various secondary rocks at $\mathrm{D}, \mathrm{E}, \mathrm{F}$, and the tertiary formations at $\mathrm{G}$. 
"And $I$ will shew wonders in the heavens, and in the earth, blood and fire, and pillars of smoke."-JOEL ii.

271. Strata, when lying in their natural undisturbed positions, invariably occupy a certain regular determinate order; so that, for instance, if groups of six different strata or formations be found in different parts of the world, that six will always be discovered in the same successional order; or, in other words, while certain strata requisite to form a complete group may be missing from the group in any one locality, those that are found together will always exhibit, if undisturbed by natural yet disarranging forces, the same order of arrangement, in their relation to each other.

272. The following Table, simplified from "Lyell's Elements," indicates the various formations included in the three groups:-

"The majority of Geologists conclude, that four or five distinct epochs of destruction and renewal may be traced in the organic remains contained in the different strata; in other words, that whole groups have been swept from existence by some powerful catastrophe, and their places supplied by other races, called into existence by the creating energy of the Almighty. The records of Geology seem to testify that such was the condition of the globe in those early periods as to temperature and other circumstances, that our present race of animals could not have then existed, and that such was the nature and constitution of those primeval beings, that they could not exist in the present constitution and circumstances of our globe; their natures being adapted to the different conditions of the earth, at earlier periods of its existence."

* Dick”s "Christian Philosopher." 
"Thou coveredst it with the deep as with a garment: the waters stood aboro the mountains." -Psaljy civ.

\section{FOSSIIIFEROUS ROCKS.}

273. [For cxplanation of the following names see the Glosiary.]

1. Recent.

2. Post-Pliocene.

3. Newer Pliocene.

4. Older Plioccne.

5. Upper Miocenc.

6. Lower Miocenc.

7a. Upper Eocene.

7b. Middle Eocene.

8. Lower Eocene.

9. Maestricht Beds.

10. Upper White Chalk.

11. Lower White Chalk.

12. Upper Greensand.

13. Gault.

14. Lower Greensand.

15. Wealden.

16. Purbcck Beds.

17. Portland Stone.

18. Kinneridge Clay.

19. Coral Rag.

20. Oxford Clay.

21. Grcat Oolitc.

22. Inferior Oolite.

23. Lias.

24. Upper Trias.

25. Middle Trias.

26. Lower Trias.

27. Magnesian Limestone.

28. Coal Measurcs.

29. Carboniferous Limestone.

30. Upper Devonian.

31. Lower Devonian.

32. Upper Silurian.

33. Lower Silurian.

34. Upper Cambrian. 34. Lower Cambrian.
\} Post-TERTIARY.

\} Pliocexe.

\} Mrocene.

$\{$ Eocene.

TERTIARY.
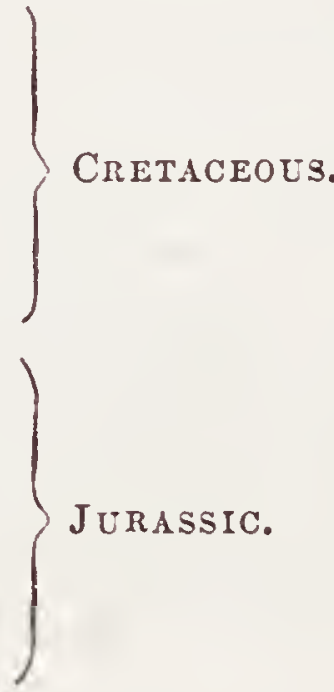

$\{$ Triassic.

SECONDARY.

PERMia.s.

$\{$ Carboniferotos

OLD RED

SANDSTONE.

PRIMALY. 
"He bindeth the floods from overflowing; and the thing that is hid bringeth He forth to light."-JoB xxviii.

274. What are the Geological Agencies that have determined the character of Continents and Islands?

The present form of all land surfaces has been produced by two causes, which have acted in succession, the one after the other : the first is a subterranean action, unattended by violent phenomena, of which the measure and direction are unknown to us; the second comprises all the causes acting at the surface, as volcanic eruptions, earthquakes, elevations of mountain chains, and oceanic currents.

275. The changes in the relative heights of the solid and the liquid portions of the surface, which have determined the eversion or subversion of the lower lands, and the present outlines of continents, must be referred to various causes, acting at different times. The most powerful among these have no doubt been elastic forces acting in the interior of the earth, sudden changes of temperature affecting great masses of rock, the unequal loss of heat in the earth's crust and in the nucleus, causing ridges and contortions, scc.

276. According to the opinion generally receired among the geologists of the present day, the elevation of continents above the sea is a real, and not merely an apparent or relative elevation, such as would be occasioned by a depression of the general sea level.

277. A remarkable elevating force is observed to be in operation throughout Norway and Sweden, which appears to attain its maximum in the north of Lapland, and to diminish gradually southwards towards Calmar and Soelvitsborg. While the whole coast of Sweden and Finland is undergoing a gradual rise, the southern coast of Sweden is being depressed.

278. What are the Physical Effects of Volcanoes?

Volcanic action was long considered solely in respect to its destructive agency, as it was understood. But it is now contemplated as a great force in nature, formative of new rocks, and transformative of those pre-existing.

279. For instance: the composition of lava differ's according to the nature of the crystalline rock of which the 
"Bow Thy heavens, O Lord, and come down: touch the mountains, and they shall smoke."-P'salar cxlir.

volcano consists, and according to the degree of heat of the interior. Vitreous volcanic rocks, obsidian, pearlstone, and

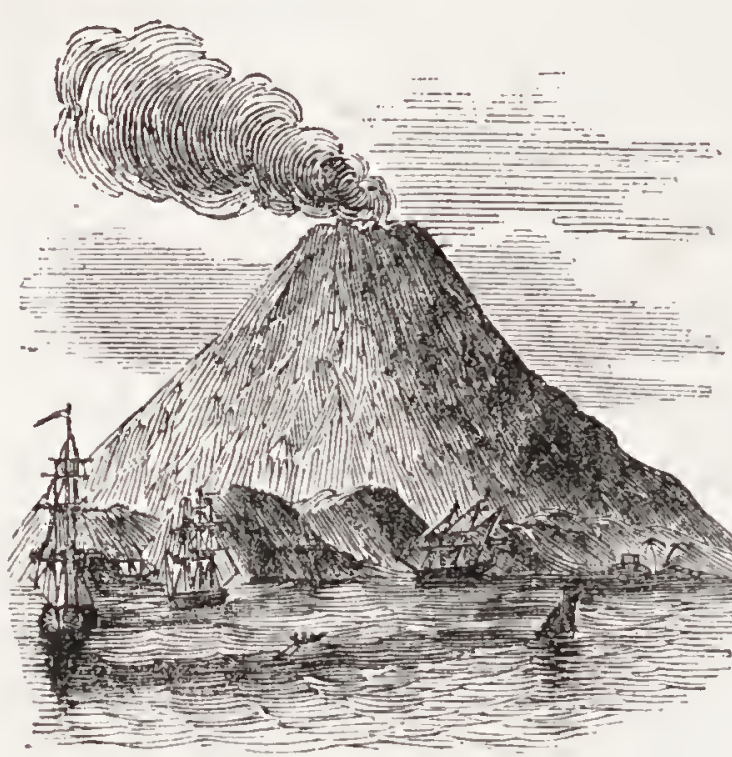

VOLCANO OF THE MOJLUCCAN ISLAYD GROUP. pumice are entirely wanting in some volcanoes; in others they proceed from the water itself, or at least from inconsiderable depths beneath it.

280. If, instead of arranging rocks according to their differences of form and superposition into stratified and unstratified, schistose and compact, normal and abnormal, we trace out and study the phenomena of formation and transformation which are still going on before our eyes, they may be distributed in the four following classes, according to their mode of origin :-

281. Erupted rocks which have issued from the interior of the earth, either by volcanic action in a state of fusion, or by plutonic action in a more or' less softened state.

282. Scdimentary rocks, precipitated or deposited from liquids in which their particles were held in solution, or suspended; these form the greater part of the Secondary and Tertiary groups.

283. Transformed or Metamorphic rocks, in which the texture and mode of stratification have been altered, either by the contact or proximity of an elupted plutonic or rolcanic rock; or, as is more frequently the case, by the action of rapours and sublimations which accompany the issue of certain masses in a state of igneous liquefaction.

284. Conglomerates, coarse or fine grained sandstones or breccias, consisting of mechanically divided fragments of the three preceding classes.

285. The production of these four kinds of rocks, as still going on 
"The hills mclted like wax at the presence of the Lord, at the presence of the Lord of the whole earth."-Psscy xcvii.

before our eyes-by the pouring forth of volcanic masses in streams of lava; by the influence of these masses on rocks previously hardened; by mechanical separation, or chemical precipitation from liquids charged with carbonic acid; and by the cementation of the detritus of rocks of every kind-may be regarded as presenting only a faint image of what took place in earlier ages during the formation of the earth.*

286. What is it that Burns in Volcanoes?

It was at one time believed that the heat which fuses the earth and metals, and produces great streams of lava, arose from the chemical action of various substances capable of generating intense heat by their mutual affinities; but it is now understood that the development of volcanic fires is not due to this cause in a direct sense, but arises from the internal terrestrial heat, acting in all cases of volcanic eruption.

287. The great number of volcanoes situated on islands, or on coasts, for a

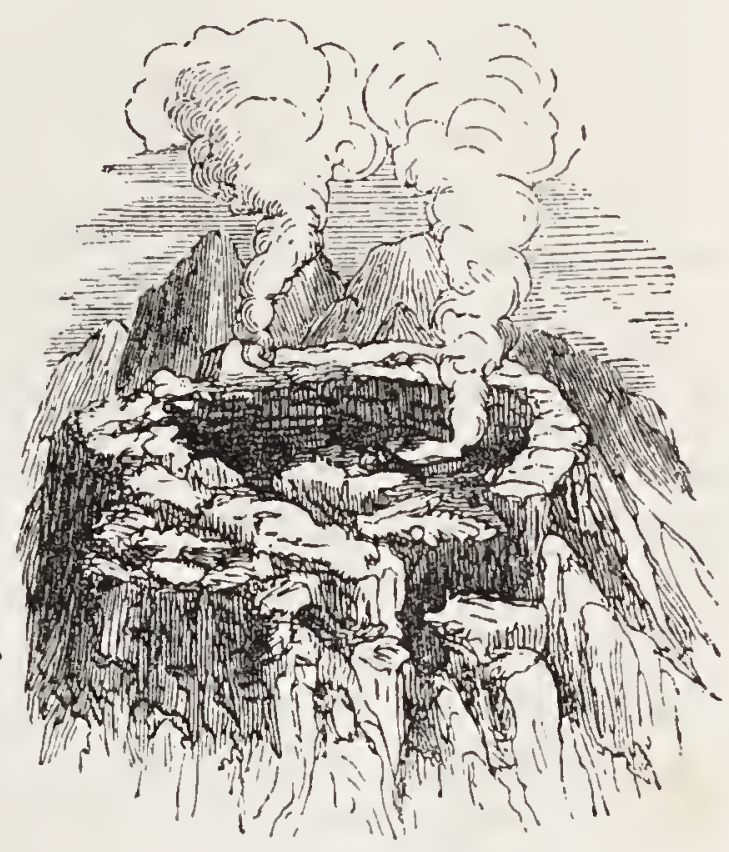

CRATER OF IETNA. time imparted the belief that volcanic activity is connected with the sea, and dependent upon it for continuance; that their action, at least in part, arose from the decomposition of large bodies of sea water, and its conversion into vapours and gases.

288. But this opinion has fallen into discredit: there are volcanoes situated great distances from the sea; and their 
"The mountains quake at Him, and the hills melt, and the earth is burned at His presence, yea, the world, and all that dwell therein."-NaHur i.

being found most commonly on sea borders probably arises from the fact that, on their first formation the land near the sea, being of a lower level than that of the interior of continents, offered by its superincumbent weight less resistance to the upheaving of volcanic cones.

289. That the earth possesses a source of internal heat is a fact which is demonstrated by the phenomena already mentioned. The increased temperature of wells and mines, the warmth of which augments in a known ratio as we descend, the raporous exhalations of the earth, its strcams of heated water, and its rolcanic eruptions, all prove the existence of such a cause. To an agent thus powerful and universal many of the modifications of the earth's surface are evidently attributable, as the fusing of the melted rocks, and the altering of those which are termed metamorphic, while its operation in existing volcanoes is alike evident. The only doubt of importance is as to the NATURE of these subterranean fires: one section of observers, among whom Humboldt, Fourier, Cordier, and Arago maintain the views of Leibnitz, as to their resulting from the original incandescence of our planet; the other attribute them to chemical agencies operating within the depths of the earth.

290. Neantime, there are various facts, such as the mean density of the earth, which is too small to allow of its being wholly a solid mass, together with the undulatory motion observed in earthquakes, with other phenomena of similar nature, which lead to the conclusion that a large part of the interior of our planet is in a state of fusion by heat, and that we are existing on the external covering of a mass of molten matter. The oscillations of such a fluid, tending towards different directions, will sufficiently account for physical phenomena of the highest relative interest and importance, such as the changes in the external aspect of the earth by the eleration of continents from the bed of the occan, the upheaval of some portions of the surface, the submergence of others, and the general variety observable in its configuration.*

291. Monnt Roa and three other volcanoes, besides conical rolcanic peaks, are found in Hawaii, the largest of the Sandwich Islands. The

* Richardson. 
"Who can stand before His indignation? and who can abide in the fierceness of His anger? his fury is poured ouc like fire, and the rocks are thrown down by lim."-Nazur $i$.

summit of Mount Roa is nearly 14,000 feet above the sea, and its crater has a circumference of about six miles and $\mathbf{a}$ quarter. The ancient crater, which has become partly quiescent, is nct less than twenty-four miles round. In May, 1813, an eruption of this mountain took place, which is thus described by the Rev. Titus Ccan, an eye-witness :-

292. "God is not only working wonders in the moral and civil, but also in the physical world around us. You have heard of the great volcanic eruption near our station in 1840. Another scene of a similar kind has recently taken place about the same distance fiom us, but in a different direction, directly in the rear of our station. On the 10th of January of the present year, and just at the dawn of day, we discovered a rapid disgorgement of liquid fire from near the summit of Mount Roa, at an elevation of about 14,000 feet above the sea.

293. "This eruption increased from day to day for several weeks, pouring out vast floods of fiery lava, which spread down the side of the mountain, and flowed in broad rivers, throwing a terrific glow upon the heavens, and filling those lofty mountainous regions with a sheen of light. The spectacle continued till the molten flood had progressed twenty or thirty miles down the side of the inountain and across a high plain which stretches between the bases of Mouna Roa and Mouna Kea.

294. "After many weeks, in company with Mr. Paris, the missionary" for Kan, a station south of Hilo, we penetrated through a deep forest, stretching between Hilo and the mountain, and reached the molten stream, which we followed to the top of the mountain, and found its source in a vast crater, amidst eternal snow. The lava had now ceased to flow upon the surface down the sides of the mountain, but it had formed for itself a subterranean duct at the depth of 50 to 100 feet. This duct was vitrified, and down this fearful channei a river of fire was rushing at the rate of fifteen or twenty miles an homr, from the summit to the foot of the mountain.

295. "We saw the subterranean stream distinctly through several large apertures in the side of the mountain, while the burnmg flood rushed fearfully beneath our feet. Our visit was attended with peril and inconceivable fatigue; but we never regretted having made it, and we returned deeply affected with the majesty, the sublimity, 
"Come and see the works of God: He is terrible in his doing toward the children of menl."-Psalsr Lxi.

the power, and the love of that God who 'looketh on the earth and it trembleth, who touches the hills and they smoke, whosc presence melts the hills, and whose look causes the mountains to flow down." "

296. The quantity of material ejected by Volcanocs is sometimes very enormous. In those of Tomboro, in Sumbawa, in 1815, ashe and scorix were thrown out sufficient to form three mountains equal to Mont Blanc, or to cover the wholc of Germany two fect dcep. The lava which streaned, in 1783, from the Skaptar Jokul, in Iceland, has becn computed at twenty-one cubic miles, a quantity equal in volume to the whole of the water poured by the Nile into the sea in a year.**

\section{What is the Cause of Hot Springs?}

'The water supplying these springs, having been carried down to a great depth, brings up the temperature of the earth

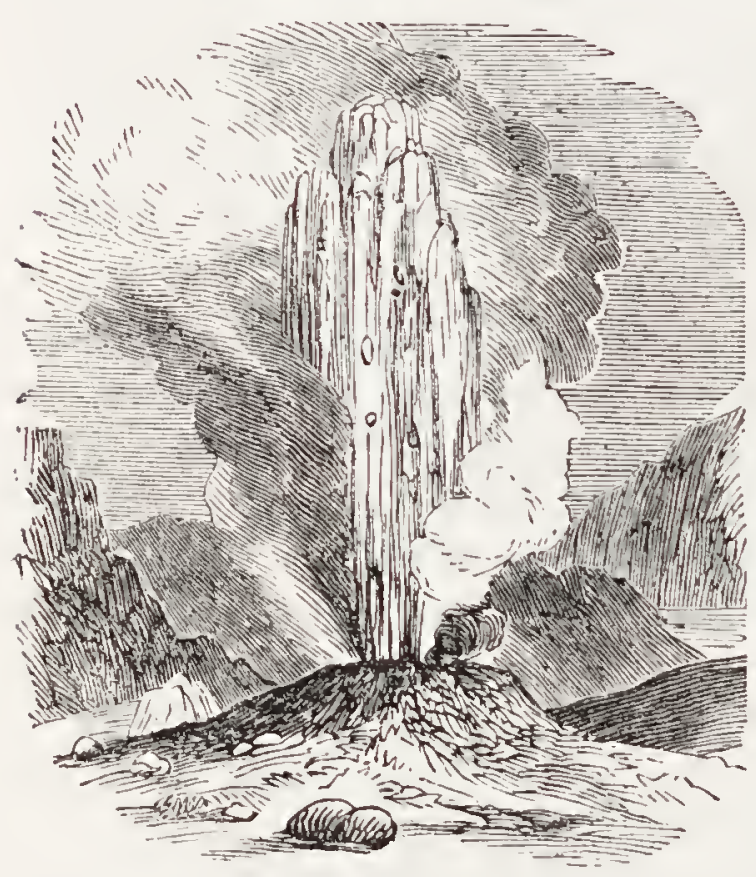

TIIE GREAT GEYSER. penetrated. Water will at the point to which it has boil at the depth of 2430 yards. Lead melts at the depth of 8400 yards.

298. The warm springs of Bath hare a temperature of from $93^{\circ}$ to $117^{\circ}$ Fahr. Three springs near Macao have temperature of $132^{\circ}, 150^{\circ}$, and $186^{\circ}$ Fahr. In the Himalayas there are springs nearly boiling; in Japan there are others fully boiling; and from the Geyser fountains, in Iceland, boiling water is spouted intermittently to the height sometimes of 200 feet. 
"Thou slialt be visited of the Lord of hosts with thunder, and with earthquale, and great noise, with storm and tempest, and the flame of devouring fire." ISAIAII Xxix.

299. The largest of the Geysers throws up at certain times a column of hot water with loud explosions, the discharge lasting for a longer or shorter time, when the watery column is succeeded by a pillar of steam, which rushes up through the air with thundering noises. The springs. are all supposed to be connected by subterranean channels with Mount Hecla, and the water to have passed over beds of lava still in a state of fusion. The basin of the Great Geyser has the appearance, when quiescent, of a circular pool. Prior to the upheaving of the waters, a dull rumbling sound is heard, then the pool becomes troubled, and jets of water and steam are soon projected, with great force and noise, frequently carrying up large blocks of stone; the earth is slightly shaken, and sounds proceed from beneath the surface like the firing of cannon. The eruption terminates by the emission of jets of steam, and by a violent gurgling of the waters. These discharges sometimes occur three or four times in twenty-four hours.

300. Why are Fishes sometimes ejected by Volcanoes?

Those volcanoes which rise high above the region of perpetual snow produce inundations and torrents of water, by which smoking scorix are hurried along with blocks of ice. Cavities in the declivity or at the foot of the volcano are thus gradually converted into subterranean reservoirs of water, with which the Alpine torrents and rivulets communicate, by numerous narrow channels. Into these the spawn of fish is conveyed through the rivulets, and they become developed, and multiply in the caverns; and when the whole mass of the volcano is powerfully shaken by earthquake shocks, these subterramean caves are suddenly opened, and fishes and mud ejected together.

301. Why do Storms of Thunder and Lightning frequently occur around the summits of Volcanoes?

Because the hot steam which, during the eruption of the volcanoes, issues from their waters and mingles with the atmosphere, condenses as it cools, and forms clouds, surrounding the columns of fire and ashes, which rise to. 
"A righteous man falling down before the wicked, is as a troubled fountain, and a corrupt spring."-PRoveriss $\mathrm{xxr}$.

the height of many thousand feet. Electric disturbance is caused by the suddenness of the condensation, and

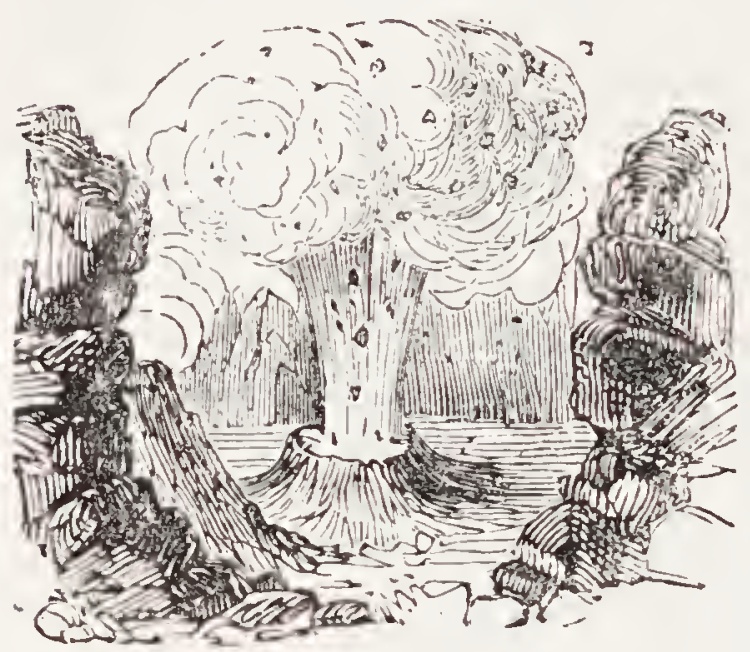

CRATER OF A VOLCANO DISCHARGING VAPOUR. by the formation of such an enormous surface of cloud. Forked lightnings. dart from the columns of ashes, and the rolling thunder of the rolcanic storm may be clearly distinguished from the sounds that issue from the interior of the rolcano. At the volcano of Katlagia, in Iceland, in 1755 , cleven horses and two men were killed by lightning from a cloud of volcanic steam.

302. Why are Springs of Water frequently found to issue from the sides of Volcanoes?

Because the vapour which rises from the volcanoes condenses, and, after permeating the rocky sides, again appears in the form of springs.

303. What is the cause of "Mud Volcanoes?"

Melted lava, gases, liquids, and mud, issuing from the earth, exhibit transitional or intermittent phenomena, all connected with the internal heat of the earth, and volcanic agencies.

304. Mud voleanoes are deserving of more attention than has hitherto been given to them. When the mud volcano of Jokmali, on the borders of the Caspian Sea was first formed, flames blazed up to an extraordinary height for a spaee of three hours, and during the following twenty-four hours they rose about three feet above the water from which mud was ejeeted. Near the village of Bakliehli, west of Baku, 
"Though the waters thereof roar and be troubled, though tho mountains shake with the swelling thereof."-PsaLx xlvi.

the column of flame rose so high that it could be seen at a distance of twenty-four miles. Enormous fragments of rock, torn doubtless from depths, were hurled to a great distance round.

305. After the violent explosion and flames which accompany the first appearance of mud volcanoes, they present to the observer an image of the constant but feeble activity of the interior of the globe. It would seem as if, soon after their first formation, the channels of communication with the very deep strata having a high temperature became obstructed, and the coldness of the mud emitted appears to indicate that the seat of activity is situated not very far fiom below the surface.

306. There is no sufficient reason why wo should assume that the subterranean forces may not, in ages to come, add new systems of mountains to those which already exist. Why should we suppose the crust of the earth to be no longer subject to the agency which has formed the ridges now perceived on its surface? Since Mont Blanc, and Monte Rosa, Sarati, Illimani, and Chimborazo, the colossal summits of the Alps and the Andes, are considered to be amongst the most recent elevations, we are by no means to assume that the upheaving forces have been subject to progressive diminution. On the contrary, the quiet we now enjoy is only apparent; the tremblings which still shake the surface in every latitude, and in every species of rock, the progressive elevation of Sweden, and the appearance of new islands of erruption, are far from giving us reason to suppose that our planet has reached a period of entire and final repose.*

307. There appears scarcely to have been an age of the world in which volcanic eruptions have not taken place in some part of the globe. Lava has pierced through every description of rocks, spread over those existing at the time, and flowed between their strata. Ever changing their place of action, eruptions have burst out at the bottom of the sea as well as on the dry land. Enormous quantities of scorix and ashes have been ejected from numbe:-!ess craters, and have formed extensive deposits in the sea, on lakes, and on the land, in which are embodied the remains of animals and vegetables that flourished in the ages when the eruptions occurred. Somo of these deposits have become

- IIumboldt. 
"And they shali go into the holes of the rocks, and into the cares of the earth for fear of the Lord, and for the glory of His Majesty, when Ile ariseth to shakc terribly the eartl.." -ISAIAH ii.

hard rock, other's remain in a crumbling state, and, as they alternate with the aqueous strata of almost every period, they contain the fossils of all the geological epochs, chiefly fiesh and salt water shell fish.*

308. One of the characteristic forms of volcanic rocks, especially of basalt, is the columnar, where large masses are divided into regular

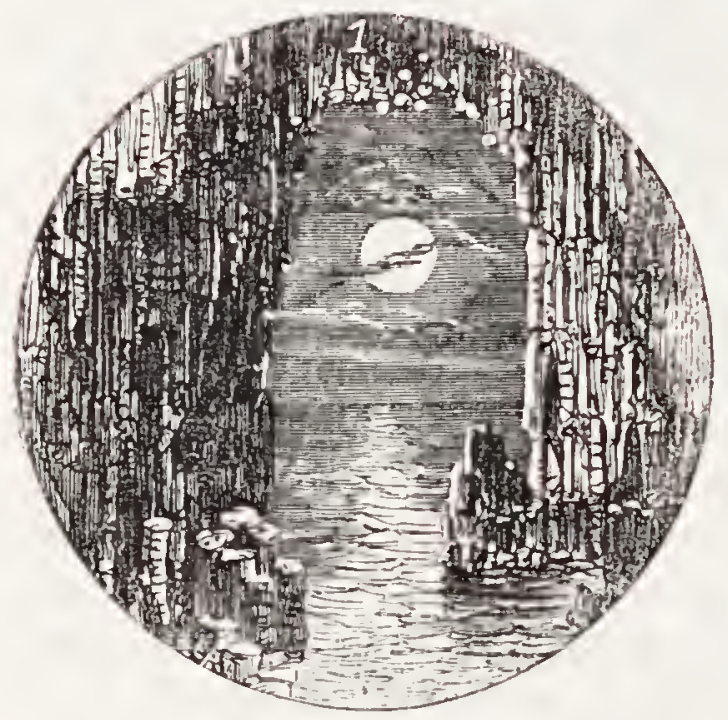
prisms, sometimes casily separable, but in other cases adhering firmly together. The columns vary in the number of angles from three to twelve, but they have most commonly from five to seven sides. They are often divided transversely, at nearly equal distances, like the joints in a vertebral column, as in the Giant's Causeuay, Ireland.

309. Sometimes each segment of the basaltic columns assumes a spheroidal, instead of an angular form, so that a pillar is made up of a pile of balls, usually flattened, as in the Cheese Grotto, in the Eifel, near the Moselle. The basalt there is a part of a small stream of lava, from thirty to forty feet thick, which has proceeded from one of the several rolcanic craters still existing on the neighbouring heights.

\section{What relation do Volcanoes bear to Earthquales?}

Active rolcanoes may be regarded as safety-valves which give vent to those internal forces by which earthquakes are caused. The danger increases when the openings of these voleanic outlets are stopped.

311. When the fissures of volcanoes become filled up with crystalline masses issuing from the interior, the free escape of the elastic fluids is impeded. They then 
"For thus saith the Lord of hosts: Yet once it is a little while, and I will shake the heavens, and the earth, and the sea, and the dry land."-Haggal ii.

accumulate, and their action against the crust of the earth shows itself in three different ways-in earthquakes, in sudden elevations, or in slow and continuous elevations, which alter progressively the relative levels of the land and the sea.

312. To man the earthquake conveys a sense of danger of which he knows not the extent or limit. The eruption of a volcano, the flowing stream of lava threatening his habitation, can be fled from; but in the enrthquake, turn where he may, danger and destruction are around him, and beneath his feet. But, though such emotions are deeply seated, they are not of long duration. The inhabitants of countries where long series of weak shocks succeed each other, lose almost every trace of fear. On the coasts of Peru, where rain scarcely ever falls, and where hail, lightning, and thunder are unknown, these atmospheric explosions are replaced by the subterranean thunder which accompanies the trembling of the earth. From long habit, and a prevalent opinion that dangerous shocks are only to be apprehended two or three times in a century, slight oscillations of the ground scarcely excite so much attention in Lima as a hailstorm does in the temperate zone.

313. What is the cause of Earthqualies?

They probably owe their origin to the high temperature of the interior and deep-seated molten stratc of the earth; conwined probably with the force of electricity; and are independent of the nature of the rocks in which they manifest themselves.

314. Earthquake shocks have been felt in loose alluvial soil. Granite and mica slate are shaken, as well as limestone and sandstone. It is not the chemical nature of the constituent particles, but the mechanical structure of the rocks, which modifies the propagation of the shock, or of the wave which occasions it. Where such a wave proceeds in a regular course along a coast, or at the foot of a mountain chain, interruptions at certain points have sometimes been remarked, and these have continued for centuries; the undulations have passed onward through the depths below, but it is never felt at corresponding points of the surface. The interrupting 
"The earth shall quake before them: the heavens shall tremble: the sun and the moon shall be dark, and the stars shall withdraw their shining." -Joec ii.

points have been regarded as a bridge, which in course of centuries yields to the recurring forces, and the way being once opened, the undulatory movement is propagated through it.**

\section{What are the Physical Effects of Earthquakes?}

Whole districts of country are elevated above their former level, and others are depressed, even to being sunk beneath the sea level, or actually beneath the sea. During their occurrence various substances are cjected from the earth, such as hot water, noxious gases, mud, black smokie, and even flames.

316. During the great earthquake of Lisbon, 1755, flames and a column of smoke were seen to issue from a newly-formed fissure in a rock. At the destruction of Riobanba, 1797, where the shocks were not accompanied by any eruption of the adjacent volcano, a singular mass, in which carbon, crystals of angite, and silicious shells were intermingled, was pushed up in numerous small conical eminences. During the earthquake of New Granada, 18:7, carbonic acid gas, issuing from fissures in the valley of the Magdalena River, suffocated many snakes, rats, and other animals which live in holes.

317. The intertropical parts of America, where sometimes, for ten months together, not a drop of rain falls, repeated earthquake shocks are regarded by them as the welcome harbingers of abundant rain and a fruitful season.

318. Earthquakes are distingnished by rapidly succeeding vertical, horizontal, or circular oscillations. The rertical and the horizontal often take place together. The mine-like explosion, the rertical action from below upwards, showed itself in the most striking manner at the overthrow of the town of Riobamba, in 1797, where many corpses of the inhabitants who perished were hurled to a height of several hundred feet on the hill of La Cullca, beyond the small river of Lican.

319. The circular carthquakes are most rare, and at the same time the most dangerous. In the great earthquake of Riobamba, in the province of Quito, 1797, and in that of Calabria, 178:3, the direction of walls was changed, withont their being overthrown, 
"The roice of Thy thunder wrs in the heaven: the lightnings liglitened the world: the earth trembled and sliook."-Psald lxxvii.

straight and parallel fields were inflected, and in fields having two sorts of cultivation there were instances of one crop taking the place of the other; the furniture of one house was thrown under the walls of another. Disputes concerning the ownership of objects which had thus been carried to distances of many hundred yards had to be decided by the Court of Justicc.

320. The noise which usually attends an earthquake is not upon all occasions simultaneous with the commotion, but sometimes occurs as much as fifteen or twenty minutes afterwards. The nature of the noise also differs greatly; sometimes it is rolling, and occasionally like the clanking of chains; sometimes abrupt, like thunder close at hand, and sometimes clear and ringing, as if vitrified masses clashed, or were bcing shattcred in subterranean cavities. The sounds are not propagatcd througl the air, but through the carth, at a great depth.

321. Subterranean roaring and thundering is sometimes leard, without being accompanied by any vibration of the eartl. This has been especially noticed in the mountain city of Guanaxuato, in the Mexican tcrritory, which is situated at a distance from any active volcano. A noise began here on the 9th of January, 1784, at midnight, and lasted above a month. From the 13th to the 16th of January, it was as if there were heavy storm-clouds under the feet of the inhabitants, in which slow-rolling thunder alternated with short-thunder-claps. Almost all the inhabitants were terrified and quitted the city, in which large quantitics of silver were stored; but the more courageous, when they had becomc accustomed to the subterraneous thunder, returned and fought with bands of robbers, who had entered the city to take possession of the treasure. Ncither at the surface nor in deep mines of the country conld the slightest trembling of the ground be perceived. The noise ceased gradually, as it had commenced; it was confined to a small space.

322. The great earthquake which destroyed Lisbon in 1755 was felt in the Alps, on the coasts of Sweden, in the West India Islands, on the great lakes of Canada, in Thuringia, in the flat country of northcin Germany, and in small inland lakes on the shores of the Baltic. It has been computed that a portion of the earth's surface, four times greater than the cxtent of Europe, was simultaneously shaken. There is no manifestation of force yet known to us (including the murderous inventions of our own race) by which a greater number of human beings 
"I will make waste mountains and hills, and dry up all their herbs; and I will make the rivers islands, and I will dry up the pools."-Isaian slii.

have been killed in the short space of a few seconds or minutes, than in the case of earthquakes: sixty thousand were dcstroyed in Sicily in 1693 ; thirty to forty thousand at Riobamba, in 1797 ; and perhaps five times as many in Asia Minor and Syria in the years 19 and 526.*

323. There is a central volcanic tract of Southern Europe where the greatest earthquakes prevail, in which rocks are shattered, mountains rent, the surface elevated or depressed, and cities laid in ruins. On each sidc of this linc of the greatest commotion therc are parallel bands of country wherc the shocks are less violent. At a still greater distance (as in Northern Italy, for example, extending to the foot of the Alps) therc are spaces where the shocks are much rarer, and more feeble, yet possibly of sufficient force to cause, by continued repetition, some appreciablc alteration in the cxternal form of the earth's crust.

324. Beyond these limits, again, all countries are liable to slight tremors, at distant intervals of time, when some great crisis of subterranean movement agitates an adjoining volcanic region; but these may be considercd as mere vibrations, propagated mechanically through the external covering of the globe, as sounds travel to almost indefinite distances through the air. Shocks of this kind have been felt in England, Scotland, Northern France, and Germany-particularly during the Lisbon carthquake.

325. Why do Great Waves of the Sea usually attend Earthqualies?

The phenomenon probably arises from the uphearal of the bed of the sea, the first effect of which is, to raise over the elevated part a body of water, the momentum of which will carry it much above the level it will afterwards assume, causing a draught, or receding of water from the neighbouring coasts, followed immediately by the return of the displaced water, which becomes impelled by its momentum much further and higher on the coast than its former level.

326. Why is a Wave-like Motion experienced upon the Land as well as on the Sea?

Because, although it is irreconcileable to our common * II umboldt. 
"Consider" the work of God: for who ean make that straight which IIe hath made crooked?"-EccLESIASTES vii.

notions of solid bodies, to imagine them capable of transmitting motions analagous to tidal waves; it is nevertheless certain that such undulations are produced.

327. The facility with which all the particles of a solid mass can be made to vibrate, may be illustrated by many familiar examples. If we apply the ear to one end of a long wooden beam, and listen attentively when the other end is struck by a pin's head, we hear the shock distinctly, which shows that every fibre throughout the whole length has been made to vibrate. It is in this way that the rattling of carriages and railway shakes the earth from some distance around.

328. While the shock propagated through the solid carth travels with extra rapidity through the land, the great sea wave follows at a slower pace, though advancing at the rate of several miles a minute. It consists in the deep ocean of a long low swell of enormous volume, having an equal slope before and behind, and that so gentle that it might pass under a ship without being noticed. But when it reaches the edge of soundings, its front slope, like that of a tidal wave under similar circumstances, becomes short and steep, while its rear slope is long and gentle. If there be water of some depth close by the shore, this great wave may roll in long after the shock, and do little damage; but if the shore be shelving, there will be first a retreat of the water, and then the wave will break upon the shore and roll far in upon the land.*

329. On the 24th of May, 1751, the ancient town of Conception was totally destroyed by an earthquake, and the sea rolled over it. The ancient port was rendered entirely useless, and the inhabitants built another town about ten miles from the sea coast, in order to be beyond the reach of similar inundations. 
"And one cried unto another, and said, Holy, holy, ho:y, is the Lord of hosts: the whole enrth is full of His glory."-Isaiall vi.

\section{GEOLOGICAL STRATA OF GREAT BRITAIN,}

\section{With their leading Fossiliferous Contents.}

330.

SUperficial ACCUMUlations.

Soils, produced by the disintegration of rocks, and the decomposition of animal and vegetable matter.

Alluvium, deposits from the ordinary action of water, forming clays, sands, gravel, \&c.

Diluvium, deposits resulting from extraordinary action of water, the forces of which have removed and deposited erratic rocks.

331.

Tertiary, or Cainozuic Strata.

Clay, formed of marino shells, pebbles, and sand, overlying beds of sand, or sandy limestone, containing organic remains, a large proportion of which are identical with existing species.

Freshuater Marl, peculiar to the Isle of Wight, and including estuary shells.

London Clay, marine groups of clay, sand, and shells, subdivided into the Upper or Barton clay group, the Middle or Bracklesham sands, and the Lower or Bognor group.

Plastic Clay group, consisting of clays, sands, lignites, subdivided into Woolwich beds and Thanet sands, containing fossils allied to those of the London clay.

332.

Secondart, or Mesozoic Strata.

Principally of marine origin, with rare and local estuary deposits; consisting of repeated alternations of limestone, flint, sandstone, sand, clay, iron ole, coals, salt, sc., with organic remains generally very distinct from existing forms of animals.

\section{Upper Mesozoic Strata.}

Chalk, calcareous, with flints, subdivided into tho Upper, Middle, and Lower clialks, of varying hardness.

Green Sand, comprising sands mole or less coloured by the silicate of iron, and elays, and subdivided into Upper Green sand, Gault clay, and Lower Green saud. 
"And the cities that are inhabited shall be laid waste, and the land shall be desolate; and ye shall know that I an the Lord."-EzEkIEL xii.

333.

Lower Mesozoic Strata.

Wealden, a fluviatilc and estuary deposit of sands, clays, \&c., divided into Weald clay, Hastings sands, and Purbeck limestone and clays.

Upper Oolite, calcareous, with limes and clays, comprising the Portland oolite and Kimmeridge clay.

Midllle Oolitc (called also the Oxford), calcareous, with sands and clays, comprising Upper calcareous grit, Coralline oolite, Lower calcareous grit, Oxford clay, Hackness rock, and clay.

Lower, or Bath Oolite, calcareous, with clays and sands, comprising in the South of England Cornbrash, Honiton sands, Forest marble, Bradford clay, Great oolite, Fuller's earth rock, Inferior oolite, and Ferruginous sand, with concretionary masses holding shells.

Lias, limestone and clay or shale, comprising Upper lias shale, Lias limestone, Lower shales, and bone beds.

\section{New Red Sandstonc System.}

New Red Sandstone, comprising variously coloured clays, sands, \&c., arranged with the Upper variegated marls, gypsum salt, Kenper sandstone, red and white conglomerate, in which organic remains are exceedingly rare.

334. Primary, or PaI.eozolc aNd Hypozolc Strata.

The Palæczoic rocks, containing organic remains, mostly of marine tribes, and generally extinct; the Hypozoic rocks deficient in fossils.

\section{Upper Palaozoic Strata.}

Permian Series, comprising Limestones, Clays, and Sandstones, arranged into Knottingley limestone, Gypseous Red marls, Bolsover limestone, Marl slate, and Red sandstone, in which Plants of thc subsequent Coral species appear.

Coal, about one thousand yards thick, the subdivisions of which are of a local character, Gritstone and Shale constituting the principal mass; Flagstone and Ironstone being among the most characteristic layers. The Flants are abundant, mostly of aborescent ferns and mosses, generally of terrestrial tribes and extinct genera. The shells are mostly of estuary origin. 
"Every valley shall be exalted, and every mountain and hill shall be made low; and the crooked shall be made straight, and the rough places plain."ISAIAII $\mathrm{xl}$.

Mountain, or Carboniferous Limestone, the subdivisions of which aro of a local character, but generally consisting of Millstone grit, sandstones, shales, coals, and limestones, forming a transition group passing from carboniferous limestones to coal.

335.

Middle Palæo zoic Strata.

Old Red or Deronian Series, limestone, sandstone, clay, shale, or slate, comprising Yoredale rocks, Sand limestone, Red sandstones, forming a transition group between the carboniferous limestone and red limestone formations, conglomerates and sandstones, in which no fossils have been found, coloured marls, and concretionary limestones called corn stones, a few fossils, and flagstone beds, with a few fossil fishes.

\section{Lower Palcozoic Strata.}

Lucllow Rocks, composed of sandy grains, sometimes mixed with clay, and subdivided into the Upper Ludlow, Aymestry limestone, and the Lower Ludlow.

Wenlock, calcareous, comprising Wenlock limestone, Wenlock shale, Woolhope limestone, and Maghill sandstone. These limestones and shales contain fossil Corals and Crinoideans in great abundance; also Trilobites, \&c.

Caradoc Sandstone, comprising Shelly limestone, various sandstones, with Trilobites, and other fossils.

Llandilo, calcareous rocks, also containing Trilobites, and a few other fossils.

Festiniog, Clay slates, \&c., divided into Arenig slate and Porphyry, Trenudoc slate, and Lingula flags.

Bangor, Grits and Slates, as Harlech grits, Llanberris slates, Longmynd slates.

\section{Hypozoic Strata.}

Micha Sehist, including Chloritic schist, Talc schist, Prarty rock, Granular limestone, Gneiss, Hornblende, Schist, \&c.

Grunitic Rocks, which are not stratified, usually For $M$ THE BASIS of tuE various sTratA, and are frequently, but not by any means universally, followed by the Gnciss and Mica slate system 
"Thou visitest the earth, and waterest it; Thou greatly enrichest it with the Piver of God, which is fall of water; Thou preparest them corn when Thou hast so provided for it."-PsaLar IXF.

\title{
AIR, WATER, EARTHS, ROCKS,
}

\author{
AND THEIR RE-ACTIONS.
}

336. How does Water produce the "Disintegration" of" Rocks?

The most common and widely diffused form of decomposition is that produced on the surface of the earth by the action of rain water, in slowly dissolving out the soluble parts of rocks, and washing auray the loose incoherent grains.

337. In ordinary language we say a stone "rots away," and its clébris is washed down by the rains and streamlets, and the process does not at firstisight seem at all more complex than the expression used to describe it; yet we shall find that there are in nature many simpler things than the rotting away of a stone. To effect such a result, there came into play a

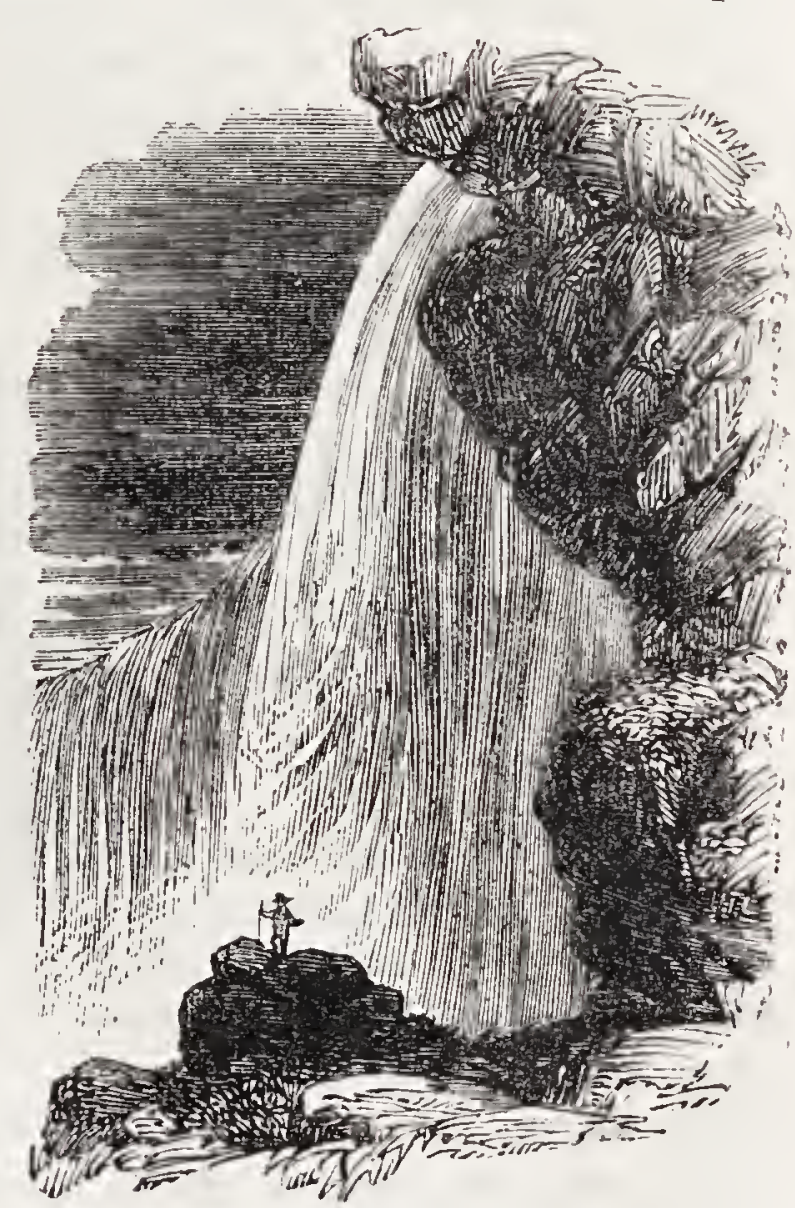

FALLS OF NIAGARA. whole category of agencies, chemical and mechanical, combined irs their operations, and blended in their effects. 
"Thou waterest the ridges thereof abundantly: Thou settlest the furrows thereof: 'Thou inakest it soft with showers: 'Thou blessest the springing tliereof." - Psalar lav.

338. A rock is said to undergo a chemical change when one or more of its component parts passes from one state of combination into another-as, for instance, when a mineral absorbs oxygen, and, from the condition of a protoxide, changes into that of a peroxide; or, parting with its silic acid, it takes an equivalent amount of carbonic acid, and in place of a silicate becomes a carbonate. Now these, and similar metamorphisms, are chiefiy produced by water permeatingr through the rocky mass, and thus no sooner does the old combination cease, than the new one which replaces it is dissolved by the slowly filtering water, and carried away either to greater depths, or to the surface. Every drop of water, therefore, that finds its way through the rock, carries away an infinitesimal portion of the mineral matter, and the stone is constantly undergoing decay.

339. A common source of the decay of rocks arises from the percolations through them of water charged with carbonic acid. Decomposing vegetation gives off a large amount of this gas, which is readily absorbed by rain water. The water sinks into the ground, filtering through cracks and fissures in the rocks, whence it afterwards reemerges in the form of springs. Now, wherever in its passage through these subterranean rocks the water meets with any carbonate, the carbonic acid contained in the liquid immediately begins to dissolve out the mineral matter, and carries it eventually to the surface.

340. Arrived at the surface, the rapidity of evaporation often causes a re-deposit of mincral. If it is lime, a white crust gathers along the sides

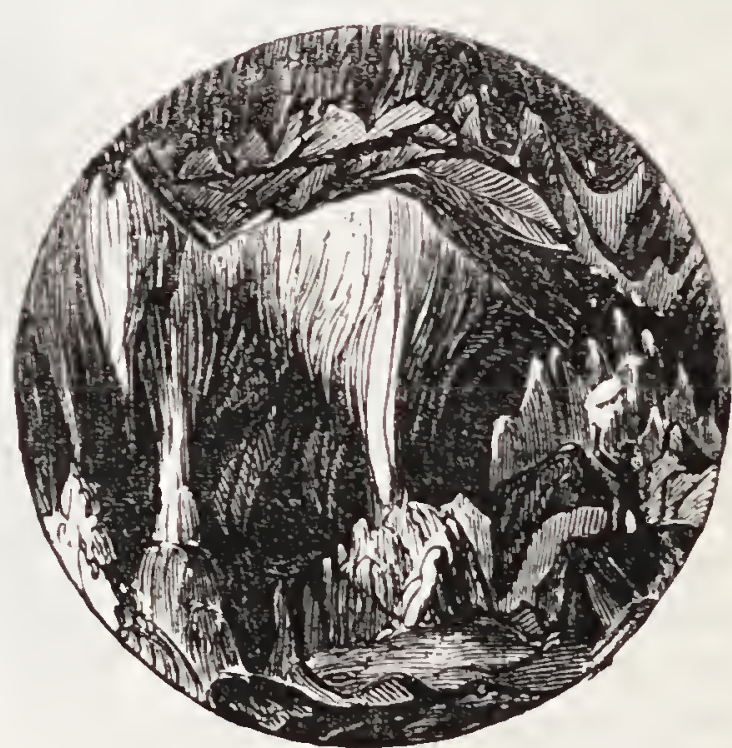

STALACTITE GROTTO. of the stream, delicately enveloping grass stalks, leaves, twigs, snailshells, and other objects. Such "petrifying" springs, as they are erroneously termed, occur abundantly in our lime-stone districts. It should be borne in mind, however, that they only produce an incrustation round the organic nucleus, and do not petrify it. 
"He made him ride on the high places of the earth, that he might eat the increase of the fields; and He made him to suck honey out of the rock, and oil out of the flinty rock."-DetTeronom xxxii.

That alone is a true petrifaction where the substance is literally fossilized, or turned into stone.

341. A familiar instance of a similar chemical process may be seen under many a bridge, and along the vaulted roof of many an old castle. Numerous tapering stalactites hang down from between the joints of the masonry resembling icicles, often of a dazzling whiteness. They are formed by the percolation of carbonated water through the mortar of the joints, the carbonate of lime thus withdrawn being deposited where the water reaches air and evaporates. In some cases, where the supply of water is too great for the amount of evaporation, part falls on the floor, and being there dissipated leaves belind a slowly gathering pile of lime called stalagmite. In some of the Eastern grottoes, the

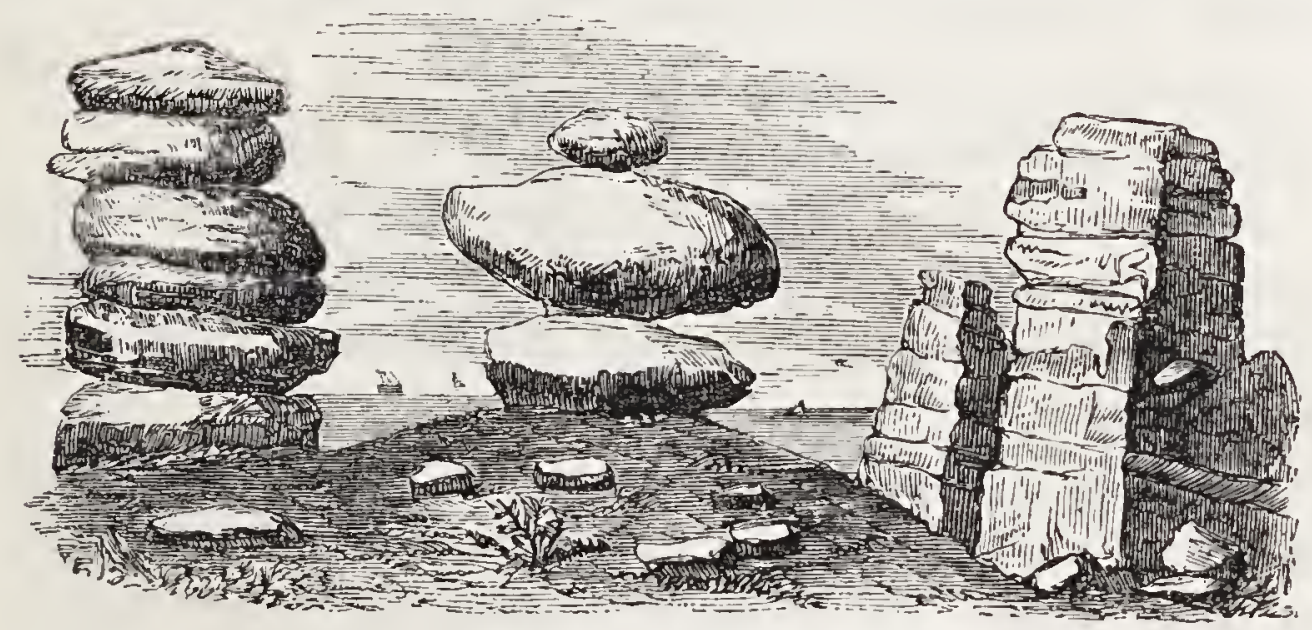

DISINTEGRATED GRANITE.

pillars from the roof have become united to those on the floor, forming the most exquisite and fairy-like combinations of arcl and pillar.

342. Among the mineral substances that most readily yield to the action of the weather are the silicates and the carbonates. The rocks containing the former belong in large measure to what we call the igneous class, such as the granites and traps; while those containing the latter from the bulk of our useful stones, such as limestone and sandstone. The removal of alkaline silicates is due to their conversion into carbonates, which are readily soluble in water. Rain falling on a rock in which they are largely present dissolves in small portions, and carries it into the soil or into streams, and thence to the ocean. Every shower in this way withdraws a minute amount of mineral matter, and tends to cause the harder 
"The lieavens are thine, the earth also is thine: as for tho world and the fulness thereof, thou hast founded them."-Psaly lixxis.

insoluble grains of the rock standing out on the surface in the form of loose pulverulent crust. The débris thus formed, where allowed to accumulate, makes an exccllent soil known to the Scottish farmers as rotten rock.

343. The tourist who has visited any of our granitic districts, such as the south-wcstern parts of Cornwall, the rugged scenery of Arran, on the hills of the Aberdeenshire Highlands, must be familiar with some of the forms of waste which the rocks of those regions display. Mouldering blocks, poised sometimes on but a slender basc, and eaten away into the most fantastic shapes, abound in some localities, while in other parts, as for instance at the summit of Goatfell in Arran, the rock weathers into a sort of rude masonry, and stands out in its nakedness and ruin, like some crumbling relic of art.*

344. What effects have Gases upon the Organic and Inorganic substances on the Surface of the Earth

The wasting effects of the atmosphere are the preparatory processes by which earthy materials are provided for rains, rivers, and the sea, to transport and deposit in new forms and situations.

345. The disintegration of granite is one of the striking effects of carbonic acid; it has been observed especially in large districts of Auvergne, especially in the neighbourhood of Clermont. This decay was called the "malady of granite," and the rock may with propriety be said to have the rot, for it crumbles to pieces in the hand. The phenomenon may, without doubt, be ascribed to the continual discharge of carbonic acid gas from numerous fissures.

346. In some instances, rounded blocks of gneiss, which have all the appearance of solidity, have been so disintegrated by carbonic acid as readily to fall to pieces.

347. 'The chemical efjects of the atmosphere are evident in buildings, on the faces of tomb-stones, which they

" Geikie's "Story of a Boulder." 
"How excellent is thy loving kindness, o God! therefore the childres of men put their trust under the shadow of Thy wings."-Psacar xxxvi.

corrode until the inscriptions become obscure, and on the surfaces of various rocks. The same process which :slowly reconverts the mortar of walls into carbonate of lime, frequently causes the pulverization and bursting of the bricks, in consequence of the expansion of the small masses of lime which they contain.

348. The surface of bricks is often covered with a saline efflorescence, which is generally nitrate of lime, but sometimes muriate of soda. The surface of the yellow limestone near Doncaster is sometimes covered with a nitrous efflorescence, and so is the calcareo-magnesian mortar made from it.

349. Carbonic acid gas is taken up by plants of every kind from the atmosphere, and, in the solid form of leaves, stalks, fruits, scales, roots, \&c., contributes annually a large amount of carbonaceous matter to the surface of the earth. The importance of this transformation of gas into the solid form will be gathered upon reference to the extensive coral formations, to be explained hereafter.

350. Oxygen is constantly entering into various combinations with metals and minerals, to which it is supplied by the atmosphere, but far more abundantly from water.

351. It is calculated that oxygen constitutes fifty per cent. of the ponderable matter of the globe, and that the crust of the earth contains forty-five per cent. of silica, and ten or twelve of alumina. Potassa contributes only seven per cent. of the unstratified rocks, but forms a considerable ingredient in many of the stratified forms; soda nearly six per cent. of some basalts, and other less extensive unstratified deposits, and enters largely into the composition of the ocean. Lime and magnesia are disseminated almost universally, in the form of silicates and carbonates. Iron, as an oxide, sulphuret, or carbonet, constitutes at least three per cent. of all known rocks; and mangancse forms about one per cent.*

* Richardson. 
"Then shall the dust return to the earth as it was: and the spirit shall return unto God who gave it."-ECchesiastes xii.

352. Why do Cathedrals, and other sione edifices, Decay Unequally on their Different Sides?

Because the stones of which they are built are affected by the corrosive action of heat and moisture. In northern zones these influences operate mostly on the south and west fionts of buildings, and in consequence those fronts decay most rapidly. This is remarkably the case with the grand Cathedral of York, built of magnesian limestone, which is in many places quite consumed on these fionts, but comparatively uninjured on the northern face.

353. The exterior of most uncrystalline rocks and buildings seems to be slowly eaten away by the moisture and carbonic acid of the air; but the influence of this destructive agent is most remarkable among the felspathic rocks, whether like granite they are originally: crystalline, or like millstone grit composed of fragmented masses. The felspathic portion of the lyypersthene rocks of Carrock Fell is so wasted that the crystals of hypersthene and magnetic iron are projected from the surface considerably. Some greenstone dikes arethus entirely decomposed to great depths from the surface; and whole rocks of granite, secretly rotten, wait only for an earthquake or a water-spout to be entirely reduced to fragments.

354. Botl carbonic acid and oxygen act very decidedly upon the metallic, and particularly the ferruginous ingredients of rocks, and thus swell and burst them to pieces. Sometimes, however, this very cause seems to harden and bind together the rock, and to render it more durable; and in general there is no certain test of the durability of any stone but experience under the same circumstances. The Bath stone, so permanent among its native hills, perishes in the salt air of Norfolk; and few calcareous free-stones of any kind long resist the carbonaceous atmosphere of London.*

355. What are the most striking Effects of Rains upon the Earth's Surface?

They are most manifest in countries subject to the greatest excess of precipitation. On the south face of 
"IIe bindeth up the waters in his thick clouds; and the cloud is not rent under them."-Joв xxvi.

the Kahsia, or Garrow Mountains, in Eastern Bengal, the depth of the rain-fall annually amounts to more than 500 inches, - and nearly all of it poured down in six months,-nearly twenty times as much as falls in Great Britain in a year. The channel of every torrent and river is swollen during the rainy season, and much sandstone horizontally stratified, and other rocks, are reduced to sand and gravel by the flooded streams. So great is the superficial waste, that what would otherwise be a rich and luxuriantly wooded region, is converted into a will and barren moorland.

356. The winds that have discharged these rains then blow northward across the Valley of the Brahmapootra, and at length arrive so dry and exhausted at the Bhootan Himalaya, that those mountains, up to the height of 5000 feet, are naked and sterile, and all their outer valleys arid and dusty. But the aërial current, still continuing its northerly course and ascending to a higher region, becomes further cooled, condensation again ensues, and a gentler precipitation takes place, and Bhootan, above 5000 feet, is clensely clothed with vegetation.

357. What is the cause of "Land-slips?"

They frequently result from the softening of the earth by heavy rains. In the neighbourhood of the Sikhim Mountains land-slips frequently occur, extending three or four thousand feet along the face of the mountains, composed of granite, gneiss, and slate, descend into the beds of streams, and dam them up for a time, causing temporary lakes, which soon burst their barriers.

358. Day and night are heard the crashing of falling trees, and the sound of boulders thrown violently against each other in the beds of torrents. By such wear and tear 
"They shall be abundantly satisfied with the fatness of Thy house; and Thou sliall make them drink of the river of Thy pleasures."-Psaly xaxri.

rocky fragments swept down from the hills are in part converted into sand and fine mud; and the turbid Ganges, during its annual inundation, derives more of its sediment from this source than from the waste of fine clay of the alluvial plains below.*

359. In attempting to ford a stream, the water, which percolates through the sand at a very rapid pace, dug out the sand beneath our feet in a second or two, and we were soon sunk so deep that we were glad to relinquish the attempt before we got half-way over; the man who preceded me was only thigh-deep, but the disturbance caused by his feet made it breast-deep for me. These said rivers remove vast masses of disintegrated rock before it is fine enough to form soil. The particles which struck against my legs as I was fording impressed me with an idea of the amount of matter removed by every freshet. In rivers where much attrition is going on, as for instance in the Vaal River, when that is slightly in flood a person diving to the bottom may hear thousands of stones knocking against each other. This process, being carried on for hundreds of miles in different rivers, must have an effect greater than if all the pestles and mortars and mills of the world were grinding and wearing away the rocks. $\dagger$

360. What is the origin of Rivers?

All rivers originate in the precipitation of water in various forms from the atmosphere, and their magnitude bears proportion to the area of country which they drain, and the amount of water precipitated by the atmosphere over the area. The sources of the water forming rivers are these :-

1. Rain, snow, and hail falling and being drained off, without penetrating the soil; and watery vapours, which become condensed upon the earth's surface.

2. Springs produced by rain-water, which has penetrated the ground, accumulated in subterrmean channels, and at

* Hooker's "IIlmalnyan Journal."

† Dr. Livingstone's "Missionary Trarels and Researches in South Africa." 

Psatur cir.

"He sendeth the springs into the ralleys, which run among the lills."-

length, after filtration through the earth, escapes at the surface.

3. From the meltings of snow and ice on the summits of mountains during the warmer seasons.

4. And water which oozes out at low levels from a wet soil in innumerable rills, not traceable to springs delivering a visible volume of water.

361. The whole extent of land drained by a river, including all its branches and tributaries, is its basin. Adjoining basins are divided from each other by tracts of land more or less elevated, and this land forms the water-shed or water-parting-meaning the boundary between some other and adjoining river basin. When the water-shed line of a river basin is sufficiently lofty to receive and retain abundant snow, it acts as a reservoir, and a store of moisture in the form of snow is stored up during the cold season. As the summer advances the snow melts, and the river is thus supplied during the warm and dry season, the supply being proportionate to the accumulation of snow.

362. Why do Rivers Drain the Waters of the Land into the Sea?

Because, in those parts of the earth subject to riverdrainage, the precipitation is greater than the evaporation; thus, the amount of water borne down by every river that runs into the sea may be considered as the excess of the precipitation over the evaporation that takes place, in the valley drained by that river.

363. This excess comes from the sea; the winds convey it to the interior ; and the forces of gravity, dashing it along in mountain torrents or gentle streams hurry it back to the sea again.

364. In other parts of the earth, the evaporation and precipitation are exactly equal, as in those inland basins such as that in which the city of Mexico, Lake Titicaca, the Caspian Sea, \&cc., are situated, which basins 
"They give drink to every beast of the field: the wild asses quench their thirst."-PSALM cir.

have no ocean drainage. If more rain fell in the valley of the Caspian Sea than is evaporated from it, that sea would finally get full and overflow the whole of that great basin. If less fell than is evaporated from it again, then that sea, in the course of time, would dry up, and plants and animals there would all perish for want of water.

365. The surface of the Caspian Sea is more than 83 feet below the level of the ocean, in its lowest part, and has an area of 18,000 square miles-nearly equal to the area of Spain. In Europe alone it drains an extent of 850,000 square miles, receiving the Volga and the Ural, and other great rivers of the north. It has no tide, and its navigation is dangerous from heavy gales, especially from the south-east, which drive the water miles over the land; a vessel was stranded in one of these storms 46 miles in land from the shore. It is 600 feet deep to the soutl, but is shallower to the east, where it is bounded by impassable swamps many miles broad. It is evident, from the saline nature of the soil and the shells it contains, that the plains. round the Caspian, the Lake Ural, and the Steppes, even to the Ural Mountains, had once formed part of the Black Sea; 57,000 square miles of that country are depressed below the level of the oceana depression which extends north wards beyond the town of Saratow, 300 miles distant from the Caspian.*

366. Why does the Condensation of Clouds by Mountaintops Economise the Advantages derivable from Rain?

In consequence of the effects of mountrins in cooling currents of moist air, and causing the condensation of aqueous vapour in the manner abore described, it follows that in every country, as a general rule, the moro elevated regions become perpetual reservoirs of water, which descends and irrigates the lower ralleys and plains.

367. 'The largest quantity of water" is first carried to the highest region, and then made to descend by steep declivities towards the sea; so that it acquires superior velocity, and removes more soil then it would do if the

* Mrs. Somerrille. 
- Let darkness and the shadow of death stain it; let a cloud dwell upon it; let the blackness of the day terrify it."-Joв iii.

rain had been distributed over the plains and mountains equally in proportion to their relative area. The water is also made by this arrangement to pass over the greatest distances before it can regain the sea.

368. The mechanical force exerted by running water in undermining cliffs, and rounding off the angles of hard rocks, is mainly due to the intermixture of foreign ingredients. Sand and pebbles, when hurried along by the violence of the stream, are thrown against every obstacle lying in their way, and thus a power of attrition is acquired, capable of wearing away the hardest silicious stones, on which water alone would make little or no impression."

369. Why are the Waters of Rivers sometimes "Black Waters?"

The peculiar colours displayed by various rivers are probably due to a solution of carburetted hydrogen, to the luxuriance of vegetation, and to the quantity of plants and herbs on the grounds over which they flow.

370. These "black waters" several times occur in the upper portion of the basin of the Oronoco and its tributaries. The Atabasso, whose banks are adorned with Carolinias and arborescent Melastomas, and the Temi, Tanmini, and Guainia are all rivers of a coffee-brown colour. In the shade of the palm grores this colour seems to pass into almost ink-black. When placed in transparent vessels, the water appears to be of a golden yellow.*

371. But there are various other causes imparting peculiar characteristics to the waters of rivers. It is well known that the stream of the Mississippi is charged with sediment of a different colour from that of the Arkansas and Red Rivers, which are tinged with red mud, derived from rocks of porphyry in "the far west." The waters of Uruguay, says Darwin, draining a granitic country, are clear and black; those of the Parana red. The mud with which the Indus is loaded is of a clayey hue; that of the Chenab, on the other hand, is reddish; that of the Sutlej is paler.

372. The same causes which make these several rivers, sometimes 
"He hath compassed the water with bounds until tho day and night come to an end."-Joв xxvi.

situated at no great distance the one from the other, to differ greatly in the character of their sediments, will make the waters draining the same country at different epochs, especially before and after great revolutions in physical geography, to be entirely dissimilar.

373. Marine currents will be affected in an analogous manner, in consequence of the formation of new shoals, the emergence of new islands, the subsidence of others, the gradual waste of neighbouring coasts, the growth of new deltas, the increase of coral reefs, and other changes.*

374. What natural Advantages are derived firom Lakes?

Being the sources of some of the largest rivers, they are of great importance for inland navigation, as well as fol irrigation; by their constant eraporation, they maintain the supply of humidity in the atmosphere, so essential to vegetation, and they beautify the country.

375. Why do Lakes tend to Equalize the Flow of Waters in Rivers?

Because they act as reservoirs. There are no less than 94,000 lakes in comnection with the drainage basin of the River St. Lawrence, which is estimated to be equal to 297,600 geographical square miles; and the river, therefore, has a very equable flow in all seasons.

376. On the contrary, where no lakes exist, inundations take place on every considerable increase of the rolume of water to be discharged.

377. In what way does the Soil tend to Equalize the Discharge of Water by Rivers?

The soil, by its porosity, acts as a reservoir, and its gradual drainage equalizes the flow of the rivers. In climates where there is no broad division of the year into "rainy" and "dry" seasons, and where the high snow-fields 
"He clave the rocks in the wilderness, and gare them drink as out of the great deptlis."-PsaLr lxxvii.

are not largely developed, the rivers are subject to no material irregularities, excepting those which somewhat rarely result from long-continued drought or rains.

378. What are the distinctions between Cataracts and Cascades?

A cataract is a large mass of water precipitating itself in one or more unbroken sheets from top to bottom of a precipice. By a cascade is

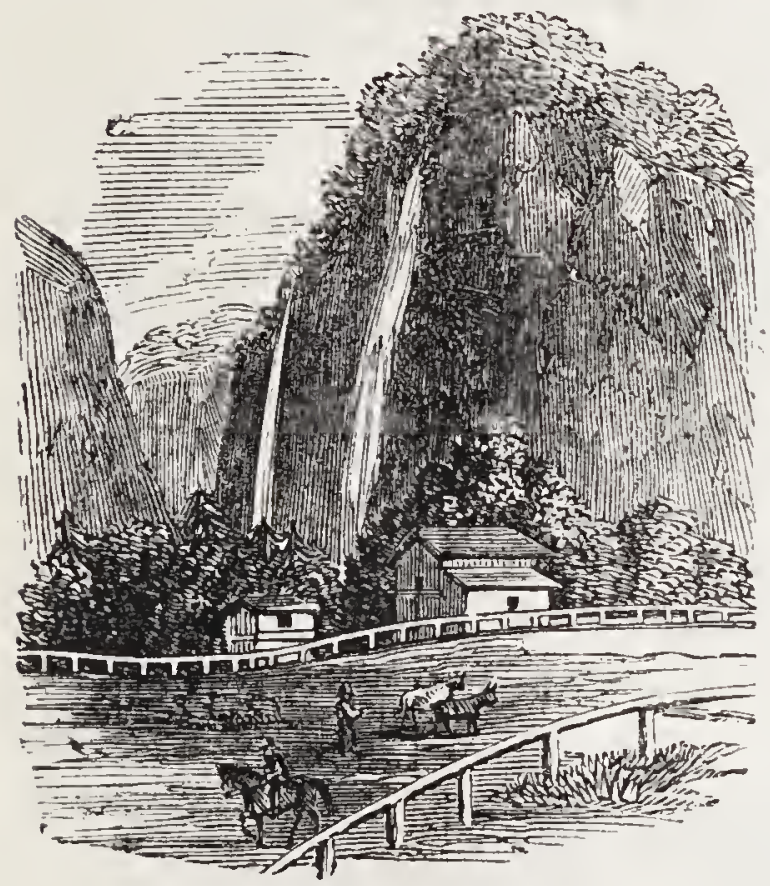
meant a succession of falls, or the leaping of water from rock to rock in its descent, as down a flight of steps.

379. The loftiest cataract in the world is to bo found in the Yohanite Valley, California, where as large a river as the Thames at Richmond makes a single leap of 2100 feet perpendicular, WATERFALLS. the total height of the fall being 3100 .

380. The Falls of Niagara, in Canada, form two splendid cataracts, one of which has a descent of 158 feet, the other of 164 feet. The traveller to the Falls hears at the distance a deep booming sound, and this becomes louder until he stands in view of the bewildering cataract which an observer thus describes :-

381. So entirely was I unprepared for the enormous volume of water, that, in the weakness of my comprehension and inability to 
"Who hath divided a watercourse for the overflowing of waters, or a way for the lightning of thunder ?"-JuB xxxviii.

grasp the scene, I was unwilling to turn my aehing eyes from the glorious spectaele, apprehending it could only endure for a season, and that the overwhelming rush of water must speedily cease. But, as 1 gazed with trembling anxiety, and marked no ehange beyond the masses of spray elouds, swayed by the wind aeross the mighty sheet which ever retained its sublime proportions, the truth began to foree itself upon me ; that for thousands of years the waters had been falling, by day and night, at all times and seasons, ever sounding, in a voice which, onee heard, ean never be forgotten, the praise of Him who bade them flow. Here, indeed, may be felt the beauty of the words in our canticle, "O ye seas and floods, bless ye the Lord, praise Him, and magnify Him for" ever!"-and it was probably with feelings of deep awe that the Indian of olden time, worshipping the Great Spirit, gave the peeuliarly appropriate name " $\mathrm{O}$ - $\mathrm{Ne}$-aw-ga-rall," the "Thunder of Waters," to this matehless seene. It is indeed eloquent "as with the voice of a great multitude-the voice of many waters-the voiee of many thunderings, saying, 'Alleluia, for the Lord God omnipotent reigneth." "

382. Why is the Noise of the rushing torrents of Cataracts Greater by Night than in the Day?

Probably the currenis of heated ascending air, by

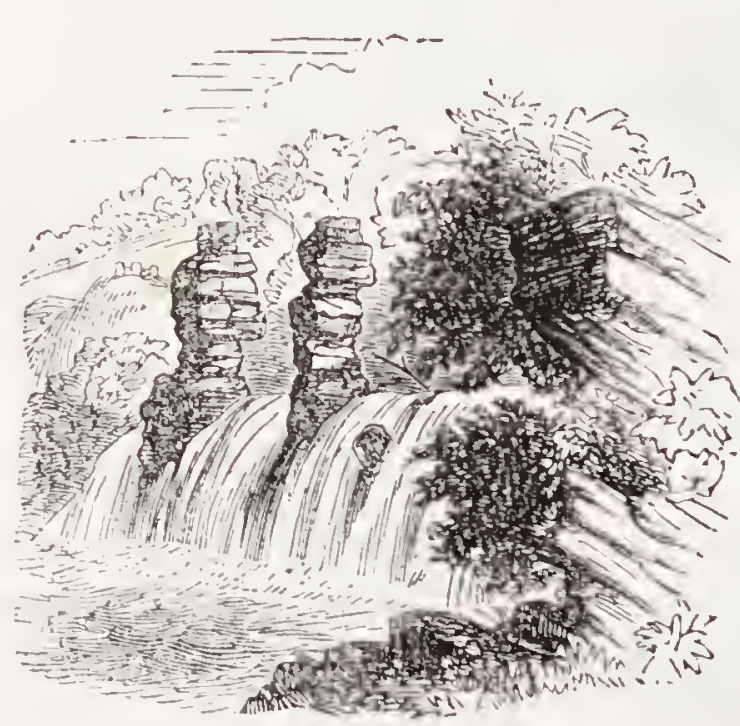
causing irregular density in the elastic medium, impede the propagation of sound during the day by the disturbances they occasion in the waves of sound; whereas during the nocturual cooling of the earth's surface, the upward currents cease.

383. One of the grandest effects of Alpine scenery arises WALLS OF THE REUSS. from the immense bodies of water either flowing into lakes, rushing wildly off into impetuous 
"But with an overrunning flood lie will make an utter end of the place thereof, and darkness shall pursue His enemies."-NAHOM i.

rivers, or flinging themselves over towering precipices and falling hundreds of feet in foaming cataracts. Of these the most remarkable are the Reichenbach, which, rising at the foot of the Wetterhorn, fall down the side of Mount Sheidec to the depth of 400 feet, and the Staubbach, which rolls perpendicularly from so vast a height as to resolve itself into a cloud of spray that looks like dust, from which it has received its name, meaning a spring of dust. The perpendicular height of this fall is said to be 930 feet. Filling up many of the chasms of the Alpine mountains, are vast bodies of frozen water, that appear to have been lashed into frightful storms and then converted into ribs of ice, the crested waves standing as they last rose, fixed in motionless rigidity. These glaciers or frozen seas form some of the most sublime and wonderful sights in these mountains.

384. The most remarkable effect of a cascade is that ceaseless undermining of its base and sides, and consequent rupture of the spout or edge of the fall, which causes by slow degrees the cascade to retire farther and farther up the mountain side, and produces those awful and still deepening portals of impending rocks which so much aggrandize the sublimity of a noble waterforce.

385. This effect may be excellently observed in the carboniferous limestone district of the north of England, where so many beautiful streams leap from the beds of limestone over perishing shales and sandstones, and, rising in foam, sap and undermine the base of a large semicircular cliff, till at length the solid limestone crown gives way, and the insatiable river renews its destroying attacks. The same thing is seen in many of the Swiss waterfalls, particularly in the manifold falls of the Geissbach.

386. Sir C. Lyell ingeniously applies the acknowlerged fact of the recession of the Falls of Niagara, which appear to have been pushed back several miles, at the rate of forty or fifty yards in fifty year's, to the possible clischarge hereafter through the St. Lawrence, of the waters of Lake Erie. Such a discharge would, of course, occasion a local. cleluge; but the lake is so rapidly filled up by sediment, that it is a question whether it will not become dry ground before the falls of Niagara shall have been pushed back so far as to be capable of emptying it. The fall of the Rhine at Schaffhausen is a grand exhibition of the erosive power of water, particularly the wearing of the base of the 
"Hast thou entered into the treasures of the snow? or hast thou seen the hail ?"-Joв Xxxviii.

two island pinnacles of limestone which now stand proudly in the midst of the currents, but will eventually be hurled down the thundering cataracts.

387. What are Glaciers?

They are vivers or fields of ice, which accumulate in elevated regions, through the freezing and accumulation of snow. The frozen mass of snow upon mountain heights above the snow-line, augmenting from year to year, would add indefinitely to the altitude of mountain summits, were it not relieved by its descent through the larger and deeper mountain valleys to regions far below the general snowline.

388. To these it slowly finds its way in the forms of rivers of ice, the consolidation of which is produced by pressure, and by the congelation of water infiltrated into the porous mass, which is always undergoing partial liquefaction, and receiving in summer occasional showers of rain on its surface.

389. In a day of hot sunshine or mild rain, innumerable rills of pure and sparkling water run in icy channels along the surface of the glaciers, which in the night shrink and come to nothing. They are often precipitated in bold cascades into deep fissures in the ice, and contribute, together with springs, to form torrents, which flow in tunnels at the bottom of the glaciers for many a league, and at length issue at the extremities from beneath beautiful caverns or arches. The waters of these streams are always densely charged with the finest mud, produced by the grinding of rock and sand under the weight of the moving ice.

390. The little village of Randa, in Switzerland, is situated in a valley beneath a high mountain called the Weisshorn, the highest peak of which is 9000 feet above the village. This mountain is covered with 
"Fire, and hail; snow, and vapours; stormy wind fulfulling his word."Psalm cxiviii.

ice and snow, but at various times portions of the vast glacier have been loosened and precipitated with tremendous violence into the valley. An accident of this sort occurred in 1636, when thirty-six persons lost their lives; and others in $\mathbf{1 7 3 6}$ and $\mathbf{1 7 8 6 .}$ On the 27th of December, 1819, at six o'clock in the morning, a large projecting part of the glacier fell on a mass of ice with a frightful crash. The snow, ice, and stones covered the fields below the village for a length of about 2400 feet, and a width of 1000 feet. The village itself was not injured by the fall, but a frightful hurricane was produced by the sudden disengagement of the immense masses of ice : the largest larch trees were torn up by the roots ; blocks of ice many feet thick were thrown to the distance of half a league beyond the village; the spire of the church was carried away; the crops were destroyed; houses and other buildings levelled to the ground, and many persons injured or killed. Several families were carried away with their louses and buried in their ruins, or in the wreaths of snow.*

391. What are the Effects of Glaciers upon Mountainous Countries?

As well as forming vast reservoirs of water, which is set fiee as the ice descends to a lower and moro temperate elevation, glaciers transport gravel, sand, and huge stones to great distances, and they smooth, polish, and score the rocky channels and the boundary walls of the beds through which they pass, so that stones thus polished and scoured, when borne to considerable distances by natural causes, have excited curiosity and wonder.

392. All sand and fragments of soft stone which fall through fissures and reach the bottom of the glaciers, or which are interposed between the glacier and the steep sides of the valley, are pushed along and ground down into mud, while the larger fragments have their angles worn off. At the same time the fundamental and boundary rocks are smoothed and polished, and often scored with parallel furrows, or with lines and scratches produced by hard minerals, such as crystals of quartz, which act like the diamond upon glass. This 
"Will a man leave the snow of Lebanon which cometl from the rocks of the field? or shall the cold flowing waters that come from another place be forsalien?" -JERExIAI Xviii.

effect is perfectly different from that caused by the action of water, or a muddy torrent forcing along heary fragments; for, when stones are fixed firmly in the ice, and pushed along by it under great pressure in straight lines, they scoop out long rectilinear furrows or grooves parallel to each other.*

393. What observations have been made in connection with the Descent of Glaciers?

It has been observed that the downward motion of ice from mountains towards valleys is a continuous and regular motion, going on day and night without starts or stops.

1. That it occurs in winter as well as in summer, though less in amount in the former.

2. That rain and melting snow accelerate the glacial motion.

3. That the centre of the glacier moves faster than the sides, and that the surface moves faster than the bottom, as is the case in the water of a river.

4. That the motion of the glacier is not prevented, nor its continuity hindered, by contractions of the rocky channel in which it moves, nor by the inequalities of its led.

394. The theory of glacial motion is this:-That a glacier is a plastic mass impelled by gravity, laving tenacity sufficient to mould itself upon the obstacles which it encounters, and to permit one portion to slide past another without fracture, except when ihe forces aro so violent as to produce discontinuity in the form of a crevasse, or of a bruised condition of the mass so acted on, that the motion of such a mass on a great scale resembles that of $a$ river, allowance being made for almost incomparably greater velocity; lence the retardation of the sides and bottom. Finally, diminution 
"As the cold of snow in the time of harvest, so is a faithful messenger to them that send him, for he refresheth the soul of his masters."-Proveuns Xxv.

of temperature retards its motion, whilst warmth and wet produce a contrary effect.*

\section{Why does Water Freeze?}

Because, when the latent heat of water is withdraun, the atoms composing the fluid arrange themselves in groups of crystals.

396. When a cold current of air passes over the surface of a lake or stream, it abstracts a quantity of heat, and, the specific gravity of the water at the surface being thereby increased, the cooled portion sinks. This circulation may continue until the whole body of fluid has been cooled down to $40^{\circ} \mathrm{F}$., after which, if the cold increase, the vertical movement ceases; the water which is uppermost expands and floats over the heavier fluid below, and, when it has attained a temperature $32^{\circ}$ Fahr., it sets into a sheet of ice. $\dagger$

397. Why is "Ground Ice" sometimes formed?

It is probable that the mechanical action of a rumning stream produces a circulation by which the entire body of water is mixed and cooled throughout; and the whole being thus reduced to the freezing point, ice forms at the bottom for two reasons-First, because there is less motion there; and secondly, because the water is in contact with solid rocks or pebbles, which have a cold surface.

398. According to the law of congelation, which governs the freezing of water, it would appear impossible that ice should ever form at the bottom of a river. Yet the occurrence of ground ice is not unfrequent; and, in coun-

* Forbes's "Norway and its Glaciers."

t See "Reason Why-General Science." 
"Ho turneth rivers into a wilderness, and the watersprings into dry ground." -Psalm crii.

tries where the intensity and duration of cold are great, rivers and torrents acquire an increase of carrying power, through blocks of this kind of ice having gravel and largo stowes frozen on to their under surfaces; they afterwards rise to the surface, and bear the stones and gravel in the direction of the current.

399. Why does not Sea-water Freeze?

Because the saline matter which sea-water holds in solution prevents its congelation, except where the most intense cold prevails.

400. But the drifting of snow from the land often renders the surface water brackish near the coast, so that it sheet of ice is readily formed there; and by this means also a large quantity of gravel is frequently conreyed from place to place, and heary boulders also, when the coast-ice is packed into dense masses.

401. In parts of the Baltic, such as the Gulf of Bothnia, where the quantity of salt in the water amounts in general to one-fourth only of that in the ocean, the cntive surface freezes over in winter to the depth of fire or six feet. Here also stones are frozen in, and afterwards lifted up about three feet perpendicularly on the melting of the snow in the summer, and then carried by floating ice-islands to great distances.

402. Professor Von Baor states, in a communication on this subject to the Academy of St. Petersburg, that a block of granite weighing a million of pounds was carried by ico during tho winter of 1837-8 from Finland to the island of Hockland, and two other hugo blocks were transported about the years 1806 and 1814 by packed ice, on the south coast of Finland, one block having travelled about a quarter of a mile, and lying about eighteen feet above the level of the sea.* 
"Hast thou entered into the springs of the sea? or hast thou walked in the search of the depth?"-Jos $\mathrm{x} \times \mathrm{x}$ riii.

403. What effect has Frost upon the Solid Matter of the Earth?

Frost is an important agent in reducing large masses to smaller fragments. Some stone, if brought to the surface in winter full of its "quarry water," will break in pieces directly.

404. What is the origin of Springs?

The generality of springs owe their origin to rain and atmospheric moisture, as is evident from the fact that they become languid, or entirely cease to flow, after long droughts, and again become more active after a continuance of rain.

405. The water discharged from the atmosphere percolates loose and gravelly soils, and descends to various degrees of depth into the earth, until it meets with an impervious bed, where it accumulates as in a reservoir, and when it exceeds the capacity of the reservoir it oozes out through the most direct opening it can find.

406. We cannot, therefore, be surprised that springs should be thrown out on the side of a hill whore the upper strata consist of chalk, sand, or other penetrable substances, while the subjacent are composed of clay or other impervious soils. The only difficulty, indecd, is to explain why the water does not ooze out everywhere along the line of junction of the two formations, so as to form one continuous land-soak, instead of a fow springs only, and these far distant from each other.

407. The principal cause of the springs appearing only at a few points is, first, the frequency of rents and fissures, which act as natural drains; secondly, the existence of inequalities in the upper surface of the impenetrable stratum, which lead the water, as ravines and valleys do on the external surface of a country, into certain low levels and channels.

408. What is the cause of Mineral Springs?

Mineral springs owe their distinguishing qualities to 
"The words of a man's mouth are as deep waters, and the well-spring of wislom as a flowing brook."- 'roverss xviii.

the nature of the mineral beds through which they percolate The minerals taken up in solution by waters consist of a variety of substances, but chiefly salts, with bases of lime, magnesia, alumina, and iron, combined with carbonic, sulphuric, and muriatic acids. Muriate of sola, silica, and free carbonic acid are frequently present.

409. So great is the quantity of muriate of soda in some springs that they yield one-fourth of their weight in salt. They are rarely, however, so saturated, and generally contain, intermixed with salt, carbonate and sulphate of lime, magnesia, and other mineral ingredients. The brine-springs in Cheshire are the richest in our country, those of Northwich being almost saturated. Those of Barton, also, in Lancashire, and Droitwich, in Worcestershire, are extremely rich. They are known to have flowed for more than 1000 years, and the quantity of salt which they have carried into the Severn and Mersey must be enormous. These brine-springs rise up through strata of sandstone and red marl, which contain huge beds of rock salt.

410. The mineral concretions formed by the waters of the Gieat Geyscr of Iceland corer an extent of four leagues. This curious formation may be seen passing by insensible gradations from a loose friable state, the result of a rapid deposition, to the most compact and transparent masses, in which impressions of the ?eaves of the birch tree and portions of the stems are distinctly perceptible. Rushes and various kinds of mosses, converted into a white silicious rock, in which the minutest fibres are preserved, also occur; but on the margin of the Geysers, from the splashing of the water, the depositions resemble large cauliflowers; and on breaking these masses regetable impressions are often discovered.

\section{What are Artesian Welle?}

'These are wells sunk to a considerable deptl in the earth, upon a method long practised in Artois, from which the name is derived. Experience in boring them shows that at various depthis in the earth there are sheets, and in some places currents, of fresh water. 
"Ile sayeth to the deep, Be dry, and I will dry up thy rivers."-Isaral xlip.

412. The instrument employed in sinking these wells is a large auger, and the cavity bored is usually from three to four inclies in diameter. When a hard rock is met with, it is first triturated by $\mathbf{a}$ rod of iron, and the materials, being thus reduced to small fragments or powder, are readily extracted. To prevent the sides tlus bored from falling in, a jointed tube, either of wood or metal, is inserted. It frequently happens that, after passing through hundreds of feet of retentive soils, a water-bearing stratum is at length pierced, when the fluid immediately ascends to the surface and flows over. The first ruslr of the water up the tube is often violent, so that for a time the water plays like a fountain, and then, sinking, continues to flow tranquilly. This spouting of the water, in the first instance, is probably owing to the disengagement of air and carbonic acid gas, for both of these have been found to bubble up with the water. From a well at Hammersmith the rush of water from a depth of 360 feet was so great as to inundate several buildings, and do considerable damage. In 1851 the total supply obtained from the chalk near London was estimated at about twelve million gallons a day, and, as some wells were opened, it was found that the level to which the water rose decreased, showing the limited capacity of the subterranean reservoir.

413. What is the "Reproductive Agency of Rivers?"

Rivers are reproductive when they form alluvial plains by depositing the earthy matters of which they denude the land along their course.

414. The Alluvial Plain of the Mississippi begins to be of great width below Cape Girardeau, fifty miles above the junction of the Ohio. Here it is about fifty miles broad, south of which it contracts to about thirty miles at Memphis, expands again to eighty miles at the mouth of the White River, and then, after various contractions and expansions, protrudes beyond the general coast-line in a large delta, about ninety miles in width. The area of the great plain thus defined has been estimated at 31,200 square miles, with a circumference of about 3000 miles, exceeding the area of Ireland.

415. The Delta of the Nile is another grand example of this agency. That Egypt was "the gift of the Nile," was the opinion of her priests before the time of Herodotus. The configuration and composition of the low lands leave no room for doubt that the sea once washed the 
"He turned the sea into dry land: they went through the flood on foot: there did we rejoice in Him."-Psalar lxvi.

base of the rocks on which the Pyramids of Memphis stand, the present base of which is washed by the inundation of the Nile, at an elevation of seventy or cighty feet above the Mediterranean. The distance between Memphis and the most prominent part of the delta, in a straight linc north and south, is about 100 geographical miles; the length of the base of the delta is more than 200 miles, if we follow the coast betwcen the ancient extreme castern and western arms; but as these are now blocked up, that part only of Lower Egypt which intervenes betwcen the Rosetta and Damietta branches is usually called the Delta, he coast line of which is ninety miles in length.

416. Lakes exert a like reproductive agency, but the strata formed by lakes, unlike those deposited by rivers, remain in the greater part covered by water, until changes in the earth's configuration occur, by which the water is withdrawn. The most characteristic distinction betwcen the deltic deposits of lakes and rivers consists in the nature of the organic r'cmains which become embedded in them, for in the case of a lake it is obvious that these must consist exclusively of such genera of animals as inhabit the land or the waters of a river or lake; whereas, in the other case there will be an admixture, and most frequently a predominance, of animals which inlrabit salt water.

417. It is thus that, to some extent at least, the encroachments of the sea upon the land are compensated. Imperfect as is our information of the changes which deltas have undergone within the last threc thousand year's, thcy are sufficieut to show how constant an interchange of sea and land is taking place. In the Mediterranean alone, many flourishing inland towns, and a still greater number of ports, now stand where the sea rolled its waves sincc the era of the early cirilization of Europe. If we could compare with equal accuracy the ancient and actual state of all the islands and continents, we should probably discover that millions of our race are now supported by lands situated where deep seas prevailed in earlier ages. In many districts not yet occupied by man, land animals and forests now abound where ships once sailed; and, on the other hand, we shall find that inroads of the occan have been no less considerable.*

\section{What are Deltas?}

The waters receding from the land generally fall off on three sides, leaving the land in a triangular form, 
"As the waters fail from the sea, and the flood decayeth and drieth up."JoB xiv.

which, being the form of the letter $\Delta$ of the Greek alphabet, takes the name of delta. These deltas constitute plains, rendered fertile by the waters of the rivers by which they are formed, as the Nile, the Mississippi, \&c.

419. The original cause of a delta is sometimes a natural obstacle, which splits the stream into two branches, but it more commonly results from a bank deposited by the river itself.

420. A vast quantity of eartly and other matter is conveyed towards the sea by rivers. The Ganges has been computed to deliver into the sea annually $534,600,000$ tons of solid matter; the Mississippi 292,700,000; and the Irawadi 102,500,000. No wonder, then, that in

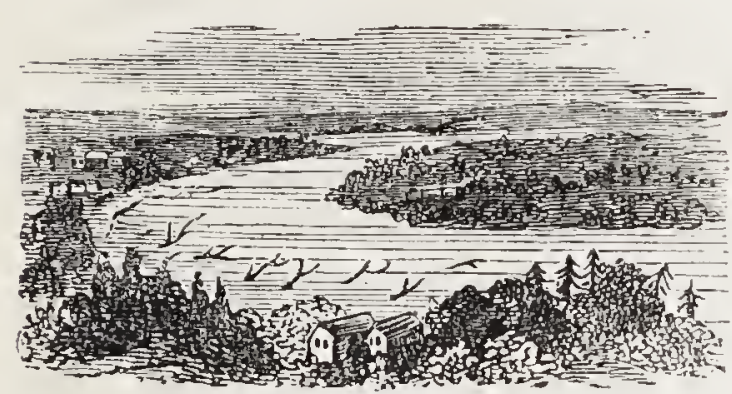

DELTA. the course of ages deltas should accumulate. The deltas of the Mississippi and the Lena carry out the rivers to great distances, and form very projecting points, that of the Mississippi in particular, which is singularly ramified, and in which the main channel prolongs itself, on land of its own formation, like the claw of some web-footed bird, far into the Gulf of Mexico, being increased by immense quantities of drifted trees, which meet together, and form a vast floating mass. One of these, in 1816, was estimated to contain upwards of $250,000,000$ cubic feet of timber, accumulated, in consequence of some local obstruction, in only 38 years.*

421. Why are the Waters of Streams and Rivers less rapid at their Sides than in their Centres?

Because the water that runs at the sides is retarded by friction against the banks. So, also, the stream at the bottom is retarded, and the greatest velocity is at the centre and on the surface of a stream. (There may, however, be local or accidental currents that exhibit exceptions to this rule.) 
"He divideth the sea with His power, and by His understanding He smitetl through the proud." - Јов xxvi.

When the velocity is sufficiently great, the soil composing the sides and bottom gives way. A velocity of three inches per second at the bottom is sufficient to tear up fine clay; six inches per second, fine sand; twelre inches per second, fine gravel; and three feet per second, stones of the size of an egg.

422. But a question naturally arises, how the more tranquil rivers of the valleys and plains, flowing on comparatively level ground, can remove the prodigious burthen which is discharged into them by their numerous tributaries, and by what means they are enabled to convey the whole mass to thc sea? If they had not this removing power their channels would be annually choked up, and the ralleys of the lower country, and plains at the base of mountain chains, would be constantly strewed over with fragments of rock and sterile sand.

423. But this evil is prevented by a gcneral law regulating the conduct of running water-that two equal streams do not, when united, occupy a bed of double surface. Nay, the width of the principal river, after the junction of the tributary, sometimes remains the same as before, or is even lessened. The explanation is afforded by the fact, that the addition of a smaller river augments the velocity of the main stream, often in the same proportion as it does the quantity of water. The causc of the greater velocity is, first, that after the union of trro rivers the water, in place of the friction of four shores and tuo beds, has only relatively half the amount of friction to overcome. And further, the main body of the stream being more distant from the banks, flows on with less interruption. And lastly, because a greater quantity of water moving more swiftly digs deeper into the river's bed. By this beautiful adjustment, the water which drains the interior country is made continually to occupy less room as it approaches the sea, and thus the most valuable part of our continents, the rich deltas, and great alluvial plains are prevented from being constantly under water.

424. What causes the formation of Estuaries?

The formation and keeping open of estuaries are due to the combined influence of tidal currents and rivers; for when the tide rises a large body of water suddenly enters the mouth of the river, where, being confined within narrower 
"From the rising of the sun unto the going down of the same, the Lord's name is to be praised."-Psatar cvii.

bounds, while its momentum is not destroyed, it is urged on, and having to pass through a contracted channel, rises and runs with increased velocity, just as a stream when it reaches the arch of a bridge scarcely large enough to give passage to its waters, rushes with a steep fall through the strch.

425. During the ascent of the tide, a body of fresh water flowing down in an opposite direction from the higher country is arrested in its course for several bours; and thus a large lake of fresh and brackish water is accumulated, which when the sea ebbs is let loose, as on the removal of an artificial sluice or dam. By the force of this retiring water, the alluvial sediment both of the river and of the sea is swept away, and transported to such a distance from the mouth of the estuary that a small part only can retur'n with the next tide.*

426. What is meant by "Valleys of Denudation?" .

By this term is understood valleys enclosed between hills, the strata of which correspond exactly, so that the valley has evidently been scooped out from their substance.

427. If you discovered among the ruins of a city fragments of wall, recurring at intervals, and standing in the same line, and if upon closer examination you ascertained that the different portions were built of the same materials, in precisely the same order, so that rows of brick, travertine, and tufo succeeded one another at intervals throughout, and with corresponding dimensions, assuredly you would conclude that the different fragments had originally formed one continuous wall, and that the breaches interposed were the result of time or violence. +

428. We are forcibly impressed with the slowness of these operations at the present day. Lakes are ascertained to shoal up in the proportion of only a foot in a century; and the deposits of the sea are known to be correspondingly tardy of accumulation. Hence we find, that

* Sir C. Lyell.

+ Wiscman's "Connexion between Science and Revealed Religion." 
"For thus saith the Lord, Ye shall not see wind, neither silall ye see rain: yet that ralley shall be filled with water, that ye may drink, both ye, and your cattle, and your beasts."-2 KIxgs iii.

during the cntire historic period the physical geography of our globe, with the exception of local and minor modifications, Las remained unaltered. The oceans, rivers, lakes, and mountains recorded in Scripturc form the physical features of the same regions at the prescnt day; the ocean which Crsar crosscd still separates the Briton from the Gaul; thc same rivers water the capitals of the same countries of Europe; whilc the samc Vesuvius, which overwhelmed Herculaneum and Pompeii, still thrcatens the surrounding districts; and the same submarinc volcanic agency which alarmed the Roman people continues in activity, and produces similar phenomena at the present day.*

420. To see rain-and-time-ploughed furrows winding in unccrtain directions over the horizontal lime-stones on a hill top, like a slow river on a level plain, but running a straight downward course on the slopes, like a stream descending from its parent mountains, is enough to impress on every beholder a secure conviction that the cxcavation of valleys must be explained on similar principles; that, as the feeble currents of dcscending rain, aided by atmospheric action through a long: course of time, liave bcen sufficient to plough their little courses, so the greatel action of cxisting streams has been sufficient to work out their actual channels, though the cxcavations of the broad valleys in which they run may have been accomplished by more violent and voluminous watcrs, flowing in directions predetermined by ancient subterranean movements.

430. It is probablc that the slow but incessent action of rain, bcating perpetually on the hard and soft surfaces of the carth, and removing grain by grain the materials looscned by the corrosion of gases, or the expansive agency of frost, may be, in a long scries of years, morc important in its effects than the violent water-spout, or the ravaging inundation of a bursting lake. $\dagger$

431. What is meant by "Valleys of Dislocation?"

These are caused by fissures of various dimensions, some of colossal size, which have been found during the upheaval and separation of the strata in the region of which they form a part. They frequently present steep escarpments, the strata on each side frequently bearing evidence of former continuity.

* Richardson.

$\dagger$ Philips. 
"The high hills are a refuge for the wild goats, and the rocks for the conies." -Pzalir civ.

432. Besides these are "Valleys of Undulation," produced by two neighbouring elevations, which, by lifting the strata on each side without occasioning a fracture or dislocation, have left a valley between, towards the middle of which their places are inclined, and of which they form the sides; and "Valleys of Elevation" which owe their origin to the circumstance that certain beds, having been originally raised in the form of a wave, have subsequently been exposed to the action of water and that a peculiar stratum harder than the rest, having resisted the abrading force, has formed a valley, as it were, lying in the breast of the elevation.**

433. What is the cause of Ravines?

Ravines may be caused by the splitting of rocks or earth during the upheaval of underlying strata, or by the denu-

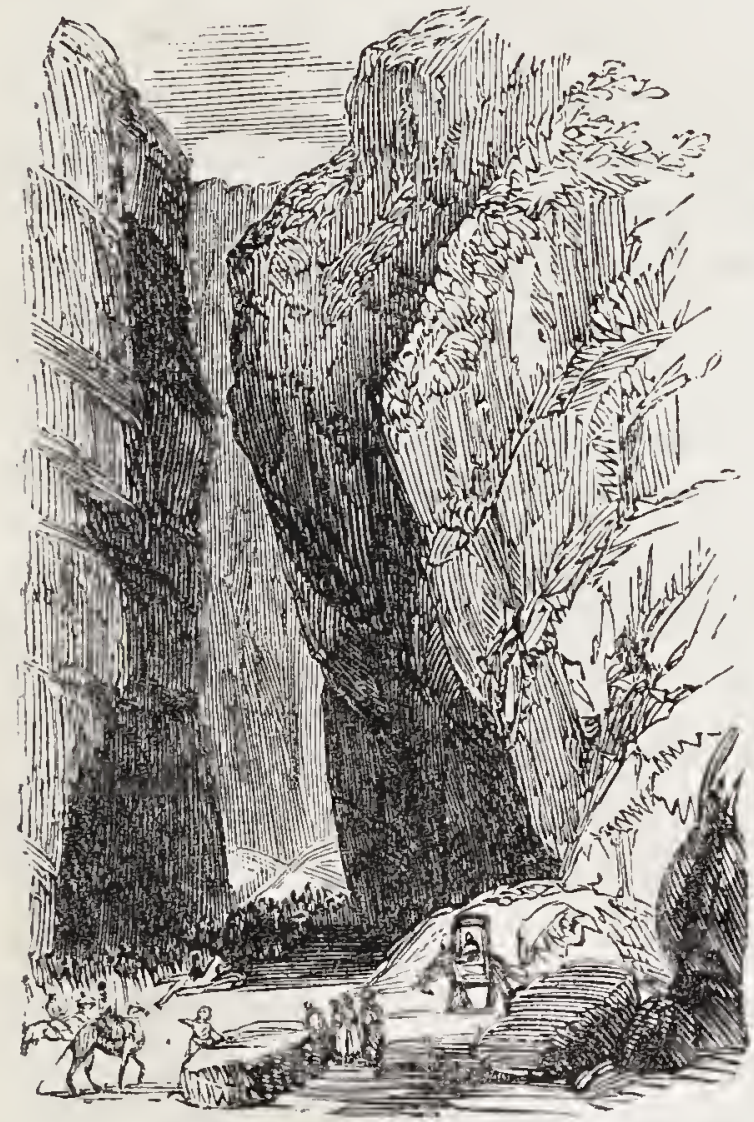

MOUNTAIN RAVINE. dation of rocks, by the washing away of loose earth filling the interspaces. They frequently occur in countries from which forests have been recently removed, and the exposure of the previously shaded earth to the heated rays of the sun gives rise to extensive earth-cracks. When these cracks are subsequently acted upon by streams of water they become beds for rivers, and sometimes they widen and deepen to such an extent as to present the seat of new valleys.

* Richardson. 
"Speak to the earth, and it shall teach thee: and the fishes of the sea sliall declare unto thee." -Јов xii.

434. In regard to the transporting power of water acting upon lavines, the beds of rivers, \&c., we may often be surprised at the facility with which streams of a small size, and descending in a slight declivity, bear along coarse sand and gravel; for we usually estimate the weight of rocks in air, and do not reflect on the compensative buoyancy when submerged in a denser fluid. The specific gravity of many rocks is not more than twice that of water, and very rarely more than three, so that almost all the fragments propelled by a stream have lost a third, and many of them half of what, we usually term their weight.*

435. Why are Sea-shells found upon various Mountains in Great Britain?

Because at an unknown period the island was submergedat least a height of 1700 feet, which now towers abore the sea, was then concealed in the bosom of the ocean.

436. The proofs lie plain and palpable before our eyes in the soft detrital masses, mixed in many places with marine shells. Grarel, sand, and common salt are widely spread over the lower regions of the island. The two former are found in some places at a very great height; in Argyleshire at about 1200, and in Wales at 1500 feet. In every valley in Scotland there are great tracts of gravel mixed with sand, forcing upon attention the fact of the former submersion of the land under the sea. When the sea stood from 1200 to 1500 feet above its present level, what was Britain? An archipelago of mountain islets, extending between Wales and Sutherland.

437. Why have we reason to believe that all Land Surfaces have been Subject to the Action of Water?

Because no new strata are thrown down on dry land, which remains nearly the same from year to year; whereas, in many parts of the bottom of seas and lakes, mud, sand, and pebbles are annually spread out by rivers and currents. There are also great masses of limestone growing in some seas, or in mid-ocean, chiefly composed of corals and shells. 
"And the waters prevailed exceedingly upon the carth, and all the high hills that were nnder the whole heaven were covered."-GENESIS vii.

438. The dry land is, indeed, exposed almost everywhere to gradual waste. Forests may be as dense and lofty as those of Brazil, and may swar'm with quadrupeds, birds, and insects; yet at the end of ten thousand years, one layer of black mould a few inclies thick may be the sole representative of those myriads of trees, leaves, flowers, and fruits-those innumerable bones and skeletons of birds, quadrupeds, and reptiles which tenanted the fertile region. Should this land be at length submerged, the waves of the sea may wash away in a few hours the scanty covering of mould, and it may merely impart a darker shade of colour to the next stratum of marl, sand, and other matter newly thrown down.

439. So, also, at the bottom of the ocean, where no sediment accumulates, seaweed, zoophytes, fish, and even shells may multiply for ages and decompose, leaving no vestige of their own form or substance behind. Their decay in water, although more slow, is as certain and eventually as complete as in the open air.* Nor can they be perpetuated for indefinite periods in a fossil state, unless imbcdded in some matrix which is impervious to water, or which at least does not allow a free percolation of that fluid, impregnated as it usually is with a slight quantity of carbonic or other acid. Such a free percolation may be preventcd either by the mineral nature of the matrix itself, or by the superposition of an impenetrable stratum; but if unimpeded, the fossil shell or bone will be dissolved and removed, particle after particle, and thus entirely effaced unless petrifaction happen to take place. $\dagger$

440. The sea is a powerful and ever-active agent of destruction, and the shores of our island present extensive proofs of its devastating: power. We find that lofty cliffs and rocky promontories arc in a state of decay, more or less rapid in proportion to the character of the materials which compose them, and the power they possess of resisting its abrading force.

441. Commencing with the shores of Orkney and Shetland, we obserre the effects of the waves on the primary formations of those distant isles; and proceeding to the mainland, we notice like traces of devastation along the eastern coast of Scotland, where tracts of land, villages, and towns are recorded to have been swcpt away by the sea.

* [Except probably at great deptlis of the sea, where the enormous pressure prevents the escape of the gases of decomposition.]-ED. R. W.

$\dagger$ Sir C. Lyell. 
"I am the Lord thy God, that divided the sea, whose waves roared: the Lord of Ilosts is His name." - IsAlAII li.

442. On passing the English border, we find the eoasts of Northumberland and Durham presenting similar marks of destruction, which are recorded in the historical descriptions of those distriets. On the shores of Yorkstive the same scene of devastation presents itself; several villages have been destroyed, of which, in some cases, a mere vestige, in others the name only remains, the amount of denudation depending largely on the nature of the eliffs, and their greater or less capability of resisting the waves.

443. Thus, at Bridlington, the cliffs are eomposed of plioeene deposits resting on the ehalk, a great portion of whiel have been swept away. The town and port of Ravenspurn, at which Henry VI. landed on his enterprise of dethroning Richard II., now exists only in the listorical reeords of that event. The low coast of Lincolnshire is protected by embankments, the destruction of whieh, by inundations, has at various periods occasioned the most disastrous rosults. Tracts of this fenny distriet, embanked and drained by the Romans, were lost after the departure of that people, by the deeay of the barrier's, and the inroad of the sea.

444. The coasts of Norfoll and Suffolk, being composed of softer materials, exhibit a striking example of the destructive power of the neean in the ruin of the eliffs; while the deposits of bars and sandbanks composed of the detritus thereof, act as barriers, and prevent its farther encroachments.

44j. While tracts of land and villages, together with the old town of Cromer and of Dunwich, have been swept away by the ocean, various districts have been won from the deep. History and tradition reeord the fact that the sea onee extended to Norwich, on an arm of which it. is reeorded in Saxon manuseripts to lave been situated; while aneient cliffs, existing far inland, prove that the sea has reeeded still more considerably from its ancient limits. Extensive devastation is observed along the coast of Essex, which is Iargely eomposed of strata appertaining to the London elay formation. The town of Haruich, stated to be the representative of a more ancient submerged town, ealled Orwell, is in inevitable danger of sliaring the fate of its predeeessor.

446. The coasts whieli surround the estuary of the Thamcs present examples of the countervailing destruetion and restoration of the land.

447. While the eliffs of the Isle of Sheppy, which consist solely of 
"O that thou hadst hearkened to My commandments! then had thy peace been as a river, and thy righteousness as the waves of the sea."-Isalar diviii.

London clay, are constantly wearing away, the channel which separated the Isle of Thanet from the mainland of Kent, has shoaled up, and formed new land. The Goodwin Sands are said to have constituted the estates of Earl Goodwin, which were submerged beneath the waves. Pursuing the inquiry along the coast of Kent, we find the work of devastation still in progress. The firmer cliffs of the chalk are undermined and destroyed as surely as the more yielding strata of the London clay. The cliffs of Dover are thus sapped, and considerable falls. constantly occur. At Folkestone, the same accidents are produced in a manner analogous to that which takes place at the south side of the Isle of Wight, in strata of the same geological formation, and which have given rise to the celebrated undercliff of that island. The chalk at Folkestone rests inclined on the gault, or blue clay. The water which passes through the porous strata so moistens the clay, as to occasion the overlying mass to slide down the inclined plane formed by the subjacent deposit, and thus to produce falls of enormous extent. The sand cliffs. of Hastings have suffered considerable destruction.

448. The chalk cliffs of Beachy Head have undergone like abrasion and disintegration. An enormous mass of rock, three liundred feet in length, and thirty in breadth, was precipitated some thirty years ago, and similar falls have since repeatedly occurred.

449. At Brighton, in the reign of Elizabeth, part, though not the whole, of the ancient town was situated, under the cliffs, on the spot where the Chain Pier now extends into the sea ; in the year 1665 , twentytwo tenements had been engulphed by the waters, but one humdred and thirteen still remained, which werc destroyed by the great storm of 1705.* The waste still continues; the road called the Marine Parade has repeatedly been narrowed; a battery formerly stood at the bottom of the New Steine, the site of which is now swept away.

450. Proceeding westward along the Sussex coast, we find various instances of land having been engulphed; several large churches, built in the immediate vicinity of the sea, are extremely disproportioned, in size and endowment, to the scanty population by which they are surrounded.

451. In investigating the Southern coast, we find the same conditions prevailing the bays are scooped out of softer deposits, while

* Dr. Mantell's "Geology of Sussex." 
"He stilleth the noise of the seas, the noise of their waves, and the tumult of the people."-PSALII IXV.

the liarder rocks, which have withstood the aetion of the waves, constitute the promontories and headlands. The latter are in a continual course of abrasion, their destruction being more rapid where the substratum consists of clay. Such is the case in the Isle of Wight, and the peninsulas of Portland and Purbeck.

452. The great landslip of December 24 th, 1839, which oecurred on the coast between Lyme and Axminster, was produced under similar cireumstances, the upper beds eonsisting of strata belonging to the elialk and greensand formations, the lower being eomposed of clay appertaining to the lias. The springs traversing the greensand had previously loosened the upper beds, and, by moistening the elay, produeed frequent falls, forming a kind of undercliff. On this occasion the season had been unusually wet, and, the upper strata having beeome saturated with moistmre, the clays had been rendered slippery, and the entire mass was set in motion; the whole of the beds above the lias, comprising masses of chalk, ehort, and greensand, were precipitated over the subjaeent beds of lias.

4j3. The neighbouring coast of Devon presents evidenee of like action; but, owing to the firmer nature of the rocks of that distriet, eonsisting largely of sandstones and limestones, appertaining to the Deronian and carboniferous groups, the action of the wares is less evident, and appear's to have been less rapid; while on the adjaeent shore of Cormucll the still harder and more erystalline eharacter of the phitonic rocks, the granites, syenites, greenstones, and the like, evince feebler marks of the ageney of the sea; and no perceptible change, of any importance, is recorded to have taken place in the configuration of the coast during the records of man. The general principles which are remarked in other loealities are observable here; the softer rocks being gradnally lollowed out into creeks and bays, while the larder strata are left to protrude as headlands; the results being proportionate to the rarious eauses arising from the unequal resistanee of the roeks, the power of currents, tides, waves, and breakers, and the original form of the coast-line. Proceeding round the Land's End, the same description applies to the northern shores of Devon, Somerset, and the adjaeent distriets of WVales.

4i4. On the Chcshire coast the cliffs, composed of the softer elays and maris of the new red sandstone, liave yielded immensely to the 
"I beheld, ant lo, the fruitful place was a wilderness, and all the cities thereof were broken down."-JEREMIAH iv.

advance of the ocean, and, though, in the estuary of the Severn, land both in Somersetshire and Gloucestershire, has, to a considerable extent, been formed, yet the loss on this part of the coast far exceeds the gain.**

455. The Zuyder Sea was formerly a small inland lake, formed by an arm of the Rhine; but in the thirtecnth century the sea covered a large part of the surrounding continent, and formed this basin. In 1421 the sea swallowed in one night seventy-two villages, with one hundred thousand inhabitants, in the neighbourhood of Dordrecht, and changed the whole surrounding country into a lake. In the same manner the Dollart, near East Friesland, was formed in the thirteenth century by the sea overflowing a well-cultivated tract of land. Much of the westcrn coast of Sleswick has been swallowed by the sea. The island of Norstrand was buried in 1634 almost entirely by the waters, and of Heligoland nothing remains but the rocks. Many more events like thesc may have happened in ancient times which are not recorded in history. Several straits bear certain traces of the sea having broken through them; and many groups of islands have evidently been torn from one another by the action of the waves. Between Calais and Dover an isthmus probably existed in former times which has been broken through by the waves, for the soil lises on both sides, forming a kind of dyke, exlibiting corresponding strata; and the ridge of mountains which in France terminates at Calais, rises at the point of land in Kent in the samc direction, and contains the same minerals, according to Desmarets. The three straits which lead from the ocean into the Baltic lave probably been formed by the breaking through of the sea, as the name seems to show, for the old national word belt still signifies, in Friesland, an inroad of the sea. It was bclieved by the ancicnts that Sicily liad in former times been connected with Calabria, but was afterwards severed from it by the raves. According to an old tradition, which seems to be confirmed by the existence of the rock called Adam's Bridgc, Ceylon was formerly connected with Coromandel; and there is no probability that the Straits of the Dardanelles, of Constantinople, and of Gibraltar, originally existed in their present state. Most likely

* Richardson's "Introduction to Geology." 
"O Lord, how manifold are Thy works! in wisdom hast Thou made them all: the earth is full of Thy riches."-PSALsI civ.

America, too, was comnected formerly with Asia by a natural bridge, over which the first inhabitants came, and which was afterwards. destroyed by the wayes. The indented outline of almost all coasts, and the situation of most islands, bear distinct marks of violent disruption by the action of water.*

456. Why are the Geological Deposits arranged into three Great Divisions_"Primary," "Secondary," and "T'ertiary?"

The plutonic and metamorphic rocks originally bore the name of primary, it being supposed that they were formed before all others. It was found, however, that they were of various ages; that some of them had been erupted as late as the close of the secondary, and other's during the tertiary period, having entered and penetrated the strata of that date:

457. That the so-termed transition strata, as the secondary were called, were in like manner of various geological dates and characters; and the result has been the adoption of the arrangement now generally received, by which-

458. The primary rocks, as they were previously termed, are distinguished as plutonic or unstratified, and metamorphic or stratified, while the term "transition" is virtually abolished.

459. The whole series of fossiliferous deposits, from the earliest up to the chalk, are still termed secondary, the inferior beds up to the carboniferous series being sometimes styled the lower; those from the carboniferous system to. the oolite, the middle; and the wealden and chalk, the upper.

460. The strata which overlie the chalk retain the 
"If I should count them, they are more in number than the sand: when I awake I am still with Thee." - I'salar cxxxix.

name of tertiary, being generally formed out of the fragments and ruins of the earth's surface.

461. The loose and superfieial beds of sand, loam, and gravel are denominated modern alluvium; and as these last in some distriets are strewn with boulders and masses of primary roek, suel deposits with some others are termed ancient alluvium, the beds of gravel, sc., being supposed to be the result of ageneies still in operation, while the drift and boulders are regarded as the effeet of violent floods or inundations whieh have ceased to aet on our globe.*

462. What Changes occur upon the Earth's Surface through the Drifting of Sands?

Sandbanks are sometimes thrown up beyond the reach. of tides, and driven by the wind inland; thus effecting the desolation of whole regions by their slow but certain progress.

463. Egypt instantly presents herself to the imagination, with her strpendous Pyramids, the sepulchres of a mighty raee of monarels, and the wonder of the world; her temples and palaces, once so splendid and massive as to bid defiance to the ravages of time; her plains and valleys, formerly teeming with abundanee and supporting a numerous population; now stripped of her ancient glories, her fairest regions depopulated and converted into arid wastes; her eities orerwhelmed and prostrate in the dust, and the temples of her gods half buried beneath the sands of the desert.

464. The drifting of the sands of the Lybian desert by the westerly winds, has left no lands capable of eultivation on those parts of the western bank of the Nile which are not sheltered by mountains; while in Upper Egypt whole districts are eovered by moveable sands, and here and there may be seen the summits of temples and the ruins of cities which they have overwhelmed. Nothing can be more melancholy than to walk over villages swallowed up by the sand of the desert; to trample under foot their roofs and minarets; and to reflect that yonder were eultivated fields, that there grew trees, that here were the

* Richardson. 
"And every one that heareth these sayings of Mine, and doeth them not, shall be likened unto a foolish man, which built his house upon the sand."S. MaTTHEW vii.

dwellings of men, and that all have now vanished. The sands of the desert were in ancient times remote from Egypt, and the oases which still appear in the midst of this sterile region are the remains of fertile soils which formcrly extended to the Nile.

465. On many parts of the shores of Scotland sand-floods have eonverted tracts of great fertility into barren wastes; and on the northern eoast of Cornwall an extensive district has becn eovered by drifted sand, which has become consolidated by the percolation of water holding iron in solution, and in some places forms ranges of low mounds and hills forty feet high. The sand lias evidently been drifted from the sea by hurricanes, probably at a very remote period. It is first seen in a slight but increasing state of aggregation on several parts of the shore in the bay of St. Ires. Around the promontory of New Kaye the sandstone occurs in various degrees of induration, from that of a friable aggregate, to a stone so eompact as to be broken with difficulty by the hammer, and which is used in the eonstruetion of buildings. Upon examining the stone with a lens, it appcars to be prineipally made up of comminuted shells; and it is worthy of remark that the shelly particles are frequcntly spherieal from the previous operation of water, and some portions of the roek elosely resenble the aneient limestone enlled oolite. The rocks upon which the sandstone reposes are clay-slate and slaty limestone, and the water effecting their deeomposition may have thus obtained the iron, alumina, and other mineral matters by which the loose sand has been converted into sandstone.*

\section{What is the Simoor?}

The simoon is a hot wind which occurs in most countries that are at no great distance from sandy deserts, and blows always from the quarter in which the desert is situated. A considerable quantity of fine sand is generally suspended in the air, which has been collected by the winds in rushing over the deserts.

467. Simoons affect the human system very powerfully, produeing great feebleness, and sometimes death. They usually consist of hot and eold puffs of wind; and the difference of the temperature between these puffs, which is stated to amount to more than twenty degrees of Fahren- 
"For now it would be heavier than the sand of the sea; therefore my words are swallowed up."-Jов vi.

heit's thermometer, is probably one of the reasons of their effect on animal bodies being so great. It is also thought that the hot puffs bring a pestilential ail, as a putrid and sulphureous smell is perceived when they blow. To shelter themselves from the effects of the wind, the Arabs cover their faces with the kapieh, a handkerchief which they wear on their heads.

468. Mr. Bruce, the celebrated African traveller, describes the effect of the simoon, accompanied by pillars of burning sunds. He says, "We were at once surprised and terrified by a sight, one of the most maguificent in the world. In the vast expanse of desert, from west and to the north-west of us, we saw a number of prodigious pillars of sand at different distances, at times moving with great celerity, and at other's stalking on with a majestic slowness; at intervals we thought they were coming in a very few minutes to overwhelm us; and small quantities of sand did actually more than once reach us. Again they would retreat, so as to be almost out of sight, their tops reaching to the very clouds. There the tops often separated from the bodies; and these, once disjoined, dispersed in the air, and did not appear more. Sometimes they were broken near the middle, as if struck with a large cannon-shot. About noon they began to advance with considerable swiftness upon us, the wind being very strong at north. Eleven of them ranged alongside of us about the distance of three miles. The diameter of the largest appeared to me at that distance as if it would measure ten feet. They retired from us with a wind at south-east leaving an impression upon my mind to which I can give no name, though surely one ingredient in it was fear, with a considerable deal of wonder. It was in vain to think of flying; the swiftest horse or fastest sailing ship could be of no use to carry us out of this danger.

\section{Why do Plants sometimes Arrest the Drifting of} Sands?

There are some of the grasses which have a long creeping stem, which grows near or upon the surface, sending down roots into the soil, and developing leaf and flower buds at intervals. This peculiarity is of great service to man in connection with the grass named Sand-Reed, and others, which can vegetate amidst dry and shifting sand, 
"A stone is heavy, and the sand weighty; but a fool's wrath is hearier than them both."-Proveris xivii.

and are hence employed to give firmness to embankments which they pierce with an entangled web of stems and roots that offers a resistance rarely overcome by the force of storms, and is renewed as fast as it is destroyed.

470. Such grains do not increase so much by seeds as by the multiplication of buds; cattle will not eat them, and. hence they are providentially adapted to escape that mode of destruction; but when they have been uprooted by the thoughtlessness or ignorance of man, the most ruinous evils have resulted. In Scotland, large tracts of once fertile country have been hitherto rendered barren, by the cncroachment of sand-mills, which liave given them the desert-like aspect of Egyptian plains; and this encroachment has resulted from the impolitic destruction of the matgrasses which were pulled up by the country people for fuel to such an extent, that an act of Parliament was first passed about a hundred years ago, imposing a penalty for destroying the grasses.*

471. What is the origin of Sandstone?

Sandstones are primarily mechanical deposits from agitated water. The portion of the crust of the earth lying abore the primitive rocks is composed principally of sandstones and limestones alternating with each other.

472. The kinds of rock which are known by the name of sandstone consist of coarser or finer granules of quartz, felspar, and mica, with little fragments of granite, clay, slate, \&c., connected by a cementing substance.

473. When the component particles are large they form what is called breccia, and conglomerate, which frequently exhibit transitions into sandstones. The sandstones include

- Dr. Carpenter. 
"Therefore sprang there even of one, and him as good as dead, so many as the stars of the sky in multitude, and as the sand which is by the sea shore innumerable."-HEBREws xi.

as many formations as limestones. The hardest kinds are used for buildings and for mill-stones; those of particularly fine texture, for whetstones and hones.

474. By an infiltration of crystallized carbonate of lime, sand is converted into sand-stone,-firagments of soft clialk are transmuted into solid rock, as in the Coombe Rock of Brigliton,-and accumulations of beach and gravel into a hard conglomerate, as in the example of the ancient shingle-bed of the cliffs at Rottingdean,-sliells, into a building stone, as in the mass from Florida,-and the detritus of shells and corals, into limestone. By this agency the bones of animals are permeated with calcareous spar, and their medullary cavities lined witl crystals of carbonate of lime; and clay, which has cracked by drying, has its fissures filled up, and becomes consolidated into those curious masses callcd septaria, which, when polished, form the beautiful table-slabs for which Weymouth is cclebrated.

475. Water charged with a large proportion of iron, acts an important part in the consolidation of loose materials, converting sand into ironstone, and beach or shingle into a ferruginous conglomerate. On Clapham Common, and in other places in the vicinity of London, large blocks of a very compact breccia occur, being masses of chalkflints more or less broken and rolled, cemented together by an infiltration of iron. In the example of a horse-shoe firmly impacted in a mass of pebbles and sand, from the sea-beach at Eastbourne, the cement which binds the mass is dcrived from the iron. Nails are frequently found in the centre of a nodule of hard sandstone formed by this process; the nail having supplied the water with the material by which the surrounding sand has become concreted into stone.

476. What is the origin of Limestone?

To explain the origin of the vast masses of stratified limestone is a matter of considerable difficulty. In a great majority of instances the limestone formed at the present day is the result of chemical forces, or of vital forces controlling chemical action; and the same was probably the case in the earlier periods.

477. In particular instances, calcareous denosits have 
" $A$ land wherein thou shalt eat bread without scarceness, thou shall not lack anything in it: a land whose stones are iron, and out of whose hills thoul mayest dig urass."-DEuTERosioxr viii.

partially or wholly a mechanical origin, as when a stream brings down the waste of a chalky or oolitic district.*

478. Chalk is a variety of limestone, a carbonate of lime; when pure, unmixed with any other material save a little magnesia or alumina. Layers of flint noctules, at intervals of four to six feet, are found in chalk.

479. Primitive limestone is of granular crystalline character, and in a few rarieties looks rery like fine white sugar. This kind of limestone is technically termed marble, and is highly valued for purposes of sculpture.

480. Why are Flint Nodules found in Chalk?

It seems probable that, in the formation of the chalk from the decomposition of sea water then holding lime and silica in solution, the carbonate of lime and silica fell to the bottom together, and that the latter substance, of which fint is formed, was especially attracted by the silicious organic remains then lying on or beneath the beds, so as to collect round the sponges, echini, \&c., in the manner that oolitic matter has been collected round shells, the lias round ammonites, the carbonate of iron round ferns, \&c.

481. What is the source of Lime in Sea TFater?

The lime contained generally in sea water, and secreted so plentifully by shell and coral forming animals, may have been derived either from springs rising up in the bed of the ocean, or from rivers fed by calcarcous springs, or impregnated with lime derived from disintegrated rocks.

482. If the sites of the mineral springs of Tuseany were to be submerged bencath the sea, no one can doubt for a moment that they would supply materials for the most extensive coral reefs. The importance of these springs is not to be estimated by the magnitude of

* Phillips's "JIanuai of Geoiogy." 
"Thy righteousness is like the great mountains; Thy judgments are a great deep : 0 Lord, Thou preservest man and beast."-Psaci xxxvi.

the rocks which they have thrown down on the standing sides of the hills, although of these alone large cities might be built; nor by a coating of travertine that covers the soil in some districts for miles in length. The greater part of the calcareous matter passes down in a state of solution to the sea, and in all countries the rivers which flow from chalk and other marly and calcareous rocks carry down great quantities of lime into the ocean.

483. What is Silex, or Silica?

Silex, or the earth of flint, is a combination of the metallic base called silicon with oxygen, forming a mineral which constitutes so large a portion of the rocks and strata, that it is computed to form, either in a pure or combined state, nearly one-half the solid crust of the globe. The flints from the chalk cliffs, the boulders and gravel on our sea shores, and the pebbles of agate, quartz, and chalcedony, are well-known examples of the usual varieties of silex.

484. Silica comprises the principal constituent of a series of precious stones, the commonest form being that of rock crystal, only the purest varieties of which are valuable and expensive only in large masses. It occurs in cavities and weir-like spaces, principally in the primitive rocks. These are called in Switzerland crystal caves, or chambers, and often contain a considerable abundance of such crystals, which sometimes occur perfectly pure, weighing sereral hundredweight.

485. The mass of rocks is composed of not more than some eight or nine simple minerals. These are -1 , quartz; 2 , felspar ; 3, mica ; 4, hornblende; 5 , carbonate of lime; 6 , talc, comprising chloritc and steatite $; 7$, angite $; 8$, serpentine $; 9$, ironstone. Other minerals, which either form rocks of small extent, or enter so largely into their composition as to modify their character, are the following:-Sulphate of lime, diallage, chloride of sodium, coal, bitumen, garnet, schorl, staurotide, epidotc, olivine, and pyrites. A few of these minerals exist in masses so large as to be denominated rocks, as quartz, carbonate of lime, sulphate of lime, salt, coal, and pyritcs; but in general some two, 
"As coals are to burning coals, and wood to fire, so is a contentious man to kindle strife."-Proverbs xxvi.

three, or four are united to constitute a rock, as mica, quartz, and felspar to produce granite.*

486. What is the origin of Rock-salt?

The origin of the enormous subterranean beds of rocksalt is as imperfectly understood, as that of the saltness of the waters of the ocean. That many of the deposits of salt may have originated simply from the cvaporation of sea vater pent up in lagoons, lakes, or inland seas, is a generally received, and not improbable supposition; but the absence of organic forms of any kind, has been regarded as an objection to this conclusion. The red colour of the salt is occasioned by oxide of iron, which may have been derived from decomposed trap-rocks. $\uparrow$

487. What is the origin of Coal?

Coal is composed of altered vegetable structures. It may be compared to a great extent to branches, fragments of roots, \&c., which are buried in peat bog. The coal-beds are the remains of a dense vegetation. In some collieries an observer may, as it were, see beneath such an accumu-

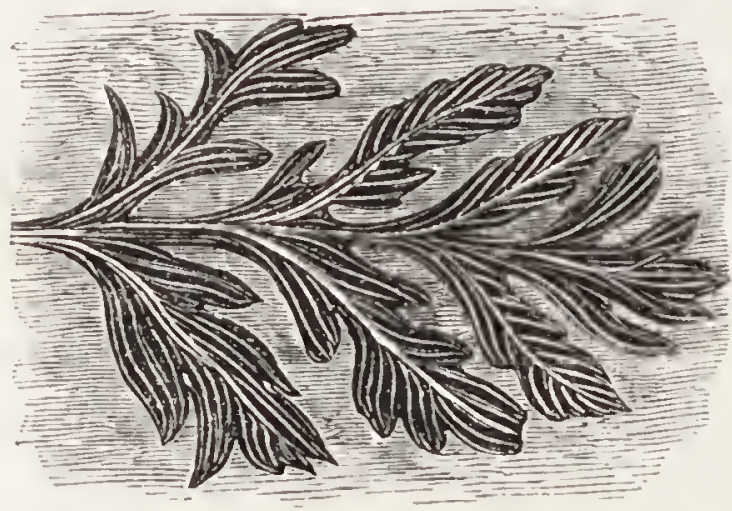

VEGLTABIE COAL IOOSSIL. lation of plants in muddy ground, the ends of the upright stumps, like so many irregular wings, scattered overheal, the long prostrate stems strewed among them, and a nultitude of ferns of various kinds, and other plants matted together; the whole presenting the appearance of a growth of plants in soft or

* Richardson.

† See Mr. Bakewell's "Introduction to Geoiogy," for a full aceount of the most important deposits of salt, and the theories respecting them. 
"As smoke is driven away, so drive them away; as wax melteth before fire, so let the wicked perish in the presence of God."-Psalur lxviii.

wet ground, if not shallow water, mud, mingled with various portions of them.

488. Often the plants appear to have partly grown in the same locality, and partly to have been drifted into it; sometimes from an adjoining situation, at others from. distant places.

489. Coal has been found at Sta. Fe de Bogota up to a lieight of 8000 feet above the level of the sea, and near. Whitehaven at a depth of more than 1800 feet below that level. The carboniferous formation is very widely diffused, and not only Great Britain, but Germany, the north of France, and Belgium, lave abundance of rich coal-mines. They occur also on the left bank of the Rhine, in Westphalia, the Hartz, Bohemia, Thuringia, Saxony, Siberia, \&c.

490. The Belgian pits yield annually about 3,200,000 tons; the Prussian, 2,000,000; those of the Austrian dominions, 350,000 tons. But the most important are those of Great Britain." The pits of Newcastle alone annually furnish 10,000,000 tons; and there are also mines of vast extent in South Wales, Scotland, the Midland Counties, \&c. The yearly product of the coal-mines of Great Britain exceeds $20,000,000$ tons, and occupies more than 100,000 persons. The anmual value is said to amount to $£ 9,000,000$. Portugal, Spain, and Italy contain little-known coal-mines, as also do Sweden, Norway, and Russia; China is said to be very rich in them, and they are very extensive in North America.

491. The first attempt to apply the carburetted hydrogen of coal to illumination was made experimentally by Lord Dundonald, in 1786. The successful introduction of gas-lighting is due to Murdoch, about 1789; but the lighting of the streets was not effected till 1812 in London, and 1815 in Paris. The lighting of London for one year requires $2,646,000,000$ cubic feet of gas, and the production of this consumes 18,150 tons of coal; in the longest nights, 13,000,000 cubic feet of gas are burnt, which are obtained from 895 tons of coal.* These amounts must have greatly increased since they were last estimated. 
"For a fire is kindled in Mine anger, and shall burn unto the lowest hell, and shall consume the earth with her increase, and set on fire the foundations of the mountains."-DEUTERoxomy xxxii.

492. Why do Coal-beds sometimes take Fire?

Their ignition is ascribed to the decomposition of sulphuret of iron, contained in the coal. The combustion goes on very slowly at a certain depth, because there is mostly a deficient access of air. The burning coal of Duttweiler has been on fire 130 years, the Fanny Pit, in Upper Silesia, has been burning since 1823 .

493. Explosions in coal mines are caused by the pit gas, as it is called, becoming liberated from the coal-beds, and accumulating in cavities, where it mixes with atmospheric air, and forms a highly explosive compound. This mixture becoming inflamed, fearful explosions ensue, often blowing up parts of the mines, and burying ererything in ruins. These are the dreadful "fire-damps" which, from 1827 to 1842, killed or crippled some 9600 workmen in the pits of England, France, and Belgium.

494. What Proofs are there of the Vegetable Origin of Coal, besides the Carbonized fragments of Plants?

'The chemical constitution of the wondy parts of plants is exactly analogous to the chemical constitution of coal.

495. Many of the plants fossilized in coal are of unknown types, and some are too imperfect to permit any botanical deductions. But it seems evident that they were chiefly plants that grew upon the land; they appear to be often analogous to tropical tribes of rascular cryptogamic and coniferous plants.

496. It is probable that the land upon which the plants grew was in a high degree subject to heat and moisture, more so than even the coasts and islands of tropical seas.

497. What Determined the Present Situations of the Coal-beds?

It is probable that the vegetables of some coal-beds grew 
"The Lord talked with you face to face in the mount out of the midst of the fire."-DEUTERonomy $\nabla$.

where their remains are now carbonized; that other coal-beds arose from trees and plants swept down from the land into fresh water lakes; that others were formed in estuarics alternately traversed by floods from the land, and tides from the sea; and that some land plants were transported far into the deep and tranquil ocean.

498. Why, in some Coal Districts, are several Coal-beds found Overlying each other?

Because they have been produced by successive vegetalle growths, broken by corresponding interruptions, over the same seas. In all coal-beds are very many thin alternations of pure coal and impure coal, with sometimes thin lamina of clay, impressed with the forms of plants above and below, and in some cannel coal-beds are layers of fresh water shells.

499. 'The decay of one growth of vergetation appears to have been followed by the drifting of sand and finer sediments over the same area, accompanied by watery action of some kind, occasioned by local subsidence of the land. This ceasing, forests again overspread the same area, to be again covered up by watery action bringing sediments, in consequence of further subsidence.*

500. While areas of fair size are known by colliery workings to have had numbers of vertical stems tranquilly covered over by detrital matter on a particular geological plane, so that a forest of this kind of vegetation has been contemporaneously entombed, it sometimes occurs that there is good evidence of similar conditions having produced similar results more than once over the same area. Of the facts brought to light on this head, though it may be well known in many coal districts that vertical stems of plants are found at more than one geological level, the occurrence of one series of vertical stems above others seems to have been hitherto in no artificial or natural sections better 
"And the waters shall fail from the sea, and the river shall be wasted and dried up."-ISAIAH zix.

exhibited than in the eoal distriets of Nova Scotia and Cape Breton, where several of these planes of vegetation, the stems of plants still standing in their places of growth, are seen above each other.

501. Sir Charles Lyell describes ten forests of this kind, as oceurring above each other, in the cliffs between Minudie and the South Joggins, at the head of the Bay of Fundy. The thickness of the mass of beds containing the upright stems is estimated at about 2500 feet, and the usual height of the trees is from six to eight feet; but one was seen apparently 25 feet high, and two feet in diameter, with a considerable bulge at the base.

502. The aecumulations of mud, silt, sand, and sometimes gravel, intermingled with the layers of fossil vegetation, these layers based upon a soil, probably moist or wet, in whieh the roots of certain plants freely grew, while rertieal stems occurred, as much as 15 or 20 feet ligh, and two to four feet in diameter, even planes of these old forests being found above eaeh other in limited sections, must have been gradually submerged, so that at intervals the soil was sufficiently exposed to, or near the atmosphere, that the seeds embedded amid them could come under their proper conditions of growth. A trough or other cavity, or slightly-inclined plane or shore, gradually filled up to the level of the atmospliere, would only give one layer of vegetation, whereas in some coal districts, where the seams of eoal are reckoned with the soils on and in which their constituent plants grew, fifty or more intervals of growth may have occurred.**

503. Dr. Buckland has given a very vivid description of the fossil coal forests. He says :- "The finest example I have ever" witnessed is that of the coal-mines of Bohemia. The most elaborate imitations of living foliage upon the painted ceilings of Italian palaces, have no comparison with the beanteous profusion of extinct regetable forms with which the galleries of these instructive coal-mines are overhung. The roof is covered with a canopy of gorgreous tapestry, enriched with festoons of the most graeeful foliage, strung in wild and irregular proportion over every portion of the surface. The effect is heightened by the eontrast of the coal-black colour of these vegetables with the light ground-work of the rock to which they are attached. The spectator feels himself transported, as if by enchantment, into the forcsts of

De la Biche. 
"To satisfy the desolate and waste ground; and to cause the bud of the tonder herb to spring forth."-Jos xxxviii.

another world; he beholds trees of forms and eharacters now unknown upon the surface of the earth presented to the senses almost in the beauty and vigour of the primeval life; their sealy stems and bending branches, with their delieate apparatus of foliage, are all spread forth before him, little impaired by the lapse of eountless ages, and bearing faithful reeords of extinct vegetation."

504. What is the origin of Peat Marshes?

The opinion is entertained that most of the peat marshes of the north of Europe occupy the areas of ancient forests of oak and pine; that the fall of trees from the effect of storms, or natural decay, by obstructing the natural drainage of a district, has given rise to these marshy areas; hence the trunks and branches of oaks, firs, \&c., are frequ.ently found beneath the peat moss, which is annually augmented by the peculiar mode of growth of the moss, which throws up a succession of shoots to the surface, while the parent plants decay, and add a new layer to the surface of the soil.

505. The bodies of men and animals are frequently found at great depth in peat bogs, in a high state of preservation. In some instances the bodies are converted into a fatty substance resembling spermaceti.

506. A fact of considerable interest is the occurrence of coal in peat bogs, proving the conversion of vegetable matter into a mineral, the origin of which, but a few years since, was deemed questionable, takes place at the present time, when circumstanees are farourable for the production of the bituminous fermentation. In Limerick, in the district of Maine, North Ameriea, there are peat bogs of considerable extent, in which a substance exactly similar to cannel coal is found at the depth of three or four feet frem the surface, amidst the remains of rotten logs of wood, and bearer-sticks. The peat is twenty feet thiek and rests upon white sand. This coal was discovered on digging a ditch to drain a portion of the bog, for the purpose of obtaining peat for manure. The substance is a bituminous eoal, eontaining more bitumen than is found in any otker variety. Polished sections of the 
"For the waters of Nimrim shall be desolate; for the hay is withered away, the grass failetll, there is no green thing."-Isaiau xr.

compact masses exhibit the peculiar structure of coniferous trees, and prove that the coal was derived from a species allied to the American firs.

507. Independently of the trees imbedded in peat bogs and morasses, there are also found entive forests buried deeply in the soil, the trees having their roots, trunks, branches, fruits, and even leaves, more or less perfectly preserved. Numerous accumulations of this kind have been discovered on the coasts of England, occupying low alluvial plains, that are still subject to periodical inundations. The trees are cliefly of the oak, hazel, fir, birch, yew, willow, and ash ; in short, almost every kind tliat is indigenous to this island, occasionally occurs. The trunks, branches, sc., are dyed throughout of a deep ebony colour, by iron; and the wood is firm and heavy, and occasionally fit for domestic use. In Yorkshire this kind of wood is sometimes employed in the construction of liouses."*

508. What are the agencies that produce Petroleum Springs, Pitch Lalies, \&०c.?

Springs of which the waters contain a mixture of petroleum, and the various minerals allied to it, as bitumen, naphtha, asphaltum, and pitch, are very numerous, and are, in many instances, doubtless connected with subterranean fires, which set free the more subtile parts of the bituminous matters contained in the rocks.

509. It is probable that the great pitch lake of Trinidad owes its origin to a similar cause. In that district all the circumstances are now combined from which deposits of pitch may have originated. 'The Orinoco has for ages been rolling doun great quantities of woody and vegetable bodies into the surrounding sea, where, by the influence of currents and eddies, they may be arrested, and aecumulated in particular plinees. The frequent oecurrence of earthquakes in those parts lends countenanee to the opinion that these vegetable substanees may have undergone, by 
"As cold waters to a thirsty soul, so is good news from a far country."Proveriss xxy.

the agency of subterranean fire, those transformations and chemical changeswhich produce petroleum, and upon subsequent exposure to the air it becomes inspissated, and forms the different varieties of pine and eurthy pitch, or asphaltum, so abundant in the island.

510. Why is the Deep Water of the Mecliterranean Sea of a Higher Temperature than the Deep Water of other Seas?

Because, at the Straits of Gibraltar, where the surface water of the Atlantic flows in as a westerly current, a counter current prevails heneath, and prevents the influx from the ocean of the cold current from the Pole.

511. Why have we reason to believe that the Antarctic Circle encompasses Large Masses of Land?

The unexplored area around the South Pole is about twice as large as Europe. This untravelled region is circular in shape, its circumference measuring not less than 7000 miles. Its edges have been penetrated here and there, and land, wherever seen, has been high and rugged. Explorers, as far as they have penetrated within the circle, tell of high lands, and mountains of ice ; and Captain Ross saw volcanoes burning in the distance.

512. Moreover, the great frequency of icebergs proceeding from the Frigid Zone of the South, is evidence in favour of Antarctic shore-lines of great extent, of deep bays where they may be formed, and of lofty cliffs where they may be launched.

513. The belt of ocean that encircles the globe on the Polar side of $55^{\circ}$ south is never free from these icebergs. They are found in all parts of it all the year round. Many of them are miles in extent, and hundreds of feet thick. The nursery for the borgs to fill such a field must be immense; such a nursery cannot be on the sea, for 
"For as the lightning cometh out of the east, and shineth unto the west, so shall also the comiug of the Son of Man be."-S. Matruew xxiv.

icebergs require to be fastened firmly to the shore until they attain a full size.

514. What are the efjects of Lightning upon the Earthis Surface?

Remarkable effects of lightning in precipitating large masses of rock from elevated situations are recorded. At Funzie, in Fetlar, about the middle of the eighteenth century, a rock of micha-schist, 105 feet long, ten feet broad, and in some parts four feet thick, was torn by lightning from its bed, and broke into three large, and several smaller fragments. One of these, twenty-six feet long, ten broad, and four thick, was simply turned orer. Another, which was twenty-eight feet long, seventeen broad, and five thick, was liurled across a high point to the distance of fifty yards. Another mass, about forty feet long, was thrown still further, in the same direction, into the sea.

515. Why may Fire and Water be regarded as Antagonistic Forces operating upon the Earth?

Because the aqueous agents are incessantly reducing the inequalities of the earth's surface to a level; while the igneous are equally active in restoring the unevenness of the earth's crust, partly by heaping up new matter in certain localities, and partly by depressing one portion, and forcing out another, of the earth's envelope.

516. But sometimes the inneous and aqueous forces co-operate to produce a joint effect, to which neither of them unaided by the other could give rise,-as when repeated earthquales unite with running water to widen a valley; or when a thermal spring rises up from a great depth, and conveys the mineral ingredients with which 
"He looketh to the ends of the earth, and seeth under the whole hearen,"

it is impregnated from the interior of the earth to the surface.

517. Sometimes the organic combine with the inorganic causes: as when a reef, composed of shells and corals, protects one line of coast from the destroying powar of tides or currents, and turns them against some other point; or when drift timber, floated into a lake, fills a hollow to which the stream would not have had sufficient velocity to convey earthy sediment.

518. The crust of the earth, although an infinitesimal quantity when compared with the mass of the glabe, is of immense extent and importance. As regards its thickness, which is estimated at about ten miles, it bears, in a physical point of view, no greater relation to the mass of the globe, than that which would be offered by the thickness of paper to the diameter of an orange; regarded under another aspect, it is the theatre of land and water, of mountain and valley, of ocean, river, and lake, and affords a sphere for the existence of the animal, vegetable, and mineral kingdom.**

519. What becomes of the Heat Discharged from the Interior of the Earth?

It is believed that heat, as well as being expended by the more remarkable phenomenon of volcanoes, is continually passing by radiation from the interior of the globe into the planetary spaces. At the same time no mode in whicle the heat thus thrown off can be restored agrain to the earth is recognisable.

520. Therefore, there must be a gradual diminution of the earth's eternal heat, and a progressive exhaustion of the elements by which that heat is sustained. But 
"To make the weight for the winds; and He weigheth the wators by measure,"

the process is so slow as escape the power of man's calculation.

521. Why does the Nature of the Soil affect the Temperature of Countries?

'This is principally owing to the greater or less power any soil possesses of absorbing and radiating heat.*

522. Thus, sandy soils are subject to become rapidly and intenseiy heated, and when the sun's rays are withdrawn they readily radiate into the atmosphere the heat they have acquired, thus increasing the atmospheric temperature.

523. Clayey soils, on the other hand, become slowly heated, and as slowly cooled.

524. Swampy grounds chill the air, and extensive forest tracts have a similar effect.

525. The variations of temperature of different regions depend in a great degree on the character of the bottom of the aërial ocean, or on the nature of the floor or base, whether land or sea, on which the atmosphere rests. Seas, often traversed by currents of warmer or colder water, have an cffect very different from that of continental masses, or of islands, which latter may be regarded as shallows in the aërial ocean, and which, notwithstanding their smail dimensions, exert often to a great distance a notable influence on the climate of the sea. In continental masses we must distinguish between sandy deserts devoid of vegetation, sarannahs or grass plains, and forest-corered districts.

526. Why do Forests affect the Temperature and Itumidity of Conntries?

They act in three various ways-by shutting off the rays of the sun and producing shade, by evaporation, and by ractiation.

527. Forests, which in our temperate zone consist of trees living in "society"-that is, many individuals of one or of a few kinds, as oaks,

* See "Gardeners and Farmers' Teason Why." 
"To dwell in the cliffs of the valley, in caves of the earth, and in the rocks." - Joв $\operatorname{xxx}$.

beeches, and birches, \&c.-but in the tropics of an immensc variety living separately or "linsociably," protect the ground from the direct rays of the sun, evaporate fluids elaborated by thcmselves, and cool the strata of air in immediate contact with them by the radiction of heat from their leaves. The latter are far from being all parallel with each other; they are, on the contrary, variously inclined, which increases the effect of radiation.

528. Thus, cultivation not unfrequently effects a change of the climate in a country ; for if marshes are drained, or forests cleared, the temperature will be raised.

529. Such has been the case in some parts of North America, where the clearing of forests and the progress of cultivation have improved the climate and rendered the winters milder. The destruction of woods has, however, proved highly detrimental to the climate of some regions. The sultry atmosphere and dreadful droughts experienced in the Cape Verde islands are attributed to the destruction of the trees in those islands; whilst a remarkable improvement has taken place in the climate of the Island of Ascension since that has been brought to cultivation.

530. What is Crystallization?

The particles of liquid and gaseous bodies, during the formation of solids, sometimes cohere together in an indiscriminate manner and give rise to shapeless masses; but they occasionally attach themselves to each other in a certain order, so as to constitute solids possessed of a regularly limited form. Such bodies are called crystals, and the natural process by which they are formed is termed crystallization.

531. What is Petrifaction?

In a true petrifaction the substance becomes more or less completely mineralized; if we break it, we find that every part of its structure has undergone a change. Wood, for instance, is often entirely transmuted into flint or chalcedony, and may be cut so thin that, with a powerful lens, the 
"Behold now Behemoth, which I mare yith thee; he eateth grass as an ox. ILis bones are as strong pieces of brass; his bones are like bars of iron;"

ramifications of the vessels and the structure of the tissues may be seen, and from their form and disposition we may determine the particular kind of tree to which the specimen belonged, although it may have been enshrined in the stone for ages. When bone is petrified the same phenomena are observable; the most delicate parts of the internal structure are preserved, and all the cells are filled up with calcareous spar, which is oftentimes of a different colour from that of the walls of the cells, and thus a natural anatomical preparation of great beauty and interest is formed.

532. The mineral substances of whieh petrifactions are generally composed, are calcareous, silecious, or argillaeeous, in various states, and differently mixed. Of those that are ealcarcous, the greater part are earbonates; fluate of lime sometimes serves as a matrix, but it rarely forms the substance of the fossil. Sulphate of lime sometimes lines the cavities left by destroyed fossils, but does not itself form them. Sulphate of barytes liardly erer forms fossils. Of the metals which contribute to the formation of fossils, the most common are iron and eopper, rarely lead or zinc, and still more rarely, silver; they are gonerally earbonates or sulphurets. 
"He lieth ander the shady trees, in the covers of reeds and fens. The shady trees cover him with their shadow ; the willows of the brook compass him about." "

FOS SIL.

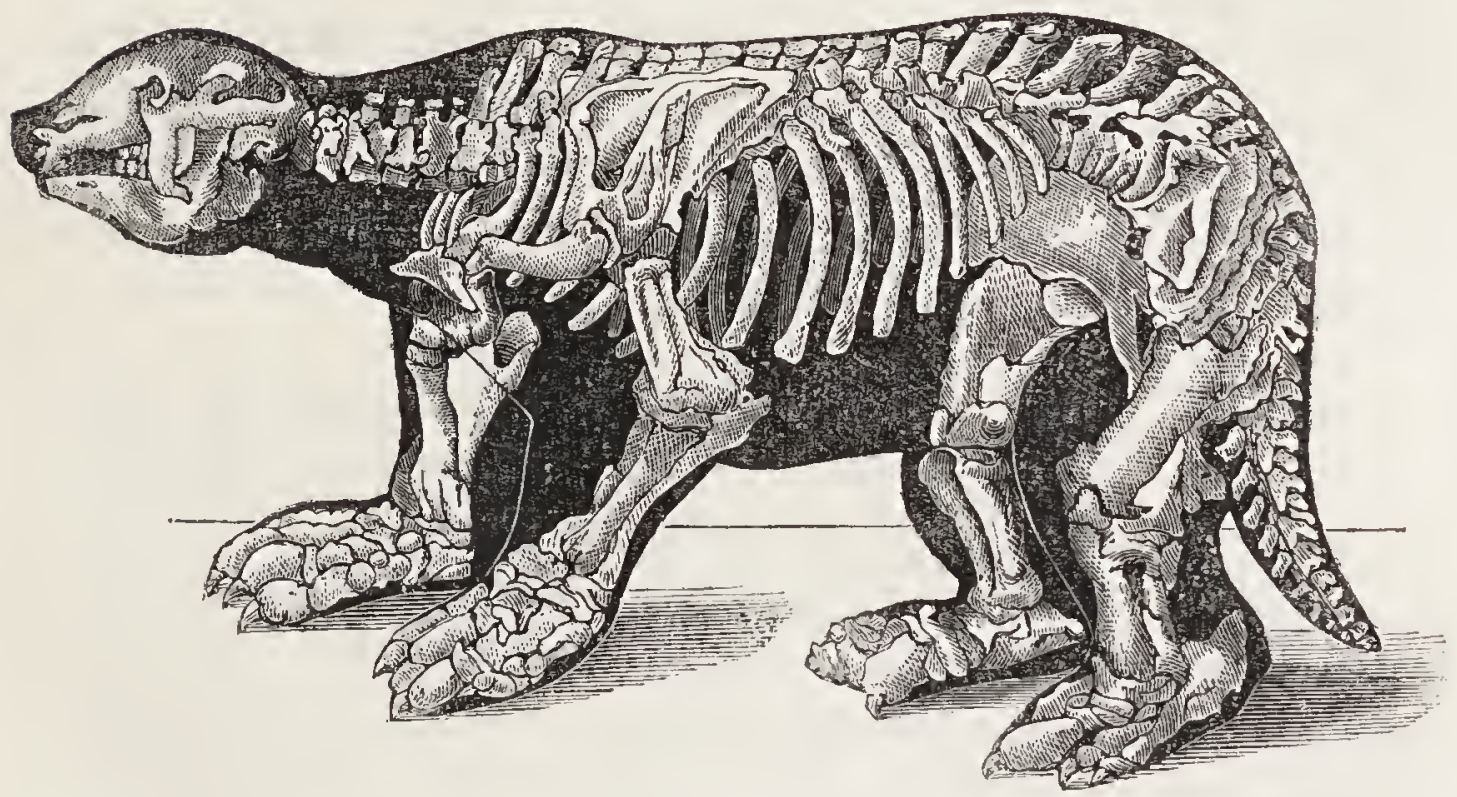

TIIE MEGATHERIUM.

533. Why are Fossil remains found almost Exclusively in Strata that have been deposited by Water?

This circumstance is readily explained, when we consider that the bones of all dead creatures that may be left uncovered upon dry land, are in a few years entirely destroyed by various animals and the decomposing influence of the atmosphere. If we except the few bones that may have been collected in caves, or buried under land slips, or the products of volcanic eruptions, or in sand drifted by winds, it is only in the strata formed by water that any remains of land animals can have been preserved. 
"Behold, he drinketh up a river, and hasteth not; he trusteth that he cun draw Jordan into his mouth. He taketh in with his eyes; his nose pierceth through snares." - JOB $\mathrm{xl}$.

534. Why do Successive Groups of Strata contain Distinct Fossils?

As the ages of the world have been marked by a continual extinction of species, and introduction of others into the globe, it follows that the fossils of strata formed at two distant periods on the same spot, will differ even more certainly than the mineral composition of the strata. Rocks of the same kind have sometimes been reproduced in the same district, after a long interval of time, whereas there are no facts leading to the opinion that species which have once died out have ever been reproduced.

535. The submergence, then, of land, must be often attended by the commencement of new sedimentary deposits, characterized by a new set of fossil animals and plants, while the reconversion of the bed of the sea into land may arrest at once and for an indefinite time the formation of genlogical monuments. Should the land again sink, strata will again be formed; but one or many entire revolutions in animal or vegetable life may have been completed in the interval.*

536. In what respects do Fossilised Organic Remains afford Evidences of the Divine TVisclom?

From the high state of preservation in which many of these remains are found, we may deduce the most conclusive proofs that the creatures from which they are derived were constiucted with a view to the varying conditions of the surface of the earth, and to its gradually increasing capabilities of sustaining more complex forms of organic life, adrancing through successive stages of perfection. $\uparrow$

* Sir C. Lyell.

† Dr. Buckland"s "Geology and Nineralogy. 
"I made me poois of water, to water therewith the wood that bringetl forth trees."-Ecchesiastes ii.

537. What is the process by which Organic Substances Embedded in the Earth become Petrified?

Although the manner in which organic substances become petrified cannot be clearly explained, the process is, under favourable circumstances, continually going ou. In some cases the most perishable, and in others the most durable, portions of plants are preserved-variations which doubtless depend on the time when the mineral matter was supplied. If introduced immediately, on the first commencement of decomposition, then the most destructible parts are lapidified, while the more durable do not waste away till afterwards, when the supply has failed, and it never becomes petrified. Opposite circumstances produce corresponding results.

538. A series of cu rious experiments, by Professor Göppert, of Breslau have resulted in the production of some very curious imitations of fossil petrifactions. He placed recent forns between soft layers of clay, dried these in the shade, and then gradually heated them until they were red-hot. The result was, the production of so perfect a counterpart of fossil plants as might have deceived an experienced geologist. According to the diffcrent degrees of heat applied, the plants were obtained in a brown or perfectly carbonized condition; and sometimes, but more rarely, they were in a black shining statc, adhering closely to the layer of clay. If the red heat was sustaincd until all the organic inatter was burnt up, only an impression of the plant remained.

539. The same experimentalist stceped plants in a moderately strong solution of sulphate of iron, and left them immersed in it for several days, until they were thoroughly soaked in the liquid. They were then dried, and kept heated until they would no longer shrink in volume, and until cvery trace of organic matter had disappeared. On cooling them he found that the oxide formed by this process had taken the form of plants. Other experiments proved that the mineralisation of organic bodies can be carried much furtler in a short time than had been previously supposed.* 
"Thou hast forgotten the God of thy salvation, nnd has not been mindful of the rock of thy strentrin, therefore shall thou plant pleasant plants, and shalt set it with strange slips." -Isaiall xvii.

540. Why does Wood, after long Immersion in Water, acquire an Increased Specific Gravity, and Sint?

Wood floats on the surface, not because the woody portion is specifically lighter than the water, but because it is full of pores containing air. When soaked for a considerable time, the water makes its way into these pores, and the wood becomes water-logged, and sinks. The time required for this process raries in different woods, but several kinds may be drifted to great distances, sometimes across the ocean, before they lose their buoyancy.

541. If wood be sunk to vast depths in the sea, it may be impregnated with water suddenly, by the great pressure of the water. On one occasion a whale dragged a boat under water, to the depth of several thousand feet. The sunken boat was recovered by great labour, and was found to be so lreavy that it required a boat at each end to keep it from sinking; its pieces sank in water like stones, and were useless even for fire-wood.

542. Although the remains of terrestrial regetation, borne down by aqueons causes from the land, are chiefly deposited at the bottom of lakes, or at the mouths of rivers, yet a considerable quantity, drifted about in all directions by currents, may become embedded in any marine formation, or may sink down, when water-logged, to the bottom of unfathomable abysses, and then accmnulate without intermixture of other substances.**

543. What was the origin of the Submarine Forests found on British Coasts?

In some instances these have resulted from the subsidence of the land. A submarine forest has been traced for several miles along the northern shore of the county of Fife. A submarine forest occurs at the mouth of the Parret, in Somersetshire, on the south side of the Bristol Channel. A bed of peat is there seen below the level of the sea, and 
"The floco breaketli out from the inhabitant, even the waters forgotten of the foot; they are driod up, they are gone away from men."-Јов xxviii.

the trunks of large trees, such as the oak and yew, having their roots still diverging as they grew, fixed in the clay.

544. But there are some cases which require a different explanation. A fir-wood lies beneath the near level of the sea at Bournemouth, in Hampshire. It is supposed that at some former period the Bourne Valley extended further, and that its extremity consisted, as at present, of boggy ground, partly clothed with fir-trees. The bog rested on a bed of pebbles below the peat; and the sea, in its progressive encroachments, eventually laid bare, at low water, its sandy foundations; upon which a stream of fresh water, rushing through the sand at the fall of the tides, carried out loose sand with it. The upper stratum of regetable matter, being matted and bound together by the roots of trees, remained, but, being undermined, sank down below the level of the sea, and then the waves washed sand and shingle over it.*

545. There runs around the shores of Great Britain a flat terrace of unequal breadtl, backed by an esearpment of varied height and character, which is known to geologists as the old coast-line. On this flat terrace most of the sea-port towns of the empire are built. The subsoil which underlies its covering of vegetable mould consists usually of stratified sands and gravels, arranged after the same fashion as on the neighbouring beach, and interspersed in the same manner. with shells.

546. The escarpment behind, when formed of materials of no great colerency, sueh as gravel or clay, exists as a sloping, grass-covered bank-at one place running out into promontories that encroacl upon the terraee beneath-at another reeeding into picturesque bay-like recesses; and where composed, as in many loealities, of rock of an enduring quality, we find it worn, as if by the aetion of the surf, in some parts relieved into insulated staeks, in other's hollowed into deep eaverns. $t$

* Sir C. Lyell.

+ Hugh Miller. 
"Thou didst walk through the sea with Thine horses, through the heap of great waters." - НАBAKKUK iii.

547. Why are Organised Remains Unequally Diffused in the various Formations?

Because in the history of the earth violent and unusual actions have occurred locally, though orcr cxtensive areas. These causes have operated to produce a rapid accumulation of ccrtain strata, accompanicd by the sudden destruction of the then existing inhabitants of the scas.

548. The fossil fishes of Torre d'Orlando, in the Bay of Naples, appear to have perished suddenly. An entire shoal seems to have been destroyed at once, at a place where the watcrs were either contaminated by some noxious impregnation, or overcharged with heat; which may have resulted fiom the rolcanic action of Mount Vesurius.

519. At the present time, fishes are known to perish from an excessive admixture of mud with the water of the sea, during extraordinary tempests. A sudden irruption of salt water into lakes or estuarics previously occupied by fresh water, or a sudden occupation of a portion of the sca by an immense body of fresh water from a bursting lake, or unusual land-flood, is often fatal to large numbers of the inhabitants of the waters thus respectively interchanged.

550. The circumstances under which fossil fishes are found at Monte Bolca, seem to indicate that they perished suddenly on arriving at a part of the then existing seas, which was rendered noxious by volcanic agency, of which the adjacent basaltic rocks afford abundant evidence. The skeletons of those fish lie parallel to the laminæ of the strata of the calcareous slate; they are always entire, and so closely packed on one another that many individuals are often contained in one block. All these fish must have died suddenly on this fatal spot, and have been speedily buried in the calcareous sediment then in course of deposition. From the fact that certain individuals have eren preserved traces of colour upon their skin, we may be certain that they 
"Tet I had planted thee a nohle vine, wholly a right seea: how then art thou turned into the degenerate plant of a strange vine unto me?"-JEIEMIAH ii.

were entombed before decomposition of their soft parts had taken place. Many of the fishes in some deposits have a distorted attitude, which is due to the unequal contraction of the muscular fibres, which causes fish and other animals to become stiff during a short interval after death. As these fishes retain the rigid attitude, they must have been buried before decomposition took place.*

551. Why may we infer that the Earliest Plants were Algee and their allied forms?

When we investigate the many different strata which lie one above another, we find that those lowest down, although partly deposited from water, do not contain the slightest trace of animals or plants. Upon the primitive rocks rest certain others, in which the vegetable kingdom is represented only by fucoids, or sea-weeds, while they contain abundance of marine animals. Hence it is considered that no animals or plants existed in the periods in which the lowest rocks were formed, and that the first forms of vegetation were those of sea weeds.

552. So far as is yet known, animals and plants appear together. We have seen that the first remains of animal life are scarce; and, as the existence of any kind of animals implies the prior, or at least the contemporaneous, existence of vegetables, to afford them sustenance, the presence of sea weeds in strata coeval with these ancient animals, and their continuance onwards throughout all formations of marine origin, is a matter of probability, which has been confirmed by the results of actual observation.

553. There appear no traces of a terrestrial vegetation, until we reach the uppermost beds of the Upper Silurian System. Fossilised sea-wecds occur in repeated thin layers among the Transition strata of North America. Similar deposits havc also been found in the Grauwacke of Central Pennsylvania; in one place seven courses of 
"But he answered and said, every plant which n.y heavenly Father hath not planted, shall be rooted up."-JIATTIEW Xv.

plants are laid bare in the thiekness of four feet; in another, one hundred eourses within a thiekness of twenty feet. Fucoids have also been found in great abundanee in the Grauwaeke-slate of the Maritime Alps. They have also been found dispersed abundantly through shale of the lias formation, from a well at Cheltenham; and in the Upper Greensand, near Bognor, in Sussex.

5i5. Marine vegetation is divisible into different systems, like those prevailing on the land; but they are mueh fewer, as we might have expeeted, the temperature of the oeean being more uniform than that of the atmosphere, and consequently the dispersion of speeies from one zone to another being less frequently elreeked by the intervention of uneongenial elimates. The proportion also of land to sea thronghout the globe being small, the migration of marine plants is not so often stopped by barrier's of land, as is that of the terrestrial species by the oeean. The number of hydrophytes, as they are termed, is rery eonsiderable, and their stations are found to be infinitely more raried than conld have been antieipated; for, while some plants are corered and uneovered daily by the tide, other's lie at the depth of several linndred feet.**

555. The long upward march of the animal kingdom takes its departure as a starting-point from a thick forest of algre. In Bohemia, Sweden, the British Islands, and North Ameriea-whereever what appears to be the lowest, or at least one of the lowest zones of life, has yet been detected - the roeks are found to be darkened by the remains of algae, so abundantly dereloped in some cases, that they compose, as in the aneient Lower Silurians of Dumfriesshire, impurc beals of anthraeite several fect in thickness. Apparently from the original looseness of their texture, the individual plants are but indifferently preserved; nor ean we expeet that organisms so aneient and frarile should exhibit any very close resemblanee to the plants whieh darken the half-tide roeks of onl coasts at the present time.t

556. What Evidence is afjorded by the Fossil Remains of Ferns upon Changes of the Earth's Temperature?

Finding that the fossil remains of ferns decrease continually in number as we ascend from the most ancient 
"In the day shalt thou make thy plant to grow, and in the morning shalt thou malie thy seal to flourish; but the harvest shall be a lieap in the day of grief and of desperate sorrow."-Isaiah xvii.

to the recent strata, it is a reasonable inference that the earth has undergone successive changes of climate and diminutions of temperature. The circumstances most fivourable to the growth of ferns are humidity, shade, and heat.

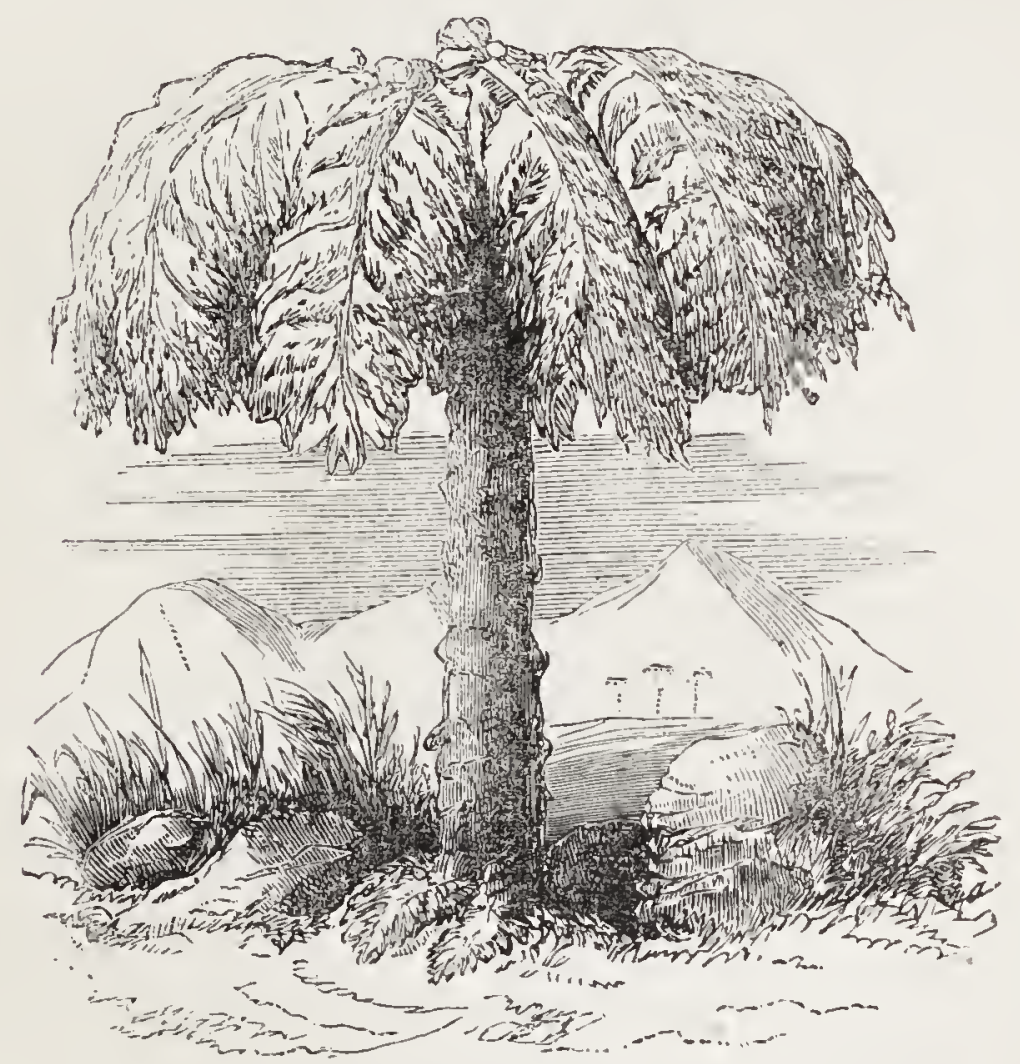

TREE TERN.

In the great coal formation there are above 120 known species of ferns, forming about one-half of the entire known flora of this formation. Fragments of arborescent ferns occasionally are found in the same formation. M. Brongniart considers these circumstances as indicating a vegetation analogous to that of the Isiands of the Equinoctial regions of the present earth; and infers that the same conditions of heat and humidity which favour the existing vegetation of these islands, prevailed in still 
"And every plant of the field before it was in the earth, and every herb of the field before it grew: for the Lord God had not caused it to rain upon the earth, and there was not a man to till the ground."-Ge.vesis ii.

greater degree during the formation of the Carboniferous Strata of the Tertiary kingdom.

557. The forms of vegetation that flourished during the Carboniferous Era seem to have been in large measure marshy plants, lusuriating on low muddy delta lands, like the cypress swamps of the Mississippi, or the Sunderbunds of the Ganges. We can picture but faintly the general scenery of those old forests from the broken and carbonized remains that have come down to us; but, though somewhat monotonous, it must have been eminently beautiful in detail. The Sigillarix raised their seulptmed stems and lofty waving wreaths of fionds high over the more swampy grounds, while a thick underwood of Ferns and star-leaved Asterophyllites clustered amid the shade below. The Lepidodendra shot forth their spiky branehes from the margin of green islets, and dropped their catkins into the sluggish water that stole on among the dimpled shadows nnderneath. 'Tree Ferms spread out their broad pendent fronds, and wripped the ground below in an almost twilight gloom.

558. Thickets of tall Reeds rose out of the water', with stems massive as those of our own forest trees, encircled at regular distances by wreaths of painted leaflets, and bearing on their summits club-like catkins. Far away, the distant hills lay shaggy with Pine-moods, and nursed in their solitudes the springs and rivulets that worked a devious course through forest, glen, and valley, until, united into one broad river, they erept through the rieh foliage of the delta, and finally passed away out to sea, bearing with them a raried burden of driftwood, pine-trees from the hills, and stray leaves and eones from the lower grounds.

559. How different such a seene from that now presented by the very same areas of country! 'I hose old delta lands are now our eoal ficlds, and have exehanged the deep stilness of primeval nature for the din and turmoil of modern mining distriets.

560. In those ancient times, not only was man uncreated, but the carth as yet lacked all the higher types of animal forms. None of the creatures that we see aromind us existed then; there were no Sheep, nor Oxen, Horses, Deer, nor Dogs. Neither were the quadrnpeds of other lands represented; the forests nourished no Lions nor Tigers, no Wolves nor Bears, no Opossums nor Kangaroos. In 
"As for the earth, out of it cometl bread, and under it is turned up as it were fire." $-J o B$ xxviii.

truth, the land must have been a very silent one, for we know as yet of no animated existence that could break the stillness, save perchance some chirping Grasshopper, or droning Beetle, or quivering DragonAy. No Bee hummed along on errands of industry; it is doubtful, indeed, whether honey-yielding flowers formed part of the Carboniferous flora; no Lark carolled blithely in the sky, nor Rook croaked among the woods. All was still; and one might, perhaps, have stood on some of those trec-crested islets, and heard no sound but the rippling of the water along the reedy and sedgy banks, and the rustling of the gloomy branches overhead.

561. But the lifelessness of the Carboniforous forests uas amply compensated by the activity that reigned in the river, lagoon, and sea. Coral groves gleamed white beneath the waves; Fishes of many a shape disported in stream and lake, and the bulkier forms, armed in massive plates of bone, ascended the rivers, or hunted the deeper recesses of the open sea. In some beds of rock the remains of these various animals lie crowded together like drifted tangle on the senshore, and the whole reminds us of a vast cemetery or charnel-house. The bones lie at all angles, many of them broken and disjointed, as though the owner had died at a distance, and lis remains, sadly mutilated on the way, had been borne to their last resting-place by the shifting currents; others lie all in place, corered with their armature of scales, as though the creature, conscions of approaching dissolution, had sought ont a sheltered nook and there lain down and died.**

562. Why may we infer that the Temperature of the Earth's Surface was Greater in the Earlier Epochs than at Present?

If we take a general view of the remains of both marine and terrestrial vegetables that are distributed through the three great periods of geological history, we find a marked division of them into three great groups, each respectively indicating the same successive diminutions of temperature upon the land, which have been inferred from the remains of the vegetation of the sea. 
"There went up a smoke out of his nostrils, and fire out of his mouth deroured: coals were kindled by it."-II SAJIEL xxii.

503. Thus, in strata of the Transition scries, we have an assoeiation of a few existing families of Endogenous plants, chiefly ferns and Equisetacec, with perhaps extinct families, both Endogenous and Exogenous, which some modern botanists have considered to indicate a climate hotter than that of the Tropics of the present day.

504. In the Secondary formations, the speeies of those most early families beeome much less numerous, and many of their genera, and eren of the families themselves, entirely cease; and a large increase takes place in two families that comprehend many existing forms of regetables, and are rare in the coal formaticu, viz., Cycadea and Conifere. The united characters of the groups assoeiated in this series indicate a climate whose temperature was similar to that uhich prevails within the present Tropics.

565. In the Tertiary deposits, the greater number of the families of the first series, and many of those of the second, disappear, and a more complieated Dicotyledonous vegetation takes place of the simple forms which predominated through the preceding periods. Smaller Equisetacere also succeed to the gigantic Calamites. Ferns are reduced in size and number to the scanty proportions they bear on the sunken verge of our temperate climates; the presence of Palms attests the absence of any severe degree of cold, and the general character marks. a climate nearly approaching to that of the Mecliterrancan."

560. The submarine vegetation also admits of three great divisions, which charaeterise to a certain degree the plants of the frigid, temperate, and torrid zones; that an analogous distribution of the fossil submersed Alga appears to have placed in the lowest and most ancient formations genera allied to those which now grow in regions of the greatest heat, whilst the forms of marine regetation that succeed eacl other in the Secondary and Tertiary periods seem to approximate nearer to those of our present chimate, as they are respectively enclosed in strata of more reeent formation.

567. Why are the Remains of Terrestrial and Fresih and Salt Water Animals found Fossilized together?

These deposits were doubtless formed in estuaries where the waters of seas, lakes, and river's mingled. Such 
"And the sea gave up the dead which were in it."-Revecktons xx.

conditions are analogous to those which are now to he observed near the deltas of the Nile, the Mississippi, and other great rivers.

568. Thus, we find a strata of oyster shells, that indicate the presence either of sals or brackish water, interposed between limestone strata filled with fresh-water shells among the Purbeck formations; so also in the sands and clays of the Wealden formation of Filgate Forest are found fresh-water and lacustrine shells, intermixed with remains of large terrestrial reptiles.

569. From one limited tract of sea-bottom on the Norfolk coast, the fishermen cmployed in dredging for oysters brought ashore, in the course of thirteen years, no fewer than tuo thousand elephant's grinders, besides great tusks and numerous portions of skeletons. It was calculated that these remains must have belonged to as many as five hundred individual mammoths of English growth; and, various in their states of preservation, and belonging. to animals of which only a few at a time could have found sufficient food in a limited tract of country, the inference seems inevitable that they must have belonged, not to one or two, but to many succeeding generations of elephants.

570. Why is Geology indebted for many of its Facts to Shell-forming Animals?

Because the enduring nature of the calcareous coverings which those animals had the power of secreting, has placed our knowledge of Fossil Shells almost on a footing with that of recent Conchology, and throws considerable light upon the ancient conditions of the earth.

571. In the present state of the science it is chiefly by aid of shells that we are enabled to arrive at several important conclusions; for of all classes the Testacece are the most 
"Truly in vain is salvation hoped for from the lills, and from the multitudes of mountains: truly in the Lord our God is the salvation of Israel."-JEremian iii.

generally diffused in a fossil state, and may be called the medals principally cmployed by nature in recording the chronology of the past.

572. We find many and various forms both of uniralve and biralie shells, mixed with numerous remains of artieulated and radiated animals, in the most aneient strata of the transition period that contain any traces of organic life. Many of these shells agree so closely witlr

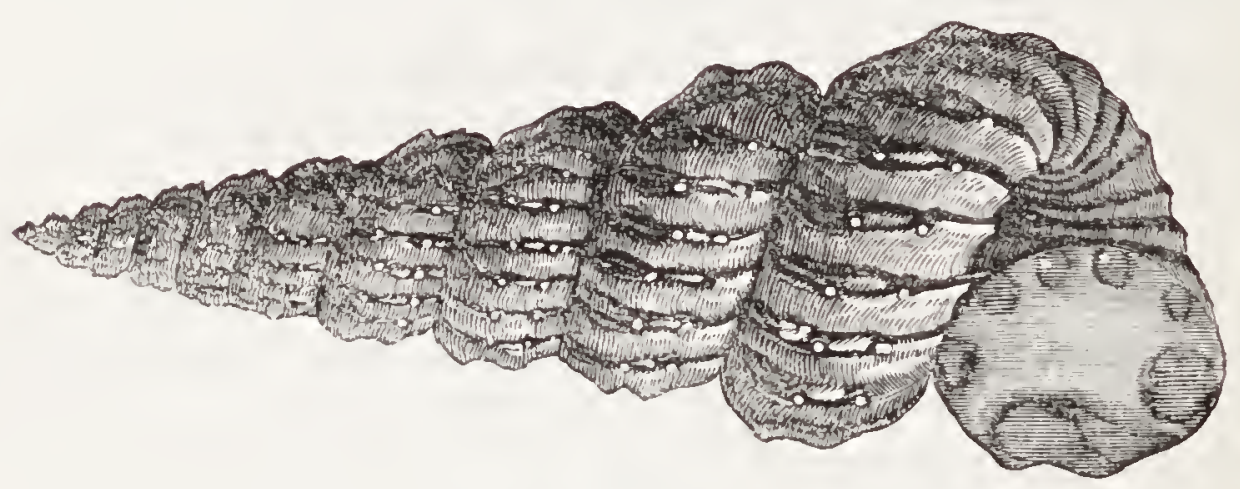

TURRULITE.

existing speeies, that we may infer their formations to have been the same, and that they were inhabited by animals of form and habits similar to those which fabrieate the living silells most nearly resembling them. All turbinated and living shells are construeted by mollues of a higher order than the Conchifers, whieh eonstruct bivalves; the former have heads and eyes. The Conehifers, or eonstruetors of bivalves, are withont either of these important parts, and possess but a low degree of any other sense than toneh or taste. Thus, the Molluse whieh oecupies a Whelk or a Limpet shell, is an animal of a higher order than the Conchifer enelosed between the two ralves of a MIussel or an Orster shell.

573. Lamarek has divided them into two great seetions, viz., herbivorous and carnivorous; the earnivorous are also divisible into two families of different office, the one attaeking and destroying living bodies, the other eating dead bodies that have perished in the eourse of nature, or from aceidental eauses, after the manner of the Hyænas and Vultures, which by preferenee live on carrion. The same principle of eeonomy in nature, whieh causes the clead careases of the hosts of terrestrial herbivorous animals to be aeeelerated in their deeomposition by forming the food of numerous carnivora, appears also to have been 
"And they shall look unto the earth; and behold trouble und darkness, dimness of anguish; and they sliall be driven to darkness."-IsAini viii.

applied to the submarine inhabitants of the most aneient as well as of the existing seas; thus converting the death of one tribe into the nutriment and support of life in others.

574. Most collectors have seen upon the sea shore numbers of dead shells, in whieh small circular holes lave been bored by the predaeious tribes for the purpose of feeding upon the bodies of the animals eontained within them. Similar holes oeeur in many fossil shells of the Tertiary strata, wherein the shells of earnivorous Traeleelipods also abound; but perforations of this kind are extremely rare in the fossils of the older formation.

\section{Why are Stone Lilies so called?}

From a fanciful resemblance to lities. They are fossil remains which have long been known as Encrinites, and have lately been classed under a separate order of the name of Crinoüdea. Successions of strata, each of many feet in thickness, and many miles in extent, are often half made of the skeletons of these radiated animals. The Entrochal Narble of Derbyshire, and the Black Rock in the cliffs of carboniferous limestone near Bristol, are well-known examples of strata thus composed; and show how largely the bodies of animals have occasionally contributed by their remains to increase the wolume of materials of the mineral world.

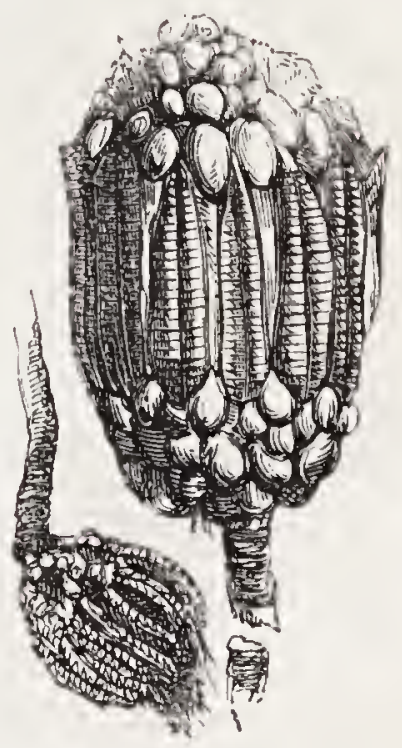

CRINOIDEANS.

576. Although the representatives of Crinoideans in our modern seas mre of rare oeeurence, this family was of vast numerical importance among the earliest inhabitants of the aneient deep. The bony portions folmed the great bulk of their bodies, as they do in Star-fishes; the calcareous matter of these little bones was probably seereted by a perioseum which, in cases of accident, to which bodles so delicately constructed 
"Let the heavens be glad, and let the earth rejoice: and let men say anong the nations, 'lhe Lord reigneth."-I Chroviches xi.

must have been exposed in storny seas, seems to have had the power of depositing fresh matter to repair casual injuries, as Crabs and Lobsters reproduce their lost elaws and legs, and many Lizards their tails and feet. The arms of Star-fishes also, when broken off, are reproduecd in a like manner.

577. We may judge of the degree to whieh the individuals of these species multiplied among the first inhabitants of the sea, from the countless myriads of their petrified remains, which fill so many limestone bedis of the transition formations, and compose vast strata of Entrochal Marble, extending over large tracts of country in Northern Europe and North America. The substance of this marble is often almost as entively made up of the petrified bones of Crinoüdeans as a corn-rick is composel of. stracs. Inn applies it to construct his palace and adorn his sepulehre; but there are few who know, and still fewer who duly appreciate, the surprising fact, that mucl of this marble is composed of the skeletons of millions of organised beings, onee endowed with life and susceptible of enjoyment, which, after performing the part that was for a while assigned to them in living nature, have contributed their remains towards the eomposition of the mountain masses of the earth.*

578. What function do Polypes fulfil in the Sea?

We find them acting as scavengers of the lowest class, perpetually employed in cleansing the waters of the sea from impurities, in the same mamuer as the insect tribes, in their various stages, are destined to find their food by devouring impurities caused by dead animal and regetable matter upon the land.

579. Why may we be assured that the Humblest forms of Life have exerted Great Influences upon the Earth?

Because the microscopic examination of a mass of rude and lifeless limestone or sand discloses the cmious fact that large portions of ats substance have once formed parts of living bodies.

580. It is surprising to consider that the walls of our * Dr. Bucliand. 
"One generation passeth away, and another generation cometh; but the earth abideth for ever."--Ecclestastes i.

houses are sometimes composed of little else than comminuted shells, that once were the dwellings of other animals, at the bottom of ancient seas and lakes.

581. A great part of the present surfuce of the earth is derived from the remains of animals that constituted the population of ancient seas. Many extensive plains and massive mountains form, as it were, the great charnel-houses of preceding generations, in which the petrified exuvix of extinct races of animals and vegetables are piled into stupendous monuments of the operations of life and death.

582. At the sight of a spectacle so imposing, so terrible, as that of the wreck of animal life, forming almost the cntire soil on which we tread, it is difficult to refrain from wonder at the causes by which such great effects have been produced.

583. Why are Trilobites objects of Great Interest in the Study of Geology?

Because they were some of the first-created inhabitants of our planet. The great extent to which they are distributed over the surface of the globe, and their numerical abundance in the places where they have been discovered, are remarkable features in their history; they occur at most distant points, both of the Northern and Southern Hemispheres. The fossils of this family have long attracted attention, from their strange peculiarities of configuration.

584. The family appears to have been annihilated at so early a period as the termination of the carboniferous strata; they nevertheless present analogies of structure which place them in near approximation to the inhabitants of existing seas. An approx imation to the character of "Trilobites occurs in the Limulus, or King Crab, a genus now most 
"Where wast thou when I laid the foundation of the earth? declare, if thou hast understanding."-Jon xxxviii.

abundant in the seas of warm elimates, chiefly in those of India, and of the coasts of America.

585. The anterior segment of the Trilobites is composed of a large semicircular or erescent-shaped shield, succeeded by an abdomen or

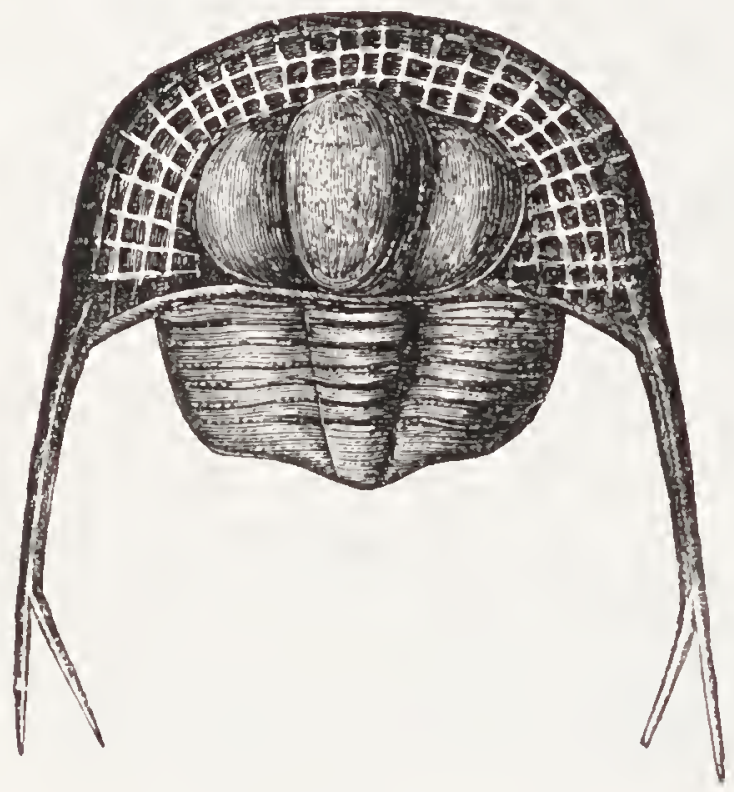

SILURIAN TRILOBITE.

body, composed of numerous segments folding orer each other, like those in a Lobster's tail, and generally divided by two longitudinal furrows into three ranges of lobes, from whieh they have derived the name Trilobites. Behind this body, in many species, is placed a triangular or semilumar tail or post-abdomen less distinctly lobed than the body.

5s6. The eyes of Trilobites were compound, like those of Butterflies and Dragonflies, which are adapted to produce distinet vision through the medium of a number of minute facets or lenses, placed at the extremity of an equal number of eonical tubes or microscopes. In one species, each eyc has been found to eontain at least 400 nearly spherical lenses, fixed in separatc eompartments on the surface of the cornea. The form of the general cornea is peculiarly adropted to the uses of an chimal destined to live at the bottom of uater: to look downwards was as much impossible as it was unnecessary to a creature living at the bottom, but for horizontal vision in every direction the contrivance was complete. The form of each eye was incomplete only on that side which ras dircetly opposite to the eorresponding side of the other eye, and in which, if facets were present, their ehief range would be towards each other across the head, where no rision was required. The extcrior of each eye, like a cireular bastion, ranged nearly round three-fourths of a circle, each eommanding so mueh of the horizon that where the distinct rision of one eye ceases that of the other eye begins, so that in the horizontal direction the eombined range of both eyes was panoramic. We must regard these organs with feelings of no ordinary kind, when 
"As the mountains are round about Jelusalem, so the Lord is round about His people from henceforth even for ever."-PsaLj cxxr.

we recollect that we have before us the identieal instruments of vision. through which the light of heaven was admitted to the sensorium of some of the first-created inhabitants of our planet.* And that these delicate organs should come down to us through untold ages in a state of sufficient preservation for the microscope to reveal their beautiful and perfect structure is matter for surpassing wonder.

587. Why does the study of the Organs of Vision of the Trilobites throw material light upon certain Geological Problems?

Because it appears obvious that the waters wherein the Trilobites maintained their existence through the entire period, could not have been that turbid and chaotic fluid from the precipitates of which some geologists hare supposed the materials of the surface of the earth to be derived; the structure of the eyes of these animals is such, that any kind of fluid in which they could have been efficient at the bottom must have been pure and transparent enough to allow the passage of light.

588. With regard to the atmosphere, also, we infer that, liad it materially differed from its present eondition, it might so far liave affected the rays of light that a colresponding difference from the eyes of the existing Crustaceans would have been found in the organs on whieh the impressions of such rays were then received.

589. Regarding light, we learn, from the resemblanee of these most ancient organisations to existing eyes, that the material relations of light to the eye, and of the eye to light, were the same at the time when Crustaeeans, endowed with the faculty of vision, were first placed at the bottom of the primeval seas, as at the present moment.

590. Thus, we find among the earliest organic remains an optieal instrument of most curious eolstruetion, adapted to produee vision of a peculiar kind, in the then existing representatives of one great elass in the articulated division of the animal kingdom. If we slould diseover a mieroseope in the head of an Egyptian mummy, or beneath the ruins 
"Happy is he that hath the God of Jacob for his help, whose hope is in the Lord his God!"-P'salur cxlvi.

of Herculaneum, it would be impossible not to understand the laws of atmosphere and light to which the lenses of such an instrument were adapted. The same inference follows, but with cumulative force, when we see nearly four hundred microscopic lenses set side by side in the compond eye of a fossil Trilobite.*

591. The Geologist knows no more unique family than the Trilobites - a family in close nicely-jointed sliells. The armourer of the Mirllle Ages might have found almost all the contrivances of his craft anticipated, with some adaptations he had failed to discover, and which-after receiving so immense a development during the middle and later times of the Silurian period, that whole rocks uere formed almost exclusively of their remains-gradually died out in the times of the Old Red Sandstone, and disappeared for ever from creation after the Carboniferous Limestone had been deposited. And yet, though the whole family perished myriads of ages ago, how admirably does it exhibit the articulated type of being, and illustrate that unity of design which, amid endless diversity, pervades all nature.*

592. What was the origin of Fossil "Footprints" and "Rain-chops?"

Certain mud-flats are almirably adapted to receive and retain mariings that may be made upon their surfaces. 'Those that are found at low tide on the border's of the Bay of Fundy may be cited as an example. 'The sediment with which the waters are charged is extremely fine, being derired from the destruction of cliffs of red sandstone and shell; and as the tides rise fifty feet and upwards, large areas are laid dry for nearly a fortnight between the spring and neap tides. In this interval the mud is baked in summer by a hot sun, so that it solidifies and becomes trarersed by cracks caused by shrinkage; and upon these surfaces, which become afterwards covered by new deposits, the footprints of birds, and the impressions of worm-tracks and rain-drops, are often rendered perananent.

* Dr. Buckland. + Hugh Miller"s "Testimony of the Rocks." 
"As the bird by wandering, as the swallow by flying, so the curse causeless shall not come."-Proverbs xxvi.

593. Scotland has recently afforded evidence of the existence of more than one species of terrestrial reptiles during the period of the New Red or Variegated Sandstone formation. Similar impressions have been

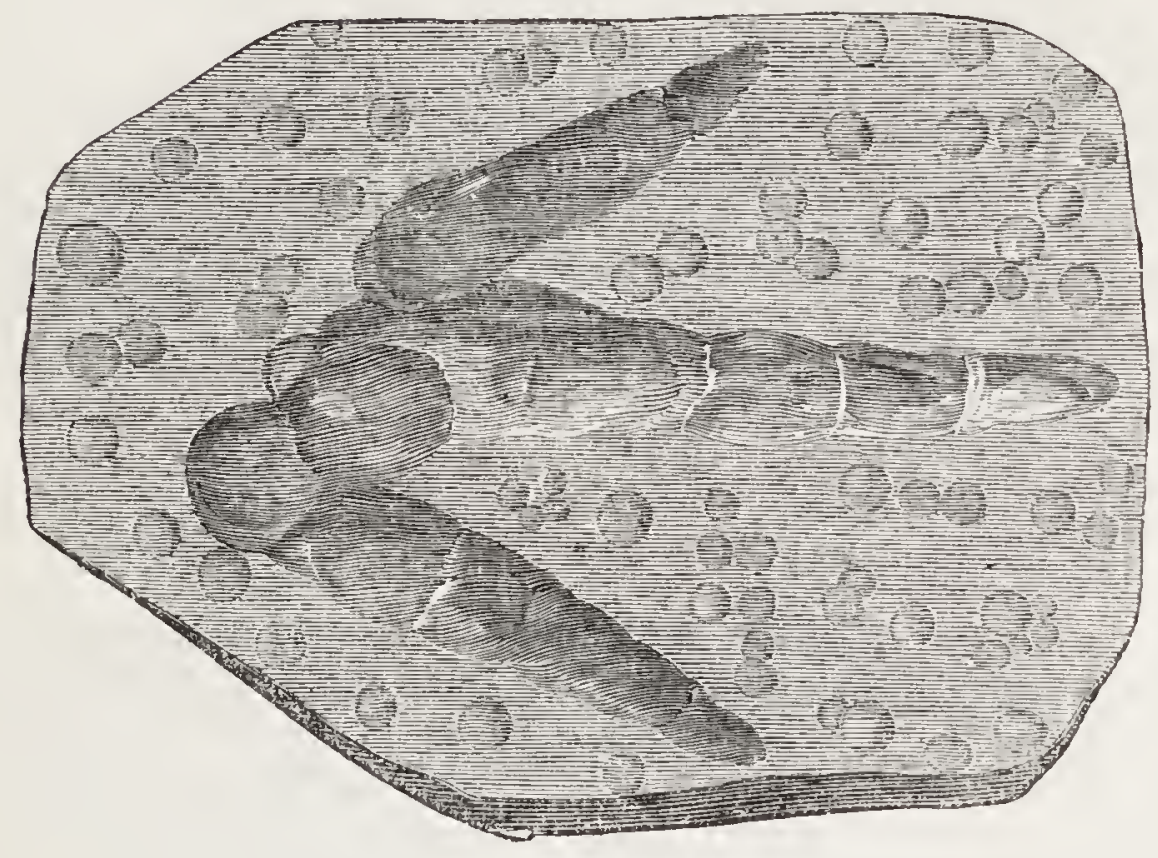

IMPRINT OF THE FOOT OF A BIRD, AND MARKS OF RAIN-DROPS, ON A SLAB OF SANDSTONE.

discovered about ten miles south of Corn Cockle Muir, in the Red Sandstone quarries of Craigs, two miles east of the town of Dumfries, and a still later discovery of fossil footsteps has been made in Saxony, at the village of Hesseberg, in several quarries of Grey Sandstone, alternating. with beds of Red Sandstone, nearly of the same age with that of Dumfries.

594. Why are some of the Quarries in which Footsteps are found Destitute of Bones of the Animals they represent?

This circumstance may perhaps be explained by the nature of the siliceous sandstone having been unfavourable to the preservation of organic remains. Conditions which would admit of the entire obliteration of bones, would in no way interfere with the preservation of impressions made by feet, and speedily filled by a succeeding deposit of 
"And God created great whales, and every living creature that movcth, which the waters brought forth abundantly, after their lind."-GExesis i.

sand, which would assume, with the fidelity of an artifieial plaster mould, the precise form of the surface to which it was applied.*

595. In 1844 footprints of a reptile, related to the Salamanders, were found in the coal measures of Rhenish Bararia; and in 1847 marks of three species of another genus were obtained from the coal of Saarbriick, between Treves and Strasburg. The footprints of a large quadruped, probably Batrachian, were also observed in the carboniferous rocks of Penusylvania in 1844; and the bones of a reptile in the coal of North America were detected in 1852. Bones lave also been found in some of the sandstone quarries, with the fontsteps.

596. Why is the study of Fossil Fishes of Great Importance in relation to Geology?

Beeause of the formation of a vast proportion of the surface of the earth beneath uater. The study of fossil Ichthyology is, therefore, of peculiar importanee to the geologist, as it enables him to follow an entire elass of animals, of so high a division as the vertebrate, through the whole series of geological formations, and to institute comparisons between their various conditions during the suecessive periods of the earth's formation.

597. 'The eharaeter of fishes is so surely and constantly indieated by their scales, that the preservation of a single seale will often announee the genus and even the species of the fish fiom which it was derived. A further adrantage arises from the faet, that the enamelled eondition of the seales of most fishes whieh existed during the earlier geological epochs, rendered them much less destruetible than their internal skeletons; and eases frequently occur where the entire seales and figure of the fish are perfeetly preserved, whilst the bones within these scales have 
"Shall the flocks and the herds be slain for them, to suffice them? or shall all the fish of the sea be gathered together for them, to suffice them?"-Numbelis xi.

altogether disappeared, the enamel of the scales being less soluble than the more calcareous material of the bone.

598. The eharaeter of fossil fishes does not change imperceptibly from one formation to anothcr, as in the case of many Zoopliytes and Testaceæ; nor do the same genera, or even the same families pervade successive series of formations; but their changes take place abruptly, at certain points in the vertical succession of the strata, like the sudden clanges that occur in fossil reptiles and mammalia. Not a single species of fossil fishes las yet been found commou to auy two great geological formations; nor in our present seas.

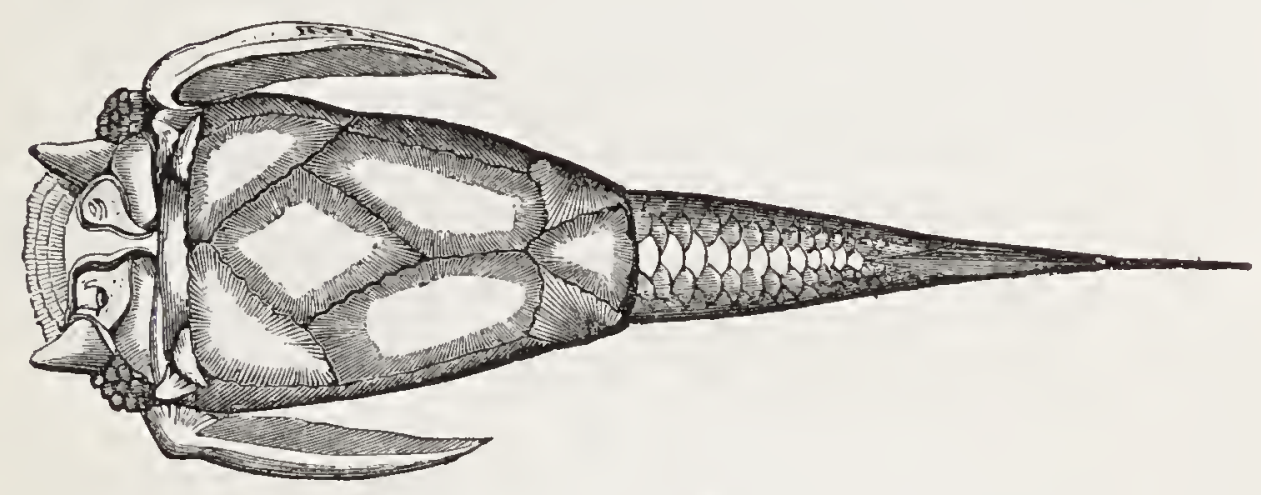

PTERICITTHYS CORNUTUS.

599. The voracious family of Samroids, or lizard-like fishes, first claim attention. Their teeth equal in size those of the largest crocodiles; they occur in the lower regions of the Coal formation near Edinburgh. Their prodigious size shows the magnitude which fishes of this family attained in the Carboniferous era.* But the same early epoch was marked by the presence of large numbers of fisles that fed ou decayed sea-weed and soft animal substances at the bottom of the water ; their teeth were small and numerous, and set together like the Lairs of a brush.

600. The fishes of the Old Red Sandstone present very unconth forms, covered with bony framework. The Pteriehthys (winged fisli) figured in the engraving is a striking example. This was one of a group remarkable for the large size of the bony plates comparcd witl that of the animal, and also for the distinet and peculiar forms of such

* Dr. Buckland. 
"Speak to the earth, and it shall teach thee, and the fishes of the sea shall declure unto thee."--Jow xii.

plates. There were also bony coverings to the fins, and a projeeting tail, giving the appearanee of a winged animal. The arms were weapons of defence, which were ereeted in moments of danger or alarm, and at other times lay close by its side. The sole instrument of motion was the tail.* The leading elaracter of the fishes most numerous in this formation consisted in a peculiar armature of all parts of the moutl, with a parement of thiek, round, and flat teetl. 'The use of this peculiar apparatus was to crusl small shells and small Crustacex, and to comminute putrescent sea-weeds.

601. The fishes of the Chall formation present remarkable changes. Genera of the first and sceond orders (Placoidian and Ganoidian) whieh had prevailed exelusively in all formations till the termination of the Oolitie series, eeased suddenly, and were replaeed by genera of new order's (Ctenoidian and Cycloridian), then for the first time introineed. Nearly two-thirds of the latter are now extinct; but these approael nearer to fishes of the tertiary series than to those which had preecded the formation of the elalk. Comparing the fishes of the Chalk with those of the elder tertiary formation of Monte Bolea, we find not one speeies, and but a few genera that are eommon to botll.

602. The fishes of the Tertiary formation exhibit also remarkable changes. The fishes of the Crag of Norfolk, and the superior subAppenine formation, as far as they are yet known, appear for the most part related to genera now common in tropical seas, but are all of extinet speeies.

603. This important family of vertebrated animals presented gradations of structure amongst the earlicst inhabitants of our planct, and has ever performed the same important funetions in the general economy of nature as those discharged by their living representatires in our modern seas, lakes, and rivers. $\dagger$

604. The carliest fishes seem to hare been all Placoids-those which to an internal eartilaginous skeleton unite an externa! urmature of plates. With the Old Red Sandstone originated the Ganoids-those that are eorered, whatever the eonsisteney of their skeleton, by a nearly continnous armour of enamelled bone, or by great bony plates that loek into each other at their edges; and for untold ages the entire 
"Prophesy upon these dry bones, and say unto them, o ye dry bones, hear the word of the Lord."-EZEKLEL xxxrii.

class of fishes consisted, so far as is yet known, of but these two order's. During the times of the Old Red Sandstone, of the Carboniferous, of the Permian, of the Triassie, and of the Oolitic systems, all fishes, though apparently as numerous individually as they are now, were comprised in the Ganoidal and Plaeoidal order's. At length, during the ages of the Chalk, the Cycloids-fishes whose scales resemble those of the Salmon-and the Ctenoids, having scales like those of the Pereh, were ushered in, and were gradually developed in ereation until the liuman period, in which they seem to have reached their culminating point, and now many times exeeed in number and importance all other fishes. We do not see a Sturgeon (our British representative of the Ganoids) onee in a twelvemonth; and though the Skate and Dog-fish (our representatives of the Placoids) are greatly less rare, their number bears but a small proportion to that of the fishes belonging to the two prevailing orders, of whieh thousands of boat-loads are landed on our coasts every day."

605. Why is the Plesiosanms so named?

From two Greek words-plesion, near to, and saura, a lizard. Of this animal, Cuvier asserts that its structure is the most monstrous that has yet been found among the ruins of a former world.

606. To the head of a lizard it united the teeth of a crocodile, a neck resembling the body of a serpent, a trunk and tail having the proportions of an ordinary quadruped, the ribs of a clamelion, and the paddles of a whale. The first specimens were discovered in the lias of Lyme Regis, about the year 1823, and other examples liave since been recognized in the same formations in different parts of Engiand, Ireland, France, and Germany, and in formations of various ages, from the muschelkalk upwards to the chalk.

607. The Plesiosauri appear to have lived in shallow seas and estuaries, and to have breathed air, like our whales. The most remark- 
"And behold they were dead bodies fallen to the earth, and none escaped."2 Chronicles $\mathrm{xx}$.

able feature of the genus is the extraordinary extension of the neck to a length almost equalling that of the body and tail together. The tail, being comparatively short, could not have been used, like the tail of fishes, as an instrument of rapid impulsion in a forward direction, but was probably employed as a rudder on the surfaee, and to elevate or

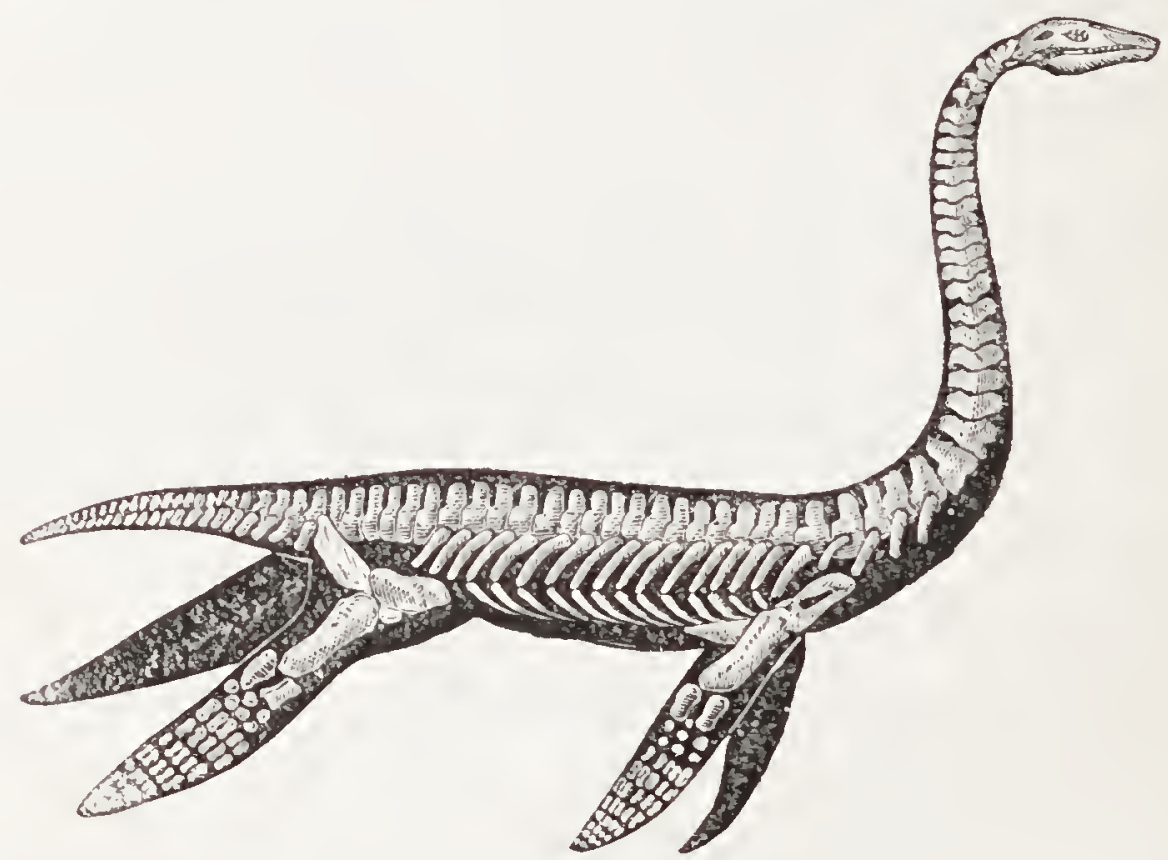

PLESIOSACTUS DOLICIODEIRUS.

depress the body in aseending or deseending the water. The compound eharacter of the ribs probably gave it the porer of eompressing air within its lungs, and in that state taking it to the bottom. 'That it was aquatic is quite evident from the form of the paddles; that it was marine is almost equally so, from the remains with which it is universally assoeiated; that it may have occasionally risitel the shore, the rescmblanee of its extremities to those of the turtle may lead us to eonjecture. Its motions, however, must lare been rery awkward on land; its long neck must have inpeded its progress through the water, for whieh reason it probably suam upon the surface, arehing its long neek like the swan, and oeeasionally darting it down at the fish whieh lappened to eome within its reach. It may, perhaps, have lurked in shoal water along the coast, eoneealed among sea-weed, and, raising its nostrils to a level with the surface from a eonsiderable depth, may lave eaptured its prey from this position of eoncealment, and at the same time found a seeure retreat from dangerous enemies. 
"Tou remumbrances are like unto ashes, and your bodies to bodies of clay." -Joв xiii.

608. The Pterodactyles form a genus presenting more singular anatomical eombinations than are to be found in any other creatures yet discovered amid the ruins of the ancient carth. 'The structure of these animals is so exceedingly anomalous, that the first one discovered was considered by one naturalist to be a bird, by another as a speciez of

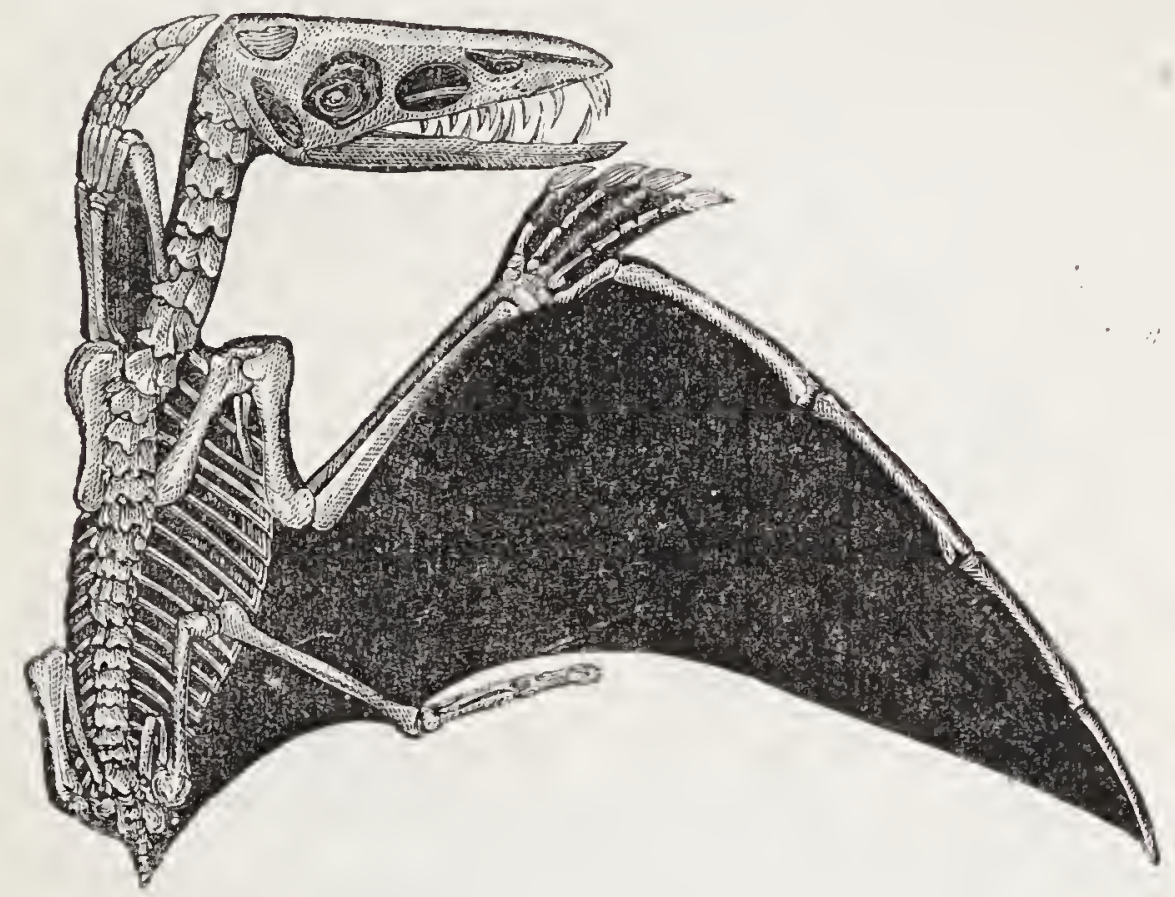

PTERODACTYIUS CRASSIROSTIS.

bat, and by a third as a flying reptile. This extraordinary discordance of opinion arose from the prescnce of cluaracters apparently belonging to each of the three classes to which it was referred; the form of its head, and length of neck, resembling those of birds, its wings approaching to the proportion and form of those of bats, and the body and tail approximating to those of ordinary mammalia. These characters, connected with a small skull, as is usual among reptiles, and a beak furnished with not less than sixty pointed tceth, prescnted a combination of apparent anomalies.

609. The Pterodactylcs are ranked by Cuvier among the most extraordinary of all the extinct animals that have come under his consideration; and such as, if we saw them restored to life, would appear most strange, and unlike anything that exists at present. The specimens found vary from the size of a snipe to very gigantic dimensions, the crpanse from wing to wing being no less than twenty-seven feet. 
"Wisdom is before him that hath understanding, wut the eyes of a fool are in the ends of the earth."-Proverns xvii.

610. Their eyes were of enormous size, from which we may infer that they flew by night; and that some of them forl upon night-flying insccts, of much larger size than any that are now known. From their wings terminating in projecting fingers, terminated by long hooks, they must have been able to climb the rough surfaces of rocks, or suspend thomsclves from trees. The head and teeth of two species of Pterodactyle are so much larger and stronger than is necessary for the capture of insects, that the larger species of them may have fed on fishcs, darting upon them from the air, after the manner of sea swallows and solan geese, and they may also have proyed upon the few Marsupial animals which then existed upon the land. The study of t!hese wonderful mechanisms shows that even in the most distant eras the same care of our all-wise Creator, which we witness in the mechanism of our own bodies, and those of the myriads of inferior creatures that move around us, was extended to the structure of creatures which at first sight seem made up only of monstrosities.**

611. Why may the habits of Extinct Animals be inferrect from their Remains?

An example or two may suffice in explanation. The Dinotherium was probably the largest of the terrestrial Mammalia; the lower jaw and the tusks exhibit an extraordinary arrangement, adapted to the peculiar habits of a gigantic herbirorous aquatic quadruped. The most remarkable bone of the body yet found is the shoulder-blade, the form of which more resembles that of a mole than of any other animal, and indicates a peculiar adaptation of the fore leg to purposes of digging, an indication which is corroborated by the remarkable structure of the lower jaw.

612. It is mechanically impossible that a jaw, nearly four feet long, loaded with such heavy tuslis at its extremity, could have been otherwise than cumbrous and inconvenient to a quadruped living on dry land. No such disadvantage would have attended this structure in a large animal desfined to live in vater; and the aquatic habits of the family 
"They shall lie down together, they shall not rise; they are extinct, they are quenched in tow."-Isaiah xxiii.

of tapirs, to which the Dinotherium was most nearly allied, render it probable that, like them, it was an inhabitant of lakes and rivers.

613. To an animal of such habits the weight of the tusks sustained in water would have been no source of inconvenience; and, if we suppose them to have been employed.

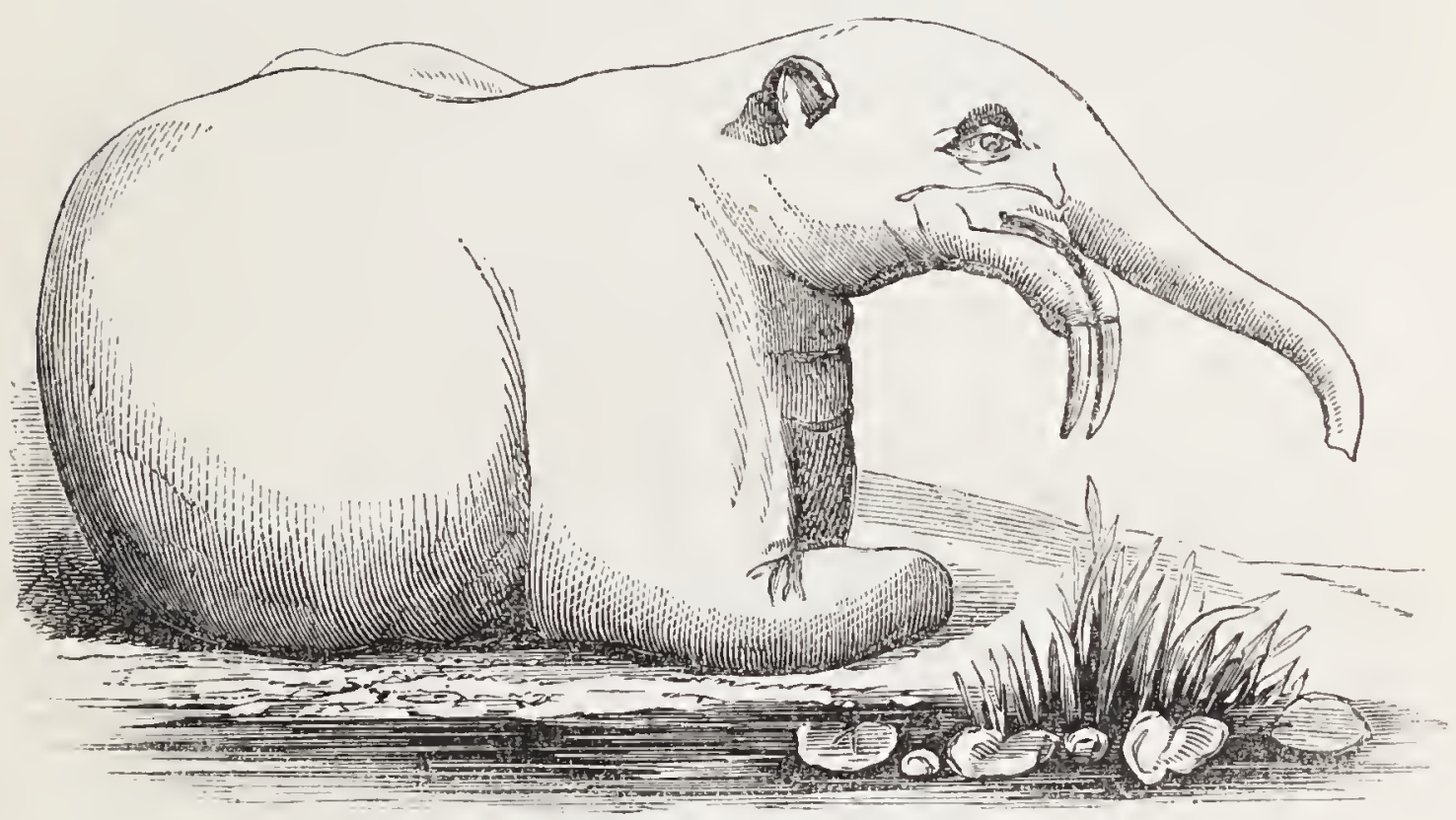

DINOTHERIUM.

as instruments for raking and grubbing up by the roots large aquatic vegetables from the bottom, they would combine the mechanical powers of the pick-axe with those of the horseharrow of modern husbandry. The weight of the head, placed above these downward tusks, would add to their efficiency, the more so as the skull was obviously connected with very powerful muscles, which would give that peculiar movement to the head which would enable the tusks to dig into and tear up the earth.

614. The following will show hov the species of an animal may be determined by the inspection of a single organ. It is from the correspondence between single characters and general plans of structure 
"Confidence in an nnfaithful man in time of trouble is like a broken tootl, and a foot out of joint."-PRoverus xiri.

that the nature of the whole animal is determined, from a single fragment of its skeleton, or from one of its teetl. In no animal is the body made up of a number of diseonneeted parts, united, as it were, at hazard; for all its organs liave a more or less intimate eonnection with eaeh other, so that there is a kind of harmony amongst them all, and between every part and the entire strueture.

615. Thus, the simple inspeetion of the tooth represented in the accompanying figure, suffices to diselose to the scientifie naturalist the foilowing facts regarding the animal to whieh it belonged. In the first plaee, there must have been a bony framework, in which this tooth was planted, and whiel gave support to the lest of the body; and as this internal framework does not exist in any other animals than those of the vertebrated series, we know that the animal in question had the brain and spinal cord, the eomplete set of organs of the senses, the red blood, se., whieh belong to the sub-kingdom only.

616. Further, there are certain characters about the roots of this tooth which enable the anatomist to feel eertain that it must hare becn implanted in a decp socket, which is only the case in mammals and reptiles; and he may further determine from them that the animal belonged to the former, and that it must, thcrefore, hare possessed the organization which is peculiar to it.

617. Again, by the form of the erown of the tooth, it is easily shown that it was destined to divide animal fiesh, and that it eonsequently

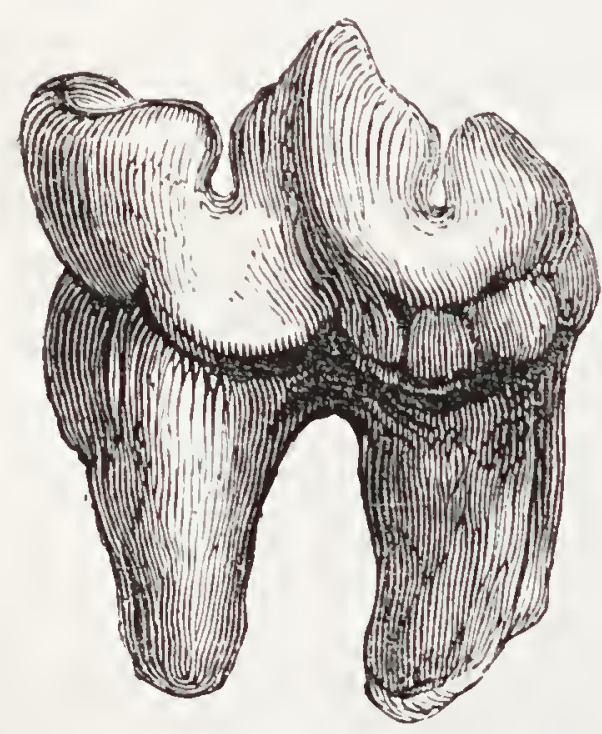
belonged to a camivorous quadruped. To digest the flesh, the animal must have had a stomach and intestinal eanal formed upon a eertain plan; and, in order to obtain its prey, it must have had appropriate organs of loeomotion and prehension. Its extremities must have terminated in separate toes, and these must liave been armed witl elaws. The limbs must have been furnished with rery powerful muscles, to enable the animal to give elrasc to its prey, ol to spring upon it mawares, and afterwards drag it to its den. The head, also, must hare been eonneeted witl the 
"He sliall be buried with the burial of an ass, drawn and cast forth beyond the gates of Jerusalem."-JeremaIr xxii.

spinal column by ligaments and muscles of great power, attaclied to elevated portions of the rertebra, in ordcr that it might have the power of lifting the heavy bodies which the animal desired to remore. The lower jaw must have becn connected with the upper by a linge, admitting but a scraper-like action, by which the edges of the cutting teeth were constantly kept sharp; and the muzzle must not liave been vcry protuberant, otherwise the strength of the muscles which raise the jaw wonld be applied at a great disadvantage. The cranial cavity must have been comparativcly large, in order that the size of the brain might correspond with the degree of vitality which the habits of the animal required. By inferences of this kind, and under the guidance of our knowledge of the forms at present existing, all the leading peculiarities of an animal may be deduced from any characteristic portion of it; for, if any part essential to the action of the remainder had been deficient, the animal could not lave maintained its cxistence.**

618. The remains of the Mrgathorium have becn found chiefly in the southern regions of South America, and most abundantly in Pariguay. Wc have here to contemplate a gigantic quadruped, ipparently ill-proportioned as a whole, and whosc mombers seem incongruous and clumsy. The bones of the head most nearly resemblc those of a Stork; the long and broad bonc dcscending from the end of the skull must have been auxiliary to the power of great muscles giving motion to the lower jaw. The anterior part of the muzzle is so strong and substantial, and so perforated with holes for the passage of nerves and ressels, that we may be sure it supportcd some organ of considerable size; a trunk was needless to an animal possessing so long a neck; the organ was probably a snout, something like that of the Tapir, sufficiently elongated to gather up roots from the ground. The partition of the nostrils also, being strong and bony, gives further indication of the presencc of a powerful organ appended to the nose; sucl an apparatus would have afforded compensation for the absence of incisor teeth and tusks; and, having no cutting teeth, the Megatherium could not have lived on grass; while the structure of the molar teeth, resembling the compound molars of the Elephant, shows that it was not carnivorous. The teetl of the

* See the "Reason Why, Natural History", for interesting riews of the adaptation of animal forms. 
"Who knoweth not in all these things that the hand of the Lord hath wronght this?" -JoB xii.

Megatherinm, together with the bony and museular strueture of the head and jaws, exhibit the perfection of machinery for masticating large roots and branches

619. The tail was long, and eomposed of vertcbræ of enormous magnitude; the diameter of the tail at its largest end, must have been at least two fect; and its eireumferenee about six feet. This enormous tail would give support to the bocly in rarious positions, facilitate the turning of the animal, and serve for a formidable instrument of defenee to an animal subjeet to attack from behind while drinking or feeding.

620. In the shoulder-blade and eollar-bone there were great provisions to give strength and motion to the fore legs, admitting of free motion in different directions. The entire fore foot must hare been about a yard in length, and more than twelve inches wide, forming, together with the freedom of the arm, a most efficient instrument for moving the enth from that depth within which suceulent roots are usually abundant. The elaws of the toes were set obliquely to the ground, like the digging elaws of the Mole, a position which made them instruments of greatcr power for purposes of exearation.

621. The enormous size of the pelvis, the strength of the tail, and breadtl of the fect, must have been of great adrantage to the animal, when standing on three legs, whilst the fourth was occupied in digging. From the enormous size of the pelris, it follows that the abdominal earity mas extremely large, and the risecra volu.. minous, and adripted to the digestion of regetable food. The haunehes of the Megatherium were more than nine feet wide, and its body twelve fect long, and eight ligh ; its feet wore a yard in length, and tcrminated by gigantie elaws; its tail was mueh longer than the tail of any cther beast among extinet or living terrestrial manmalia. Thus hearily eonstrueted, it could neither run, nor leap, nor burrow under the ground, and all its movements must have been necessarily slow; but what need of rapid locomotion to an animal whose oceupation of digging roots, or mprooting trees for food, was ahnost stationary? and what need of speed for flight from foes to a ereature who, by a single stroke of lis paw, or lash of his tail, eould in an instant liave clemolished the Cougnar or the Crocodile? 
"For the Lord thy God bringeth thee into a good land, a land of brooks of water, of countains and depths that spring out of ralleys and hills."-DEuterovomr viii.

622. Why may the comparatively Recent Origin of Man be regarded as a Geological Demonstration?

No conclusion is more fully established than the fact of the total absence of any vestiges of the haman species throughout the entire series of geological formations. The circumstance of no human remains having been found in conjunction with those of extinct animals, may be alleged in confirmation of the belief that those animals lived and died before the creation of man."*

623. No inhabitant of the land exposes himself to so many dangers on the water's as man, whether in a savage or a civilized state; and there is no animal, therefore, whose skeleton is so liable to become imbedded in laeustrine or submarine deposits. Nor can it be said that his remains are more perishable than those of other animals, for, in ancient fields of battle, the bones of men have suffered as little decomposition as those of horses which were buried in the same grave. But eren if the more solid parts of our species had disappeared, the impression of their forms would have remained engraven on the rocks, as have the traces of the tendercst learcs of plants, and the soft integuments of many animals. Works of art, moreover, composed of the most indestruetible materials would have outlasted almost all the organic contents of the scdimentary rocks. $\dagger$

624. The occasional discovery of human bones and works of art in any stratum within a few feet of the surface, affords no eertain evidence of such remains being coeval with the matrix in which they are deposited. The universal practice of interring the dead, and frequent eustom of placing various instruments and utensils in the ground, offer a ready explanation of the presenee of bones of men in situations aecessible for the purposes of burial. The most remarkable recorded ease of human sheletons imbedded in solid limestone rock is that on the shore of Guadaloupe. There is, however, no reason to consider these bones to be of ligh antiquity, as the roek in which they oceur is of very recent formation, and is eomposed of argrlutinated fragments of shells and eorals which inhabit adjacent water. Sueh

* Dr. Buckland (1858).

† Sir C. Lyell. 
"Behold, he breaketh down, and it cannot be built again; he shutteth up a man, and there can be no opening."-Jou xii.

Find of stone is frequently folmed in a few years from sand-banks composed of similar materials, on the shores of tropical scas.

625. F. T. Buckland, Esq., states that he has scen sections of these Guadaloupe bones, and cxamined thin sections of them under a microseope. He describes them as not truly "fossil;" for, whereas in true fossil bones the substance of the bone, having entirely disappeared, bccomes replaeed by mineral mattcr, in the Guadaloupe speeimen the ealearcous or fossilizing mattcr is not found thoroughly ineorporated with the animal and earthy bases of the bone, but seattered about irregularly in the form of numerous small and separate erystals, these erystals having bcen deposited in the minute eavities of the bone from the water in whieh they were held in solution.

626. Frequent discorerics hare also becn made of human bones, and rude works of art, in natural earcrus, sometimes enclosed in stalagmite, at other times in beds of earthy materials, whicl are interspersed with bones of extinct spceics of quadrupeds. These eases may likewise be explained by the common praetiee of mankind in all ages, to bury their read in sueh eonvenicnt repositories. Many of these earcrins have been inhabited by savage pcople, who, for convenienee of oeeupation, have repeatedly disturbed portions of soil in which their predeeessor's may have been buried. Such disturbanees will explain the occasional admixture of fragments of human skeletons and the bones of modern animals witl those of extinet species, introduced at morc carly periods, and by natural causes.

627. The human bones found in the cares of Liège are in a state of less decay than those of the cxtinct speeies of beasts; they are aceompranied by rude flint linives, and other instruments of flint and bone, and are probably derived from uneivilized tribes that inhabited the caves. Many of the bones appear to have bcen brought together, like those in the Cave of Kirkdale, by the agency of Hycenas, and have evidently bcen gnawed by these animals; others, partieularly those of Bears, are not broken or gnawed, but were probably collected in the same manner as the bones of bear's in the Cave of Gailenreuth, by the retreat of those animals into the reccsscs of carcrins on the approach of reatl.**

628. The Care of Atarusse, on the Orinoco, is not, properly * Dir, Dackland, 
"And God said, Let us make man in our own image, after our likeness; and let them liave dominion over the fisl of the sea, and orer the fowls of the air, and over the cattle, and over all the earth, and over every creeping thing."-Genesis i.

speaking, a cave, but rathcr a vaulted roof, formed by a far overhanging cliff, the cavity laving apparently been formed by the waters when at thcir ancient level. This place is the vault or cemetery of an extinct nation. Humboldt counted about 600 well-preserved skelctons placed in as many baskets woven from the stalks of palm-trees. The skeletons are so perfect that not a bone or a joint is wanting.

629. Why do Geologists affirm that the Earth undervent ci series of Changes that fitted it as a Habitation for Man?

Because those forms of vegetables and animals which are most necessary for man did not exist in the period of the eartier Geological formations. 'The earth's geological history exhibits an upward progress from dead matter to the humbler forms of vitality, and from thence to the higher. And after great cattle and beasts of the earth had, in due order, succeeded inanimate plants, sea-monsters and moving creatures that had life, the moral agent, MAN, entered upon the scene.

630. Agassiz, a geologist, whose statements must bc received with respect by every student of the science, finds reason to conclude that the order of Rosacce-an order of plants more important to the gardener than almost any other, and to which the apple, pear, quince, cher'y, plum, peach, apricot, nectarine, almond, raspberr'y, strawber'ry, blackberry, and the various bramble-ber'ries all belong, together with all the roses and the potentillas-was introduced only a short time previous to the appcarance of man. And the true grasses-a still more important order, which, as the corn-bearing plants of the agriculturist, feed at least tuo-thirds of the human species, and in their numerous varieties form the staple food of the grazing animals-rarely appear in the fossil state. They are peculiarly plants of the human period.

631. As therc are order's of plants, such as the Rosaceæ and the Grasses, that scarcely preceded man in their appcarance, so there are families of Fishes that seem pcculiarly to belong to the human period. Of these, there is a family very familiar on our coasts, and which, thougl it furnishes none of our higher aquatic luxuries, is remarkable for the numbers of the human family which it provides with a whole- 
"He cometh forth like a flower, and is cut down: he flecth also as a shadow, and continueth not."-Jö xir.

some and palatable food. The families to which the Salmon and the Turbot belong were ushered into being as early as the times of the clialk; but the Cod family - to which the Cod, the Haddock, the Dorse, the Whiting, the Pollock, the Hake, the Torsk, and the Ling belong, with many other uscful and wholesome species-did not precede man by any period of time appreciable to the geologist.

632. The first Bee makes its appearance in the amber of the Eocene, locked up hermetically in its gem-like tomb--an embalmed corpse in a crystal coffin, along with the fragments of flower-bearing shrubs and trces. Becs and Butterflies are present in increased proportions in the latter Tertiary deposits; but not until that terminal creation to which we ourselves bclong was ushered on the scene did they reccive their fullest derelopment.

633. Thesc facts tell that man's world, with all its griefs and troubles, is more empliatically a world of flowers than any of the creations that preccled it. The geologist accepts the Bee as a sign in the history of the carth. Hcr entombcd remains testify to its gradual preparation as a place of habitation, for a creature destined to seek delight for the mind and the eye as certainly as for the grosser senses, and especially marks the introduction of the stately forest trees, and the arrival of delicious flowers.

031. Curier was unable to detect any difference between the sheleton of a fossil horse and that of our domestic breed; a fossil goat of the same periud cannot be detected from the domesticated animal; and one of onr two fossil oxen does not differ more from some of the existing breeds than thesc have, in the course of time been made, chiefly by artificial means, to differ among themselves.

635. But of one of our clomestic tribss no trace has yet been found in the rocks. This is the Sheep, that soft and harmless creature, that clothes civilized man everywhere in the colder latitudes with its fleece, that fceds him with its flesh, that gives its borels to be spun into the cat-gut with which he refits his musical instruments, whosc horns he has learned to fashion into a thousand useful trinkets, and whose skin, converted into parchment, serred to convey to later times the thinking of the first full blow of the human intellect across the dreary gulf of the Middle Ages.* 
"All fiesh is grass, and all the goodliness thereof is as the floirer of the ficld."ISAIAII $\mathrm{xl}$.

\section{PIA NTS.}

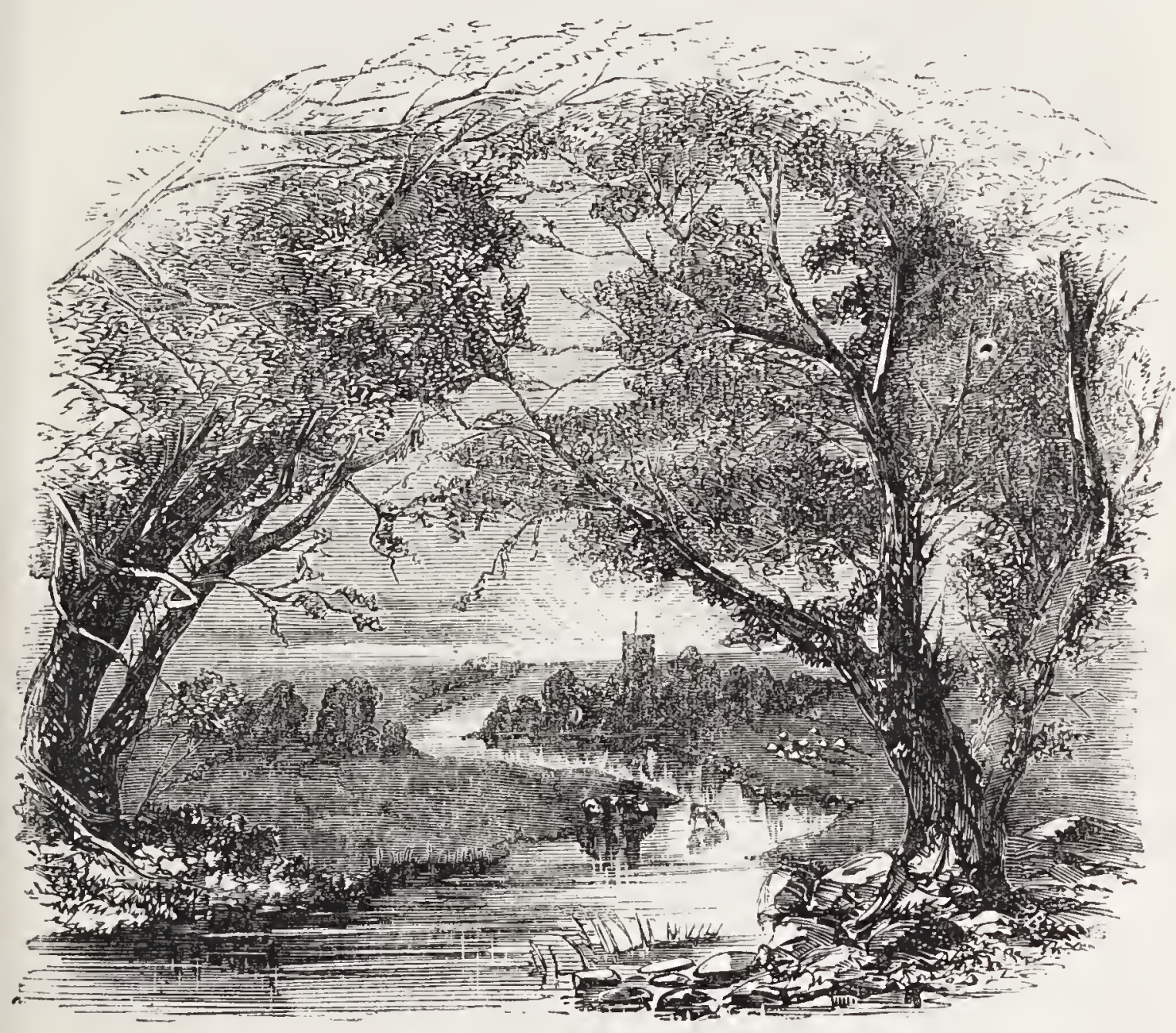

636. What are the Teading Characteristics of Plants?

Vegetables can scarcely be said to rank lower than Animals in Creation, for all animals are either directly or indirectly dependent upon vegetables for their sustenance, and must cease to exist if they were destroyed. Plants are of all sizes, from the microsconic Mushroom, invisible to the 
"The wilderness and the solitary place shall be giad for them; and the desert shall rejoice, and blossom as the rose."-IsAian xxxy.

naked eye, to the sturdy Oak and the Cedar of Lebanon, and from the slender Willow to the Banian tree, under whose shade 7000 persons may find ample room to repose.

637. A thousand different shades of colour distinguish the different specics. Evcry one wcars its peculiar livery, and is distinguished by its own native hues; and many of their inherent beauties can be distinguished only by the aid of the microscope. Some grow upright, others creep along in a serpentine form. Some flourish for ages, others withcr and decay in a few months; some spring up in moist, others in dry soils; some turn towards the sun, others shrink and contract when we approach to touch them.

638. Not only arc the different spccies of plants and flowers distinguished from each other by their different forms, but even the different individuals of the same species. In a bed of Tulips or Carnations, for cxample, there is scarccly a flower in which some peculiarity may not be observed in its structurc, sizc, or assemblage of colours; uor can any two flowers be found in which the shape and shades are cxactly similar.

639. Of all the liundred thousand millions of plants, trees, herbs, and flowers with which our globe is variegated, there are not, perhaps, two individuals precisely alikc in every point of riew in which they may be contemplated; yea, there is not, perhaps, a single leaf in the forest, when minutcly cxamined, that will not be found to differ, in certain aspects, from its fellow. Such is the wonderful and infinitc diversity with which the Creator has adorned the regetable kingdom.

640. In every region on the surface of the globe an endless multiplicity of objects, all differing from one another in shape, colour, and motion, present themselves to the view of the beholder. Mountains covered with forests, hills clothed with verdure, spacious plains adorned with vincyards, orchards, and waring grain; nakcd rocks, abrupt precipices, extended rales, decp dells, meandcring rivers, roaring cataracts, brooks and rills, lakes and gulfs, bays and promontories, seas and oceans, carerns and grottoes, meet the eyc of the student of nature in every country, with a rariety which is at once bcautiful and majestic.* 
"They drop upon the pastures of the wilderness: and the little hills rejoice on every side."-PSALIS lxv.

\section{Why are Vegetables so videly Diffused?}

Regarding them in an economic light as the food of animals, they constitute the provision made by the Creator for living creatures, and their wide distribution affords an illustration of Divine bounty.

642. On no part of the earth's surface-under no peculiarities of soil or climate-is vegetation of some kind or other impossible. Every distinct tribe of plants flourishes naturally under peculiar conditions, some preferring a warm atmosphere, others a cool one; some only luxuriating in moisture, and others in the opposite condition of dryness; some requiring the most intense light, and others only growing in darkness.

643. Some plants are capable of enduring a great degree of heat. In one of the Geysers of Iceland, the water's of whieh are hot enough to boil an egg in four minutes, a speeies of Chara (a description of water-moss) has been found growing and reprodueing; and vegetation of a humble kind has been observed in the boiling springs of Arabia and the Cape of Good Hope.

644. Extreme cold is not futal to every form of vegëtable life. The snow which eovers mountains is in some plaees reddened for miles by a minute vegetable, whieh has been supposed, from its very rapid increase, to have fallen from the sky, and whieh has, therefore, been commonly ealled red snow.* The Licken, which forms the winter fond of the Rein-Deer, grows entirely buried beneath snow, and its quantity may be judged of by the number of animals whieh find in it their sole support during a eonsiderable part of the year.

645. Many Plants possess a high degree of vitality. There is a kind of Club Moss inhabiting Peru whieh is liable to be entirely dried up. It then folds in its leaves, and contraets its roots, so as to form a ball, whieh, apparently quite devoid of life, is driven about by the wind. As soon, however, as it reaehes a moist situation, it sends the

* In some instances the red appearance of the snow has arisen from animalcules; in others from minute vegetables. 
"Thou crownest the year with Thy goodness; and Thy paths drop fatness."PSALM lXF.

roots into the soil, and unfolds to the atmosphere its leares, which speedily assume the bright green of healthy vegetation. The Rose of Jericho is the object of similar transformations, and the common mosses exhibit the same vitality in a less degree. Seeds and bulbs uniolled fiom among the bandages of Egyptian mummies have retained their vitality for an almost incredible number of years.

646. Many of the Fungus Tribes have been found growing in Caverns and Mines, to which no rays from the sun, either direct or reflected, have access, and even more perfect plants have been known to regetate in similar situations. It will be hereafter shown that this humble tribe of plants is the instrument, to a great extent, of fixing noxious gases which accumulate in the undisturbed fastnesses of forests, in cares, cellars, and other places shut out from the access of pure air.

647. Sea-ueeds have been drawn up from the depth of more than one hundred fathoms, to which depth the sun's rays do not

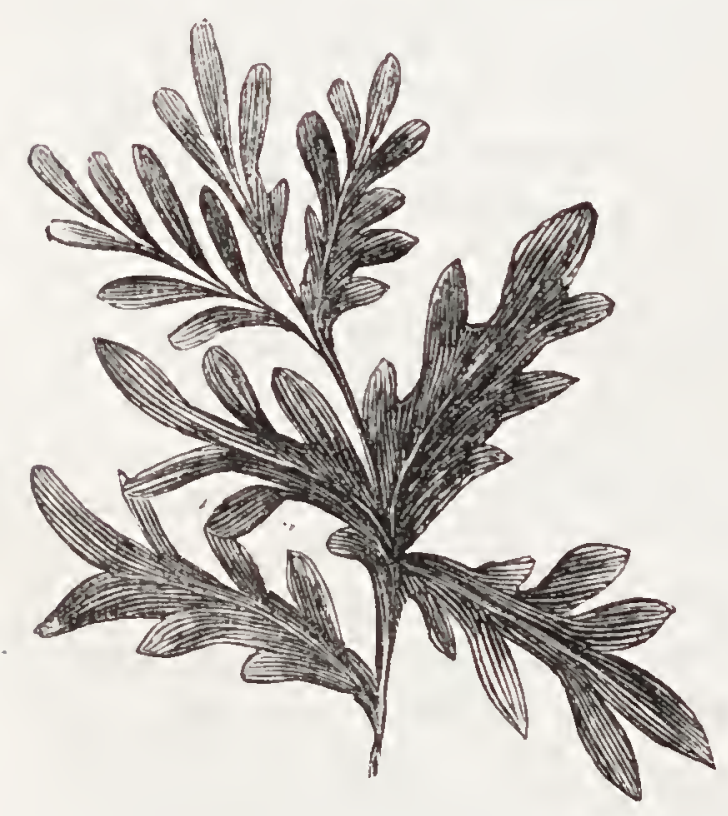

SEA-WEED. penetrate in any appreciable proportion. The distribution of different species through the ocean is influenced by latitude, by the depth of water, and by currents, nearly in the same manner as the higher plants are affected by temperature, elevation above the sea level, and the conditions of the atmosphere as to dryness and calmness. Some species can thrive well under considerable variation in these conditions, whilst other's are dependent upon certain states of them for their existence. The former, therefore, are extensively diffused, being found along many shores, whilst the latter are rarer, and only inhabit particular spots in which these conditions are met with. Contrary to what might have been expected-considering that the Algæe do not imbibe any nourishment by the spreading root-like fibres which attach them to the solid masses of the shore-it has been shown that they do not 
"And I will raise up for them a plant of renown, and tiey shail be no more consumed with hunger in the land, neither bear the shame of the heathen any more." -EZEKIEL xxxiv.

grow indifferently on all kinds of rocks, but that if, for example, along the same line of coast there be an alternation of limestone and granite rocks, some species will attach themselves in preference to the former, and others to the latter. This curious fact can only be explained by the supposition that small quantities of the mineral matter are dissolved by the water of the neighbourhood, and that in this manner they act upon the plant.*

648. Why are certain Classes of Plants more Fertile than others?

The fertility and the utility of plants appear to have been appointed by Divine wisdom in the strictest harmony. $A$ remarkable analogy is observable also in the degree of fertility of the respective vegetables and animals. Among the animals which are destined for the food of man, the species are upon the whole prolific in proportion as they are either small in size, or inferior as to the nutritive quality of their flesh. The Cow, which is a large animal, produces one usually at a birth; the Sheep, very commonly two; Pigs, several.

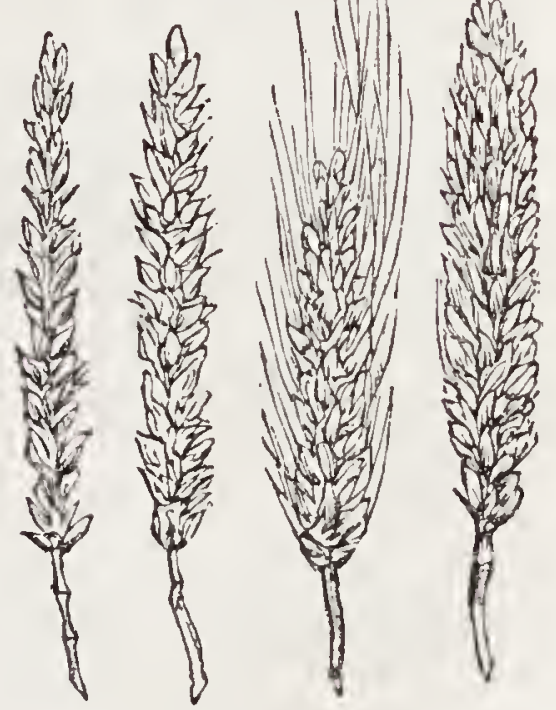

REPRODUCTION OF WHEAT. Poultry, which are comparatively small, are capable of rearing a numerous brood; and Fish, which are of a less, nutritive nature, and generally smaller than quadrupeds; are still more prolific.

649. And in the Vegetable species which are destined for the food of man, the numerical quantity of the product in a given area is greater or less in proportion to the individual size of the fruit produced. Dates, which are smaller than

* Dir. Carpenter. 
" $A$ s for mar, his days are as grass : as a flower of the field, so he flourisheth;"

Cocoa-nuts, are produced in greater numbers than the latter ; and in a square yard of soil, a much greater number of grains of Rice or Wheat is produced than of roots of the Potato.

650. Another analogy may be observed with reference to the palate. The taste of the flesh of those species which constitute to man the staple of animal food is acceptable to most palates, and is neither so rich as to clog the appetite on the one hand, or invite it to luxurious indulgence on the other ; nor so devoid of flavour as to deter us from taking a proper quantity. And is it not the same with regard to those Vegetables which are among the most ordinary and necessary articles of food? If Corn, the Potatoe, and the Cocoa-nut had the pungency of euphorbium, the nauseating quality of ipecacuanha, the heat of pepper, or the lusciousness of sugar, on the one hand, or the insipidity of powdered chalk on the other,-what an undertaking it would be to satisfy the cravings of hunger with any one of those vegetables :

651. In the Animal Fingdom, all those species which serve extensively for food, as Oxen, Sheep, and Swine; the Turker, Fowl, and Duck; the Salmon, Cod, Herring, sc., are either naturally of a gregarious nature, or are easily kept together, by human means, in large bodies; and therefore are much better adapted to the pmpose of supplying food to man than if they were either solitary or scattered in small groups.

652. And so it is with respect to the Vegetables clicfly used for food; they are capable of being cultivated gregariously as it were, with comparatively little labour and attention. Thus, in our own, and other European countries, the daily labourer, after his hour's of hired work for others, can cultivate his own private field of wheat or potatoes with very little additional expense of time or trouble. And as to the cultivation of the tropical fruits, scarcely any labour is required for that purpose. 
"For the wind passeth over it, and it is gone; and the place thereof shall know it no more."-PsaLM ciii.

653. The species of vegetables already known amount to about 60,000 , thongh there is reason to believe the actual number is above 100,000 , and fiom the general analogy of nature we may conclude that no species exists without its use in the economy of the earth. Among the number which supply food to man, by far the greater proportion consists of those which may be considered as luxuries, or as affording an agreeable and sometimes useful variety. Of those species which afford that kind of nutritive matter which is contained in "the staff of life," or bread, the number is ver'y small; leguminous plants, wheat, aice, the fruit, pith, and other parts of some of the palms and bananas, and such farinaceous roots as the potato, \&cc., comprising nearly the whole amount.*

654. How do Barren Surfaces First become Covered with Vegetation?

From the materials of the most sterile rock, and even from the yet recent cinclers and lava of the volcano, naturo prepares the way for vegetable existence. The slightest crevice or inequality is enough to arrest the invisible germs that are always floating in the air ; and the humble plants which spring from these soon overspread the surface, deriving their chief nutriment from the atmosphere. Having completed their allotted period of existence, they die and decay; but their death is only a preparation for the appearance of higher forms of vegetable structure.

655. They are followed by successive tribes of plants, of gradually increasing size and strength, until, in the course of years, the sterile rock is converted into a natural and luxuriant garden, of which the productions, rising from grasses to shrubs and trees, present all the varieties of the fertile meadow, the tangled thicket, and the widely-spreading forest.

656. Lichens and Mlosses are among the plants that 
"I beheld the mountains, and, 10, they trembled, and all the hills mored lightly." JEREMIAH iY.

clothe the bare places of the earth. The first green crust upon the cinders with which the surface of Ascension Island was covered consisted of minute Mosses. This tribe forms more than one-fourth of the regetation of Melville. Island, one of the most northerly spots in which any plants have been observed; and the black and lifeless soil of New Shetland, one of the islands nearest the South Pole, is corered with specks of moss struggling for existence.*

657. Standing upon the summit of Etna, whose mountain cone is 11,000 feet high, and more than ninety miles in circumference at the

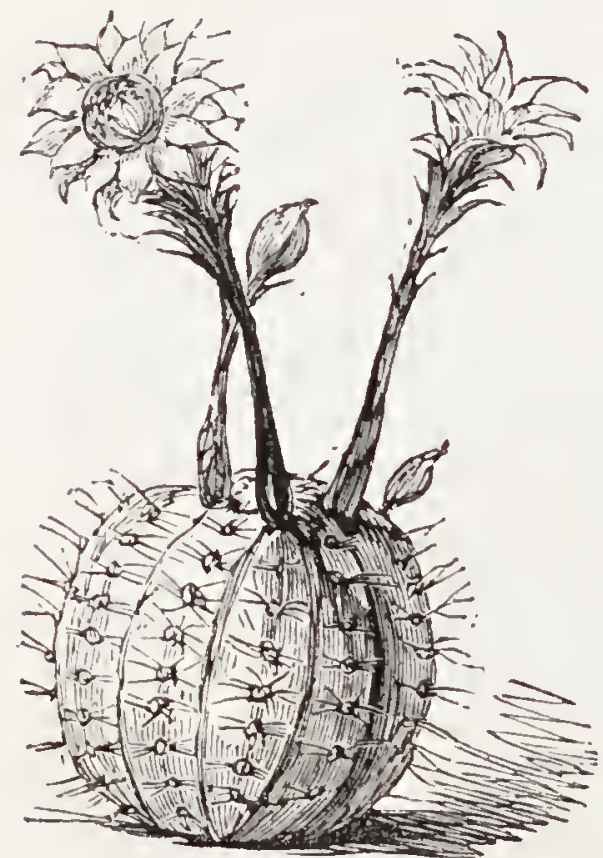

CACTUS: A LAYA-FERTILISER. base, lava is seen stretching in all directions along its sides, havingflowed down like rivers, and these are especially perceptible where they break through the zone of trees which girdles the mountain about half-way up. By examining and comparing these lava-streams, which are of different ages, we have an opportunity of seeing how the regetation is gradually formed. Some lava blocks are still quite naked, others have only a few plants scattered here and there in hollows and crevices, and in others a layer of decaying vegetation is beginning to form mould, in which more plants can by degrees strike root.

The lava upon Vesurius and other volcanoes exhibits the same plrenomenon as to the gradual development of vegetation.

658. The plants which first settle upon the naked lava are especially those lower plants which are called Lichens. Certain succulent and fleshy plants, chiefly nourished by the vapour of the air, which they absorb by the stem and leaves, are among the earliest inhabitants.

- Dr. Carpenter's "Vegetable Physiology." 
"He maketh me to lie down in green pastures: he leadeth me beside the still waters."-Psaly xxiii.

of lava surfaces, and this is especially the case with the Cactus, or Indian fig, which is industriously planted on the lava to render it fertile.

659. What Beneficent Designs are to be observed in the Geographical Distribution of Plants?

In addition to the numerous ways in which Providence meets all the wants of mankind, we see that they are arranged for in such a way as their local situation requires. Thus Wheat, which contains a more strengthening principle of nutrition than the product of the Palms and Arrow-root, and is, therefore, better calculated to support the hardier efforts of the inhabitants of temperate or cold climates, will not grow readily in intertropical climates, and the Palms and kindred plants of intertropical regions cease to be productive if cultivated much beyond the tropics.

660. The Orange, Lemon, Water Melon, Grape, and Fig, which are easily cultivated in warm climates, by the abundance of their juices are enabled to allay the sensation of heat and thirst, and to repair the loss of that natural moisture of the body which is continually passing from it in the form of either sensible or insensible perspiration. Even in the temperate climate of our own island, how many days are there during the summer in which such fruits are most refreshing!

661. But the Lemon, at the same time that, on account of its grateful and aromatic flavour, it is an excellent accompaniment of cooling and healthful beverages, is a direct antidote and remedy from one of the most dreadful diseases to which mariners are subject. Sea-scurvy, in fact, has all but disappeared since the general adoption of this remedy.* 
"The hay appeareth, and the tender grass sheweth itself, and herbs of the mountains are gathered."-l'Rovelibs xxvii.

662. Why are some Plants more Scarce than others?

The comparative rarity of plants depends in some degree upon the power they have of adapting themselves to variations in the conditions of their growth. Those that possess but slight powers of adaptation are necessarily restricted to certain localities favourable to their growth, and are hence considered rare plants.

663. For example: there are certain species which require that the air surrounding them should contain a minute quantity of salt, dissolved in its moisture ; these, therefore, abound near the sea shore; but they are seen to spring up in the neighbourhood of salt works, or on lias soils which contain a good deal of saline matter, even many hundred of miles inland,-their seeds being conveyed by the wind or by birds, which liave spread them over the whole surface of the earth, but there only meeting with the conditions they require for their development. Such are comparatively rare.

664. On the other hand, there are many which can grow in almost any situation, and which can adapt themselves to a great variety of circumstances, often exhibiting evident clanges, not only of aspect, but of individual form. Many of these are among the most serviceable to man, on account of the improvements which can be effected in them by cultivation.

665. Why do certain Tribes of Plants abound in particular Aspects and Situations?

Because each species appears to be adapted to particular circumstances. Such plants as avoid a high degreee of light seek the north side of the masses upon which they grow. Others which require light seek a southem aspect, whilst 
"Cast thy bread upon the waters: for thou shalt find it aster many days." SCCLESIASTES Xi.

those of intermediate habits frequent the eastern and the western sides.

666. Successions of vegetable growths, indicating these peculiarities, are found on ascending high mountains between the Tropics, such as the Peak of Teneriffe.

667. This adaptation of plants to particular aspects may be often seen, on a small scale, on the exterior of old towers, the large trunks of trees, \&c., as shown by the growth of Brambles, Ivy, Mosses, Lichens, and Fungi.

668. Neither of these Tribes would flourish if transferred to the circumstances of the other; and, opposite as these circumstances are, we observe that the Creator has adapted living beings to inhabit each, with equal suitableness. Thus, vegetation of some kind or other is found under almost every condition of climate.

669. What Agencies are principally instrumental in the Distribution of Plants?

The movements of the atmosphere, in its calmest state, are quite sufficient to transport to considerable distances seed furnished with downy appendages of winglets, as is the case with many plants, and the minute spiracles of the Cryptogamia, which are light as the finest powder.

670. While ordinary winds convey the sand-dust of the Sahara and the American plains many thousands of miles, it may be conceived that seeds-even those that are comparatively heary-are borne far from home by the hurricane. Two Jamaica lichens, which had never been seen in France before, were found growing on the coast of Brittany, 
"The pastures are clothed with flocks; the ralleys also are covered over witl: corn; they shout for joy, they also sing."-Psaws $1 \mathrm{XY}$.

the offspring of spiracles which had been swept across the Atlantic.

671. The Mountain Torrent washes down into the valley the seeds that have accidentally fallen into it, or have been swept away by its overflows. Rivers answer the same purpose more extensively, and also the Ocean Currents. The Nicker 'Tree, one of the leguminous tribe, has been raised from seed borne across the Atlantic by the Gulf Stream.

672. Animals of the sheep and goat hinds, with the horse, deer, buffalo, and others, widely disperse several species of plants, the seeds of which, furnished with an apparatus of barbs and hooks, adhere to their coating.

673. In the same manner seeds are widely diffused by firds; seeds also pass through the digestire organs of birds, uninjured as to their vitality.*

674. Why do Plants possess a ligh degree of Vitality?

In this we recognise a wise provision for the permanence, increase, and diffusion of the great food-yielding kingdom upon which the life of animals depends. Plants, having no power of locomotion, cannot transport themselves as animals can do; but they may be separated from their native soil, and their vital functions suspended for days, or even weeks, while they are borne to distant parts, when all their vital actions may be renewed by the restoration of the needful conditions. In the case of seeds the duration of vitality is very remarkable, though it differs greatly; and it is to be observed, as a law to which there will be found few exceptions, that the more useful the species the greater is the duration of the vitality of its sceds.

675. To the eastward of Stirling there is a large peat bog, a great * Rer. W. Miliner. 
"The beasts of the field cry also unto Thee; for the rivers are dried up, and the sire hath devoured the pastures of the wilderness."-JoEL i.

part of which has been flooded away by raising water from the River "'eith, and diseharging it into the Forth: the objeet of this proeess being to lay bare the under soil of clay, which is then cultivated. The clergyman of the parish was on one oecasion standing by, while the workmen were forming a ditch in this clay, in a part which had been covered with fourteen feet of peat earth; observing some seeds in the clay which was thrown out of this ditch, he took them up and soweủ them; they germinated, and produced a species of ehrysanthcmum. A very long period of year's must have elapsed whilst the seeds were getting their eovering of elay, and of the time neeessary to produce fourteen feet of peat-earth above this it is scareely possible to form an idea, but it must have been (in the natural eourse of things) extremely great.

676. The following eireumstanee, which oeeurred about thirty years ago in the state of Maine, in North Ameriea, is, perhaps still more lemarkable. Some well-diggers, when sinking a well at the distanee of about forty miles from the sea, struek, at the deptl of about twenty feet, a layer of sand; this strongly exeited curiosity and interest, from the cireumstanee that no similar sand was to be found anywhere in the neighbourhood, or anywhere nearer than the sea beach. As it was drawn up from the well it was placed in a pile by itself, an unwillingness having been felt to mix it with the stones and gravel, which were also drawn up. But when the work was nearly finished, and the pile of stones and gravel were to be displaeed, it was found necessary to remove also the sand-heap. This, therefore, was seattered about the spot on which it had been formed, and was for some time seareely remembered. In a year or two, however, it was pereeived that $a$ great number of small trees had sprung from the ground over which the sand had been strewn. These trees became, in their turn, objeets of strong interest, and eare was taken that no injury should eome to them. At length it was aseertained that they were beaeh-plum trees, and they actually bore the beach plum, which had nover before been seen, except immediately upon the sea shore. These trees must, therefore, have sprung up from seeds whieh had existed in the stratum of sea sand pierced by the well-diggers; and until this was dispersed in sueh a manner as to expose them to the air they remained inactive.

677. An instance is on record presenting satisfactory proof of the 
"Understanding is a well-spring of life unto lim that hath it: but the instruction of fools is folly."-Proverbs xii.

lapse of at least 1600 or 1700 years, and is related by Dr. Lindley. "I have now before me," he says, "three plants of raspberries, which have been raised in the gardens of the Horticultural Society from seeds taken from the stomach of a man, whose skeleton was found thirty feet below the surface of the earth, at the bottom of a barrow which was opened near Dorchester. He had been buried with some coins of the Emperor Hadrian."*

678. What are the Effects of Light upon Vegetation?

Light is a prime mover in every change that occurs in plants, from the moment the germ emerges from the soil. 'The faded colour of the interior leaves of the lettuce, and other culinary vegetables, is the result of such a degree of compression of the body of the plant as excludes the aldmission of light beyond the exterior leares.

679. To the stimulus of light science ascribes the powers which plants possess of separating carbon from the air breathed by their leaves, and secreting it within their tissues for the purpose of building up their characteristic woody structure.

680. If a branch of iry, or of any spreading plant, happen to penetrate during the progress of its regetation into a dar\% cellar, or any similar subterraneous situation, a total loss of colour takes place, accompanied by such alterations in its growth as often to mask its original form.

681. This is because the plant respires through the agency of certain organs upon its leaves called stomata, and these organs are stimulated to action by the mesence of light. If a plant, accustomed to grow in open day, be kept for some time in the dark, it becomes unhealthy, and, as it were, dropsical, and will generally die if not restored to its usual condition. 
"I beheid the earth, and, 1o, it was without form and void; and the hearens, and they had no light."-Jeremin iv.

682. The total result is, that all the native bcauties and uses of a vegetable growing under these circumstances are lost; the eye is neither delighted by any variety or brightness of colour, nor is the sensc of smell gratified by any fragrance; the degeneracy of its fibre into a mere pulp renders it unfit for any mechanical purpose; and the resinous and other principles on which its nutritive and medicinal virtues depend, ccase to be developed. In somc instances the bleaching or etoliation of plants is useful in correcting the acrid taste which belongs to them in their natural state-as is thc case of endive and celery.

683. How necessary light is to the health of plants, may be inferred from the eagerness with which they appear to seek it. How intently does the sunflower watch the daily course of the sun! How do the countless blossoms nightly droop when he returns, and the blanched plant strive to reach an open chink through which lis light may reacli it! A potatoe has been observed to grow up in quest of light from the bottom of a wcll ten feet deep; and in a dark cellar, a shoot of twenty feet in length has been met with, the extremity of which had reached and rested upon an open window.*

684. It is to vegetable substances that we are chicfly indebted for the means of artificial light. The carburetted hydrogen gas, which is now so extensively used for purposes of illumination, is distilled from coal, itself the produce of fossilized plants. The nature of the ether of light is unknown, but it is highly probable that it is capable of absorption and illimitable compression, and it is quite possible that plants absorb and fix light in their substance, in the sanc manncr as they absorb and fix carbonic acid gas, which they restore to its original state under combustion. If this be truc, we have to contemplate the grand fact, that the light artificially obtained, by which we lengthen our winter days and equalise the hours of joy and labour throughout the year, is the same light which shone upon the great forests of the earth in the earlier ages of the world.

68.5. The influence of Light on the colours of Plants and Animals is well shown in the sea. Near the shores we find sca-weeds of the most beautiful tinctures, particularly on the rocks, which are left dry by the tides; and the rich hues of Actinice, which inhabit shallow 
"The sun also ariseth, and the sun goeth down, and hasteth to his place where he arose."-Ecclesiastes i.

water, must have been observed. The Fishes which swim near the surface are also distinguished by the variety of their colours, whereas those that live at greater depths are grey, brown, or black. It has been found that after a certain depth, where the quantity of light is so reduced that a mere twilight prevails, the inhabitants of the ocean become nearly colourless.*.

686. What are the effects of Ileat upon Plants?

Heat, as well as light, is a vital agent in the development of plants. It influences vegetation from the shooting of the germ to the perfection of the frit, but its greatest influence appear's to be exerted at the time when the flower is dereloped, and the seed perfected. $\dagger$

687. The want of sufficient heat arrests vegetable growth in the Winter; and it is the warmth of Spring which calls forth stems and leaves, the higher heat of Summer which develops the flowers, and ripens the fruit and seeds. It is the warmer climate which gives to Southern Europe a richer vegetation than is presented by Northern Europe, and the still warmer climate within the Tropics that produces the greatest abundance and variety of plants. But the efjects of heat are modified by the difjerent natures of plants: the degree of warmth which produces the phenomena of vitality in one is incapable of awakening them in another.

688. How is Vegetation First Established upon New Islands?

Certain trees are endowed with the power of taking root rpon rocky foundations, covered only with the most scanty amount of soil. Such is the Cocoa Nut Palm, which so early and constantly establishes itself upon Coral Islands. "This tree will grow in situations where scarcely any other'

* II unt's "Poetry of Scienee."

$\dagger$ See the "Gardeners and Farmers' Reason Why." 
"If the Lord delight in us, then he will bring us into this land, and give it us; a land which floweth with milk and honey."-NuMBERs xiv.

plant can thrive. It is found in almost all the islands of Polynesia, even in these as yet untenanted by Man. This is easily accounted for, when it is considered that the cocon nut may float a long time in the sea without the seed receiving any injury, in consequence of its protection by the fibrous husk and dense shell; but when cast up by the currents or drifts of the ocean on the low shores of those islands, the husk gradually separates under the combined influence of the sun, air, and occasional moisture, and allows the seed to be acted upon by those influences which will excite it to germination.

689. And what tree so useful to the islander? Thcre is no part of it which may not be applied to some useful purposc. Not only cabins for poor people, but large houses, are constructed entirely with materials afforded by it: the trunk supplying rafters, and the leaves, when plaited, making roofs and walls which are impcrvious to rain. Sometimes not a nail is used in the construction of a house, the rafters, \&c., being fastened on with string made of the fibrous envelope of the nutshell. From the same fibres ropes used in boats and shipping are made. A fine tree is produced in about eight years, which bears fruit twice or thrice in the year. The half-ripe nut contains sometimes three or four pints of a clear fluid, fragrant and pleasant to the taste, and the nut itself is highly nutritious. Baskets, bottles, cups, and other articles of great use to the islanders are also made of the fibres and nutshells.

690. In these islands also the Bread-fruit Tree flourishes, and constitutes the most important food-plant of the natives. This noble and beautiful tree has a richly-foliaged crown, and bears a great number of very mealy fruits, which, when cooked, taste like wheaten bread. These trees are sufficient to support a man for eight months of tlee year, during which long period they bear fruits which gradually ripen. During the remainder of the year, fruits are eaten which have been placed in pots and undergone a kind of fermentation. Ten trees are estimated to yield sufficient food for a family. But the trce has othcr uses; the wood is used for canoes and furniture, and the bark for numerous textile fabrics. 
"The grass withereih, the flower fadeth; but the word of our God shill stand for ever."-IsAiAh xv.

\section{What effect have Plants upon the Atmosphere?}

Plants are the purifiers of the atmosphere, counteracting the effects of animal life, and various processes of decomposition. They also, by their transpiration, impart a degree of humidity to the air which surrounds them. Inrert a glass globe over a plot of turf, or insert into it a branch of a growing tree, closing the opening of the globe, and the glass will soon be found corered with transpired moisture.

692. The effect of plants in this important respect can best be seen by reference to their separating carbonic acid from the air, and fixing it in a solid form in their substance. It should, however, be understood that they obtain carbon chiefly from the air, but partly from the vegetable mould of the soil. They are fitted by nature to draw their sustenance from the air, the earth, or from both, according to circumstances. 'The proportion which they derive from each source partly depends upon the nature of the plant, the period of its growth, the nature of the soil in which it is planted, the abundance of carbon presented either to the root or the leaves, the duration and intensity of sunsline, and other circumstances of a similar kind. They have, in fact, the power of adapting themselves to the conditions in which they are placed.*

693. It may be thought incredible that the enormous quantity of carbon which enters the composition of a single tree, should ever have been eontained in the atmosphere, sinee any given quantity of air eontains only about one-thousandth of its weight of earbonic acid, and the gas itself is composed of only about 27 parts of solid earbon in every 100. Eut it must be remembered that, as the weight of air pressing upon every square inch of the earth's surface is $15 \mathrm{lb}$, the

* See "Gardeners and Farmers' Reason Why." 
"The grass withereth, the flower fadeth : because the spirit of the Lord bloweth upon it: surely the people is grass." - Isaials $\mathrm{xl}$.

pressure upon a square foot will be $216 \mathrm{lb}$.; and, as the surface of the earth can be almost exactly calculated, it may be shown that in the whole atmosphere surrounding the earth at least three thousand million million pounds of solid carbon must be contained-a quantity which will not only explain the phenomenon as to single trees, but which is probably more than the weight of all the plunts, and of all the beds of coal, which exist upon and within the earth. The quantity of carbon existing in sea-water, in various combinations, is mobably greater.

694. The constant maintenance of this ingredient in the atmosphcre, so as to supply the enormous drain upon it which active vegetation induces, is owing to changes of an opposite character taking place as constantly. Every animal is incessantly engaged in converting the oxygen of the air into carbonic acid, by the process of respiration or breathing. Of the solid carbon taken in by it as food, which is all derived, either directly or indirectly, from vegetable matter (since every animal is supported either upon vegctable substances, or upon the flesh of other animals which subsist on them), a portion is constantly being restored to the gaseous form in this manner. A single man daily converts nearly 18,000 cubic inches of the oxygen of the air into carbonic acid, by the carbon disengaged from his lungs, and the enormous amount that must be daily formcd by the whole liuman and animal population of the globe may thus be perceived. Again, the combustion of vegetable substances-coal, wood, \&c.-is a vast and continual source of the renewal of the supply drawn by vegctation from the atmosphere. It has been calculated that the small town of Giessen, in Germany, possessing a population of about 7000 inhabitants, converts more than 1000 cubic feet of oxygen into carbonic acid by the combustion of wood as fucl; and in an English manufacturing town, where the proportion of coal used is far greatcr, the amount would be at least twice as much in proportion to the size.

695. Why may Fungi be regarded as of great Use in the Economy of Nature?

Although, in the production of Rot and Mildew, under certain circumstances, they occasion decay and loss, the 
"He shall grow up before lim as a tender plant, and as a root out of a dry ground: for he hath no form nor comliness; and when we shall see him, there is 110 beauty that we should desire him."-IsaiaH liii.

benefits they confer upon man far outweigh their occasional devastations.

696. To Fungi may be justly applied the designation which has been conferred upon Insects, that of being
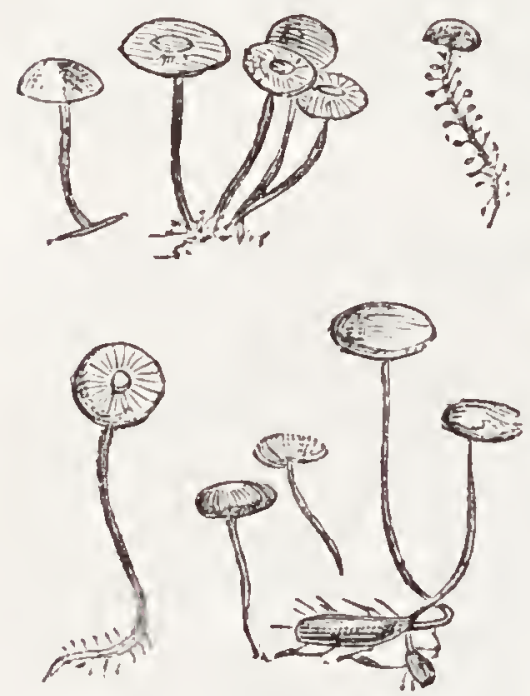

FUNGI. "scavengers," for they labour with astonishing effect in the removal of refuse and decaying substances which, when left upon the surface of the earth, would prove not merely useless, but injurious incumbrances. Their rapour-like germs float about in the atmosphere, in countless myriads, only waiting for the presence of a congenial soil, on which to alight and grow. As long as there is no decomposing matter to be remored, these spores remain inactive-the "scarengers" are unemployed, but as soon as any quantity, large or small, of decaying animal $\mathrm{O}^{\prime}$ ' regetable matter, is left exposed, it is soon covered with a deposition of spores which rapidly develop themselves into Fungi.

697. They not only remove decomposing substances, but absort noxious exhalations, which would be spread through the atmosphere; and the greater the necessity which demands them, the more rapidly do they multiply. The benefits they confer in these respects can scarcely be conceived. One species has been known to attain the weight of thirty-four pounds in six weeks; and on the Continent Fungi of the same tribe have grown to upwards of one hundred pounds, having begun from a point not perceptible to the naked eye.* 
"And I will lay it waste: it shall not be pruned nor digged; but there shall come up briers and thorns: I will also command the clouds that they rain no rain upon it."-ISAIAH r.

\section{What is the cause of Malaria?}

In many districts it is to be accounted for by the decomposition of animal and vegetable substances, which occurs when a high degree of temperature acts upon stagnant or slowly moving water. This explains most of the phenomena, but not all; other explanations are to be found in the volcanic character of the soil, and other circumstances which promote the escape from the earth of various noxious gases.

699. The Pontine marshes abound in water; the marshes near Viareggio, the Lentinian morasses, the country round the outlet of the Ombrone and Cesnia, the lagunes of the Adriatic Sea, the mouth of the River Po, the Mantuan morasses, the rice-fields in the valley of the Po, and the Fens of Lincolnshire, all offer examples of unhealthy atmosphere. The places of considerable elevation, where malaria shows itself, have likewise stagnant water, - as the lakes of Perugia, of Bolsena, and Fucino.

700. Noxious air arises on the coasts in those places, particularly where the fresh and salt waters become inter. mingled, which is the case when the rivers or lakes have but a slight fall, so that the sea invades the fresh waters at high tide. The animals and plants of the fresh water are liable to destruction by sea water, and vice versấ; and in this way a quantity of decaying organic matter becomes accumulated. The beneficial influence exhibited by drainage, as in the Fens of Lincolnshire, and other measures preventing the admixture of fresh and salt water, support this explanation.

701. If it were possible, with the bodily as with the mental eye, 
"He shall shake off his unripe grape as the vine, and shall cast off his flower as the olive." $-J O B ~ x v$.

to bohold the constitution of the atmosphere which surrounds our eartl, we should view a compound probably the most complex in nature; for into this circumambient ocean of air are carried up whatever exhalations arise not only from the earth itself, but from every organised form of matter, whether living or in a state of decomposition, that is found upon the eartl's surface; the dews of morning, the balms of evening; the fragrance of every plant and flower; the breath and characteristic odour of every animal; the rapour invisibly arising from the surface of the whole 0. ean and its tributary streams; and, lastly, those circumscribed and baneful effluvia, however generated, which, when confined to definite portions of the atmosphere, produce those various forms of fever which infest particular districts; or those more awful and mysterious miasmata which, arising in some distant region, and advancing by a slow but certain march, carry dismay and death to the inhabitants of another hemisphere.*

702. What are the leading facts in connection with the Geographical Distribution of Plants?

Vegetation occurs over the whole globe under the most opposite conclitions. Plants flourish in the bosom of the ocean as well as on the land, under the extremes of cold and heat in Polar and Equatorial regions, on the hardest rocks, and the soft alluvium of the plains; amidst the perpetual snow of lofty mountains, and in springs at the temperature of boiling water, in the dark vaults of carerns, and on the walls of mines, as well as upon the face of the earth, ficely exposed to light and air. But these direrse conditions have different species and genera.

703. By species we are to understand so many individuals as intimately resemble each other in appearance and properties, and agree in all their permanent characters. But an established species may frequently exhibit new varieties, depend-

* Liidd's "Adaptation of External Nature to Jan." 
"I will give you the rain of your land in his due season, the first rain and the latter rain, that thou mayest gather in thy corn, and thy wine, and thine oil." DECTERONOMY $\mathrm{xl}$.

ing upon local and accidental causes; but these are imperfectly, or for a limited time only, perpetuated.

704. A genus comprises one or more species similas to each other, but essentially differing in formation, nature, and in many adventitious qualities from other plants. A tribe, family, group, or order comprises several genera.

705. Distinct vegetable regions may be observed on passing from South to North through different climatic zones, defined as to their limits by the isothermal curves, or lines of equal summer temperature, and not by the parallels of latitude.

706. Similar changes of vegetation mark a perpendicular ascent through the decreasing temperature of the atmosphere. A succession of plants appear on the tropical mountains, which rise above the snow line, corresponding to those which are encountered in cold latitudes.

707. Why do Isolated Mountains best display the Zones of Climatic Vegetation?

Because, rising high into the atmosphere, the sides of such mountains undergo all the climatic modifications found upon the earth's surface in a direction from the Equator to the Poles. Hence they present, upon a comparatively limited surface, distinct botanical regions, clearly illustrating the effect of climatic influences upon the vegetable orders.

708. Mount Etna is divided into three great regions-the fertile region, the woody region, and the bare or desert region. But each of these is susceptible of sub-divisions defined by the presence of ccrtain families of plants, forming seven botanical zones.

709. First,-The sub-tropical zone, which does not rise more than 100 feet above the level of the sea, is characterised by the Palm, Banana, Indiau Fig, Sugar-cane, varieties of Mimosa and Acacia, which with us are only found in conservatories. 
"Who covereth the heaven with clouds, who prepareth rain for the eartl, who makctl grass to grow upon the mountains."-Psacar cxlvii.

710. Second,-The hilly zone rises about 2000 feet, characterised by the Orange, Lemon, Sliaddock, Maizc, Cotton, and Grape plants.

711. Third,-The woody zone lies between the height of 2000 and 4000 feet, where the Cork-tree flourishes, several kinds of Oak, the Maple, and enormous Chcstnuts.

712. Fourth,-The zone of 4000 to 6000 feet is distinguished by the Beech, Scotch Fir, Birch; and, among small plants, by Clover, Sandwort, Chickweed, Dock, and Plantain.

713. Fifth,-The sub-Alpine zone, between the elevation of 6000 and 7500 feet, produces the Barbcrry, Soapwort, and Juniper.

714. Sixth,-The zone between 7500 and 9000 feet has almost all the plants of the fifth, with the fleshy and jagged Groundsel.

715. Scventh,-The narrow zone between 9000 and 9200 fect only produces a few Lichens, bcyond which there is complete sterility.

716. The Peali of Teneriffe exhibits five botanical districts, thus distinguished :-

717. First,--The region of Africa, from 0 to 1248 feet, com'prises Palms, Bananas, the Sugar-cane, various spccies of arborescent plants, whosc naked and tortuous trunks, succulent leares, and bluish green tints are representative of African vegetation.

718. Second,-The region of Vines and Cereals, 1248 to 2748 feet, comprises, besides the Vine ard Grain-bearing Grasses, the Olire and the fruit-trees of Europe.

719. Thisd, - The region of Laurels, 2748 to 4350 fect, including four specics, the Olive, an Oak, the Iron-tree, the Arbutus, and other evergrecns. The Ivy of the Canaries and rarious twining shrubs cover the trunls of the trecs, and numerous species of Fern occur, with bcautiful flowering plants.

720. Fourth,-The region of Pines, 4350 to 6270 feet, charactcrised by a vast forest of trees resembling the Scotch Fir, intermixed witl Juniper.

721. Fifth,-The region of the Retana, 6270 to 11,061 feet, a species of Broom, which forms vases in the midst of a desert of ashes, 
"Then I will give you rain in due season, and the land slall yield her increase, and the trees of the field shall yield their fruit."-Leviticus xxi.

ornamented with fragrant flowers, and furnishing food to goats, which run wild on the Peak. A few Gramineous and Cryptogamic plants are observed higher, but the summit is entirely destitute of vegetation.

722. Vegetable forms are clivided into three great classes, which differ materially in their structure:-1. Cryptogamous plants-those which have no flowers, properly so called-Mosses, Lichens, Fungi, and Ferns; as distinguished from those which are phrenogamous, or flowerbearing, to which the two following classes belong. 2. Endogenous plants, which have stems increasing from within, also called Monocotyledons, from liaving only one seed-lobe, as the numerous Grasses, Lilies, and the Palm family. 3: Exogenous plants, which have stems growing by additions from without, also called Dicotyledons, from the seed consisting of two lobes: the most perfect, beautiful, and numerous class, embracing the forest trees, and most flowering shrubs and herbs.

723. The Exogens furnish examples of gigantic size and great longevity. In South America, on the banks of the Atabapo, Humboldt measured a Bombax caiba more than 120 feet high, and 15 in diameter'; and near Cumana he found the $Z a-$ mang del Guayra, a species of mimosa, the pendent branches of the hemispherical head having a circumference of upwards of 600 feet. The Adansonia, or baobab of Senegal, though attaining no great height, rarely more than fifty feet, has a trunk with a diameter sometimes amounting to 34 feet; while the Pinus

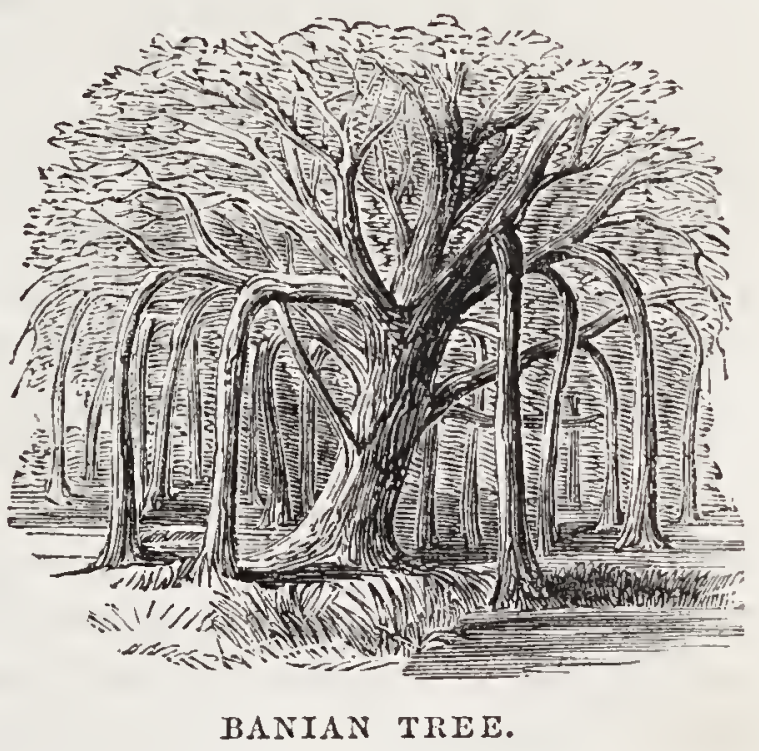

Lambertiana, growing singly on the plains west of the Rocky Mountains has been found 250 feet high, 60 feet in circumference at the base, $4 \frac{1}{2}$ feet in girth at the height of 190 feet, yielding cones 11 inches round and 16 long. The Pinus Indicus, or banian tree, sending out shoots from its horizontal branches, which, reaching the ground, take root and form new stems, till a single tree multiplies almost to a forest, has been observed covering an area of 1700 square yards. 

ЈоB $\mathrm{v}$.

"Who giveth rain upon the earth, and sendeth waters upon the fields."-

7:24. The Cryptogamous plants afford the most numerous examples of wide diffusion. A lichen indigenous in Cornwall, stricta aurata, is
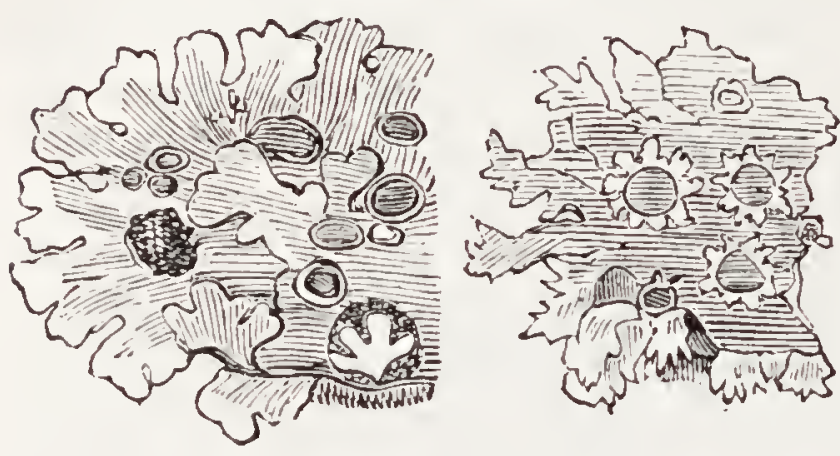

LICHENS. also a native of the West India Islands, Brazil, St. Helena, and the Cape of Good Hope; while 38 lichens and 28 mosses arc common to Great Britain and Australia, though the general regetation of the two districts is remarkably discordant. Some species of Endogenous plants are also widely distributed, the Phleum alpinum of Switzerland occurring without the slightest difference at the Strait of Magellan, and the quaking grasses of Europe in the interior of Soutl Africa. But only in very few instances are the same spccies of Exogenons plants met with in regions far apart from each othcr; and generally speaking, in passing from onc country to another, we cncounter a new flora, for if the samc genera occur the species are not identical, while in districts widely separated the genera are different.

725. The Crytogamic plants, Mosses, Lichens, Fcrns, and Fungi, are to the whoie mass of pliænoganic regetation in the following proportions in different districts:-Equatorial latitudes, 0 deg. to 10 deg., on the plains 1-25th, on the momntains 1-5th ; mean latitudes, 45 deg. to 52 deg., $\frac{1}{2}$; lighh latitudes, $67 \mathrm{dcg}$. to $70 \mathrm{dcg}$., proportion about equal. Thus, the proportion of the flowerless regctation to the flowering increases from the Equator to the Poles. But the family of Ferns, vicwed singly, forms an exception to this law, decreasing as we depart from Equinoctial countrics, 1-20th in equatorial and 1-70th in mean latitudes, and not found at all in the high latitudes of the new world.

726. In Equinoctial and Tropical countrics, where a sufficicnt supply of moisturc combines with the influence of light and heat, vegetation appear's in all its magnitude and glory. Its lower orders, Mosses, Fungi, and Conferva, are very lare. The Fcrns are aborcscent. Reeds ascend to the lieight of a liundred feet, and rigid grasses rise to forty. The forcsts are composed of majestic leafy evcrgreen trees bearing brilliant blossoms, their colours finely contrasting, scarccly any tro 
"The cedar of the house within was carred with knots and open flowers: all was cedar; there was no stone seen."-I Lings vi.

standing together bcing of the same species. Enormous creepers climb thcir trunks; parasitical Orchidæ hang in festoons from branch to branch, and augment the floral dccoration with scarlet, purplc, bluc, rose, and golden dycs. Of plants used by man for food, or as luxuries, or for medicinal purposes, occurring in this region, Rice, Bananas, Datcs, Cocoa, Cacao, Bread-fruit, Coffee, Tca, Sugar, Vanilla, Peruvian Bark, Pepper, Cinnamon, Cloves, and Nntmegs, are either charactcristic of it as principally cultivated within its limits, or entirely confined to them.

727. Rice (Ory a sativa), the chief food of, perhaps, a third of the human race, is cultivated beyond the tropics, but principally within them, only where there is a plentiful supply of water. It has never been found wild; its native country is unknown, but probably souther'n Asia.

728. Bananas, or Plantains (Mrusa sapientum et paradisiaca), are cultivated in intertropical Asia, Africa, and America. The latter species occur in Syria. The Banana is not known in an uncultivated state. Its produce is enormous, estimated to be, on the same space of ground, to that of Wheat as 133 to 1 , and to that of Potatoes as 44 to 1.

729. Dates (Phonix dactylifera) and Cocoa (Cocos mucifera), belonging to the family of Palme. The Palms, remarkable for their elegant forms and importance to man, contribute more than any other trecs to impress upon the vegetation of tropical and equinoctial countrics its peculiar physiognomy. The Date Palm is a native of Northern Africa, and is so abundant between the Barbary States and the Sahara that the district has been named Biledulgerid, the land of dates. As the descrit is approached, the only objects that break the monotony of the landscape are the Date Palm and the tent of the Arab. It accom.. panies the margin of the mighty desert in all its sinuosities from the shores of

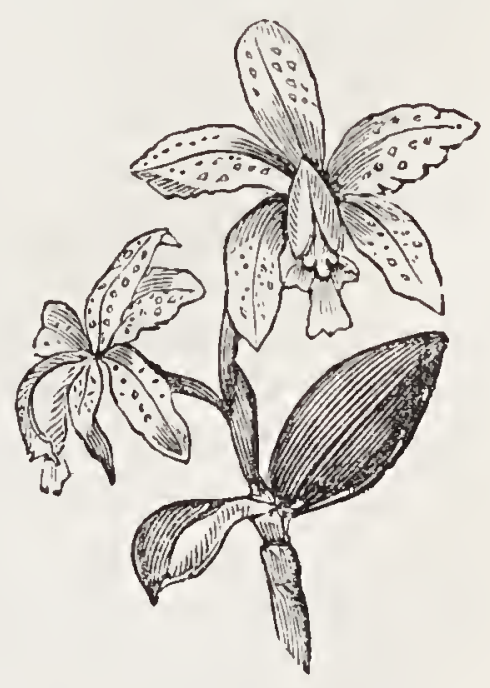

ORCHID. the Atlantic to the confines of Persia, and is the only vegetable affording subsistence to man that can grow in such an arid situation. The annual produce of an individual is from 150 to $2601 \mathrm{bs}$. 
"Let the field be joyful, and all that is therein; then shall all the trees of the wood rejoice."-I'sALis xcvi.

weight of fruit. It is spread throughout the torrid zone, but occurs most abundantly in the islands of the Indian Archipelago. The

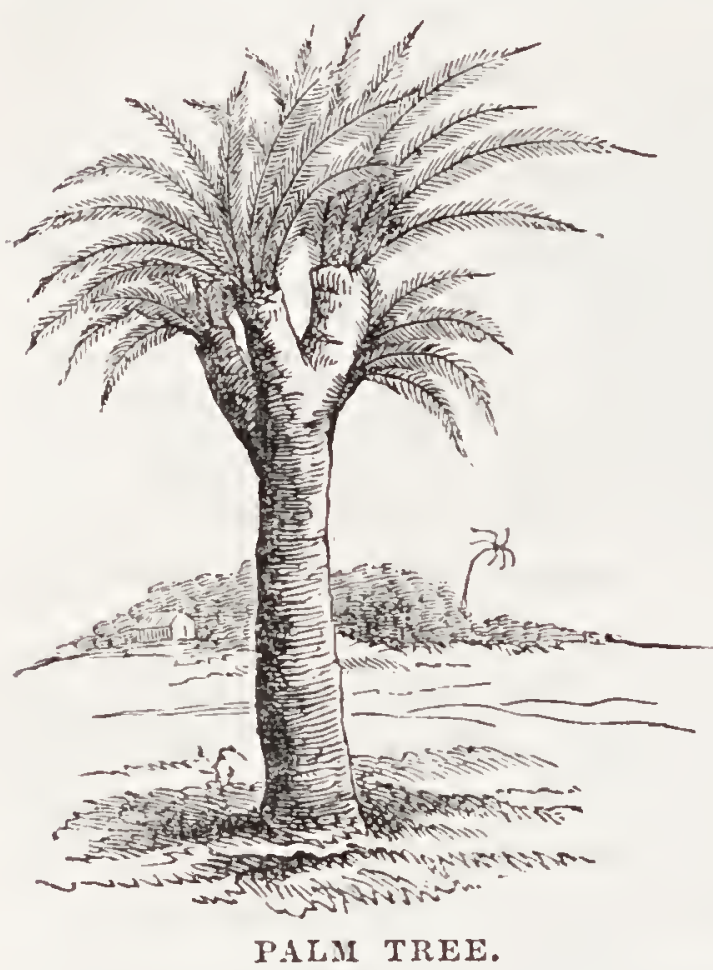
family of Palms is, supposed to contain a thousand species, some of large size, forming extensive forests.

730. Cacoa (Theobroma cacao), from the seeds of which chocolate is prepared, grows wild in Central America, and is also extensively cultivated in Mexico, Guatamala, and on the coast of Cumana.

731. Bread-fruit tree (Artocarpus incisa), a native of the South Sea Islands and Indian Archipelago, grows also in Southern Asia, and has been introduced into the tropical parts of America; but the fruit is not equal to the baliana as an article of human food.

732. Coffee (Coffea Arabica). The bush has probably for its native region the Ethiopian highlands, from whence it was taken in the fifteenth century to the higlulands of Yemen, the southern part of the Arabian peninsula. It has been introduced and is now extensively cultivated in British India, Java, Ceylon, the Mauritius, Brazil, and the West Indies; but the quality is inferior, which makes the climate of the Nocha coffee district of importance, as peculiarly favourable to the plant. It grows there on hills described by Niebuln as being soaked with rain every day from the beginning of June to the end of September, which is carefully collected for the purpose of irrigation during the dry season.

733. Tea (Thea Chincnsis). The plant is indigenous in China, Japan, and Upper Assam. In the latter country it has recently been found in a wild state, and is in process there of extensive cultivation. As the plant is hardy, its culture has rery lately been attempted in the south of France, and apparently with complete 
" My doctrine shall drop as the rain, my speceh shall distil as the dew, as the small rain upon the tender herb, and as the showers upon the grass."-DEUTERoNowr sxxii.

success. A similar experiment on the burning plains of Algeria completely failed, all the plants being killed by the heat, notwithstanding every precaution. Tea was first introduced into Europe by the Dutch in 1666. The leaves of the coffee plant have long been used as a substitute for tea by the lower classes in Java and Sumatra; and recently Professor Blume, of Leyden, exhibited samples of tea prepared from coffee-leaves, agreeing entirely in appearance, odour, and taste with the genuine Chinese production.

734. Sugar-cane (Saccharum officinarum), a species of Gra-

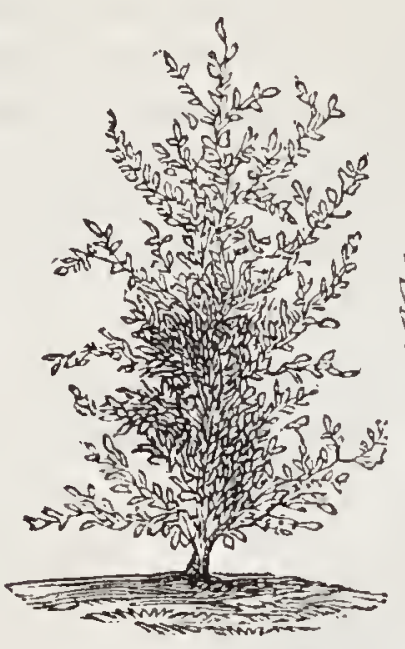

TEA SHRUB AND BLOŚSOM.

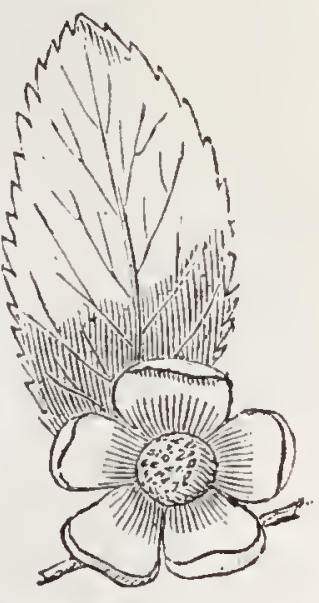

minece, occurs to some extent without the tropics, having been cultivated centuries ago in Europe, as at present scantily in the soutl of Spain. But it properly belongs to the torrid zone, and has for its principal districts the Southern United States, the West Indies, Venezuela, Brazil, the Mauritius, British India, China, the Sunda and Phillippine Islands. The plant was found wild in several parts of America on the discovery of that continent, and occurs in a wild state on many of the islands of the Pacific.

735. Vanilla (Vanilla aromatica), the fruit of which forms the well-known aromatic, grows wild principally in Mcxico.

736. Peruvian Bark (Cinchona officinalis), a forest tree, of which there are several species, furnishing the valuable medicine so called. It is exclusively confined to South America, and grows chicfly on the Andes of Loxa and Venezuela.

737. Pepper (Piper nigrum) belongs exclusively to the Malabar coast, where it has been found wild; Sumatra, which produces the greatest quantity; Borneo, the Malay peninsula, and Siam. Other species of Piperacea occur in tropical Amcrica.

738. Cinnamon (Laurus Cinnamomum), a small tree yielding the aromatic bark, is found native only in the island of Ceylon; but another species occurs in Cochin China. 
"Canst thou lift up thy roice to the clouds, that abundance of waters may cover thee?"-Јов xixviii.

739. Clove (Myrtus caryophyllus), a small evergrecn tree, the dried flower-buds of whieh form the eelebrated aromatic, grotrs naturally in the Moluecas, whenee it has been eonveyed to other tropical distriets. The island of Amboyna, one of that group, is the principal seat of its cultivation. The lowest temperature there is 72 deg.: the mean temperature of the year 82 degs.

740. Nutmeg (Myrstica moschata) grows naturally in several jslands of the Eastern Arelipelago, but is principally eultivated in the Banda Isles.

741. Tropieal families and forms successively ranish with an inercase c. distance from the Equator, and new phases of regetation mark the

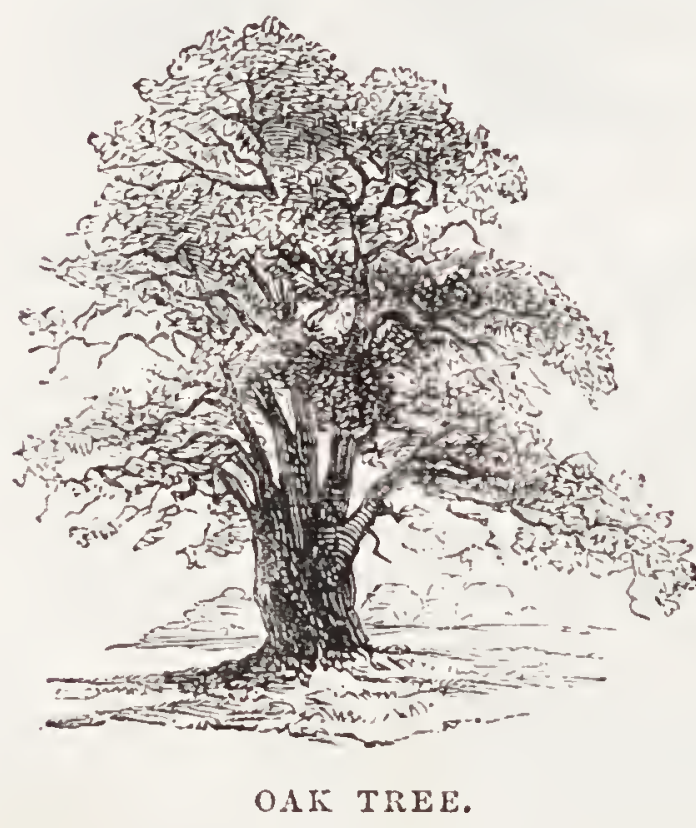
transition from hot to temperate climates. Viridly green meadows, abounding with tender herbs, replace the tall rigid grasses which form the impenetrable jungle; and instead of forests composed of towering evcrgreen trecs, woods of the deciduous elass appear, whieh east their lcaves in winter, and liybernate in the colder season -the Oak, Ash, Elm, Maple, Beceh, Lime, Alder, Bireh, and Syeamore. The cultivation of the Vine beeomes elaraeteristic with the perfection of the eereal wrasscs, and a larger proportion of herbaccous annuals and cryptogamic plants.

742. The Vine (Vitis vinifera) is less impatient of a cold winter than a cool summcr. Henee its northern limit, which eoineides with lat. $47 \mathrm{deg} .30 \mathrm{~min}$. on the west eoast of France, rises in the interior, where, though the winter's are eolder, the summer's are warmer, to lat. 49 degs., euts the Rhine at Coblentz in lat. 50 deg. $20 \mathrm{~min}$, and ascends to 52 deg. 31 min. in Gcrmany.

743. Reeeding further from the Equator, magnificent forests of the Fir and Pine tribe prerail, as in the eentral parts of Russia, on the 
"The range of the mountains is his pasture, and he searcheth after every green thing."-Joв Ixxis.

southern shores of the Baltic, in Scandinavia, and North America. But some of the cereals are no longer cultivable, and sereral timbertrees common to the temperate zone do not reach its northern limits. Gradually all ligneous vegetation disappears entirely as higher latitudes are approached, the woods having fir'st dwindled to mere dwarfs in struggling with the elements, liostilc to that state which nature destined them to assume. The limit of the forcsts is a sinuous line running along the extreme nortl of the old world and extending from Hudson's Bay, lat. 60 deg., to the Mackenzie River, lat. 68 deg., and thence to Behring's Strait. The Dwarf Birch (Betula nana), a mere bush, is the

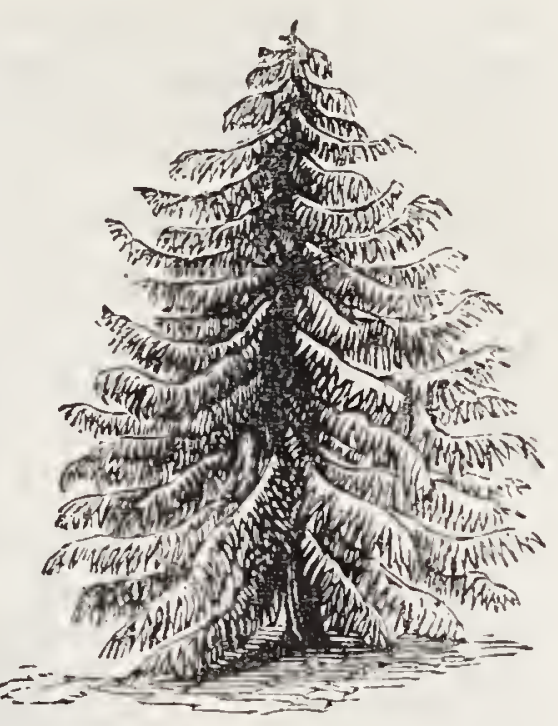

FIR TREE. last tree found on drawing near the eternal snow of the Pole. At the Island of Hammerfest, lat. $70 \mathrm{deg} .40 \mathrm{~min}$., near the North Cape, it rises to about the height of a man, in sheltered hollows between the mountains, its lower branches trailing on the ground, affording a shelter to the Ptarmigan. In the Polar zone some low flowering annuaisSaxifrages, Ranunculi, Gentians, Chickweeds, and others - flourish during the brief ardent summer; a few perennials also accommodate themselves to the rigorous climate by spreading laterally, never rising higher than four or five inches from the ground; till finally no development of vegetable life is met with but lichens, and the microscopic forms that colour the snow.

744. In Europe Wheat ceases with a line connecting Inverness in Scotland, lat. 58 deg., Drontheim in Norway, lat. 64 deg., and St. Petersburg in Russia, lat. $60 \mathrm{deg} .15 \mathrm{~min}$. Oats reach a somewhat higher latitude. Barley and Rye ascend to lat. $70 \mathrm{dcg}$. , but require a favourable aspect and season to produce a crop.

745. The northern limit of the growth of Oak, lat. 61 deg., falls shor't of that of Wheat. The Oak makes a singular leap at the confines of Europe and Asia, disappearing towards the Ural Mountains. This is the case also with the Wild-nut and Apple. The Oak and the Wild-nut, howevel, reappear suddenly in Eastern Asia, on the banks 
"He shall come down like rain upon the mown grass: as showers that water the earth."-Psalsr ixxii.

of the Argoun and the Amour; and the Apple occurs again in the Aleutian Isles.

746. Thus distinct vegetable vegions are observed on passing from. south to north through different climatic zones, defined as to their limits by the isothernal curves, and not by the parallels of latitude.

747. Why do whole Districts sometimes appear to be suddenly covered with MLsses?

Because Mosses, during a long drought, dry up, and almost clisappear. When moistened by rain, they suddenly
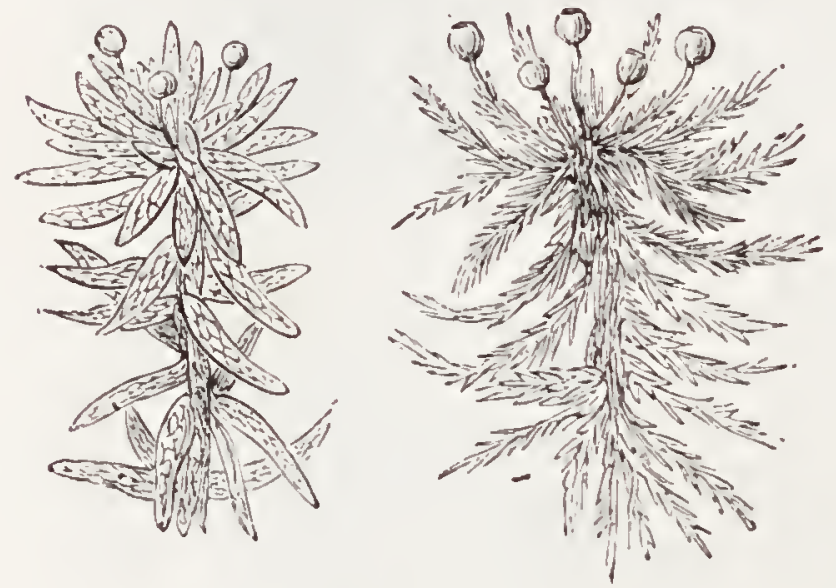

MOSSES. regain their greenness, and appear to have rapidly clothed a place previously barren - such as a heath, old wells, the trunks and guarled. roots of trees, \&c.

748. Mosses seem to labour to produce vegetation in newlyfound countries, where soil has obtained no existence; and in older districts they fill up and consolidate bogs, and form rich vegetable mould for the growth of larger plants, which they also protect from cold in the winter.

749. They likewise clothe the sides of lofty hills, and mountain ranges; and powerfully attract and condense moisture, and thus become to surrounding vegetation the source of refreshing streams.

750. What uses may be recognised in the instance of Plants that appear to possess no direct evident value?

There are many Plants which, though they neither 
"These were the potters, and those that dwelt among plants and hedges: there they dwelt with the king for his work."-I Curoniches iv.

produce fruit of any value, nor are capable of being applied to any of the common purposes of the arts, are yet of the highest value as a natural defence to cultivated lands, against the incursions of cattle and the chilling influences of bieak winds. The quickset of our common hedges is an instance, and of its utility in this country no one can form an adequate idea. Of the extent of its application it would not be easy to make a correct estimate, but, when we consider how many public roads and how many private enclosures are bounded by a fence of quickset, it becomes probable that the linear extent of hedges of this kind is, in England alone, equal to many times the circumference of the whole earth.

751. In a part of Normandy, lying between Caen and Falaise, is a district called "Le Bocage," which derives its name from the high and bushy hedges with which it abounds, and which afford shelter from the stormy winds of the Atlantic; hence they have the name of brise-vent.*

752. What causes have contributed to the absence of Plants over large Tracts of Land?

The absence of Plants over large tracts, in regions characterised on every side by the most exuberant regetation, is a geological problem which has hitherto received but little attention. It undoubtedly arises from former gevolutions of nature, such as inundations, or from volcanic convulsions of the earth.

753. When once a region loses its vegetable covering, if the sand is loose and devoid of springs, and if vertically ascending currents of air prevent the precipitation of vapour, thousands of years may elapse before organic life can 
"There shall be no grapes on the vine, nor figs on the fig-troe, and the leaf shall fade.-Jerkinall viii.

penetrate from the green shores to the interior of the dreary waste.

754. The great catastrophe by which the Mediterranean was formed, when the swollen waters of an inland sea burst their way through the Dardanelles and the Pillars of Hercules, appear's to have stripped the contiguous lands of their alluvial soil. In all lands washed by the Mediterranean, which are characterised by the tertiary and cretaceous formations, a great portion of the earth's surface is naked rock.

755. The picturesque beauty of Italian scenery depends mainly on the pleasing contrast between the bare and desolate rock, and the luxuriant regetation which, islandlike, is scattered over its surface. Where the rock is less intersected by fissures, so that the water rests longer on its surface, and where it is corered with earth, as

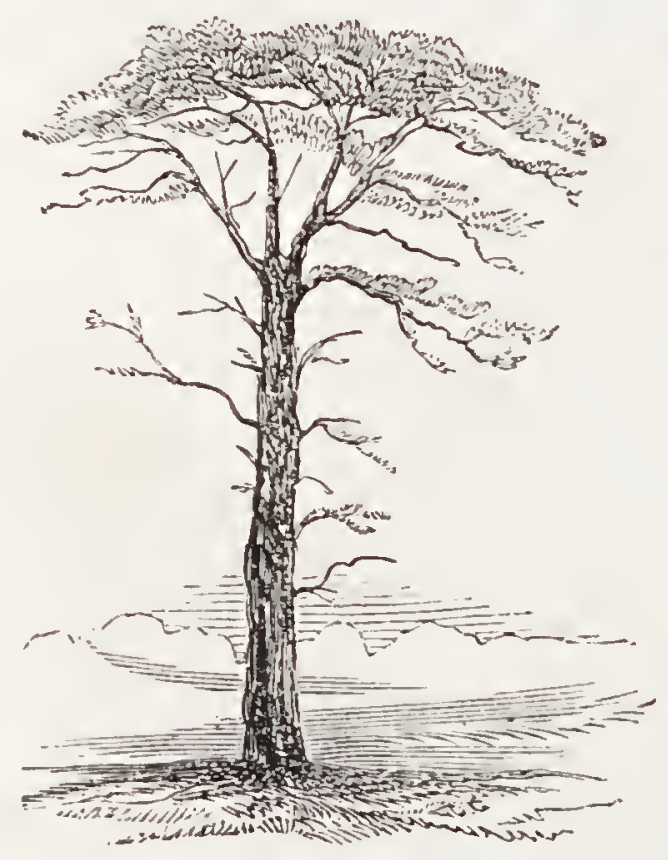

PINE. on the enchanting banks of Lake Albano, there eren Italy has her Oak forests, as shady and verdant as could be desired by the inhabitants of the North.

756. What Benefits are derived from Pines growing in Lofty and Barren Situations?

The trees are of great service in rendering ground fertile for other kinds of vegetation, by the decay of their leaves and resinous excretions. Thus we see that plants of the most opposite growths and 
"The living know that they shall die; but the dead know not anything, neither" have they any more a reward; for the memory of them is forgotten."-ECCLESIASTES ix.

dimensions subserve a similar useful purpose : the humble lichen fertilizes the barren rock, and the stately pine scatters its fertilizing leaves and cones over the poor soils of hill and monntain summits.

757. A remarkably enduring vitality is manifested in the roots of cone-bearing trees by the phenomenon of aftergrouth. The stumps of the felled white pine left in the ground form, during a succession of several years, new layers of wood, and continue to increase in thickness without throwing out shoots, branches, or leaves. The opinion is entertained by some observers, that this takes place through nourishment derived from the roots, which the extremity of the stem receives from a neighbouring living tree of the same species.

758. What are the Leading Distinctions between Organic and Inorganic Bodies?

Living beings, whether animal or vegetable, are distinguished from the masses of matter which compose the mineral kingdom, by peculiarities of form, size, structure, elementary composition, and of motion.

759. Every part of a mineral structure in which there has not been a mere mixture of components exhibits the same properties as those possessed by the whole; the minutest atom of carbonate of lime, for instance, has all the properties of a crystal calcspar, were it as large as a mountain. Hence it is the essential nature of an inorganic body that each of its particles possesses a separate indivicluatity, and has no relation but that of juxtaposition to the other particles associated with itself in one mass.

760. An organized structure, on the other hand, is made up of a greater or lesser number of dissimilar parts or 
"For every kind of beasts, and of birds, and of serpents, and of things in the sea, is tamed, and hath been timed of mankind."-JAMES iii.

organs; cach of these being the instrument of some special action or function, which it performs under certain conditions. Hence there is a relation of mutual dependence among the parts of an organized body.*

761. What are the most Remarliable Examples of the Influence of MLan upon the Distribution of Plants and Animals ?

Man not only exerts an influence over the Plants belonging to the country that he inhabits, but he brings in many foreign plants from near and distant regions, so far as the climate will permit. Our corn-plants, for instance, have been brought to us from Asia, and also most of our firut-trees and kitchen vegetables; the potatoe from America; cotton was conveyed from India to North America and Brazil; coffee from Abyssinia and Arabia to Java, the West Indies, and Brazil; many useful and oruamental plants have been obtained from North America, Asia, and the South of Europe.

762. There exist also remarkable instances of the plants introduced by man becoming greatly diffused, independently of his agency, so much so as in certain cases to displace the original Plants; the artichoke and the peach-tree afford examples of this in the pampas of South America, paralleled there in the animal kingdom by the wild horses and oxen, which have in like manner become very widely diffused over those plains. In St. Helena the original flora has been almost driven out by the foreign plants which have been introduced to the island.

763. Our common domestic animals have been conveyed to all parts of America, which was totally deroid of * Dr. Carpenter's "Animal Physiology." 
"Who teacheth ns more than the beasts of the earth, and maketh us wiser thas the fowis of heaven?"-Jов xxxy.

domestic animals before the advent of the Europeans-to. South Africa, Australia, Van Diemen's Land, New Zealand, the South Sea Islands, \&c.; and great revolutions. both in native and in human life have resulted from it. At the present time (1863) attempts are being made to acclimatise the Alpaca, from Peru, in the colony of Australia, and the success of the early experiments appears to be fully established.

764. What other infuences are exercised by Man upor the Distribution of Animals?

In other instances civilization has caused the extirpation or expulsion of many linds of animals, as the Elk, the Arrochs, and the Beaver in Northern Europe; the furred animals in North America, the Hippopotamus and Crocodile in parts of Egypt ; these and the Rhinoceros and the Giraffe at the Cape, the Lion in Greece, the Wolf and Wild Boar in Britain and Denmark.*

765. Man drives wild animals from their favouritc haunts, reduces others in number, while some become. wholly extirpated in regions tenanted by the human family.

766. In the British Islands the Stag, as well as the Fallow Deer and the Roe, were formerly so abundant that five hundred to a thousand were sometimes slain at a hunting-match. The Otter, the Marten, and the Pole-cat were also in sufficient numbers to be pursued for the sake of their fur; but they have by degrees been. realuced to very small numbers. The Wild Cat and the Fox have also been sacrificed throughout the greater part

* For many interesting particulars as to Varieties, and the means by which they. are produced, see "Reason Why, Natural History," and "The Gardeners and: Farmers' Reason Why." 
"A whip for a horse, a bridle for the ass, and a rod for the fool's back."Proverbs xxvi.

of the country, for the security of fowls and other useful animals. Badgers have been expelled from nearly every district which at former periods they inhabited.

767. There are some that have been wholly extirpated, such as the ancient breed of indigenous Horses, and the Wild Boar; of the Wild Oxen, a few remains are still preserved in some of the old English parks. The Bearer, whose fur is of considerable value, had become scarce at the close of the ninth century, and by the twelfth century was only to be met with in one river in Wales, and another in Scotland. The Wolf, once so much dreaded by our ancestors, maintained its ground in Ireland so late as the beginning of the eighteenth century, thongh it had been extirpated in Scotland thirty years before, and in England at a much earlier period. The Bear, which in Wales was regarded as a beast of the chase equal to the Hare or the Boar, only perished as a native of Scotland in the year 1057.

768. 'The Eagles, larger Hawks, and Ravens have disappeared from the more cultivated districts. The haunts of the Mallard, the Snipe, the Redshark, and the Bittern have been drained equally with the summer dwellings of the Lapwing and the Curlew. But these species still linger in some portions of the British Isles; whereas the larger Wood Grouse, formerly natives of the Pine forests of Ireland and Scotland, have been destroyed within the last sixty years.

769. These changes relate only to the larger and more conspicuous animals inhabiting a small spot on the globe; but they cannot fail to exalt our conception of the enormous revolutions which in the course of several thousand years the whole human species must have effected. The number of human beings now peopling the earth is supposed to amount to eight hundred millions, so that we may easily 
"Thou shalt not muzzle the ox when he treadeth out the corn."-DEUT. xxv.

understand how great a number of beasts of prey, birds, and animals of every class this prodigious population must have displaced, indepen. dently of the still more important consequences which have followed from the derangement brought about by man in the relative numerical strength of particular species.*

770. The $\mathrm{Ox}$ and the Horse, like the farinaceous Ceralia, have followed man over the whole surface of the globe, from India to Northeru Siberia, from the Ganges to the River Plate; from the African sea-shore to the mountain plateau of Antisana, which is higher than the summit of Teneriffe. The Ox, wearied from the plough, reposes, sheltered from the noon-tide sun, in one country by the quivering shadow of the northern Birch; in another by the Date Palm. The same species which in the east of Europe has to encounter the attacks of Bears and Wolves, is exposed in other regions to the assaults of Tigers and Crocodiles. $\dagger$

771. Enormous as are some animal forms, the mass of vcgetation on the carth far exceeds that of animal organisms; for what is the value of all the large living Cetacea and Pachydermata, when compared with the thickly-crowded colossal trunks of trees of from eight to twelve feet in diameter, which fill the vast forests covering the Tropical region of South America, between the Orinoco, the Amazon, and the Rio da Madeira. And although the character of different portions of the earth depends on the combination of external phenomena -as the outlines of mountains, the physiognomy of plants and animals, the azure sky, the form of clouds, and the transparency of the atmosphere-it must still be admitted that the vegetable mantle with which the earth is decked constitutes the main feature of the picture.

772. Animal forms are inferior in mass, and their powers of motion often withdraw them from our sight. The vegetable kingdom, on the contrary, acts upon our imagination by its continued presence, and by the magnitude and variety of its forms. In the animal kingdom the forms which we term "microscopic" occupy the largest space, in consequence of their rapid propagation. The minutest of the Infusoria have a diameter which does not exceed $\frac{1}{5000}$ of a line, and yet these silicious-shelled organisms form in humid districts subterranean strata of many fathoms in depth. 
"Ask now the beasts, and they shall teach thee; and the fowls of the air, and" they shall tell thee."-Joв xi.

\section{A N I MALS.}

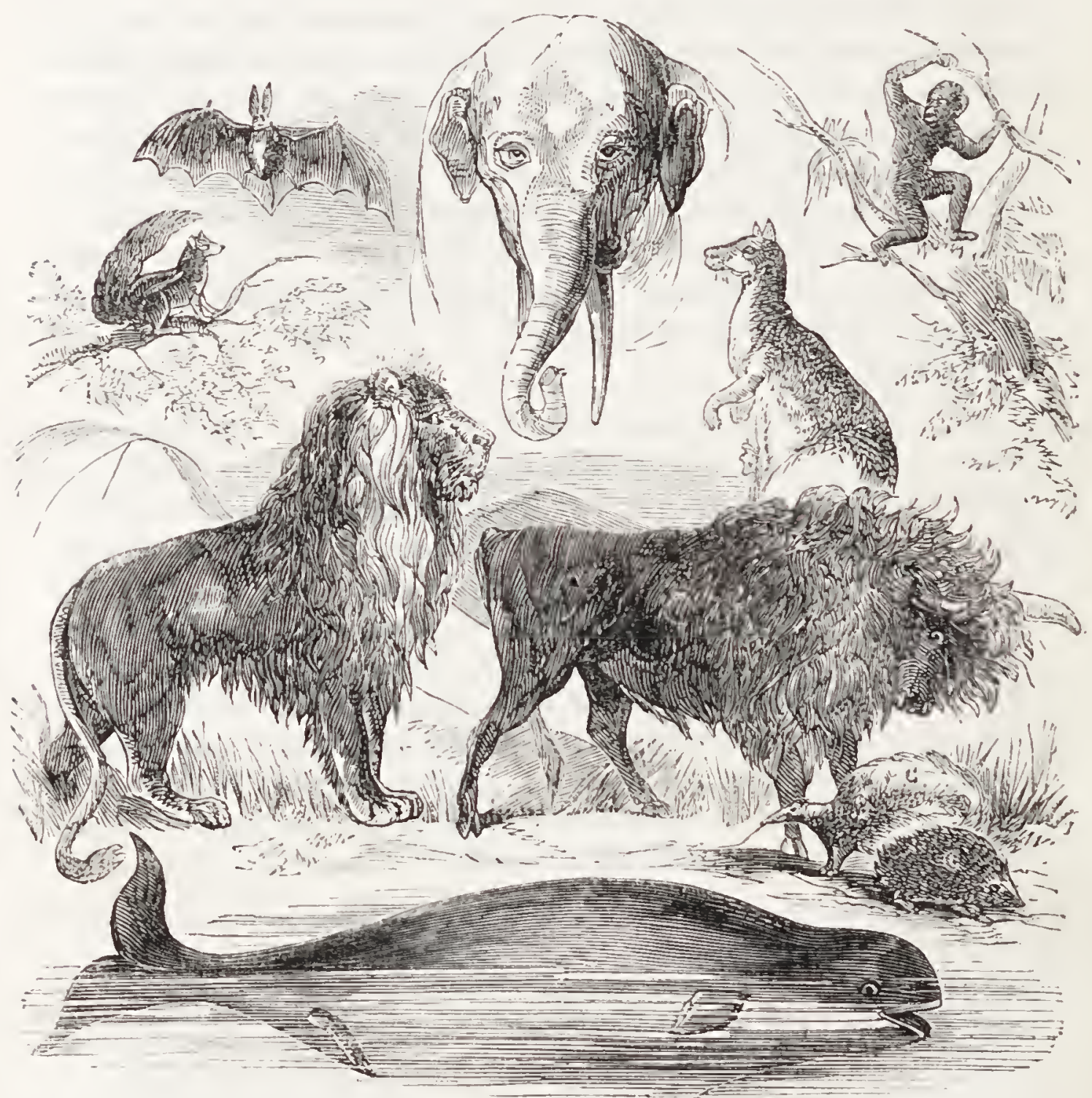

773. Why are certain Divisions of the Earth characterized by Particular Animals?

It appears evident that the various tribes of organised beings were originally placed by the Creator in certain 
"The sparrow hath found an house, and the swallow a nest for lierself, where she may lay her young, eren thine altars, O Lord of hosts, my king and my God."Psalur ixxxiv.

regions, for which they are by their nature peculiarly adapted. Being thus placed upon the earth, they were left to disperse themselves to as great a distance from the original centre of their existence as was compatible with its physical capabilities, and with those unknown laws by which the Creator has regulated the geographic distribution of $\mathrm{His}$ creatures.

774. The opinion that those conditions which regulate the geographic distribution of species are limited to circumstances connected with temperature, food, situation, and antagonistic races, is totally insufficient to account for the phenomena of animal geography. We know, indeed, that these causes, either singly or collectively, have great influences on local distribution, but they have nothing to do with the geographic distribution of animals indigenous to large continents.

775. Looking at the animal world, we may see thousands of beings endowed with powers of locomotion which have been utterly denied to man. The Swallow, darting like au arrow through the air at the rate of sixty miles an hour, seems to mock the speed of our swiftest ships; the Curlew runs rapidly on the ground, mounts on the breaking surge, or swiftly flies from one continent to another, thus traversing with perfect ease three elements-the earth, the air, and the sea. Thousands, in short, of tiny birds perform journeys, every spring and autumn, any of which, to us, would be the occupation of a year. Now, the theoretical conclusion we should make, on considering these facts, would be, that animals so peculiarly gifted with the power of locomotion, would use it to wander in every clime; that they would spread their races in every region of the earth where food could be procured, or 
"For every creature of God is good, and nothing to be refused, if it be receired with thanksgiving."-I Tدrotur iv.

where they could enjoy a fit temperature. Yet these deductions are diametrically opposed by facts. The Swallow of England might reach America or China in as short a space of time as it would travel to Africa, and in either country would find food and warmth congenial to its nature; but it has been appointed to pursue a certain course, and from that course it never deviates. This is only one out of a thousand circumstances to prove that the limits of cvery animal have been fixed by an Almighty fiat-" Hither shalt thou come, but no further."

776. The total number of species of animated creatures known to exist at present may be estimated at about 155,000, which Zoologists have classed as follows :-

1. Vertebrata, viz:-

Mammalia .

Birds

Reptiles

Fishes

$$
\begin{array}{r}
\text { Species. } \\
1700 \\
6000 \\
1500 \\
6000 \\
\hline 15,200 \\
10,000 \\
120,000 \\
10,000 \\
155,200
\end{array}
$$

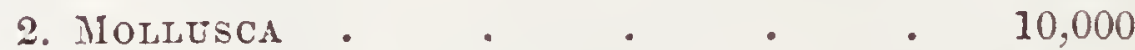

3. Articulata, including Insects . . 120,000

4. Radiata . . . . 10,000

777. Our World is capable of sustaining a much greater number of inhabitants than has yet ever existed upon it at any one time. And, since we are informed in the sacred oracles that God "created it not in vain, but formed it to be inhabited," we have reason to believe that, in future ages, when the physical and moral energies of mankind shall be fully exerted, and when peace shall wave her olive-branch

- Swainson's "Classification of Animals." 
"I have planted, Apollos watered; but God gare the increase. So then neither is he that planteth anything, neither he that watereth, but God that gireth the increase."-I. CoRINTH. iii.

over the nations, the earth will be much more populous than it has been, and those immense deserts where ravenous animals now roam undisturbed, will be transformed into scenes of fertility and beauty.

778. If it be admitted that the produce of twelve acres of land is sufficient to maintain a family consisting of six persons, and if we reckon only one-fourth of the surface of the globe capable of cultivation, it can be proved that the earth could afford sustenance for 16,000,000,000 inhabitants, or about twenty times the number that is presently supposed to exist. So that we have no reason to fear that the world will be over-stocked with inhabitants for many ages to come.*

779. Whence proceed the Infusoria and Animalculce that appear to Generate Spontaneously?

Minute infusorial animalcules are probably distributed through the air, after being passively borne up by currents of watery vapour. This appears the more probable since Ehrenberg has discovered that the dust or sand which mariners often encounter in the vicinity of the Cape de Verd Islands, and even at a distance of 350 geographical miles from the African shore, contains the remains of various species of animalcules.

780. Not only in the Polar Regions is there an uninterrupted development of active microscopic life, where larger animals can no longer exist, but we find that the microscopic animals collected in the Antarctic expedition of Captain Ross exhibit a remarkable abundance of unfamiliar and often most beautiful forms. Even in the residuum obtained from the melted ice floating about in 
" Behold I will send swarms of flies upon thee, and upon thy servants, and upon. thy people, and into thy houses; and the houses of the Egyptians shall be full of strarms of flies, and also the ground whereon they are."-Exodus vii.

round fragments in the latitude of $70^{\circ} 10^{\prime}$, there were found upwards of fifty species of animalcules. In the Gulf of Erebus, other animalculie forms were brought up by the lead sunk to a depth of from 1242 to 1620 feet.

781. Whecl-animalcules and a host of microscopic insects are lifted by the winds from the evaporating waters below. Motionless, and to all appearance dead, they float on the breeze, until the dew bears them back to the nourishing earth, and, bursting the tissue which incloses their transparent bodies, instils new life and motion into all their organs. Many of these, perhaps, float for years in the highest strata of the atmosphere, until they are borne down by the winds.

782. Of the Infusoria, and other beings, entire mountains have been formed, although microscopes of the highest powers are required to detect an individual. Higher in the scale, even among Insects, the most remarkible conditions of increase are observed. Some Silkworms lay from 1000 to 2000 eggs; the Wasp deposits 3000 ; the Ant from 4000 to 5000. The Queen Bee lays between 5000 and 6000 egges, and in one season the number may amount to 40,000 or 50,000. But, above all, the White Ant produces 86,400 eggs each day, which for a lunar month gires the astonishing number of $2,419,200$ - a number far cxceeding that produced by any other known animal.*

783. What striting Analogy is there between the Distribution of Animals and Plants?

The Animal creation, like the Vegetable, is found to vary with height above the sea and with latitude; the changes 
"The king had at sea a navy of Tharshish with the navy of Hiram ; nnce in three years came the nary of Tharshish, bringing gold, and silver, and apes, and pea-cocks." -1 KINGs xi.

of species in ascending the Himalaya, for instance, are similar to what a traveller would meet with in his journey from an equatorial to a high latitude. The number of land animals increases from the frigid zones to the Equator ; but the law is reversed with regard to Marine Mammatia, which abound most in high latitudes.

784. Taking a broad view of the nine order's of Mammalia, it may be stated that the tropical forests are the chief abode of the Monkey tribe ; Asia is the home of the Ape, especially the Indian Archipelago, as far as the most easterly meridian of 'Timour, beyond which there are none. They abound throughout Africa, from the Cape of Grood Iope to Gibraltar, where the Barbary Ape is found - the only place where it is met with in. Europe. Another species of Ape

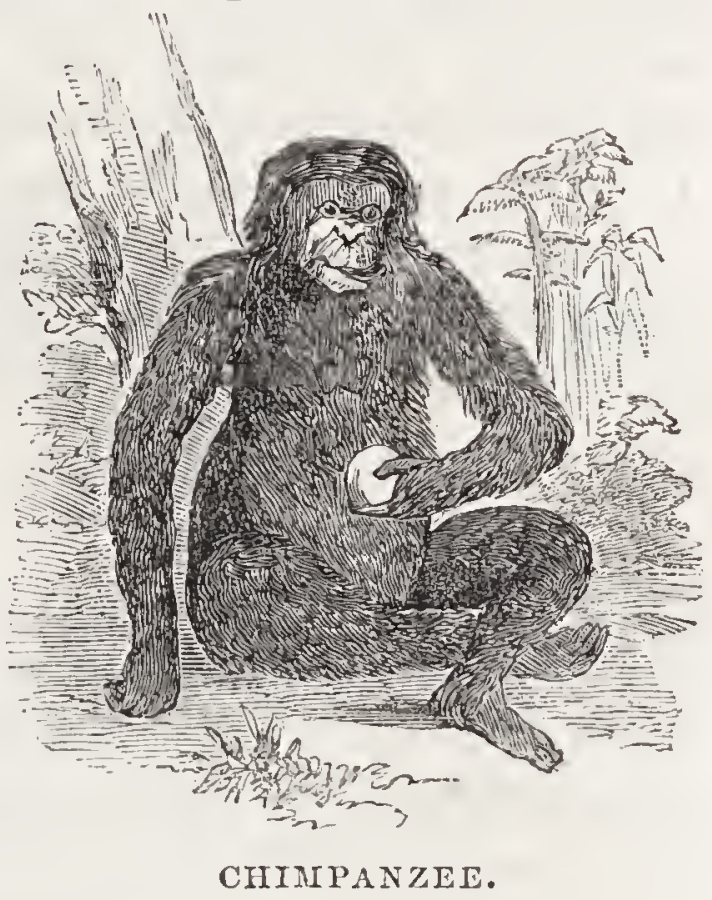
inhabits the island of Niphon, the northern limit of Monkeys, at the castern extremity of the Old Continent.

785. Many of the animals that thrive at great elevations cannot exist in less elevated and warmer regions. Groats and Sheep endure best the rarefied air and great cold of high lands; the Cashmere Goat and Angola Sheep browse on the Plains of Thibet, at elevations of from 10,000 to 13,000 feet; the Ram-a sheep with spiral horns -lives on the table-lands of Paner, which are 15,000 feet 
"In whose hand is the soul of every living thing, and the breath of all mankind."-Joв xi.

above the sea; and also the Kutch-gar-a species of sheep, with fine curling horns-they congregate in flocks of many hundreds, and are hunted by the nomade tribes of Kirghis.*

786. Innumerable attempts hare been made to keep Cats as domestic animals in the town of Cerro de Pasco, 14,100 feet above the level of the sea, but such attempts lave failed, both Cats and Dogs dying at the end of a few days in fits, in which the cats were taken at first with convulsive movements, then tried to climb the walls, fell back exhausted and motionless, and died. It seems to be in consequence of the absence of sufficient atmospheric pressure. Wild cattle on the great mountain plain of Antisana bleed from the nose and mouth when driven to an elevation of about 13,500 feet.

787. In land animals a high degree of temperature, depending on latitude, appears to have exercised a favourable influence on the development of their organization. Thus, the small and slender form of our Lizards expands in the south into the colossal, unwieldy, and mail-clad body of the formidable Crocodile. In the huge cats of Africa and America-the 'Tiger, the Lion, and the Jaguar-we find, repeated on a large scale, the form of one of the smallest of our domestic animals. $\dagger$

788. Why are Monkeys confined to certain Geographical Limits?

'Their chief use, in the limits to which they are assigned, appears to be the prevention of the too rapid increase of Birds, that would otherwise be brought to maturity in rast numbers, aided by the sun's heat. This mission the 
"Wild beasts of the desert shall lie there; and their houses shall be full of doleful creatures; and owls shall dwell there."-IsAIAH xiv.

Monkeys carry out so perseveringly that they are perpetually on the watch to rob Bird's nests; and when they want appetite or inclination to devour them, they destroy them by dashing them to the ground. Where Birds most abound, there Monkeys are most numerous also.*

789. Why are Bats very widely Distributed?

They feed chiefly upon Insects, the numbers of which they assist to keep within the necessary limits. They take the place by night which the Swallow occupies by day. Some of the species occasionally fly by day, but the habit is by no means common, and is confined to some of the Bats of tropical and warm cli-

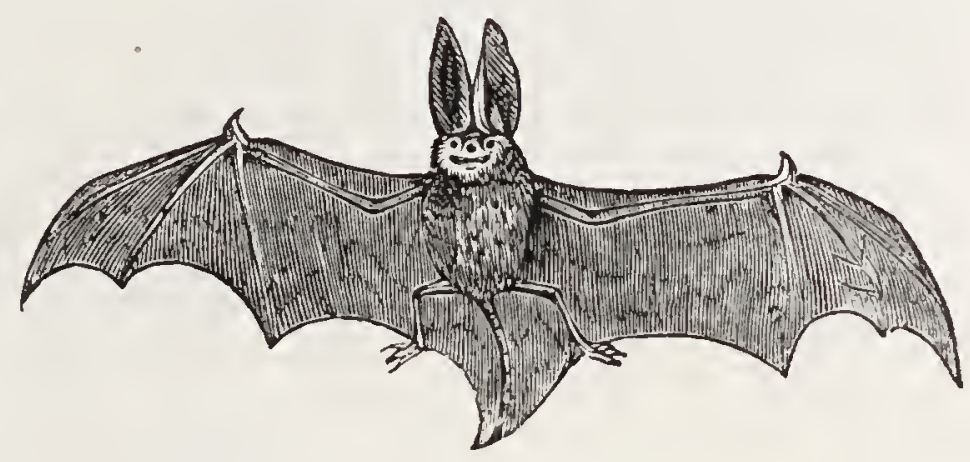

BAT.

mates that live on fruits. The common Bats, which live on Insects, are so numerous in species as to form more than a third of the whole family, and are found everywhere except in Arctic America. The Vampire is met with only in Tropical America.

790. Bats issue forth from concealment as darkness begins, and by their active flight capture such Insects as are then on the wing-Gnats, Mosquitoes, Motlis, Beetles, \&c., and their wide gape is an excellent trap for the capture of such prey. The service which they render to vegetation, by the destruction of Insects which in the larva state prey upon it, is very considerable, even in the 
"The young lions do lack, and sufier hunger: but they that seck the Lord shall snot want any good thing."-PsALII xxxir.

temperate clinates; and some of the lot countries in which they swarm by myriads could not, but for them, be inhabited.

791. In humid places on the margins of Tropical forests, Mosquitoes are troublesome enough as it is; but if the Bats did not thin their numbers, they would be utterly unbearable. 'Those species, too, which frequent towns and settlements are useful in other respects. Most of them are miscellaneous in their feeding, and not very delicate in their taste. 'They devour indiscriminately all animal substances, whether raw or dressed, and either in a recent $\mathrm{ol}^{\circ}$ putrid state, and hence they act as scavengers.

792. How are the Carnivorous Mammalia Distributed?

They are clistibuted all over the globe, though very

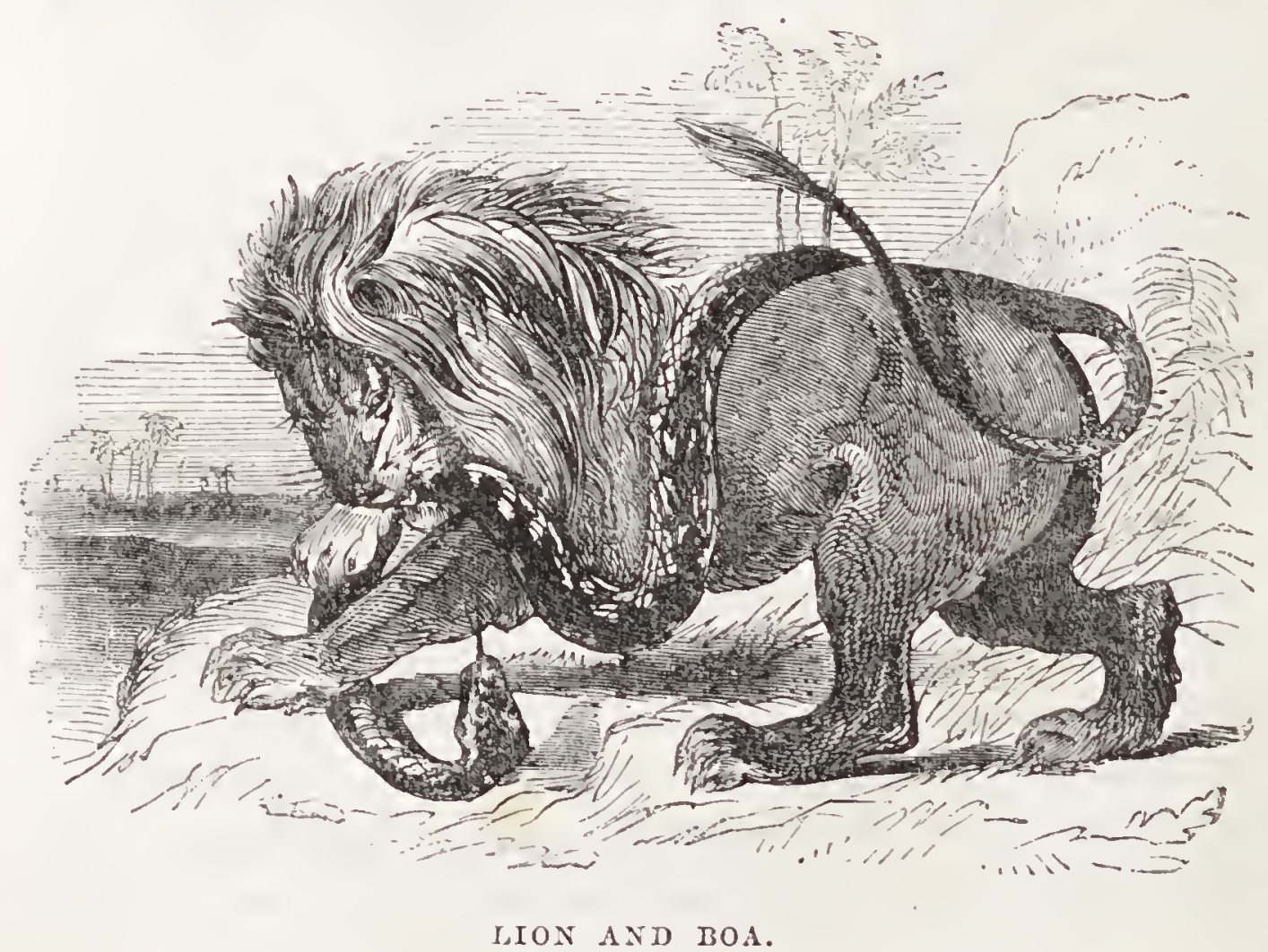

snequally. By far the majority of species, and, with the 
"The wild beasts of the desert shall meet with the wild beasts of the island, and the satyr shall cry to his fellow; the sereech owl shall also rest there, and find for herself a place of rest."-IsaialI xxxiv.

exception of Bears and Wolves, all the largest and most formidable ones, are confined to Tropical countries.

793. The Carnivora form a very large class, consisting

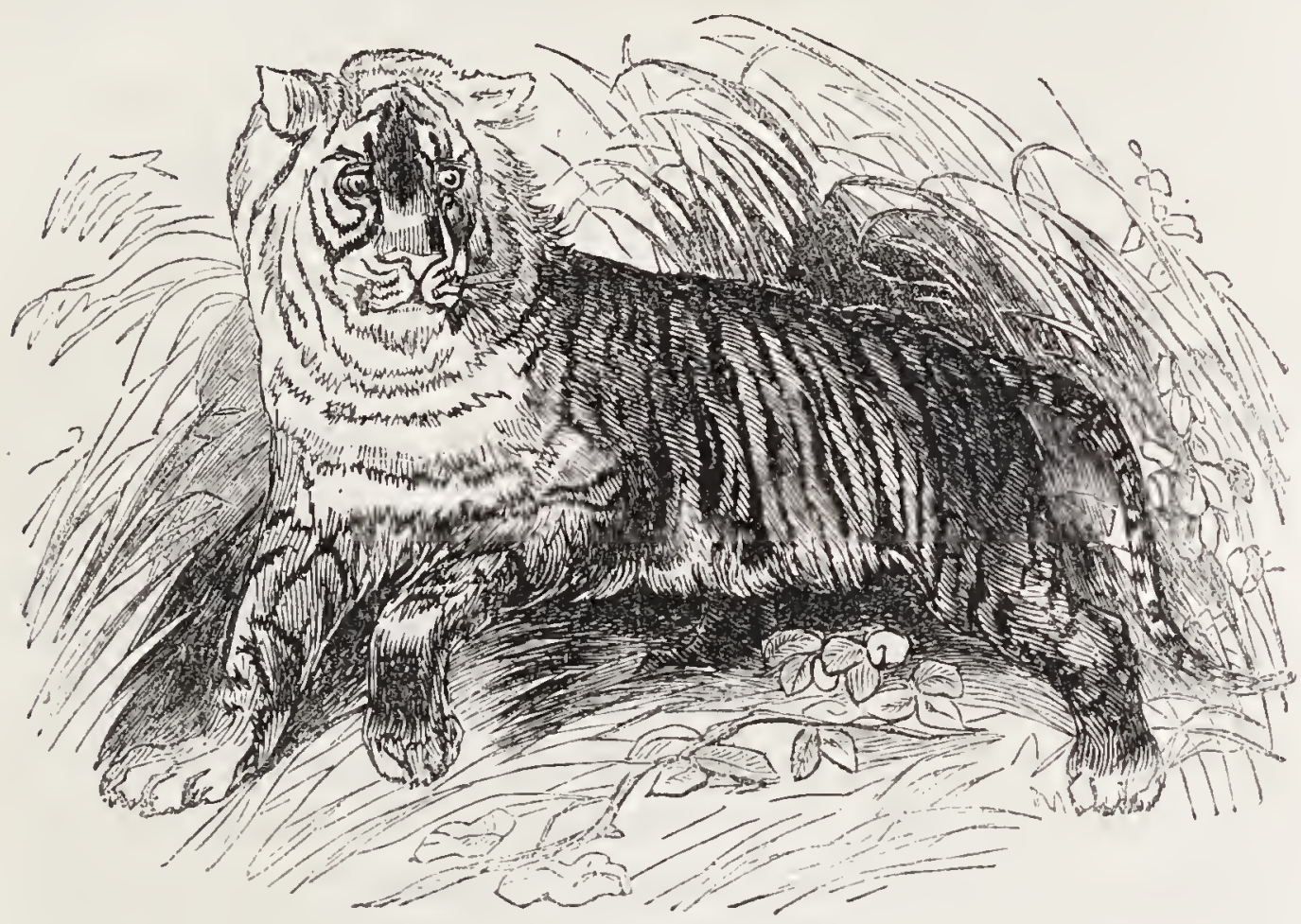

TIGER.

of 514 species, arranged in 61 genera, and divided by strong natural characteristic distinctions into five families, viz., the Digitigrades, or those clawed beasts which spring and leap on their prey, and which comprehend as Cats (feles) the Lion, Tiger, Leopard, Panther, \&c., and as Dogs (canes) the Wolf, Fox, \&c., and which comprise the most active and formidable; the Plantigrades, as Bears, Badgers, Racoons, \&c., which use the whole lower joint of the leg as their support, and stand often erect on it as a broad basis; the Insectivora, as Hedgehogs, Moles, Shrew-Mice, \&xc.; the Flying Cats, a small family confined to Tropical Asia; and the Bats. 
"The young lions roar after their prey, and seek their meat from God."Psalat civ.

794. The unequal distribution of the Carnirorous Tribes is so marked that, if we divide the world into Austral, Tropical, North Temperate, and Arctic, we shall find the proportion of species inhabiting each of these Geographical divisions to be :-

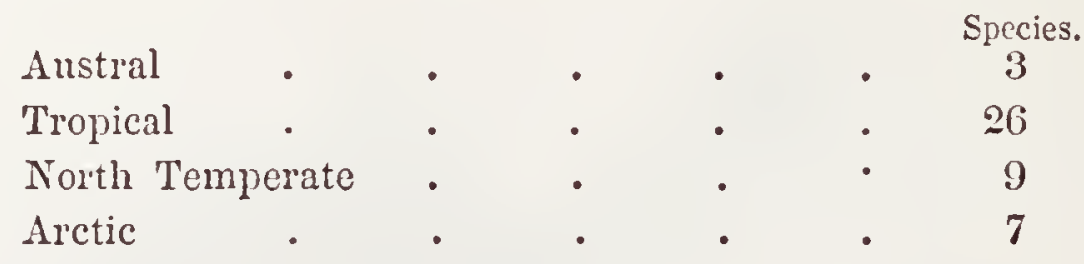

The Austral division is here held to include the extreme South America, from $40^{\circ}$ S., with Australia, and its connecting islands.

795. The Lion is found over all Africa, Egypt and the Lybian Desert excepted; and in Asia only in the districts bordering on the Euphrates, in Persia, and the jungles in India. The Tiger, whose migrations take a wide extratropical range, has its chief habitation in the forests and jungles of Bengal, the southern mainland of Asia, Jara, and Sumatra. The Puma ranges over both Americas, from $50^{\circ} \mathrm{N}$., to $53^{\circ} \mathrm{S}$.; the Jaguar is principally found in Brazil and Paraguay. The Wolf, though now nearly

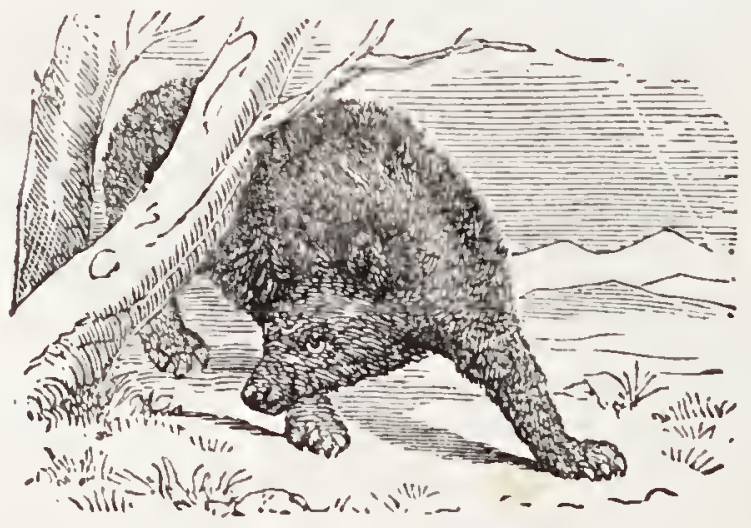

GRISLY BEAR. driven out of the more populous portions of Europe, is indigenous over the whole northern hemisphere, from the Arctic latitudes down to the Tropical ones. The Bear is largest and most formidable within the Arctic Circle as the White or Polar Bear, and in the North American forests 
"Thou makest darkness, and it is night; wherein all the beasts of the earth do creep forth." - Psalar siv.

as the Grisly Bear of the Rocky Mountains and the Western Savannahs; within the Tropics their species are not numerous, and in the Austral region none occur; neither is any species of the Insectivora native in these regions, though pretty equally distributed over all the others. The only formidable Bat is the Vampire, a West Indian and South American species, which sucks the blood of animals during sleep, and occasionally of man.*

796. Humboldt thus describes a night passed by himself in the vicinity of a forest tenanted by wild animals:-After eleven o'clock such a noise began that for the remainder of the night all sleep was impossible. The wild cries of animals rung through the woods. Among the many voices which resounded together, the Indians could only recognise those which, after short pauses, were heard singly. There was the monotonous plaintive cry of the Howling Monkeys, the whining flute-like notes of the small Sapajons, the grunting murmur of the striped nocturnal Ape, the fitful roar of the great 'Tiger, the roar of the American maneless Lion, and the peculiar cries and noises of the Peccary, the Sloth, and a host of Parrots, Parraquas, and other pheasantlike birds. Whenever the Tigers approached the edge of the forest, our Dog, who before had barked incessantly, came howling to seek protection under the hammocks. Sometimes the cry of the Tiger resounded from the branches of a tree, and was then always accompanied by the plaintive piping tones of the Apes, who were endeavouring to escape from the unwonted pursuit. When I asked the Indians why such continuous noise was heard, they answered with a smile that "the animals were rejoicing in the beautiful moonliglit, and celebrating the return of the full moon." To me the discord appeared rather to be owing to an accidental, long continued, and gradually increasing conflict among the animals. Thus, for instance, the Jaguar will pursue the Peccaries and the Tapirs, which, densely crowded together, burst through the barrier of tree-like shrubs which opposes their flight. Terrified at the confusion, the Monkeys on the tops of the trees join their cries with those of the larger animals. This arouses the tribes of Birds who build their nests in communities, and suddenly the whole 
"And the living creatures ran and returned as the appearance of a flash of lightning." -EZEKIEL i.

animal world is in a state of commotion. Further experience taught us that it was by no means always the "festival of moonlight" that disturbed the stillness of the forest; for we observed that the voices were loudest during violent storms of rain, or when the thunder echoed and the lightning flashed through the depth of the woods.

797. Why is the formation of the Kanguroo admirably adapted to its Australian habitations?

Because it is a country characterised in many parts by marshy grounds, intersected with bushy and rocky areas,

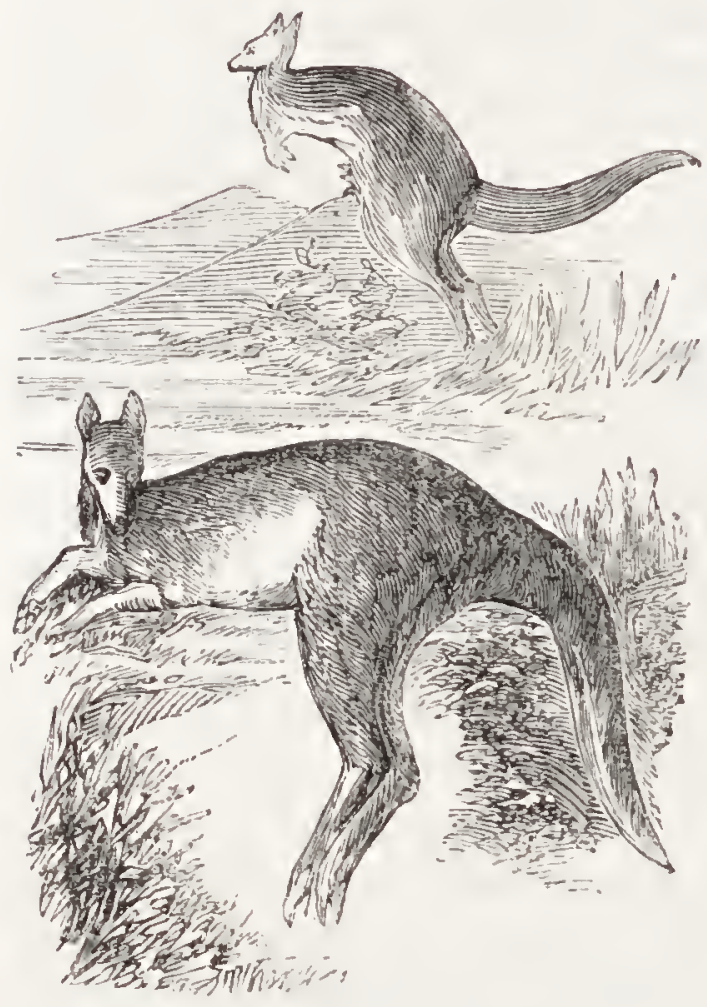

KANGUROOS. with patches of coarse grass, growing to several feet in height. The bounding movement of these animals enables them to leap over and through the obstacles by which they are surrounded.

798. The Marsupials, or those which carry their young in pouches, including Opossums, Kanguroos, Wombats, Phalangers, \&c., constitute 14 genera, including 123 species. Of these, only one genus, the Opossum, is found in America, distributed in 21 species, orer the whole continent. All the other genera belong exclusively to Van Diemen's Land, and the Islands of the Asiatic. Archipelago, as far as Java.

799. In Australia they constitute an immense majority of the Mammalian species, in which, with this exception, that singular Continent is exceedingly poor. In the Islands 
"Be not afraid, ye beasts of the field, for the pastures do spring, for the tree beareth her fruit, the fig-tree and the vine do yield their strength." -Joes ii.

of the Archipelago only seren species are enumerated, among which one Kangaroo is said to occur (in Java). In no other part of the Old World are any Marsupial animals belonging to this class found living; and if we would seek for indications of them, singularly enough it is in the fossil remains of the oolites of the South of England, the antipodes of the region which they now almost exclusively possess.*

800. These animals are distinguished by a poueh-like appendage on the under part of the females, which poueh is supported by two peeuliar bones, ealled marsupial-from the Latin word marsupium, meaning a purse, or pouch. Their young are born in a very helpless state. They are far more minute and shapeless than the young of any other of the Mammalia, not exeepting those whieh eome into the world blind and naked. The poueh answers as a sort of seeond womb, in which the young animals are brought to maturity.

801. The structure of these animals agrees with the eontingeneies under which they exist. They are subjected to eonsiderable hardships, arising from the alternate parehing and flooding of the eountries in whieh they abound-eountries whiel are not adapted for the common Manmalia in a state of nature-and, aecordingly, we find that in New Holland, whieh may be eonsidered the head-quarters of Marsupial animals, there are no uative placontal Mammalia, and suels are not very common in the other loealities of these animals. Nerw Holland, New Guinea, some of the other islands of the Archipelago, South America, and the warmer parts of North Ameriea in the ease of a single species only, are the loealities of these animals; and it is not a little remarkable that not one of them has hitherto been found in Afriea, though they oecur on both sides of it. +

802. There are various kinds of this beantiful and useful animal. They congregate in flocks, varying in number from fifteen to thirty, but are more frequently met with in threes and fours, whieh may be aecounted for by the quarrelsome disposition of the males. The Kanguroo, like most wild animais, eoneeals itself during the day, and comes 
"Go to the ant, thou sluggard; consider her ways and be wise: which having no guide, overseer, or ruler, provideth her meat in the summer, and gathereth her food in the harvest." - Proveris. vi.

out through the night. Its food is the broad sweet-leaved grass; it browses also upon herbs, and the tendrils of young gum-trees. Its erect position when thus feeding is conveniently supported by the breadth of ground covered by its long hind feet and tail. Its power of leaping enables it to spring from shrub to shrub, escaping the necessity of forcing its way through long grass or tangled underwood.

803. Why are Ant-Eaters of Great Importance in the Economy of Nature?

Because, without the check which they put upon the multiplication of Ants, the procluce of the soil, even in the most

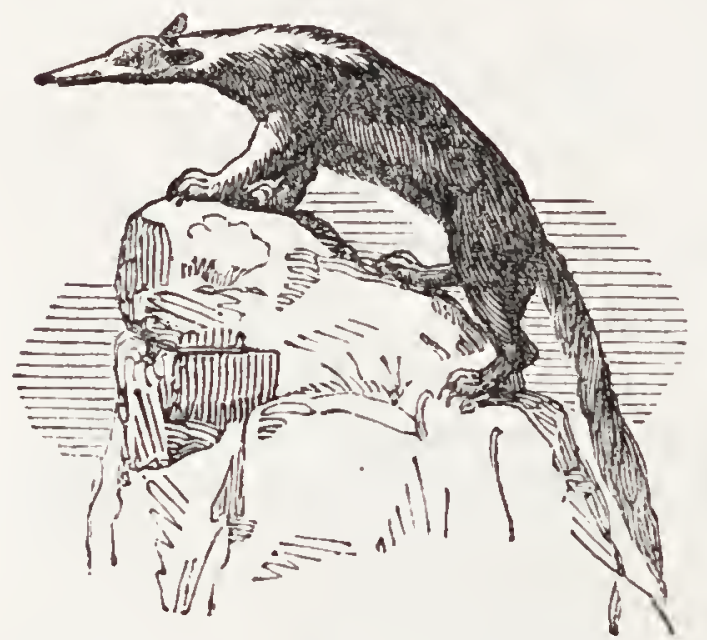

ANT-EATER. fertile parts of the world, would inevitably be destroyed. It seems almost incredible that so robust and powerful an animal as the Anteater, or Ant-bear, can procure sufficient subsistence from Ants alone; but this circumstance has nothing strange for those who are acquainted with the tropical parts of America, where the ant-hills often almost touch one another for miles together.

804. The ant-hills of South America are often more than twenty feet in diameter, and many feet in height. These wonderful edifices are thronged with two-hundredfold more inhabitants, and are proportionally far more numerous, than the small ones with which we are better acquainted. Breeding in vast numbers, and multiplying with great celerity and profusion, the increase of these insects would soon enable them to swarm over the greatest 
"Thou makest darkness, and it is night, wherein all the beasts of the field do creep forth." - PsALX XXY.

extent of country, were not their propagation and diffusion limited by the active exertions of that part of the animal creation which continually subsist by their destruction.

805. The genera of Edentata or toothless animals (the Slotlis, Armadillos, Ant-eaters, Marises, \&c., eight in number) are equally divided between the Americas and the rest of the world; the former, however, being rather richer in species. The Sloths live entirely in the trees, chiefly in the Brazilian forests; the Armadillos range through Central and Southern America, as far as the 43rd degree of South latitude.

806. Why are Sloths exceedingly useful in the Forests which they inhabit?

The two-toed Sloth inhabits the deep and luxurious forests of South America, in which the trees are of giant growth, always green, and so close that rarely a beam of the vertical sun reaches the earth; they extend over districts so wide, and so festooned and interlaced with twining plants, that winds, which would level a single tree to the ground barely agitate their branches. In order that there may be seeds and successions of races in those luxuriant forests, it is necessary that there should be consumers of the superabundant foliage, which otherwise would perish from the excess of its own exubelance,

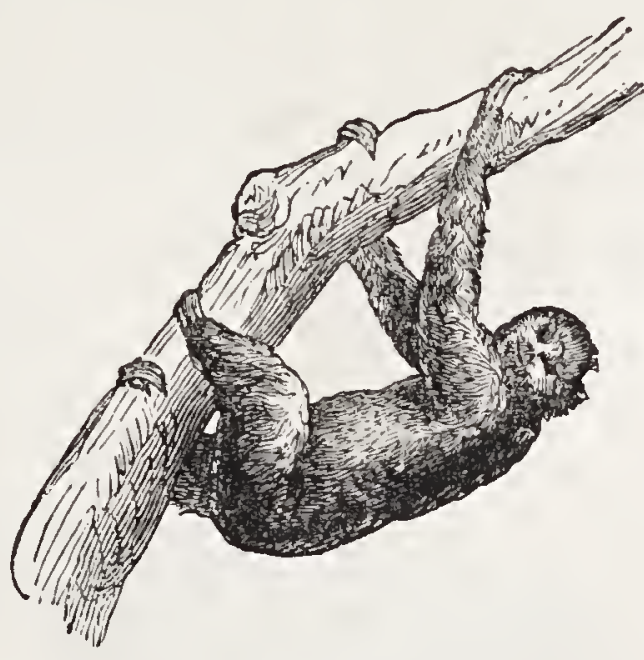

SLOTH. leaving the naked and carpetless earth to be converted, by the fervour of the tropical sun, into an arid waste, upon which no living thing could exist. If the forests were to be destroyed in this manner, or, indeed, in any way 
"Every beast of the forest is mine, and the cattle upon a thousand hilis. I know all the fowls of the mountains; and the wild beasts of the field are mine."-PsALs 1.

but one in which their place should be occupied by a close surface of vegetation, the rain would depart also, and the land would pass beyond the power of human skill and libour to bring it back to usefulness, either for man, or for any other living creature.

807. Wherever the earth is green, there are brousing animals appointed to consume the pasturage or the foliage and to aid also the great scheme of nature in its successional changes. In the tropical forests, the green is not upon the surface of the ground, but upon the tops of the trees, and the browsing animals destined to consume it must have an inverted position, to enable them to make the foliage of the trees their pasture.

808. A pasture suspended in the air must have those which feed upon it suspended in the air also; and they camnot be placed above the leaves, because the latter afford no footing for an animal in size adequate to the consumption it is necessary to accomplish ; they are, therefore, suspended beneath the foliage, and in this manner they are brought in closer comnection with the branches, which alone could afford them support.

809. Why does the number of Armadilloes generally Increase in the Neightrourhood of Colonies?

Because, as well as eating insects and roots, they derour

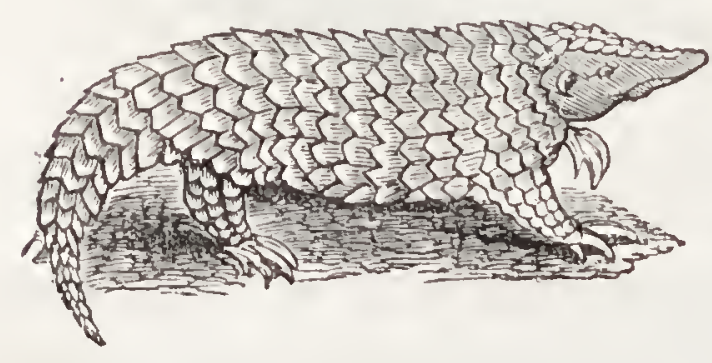

ARMADILLO, the carcases of animals. In the neighbourhood of colonies a great many wild animals are killed for their skins, and the increase of the number of carcases promotes the increase of the Armadilloes, who act as scavengers. 
"Man that is in honour, and understandeth not, is like the beasts that perish." -

810. What is the Distribution of the Order of Pachydermata?

Of the thirty-nine species none are Australian, and one only European (the wild Boar). The Elephant is limited to Southern Asia, Scythia, the Archipelago, and Central and Southern Africa; the Hippopotamus is exclusively African; the Rhinoceros ranges with the Elephant, or nearly so. The Swine and the Horse (including the Wild Ass and the Zebra) are the most numerous in species of this class, nine species of the former being scattered over Europe and Asia, three (the Wart-hogs) in Africa, and two (Pectaries) being the South American representatives of this family. The Wild Ass frequents the deserts and high plateaux of Asia, and the Zebra is exclusively African. The Pachydermata have been introduced into North America by man. In the southern part of that continent the only indigenous species is the Tapir, which is also found in the Indian Archipelago, and the southern provinces of the Chinese Empire.

811. In what manner do the larger Pachydermatc fulfil the Purposes of Nature in the places they Inhabit?

The Hippopotamus devours an enormous quantity of coarse vegetable matter, much greater than is consumed by any other animal. Its office is to clear the river's of those vegetable remains which, if allowed to accumulate in countries where vegetation is rapid, would choke up all the passages and turn the flat lands into marshes. Neither the Elephant nor the Rhinoceros, coarse as their subsistence may be, could live on the same kind of food as the Hippopotamus.

812. In like manner the Rhinoceros consumes a great amount of rank vegetation in forests, and on the borders 
"Thou shalt be in league with the stones of the field: and the beasts of the field shall be at peace with thee."-Psals xxiii.

of rivers and marshes. When branches or tangled roots offer considerable resistance to these clearing processes, the Rhinoceros uses its horn or horns as a kind of punch or axe to sever the fibre. 'The Hippopotamus makes similar use of its large teeth, and the Elephant occasionally of its tusks. The importance of these operations in clearing forests, rivers, and marshes can scarcely be estimated.

813. Dr. Livingstone, while travelling in Africa, fell in with troops of Elephants, exceeding in number's anything hitherto described, and so tame that he was obliged to

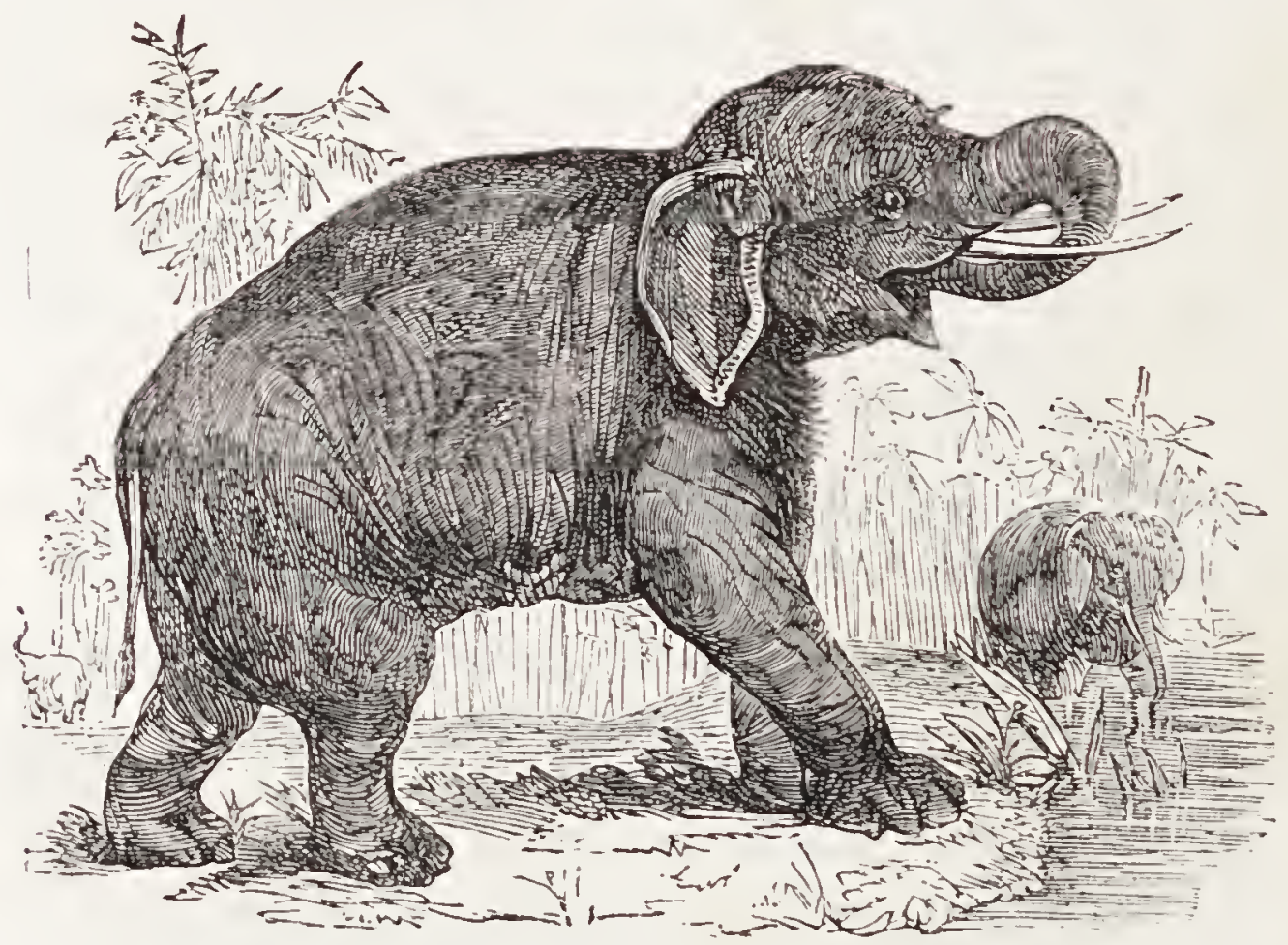

ELEPHANT.

halloo at them to get out of the way; besides Buffaloes, Giraffes, Zebras, Antelopes, Springboks, and wild Hogs in great numbers. Dr. Smith, in latitude $24^{\circ}$, in one day's march with a bullock-waggon, saw, without wandering to any great distance on either side, between fifty and one 
"Mine heritage is unto me as a speckled bird, the birds round about are against her ; come ye, assemble all the beasts of the field, come to derour."-JenemiaH xii.

liundred Rhinoceroses; the same day he saw several herds of Giraffes, amounting together to nearly a hundred. At the distance of a little more than one hour's march from their place of encampment on the previous night, his party actually killed on one spot eight Hippopotamuses, and saw many more. In the river there were likewise Crocodiles.

814. Besides these large animals there are enormous herds of Antelopes, which can be compared only with the flocks of migratory Birds. The numbers, indeed, of the Lion, Panther, and Hyæna, and the multitude of Birds of prey, plainly speak of the abundance of the smaller quadrupeds. One evening seven Lions were counted prowling at the same time round Dr. Smith's encampment. The carnage each day in Southern Africa must be terrific. The African vegetation upon which the herbivorous animals feed, does not exhibit that luxuriance which might be anticipated; the larger quadrupeds no doubt roam over wide districts in search of it. But the vegetation has a rapid growth; no sooner is a part consumed than its place is supplied by a fresh stock.*

815. What are the Adaptations of the Camel to its Geographical Distribution?

By the conformation of the Camel's stomach, he is enabled to subsist for many days without water, and to feed on the dry coarse shrubs he finds on his arid journey; while his feet, admirably adapted to the regions in which he lives, enable him to perform journeys across the burning sands that no other animal could perform without injury or damage.

816. The natural climate of the Camel extends from Mauritania, in Northern Africa, for a zone of 900 miles,

\footnotetext{
* Darwin's "Voyage Round the World."
} 
"The beasts of the field cry unto thee: for the rivers of waters are dried up, and the fire hath devoured the pastures of the wilderness." -JoEI i.

as far as China. 'The Dromedary, or Arabian Camel, has one hunch on its back, four callous protuberances on the fore legs, and two on the hind ones. The Bactrian Camel has two hunches on its back.

817. The hunches are an accumulation of a peculiar species of fat, which is not liable to be acted upon by the great heat

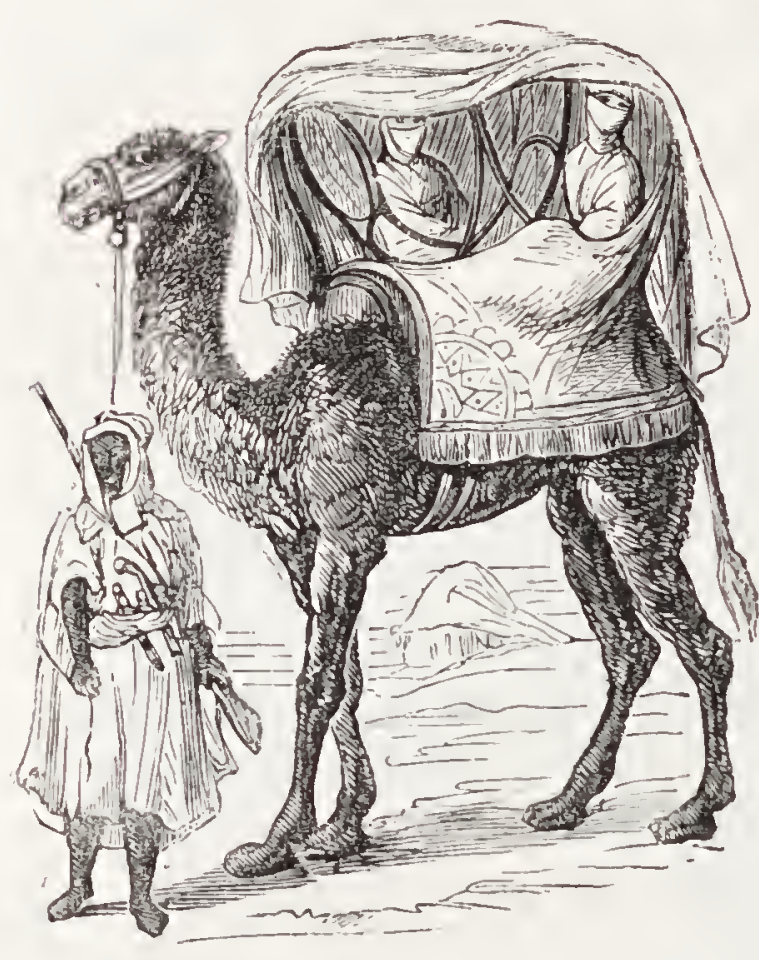

CAMEI CONVEYING ARAB LADIES. to which the animal is exposed. It is, in fact, a store of nourishment, beneficially provided against a day of want, when a supply of food cannot be obtained. 'The Dromedary or Camel can exist for a long period upon their humps alone; and they do not die of starvation until the fat thus accumulated has been entirely consumed.

818. The callosities on their breasts and legs serve as cushions. These animals do not lie on their sides, but rest and sleep with their knees bent under their bodies, and their breasts upon the ground; these parts therefore require to be guarded from the heat of the earth, and also strengthened to resist the weight of the body.

S19. The Camel constitutes the wealth and importance of the Arab, without which he could neither' subsist, carry on his trade, nor travel over sandy deserts. Camel's 
" And he made his camels to kneel down without the city by a well of water at the time of the evening, even the lime that women go out to draw water." Genesis xxiv.

milk is a common food, and the hair is manufactured into cloth, shawls, and mantles; while the skin is used as a covering for tents. In the poetry of the East, the Camel is designated as the "land-ship," or the "ship of the desert."

820. The Camel is, however, not only the carrier in the desert, and the medium for maintaining communication between different countries, but the main requirement of a nomadic mode of life in the patriarchal stage of national development, in the torrid region of our planet, where rain is either wholly or in a great degree absent. No animal's life is so closely associated by natural bonds with a certain primitive stage of the development of the life of man, as that of the Camel among the Bedouin Arabs, nor has any other been established in like manner by a continuous historical evidence of several thousand years.

821. The Llama of the New World is analogous to the Camel of the Old, but smaller in size, being only about four feet four inches ligh in the shoulder, while the Camel is from five to seven; it "is a native of the mountainous districts of South America, but is now being acclimatised, together with the Alpaca, in Australia, to which continent it has recently been introduced, with every prospect of greatly enriching the productiveness of that great

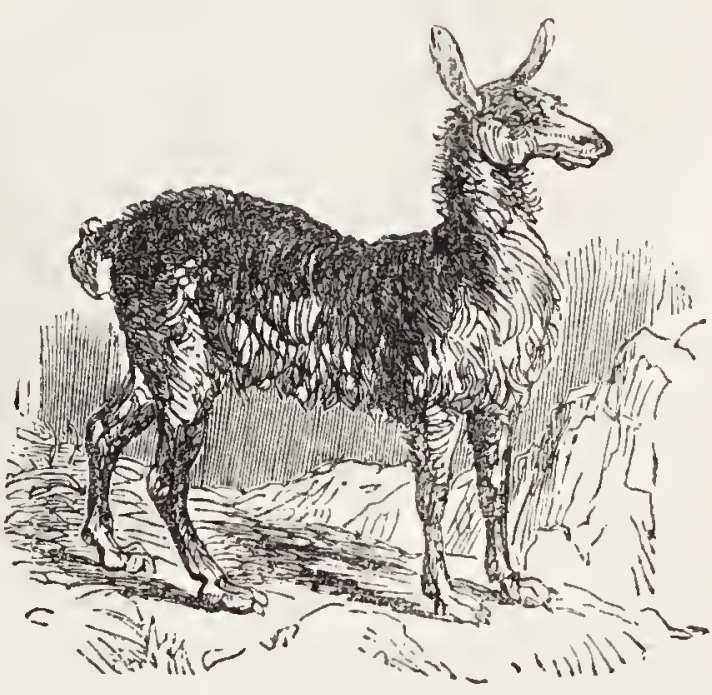

TIIE LLAMA. and growing country. The only ruminating animals except 
"Every beast that parteth the hoof, and cleaveth the cleft into two claws, and cheweth the cud among the beasts."-DEUT. ziv.

the Deer, that existed in South America prior to the conquest, were the four allied species, the Llama, the Alpaca, the Vicuna, and the Guanaco: the first three are exclusively confined to the colder and more elevated regions of the Peruvian Andes; the last has a wider geographical range, extending to the plains of Patagonia and even to the southernmost extremity of the continent.

822. What are the Peculiar Adaptations of the Giraffe?

'The food of the Giraffe is either herbage or the foliage and tender shoots of trees. The admirable formation of the animal allows it either to graze in the open champaign grounds, or reach the succulent tops of trees in the forests. The Giraffe ranges widely over the south of Africa, from the northern banks of the Orange River to the Great Desert; it is found also in Mongola and Abyssinia.

823. The great peculiarities of this animal which adapt it for its native haunts are, its long neck; the height of its fore contrasted with the hind legs, being in front, from hoof to horn, sixteen or twenty feet, while from heel to croup it is seldom more than a third of that height; the small and remarkably beautiful head, embellished with two slender horns, covered with a velvety skin, and surmounted at the top by bristly hair; the large quick eyes, set prominently near the back of the head, to enable it to keep watch while feeding amidst the foliage; and the long prehensile tongue, which gathers the twigs and leaves into bunches, without which the animal could obtain only a limited supply of food.

82 . Of the large amount of vegetable matter which 
"I will make them a forest, and the beasts of the field shall eat them."-Hoses ii.

these and other noble inhabitants of the forests and morasses consume daily, some idea may be formed when

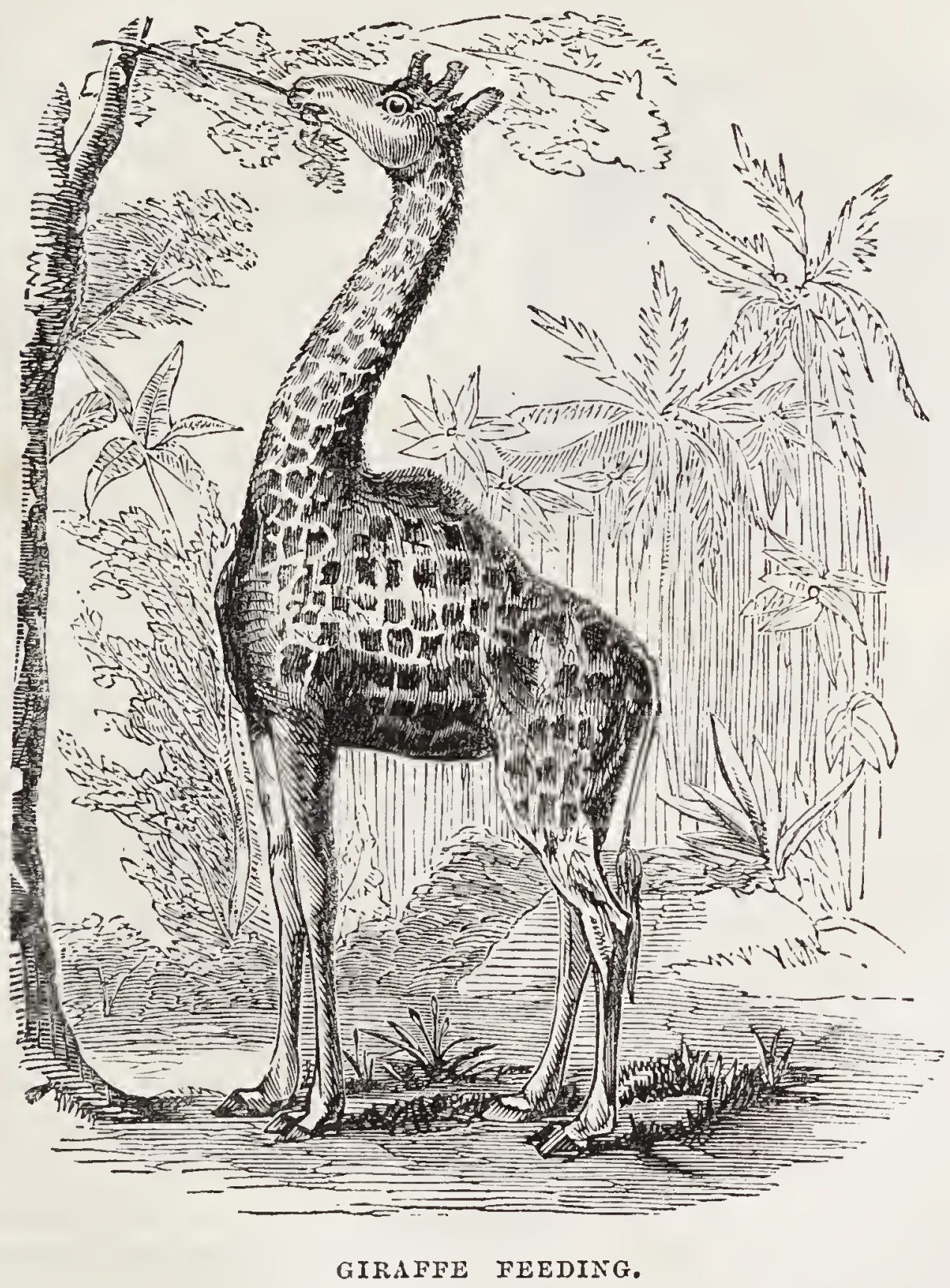

it is stated that a single Giraffe in a state of confinement will consume about forty pounds of mixed vegetables daily. 
"The way of the slothful man is as an hedge of thorns: but the way of the righteous man is made plain."-Proverrs $x \nabla$.

825. What is the Geographical Distribution of the Order Roclentia?

The Rodentia, though not a very numerous class, enjoy

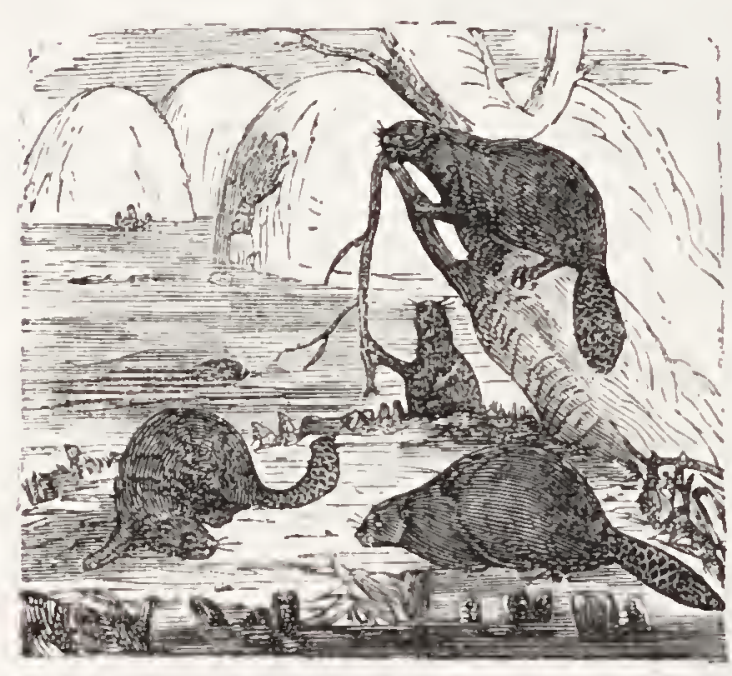

BEAVERS.

a wide distribution. Of the various genera, fortyfour belong exclusively to America, and five exclusively to Australia. Among the most remarkable are the Beavers and the Por. cupines. The Beaver formerly inhabited Britain. Of the Porcupines serentyseren species belong to America, and only six to the Old World. The common Porcupine is a native of Southern Europe. The class includes also the Squirrel, Hare, Rats, and Mice.

826. The Beaver presents one of the strongest instances of instinetive sagaeity and industry whieh ean be met with in the animal creation. It is gregarious, living in soeieties of two and three hundred, whose labours are employed for the general good, and their settlements are made either in ponds so deep as not to allow of their being frozen to the bottom, and whieh have streams of water running through them, or in rivers. Having determined on the place in whiel to ereet their habitations, the first business consists in forming a dan, and for this purpose they stop the stream in the plaee most favourable for their operations.

827. The dam is raised by driving stakes of five or six feet length into the ground at different distanees, interweaving them with branehes of trees, and filling the interstiees with clay, stones, and sand, which they ram down very firmly with their tails. The foundation of the dam is ten or twelve feet thiek; the top is not more than two or three feet broad, presenting a perpendicular faee to the strcam, whilst the slope is plaeed on the outside, where, as grass 
"And he had sheep, and oxen, and he asses, and men scrvants, and maid servants, and she asses, and camels." -GENEsis xii.

grows, the dam is rendered more solid. In this way they build a dam not unfrequently a hundred fect in lengtl.

828. Within the embankment near the edge of the shorc are built the dwellings, which are from ten to twenty-five in number; these are raised upon piles, and sometimes consist of two or thrce stories, for convenience of cliange in case of floods. The liouses are of a round or oval form, with a vaulted roof, the walls about two feet thick, formed of earth, stones, and sticks, but neatly plastered within, and to each are two entrances, one towar'ds the water, and the other facing the land. Their height above the water is about eight feet. In one habitation reside from two to thirty Beaver's, each animal having its own bed of moss, and each family its own winter stock of provisions, consisting of the bark and small branches of trees, which are kept in the water, and fetched within as required.

829. What is the Geographical Distribution of the Order Ruminantia?

Of these there are eight genera, and one hundred and eighty species. The Old World claims two species of Camels, seven Musk Deer, thirty-seven Deer, two Giraffes, forty-seven Antelopes, eighteen Goats, twenty-five Sheep, eighteen Oxen: the New World, three Llamas, fourteen Deer, one Antelope, two Goats, two Sheep, two Oxen.

830. Among Deer, the Rein-deer is by far the most important as an animal of wonderful endurance, speed, and docility-the special gift of Providence, as it would seem, to the inhabitants of the regions bordering on the Arctic Circle. 'The Cameleopard is exclusively African; and of its two species, the one belongs to North, the other to South Africa. The Antelope, also, although represented in Europe by the Chamois, in America by the Springbok, and in Asia by eleven other species, is yet an African animal, both in respect of the number 
"Then Saul took three thousand chosen men out of all Israel, and went to seek David and his men upon the rocks of the wild goats."-SAsruel xxiv.

of the species, and of the countless multitudes of indiriduals which, in their migrations in search of water, are

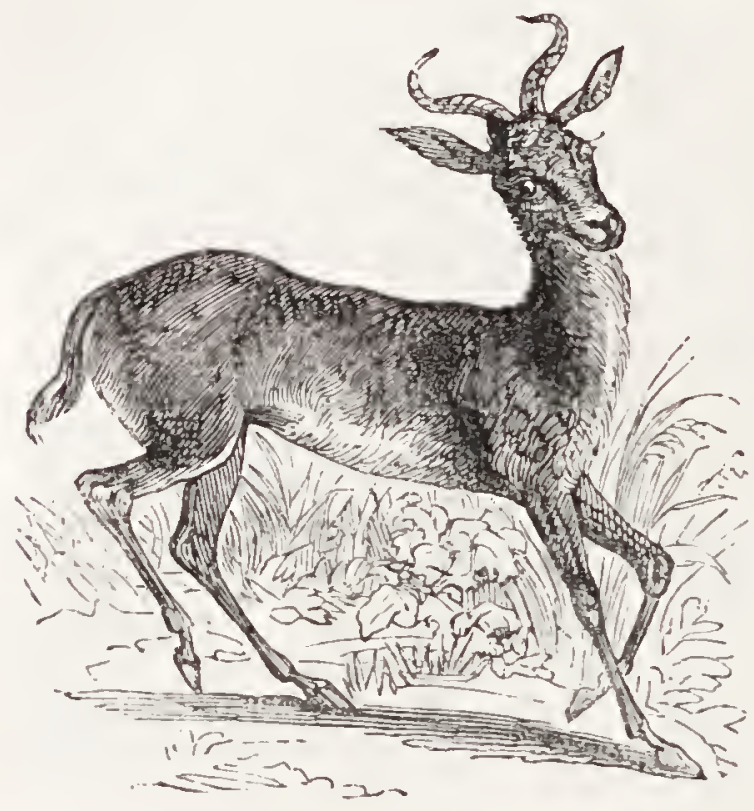

ANTELOPE.

described as covering the whole surface of extensive tracts of country like the waves of the sea.

831. Among Goats, the Ibex firequents the more elevated regions of the Swiss Alps; and the Asiatic species frequent the Taurus Mountains and Kamstchatka. 'The Sheep, domesticated in Europe, would appear to be traceable to Western Asia, where, as well as in Africa, the wild species frequent the more inaccessible mountain districts. Of the two American species, the Argoli of the Rocky Mountains is remarkable for the enormous horns of the ram.

832. Among Oxen, the South African Buffalo is wild and ferocious, and the Indian domesticable. The American Bison exists in immense herds on the nortli-western American prairies. The Must $O x$ is the only considerable $\mathrm{Ru}$ minant in the Arctic regions of America. It inhabits the country about Hudson's Bay, is con-

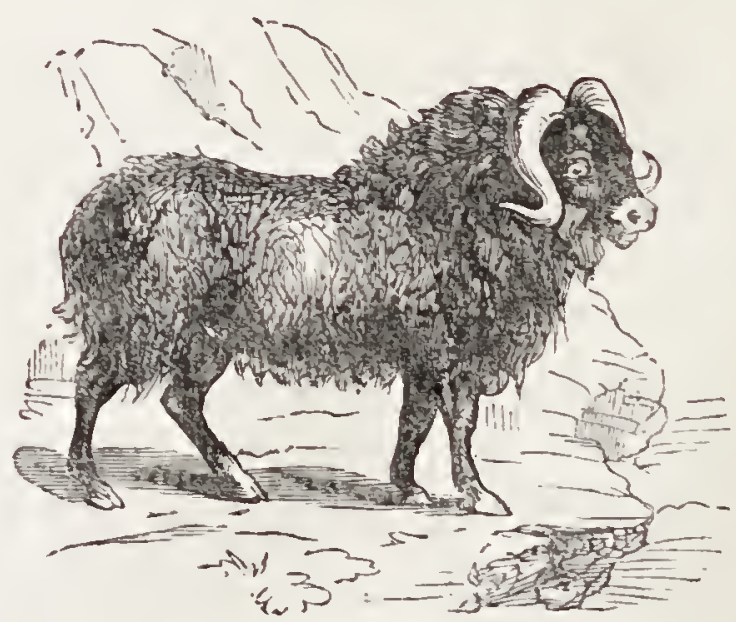

MUSE-OT. siderably smaller than the common Ox; the legs short and 
"Speak to the earth, and it shall teach thee, and the fishes of the sea shall declare unto thee." -JoB ix.

thick, and the hair long, fine, and matted. Australia produces no ruminant animal.

833. What are the Adaptations of the Marine Mammalice to their Geographical Distribution?

The Polar Seas are the habitations of the Marine Mammalia, some of them the largest of living creatures; as their name implies, they suckle their young, and are distinct from fishes through this and other peculiarities. 'They form two distinct families, Whailes and Seals. Seven species of the Seal tribe live in the Arctic Ocean and the North Atlantic;

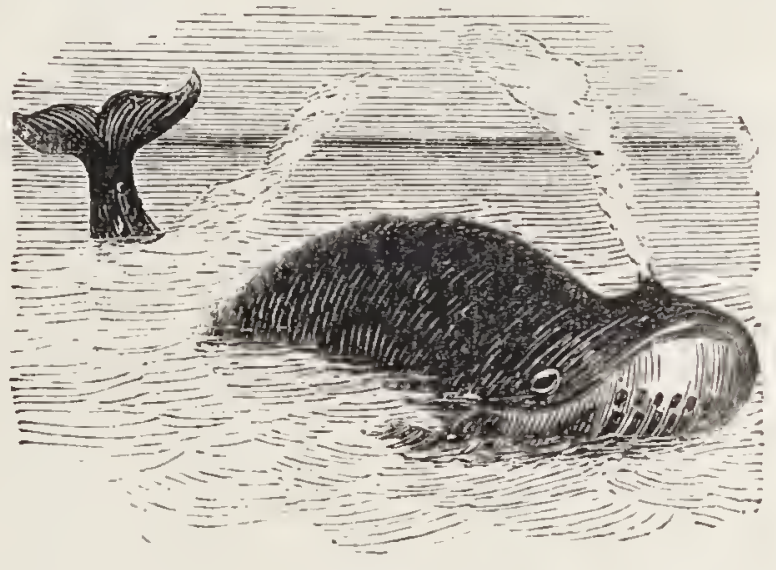

WIIALE. but the Greenland Seal, the Bearded Seal, and the Phoca Lepoina, are also found in the high latitudes of the North Pacific.

834. The order Cetacea includes the Whale, Dugong, Dolphin, Porpoise, \&c. As these animals trarerse the ocean in pursuit of their prey, the limits of their geographical distribution will differ in some degree from that of terrestrial animals, and be determined rather by the seas they inhabit than by the shores they occasionally frequent. Some of the species, which are herbivorous, live within the Tropics, and find ample sustenance in the abundant Algx of the intertropical seas.

835. A remarkable adaptation is found in the Whales, properly so called, which have no teeth, but are furnished with lamince of bone, inserted in the upper jau, the extreme 
"Even the sea monsters draw out the breast, they give suck to their young ones; the daughter of my people is become crue!, like the ostriches in the wilderness." - Lajientations, iv.

filments of which act as a lind of net to catch the small marine animals, which form their principal food, and to the abundance of which we have already alluded. The Greenland Whale is the largest animal known to inhabit the water of this or former ages of the earth. When fully developed, it is from fifty to seventy feet in length, and from thirty to forty in circumference.

836. The bones of the upper jaw in this huge species are composed of a kind of fibrous horn, which supplies mankind with what is called whalebone, fringed with filaments at the edges, which serve to retain the worms, mollusca, and small sea insects on which these monster's feed, their organs not being fitted to swallow that kind of food which we might suppose to be proportioned to their bulk. The lower jaw, which is deroid both of teeth and the horny lamina, lodges a very thick and fleshy tongue, and, when closed, embraces the internal part of the upper jaw, so as to make a lind of rim for the strainer which the filaments form. The water ejected though the "blowers" of Whales is first passed through this strainer, and yields myriads of small creatures to the support of these monster's of the deep. When open, a Whale's month (of the largest size) is capable of receiving a ship's jolly-boat with her crew between the jaws!

837. The Walrus exhibits a different but an equally striking adaptation. It is endowed with large tusks, which enable the animal to mow down or to turn aside the great fields of sea-weed among which it finds crustaccous and molluscous animals, such as Lobsters, Crabs, Whelks, \&c. These tusks are also useful to enable the animal to lift its cumbrous and heavy body over the blocks of ice 
"IVhoso is wise, and will observe these things, even they shall understand the loving kindness of the Lord." -Psam cvii.

among which it lives. This it accomplishes by fuxing its tusks in the ice, using them as a lever. They cnable the animal to raise itself out of the water, by holding on upon a rock or iceberg, just as the Parrot steadies himself by his bill.

838. Seals are found in greatest numbers in estuaries and straits, because the fishes upon which they feed congregate in the currents of these narrow places. The nostrils of

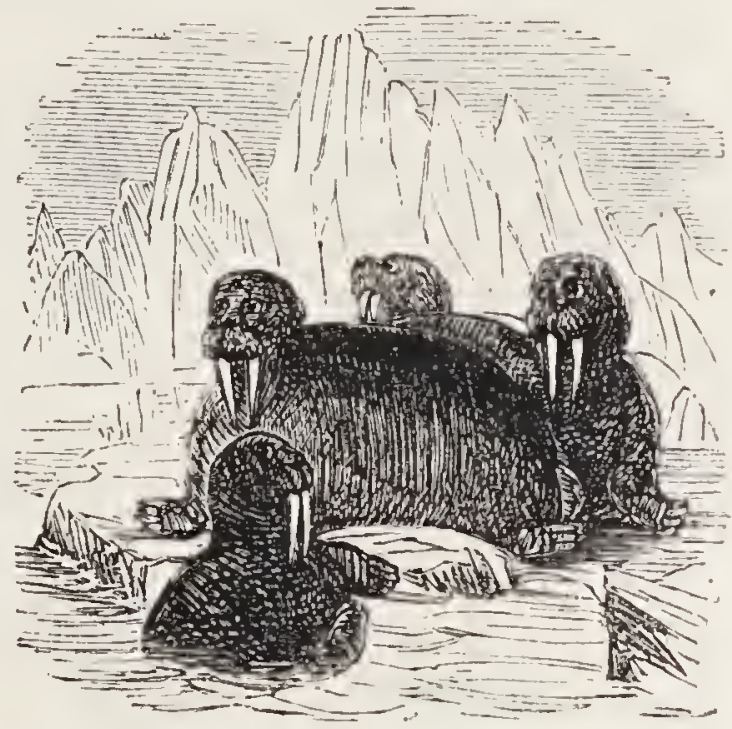

GROUP OF WALRUSES.

Seals are surrounded with long bristly hair's, which are instruments of touch, just as the whiskers of the Cat. These instruments are exceedingly useful in exploring the crevices and irregular surfaces of icebergs beneath the water, where fishes take shelter and conceal.

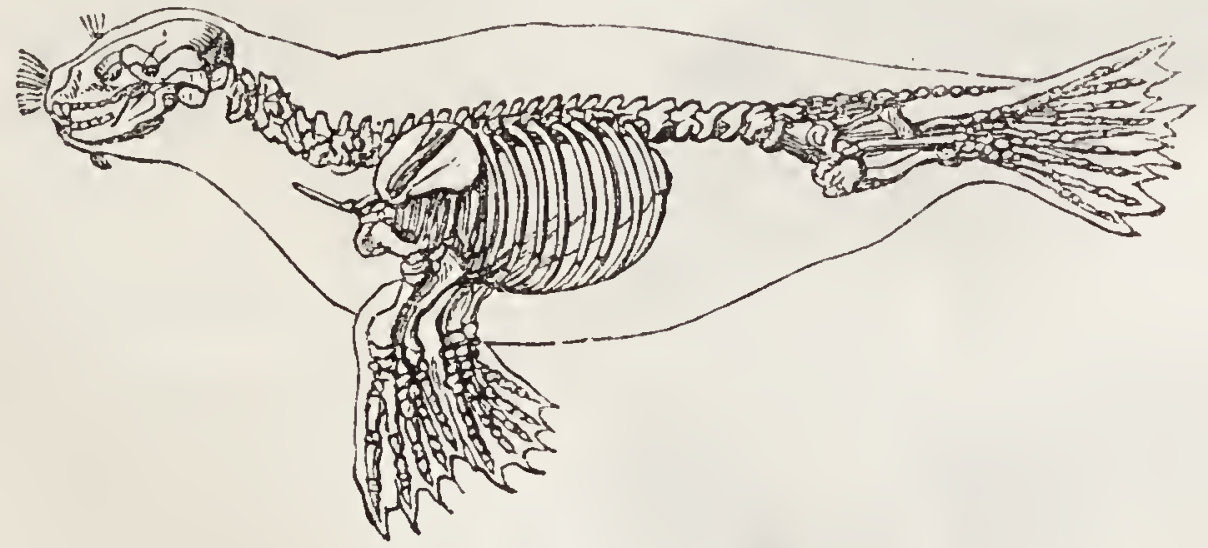

ANATOMY OF THE SEAL.

themselves. The nostrils of Seals are capable of being closed or opened at the will of the animal, by which it is cnabled to licep beneath the water for a considerable 
"There shall the great owl make her nest, lay, and hatch, and gather under her shadow; there shall the vultures also ve gathered, every one with his mate." -Isalall xxxiv.

period; and their eyes are peculiarly constructed, so as to adapt themselves to the functions of vision either in water or in air.

839. What is the Geograplical Distribution of Birds?

Although, from their powers of flight, birds might be expected to be little influeneed by geographical limitations, it will be found that they, like quadrupeds and plants, are subject to definite geographical lmits, circumscribing particular groups. The common grouse of Britain affords a striking example of this arrangement, as it is nowhere met with out of this kingdom; and other instances occur of a very scanty area containing a species not to be found in any other region.

840. The celebrated Birds of Paradise are exclusively confined to a small part of the Torrid Zone, embracing

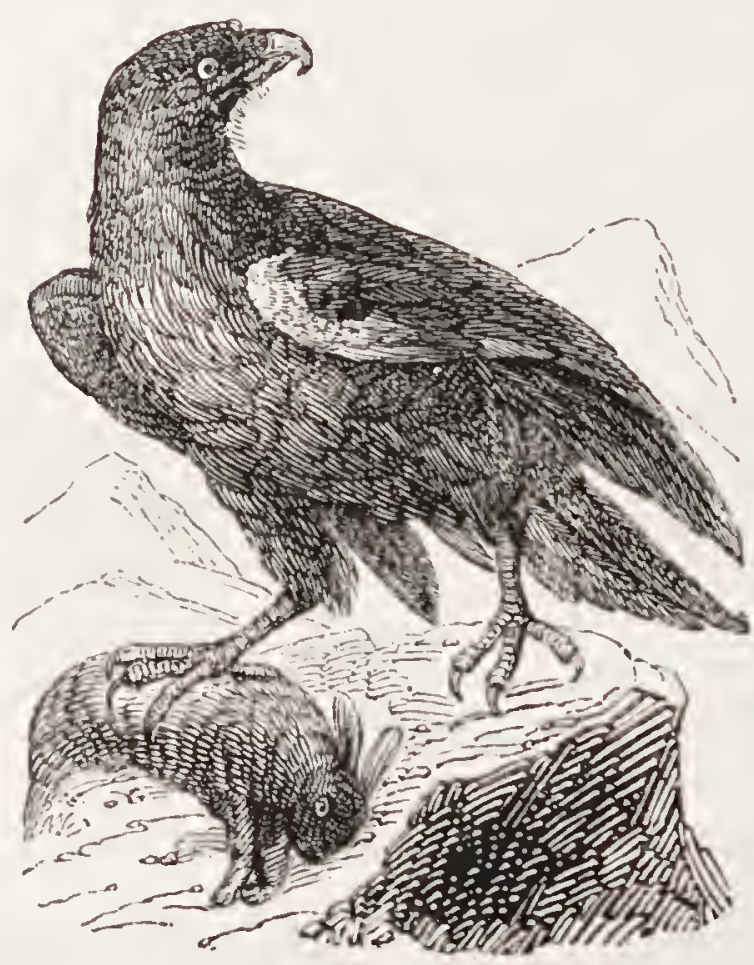

THE GREAT EAGLE. New Guinea and the contiguous islands; and the berutiful Lories are inhabitants of the same districts, being quite unknown to the New World. Parroquets are chiefly occupants of a zone extending a few degrees beyoud each 'Tropic; but the American group is quite distinct from the African, and neither of these has one in common with the Parrots of India.

841. The Great Eagle is limited to the highest summits of the Alps; and the 
"The fores have holes, and the birds of the air have nests, but the Son of Man hath not where to lay His head."-Matruew viii.

Condor, which soars above the Peak of the loftiest of the Andes, never quits that chain. The Imperial Eagle is a native of the highest mountains of Central Europe; the Golden Eagle is a native of Europe and North America ; the Bald Eagle is common to both continents of America, inhabiting the shores of the ocean, and the beetling cliffs of lakes and rivers.

842. Humming Birds are entirely limited to the Western Hemisphere, where a particular species is sometimes bounded by the range of an island, while others are more extensively spread. These birds include an immense number of species, upwards of two hundred of which have been distinguished into genera by modern ornithologists. They swarm in the Tropical regions of America, in the great archipelago lying between Florida and the mouth of the Orinoco, and on the mainland of

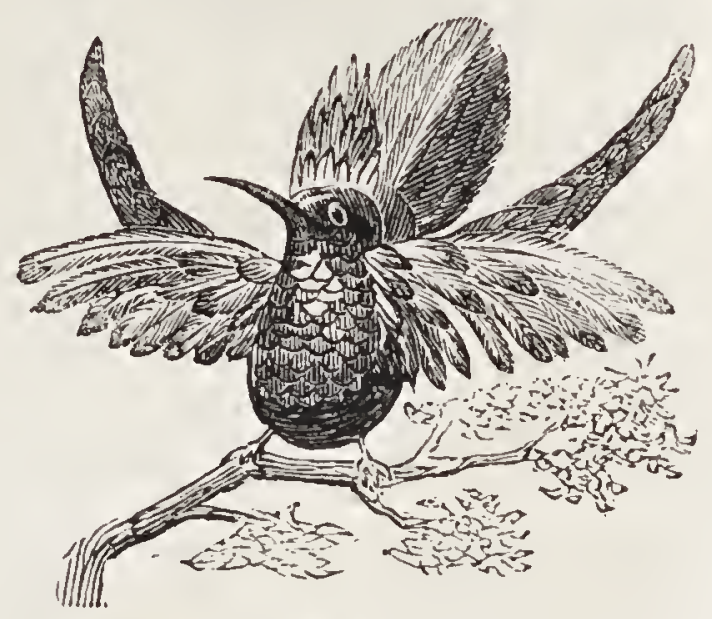

HUMING BIRD. the Southern continent of America, till it passes the Tropic of Capricorn, only two species extending far into the nortliern continent.

843. Among the birds incapable of flight, which rival quadrupeds in their size, the intertropical countries of the globe have their distinct species, presenting similar general features of organisation, as the Ostrich of Africa and Arabia, the Cassowary of Java and Australia, and the Toyou of Brazil.

844. In the Arctic regions we meet with species peculiar 
"Deliver thyself as a roe from the liand of the hunter, and as a bird from the hand of the fowler."-Proveriss.

to them, such as the Lapland Owl, and the Eider Duck, from whose nests eider-down is obtained. Several fumilies of

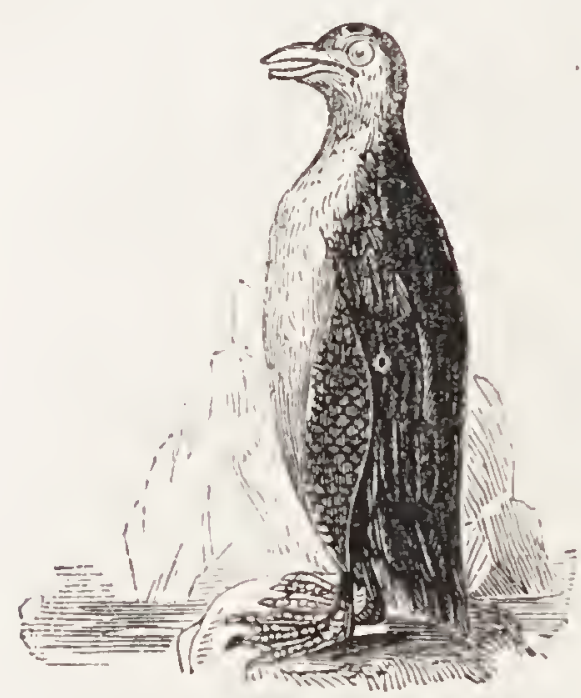

ALBATROSS. maritime birds are likewise limited to particular ocennic localities. Approaching the forticth parallel of latitude, the Albatross is scen floating upon the surface of the wares, and soon afterwards the Frigate and other' 'Tropical Birds, which never wander far beyond the Torrid Zone.

845. Aggregation into immense flocks is a distinguishing feature of several species, especially of the aquatic order, which form separate colonies, building their nests in the same state, though other spots equally adapted are at no. great distance. Hence the Vogel-bergs of the northern seas, one of which, at Westmannsharn, in the Faroe group, seldom iutruded upon by man, presents a most extraordinary spectacle to the risitor. Thousands of Guillemots and Auks swim in groups around the boat which conveys man to their domain, look curiously at him, and vanish beneath the water to rise in his immediate neighbourhood. The Black Guillemot comes close to the very oars. The Seal stretches his head above the wares, not comprehending what has disturbed the repose of his asylum, while the rapacious Skua pursues the Puffin and the Gull.

846. High in the air the birds seem like bees clustering about the rocks, whilst lower they fly past so close that they might be knocked down with a stick. On some low rocks, scarcely projecting above the water, sit the gloomy 
"If a bird's nest chance to be before thee in the way in any tree, or on the ground, whether they be young ones or eggs, and the dam sitting upon the young, or mpon the eggs, thou shalt not take the dam with the young." -DEuT. xxit.

Cormorants, turning their necks on evely side. Next are the Skua Gulls, regarded with an anxious eye by the Kittiwakes above. Nest follows nest in crowded rows along the whole breadth of the rock, and nothing is visible but the heads of the mothers, and the white rocks between. A little higher on the narrow shelves sit the Guillemots and Auks, arranged as on parade, with their white breasts to the sea, and so close that a hailstone could not pass between them.

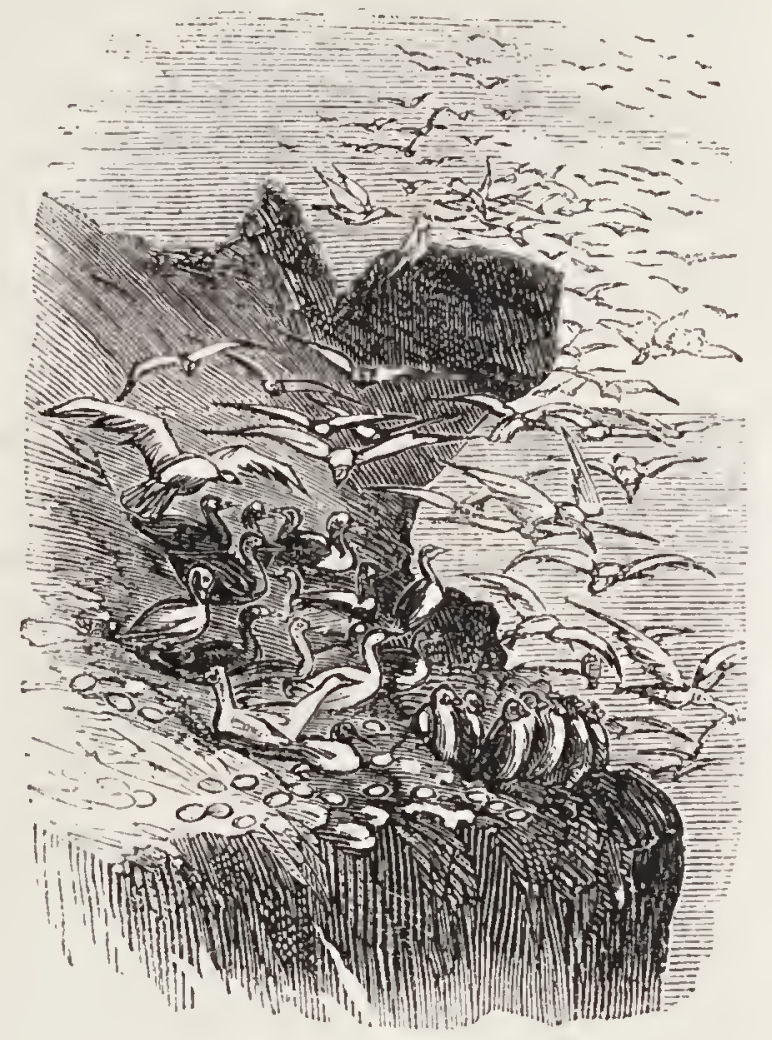

VOGEL-BERG, OR IIRD ROCK. The noise of the multitude of birds is confounding.

847. An uninhabited island exhibits some remarkable features, especially with regard to the tameness of animals that are stranger's to man. The following description is by Capt. Wilkes, of the United States Navy:- "The landing on a coral island effectually does away with all preconceived notions of its beauty. That verdure which seemed from a distant view to carpet the whole island, was in reality but a few patches of wiry grass, obstructing the walking, and offering neither fruit nor flowers to the view; it grew among the rugged coral débris, with a little sand and regetable earth. It is somewhat surprising that trees forty or fifty feet high should have found sufficient soil to protect their growth.

848. "The number of birds on the island was incredible, and they are so tame as to require to be pushed off their nests to get their eggs. The most conspicuous among them was the Frigate bird; many of the 
"Where the birds make their nests, as for the stork, the fir-trces are her home."-Psalar civ.

trees were covered with their nests, constructed of a few sticks. The old birds were seen, as they flew off, inflating their bloor-red pouches to the size of a child's head, and looking as if a large bladder were attached to their necks. The Gannets, Sooty-terns, and the beautifui Tropic-bird were in countless numbers, the former guarding their eggss (which were laid on the ground without nests) with care, remaining by them, and eren suffering themselres to be captured without resistance. 'Their hoarse croaking was quite deafening.

849. "Some àroll sights were seen of Crabs walking off with Snakes, and both again seized by some stout bird and borne away. Armies of soldier or Piratical Crabs were seen moving in all directions with their shells. We found no use for our guns, powcer, and shot; as many specimens as we could desire were taken with the hand, both old and young. In some cases the Tropic-birds were taken off their nests, and from others their eggs mere taken without disturbing them. Indeed, I have never scen any barn-yard fowls half so tame.

850. "The rarious Snakes, the many-coloured Fish, the great Eels, enormous and roracious Sharks, shells, large Molluses, curious Lepidoptera, and Spiders seemed to have quiet possession, their webs stretching in every direction, and occasioning us much annorance. Ali gave a novelty to the scene that highly interested and delighted us."

851. Why are Reptiles confined to very narrow Geosiraplical limits?

One reason, at least, may be found in the fact that they are confined to limited geographical regions by the imperfection or total want of organs of locomotion. Another reason may be found in creative design: if creatures like the Boa and the Rattle-suake could spread themselves from the hot to the temperate latitudes, and diffuse themselves generally orer the earth, they would prove serious pests, and formidable enemies to a great number of useful races.

852. The range of the large reptiles is, in general, quite as limited as that of some orders of the terrestrial mammalia. The great Saurians sometimes cross a considerable 
"The flowers appear on the earth; the time of the singing of birds is come, and the voice of the turtle is heard in our land." - Soc. Soxg, ii.

tract, in order to pass from one river to another; but their motions by land are generally slower than those of quadrupeds. By water, howerer, they may transport themselves to distant situations more easily. The large Alligator of the Ganges sometimes descends beyond the brackish water of the delta into the sea; and in such cases it might chance to be drifted away by a current, and survive till it reaclied a shore at some distance.

853. Turtles migrate in large droves from one part of the ocean to another, during the ovipositing season, and they find their way annually to the island of Ascension, from which the nearest land is 800 miles distant. Some of the smaller reptiles lay their eggs on aquatic plants; and these must be often borne by rivers, and conveyed to distant regions in a manner similar to the dispersion of seeds. A noble specimen of the Boa Constrictor was conreyed to the island of St. Vincent about the year 1827. It was transported round the trunk of a large cedar tree, which had probably been washed out of the bank by the floods of some great South American river, while its huge folds lnung on the branches, as it waited for its prey.

\section{What is the Geographical Distribution of Fishes?}

We are less acquainted with the habitations of marine animals, and their geographical limits, than with the srouping of the terrestrial species. There appears, however, a remarliable distinctness of character between the inhabitants of the secis, on the north and the south of the Equator.

855. The only fresh-water fish that is common to both Europe and North America is the Pike, but it is curious that this fish is unknown to the westward of the Rocky Mountains, the very coast which approaches nearest to 
"Master, we have toiled all night long, and have taken notling; nerertheless, at thy word, we will let down the net. And when they had clone this, they enclosed a great multitude of fishes, and the net brake."-LCkE r.

the old Continent. Fresh-water fish in China agree closely with those of the peninsula of India, but the species are not the same.

856. In the distribution of marine fish, the interposition of a Continent, stretching from the Tropics far into the temperate or colder parts of the ocean, separates different groups of marine families; so with respect to fiesh-water species, the intrusion of arms of the sea rumning far to the northwards, or the interposition of a lofty mountain-chain, effects the same thing. The freshwater fish of the Cape of Good Hope, and the South American ones, differ from those of India and China.

857. Why are Fishes admirably adapted to their appointed. part in Nature?

The peculiar formation of their bodies is well suited to the element in which they are appointed to live; and the swiftness of their motions, to the widle and almost boundless range uhich they cnjoy. 'The elongated oval forms of their bodies fatcilitate their motion in

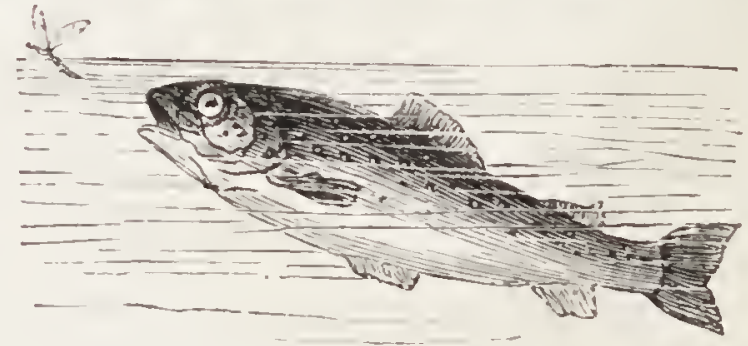
their natural element; and many of them are provided with air-bludder's, by increasing or reducing the air in which, they facilitate their rising or sinking in the water.

S5S. By the migrations of fish, an abundant supply of wholesome food is periodically bestowed upon the inhabitants of shores remote from each other.

859. The uses of fish are of vast importance. Of all the classes of animals, there is not one which affords so great a number of species useful as food to man. The supply in the seas around Great Britain 
"We remember the fish, which we did eat in Egypt freely; the cucumbers, and the melons, and the lecks, and the onions, and the garlick."-Nurbers xi.

may be said to be inexhaustible. A very considerable portion of our coast population are more or less engaged in fisheries, and the shores are indented with bays and harbour's whicl facilitate their employment, and render it an important branch of national industry. The River fisheries, also, of Great Britain are of considerable extent, particularly those of the Salmon, both in Scotland and Ireland, from which immense revenues are derived. The value of the entire annual produce of the foreign and domestic fisheries of Great Britain is estimated at between five and six millions sterling.

860. Besides its use as an article of food, fish is also cxtensively employcl as a manure, certain properties in the bones and flesh being conducive to vegetation. The kinds of fish employed are numerous. Those most eommonly employed are Sprats, Sticklebacks, the refuse of Pilchards, Herrings, Whale-blubber, and shell-fish. Sprats are used very extensively in Essex, Kent, and Sussex. Upon the hopgrounds adjoining the Medway from sixty to a hundred bushels per acre are usually applied. For ordinary grain erops, Sprats are used at the rate of from twenty to thirty bushels per acre, and are sown by hand upon the fallows, before the seed is deposited. They are also admirably adapted for compost with earth, in which state they form a eapital dressing for turnips and green crops. Sticklebacks are prineipally used in the fens of Lincolnshire and Cambridge, where they are found in large quantities.

861. The refuse of Pilehards is rery generally used as a manure. From eight to ten thousand persons on the south coast are usually employed at sea and on shore in this trade. Whale-blubber, mixed with earth, is found to answer extremely well upon arable and pasture land, producing most luxuriant erops, and leaving its good effects for two or three years. Shell-fish are found to prove an excellent manure; especially some of the species which excel in phosphates, and are therefore of more permament influence than other sorts of fish. Thus we find that the constantly aceuriulating treasures of the sea enrich and beautify the land.

862. How do Fish first find their way to Newlyformed Lakes and Ponds?

Wild geese, ducks, and other birds subsist in their 
"And he said unto them, Cast the net on the right side of the ship. and ye shall find. They cast, therefore, and now they were not able to draw it for the multitude of fishes."-Juis xxi.

migrations on the spawn of fish; and it sometimes happens that when, two or three days afterwards, they void tlie spawn, some of the eggs retain their vitality unimpaired.

863. The minute eggs of fish sometimes become entangled in the feuthers of water-fowl. These eggs, when the birds alight to refresh and wash themselves in the water, may, often contribute to propagate swarms of fish, which, in due season, will again supply the birds with fool.

864. Some large Water-beetles, also, are amphibious, and in the evenings quit their lakes and pools, and, flying in the air, transport the minute ora of fishes to distant water's. In this manner some naturalists account for the fry of fish appearing occasionally in small pools caused by leary rains.

S65. We have ourselves seen a small fish in a little pool of water, the bed of which was merely the deep foot-print of a horse's hoof. Wondering how it came there, we examined the country, and at a little distance found a large pond, at which horses went down to drink. The spawn of a fish had doubtless been transported by the hor'se's loof to the place where we found it, a fall of rain supplying the necessary conditions to its levelopment.

866. Among the Fishes, Sponges, Mednsie, sce., of the northern and southern seas, there appear to be essential eharacters of distinetion between the analogous speeies. On eomparing, also, the fresh-water fish of Europe and North America, it is found that the only speeies whieh is mequivocally common to the two Continents, is the Pike; and it is eurions that this fish is unlinown to the westward of the Roeky Momtains, the very eoast whieh approaches nearest to the old Continent. The gencra of fresh-water fish in Clina agree elosely with those of the peninsula of India, but the speeies are not the sime. As in the distribution of marine fish, the interposition of a continent, stretehing from the tropics far into the temperate or colder parts of the oecan, 
"l'he fishes of the sea, and the fowls of hearen, and the beasts of the field, and all creeping things, that creep upon the earth, and all the men that are upon the face of the earth, shall shake at my presence."-EzEkıL xixviii.

separates different groups, so, with respect to the fresh-water species, the intrusion of arms of the sea, ruming far to the nortliwards, or tle interposition of a lofty mountain chain, effects the same thing.

867. Why do Archipelagoes and Coral Islands favour the Migrations of Fish?

Because the shores of the islands supply the fish with their appropriate yood, and afford places for the deposit of spawn.

868. The migrations of the Salmon, Herring, \&xc., are analogous to the periodical flights of birds. The Salmon, towards the season of spawning, ascends rivers for hundreds of miles, leaping up the cataracts which it meets in its course, and then retreats to the deptlis of the ocean.

869. The Herring and the Haddock, after frequenting certain shores, in vast shoals, for a series of years, desert them again, and resort to other stations, followed by the species which prey on them. Eels are said to descend into the sea for the purpose of producing their young, which return into the fresh water in myriads, extremely small in size, but possessing the power of surmounting every obstacle which occurs in the course of a river, by applying their slimy and glutinous bodies to the surface of rocks, or the gates of a lock, even when dry, and so climbing over it.

870. The Herring is essentially a northern fish, seldom found so far south as the Bay of Biscay in Emrope, or the const of Carolina in America. Like plants that, flourishing in certain climates only, become fewer and more stunted the nearer they approach the limits of their zone, Herrings decrease in number and size as they approach their assigned southern boundary-those caught on the southern shores of England being considerably smaller than those which frequent the coast of Norway. About the mouth of July the grand array of Herrings is found northward of the Sletland Islands, in distinct columns five and six miles long, and three or four miles broad. Pressing inward to the shailows, they drive the sea before them in a continuous ripple. 
"I will have thee thrown into the wilderness, thee and all the fish of thy rivers: thou shalt fall upon the open fields; thou shalt not be brought together nor gathered. I have given thee for meat to the beasts of the field."-EzEkIEL xxix.

Sornetimes they sink down fathoms deep for a few minutcs, then again rising to the surfacc, they sparkle in the sum, like diamonds. During the calm summcr night the scenc is indeseribably brilliant, from the intense scintillations of phosphorie light exhibited by the countless myriads of moving fish. The number of living creatures in these shoals mould be eompletely beyond belief, if we did not know that the spawn of a single herring has been found to eontain 36,000 eggs.*

\section{Why do certain Fishes Migrate in large Shoals?}

Because large numbers of them are acted upon by the same necessity at the same time; they therefore move together by a common impulse, to fulfil a general purpose. All fishes that are known to swim in shoals are solitary, except when the necessity for spawning approaches, and then the prevailing need brings them together in large numbers.

872. It was at one time believed that Herrings migrated from the Northern Seas towards the South. But this opinion is now abandoned. They inhabit deep waters, and when the spawning season approaches, they resort in immense shoals to the shores of bays and estuaries. They spawn once a year about the period of the autumnal equinox; but they are somewhat capricious in their norements, occasionally shifting their spawning places. The principal fisheries are off the Scottish and Norfolk coasts.

873. Pilchards abound in the Mediterranean, but, like the Herring, are migratory. The chief Pilchard fisheries are along the coast of Dalmatia, in the Gulf of Venice; on the coast of France, between Belle Isle and Brest; and along the shores of Devonshire and Cornwall. It is a saying of the Cornishmen, that the Pilchard is the smallest fish in size, yet the most numerous and the most profitable of any they take ont of the sea. The number obtained from 
"And it shall come to pass, that the fishers shall stand upon it from Engedi even unto En-eglaim; they shall be a place to spread forth nets; their fish shall be according to their kinds, as the fish of the great sea, exceeding many."-EzER IEI xlvii.

the nets at one shooting is amazingly great. A few years ago there were at one time enclosed in St. Ives Bay 15,000 hogsheads of fish, which realised the enormous sum of over $£ 30,000$, liaving sold at about 45 s. per hogshead-a fact which we ascertained afterwards at St. Ives, while in conversation with one of the seine-owners.

874. The money paid annually, on an average of ten years, for Pilchards exported from Cornwall, amounted to $£ 49,533$ 10s. Upwards of 30,000 hogsheads are anmually consumed in England, and more than 100,000 have beeu exported in one year.

875. Why do the hatits of Fishes, and other Marine Animals, assist the Study of the Physical Geography of the Sea?

Because marine animals, to a great extent, follow those currents of the ocean the temperature of which is congenial to their habits. Whales first pointed out the existence of the Gulf Stream by avoiding its warm waters. Along the coasts of cold or temperate climates, all those delicate animals and marine productions which delight in warmer waters are wanting; thus indicating by their absence the cold currents from the north.

876. In the genial warmth of the sea about the Bermudas on one hand, and Africa on the other, we find in great abundance those delicate shell-fish and coral formations which are altogether wanting in the same latitudes along the shores of South Carolina. 'The same obtains in the west coast of South America, for there the cold current almost reaches the Line before the first sprig of coral is found.

877. The Sperm Whale is a warm water fish. The "Right" Whale delights in cold water. An immense number of log-books of whale ships have been examined, with the view of detecting the parts of the ocean in which the Whales are to be found at different seasons of the 
"And I said, Oh that I lad wings like a dore! for then would I fly away, and be at rest. So, then would I wander far off, and remain in the wilderness."-PsaLy iv.

year. In the course of these investigations, the discovery was made that the torrid zone is to the Right Whale of the Northern Hemispliere as a sea of fire, through which he camnot pass, and into which he nevel. enters. The faet was also brought to light that the Right Whale of the Northern Hemisphere, and that of the Southern, are two different animals; and that the Sperm Whale has never been known to double the Cape of Good Hope: he doubles Cape Horn.

878. A few years agro, great numbers of Bonita and Albereoretropical fish-following the Gulf Stream, entered the English Channel, and alarmed the fishermen of Cornwall and Devonshire by the havoc which they ereated among the Pilchards. Certain kinds of fish, much esteemed in Virginia and the Carolinas, when taken on the narm coral banks of the Bahamas lose their flarour, and are held in no esteem. A current of cold water from the soutl sweeps the shores of Chili, Perrt, and Columbia, and reaches the Gallipagos Islands under the line. Thronghout this whole distanee the world does not afford a more excellent supply of fish. Yet out in the Paeifie, at the Soeiety Islands, where eoral abounds, and the water preserves a higher temperature, the fish, though they vie in gorgeousness of eolouring witl the birds, plants, and inseets of the tropies, are held in no esteem as an article of food. Sailor's, even after long royages, prefer their salt beef and pork to a meal of fish taken there.

879. The few ficts which we liave bearing upon this subject, seem to suggest as a point of the inquiry to be made, whether the liabitation of eertain fish does not indicate the temperature of the rater; and whether the eold and warm currents of the oeean do not constitute the great high-ways through which migratory fishes travel from one region to another. Why should not fish be as much the creatures of climate as plants, or as birds, or other animals of land, sen, or air? Indeed, we know that some kinds of fish are only fomd in certain climates. In other words, they live where the temperature of the water ranges between certain degrees.*

880. How do Changes in Physical Geography affect the Distribution of Animals?

The numbers and distribution of species are affected in two ways by changes in the physical geography of the earth. First, these changes promote or retard the migration 
"As soon as they were eome to land, they saw a fire of eoals there, and fish linid thereon, and bread. Jesus saith unto them, Bring of the fish which ye have now cuught."-Jons xxi.

of species; secondly, they alter the physical conditions of the localities which species inhabit.

881. If the ocean should gradually wear its way through an isthmus, like that of Suez, it would open a passage for the intermixture of the aquatic tribes of two seas previously disjoined, and would, at the same time, close a free communication which the terrestrial plants and animals of the two continents had before enjoyed.

882. These would be, perhaps, the most important consequences, in regard to the distribution of species, which would result from the breach made by the sea in such a spot; but there would be others of a distinct nature, such as the conversion of a certain tract of land, which formed the isthmus, into sea. 'This space, previously occupied by terrestrial plants and animals, would be immediately delivered over to the aquatic; a local revolution which might have happened in innumerable other parts of the globe, without being attended by any alteration in the blending together of species of two distinct regions.

883. What is the Geographical Distribution of Reptiles?

Of the great Lizaids, those which inhabit the Granges differ from those of America or the Nile. The Monitor' of New IIolland is specifically distinct from the Indian species, and these latter differ from the African, and all their congeners in the Nery World.

884. So in regard to Snalies: we find the Boa of America represented by the Python, a different though nearly allied genus, in India. America is the country of the Rattlesnakes; Africa of the Cerastes; and Asia of the Hooded Snake, or Cobra di Capello.*

885. With very few exceptions, all reptiles are ovipa- 
"Look not thou upon the wine when it is red, when it giveth his colour in the cup, when it moveth itself aright. At the last it viteth like a serpent, and stingeth like an adder."-Proverss xiii.

rous, or produce their young from eggs; they partake of both terrestrial and aquatic forms, and many are amphibious; they all increase in numbers towards the Equator, and few live in the colder latitudes. The number of species of Reptiles in the Torrid Zone is at least double that in the Temperate; Australia has ferer than Europe; and of all places in the whole world Java is perhaps richest in animals of this orler. America possesses more than half of all the species known, the maximum being in Brazil, but every one of them is peculiar to the New Continen.

886. Why are Serpents Confined to very Norrow Geographical Limits?

'Their appointed position appears to be, like that of the monkeys, to reep in chect the number of birds and vermin,

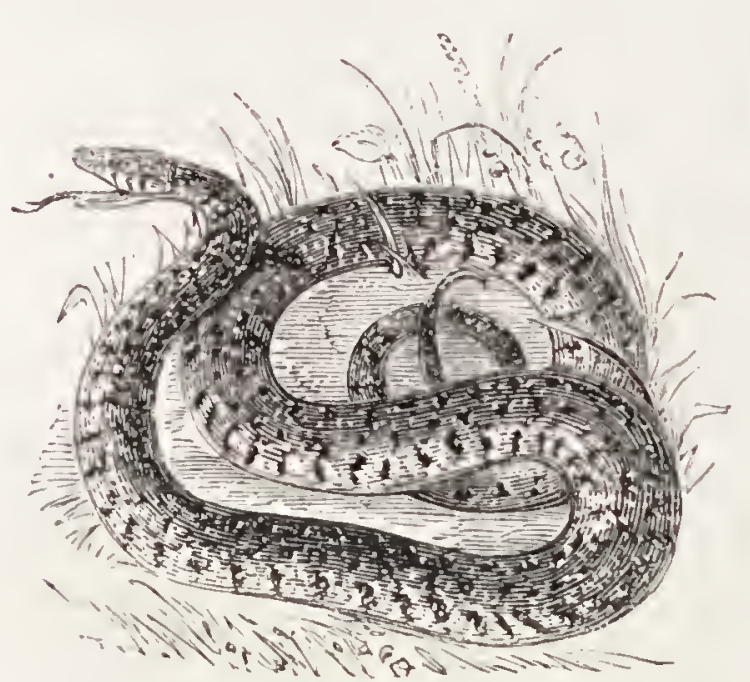

SER PENT. and for this reason they are confined chiefly to tropical countries. Their restriction within narrow limits is provided for by their deprivation of locomotive organs. If creatures like the Bon and the Rattlesnake could spread themselves from the hot to the temperate latitudes, and diffuse themselves generaily, they would prove serious pests and formiclable enemies to the more useful animals.

887. The Bucephalus viritis climbs trees in search of birds' eggs, and is soon discorered by all the birds in the neighbourhood collecting and sounding an alarm. The fings of this species are not so much formed for injecting 
"Behoid I give unto you power to tread on scrpents and scorpions, and over" all the power of the enemy; and nothing shall by any means lurt you."-Luke xx.

poison on external objects, as for preventing the escape of any animal or bird of which they have got hold.

888. The Dasypeltis inoratus has small teeth, which allow the passage of thin-shelled eggs without breaking, till within the gullet, or about two inches behind the head. There they come in contact with the gular teeth, which crack the shells without the contents being spilled, as would happen if the front teeth were large.

889. Whereever Mice abound in Africa, Serpents may be expected, for the latter prey upon the former. These reptiles excite none of that loathing which we experience when sitting reading about them in England. Even the most venomous sorts bite only when put in bodily fear, or when trodden upon.

850. Some of the Scrpents are particularly venomous. One species which we killed at Kolobeng continued to distil clear poison from the fangs for hours after its head was cut off. So copious is the supply that, when a number of dogs attack it, the first bitten dies almost instantaneously; the second is about five minutes, the third is an hour or so, while the fourth may live several hour's. This reptile makes great havoc in the cattle-pen.

891. Some Snakes are caten, such as the Python, of which the largest specimens are about fiftecn or twenty feet in length. They live on small animals, chiefly the rodentia. To man they are perfectly harmless. One which we shot through the spine was eleven feet ten inches long, and as thick as a man's leg. It was still capable of lifting itself up about five feet high, and opcned its mouth in a threatening manner, but its inclination was to crawl away. The flesh is much relished by the Bakalahari and Bushmen.*

892. What part do Alligators, Crocodiles, \&c., fulfil in the Plan of Nature?

They are to a very great extent the scavengers of great 
"They return at evening: they make a noise like a dog. Behold, they belch out with theil mouth; swords are in their lips."-Psalsi lix.

water-courses, into which dead and putrifying animal bodics are washed or thrown. But for animals of this description, the banks of great rivers, in the hot countries which they inhabit, would be more pestiferous and deadly than they now are.

393. The great feasting time of the Alligator is during the floods, when, placing himself in the lakes formed in

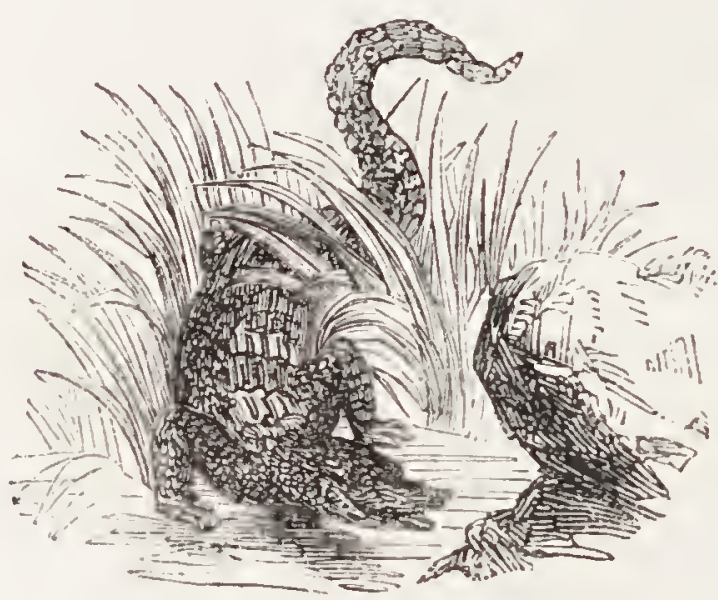

ALLIGATOR. the woods, he awaits the arrival of animals, dead or alive, which, swept away by the waters, are collected in the eddies of these artificial lakes. Here he finds food in abundanceanimals of all sorts, will and tame, washed from the land ; birds, snakes, and even human bodies, hurled over the rapids, and brought to this tranquil harrest ground of the devouring Alligator; and for the six or eight weeks the feasting lasts, his jaws are perpetually clashing upon the varied repast so abundantly brought to his appetite, till he becomes so fat and repleted, as to be able to go through the rest of the year with little more than an occasional snack.

891. 'The number of Alligators in African rivers is prodigious, and they are more savage in South Africa than elsewhere. Children are frequently carried off by them ; for, notwithstanding the danger, they generally play at the river-side when they go down for water. Many calves are also lost, and it is seldom that a herd of cows swim across a river without some loss. 
" He sent divers sorts of flies among them, which devoured them; and froms, which destroyed them. He gave also their increase unto the caterpillar, and their libour unto the locust." -P'PALM Ixxiii.

\section{What is the Geographical Distribution of Insects?}

As almost all insects are winged, they can readily spread themselves wherever their progress is not opposed by uncongenial climates, or by seas, mountains, and other physical impediments; and they are sometimes carried beyond these bounds by violent winds, which may in a few hours carry them to rery considerable distances.

896. All the insects brought from the eastern parts of Asia and China, whatever be their latitude or temperature, are distinct from those of Europe and of Africa. Although the insects of the United States often resemble very nearly our own, they are, with very few exceptions, specific-

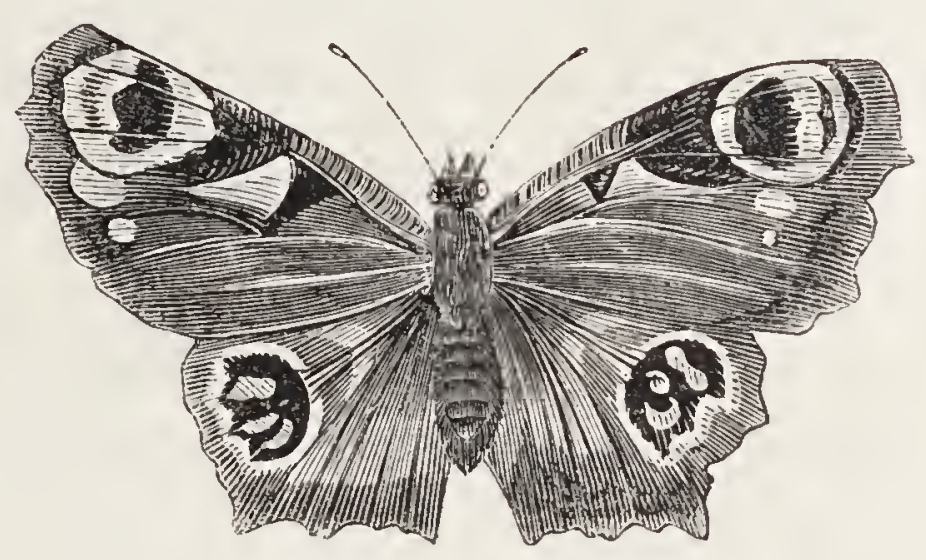

PEACOCK BUTTERFLY. ally distinguishable by some characters. In South America, the equinoctial lands of New Granada and Peru on the one side, and of Guiana on the other, contain for the most part distinct groups; the Andes forming the division, and interposing a narrow line of severe cold between climates otherwise very similar.*

897. Insects increase in kinds and in numbers from the Polcs to the Equator; but the increase does not take place at the same rate every where. The Polar regions have very few specifically or individually; their numbers increase in Tasmania and New South Wales; they are still more abundant in Southern and Western Africa, Columbia, and in the plains west of the Brazils; North America has 
"Ire hath made everything beautiful in lis time: also he hath set the world in their heart, so that no inan can find out the work that God maketh, from the beginning to the end."-ECCLESIASTES iii.

fewer specics than Europe in the same latitude, and Asia has fer varietics of specics in proportion to its great cxtent; Caffiraria, the African and Indian Islands, posscss nearly the same number of spccies, but by far the richest of all, both in species and numbers, are those of Central and Intertropical America.

898. Bectles are an cxception to the law of increase touvards the Equator, as they are infinitcly more numerous in species in the temperate regions of the northern hemisphere than in tropical countries.

899. The location of insects depends upon those of the plants which yield them food; and as almost cach plant is peoplcd with inhabitants peculiar to itself, insects are distributcd over the earth in the same manner as vegetables; but it is cxtraordinary that, notwithstanding their powers of locomotion, insccts often remain within a particular compass, though the plants, and all other circumstances in their immediatc ricinity, appear cqually favourable for their habitation.*

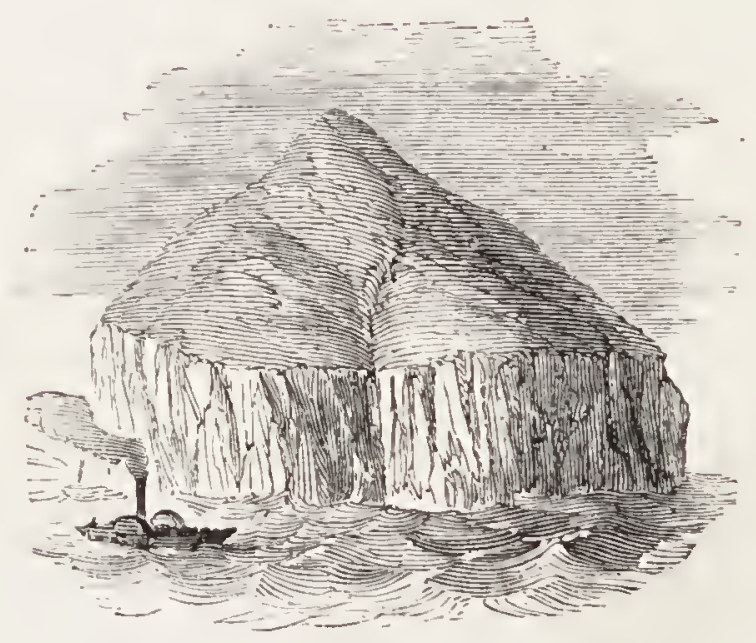


"What is man that Thou art mindful of him? and the son of man, that Thou visitest him."-PSAL3r viii.

\section{GEOGRAPHICAL DISTRIBUTION OF MAN;AND} VARIETIES OF THE HUMAN SPECIES.

900. What is the Leading Distinction between Man and the Inferior Animals?

Animals are born what they are intended to remain. Nature has bestowed on them a certain rank, and limited the extent of their capacity by an impassable decree. Man she has empowered and obliged to become the artificer of his own rank in the scale of beings by the peculiar gift of improvalle reason.

901. There are writers who have taken an extraordinary pleasure in levelling the broad distinction which separates man from the brute creation. Misled to a false conclusion by the infinite variety of Nature's productions, they have described a chain of existence connecting the vegetable with the animal world, and the different orders of animals one with another, so as to rise by an almost imperceptible gradation to the lowest of the human race, and from these upwards to the most refined.

902. But, if a comparison were to be drawn, it should be taken, not from the upright form, which is by no means confined to mankind, nor even from the vague 
"Iin doth not live by bread alone, but by every word that procceleth out of the mouth of the Lord dotll man live."-Devr. viii.

term "reason," which cannot always be accurately" separated from instinct, but from that power of mogressive and improvalle reason which is man's peculiar and exclusive endowment. It has been sometimes alleged, and may be founded in fact, that there is less difference between the highest brute animal and the lowest savage than between the savage and the most improved man. But, in order to warrant the pretended analogy, it ought to be also true that this lowest savage is no more capable of improvement than the Chimpanzee or the Orangoutang.*

903. Why are the Human Races more widely Distributed than any others?

Because Man, although naturally formed to inhabit but one element, is yet enabled by his slill to trarerse vast oceans, and by the peculiarity of his constitution to live in all climates which produce vegetation. In his matural state, lie is among the least qualified of living beings for making rapid transitions from one part of the earth to amother: and yet he has peopled its entire surfice.

904. Mran is matonically formed for an upright position, admirably adapted to permit the free use of his two arms, to which are affixed hands of exquisite structure, as instruments that, directed by his mental power, give him a superiority over all the other inlabitants of the world, and (connceted with his capacity of communicating ideas to his fellows by the variations of sound, for which his organ of voice is consummately formed) place him at an immcasurable distance above the inferior animals. 
"Although affliction cometh not forth of the dist, neither doth trouble spring out of the ground; yet man is born unto trouble, as the sparks fly upward."-Jon v.

905. His eonstitution adapts itself to every climate, and he is found the same superior ereature wherever he exists. Yet he is in himself a defenceless being; no other animal is so destitute of instinet; no other remains so long in a state of infuntile weakness. His powers begin to develope when his reason and observation begin to aet, and that only after years of maternal care.

906. His brain is larger than that of any other animal, and his extermal sensations are more delicate and acute, as is demonstrated by the peeuliar nicety of seeing, hearing, and smelling in the native Americans, and that of touch in all the race. His food consists of animal and regetable productions of almost every description, but in general they must be cooked before they are employed.

907. Like all other animals, man is affected by climate, food, and the nature of his oceupations; and, though varying in colour and size, yet all are so similar as to indicate their origin from one primitive parentage, whether they inhabit aboriginal forests, or rom the trecless wastes of the Siberian deserts.

908. Why is it Believed that all the Varieties of Man sprung from one Common Origin?

Because the Scripture listory of Man's formation is entirely confirmed by scientific investigations into the unity of his origin. We contemplate, among all the diversified tribes who are endowed with reason and speech, the same internal feelings, appetites, aversions; the same inward convictions, the same sentiment of subjection to invisible powers, and, more or less fully developed, of aeeountability to unseen avengers of wrongs, and agents of retributive justice, from whose tribunal men eannot even by death escape. 
"Behold, happy is the man whom God correcteth; thercfore despise not thou the chastening of the Almighty."-JOB $\mathrm{v}$.

909. We find everywhere the same suseeptibility, though not always in the same degree of forwardness or ripeness of improvement, of admitting the eultivation of these universal endowments, of opening the eyes of the mind to the more elear and luminous views which Christianity unfolds, of becoming moulded to the institutions of religion and of cirilised life: in a word, the same inward mental culture is recognised in all the races of men. When we compare these facts with the observations which hare been heretofore fully established, as to the speeifie instincts and separate physical endowments of all the distinet tribes of sentient beings in the universe, we are entitled to draw confidently the conclusion that all human races are of one species and one family.*

910. A "furir-haired" native of Europe migrates with his family, and settles among the "woolly-haired" and swarthy inhabitants of Afriea. Do his deseendants in the lapse of a eentury, born under a scorching sun, begin to assume any of the charaeteristies of the raees that surround them? Do their lips gradually beeome thiek, their noses flattened, and their complexions blaek? Assuredly not; the supposition is refuted by experience to the eontrary.

911. Again, does an African diet, or a change of eostume, create any ehange in their form or their mental perceptions? are their national eharacteristies, in short, in any degree lost, so long as their race is preserved pure? Let the Spaniards, settled for more than two eenturies among the eopper-eoloured Indians of Mexico and Spain -the Dutch boors of Southern Africa-the descendants 
"Knowest thou not this of old, since man was placed on the earth, That the. triumphing of the wicked is short, and the joy of the hypocrite but for at moment ?"-JоB xx.

of the whites who first settled in the West Indiesabove all, the Jews, now scattered "among every nation under heaven"-let these give answer to such questions. Such living testimonies, known to all, should at once have dispelled the illusion which many writers have indulged in, that temperature, food, clothing, and other secondary influences were the chief causes of that extraordinary variation in the aspect of the human species, which the different nations of the earth exhibit, and which, so long as each race is preserved pure, is unchanging and unchangeable.*

912. There are families of nations more readily susceptible of culture, more highly civilized, more ennobled by mental cultivation than others, but not in themselves more noble. All are alike designed for freedom-for that freedom which in rude conditions of society belongs to individuals only, but, where states are formed and political institutions enjoyed, belongs of right to the whole community.

913. If we would point to an idea which all history throughout its course discloses, as ever establishing more firmly and extending more widely its salutary empire-if there is one idea that contributes more than any other to the often contested but still more often misunderstood perfectibility of the whole human species, it is the idea of our own common humanity, tending to remove hostile barriers which prejudices and partial views of every kind have raised between men, and to cause all mankind, without distinction of religion, nation, or colour, to be regarded as one great fraternity, aspiring to one common aim-the free development of their moral faculties. This is the ultimate and 
" Man that is born of woman is of a few days, and full of trouble. He cometh forth like a flower, and is cut down: he fleeth also as a shadow, and continueth not." -Jor dir.

highest object of society; it is also the direction implanted in man's nature, leading towards the indefinite expansion of his inner being.*

91t. What Causes the Different Complexions of the Varieties of Men?

A variety of causes have to be considered; the most important of them are-climate, organization, inter-marriage, and exceptional circumstances. The influence of climate is shown by the fact that every geographical zone is more or less marked by a distinctive colour. Black prevails under the Equator, copper colour under the Tropics, olive and fair towards the Poles.

915. The influence of organization is shown in many instances; the Moors, who have lived for ages under a burning sun, still have white children, and the offspring of Europeans in the Indies have the original tint of their progenitors.

916. Different complexions are in some cases intermixed by immigrant races, and white and black people dwell together, and complexions are modified by the offspring of marriages between members of the different races.

917. But it is further and most conclusively demonstrated by an examination of the skins of the darklycoloured races, in which a secreted colouring matter is found. The skin is thicker and harder in black people than in white. The external skin of each is transparent and colourless. The colouring matter of the dark races lies in the rete mucosum or inmer skin, and this colour is seen through the transparent true stin, just as white people sce the traces of their dark reins through the same cuticle. 
"O taste and see that the Lord is goou: blessed is the man that trusteth in lim."-P'sALI Xxxir.

918. 'The influences of inter-marriage are abundantly demonstrated by the fact that the union of black and white parents generally produces children of an intermediate character, which are called mulattoes; and the effect of exceptional circumstances may be found in the somewhat rare occurrence of the birtl of piebald negroes, having their skins diversified with black and white spots, and part of their woolly hair white; of short parents producing very tall children, \&c.

919. As far as inquiries have extended at the present day, it appears that the tendency to form the colouring pigment cells of the skin is dependent in a great measure on the exposure of the skin to light. As a rule, it is found that where the sun's rays are most direct-where there is the greatest amount of light - the skins of luman beings exhibit the greatest tendency to develope these cells. The darkest-skinned races are intabitants of the Tropics.

920. We find the influence of light upon organic beings is sucl, that it affects the constitution of bodies exposed to its action. In the vegetable world, the most brilliant colours, the most powerful scents, and the most poisonous secretions, are all produced under the agency of intense light. That exposure to light has an influence in the development of the colour of the skin, is also supported by the fact that the children of all dark races are born comparatively fair, and do not become black till they liave been exposed to the light of the sun.

921. The change of colour in the human skin, from exposure to sun and air, is well known to be temporary. The discolourations which we term "tanning" or being "sun-burnt," as well as the spots called "freckles," are most incidental 
"Blessed is the man whom Thou choosest, and causest to approaeh unto Thee, that he may dwell in 'lhy courts: we shall be satisfied with the goodness of Thy house, even of 'Thy holy temple."-Psatsr lxv.

to fair skins, and disappear when the parts are corered, or no longer exposed to the sun. The children of a sunburnt husbandman, or of a sailor whose countenance bears the marks of hotter climes, are just as fair as those of the most delicate and pale inhabitants of a city.

922. Why does the Physical Conformation of the Earth exert Moral Influences upon the Races of Hen?"

As the external form of continents in the raried and deeply indented outline of their consts, exercises a beneficial influence on climate, trade, and the progress of civilization, so also, in the interior, the rariations of form in the vertical direction, by mountains, hills, valleys, and elevated plains, have consequences no less important.

923. Whatever causes diversity of form or feature on the surface of our planet-mountains, great lakes, grassy steppes, and eren deserts surrounded by a coast-like margin of forest-impresses some peculiar mark or cliaracter on the social state of its inhabitants.

924. Continuous ridges of lofty mountains corered with snow impede intercourse and traffic; but where lowlands are interspersed with broken chains, and with groups of more moderate elevation, regetable and animal: products are multiplied and varied, and different kinds! of cultivation, even under the same latitude, give riser to different wants, which stinulate both the industry and the intercourse of the inlabitants.

925. The Mongolion and Tartarian steppes, interrupted frequently by mountainous features, divide the very ancient civilization of Thibet and Hindostan from the rude nations of Northern Asia. They have in various ways exercised an important influence on the changeful destinies of man. They have compressed the population towards 
"What man is he that liveth, and shall not see death? shall he deliver his soul from the liand of the grave."-PSALY lxxxix.

the south, and have tended to impecle the intercourse of nations, and to place permanent imits to the extension of milder manners, and of artistic and intellectual cultivation, in Northern Asia.

9:26. But, in the history of the past, it is not alone as an opposing barrier that we must regard the plains of Central Asia: more than once they have proved the source from whence devastation has spread over distant lands. The pastoral nations of these steppes have shaken the world. A brown race of Turkish descent, dwelling in tents of skins, inhabited the elevated steppe of Gobi. Long terrible to the Chinese power, a part of this tribe was driven back into Central Asia. The shock thus given passed from nation to suation, until it reached the ancient land of the Finns, near the Ural Nountains. From thence various admixtures of Asiatic races broke forth; armies of Huns appeared successively on the Volga, in Pannonia, on the Marne, and on the $\mathbf{P}_{0}$, desolating those fair and furtile fields which civilized man had adorned with monument after monlument. Thus went forth from the Mongolian deserts a «leadly blast, which withered the tender long-cherished flower of art.**

927. On the other hand, contact with the ocean has unquestionably exercised a beneficial influence on the cultivation of the intellect, and the formation of the cliaracter of many nations-on the multiplication of those bonds . which should unite the whole human race-on the first knowledge of the true form of the earth-and on the pursuit of astronomy and of all the mathematical and physical sciences. This beneficial influence, enjoyed by the dwellers on the Mediter'ranean and on the shores of South-western Asia, was long limited to them; but since the sixteenth century it has spread far and wide, extending to nations living in the interior of continents. Since Columbus was "set to unbar the gates of the ocean," man has boldly adventured into intellectual as well as geographical regions before unknown to him.*

928. Whence originated the different Habits and Modes of Life for which Difjerent Tribs are Remarkable?

The physical features of a country determine not only

* IIumboldt's "Aspects."

$\dagger$ Cosmos. 
"As a bird that wandereth from her nest, so is a man that wandereth from his place."-l'hoveris xxrii.

the movements and geographical distribution of races, but give distinctive characters to the aboriginals. The people who established themselves in the frozen regions of the north, not finding enough of regetable nourishment, became munters and fishers. Necessarily separated from each other for the pursuit of sustenance, they multiplied slowly, and civilization remained unknown among such people; the arts are confined to the construction of huts, the preparation of skins for covering, and to the manufacture of spears and other weapons. The inhabitants of the northern and eastern parts of Siberia, and the savages of North America, are almost the only people who are now to be found in this primitive state.

929. Those people who feed numerous herds of cattle, in localities where it was necessary to seek new pastures for their maintenance, necessarily adopted a wandering life.

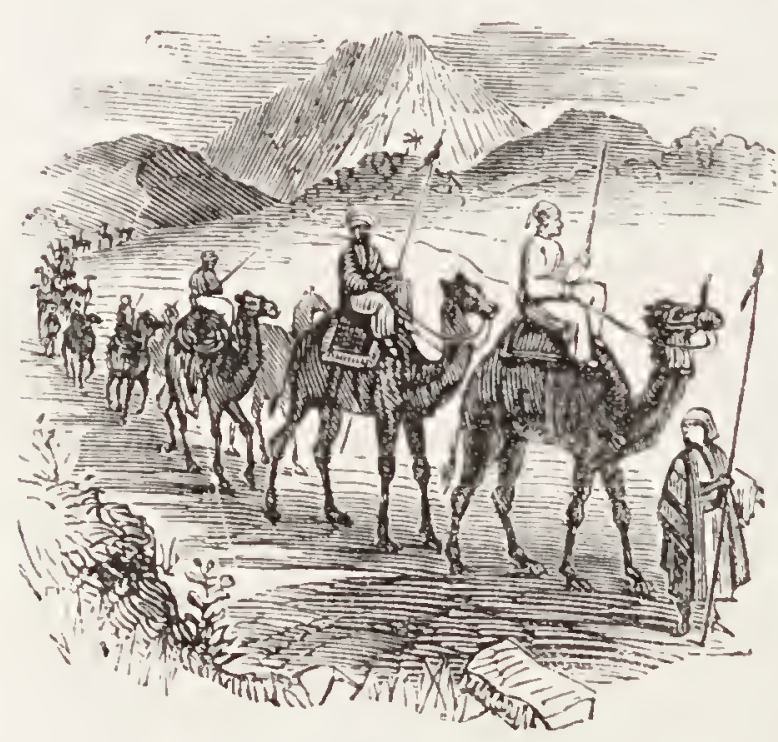

ARABS TRAVELLING. Travelling in numbers, they acquired ideas of property and of natural rights, and inequality of condition soon gave one man power over another. But the wandering life, in search of new pastures and more agreeable climates, kept them still within very narrow limits of civilization. The Laplanders in the North of Europe, the Tartars who inhabit the vast interior of Asia, the Bedouin Arabs who occupy the sands of Arabia and the North of Africa, and the Caffres and 
"What man is he that desireth life, and loveth many days, that he may" see good? Keep tlyy tongue from evil, and thy lips from speaking guile."-P'sacir xxxir.

Hottentots in Southern Africa, are the principal wandering tribes that now remain.

930. In countries where the nature of the soil, and the value of the productions, rendered an abiding residence essential, people took to agriculture, acquired property in land, developed themselves into classes or ranks, instituted laws, became less predatory and warlike; and when, in the division of labour and duty, the functions of the civilian became separated from those of the soldier, the civil portion of society cultivated various improvements, and assumed the habits of civilized men.

931. From the earliest ages; and in the fulfilment of the cursc passed on Ishmael, the Arab has been an unsettled wanderer, a few only of them dwelling in citics; the great body of the pcople roaming in solitary or united families over the face of the land, pitching their tents wherc pasture and water afford subsistence for their flocks, in whose number eonsist their wealth and comfort; the camel, as well as being a beast of burthen, yielding to the Arab the greater part of his food, as wcll as elothes, and a covering for his tent.

932. The native Arabians, or, as they call themselves, Bedouins, or sons of the desert, arc a rcmarkably clean, active, hardy, and hospitable race of men, passionately addicted to war, and following robbery as a profession. The men are slender, with black eyes and hair, full beards, and deep swarthy eomplexions; the women are much fairer, possessing eonsiderable graee, and when young are often very beautiful.

933. The natives of Lapland arc usually divided, first, into Laplander's proper, that portion of the primitive inlabitants who have preserved their manners, eustoms, and superstitions from eommixture with othcr matives. These possess the most wild, barren, and eleerless regions, namely, the glaciers and frozen mountains of Severnoi, and, drawing nearly all the requirements of life from their flocks of reindeer, have thus preserved their pastoral mode of life from age to age in unbroken uniformity. They are supposed hardly to exceed 8000 in number, and, as they form the true type of the Lap, they may be described as of low stature, stout, straight, and of a yollowish eomplexion, supposed 
"When the wicked spring as the grass, and when all the workers of iniquity do flourish; it is that they shanl bo destroyed for ever."-Psalar xcii.

to be the result of a want of cleanliness, and the smoke of their fires, by which they usually sit when the toil of the day is over. They are

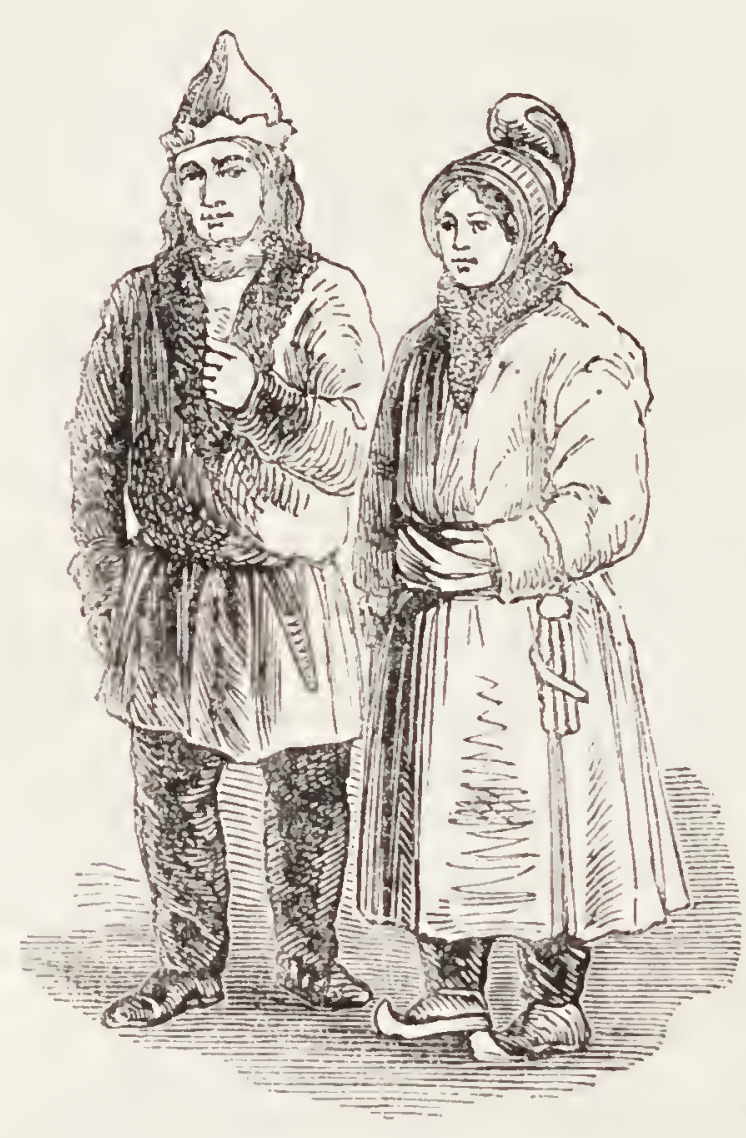

LAPLANDERS. divided into fishermen and mountaineers; the one class living upon the spoil of their lines and nets; the others, more wealthy and civilized, on the products of their herds; some of these mountaineers having as miany as 600 and even 1000 head of reindecr-the distinctive mark of power and opulence among them. The employment of the men consists in fishing, building light canoes, making sledges, harness for the deer, and attending to the culinary department of the household. The women, who are somewhat shorter than the men, and often extremely well made, are employed in making nets, drying the fish and meat for winter stores, milking the reindeer, making cheese, and taming the hiles of the slaughtered animals. Their work, however, loes not stop here; they are the tailor's of the whole establishment, as well as their own dressmakers, and fill up occasional hour's with more laborious work. The other divisions of the people are a mixture of the native Laplanders and the people adjacent, and are more or less modified examples of the primitive nation already described. "These are the Norwegian, Swedish, Finnish, or Russian Laps.

934. Why do Uncivilized Tribes frequently become more Baruarous upon their. First Intercourse with Cibilized Races?

Because, in many instances, they have been conquered, oppressed, and in most things cruclly treated. Thus they have sunk into lower depths of demoralization, and have 
"Blessed is the man that feareth the Lord, that delighteth greatiy in his commandments. Wealth and riches shall be in his house: and his rigliteousness endureth for ever."-Psalar cxii.

learnt to hate their oppressors. This is remarkably evidenced by the American Indians. On all Indian frontiers, from the above causes, there are two classes of Indian people, the one nearest to civilization, where they have become degraded and impoverished, their character changed, their worst passions inflamed, and jealousies excited by the abuses practised upon them.

935. This explanation, we hope, applics rather to the past than the present, for a more humane policy is now enfurced by nearly all governments. But it is an important fact, which should not be overlooked as an argument against the opinion that man in his lowest state is akin to the brute. There are no people on carth more loving and kind to their friends and the poor than these Indians; and yet, like all savage races, they arc correctly denominatcd cruel-and what people are not so? There is an excusc for cruelty in savage life. Personal rights have to be protected without the aid of laws; and for those ends each individual is looked upon as the avenger of his own wrongs; and if he does not punish with cruelty and with certainty, there is no security to person or pro.. perty. In the exercise of this right, the Indian not only uses a privilegc, but does what the tribe compel him to do, or to be subjected to a disgrace which he camnot outlive; so that cruelty is at the same time a right and a duty, the law of the land. The "Indian's cruelty and treachery in warfare" we hcar much of ; but cruelty and treachery in Indian and civilized warfare are much alike,* and of this the recent war in America has afforded many dreadful proofs.

936. That a better policy is now pursucd by the representatires of civilized governments engaged in exploring new countries, is mattcr for congratulation. In the Admiralty Instructions addresseci to the latc Mrr. Consul Beecroft, respecting the expedition to the River Chadda, in Central Africa, of which lie was to become the leader, the following instructions, with others of like import, weres given:- "The Pleiad being armed with a 12-pounder pivot gun, four swivels, Minié rifles and double-barrelled guns for the officers;

* Cat'in's "Life among the American Indians." 
"He hath made of one blood all nations of men, for to dwell on the face of the earth, and hath determined the times before appointed, and the bounds of their labitation."-Acts xvii.

muskets for the crew, and with boarding nettings of wire, it is not probable that she will meet with any opposition in the lower parts of the river where there may be danger. But you will remember that the best security from attack consists in the natives seeing and knowing you are well prepared to meet it. At the same time you are strictly enjoined to use the greatest forbearance towards the people, and, while retaining proper firmess in the event of. any misunderstanding, to endeavour to conciliate as far as can possibly be admitted with safety to your party. You will on all occasions enforce the strictest justice, and never, on any account, permit one of your party to ill-treat, insult, or cheat the natives."

937. What are the Principal Types of the Farieties of Mankind?

They consist of-1. The Caucasian. 2. The Mongolian. 3. The Ethiopian. 4. The American. 5. The Malay.

938. Why is the First of these Types called the Cancasian?

Because the tribe from which this great division of the human family descencled have from the earliest ages been the occupants of the mountain chain of the Caucasus, situate between the Caspian and Black Seas. 'The characteristics of this variety are, a white skin, either with a rosy tint or inclining to brown ; red checks; hair black, or of the various lighter colour's, abundant, and more or less curled or waring; irides dark in those of brown skin-light blue, grey, or greenish in the fair or rosy-complexioned; large cranium with small face, the upper front regions of the face well developed, and the face filling perpendicularly under them, oral and straight, the features well defined; narrow and rather aquiline nose; small mouth; front teeth of both jaws 
"The kings of Tarshish and of the isles shall bring presents: the kings of Sheba and Seba shall offer gifts. Yea, all kings shall fall down before him; all nations shall serve him."-Psalm lxii.

perpendicular; lips, particularly the lower, gently turned out; chin full, rounded, and bearded.

939. What are the Moral Characteristics of this Race?

In them the moral feelings and intellectual powers aro most energetic, and susceptible of the highest kerelopment and culture. The influence of this family of mankind on the history of the world has been much greater than that of either of the others. Although they form the principal part of the nations of Europe, they do not exclusively occupy this district, nor are they confined to it.

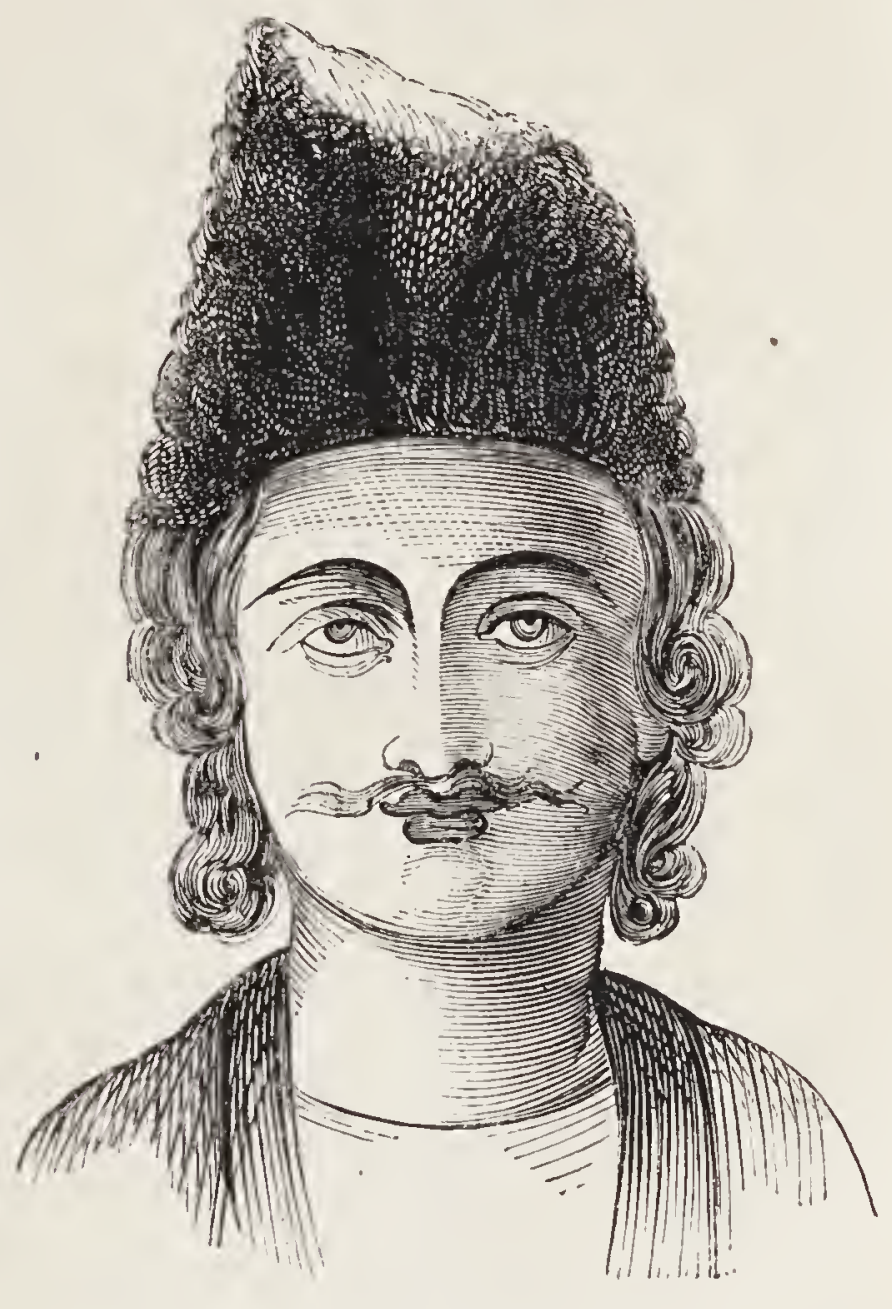

CAUCASIAN.

940. The adoption and propagation of Christianity in a pure form has been mainly due to them. It became early identified with the civilization of Greece and Rome, and, passing from the nations where it obtained early triumphs, it has become in later days the especial inheritance of the great Anglo-Saxon race, which on both sides of the Atlantic is increasing with extraordinary rapidity, 
"Ilis name shall endure for ever" his name shall be continued as lono as the smu: and men shall be blessed hil him: : all nations shall call him blessed."PSALM lixii.

and diffusing throughout the world the spirit of industry, commercial enterprise, and scientific discovery, which are the legitimate offispring of the undefiled religion of Christ.**

941. A close investigation of history will show that it is almost solety the Caucasian races velich have effected great revolutions, and that these lave taken place almost simultaneously with the increasing civilization of the former. The Caucasian races,-above all, the Enropeans,- have been able to transplant by degrees into their own humes the characteristic plants of other nations. They hare fetched the finer kinds of fruit-the almond, the apricot, and the peach-from Asia Minor and Pcrsia, the orange from China; they lave transplanted riee and cotton to the coasts of the Mediterranean, brought maize and the potatoe from America to Europe, where they now support millions of human beings, and have chiefly contributed to prevent famine in the failures of crops which have taken place. These races have, moreover, been able, by their extensive industry and their commeree, to acquire possession of the products of foreign characteristic plants which will not thrive at home. They have procured, purtly even for daily necessities, the tea of the Chinese, the coflee of the Arahs, and the rice and cotton of the Hindoos.

942. The influence of the Caueasian raees, and especially of the Luropeans, in changing the distribution of characteristic plants, and promoting civilization, becomes far more evident when we look to the colonies established in our own climates, where in some cases the comtries have passed wholly into the possession of a European population; for they have not only carried their own characteristic plants to the colonies, and thoso also whieh they had previously: transplanted into their own homes, but they have, after acquiring countries with different climatal conditions, transplanted into them such as would not flourish at home, and thus have found themselves in a position to collect the characteristic plants of almost every race around them. Thus have the European corn plants acquired a widely-spreading cultivation thoughout North America, in Mexico, and the elevated countries of South Ameriea, in Chili and Buenos 
"To make thee high above all nations, which he hath marle, in praise, and in name, and.in honour; and that thou mayest be an holy people unto the Lord thy God, :Is le lath spoken."-Deu'. xxvi.

Ayres, in the temperate parts of Australia and Van Diemen's Land; thins the vine lias become an object of cultivation in Madcira, the Canary Islands, South Africa, and the highlands of South America; thus rice and cotton are now grown in extraordinary quantities in the warmer parts of North America and in Brazil; thus lave the coffee-trce and the sugar-cane bcen transplanted into the West Indies and Brazil; the nutmeg and the clove into the Mauritius and Bourbon, and various West Indian islands; and thus has the plantation of tea commenced in Brazil, in Java, and in India, and the cultivation of New Zealand flax in New Holland.

243. The Europeans liave even convcyed characteristic plants to other races which knew how to ralue them. They liave transferred several European and Tropical plants into the South Sea Islands, which, previously unknown, are now cultivated by the natives. The remnants of the American population which are still found in the highlands of Peru, Chili, and Mexico, have acquircl European plants; in like manner the ncgroes of the west const of Africa liave received from the Europeans maize, tobacco, and other Amcrican plants. On the other liand, what other races liave done to change the distribution of cliaracteristic plants is very little: the Arabs contributed to diffuse cotton, the sugar-cane, coffee, and the date palm; but the Arabs belong to the same primary race as the Caucasians. The Chinese appear to hare procured cotton from Hindostan, and the Japanese the tea shrub from China.

944. The Europeans, and above all the North Europcans, conseruently, are those who, both in their own home and in their colonies, have been able to acquire the grcater quantity of characteristic plants of other raccs, while their own country, spccially the North of Europe, is so vcry poor in claractcristic plants, for all the important cultivated plants of Northern Europe liave been introduced (cabbage, turnips, carrets, and asparagus, which are perhaps indigenous, are among the lcss essential). We find in this a great proof of the intellectual supcriority of these races, and we have here an example that the child of the poor man, gifted with great ratural powers, industry, and activity, has fur more power over nosperity than the rich heir.** 
"Behold the nations are as a drop of a bucket, and are counted as the smail dust of the balinee: behold, he taketli up the isles as a very little thing." -Isaian xl.

\section{What are the Subdivisions or Varieties of the Caucasians?}

They are the Circassian, or true Caucasian; the SyroArabian, Hindoo, Celtic, Grecian, Italian, German, Sclaronic, \&c., and ripsies oliginally from the banks of the Indus, from whence they wandered orer Europe. A.ll the ancient and modern Europeans, except Laplander's, and the rest of the Finnish race, belong to these divisions.

946. The province of the true Caucasians lies upon the Caucasian Nountrins, between the Black and the Caspian seas. Though the numerous ralleys and plains lying within the Mountain range of the Caucasus are extremely fertile, and produce abundant crops of grain, the great wealth of the people is derived fiom their fine breed of hor'ses and immense herds of cattle. 'The inlabitants, who number' about 225,000 are a hardy, brave, and generous race, while the women have for ages been regarded as the types of female beauty, and on this account have been reared with the ostensible object of being sold to 'Turkish or Persian masters. The men chiefly employ their time in war and plunder'; when these excitements are wanting, they take to hunting and feasting.

947. The Syrian inflnence, as an element of civilisation, has probably been underralued. It was through the Syriac that two contiguous nations received much of their linowledge of what was to be learned from Greece-the Armenian and the Arabian.**

948. The Babylonians, Chaldees, and Assyrians, though differing among themselves, were evidently all of one family, and came, like the Arabs, originally from the ligh- 
"There is nothing better for a man than that he should eat and drink, and that he should make his soul enjoy good in his labour."-EcclesLastes iii.

lands of the East. 'They were, moreover, advanced in civlization, had solar and astronomical religions, with legends of Fish-men legislators, whose persons and doctrines revealed reminiscences of a deluge, though distorter into Indian forms. In their record the first dispersion of mankind was transposed from the ligh table-land of Asia to the new centre of their own locality. Regarded as a race, these people were unquestionably pure Caucasians, of the black-haired tribes, and so closely allied to the subsequent Persians that no distinction can be male between them, as they are represented in the basreliefs of Persepolis, and those of Nineveh, lately brought to light. The Syrians and Babylonians were among the first

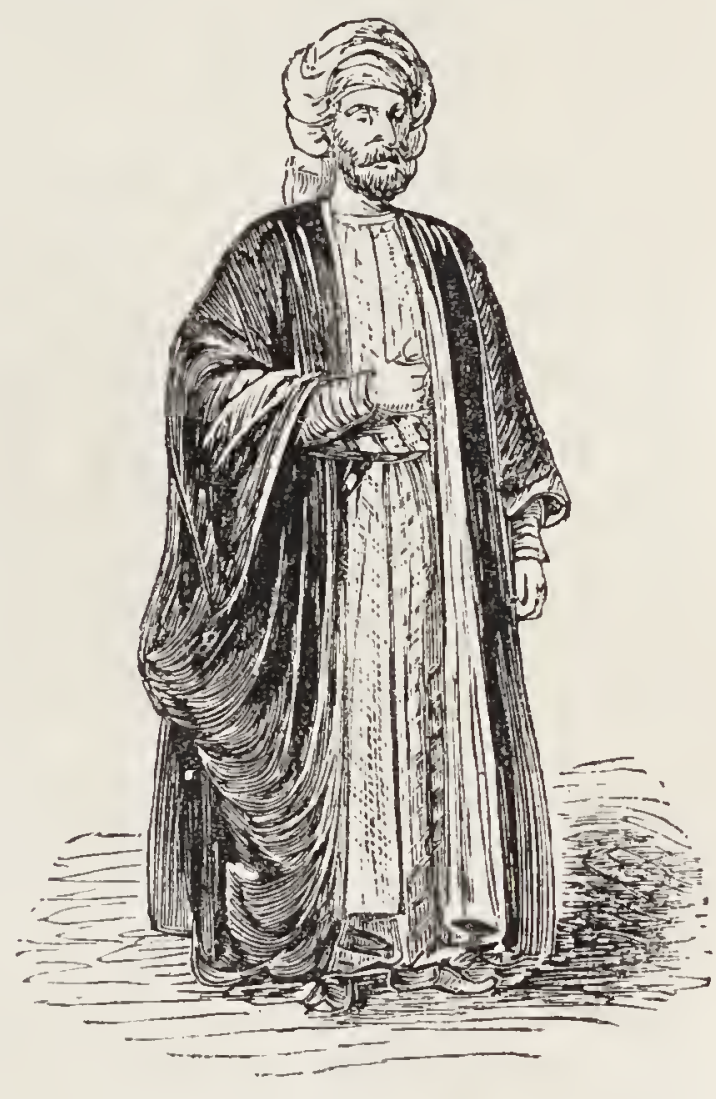

SYRIAN. builders of cities, and the first organisers of empires. 'They infuenced early civilization more through art, politics, and commerce than morally.

949. The city of Damascus is one of their most ancient foundations, and perhaps the oldest city in the world. Damascus, as we lear'n from Holy Writ, was in existence at the time of Abraham; and in the time of David it had become a place of very great importance. The city, like most Oriental towns, contains a vast number of mosques, 
"The wise man's eyes are in his head; . but the fool waiketh in durkness."ECCLESIASTES ii.

which, with their domes and minarets rising above the groves of date, olive, and cypress tress, impart a peculiarly beautiful appearance to the city. The church of John the Baptist, now converted into a mosque; the house of Ananias, and that of Judas, with whom. Paul lodged, are. still shown, and regarded as objects of great interest and: curiosity.

950. The Hindoos are divided into four castes or orders, out of which it is impossible for any one to pass, unless to a lower; when, having lost his social and religious status, the man becomes a wretched outcast, the most degraded of society. There are among them many tribes, such as the Parsees, or descendants of the Persian fire-worshippers: Amenians, Jews, and Buddhists. 'The four castes are those of the Bralmins, the priests, and the most exalted order; the Rajpoots, or princes and military order; the Taisyas, the merchant, and the trading class; and the common ranks of the people, called the Sudias. The Pariahs are outcasts who have offended against society, and are disowned by all the established castes.

951. The Celtic tribes populate the areas of Brittany, Wales, the Highlands of Scotland, the Isle of Man, England and Ireland, and are allied to the Goths, distributed through Germany and Scandinaria, Switzerland, Holland, Belgium, Great Britain and Ireland, the United States of America, Camada, \&c.

952. Why is the Second IIuman Type called Mongolian?

From the vast region of Mongolia, over which they are generally spread. 'Their greatest dovelopment is on the - contiment of Asia, although eren there they are not the. 
"I know that, whatsocver God doeth, it shall be for ever; nothing can be put sto it, nor anything taken from it: and God doeth it, that men should fear before him." -ECClesias'Tes iii.

entire possessors of the earth. The Persians of Northern and Western Persia, the Kurds, the Affghans, and others, must be regarded as belonging to the Caucasians. On the other hand, the Lapps and Finns of Scandinavia, the Magyars of Hungary, the Turks of Turkey, and others, belong to the Mongolians.

953. They are characterised by an olive colour, which in many cases is very light; black eyes; black, straight, strong,

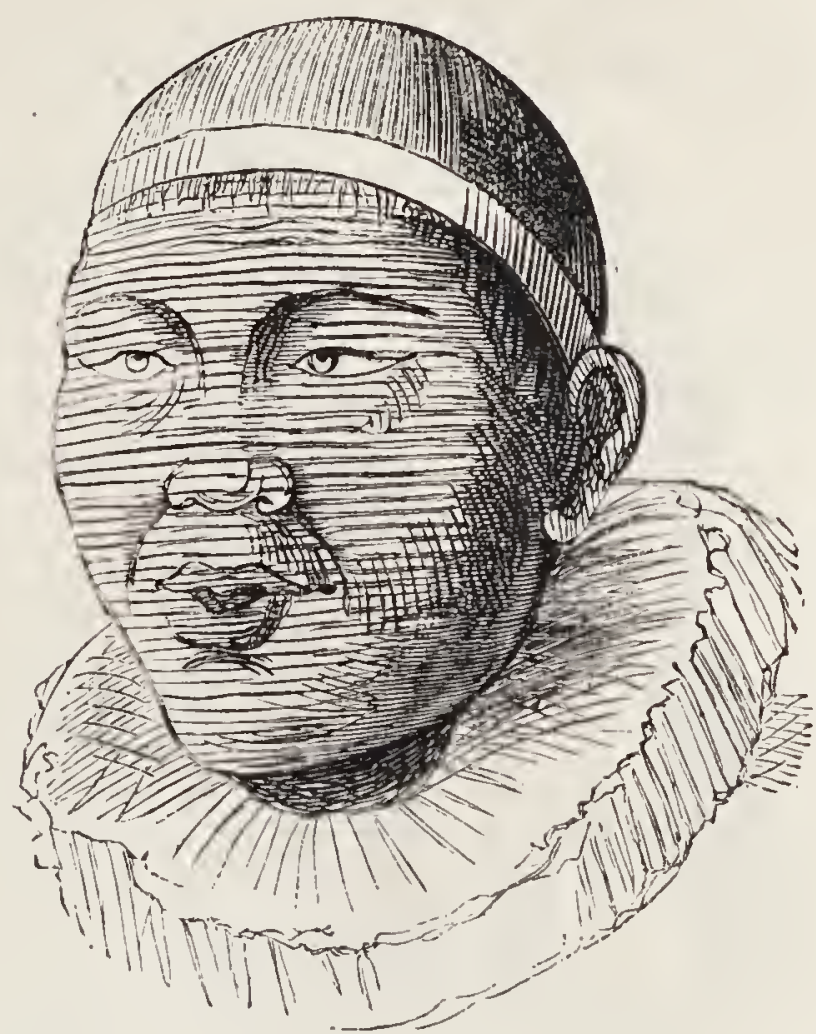

MONGOLIAN. and thin hair; little or no beard; head of square form, with low small forehead; broad and flattened face, with features running together; nose small and flat; cheeks projecting; eyes placed very obliquely; slight projection of the chin; with the ears large, and lips thick. Their stature, particularly in countries within the Arctic Circle, is inferior to that of Europeans.

954. What are the Subctivisions of this Type?

They are the true Mongols, the Tibetans, Chinese, Burmese, Siamese, Samoeids, Yeneiseians, Finns, Lapps, Esquimaux, Turks, \&c. These tribes occupy Central and 
"The noise of a multitule in the mountains, like as of a great people; a tumultuous noise of kingdoms of nations gathered together; the Lord of Hosts inustereth th: liost of the battle."-Isalan xii.

Northern Asia, the Asiatic Islands, and the Arctic consts of Asia and America.

955. Mongolia is a vast country lying in the interior of Asia, between $38^{\circ}$ and $35^{\circ}$ north latitude, and $84^{\circ}$ and $124^{\circ}$

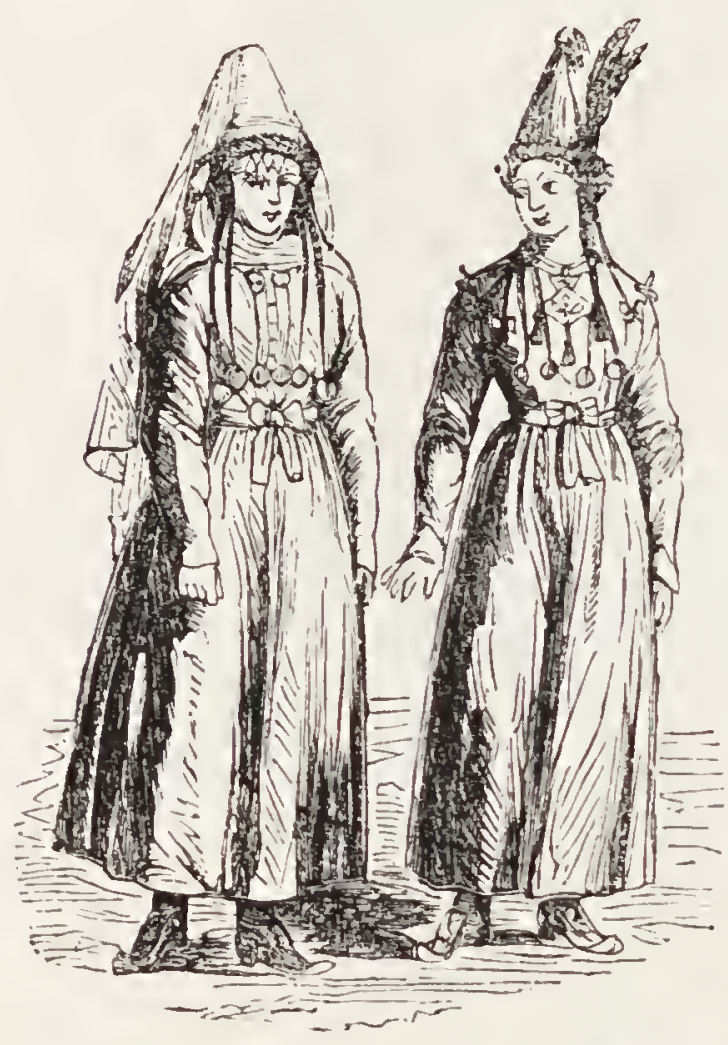

TARTAR AND MONGOL WOMEX. east longitude, having an extreme length of 1700 miles, by a breadth north and south of 1000, with an area estimated at 1,250,000 square miles. This immense region is bounded on the north by Siberia, on the south by China Proper, east by Chinese Tartary, and west by Independent 'Tartary. 'The central part. is occupied by the great sandy lesert known as the Great Grobi, a region of barren soil, 1200 miles long: by 600 wide, dotted here and there by fertile oases. With the exception of the Great Gobi, the remainder of the country is high table-land, and 3000 feet orer the sea level, stretching out in rast plains, surrounded by low ranges of mountains on its northern boundary; from this physical character, the climate of the country is often rigorous, and even coldes than Siberia.

956. The most fertile portion of Nongolia is the whole north-western belt of the Great Gobi, through which the caravan-road runs from Siberia to China, and from which rise the chief rivers of the country, the Selenga, Kerlan, 
"Let him that glorieth glory in this, that he understandeth and knoweth me, that I am the Lord which exercise loving kindness, judgment, and righteousness in the earth: for in these things I delight, saitl the Lord."-Jenemiar ix.

and Onon. This district forms a separate government of the Chinese Empire, the governor residing at Urga, the principal of the very few towns in the country; near to Urga resides the Kootookhtu, or high-priest of the Buddhists.

957. The population of Urga is about 8000 , but fully 5000 of these are Lamas, or priest-attendants on the great head of their faith. The Mongols themselves scldom inhabit either towns or villages, but lead a nomadic life, passing the summer on the banks of rivers where there is abundant pasturage for their flocks, and spending the winter at the base of some tall hill or mountain range that affords them protection from the scvere winds. The wealth of the natives consists in their numerous flucks and herds of sheep, camels, and lorses. The wild animals are antclopes, wild asses, decr, liares, foxes, squirrels, sables, and marmots.

958. The Mongols are generally satisfied with such food as their flocks supply, and seldom seek for variety, or trouble themsclves to cultivate the soil. In summer they live almost entirely on milk, using without distinction that of the sheep, camel, mare, cow, or goat. Their' ordinary drink is warm water, in which they infuse an inferior tea, with which they mix either cream, milk, or butter. They use also a spirituous liquor distilled from soll' mare's-milk. The skins of shcep, with the wool turned inwards, are used for garments by both sexes. The people are said to be of dirty habits, but are open, generous, and brave. Their chief pride is to excel in handling the bow and arrow, in martial exercises, riding, and liunting wild animals.

959. What is the Religion of the true Mongols?

They are Buddhists: for their Lamas or priests they have the most blind superstition, and attribute to them the most miraculous powers.

960. But the subdivisions include Hindoos, Mussulmen, and Europeans. Of the first, the proportion of the population is four to one Mahomedans. Besides these three orders, there are many tribes, such as the Parsees, or descendants of the Persian fire-worshippers, Armenians, Jews, \&c. The religion of the Hindoos is named, from the 
"Leam to do well; seek judgment, relicve the oppressed, judge the fatherless, 5) lead for the widow."-Isalan i.

chicf god Brahma, Brahminism. Nine-tentlis of the population of Iindoostan follow this form of worship, which acknowledges more than 300,000 inferior deitics. Self-torture and immolation are permitted; thousands of victims being annually crushed to death beneath the whechs of the car of Juggernaut, or voluntarily sacrificing themselves in the holy rivers.

961. What are the Moral Characteristics of the MIongolians?

Their characteristics and influence may be regarded as

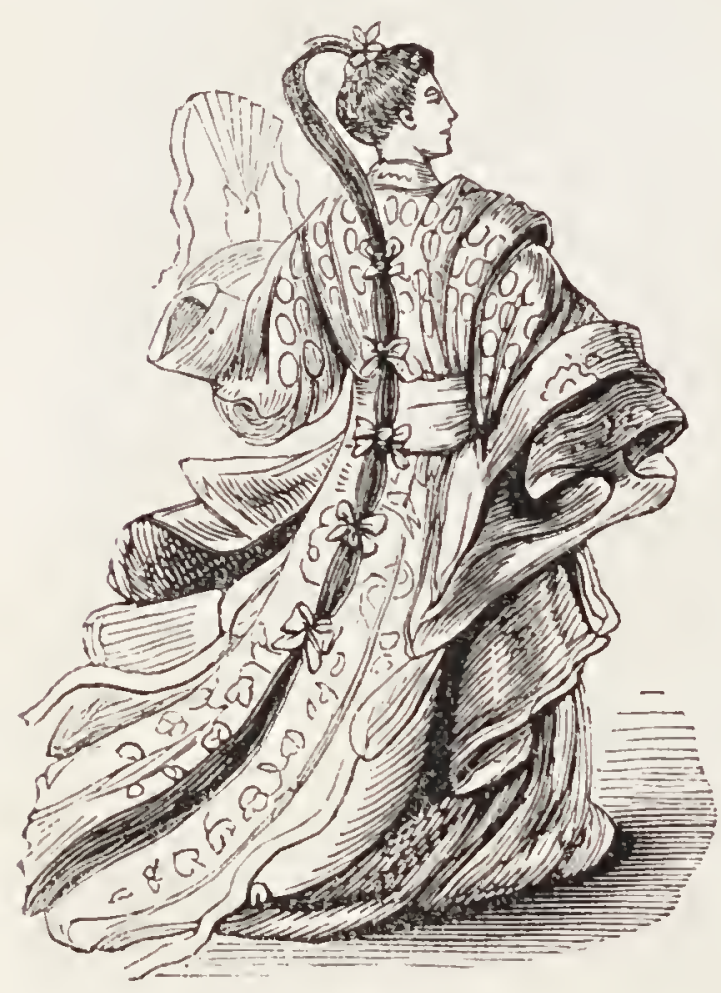

JAPANESE LADY. rather material than moral. 'They undoubtedly form by far the larger portion of the human race, and occupy a considerable space in the history of the worla. 'Tley have by the sworr cstablislied some of the largest empires that the world has scen, of which China is an example. Their cmpires hare, howerer, crumbled to pieces, and left no deep impression on the world, and those that exist appear destined to give way to the prorrress of European and American civilization.

262. The Japanese afford a good example of the great MongolTartar family; they are distinguished, like other branches of the same stock, by a broad skull, high cheek-bones, small black eyes obliquely set, long black hair, and a yellow or sallow complexion. Their chief moral characteristics are skill, perseverance, courage, and frankuess, 
"Great in counsel, and mighty in work: for Thine eyes are open upon all the ways of the sons of men: to give every one according to lis ways, and according to the fruit of his doings."-JerEMIAII xxxii.

much good humonr, courtesy, and natural politeness. Their established or state religion is that of Buddha; their language is polysyllabic, and has an alphabet of forty-seven letters, which are witten in four different forms, one of which is used exclusively by men, and another by women.

963. The original paganism of Japan is thus described. Their gods were not esteemed eternal. The first five gods originated at the separation of the elements in which the world began. A bud expanded itself between heaven and earth, and produced Iramisoko-tatsino-mi-koto, the maker of the dry land," who governed the world, as yet without form, during an incalculable space of time, which was mole than a hundred thousand millions of years. This Kami had many successors, whose reigns were nearly as long. Their temples are still places of worship in Oomi and Ise, districts of Japan. There are seven dynasties of celestial gods. The last, Tza-na-gi, standing on a bridge that floated between heaven and earth, said to his wife, "Come on; there

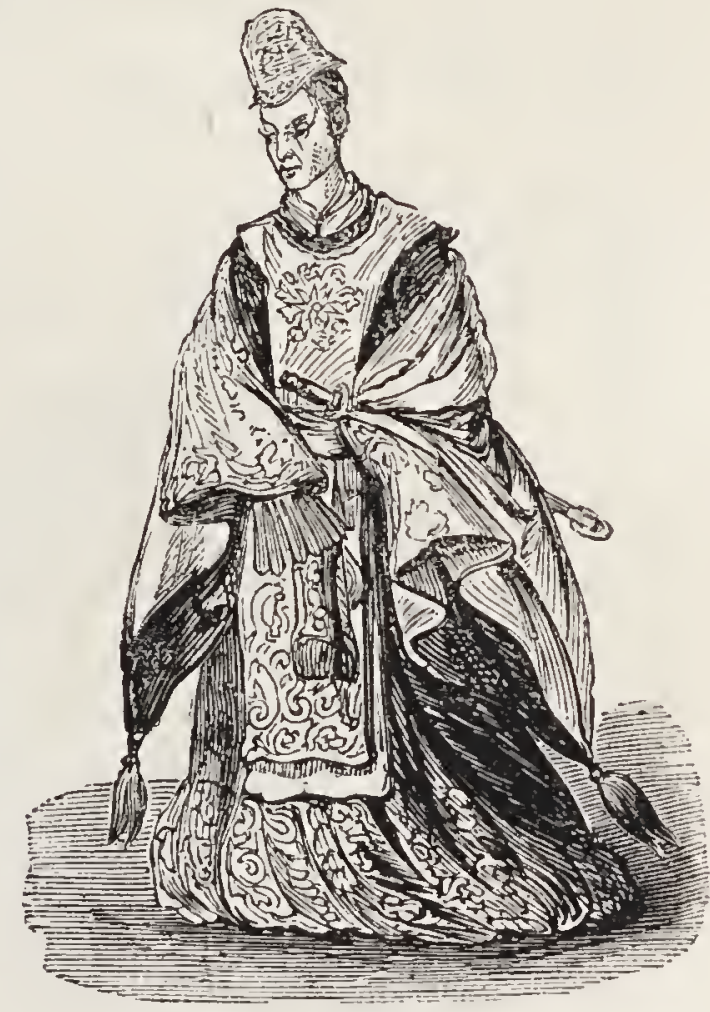

JAPANESE GENTLEMAN. mist be some habitable land; let us try to find it." He dipped his spear, ornamented with precious stones, into the surrounding water's, and agitated the waves; the drops which fell from his spear, when he raised it, thickened and formed an island, named Ono-koro-sina.

964. On this island Tza-na-gi and his wife descended, and made the other provinces of the Japanese Empire. From them descended the five dynasties, or reigns of earthly gods. From the last of these originated Tin-me-teu-mco, the ruler of men, who founded the Empire of Japan, and conquered the aboriginal tribes. From Tin-moo's reign is dated the first year of the epoch of Japanese chronology, B.C. 660. 
"Behold all souls are mine; as the soul of the father, so also the soul of the son is mine; the soul that sinneth, it shall die."-EzEkIEL xviii.

Such is the "Creation" of the Japanese. Their highest adoration is given to the Deity of the Sun; to him are subordinate all the genii and demons which govern the elements, and all the operations of nature, as well as the souls of men, who after dcath go to the gods, or to an infernal place of punishment, according to their actions on earth. Sacied festivals are licld at ccrtain seasons of the year, and at changes of the moon. The whole number of Kamis or gods worshipped by the Japanese amounts to three thousand one hundred and thirty-two. These gods are worshipped in different temples, without idols.

\section{What are the Five Great Nomadic Races?}

'They are the Ugorian, the Turkish, the Mongolian, the T'ungusian, and the Bhotiya. These various races have wandered over eontiguous regions from immemorial times; they are nearly on a level in regard to their social state. and progress in the arts of life; their moral charaeteristies, manners, and habitudes, are similiar; their religion and superstitions were in early times the same. Their languages display a family relationship.

966. Though two of their princes, a Turkish and a Mongolian Khan, have compiled the history of the Turkish and Mongolian races, and claim to have traced them from the creation of the world, it cannot be said with truth that the nomadic people of Central Asia possess any memorials of their origin. Their principal historiansthe onc a Mrussulman, the other a worshipper of Buddha-connect the origin of their respcctive races, the first, after the mamer of all Mohamcdan writers, with the particulars of the Old Testament, the other with the incarnate gods, or divinc sagcs of India, celcbrated in the fables of Buddhism. It is, however, remarkable that some extensirely spread traditions, which are more or less interworen in all their accounts, and have been collected from very distant times and places, seem to display an obscure reminiscence of the arrival of somc fugitirc bands from a remote region, who, having been sared from destruction by lighlit into the wilderness, became in progress of time the patriarchs of the nomadic tribes.* 
"When the wicked man turneth away from his wickedness that he liath committed, and doeth that which is lawful and right, ho shall save his soul alive."-EzekIEL xviii.

967. Why is the Third Tijpe denominated Ethiopian?

Because the primitive tribes were the occupants of Ethiopia (the ancient name of Africa), or the country of the dark-skinned. The Ethiopian embraces the African central tribes, and their varieties, the Negroes of Western Africa, and the Kaffirs of the South.

968. The Central Africans are marked by an elongated narrow cranium, crisp and curly hair, projecting jaws, thick lips, and black or dusky skin.

969. In the Negro the skull is narrow, or compressed at the sides, and elongated from front to back, the dome allehed and dense, the forchead convex, retreating, and narrow; the cheek-bones project forward; the bridge of the nose is small and flat, the nostrils round and wide; the mouth wide with thick lips; the hair crisp, woolly, scanty on the upper lip, and the beard chiefly confined to the point

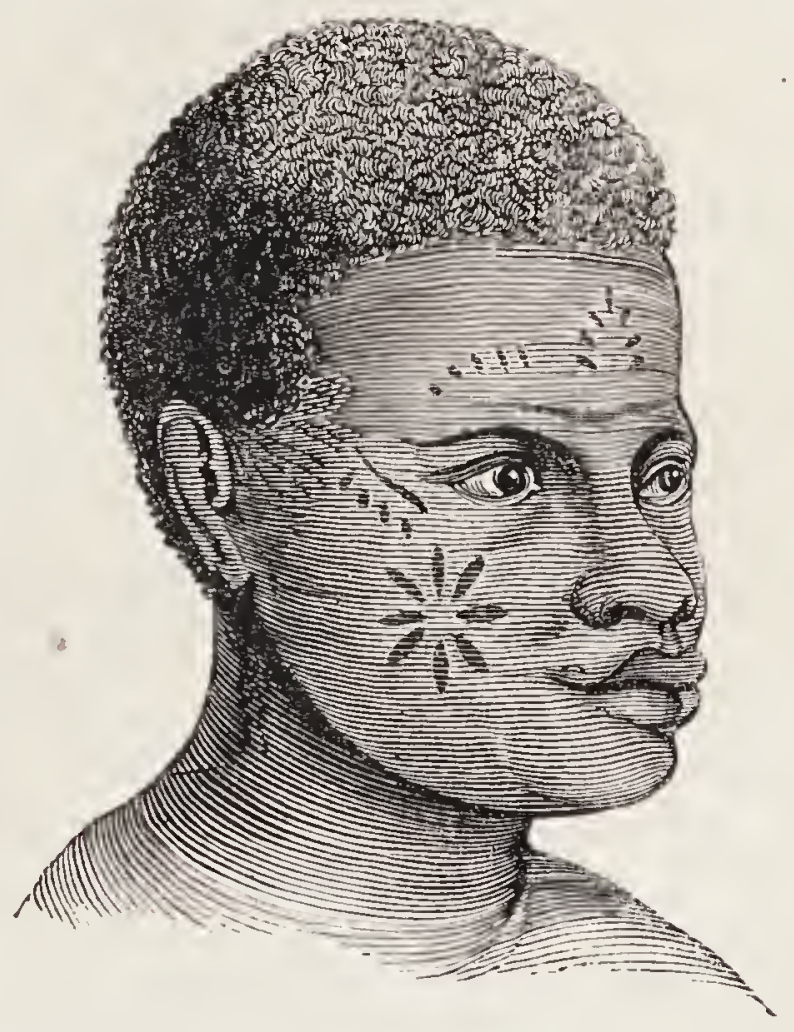

NEGRO. of the chin; feet broad and heavy, and the soles flat.

970. In the Kaffir the cranium rises ligher, and is more rounded than in the Negro; the cheek-bones project, the 
"How doth the city sit solitary that was full of people! how is she become as 2 widow! she that was great among nations, and princess among provinees, how is she become tributary!"-LaueNT. i.

eyes are small and dark, the eyelids occasionally oblique, the face tapers towards the chin, and the jaws are much less prominent than those of the Negro.

971. Among the races of Africa we find the extremes of human stature and development. We may instance the Hottentots, amongst whom four feet is the average height of the female, and four and a half feet that of the male. The Bushmen are even of smaller stature. But the Kaffirs are a strong and powerful race.

972. What are the moral characteristics of the Ethiopians?

Of the inhabitants of Africa the first and lowest in the scale of human knowledge and plyysical configuration is the Ilottentot, inhabiting the southern extremity of the continent; the-next, and far above him, is the Iaffir, extending his dominion from Natal probably as far as the Tropies; and the Negro, whose natural limits seem to be from Senegal to $16^{\circ}$ south of the Equator.

973. One of the most important and interesting facts established by Messi's. Speke and Grant during their recent African explorations, is that the Ethiopians everywhere become attached and faithful servants, wherever they find just and liumane masters. Among the European settlements the tenets of the several churches are practised with becoming sincerity, but among the native tribes the religion is only a rude incantation.

974. If we trace the intervening conntries between Egyst and Senegambia, and carefully note the physical qualities of the inhabitants, we shall have no difficulty in recognising alnost every degree or stage of deviation necessarily displayed, and showing a gradual transition from the characters of the Egyptian to those of the Negro, without any broadly-marked line of abrupt separation. The characteristic type of one division of the human species here passes 
"There is no man that hath power over the spirit to retain the spirit; neither hath he power in the day of death: and there is no discharge in that war; neither shall wickedness deliver those that are given to it."-Ecchesiastes viii.

into another, and that by almost imperceptible degrees. This gradual change is not the result of intermixtures of races on the confines of regions of old allotted to each other serarately. The intermediate tribes are not Mulattoes, nor do they resemble them; they have each their distinguishing features, which, besides their distinct lauguages, inark them as separate and peculiar laces.

\section{What are the Eastern Nubians?}

'They are a people of the Ethiopian type, wandering inliabitants of the country between the Nile and the Red Sea. The northern division of this race spread northward in the Eastern desert as far as Kosseir, and towards the parallel of Deir, bordering on the Bishari. The Bishari reach thence towards the confines of Abyssinia. The Mountain of Offir is their chief seat. The Hadharebe are still further southward, and reach to Soakin, on the Red Sea. The country of the latter contained many Christian churches or religious establishments prior to the devastation of Northern Africa by the apostles of Islam. The present Bishari are extremely savage and inhospitable; they are said to drink the warm blood of living animals; they live on flesh and milk.

\section{What are the Berberines?}

They are the Nubians of the Nile, a people well known in Egypt, whither they resort as labourers, from the higher country of the Nile. They derive their name from the valley which they inlıabit. They are a people distinct from the Arabs and all the surrounding nations. They inhabit the banks of the Nile, and wherever they can find a soil they plant date-trees, and cultivate various plants. At Cairo, whither many of them resort, they are prized for their honesty.

977. The native Nubians are of many shades of colour, from intense black to reddish brown. In temperament they are bold, frank, 
"Wislom is better than weapons of war: but one sinner destroyeth mucl good.'-ECCLESIASTES ix.

and cheerful, and more simple in their customs and incorrupt in their

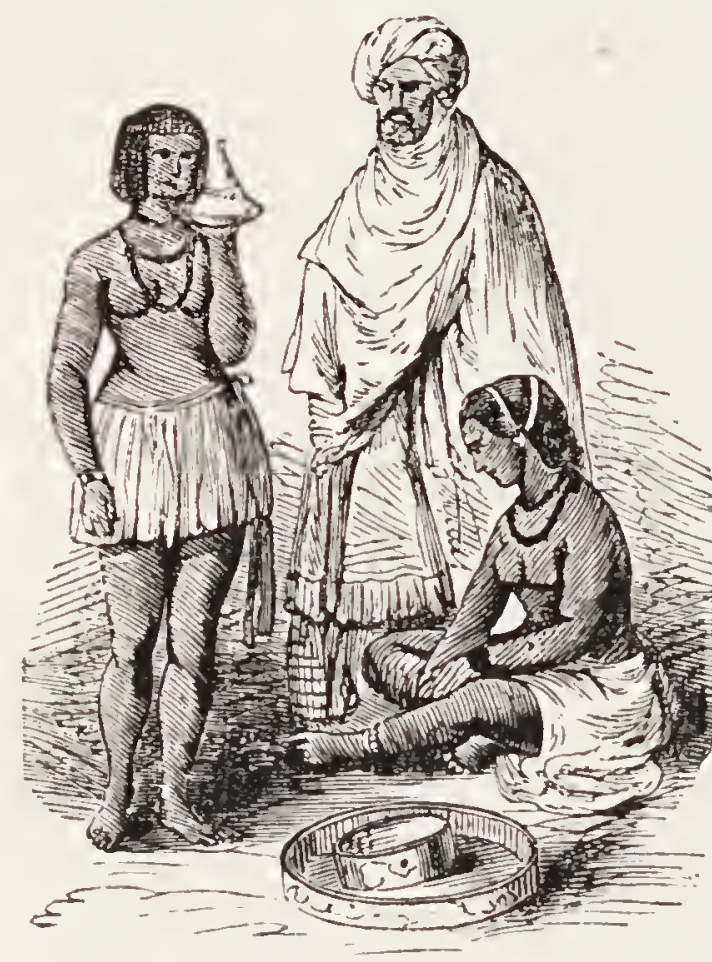

NLBI.1 S. manners than their veighbours in the countries south, cast, or west of them. The dress of the better elasses consists of a vest without sleeves, their heads are uncovered, and their feet are bare. The common people wrap a piece of cloth about their middle, or wear a short kirtle, but their ehiefs adopt a flowing mantle of cotton reaching to the feet. The grain on which they eliefly live is a kind of millet. Their habitations are low, with eartl walls, roofed with reeds, and almost always ereeted under date-trees. They avoid living in large eommunities. Their religion is in many places Malrommedan, in many others idolatrous, and, in some few which have been the scene of missionary labours, Christian.

975. What are the Abyssinians?

They are a finely-formed people, inluabiting the highlands of Abyssynia, and, although reckoned among the black races, are divided into types allied to both the Ethiopian and the European, the latter haring featiures precisely resembling those of the Beclouins of Arabia. The female Abyssinians are said to be the most beautiful of all black women.

979. What are the Race of Galla?

'They are a people extensively spread in Eastern intertropical Africa, who have become very formidable by their numbers during the last century, and threaten to orerwhelm the Abyssinian Empire. In their bodily conformation they hold an intermediate place between the Arabian and 
"Sow to yourselves in righteousness, reap in mercy; break up your fallow ground: for it is time to seek the Lord, till he come and rain righteousness upon you." HoseA X.

the Negro. They are a wild and barbarous people, principally wandering herdsmen. The extent of their country is unknown. They consist of numerous tribes that are independent of each other, but united by a common origin and language. Female government, according to ancient Ethiopian custom, exists among them, some of their tribes. being ruled by women of warlike spirit.

980. Their religion resembles that of the Kaffirs. They worship a Supreme Being, termed by them Wak, whose priests go about carrying a whip and bell with them, and with the intestines of goats twisted round their necks, making strange gestures, and uttering unintelligible sounds. Like the Ghamanists of the Siberians, and the consecrated orders of more illustrious nations, they are wizards, conjurors, gainsayers, augurs, haruspices, and physicians. Like the ancient Greeks, Etruscans, and Romans, they divine by inspecting the entrails of goats. Occasionally they pray to Wak, and accept from lim the accomplishment of their benedictions and anathemas. They have no distinct idea what Wak is, but to his priests he reveals limself in dreams. Their oaths are thus sworn :-they sit down upon a pit covered with a hide, and imprecate upon themselves that, if they do not perforn. their vors, they may fall into such a pit. They have funeral ceremonies, and believe in a future state, which is one of moral retribution. Their occupations are agriculture, as well as pasturage.*

\section{What are the Soudanian Races?}

They are the nations of blacks inhabiting the interior of Africa. The inhabitants of Africa are not all negroes: the latter term expresses an ideal type already described. In the nations of the interior of Africa, the features of the negroes of Guinea are scarcely to be recognised. The people who inhabit the interior of Africa have their heads covered with long woolly, or rather bristly hair; they wear rings of bone around their arms, and in their eyes; and around their necks they wear chains formed of the teeth of enemies they have slain in battle; they wear also teeth

* Isenberg. 
"The Lord is slow to ancer, and great in power, and will not at all aconit the wicled: the Lord lath his way in the whirlwind and in the storm, and the clouds are the clust of lis feet."-Nall $\mathrm{CM} \mathrm{i}$.

and pieces of bone, attached to locks of their hair; mark their bodies with patches of red colour, and stain their tecth. 'The physical characters of the people differ considerably. The Bornawi are more like the ideal Negro than the natives of Haüsa, the latter being very liandsome, possessing open and noble countenances, prominent noses, and expressive black eyes.

982. What are the Senegambian Nations?

The Senegambians are the nations that populate that part of Africa which contains the rivers Senegal and Gambia. The valleys of these river's form the mative land of the most powerful, numerous, and intelligent of the Africans. The

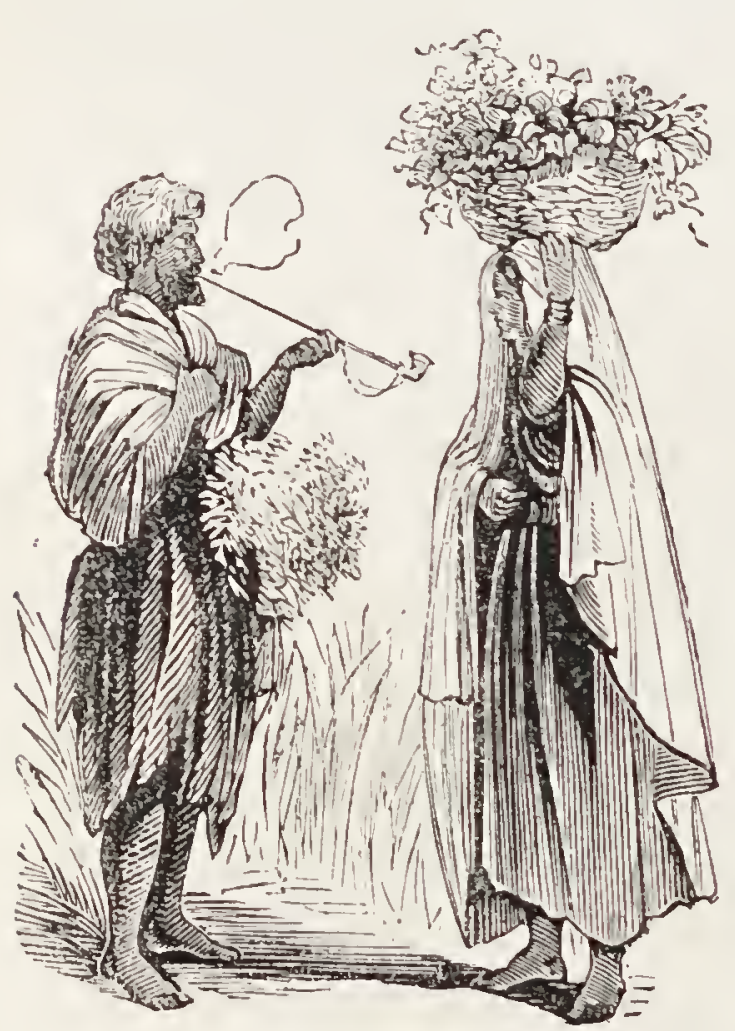

FULAHS. Senegambian nations are divided into the Mandingos, the Tolops, and the Fulals. The first are remarkable for their industry, and have greater encrgy of character than other intertropical races. They are zealous disciples of Islam, and remarkable for their abstinence from intoxicating liquors. The 'Tolops are a people of mild social character', and are described as remarliably beautiful, their features resembling those of Europeans, except that their lips are rather thick.

983. The Fulahs inhabit the border of Senegambia, about the sources of the Rio Grande, a vast slope which 
"Who is the wise man? and who knoweth the interpretation of a thing? a man's wisciom maketh his face to shine, and the boldness of his face shall be changed."ECCL estastes viii.

looks towarls the setting sum, and is cooled by the higher currents flowing from the Atlantic. 'They constitute one of the most remarkable nations in Africa. Timbri, their capital, is, like ancient Rome, a military station, or centre of conquests. Its population numbers about 9000 . This city is surrounded in part by dry and rocky deserts, and partly by mountain pastures, which feed numerous flocks of sheep and goats, and herds of oxen and lorses, unknown in the lower regions. 'The inhabitants of this Alpine country, who differ physically from the natives of the lower region, cultivate their soil with industry. 'They forge iron and silver, work skilfully in leather and wood, and fabricate cloth. They have clean and commodious dwellings, and have laal mosques and schools in their towns, since Islam. was introduced among them.

\section{What are the Saabian Races?}

The IIottentots and Bushmen have among themselves this. national appellation. South Africa, the region which they inhabit, abounds in beautiful heatlis, aloes, euphorbias, and innumerable flowering slurubs, which strikingly resemble the botany of Tasmania. The original Hottentots were herdsmen, and, clothed in sheepskins, they followed their flocks, roaming from place to place, and beguiling their movements with

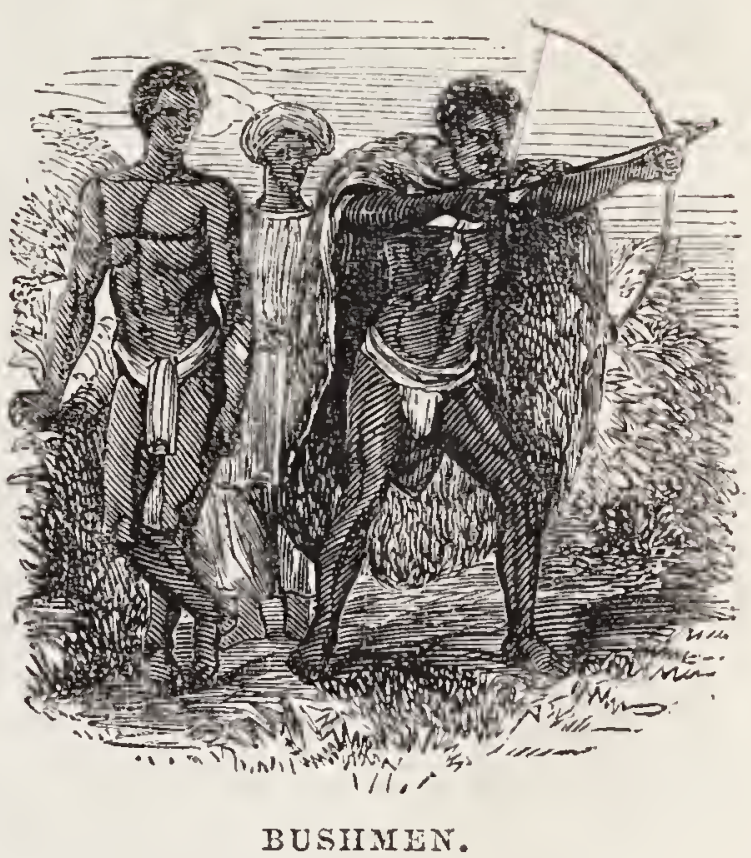

BUSIIIEN.

a monotonous but plaintive song. Their wealth consisted 
"Speak ye every man the truth to his neighboul; execute the judgment of truth and peace in your gates: and let none of you imagine evil in your hearts against his neighbour ; and love no false oath : for all these are things that I hate, saith the Lord." -Zecilariah viji.

in their herds, and in the simple utensils which they carried upon their paek-oxen, and their temporary dwellings were composed of the boughs of trees and mats. Other tribes, less fortunate than the first, lived wholly in the woods, upon the scanty sustenanee which ehance brought within their grasp. Without eattle, their only art was that of shooting with poisoned arrows animals which they could not surprise by their natural eraft, and their ahnost supernatural quickness in the chase.*

985. The Bustomen were the outcasts of the more quiet and inactive lierdsmen. They were robbers-their hand was against crery man, and they suffered reciprocally the injuries whieh they inflieted. Their deseendants are of small stature and dirty yellow colour ; their countenances repulsive; a prominent forelead, small deeply-seated and roguish eyes, a much depressed nose, and thick projecting lips are their characteristic features. Their constitution is so mueh injured by their dissolute habits, and the constant smoking of durha, that both old and young look wrinkled and decrepid; nevertheless they are fond of ormament, and decorate their ears, arms, and legs with beads, iron, copper, or brass rings; the women also stain their fices red, or paint them wholly or in part. Their only clothing, by day or nimght, is a mantle of sheepskin thrown orer their bodies, which they term a kaross. 'The dwelling of the Bushman is a low hut or cireular cavity on the open plain, into which he ereeps at night with his wife and ehildren, and which, though it shelter's him from the wind, leares him exposed to the rain. They had formerly their habitation among the 
"Son of man, they that inhabit those wastes of the land of Israel, speak, saying, Ablaham was one, and he inherited the land; but we are many; the land is given us fur inheritance." -EzEKIEL sxxiii.

rocks, in which may still be seen rude figures of lorses, oxen, or serpents.*

986. Associated with the Bushmen, Dr. Livingstone found a tribe of Bakalahari. The former, he says, are probably the aborigines of the Southern portion of the continent, the latter the remnants of the first emigration of Bechunas. The Bushmen live in the desert from choice, the Bakalahari from compulsion, and both possess an intense love of liberty. The Bushmen are distinct in language, race, habits, and appearance, and are the only real nomads in the country. They never cultivate the soil, nor rear any animal, save wretched dogs. They are intimately acquainted with the habits of the game, and chiefly subsist upon their flesh, eked out by the roots and beans and fruit of the desert. Those who inhabit the hot sandy plains have generally thin wiry forms, and are capable of great exertion and of severe privations. Many are of low stature, though not dwarfish. The specimens brought to Europe have been selected, like costermongers' dogs, on account of their extreme ugliness. $\dagger$

\section{What are the Kaffers?}

They are the warlike nomadic tribes who inlabit or wander in the plains of Southern Africa. The name was first given to them by the Arab voyagers, who so termed all savage nations, and all nations unconrerted to Islam; from the Arabs it was adopted by the Portuguese and Dutch, and at last became a general appellation. The Dutch used this name in a vague sense, applying it to nearly all the uncivilized nations of South Africa. In later times the eastern people have been termed Kaffirs, to the exclusion of the Mottentots.

988. The Kiaffirs are a tall, well-formed people, liaving regular features and well=developed foreheads, with skins varying from black to copper colour, and crisp woolly hair like that of the negro. They are, upon the whole, a very superior people to the destitute sarages

* Adolph Bonatz.

+ Missionary Travels and Researches in South Africa.

$\ddagger$ Prichard. 
"The fishes of the sea, and the fowls of heaven, and the beasts of the field, and all creepinr things that creep upon the earth, and all the men that are upon the face of the earth, shall shake at my presence, and the nountains shall be thrown down, and the steep places shall fall, and every wall shall fall to the ground."-EzEkIEL xxxviii.

who oecupy the insulated hamlets of central Negroland. They are associated in large communities under ehiefs or kings; they are seminomadie, although living in towns of considerable size and population resembling camps, which they occasionally more. Their clothing is

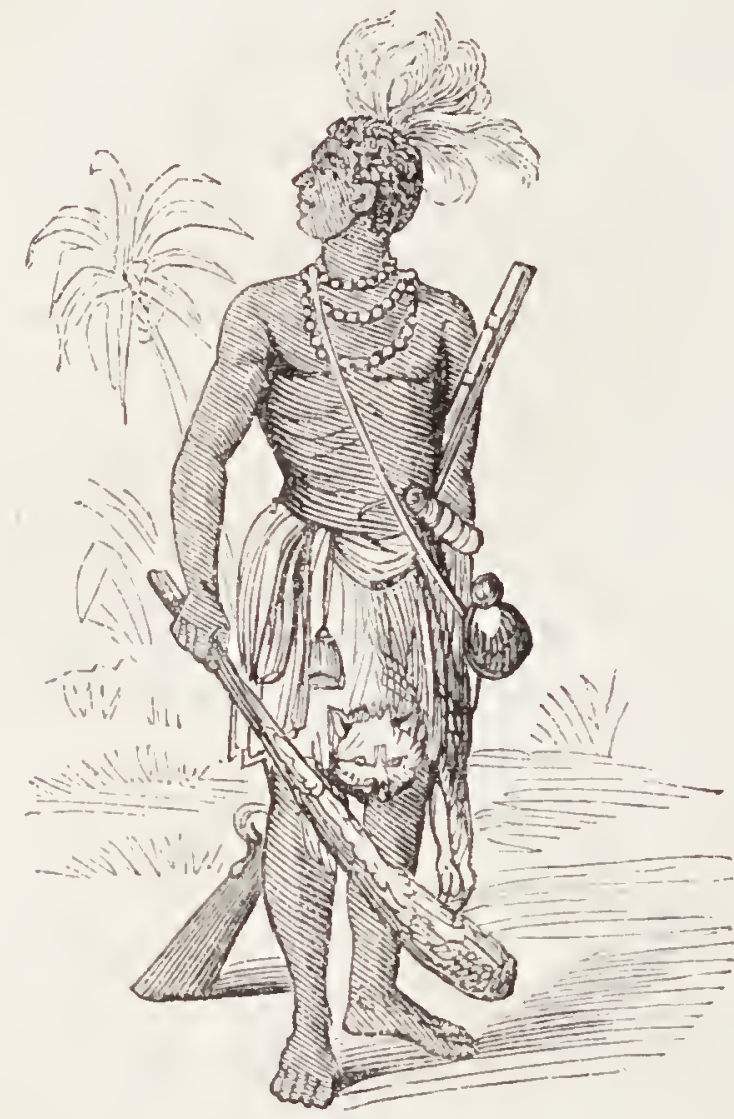

IAFPII. scanty; the men wear mantles, and the fcmales a more eomplete covering, of tamned skins. The Kaffirs have considerable herds of cattle; they practice agrieulture, have fields and gardens, eultivate maize, millet, kidney-beans, and watermelons; make bread and beer; and manufacturc earthenware out of sand and clay baked in fire. They are aequainted with the use of iron and copper, and lave the art of working these rnetals, and of mamufaeturing articles of use and ornament. In the latest Kaffir war many of them were found to have obtained and learnt the usc of fire-arms. They are not, as some have thouglit, destitute of religion. They believe in a Supreme Deing, to whom they give the appellation of Uhlunga, the "Supreme," and frequently the Hottentot name Utika, or "Beautiful." They belicve in the immortality of the soul, but have no idea of a state of reward and punishment. They pray for success in war and in hunting expeditions, belicve in the attendance of the souls of deeeased relatives, and occasionally invoke their aid. They eonceive thunder to proceed from the agency of the Deity, and if a person has been killed by lightning say that Uhlunga has been among them. On suel occasious they sometimes remove from the spot, and offer a hcifer or an $o x$ in sacrifice.**

989. On crossing the Orange River we enter an independent 
"And many of then that sleep in the earth shall swake, some to everlasting life, and some to shame and everlasting contempt." - DANILL xii.

territory, inhabited by Griquas and Beehunas. By Griquas is meant any mixed race sprung from natives and Europeans. These were of Duteh extraetion, through assoeiation with Hottentots and Bushwomen. Half-eastes of the first generation consider themselves superior to those of the seeond, and all possess in some degree the eharacteristies of both parents. Many hundreds of both Griquans and Bechunas have beeome Christians, and partially civilized, through the teaching of English missionaries. My first impression was that the accounts of the effeet which the Gospel had ind upon them were too highly eoloured. When, however, I passed on to

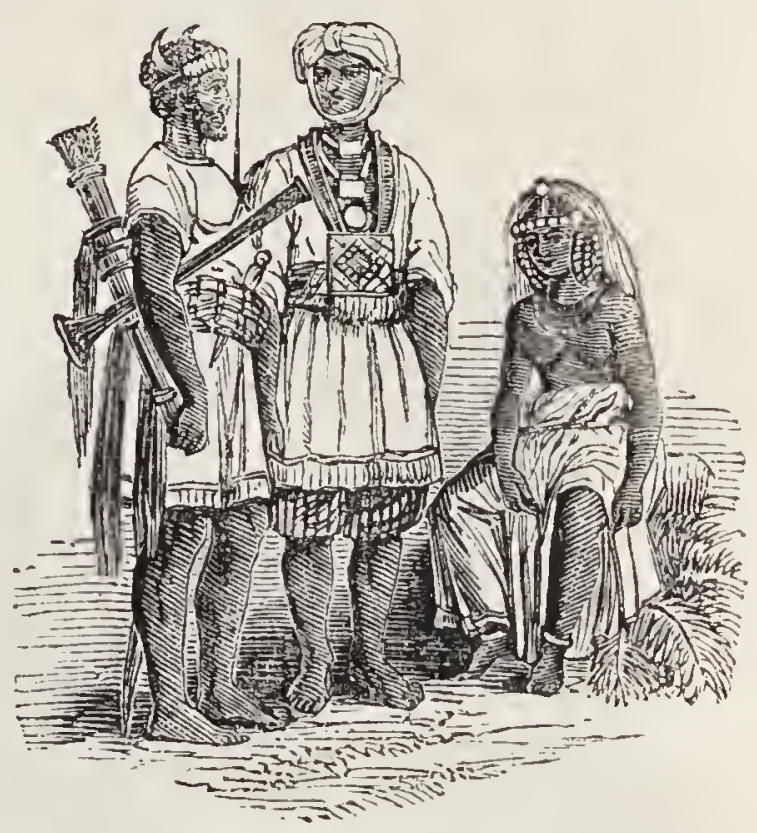

GRIQUAS AND BECHUNAS. true heathens in eountries beyond the spluere of missionary influence, I came to the conclusion that the ehange prodneed was unquestionably great.

990. The Griquas and Bechunas were in former times elad mueh like the Caffres, if the expression may be used when there was searcely any elothing at all. A bunch of leather strings about eighteen inehes long hung from the lady's waist in firont, and a prepared skin of a sheep. or antelope eovered the shoulders. The breast and abdomen were left bare. The men wore a patel of apron about as big as the erown of a liat, and a mantle exaetly like that of the women. To proteet the skin from the sun by day, and from the eold by night, they smeared themselves with a eompound of fat and oehre; the head was anointed with pounded blue nica sehist, mixed with grease. The partieles of shiniug miea, as they fell on the body, and on strings of beads and brass rings, were eonsidered lighly ornamental. They now eome to chureh in decent clothing. Sunday is well observed, and, even in localities where no missionary lives, religious meetings are regularly held, and ehildren and adults taught to read by the more adranced of their fellowcountrymen.* 
"Seek ye the Lorl. all ye meek of the earth, which have wrought this judgment; seek righteousness, seck meehness; it may be ye shall be hid in the day of the Lord's anger." - ZEPHANIAH ii.

991. Why is the American type so called?

Because it includes the Aboriginals of the American continent. Although distributed orer very wide latitudes and exhibiting considerable diversity of form, they have it

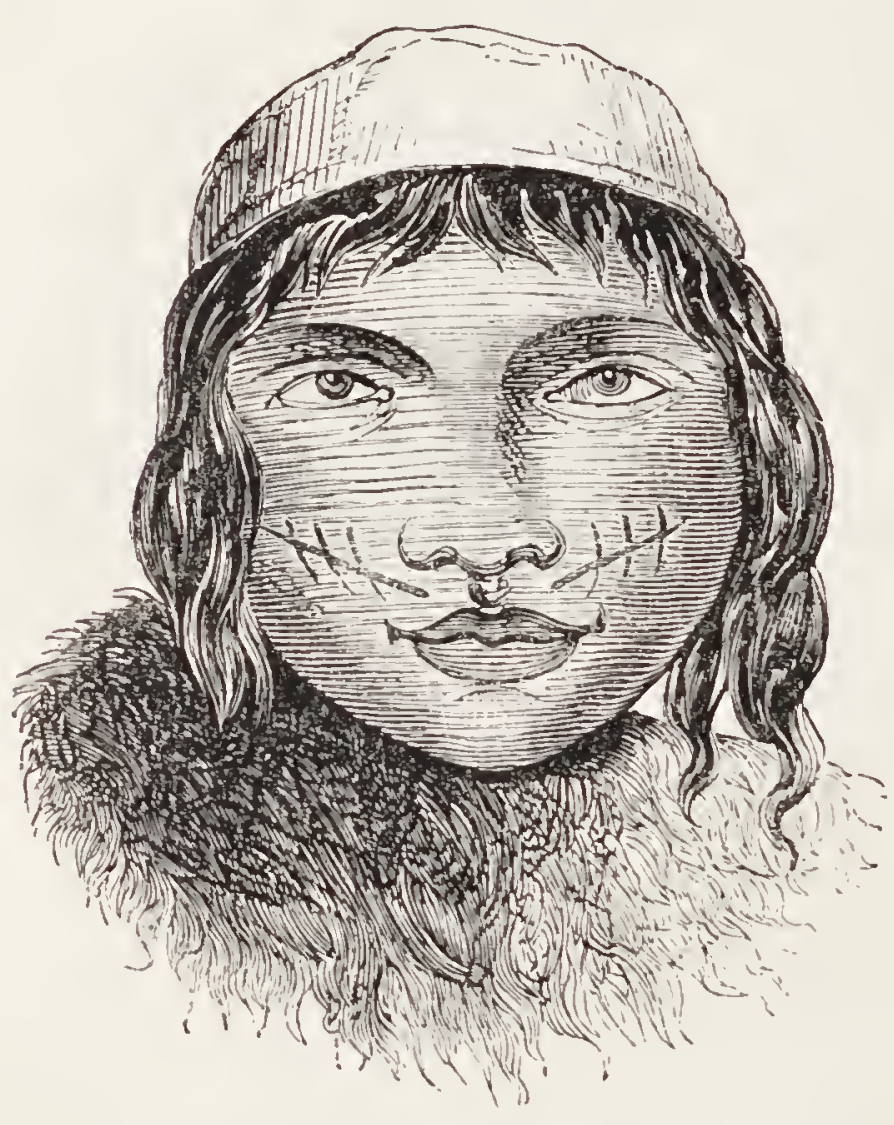

1IIIRICAN WOMAX. general physical aspect, which is common to the whole. The cheekbones arc higrl, and the forehead rather low and retreating; the nose prominent, not unSequently aquiline; jaws powerful, mouth large, lips full ; eyes small,deep-set,and black; hair coarse, black, and rather scanty; the beard stunted; skin copper coloured and glossy in some of the Northern tribes, and of a yellowishred, light brown, and sallow hue in the various tribes of: the Soutl. This type includes all the American Aboriginals, except the Esquimaux, which are Mongolian.

992. The aboriginal people of America are generally considered as a branch of the human family very distinct from the inhabitants of the old World. On comparing the American tribes together, we find reasons for belicving that they must have subsisted as a separate department of nations from the carliest ages of the world. These nations are called "Red Men;" but there are tribes equally red, 
"Thus speaketh the Lord of hosts, saying, Execute true judgment, and shew mercy and compassion, every man to his brother : and oppress not the widow, nor the fatherless, the stranger, nor the poor; and let none of you imagine evil against his brother in your heart." -ZECHARIAII vii.

perhaps more properly deserving that appellation, in Africa and Polynesia. And among the Americans some tribes are as white as many European nations; others brown or yellow; others very much resemble in colour the Negroes of Africa.*

993. No subject has been more attentiveiy investigated than the question how America became peopled; and though it is now considered settled that the aborigines found their way to the New from the Old World by the Asiatic stepping-stones of Beliring's Straits, the question is far from being determined; for, if all had migrated that way, we miglit have expected to have fonnd one race, and one colour of people, pervading the entire length of eitlier Continent. Instead of that, we find no races in other parts of the world more dissimilar than is the red hunter of the prairie to the mild, orderly, yellow-skimned Peruvian; that is, before corrupted by the white man, and when each had a distinctive type. Nor will this theory of Behring's Straits explain the anomaly of complexion found along both seaboards of either America, or explain why there were African types in latitudes directly opposite Africa, and nearly black men on the west in a line with New Guinea.

994. Why is it believed that the Native American Nations have fallen from a Higher Degree of Mental Culture into their present Barbarism?.

Because among many of the tribes are found the remains of ancient institutions indicating the pre-existence of some refinement, and an artificial state of society-such as a complicated form of government, regulated despotisms $\mathrm{or}^{\circ}$ monarchies, privileged orders, religious and legal ordinances, systematic laws connected with marriage, inheritance, and family relationships, and other customs which do not accord with the habits of rude and uncivilized nations. $\rceil^{\circ}$

995. The existence of ancient sculpture and architecture, spread over Mexico, Yucatan, and Chiapa, as well as over the high plain of Quito and other parts of South America, 
"Better is a poor and wise child than an old and foolish king, who will no more be admonished." - Ecclesiastes iii.

and the extensive works of art, consisting of fortifications and other relics, discorered in the Tennessee country, as well as in the inland parts of New Mexico, on the. Rio Gila, afford some further grounds for this opinion.*

996. What were the Toltecas and Aztecs?

The Aztecs, or Mexicaus, as well as their kinsmen and predecessors, the Toltecus, were a people who it is supposed cntered Mexico about 640 years after the Cliristian era; previous to which time the same region had been inhabited by various races, some of whom had arts and civilization, while others are said to liave been barbarians.

997. All the information the Spaniards have handed down of the early history of the Mexican people, is a loose tradition that, at a time equal to about our seventh century, the I'oltecas, a martial well-informed nation, descended from the north, and, dispossessing the inhabitants, became the masters of the country, which they continued to rule with wisdom and power for about 500 years, or till the twelfth century, when a mighty people, called the Aztecs, coming also from the north, attacked and drove out the 'Toltecas, and established their sway orer the Mexican country, the new invalers being highly civilized, and learned in most of the then existing mechanical arts. But that which distinguished them from all other nations, ancient or modern, was the art of picture uriting, a system of pictorial hieroglyphs, by which they recolded their national history, and such erents as were deemed fit to hand down to posterity.

998. Of late years the ruins of Aztec cities have been discovered in Central America, and in them temples, palaces, 
"The Lord is just in the midst thereof; he will not do iniquity ; every morning doth lie bring his judgment to light, lie faileth not; but the unjust knoweth no shame."-ZEPH. iii.

idols, and buildings, that for centuries have lain hidden in impenetrable forests, or buried beneath the abundant vegetation of some sequestered dell or dark ravine. These relics of a people and an empire long passed away, who enjoyed a high state of civilization long prior to the European knowledge of America, fill the contemplative mind with wonder.

999. The portrnits of the ancient Aztecs, and some of their divinities, are remarkable for the depression of the foreheut, giving a small facial angle; and this is a form which seems to have entered into the beau idéal of the race, and which many other Ame-

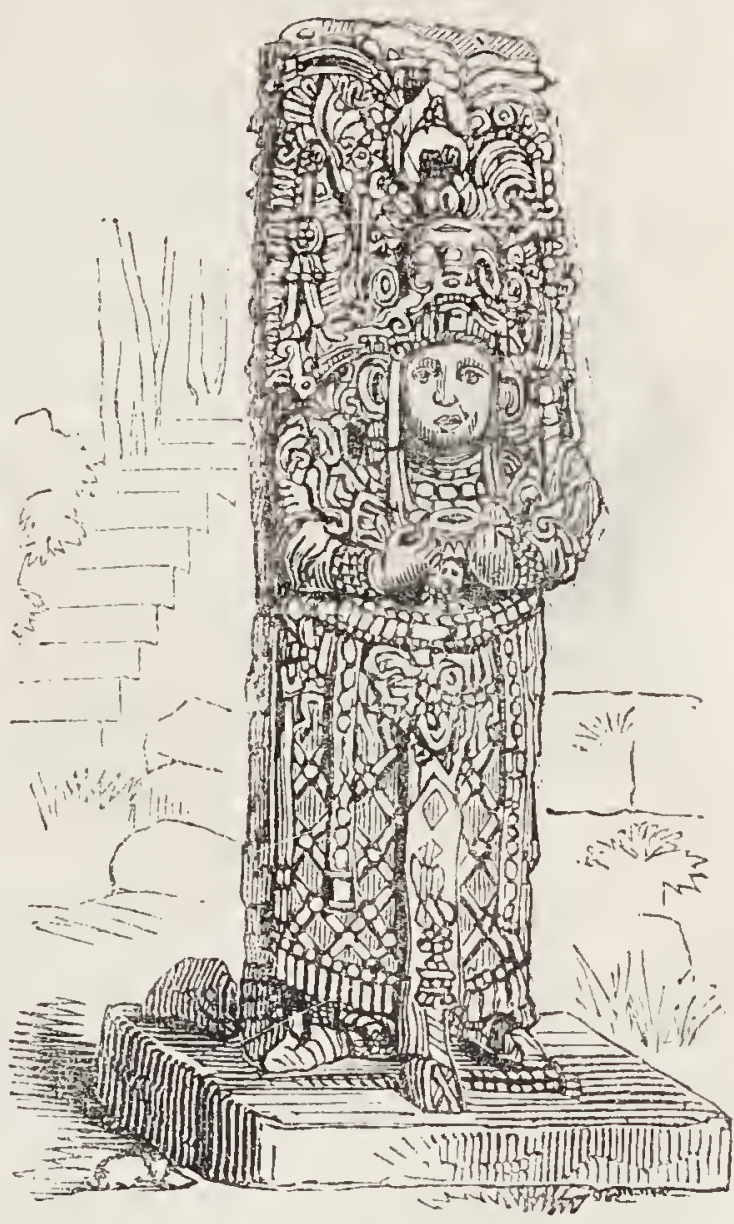

ANCIENT NEXICAN IDOL. rican nations imitate by artificial compression of the head.

1000. What are the Esquimaux?

They are an aboriginal tribe of North America, who may be traced nearly across the whole continent, from the Pacific to the Atlantic Ocean. Their name signifies "eater's of law fish." Though they liunt during their short summer, they are obliged to draw their principal sustenance from the sea, and consequently they are rarely found more than 100 miles from the sea coast. They inhabit the 
"The fool foldeth his hands together, and eateth his own flesh. Better is an handful with quietness, than both the hands full with travail, and vexation of spirit."-ECCLESIASTES iii.

shores of all the seas, bays, inlets, and islands of America, north of $60^{\circ}$ north latitude; from the eastern coast of Greenland, in longitude $20^{\circ}$, to the Straits of Behring, in longitude $167^{\circ}$ west. On the Atlantic, they reach eastward along the coast of Labrador to the

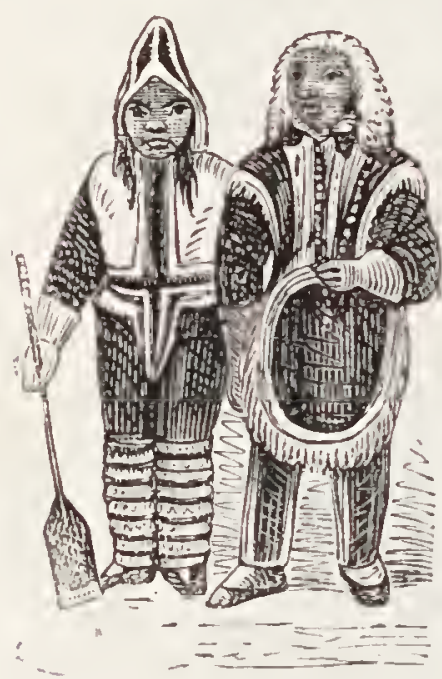

ESQUIMAUR. Straits of Belleisle, and within the Gulf of the River St. Lawrence. Towards the west they may be traced along the shores of the Pacific to the extremity of the Peninsula of Alaska, and thence to the neighbourhood of Mount St. Elias. The whole length of the coast peopled by the Esquimaux is computed to be not less than 5400 miles, without reckoning inlets of the sea.**

1001. Though inhabiting a country where the Red Skins, or Nortl American Indians, are their closest neighbours, the Esquimaux are in almost all physical points quite dissimilar, being of short stature, almost white in complexion, living chicfly on the fat or blubber of the whale, seal, and walrus, and dressed in seal-skins, which they sew together in extremely neat fashion, with thread made from filaments of the long nerves of the whale. They live either in carerns of the mountains or in huts made of sods and turf, and in the winter in round hovels constructed of blocks of snow, in the sides of which they insert sheets of ice, which answer for windows.

\section{What are the Chippervyans?}

They are another widely-spread nation in North America, 
"Who is wise, and he shall understand these things? prudent, and he shall know them? for the ways of the Lord are right, and the just shall walk in them : but the transgressors shall fall thercin." - Hosea ii.

called also Athabaskans, which designation is derived from the original name of the Lake of the Hills, and the adjoining country, which is the centre of the territory possessed by the tribes of this race. Like all Indians who live principally on fish, and who do not acquire the habits of activity proper to the hunting tribes, they are excessively indolent and filthy, and have a depraved character. They are fond of unctuous substances, and drink immense quantities of oil, which they obtain from fish and wild animals. They also besmear their bodies with grease and coloured earths. They like their meat putrid.

1003. There are, however, among them tribes that hunt and feed upon flesh; such are the Hare Indians, occupants of the valley of the River M'Kenzie, from Slave Lake to Great Bear Lake. Their condition is the most deplorable that can be imagined. They are almost entirely clothed in the skins of rabbits or hares, tagged together in the rudest fashion, with the ends of sinew. They have neither tents nor huts of any kind, living all the year round in the open air. They are a puny and stunted race, and are rapidly decreasing in numbers, and must soon disappear.

1004. There are also the Dog-Ribs, whose distribution lies due east of the Hare Indians. They live upon reindeer, which frequent their lands in great numbers, following the migrations of these animals as closely as if they formed part and parcel of the herd. They are almost entirely independent of the whites, and present a marked contrast with their neighbours of the Hare tribe. They are well clothed in the skins of the rein-deer, and have all the elements of comfort and Indian prosperity within 
"Though a sinner do evil an hundred times, and his days be prolonged, yet surely I know that it shall be well with them that fear God, which fear before Him."ECclestastes viii.

their reach. They are a healthy, vigorous, but not very active race, of a mild and peaceful disposition, but low in the mental scale, and apparently of very inferior' capacity. They receive the name of Dog-ribs from a curious tradition that they are descended from a dog.

1005. There are among some of these tribes very curious customs. Their religious ideas are very gross and confused; it is not knomn that they have any distinet ideas of a God or of the existence of a soul. They have priests or doctors, whose art eonsists in eertain mummeries intended for ineantations. When a eorpse is burned, which is the ordinary mode for disposing of the dead, the priest, with many gestieulations and eontortions, pretends to receive in his elosed hands something, perhaps the life of the deceased, which he eommunicates to a living person by throwing his hands towards him, and at the same time blowing upon him. This person then takes the rank of the deeeased, and assumes his name in addition to his own.

1006. If the deceased had a rife, she is all but burned alive with the corpse, being eompelled to lie upon it while the fire is lighted, and remain this till the heat beeomes beyond enduranee. In former times, when sho attempted to break away she was pushed baek in to the flames by the relations of her husband, and thus severely injured. When the corpse is eonsumed, she colleets the ashes, and deposits them in a little basket which she always earries about with her. At the same time she beeomes the servant and drudge of the relations of her late husband, who exaet from her the severest labour, and treat her with ever'y indignity. This lasts for two or three years, at the end of which time a feast is made by all the kindred, and a broad post, fifteen or twenty feet high, is set up and covered on the sides with rude daubs representing figures of men and animals of various kinds. On the top is a box, in whieh the ashes of the dead are plaeed, and allowed to remain until the post deeays. After this ceremony the widow is released from her state of servitude, and allowed to marry again.*

1007. What are the Alagonkin, Lenape, and Iroquois Races?

They are Indian tribes descended from those who 
"Whatsoever thy hand findeth to do, do it witl thy might; for there is no work nor device, nor knowledge, nor wislom, in the grave, whither thou goest." Ecchesiastes ix.

inhabited part of Canada, and the country, now belonging to the American States, eastward of the Mississippi. The Iroquois were a people distinct from the Alagonkins, but similar to them, yet they waged perpetual warfare with each other. The Alagonkins are distributed east and west from the Rocky Mountains to Newfoundland; north and south from Labrador to the Carolinas.

1008. Before the arrival of the Europeans, the Iroquois were dominant over their Alagonkin neighbours; but after the Europeans had settled in the New World, the Iroquois warriors were more feared than those of the Alagonkins. At present the Troquois are encompassed by Alagonkins, so as to have become isolated in respect to the other classes of Indians, and cut off from contact with them. They occupy the parts about and between Lakes Huron, Ontario, and Erie, and North Carolina, and are in one part separated by tribes of the Alagonkin division, especially the Delaware Indians. It was with the Delawares that William Penn made his celebrated treaty.

1009. The Iroquois and Alagonkins exhibit most strongly the characteristics of the North American Indians, and are the two families upon which the current notions respecting the physiognomy, habits, and moral and intellectual powers of the Red race are chiefly founded.*

\section{What are the Ojibways?}

The Ojibways, also called Chippeways, are a tribe of the northern branch of the great Alagonquin family, of which there are numerous other subdivisions. Their present geographical situation is around Lake Superior, extending north-west towards Lake Winnipeg, and west to Red River. 
"Why dost thou judge thy brother? or why dost thou set at nought thy brother? for we shall all stand before the judgment seat of Christ. For it is written, As I live, saith the Lord, every knee shall bow to me, and every tongue shall confess to God." liomans xiv.

1011. In a politicai point of view the Ojibways are more important to Great Britain than any other American tribe residing within the territory claimed by this kingdom. They are composed of about thirty bands, each having at its head a chief, and they are all subservient to one supreme head.

\section{What are the Cherolices?}

It is probable that originally they were a branch of the Iroquois. At present they occupy the valley of the Tennessee River. They constitute one of the few so-called savage nations which are increasing rather than decreasing in numbers.* They are also the most industrial of all the American families, Cherokee landholders having in some cases as much as five hundred acres under tillage, and possessing slaves. They have now a written language, written laws, and seem likely to improve in civilisation, and to preserve their name to future ages, and prove that the native races of America are capable of receiving and appropriating the blessings of Christianity. $\dagger$

1013. The males of the Cherokees, and the sub-tribes of Muscogulges, Seminoles, Chicasaws, Choctaws, and confederate tribes of the Crecks, are tall, erect, manly, and robust; their limbs well shaped, so as to for'm a perfect lruman figure; their features regular, and countenance open, dignified, and placid, with an air of heroism and bravery; the eye, though rather small, yet active and full of fire, the iris always black; and the nose somewhat aquiline. Their complexion is of a reddish brown or copper colour; their laair long, lank, coarse, and black as a raven, and reflecting the like lustre at different exposures to the light. The women of the Cherokees are tall, slender, erect, and of delicate frame; their features formed with perfect symmetry; the countenance cheerful and friendly; and they move with pleasing grace and dignity. Some of their young women are nearly as fair and blooming as European women. $\ddagger$

* Latham.

+ Prichard.

$\ddagger$ Bartram. 
"All flesh is not the same flesh : but there is one kind of flesl of men, another Iesh of beasts, another of fishes, and anotlier of birds." - I. Corinti. xv.

1014. The Cherokees are laying out fine farms and building good houses, in which they live, in many instances, surrounded by immense fields of corn and wheat. There is scarcely a finer country than that now owned by the Creeks; and, in North America, certainly no Indian tribe is more advanced in the arts and agriculture than they are.*

\section{What are the Sioux and Pawnees?}

They are Indian tribes of kindred stock, constituting one of the most widely-extended families of nations among the aboriginal races of North Ameriça. Their geographical area is Central North America, between the Mississippi and the Rocky Mountains, east and west; between Lake Winebago and the Arkansas, north and south; the valley of the Missouri, the valley of the River Platte, \&c.

1016. They constitute the third great division of North American Indians, and it is the division which comprises the tribes of the interior-of the Far West in opposition to the Sea Coast-of the prairie country in opposition to the tracts that are or have been forest-and of the foot of the Rocky Mountains. The country of the buffalo is shared between them and the Western Alagonkins. $\dagger$

1017. The trihes of Indians, whether east or west of the Rocky Mountains, cultivate nothing whatever, and those east of the Rocky Mountains subsist principally on the flesh of the buffalo. But, whether -erratic or agricultural, there is a marked difference between the habits and character of all the Indians who dwell amidst the dense forest which extends from the Atlantic to the Mississippi, and those of the inhabitants of the western prairie. These are everywhere less ferocious than those on the eastern side of the Mississippi. Like all savages, they put to death the prisoners taken in battle, but the horrid practice of inflicting on them the most excruciating torture for days together does not appear to have prevailed anywhere beyond the Mississippi.

1018. Dr. Say, during his residence among the Omahaws, a tribe of * Catlin. † Latham. 
" $A$ s by the offence of one judgment came upon all men to condemnation; eren sn by the righteonsness of one the free gift came upon all men unto justification of life." - Royuss v.

Sioux, gleaned some important particulars respecting them. They reside in their villages at most five months of the year, principally for the purpose of planting, cultivating, and gathering maize, and a few other regetables. Two winter months are employed by the men in hunting beaver and other fur animals. During the rest of the year the whole population remove to the buffalo, grounds, subsist on meat, and preserve some for future consumption. They address prayers to Wahconda, the Creator and Preserver of the World, to whom they ascribe infinite power and omnipresence. But, although they believe in a future life, it cannot be said that this vague belief has any important influence over theil conduct. Like all other Indians, they put faith in dreams, omens, and jugglers-in the power of imaginary deities of their orn creation, and of those consecrated relics to which tho Canadians have given the singular appellation of mediaic.*

\section{What are the Mandans?}

The Mandans are a division of the Sioux race, whom Mr. Catlin takes to be the descendants of Prince Madoc's Welsh army. The Mandans are remarkable for certain peculiar physical characters by which they are broadly distinguished from the Sioux, and other tribes of the same race.

1020. In the Mandan village, a stranger is struck at once by the different shades of complexion and various colours of hair which lie sees around him, and is at once almost disposed to exclaim, "These are not Indians." There are many of these people whose complexions appear as light as half-breeds; and amongst the women particularly there are many whose skins are almost white, with the most pleasing symmetry and proportion of fentures, with hazel, grey, or blue eyes; with mildness and sweetuess of expression, and excessire modesty of demeanour, which render them exceedingly pleasing and beautiful.

1021. The diversity in the colour of liair is also equally as great as t.1at in the complexion; for in the numerous groups of these people (and more particularly amongst the females, who nerer take pains to change its natural colour, as the men often do) there may be seen 
"Be not conformed to this world: but be ye transformed by the renewing of your mind, that ye may prove what is that good, and acceptable, and perfect will of God."-Romans xii.

every shade of colour of hair that can be seen in our own country, with the exception of red or auburn, which is not to be found.

1022. And there is yet one more strange and unaccountable peculiarity which can probably be seen nowhere else on earth; nor on any natural grounds accounted for, other than that it is a freak of Nature, for which she has not yet seen fit to assign a reason. There are very many, of both sexes, from infancy to manhood and old age, with hairs of a bright silvery grey, and in some instances almost perfectly white.

1023. This singular appearance is mucl oftener seen among the women than it is with the men; for many of the latter who have it seem ashamed of it, and artfully conccal it by filling their hair with glue and black and red earth. The women, on the otler hand, seem proud of it, and display it often in an almost incredible profusion, which spreads over their shoulders, and falls as low as the knee. About one in ten or twelve of the whole tribe have these grey hairs; and this strange and unaccountable phenomenon is not the result of disease or habit, but is unquestionably an hereditary character which runs in families, and indicates no inequality in disposition or intellect. The liair is coarse and har'sh as a hor'se's mane, and differs materially from the liair of other colour's, which amongst the Mandans is generally as fine and soft as silk.*

1024. What are the Tribes inhabiting the Sides of the Rocky Mountains?

The country westward of the Minetaris, and between that people and the Rocky Mountains, consists in part of elevated buffalo plains, and these are inhabited by two Indian. nations of distinct language, the Black-feet, or Black-foots, and the Rapid or Fall Indians. The Black-foots have recently been recognised as Alagonkins. They people the head waters of the south branch of the Saskatchawan River, and extend as far west as the Rocky Mountains, by which they are divided from the Thutanis. Bounded on the north by the Athabaskans, the south by the Upsarokas, the east by the Ahnenin and Crees. $\dagger$ 
"Seek Him that maketh the seven stars and Orion, and turneth the shadow of death into the morning, and maketh the day dark with night: that calleth for the waters of the sea, and poureth them out upon the face of the earth: the Lord is his name."-Asos $\mathrm{r}$.

1025. 'The Black-feet proper are divided into four bands, or families, as follows :-The Pa-e-guns, of 500 lodges; the Black-foot band, of 450 lodges; the Blood band, of 450 lodges; and the Small Rover, of 250 lodges. 'These four' bands constitute about 2500 lodges, amounting to about 30,000 souls.

1026. 'The Shosonees, or Snake Indians, in the high tracts. on both sides of the Cordillera of North America, are in perpetual warfare with the Black-feet, who prevent them from hunting the buffalo grounds. Further southward, on the Arkansas and the Platte, are the Paducas, consisting of three nations, the Cumanches, the Kiawas, and the Utahs.

1027. The Kiawas wander about the sources of the River Platte; they possess immense herds of horses, and are usually at war with the Pawnees and Tetans, as well as with the Sioux. 'The Utahs wander on the sources of the Rio del Norte. The Tetans are a powerful nation, eutirely wandering, without any attempt at cultivation, subsisting solely by the chase. Their wanderings are confined to the frontiers of New Mexico on the West, the nations of the lower Red River on the south, the Pawnees and Osages on the east, and the Utahs, Kiawas, and various unknown nations towards the north.*

1028. The Cumanches form a warlike and far-spreading nation, divided into three great tribes, the northern, southern, and middle, which are again subdivided into rarious bands, led by warriors, medicine men, or petty chiefs, with whom they traverse the prairie in all directions. The northern and middle Cumanches constantly follow the wandering buffalo, whose juicy meat forms almost their sole support; they are thence appropriately named by their neiglibours, the "Buffalo Eaters." The wide steppe is their home, and their uncon- 
"Come unto me all ye that labour and are heary laden, and I will give you rest. "Take my yoke upon you, and lealn of me; for I am meek and lowly in lieart: and ye shall find rest in your souls."-IIATritw xi.

querable love of wandering carries them from place to place orer those desolate inhospitable regions, where the pure invigorating atmosphere alone compensates for the scarcity of wood and water. Their territory is free from morasses, stagnant pools, or thick woods, where any unhealthy and fever-breeding miasmas might be generated; the currents of air find no obstacle on the boundless plain, and, as they blow freely across it, they seem to strengthen both the bocly and the mind of the dwellers on the steppe.

1029. The Cumanche Indian knows of no wealth but the buffalo and the antelope, and the horse that enables him to overtake them; with these he has food, clothing, and shelter, and desires no more; he is not troubled with cares for the coming day; and in wars with his enemies, and the management of his horsc, he finds the means of gratifying his ideas of honour. From earliest childhood to later years he is continually on horse-back; indecd, he makes but an awkward figure on foot, though he is no sooner mounted than he seems transformed; and when, with no other aid than that of the rein, and a heavy whip, he makes his horse perform the most incredible feats, he consider's himself the greatest and most independent gentleman on the face of the eartli. Troops of Cumanches may often be secn dashing about in all directions, and playing the wildest tricks; hanging now on one side of the horse, now on the other, and throwing lances or shooting arrows under his neck with the greatest accuracy at a given mark.

1030. Every Cumanche keeps a special war-hrorse, in the choice of which more regard is paid to swiftness than to any other quality. As among Arab tribes, this horse is the best friend, the most sacred possession of his master, who would not part with it for any treasure that could be offered to him, and mounts it only for war, or peculiarly festive occasions, such as a buffalo hunt; and when he returns he finds the women awaiting him at the door of his wigwam, to receive the beloved steed, and pay lim cvery attention.

1031. With exception of a few cooking and domestic utensils, the sole possessions of these Indians consist of horses and inules, many of which have evidently, from the brands upon them, been stolen from the settlements of the whites; but the appropriation of other people's goods is considered creditable, and a young man is not thought worthy to be counted in the list of warriors till he has returned from some 
"A good man out of the good treasure of the heart bringeth forth good things: and an evil man out of the evil treasure bringeth forth eril things."-

successful plundering expedition into the Nexican provinces; so that. the greatest thievcs are not only thc most opulent but the most respectable members of society. $A$ grey old warrior, who was heard praising his two sons, and declaring them the joy and support of his age, did not fail to add that they understood horse-stealing better than any young fellows in the whole nation. It is not therefore surprising that somc particularly meritorious persons have acquired a herd of from two to three lnundred of these testimonies to their prorress.*

\section{What are the Californian tribes?}

There are said to be not less than ten different races of people, speaking at least three or four peculiar languages, which are the mother tongues of all the remainder. The complexion of the Californians generally very nearly resembles that of those negroes whose hair is not woolly. Those of Northern or Upper California are a shade browner than the Oregon Indians, while some tribes in the peninsula are nearly black. In other respects they have the physiognomy of their race.

1033. 'The industrious habits of these tribes, their agriculture, domestic manufactures, fixed habitations, congregated villages of considerable size, together with their carriage, pleasing manners, and intelligence, all concur to make them the most interesting of the aboriginal populations of America. $\dagger$

1034. The Pimos and Coco-Maricopas are of clear brown complexion, different from the red skins east of the Rocky Mountains, and from the olive colour of the South Californians. The women have good figures, full chests, and finely-formed limbs. The men have small and slender limbs, and are physically quite inferior to the tribes between. the Mississippi and the Rocky Mountains. The other 
"But I say unto you, That every idle word that men shall speak, they shall gire account thercof in the day of judgment."-MatTuEw xii.

tribes are the Yumas, the Opates, the Yaquis, the Zunis, the Moquis, the Navajos, \&c., and the same general account of them will apply to all.

1035. Their houses are built of stakes and rushes; they are of a cireular form, from fifteen to twenty-five feet high, so that in some of them a man eannot stand upright; they are, in fact, used chiefly to sit and sleep in; the door-way is about three feet high; many of them are plastered all over with mud. They have ontside a kind of shed, or bower, a mere roof open on all sides, where they pass most of their time. The villages eonsist of from twenty to fifty houses, sur'ounded by gardens or cultivated fields, whieh are interseeted by small canals of irrigation. These fields are feneed in with erooked sticks, matted with prickly brishwood.

1036. They possess eonsiderable number's of horses and eattle, which are left to graze near the village during the day, and at night are brought into the eorrals, or yards, for safety. Some of them have recently obtained a few carts and waggons from passing emigrants, which they use with oxen for agrieultural purposes: they oecasionally plough with oxen. Their machinery for spinning and wearing eotton is of a very primitive order. The spinner uses a spindle of thin wood, two feet in length, passing through a block of thick dimensions, shaped like a child's teetotum, whieh is twirled round with one end resting in a wooden eip, held between the toes of the workman. The supply of cotton is rolled upon the left arm, from whieh it, is drawn out by the left hand, and conducted to the spindle, which is twirled round by the right hand. The loom for weaving is still ruder. The eotton raised by them is excellent; speeimens have been pronouneed by merchants to be equal to the best Sea Island cotton. Their pottery and basket work are varied, neat, and sometimes ornamental.

1087. The moral charaeter of these races is deeidedly good; no tribes of the whole eontinent excel them in virtue and honesty. Their ideas of the Supreme Being and a future state are vague; their souls after death are supposed to return to the banks of the Colorado, where their aneestors lived, and these to be changed into the forms of various animals; their enemies will also be found there, and, like the Northmen, they believe that the same wars will be eontinued betwcen them after death as during life. They marry only one wife, and always with 
"If God so clothe the grass of the field, which to-day is, and to-morrow is cast. into the oven, shall He not much more clothe you, o ye of little faith."-Matriew vi.

the consent of the lady, whose good graees are romantically sought by means of music, the suitor playing his flute in some retired spot near her hut daily for some hours, until she makes known her assent or he is rearied out by want of sueeess. The wife is well treated, although she has the greater share of hard work, being employed in the domestic labours of grinding corn and fetching water, besides making baskets and taking care of the children, while the husbands do little more than plant and gather the crops, and attend to their eattle, which leaves. mueh idle time on their hands.*

1038. What are the Guachos?

They are scattered tribes of Indians, who have intermarried among the Spanish descendants, and who, mixed

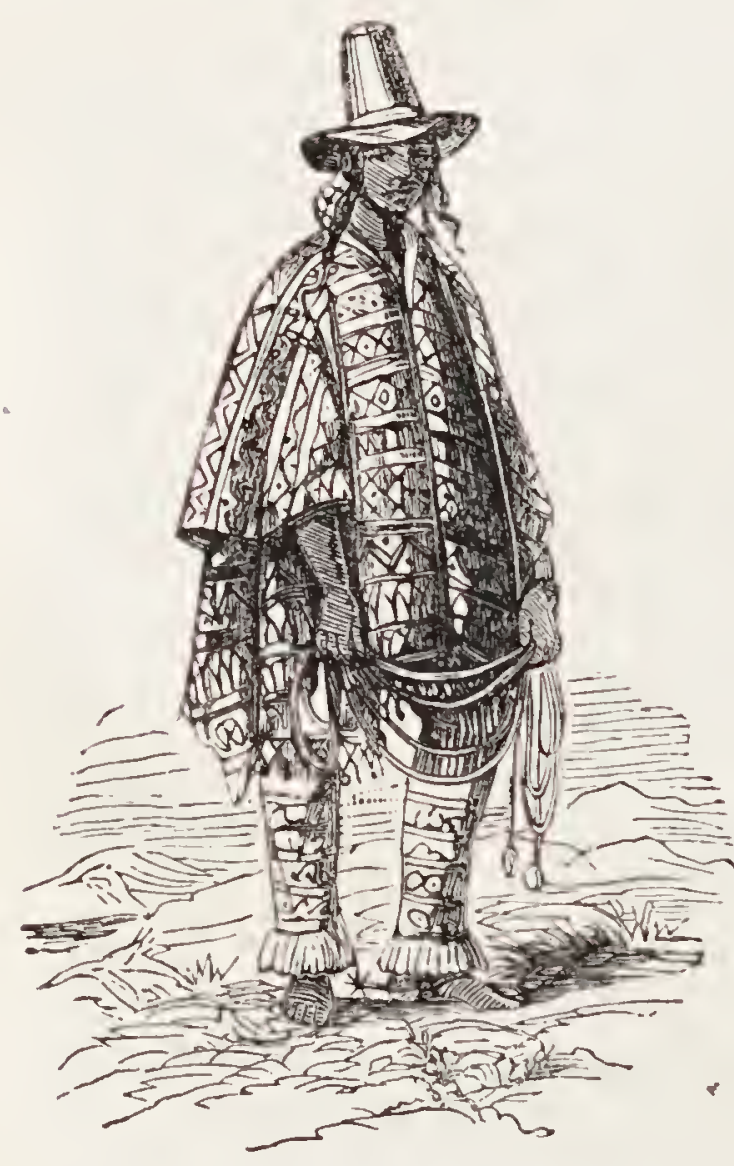

GUACHO INDIAN. in religion as in blood and manners, may be regarded as the wild sovereigns of those rast plains called the Pampas, extending from the Paraguay to the fiontier's of Los Chacos. 'These mative Guachos are possessed of vast herds of wild cattle, and roam orer the country in a state of semisarage independence. Their dwellings are constructed of wicker-work, with a hole in the roof for the escape of smoke; an enclosure for cattle adjoins the hut, and the whole is surrounded by a fence of impenetrable cactus.

1039. Their tastes and habits are as primitive as their lives. Some 
"Behold, the Lord maketh the earth empty, and maketh it waste, and turneth it upside down, and scattereth abroad the inliabitants thereof."-Isalan xxiii.

Indian corn, which they cultivate in patches round their huts, is roughly beaten into powder, or rather meal, and this, with a little brine from the salt-marshes, flattened into cakes, and baked on a hot stove, constitutes their bread. When they kill a large animal, the flesh is cut into long thin slices, and, after hanging in the air to clry, is smoked over their wood fires, and thus preserved. This charqui forms their staple food, and will keep for a long time.

1040. What are the Koluski and the Nootka Columbians?

'Ihese names are applied, the former to northern, and the latter to southern tribes of Indians who are distributed over the north-western coast of America. The northern family consists of tribes extending from the Arctic Circle, and the settlements of the Esquimaux to the Northern extremity of Quadra and Vancouver's Island. These are the Koluski, called also Ugalyachmutzi, and Kianaitzi.

1041. To this race belong the Haidals, tribes of Queen Charlotte's Island, who cultivate potatoes, which they export, in fleets of forty or fifty canoes, to the different villages of the Chemesyan nation, where potatoe fairs are held. A custom is common with these northern tribes, of females perforating the lower lip, and wearing in it a wooden ornament.

1042. The southern tribes pursue the habit of flattening the skulls of infants. These, the Nootka Columbians, include the various hordes that inhabit Nootka Sound, and the lower tracts of the Columbia River, and extend thence southward along the coast. They are more muscular than the northern tribes; their cheek-bones prominent; their complexion of a light copper hue. The flattening of their skulls in infancy appears to have no ill effect upon their intellects, but they are extremely liable to apoplexy.

1043. What are the White American Races?

They consist of certain tribes to whom there attaches 
"Lay not up for yourselves treastires upon eartl, where moth and rust doth corrupt, and where thieves break through and steal. Butlay up for yourselves treasures in heaven, where neither moth nor rust doth corrupt, and where thieves do not break through nor steal."-MATTHEW vi.

peculiar interest, from the fact that they furnish instances of a White American Nation, whose complexion, if compared with the black Californians, seems to bear a relation to climates similar to that which we trace in the Eastern Continent of the Old World, when we compare the white Europeans with the black Africans. Some of them, however, so bedaub themselves with paint that it is difficult to discover their complexion. "We prevailed upon one woman," says Captain Dixon, "to wash her face and hands, and the alteration in her appearance surprised us; her countenance had all the cheerful glow of an English milkmaid, and the liealthy red which flushed her cheek was even beautifully contrasted with the whiteness of her neck: her forehead was so remarkably clear that even the small underlying veins could be distinctly seen."

104x. What are the Quichas?

They constitute the Peruvian branch of the Andian families. It was among the nations of this stock that neariy all the civilization of South America existed. The Peruvians are well known to have inhabited cities; in their elevated plains they had flocks of domesticated animals, the llama and the alpaca; and they cultivated extensively the quinoa and the potatoe, their native plant, which served them in place of corn plants. Their woollen manufacture was comparable to the finest fabrics of Europe. They worked the precious metals, and copper and lead, but were ignorant of the more valuable use of iron.

1045. Among the Perurian nations the dominant race were the Quichuas, or Incas, distinguished by their language, which is the Quichuan. The stature of the Quichuas is low, seldom more than five feet three inches. Their average height is not abore four feet nine inches; 
"When thou prayest, enter into thy closet, and when thou hast shut the door, pray to thy Father which is in secret; and thy Father which seeth in secret shall leward thee openly."-MatrThew vi.

the women are still less. They are remarkable for a very large development of the chest and breathing organs, which arises from theil residing 1500 to 15,000 feet above the level of the sea; the atmosphere is so rarified that a much greater volume of air must be inhaled at each inspiration. than at the level of the ocean.*

1046. What are the Aymaras, Atacamas, and Changos?

These are other races of South America allied to the Peruvian groups. The Aymaras appear to be the descendants of an ancient race, who in ages long past occupied the high plains covered by the singular monuments of Tinguanaco, the most ancient city of South America, and the Lake of Titicaca.

1047. The Atacamas and Changos are two other nations, of inferior numbers, that make up the Peruvian group. The entire mass of the Peruvian nations has embraced Christianity.

\section{What are the Antisians?}

They constitute a branch of the Alpine races of South America. The territory held by the Antisian races, which are divided into numerous branches under numerous names, consists of abrupt and precipitous mountains, on which, however, a vigorous and magnificent vegetation is everywhere displayed; and of deep and gloomy valleys, where impetuous torrents rush over rocky beds.

1049. The people of these races, dwelling amid damp forests, scarcely penetrated by solar rays, are, in comparison with other tribes, almost white, and the names of some of them indicate "white men." One remarkable feature 
"Love your enemies, bless them that curse you, do good to them that hate you, and pray for them which despitefully use you."-IIATTHEW $\mathrm{v}$.

among them is, that many individuals have their skins spotted with large patches of a still paler hue. Their forms are vigorous and robust; their countenances differ from those of the Mountaineers; their languages are peculiar; and their manners barbarous and wild.

\section{What are the Pesherais?}

They are a people that inhabit all the coast of Tierra del Fuego, and both borders of the Straits of Magellan, from the Island of Elizabeth and Port Famine towards the East, they are separated from the Patagonians by the sea, and by the chain of mountains which constitutes the isthmus and joins the Peninsula of Brunswick to the continent.

1051. Unfortunate in their climate and country, they live for the most part on shell-fish, roasted or raw, sharing food with their dogs, which accompany them wherever they go. Thus they pass the most rigorous season, not under ground, like the inhabitants of the extreme North, but without the temperature having the slightest difference on their manner of life. Among them, as with all other savage tribes, the women, whom civilization spares from liard toil, are forced to engage in occupations the most fatiguing: besides the employments natural to their sex, and their duties as mothers, they row, fish, build cabins, and, even in the winter, brave the extreme rigour of cold.*

1052. In Tierra del Fuego we have one of the six extreme points of population; i.e. points from which no population has been supposed to have migrated clsewhere; Easter Island, Van Diemen's Land, the Cape of Good Hope, Lapland, and Ireland, being the other five. $†$ 
"Except your righteousness shall exceed the righteousness of the scribes and Pharisees, ye shall in no case enter into the kingdom of heuvell."-Matrilew $v$.

1053. The Patagonians, another people inhabiting Terra del Fuego and Patagonia, are remarkable for their gigantic stature. The medium height of the males is about five feet eleven inches. The women are not so tall, but are in proportion broader and stouter. They are generally plainfeatured; the head is long, flat, and broad, and the forehead low, with the hair growing to within an inch of the eyebrows, which are bare; the eyes are often placed obliquely, and have but little expression; the nose is generally rather flat, and turned up, but in some instances is aquiline; the mouth is wide, with prominent lips, and the chin is rather large ; the jaws are broad, and give the face a square appearance; the neck is short and thick; the shoulders are broad; the chest is very broad and full; but the arms, particularly the fore arm, is small, as are also the foot and leg; the body long, large, and flat, but not corpulent.

1054. Why is the fifth type called the Malay?

Because most of the tribes speak the Malay language, which in the various ramifications of this race may be traced

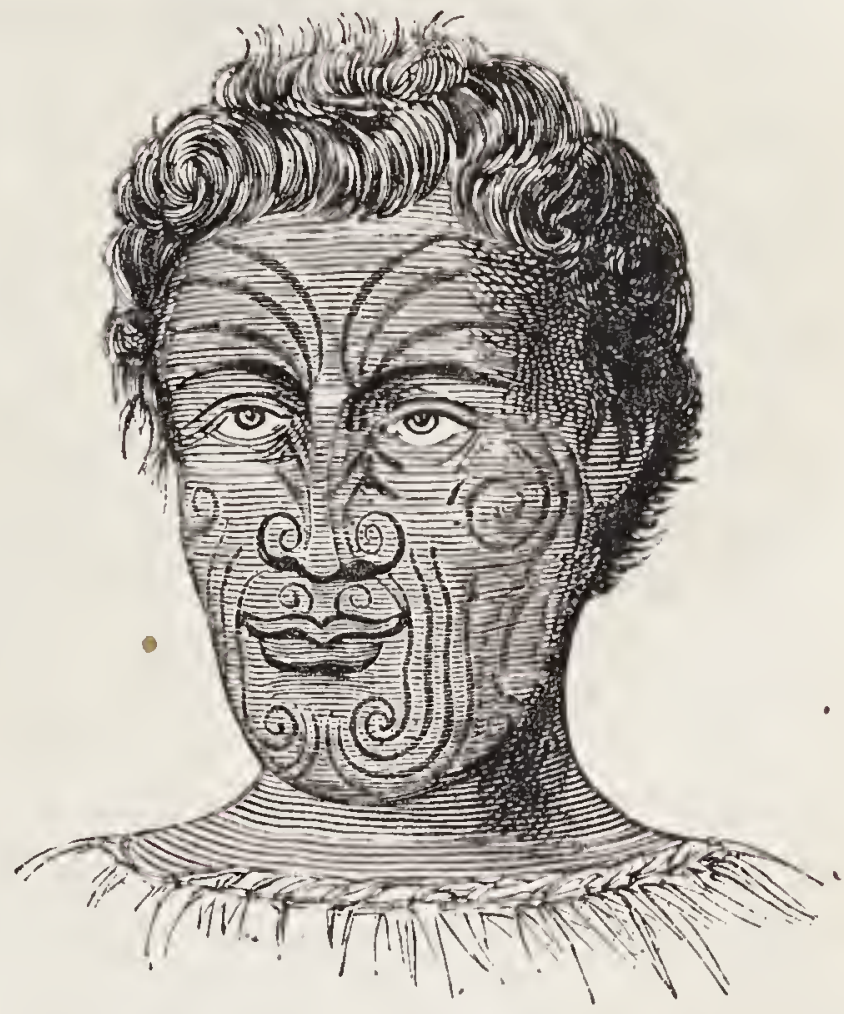

MALAY. from Madagascar to Easter Island in the South Pacific, 
"As I passed by, and beheld your devotions, I found an altar with this inscription, To the Unknown God. Whom therefore ye ignorantly worship, Him declare I unto you : God that made the world and all things therein, seeing that he is Lord of hearen and earth, dwelleth not in temples made with hands."-Acrs xvii.

half-way between Asia and America. Their characteristics are a brown colour, varying from a light tint, not deeper than that of the Spaniards and Portugese, to a deep brown approaching to black; black hair, more or less curled, and abundant; head rather narrow; bones of the face large and prominent; nose full and broad towards the point, and mouth large.

1055. To this division belong the inhabitants of the peninsula of Malacca, of Sumatra, Java, Borneo, Celebes, and the adjacent islands of Australia, Van Diemen's Land, New Guinea, New Zealand, and the numberless islands scattered throughout the South Sea.

1056. Disjointed and widely separated, these insular tracts are found to contain races of inhabitants more nearly connected with each other, and at the same time much more widely scattered, than any of the families of men who occupy the continuous lands of Asia and Africa. The habitable tracts of this region lie principally, but not entirely, within the Tropics. In longitude it may be considered as reaching, in its greatest extent, namely, from Madagascar to Easter Island, through nearly half the Equatorial region of the globe. The whole of this region is made by some geographers to constitute a fifth great division of the globe, under the name of Oceanica.

1057. The human inhabitants of Oceanica divide themselves into three groups. One of these may be termed a race or family of nations, since a real kindred, or community of origin has been proved, by affinity of language, to exist among them. The two others probably constitute as many races, since we seem able to trace them from one cluster of islands to another. 'The first are the Malayan Polynesians, 
"Yc arc the children of the prophets, and of the corcnant which God made with ora fathers, saying unto Abraham, And in thy seed shall all kindreds of the earth be blessed."-Acrs iii.

the second the Pelagian Negroes, and the third the Alforians, to which the native groups of Australia belong.

1058. The Malays constitute a nation of Southern Asia, inhabiting the countries and islands between Hindostan and China. They are a bold, roving, and energetic race of people, thoroughly addicted to war and plunder. Their residences, whether on the Malayan Peninsula, or upon the large islands, are always on the coast, driving the natives wherever they colonise from the sea-board, and shutting them up in the centre of the islands, while in the smaller isles they have exterminated the original possessors.

1059. In the north of the Malay Peninsula the Malays became intermixed with the Siamese, and in other parts with the Burmese and Celebes. Physically considered, the Malays are rather below the ordinary stature, well formed but slight, with remarkably small

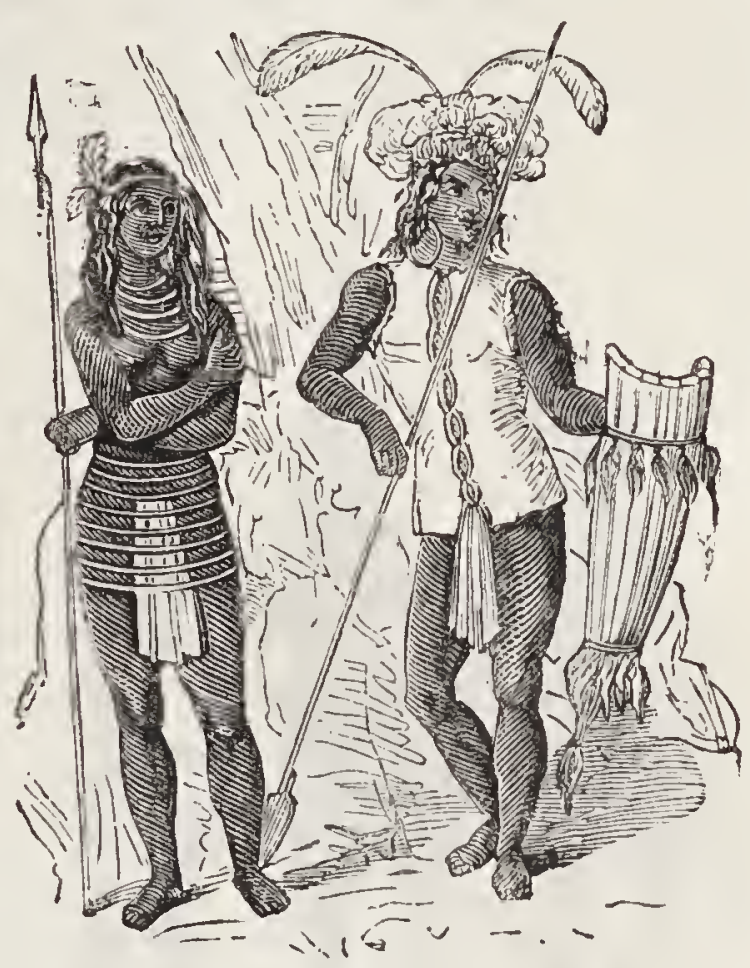

DYAKS OF BORNEO. wrists and ankles. The religion of the Malayans, thougl a mixture of Mahommedanism and the Soonee sect, is the most tolerant of all the creeds and opinions of Asia. They rarely forgive an affiront, but sooner or later take a cruel revenge. They are given to plunder, and are naturally pirates, their habit being to dart out from their back streams and hidden rivers in their proahs upon any ressel that approaclies near. their coast; but sometimes they lie in wait in large numbers upon the open seas for any vessel suspected of having a rich cargo. The Malay nation is supposed not to exceed 400,000 .

1060. Tribes of Pclagian negroes are spread along the chains of Louisiade and Solomon Isles to Santa Cruz, and thence still further to several of the New Hebrides and to New Alexandria. The island of IIallicollo appears to be peopled by a race of small negroes, whose 
"My sheep hear my roice, and I know them, and they follow me: and I gire them etcrnal life; and they shall never perish, neither shall any man pluck them out of my hand."-JoHs $x$.

lower jaws project in a remarkable manner. The Tasmanians, or natives of Van Diemen's Land, of whom but a small number survive, are decidedly of the Pelagian stock, having the same characteristic projection of the lower jaw.

1061. The Alforians are a people of peculiar physical character, who inhabit the interior of New Guinea and many of the larger islands to the southward of the Indian Ocean. The Australians, or aborigines of New Holland, are proved by their languages to have no affinity with the

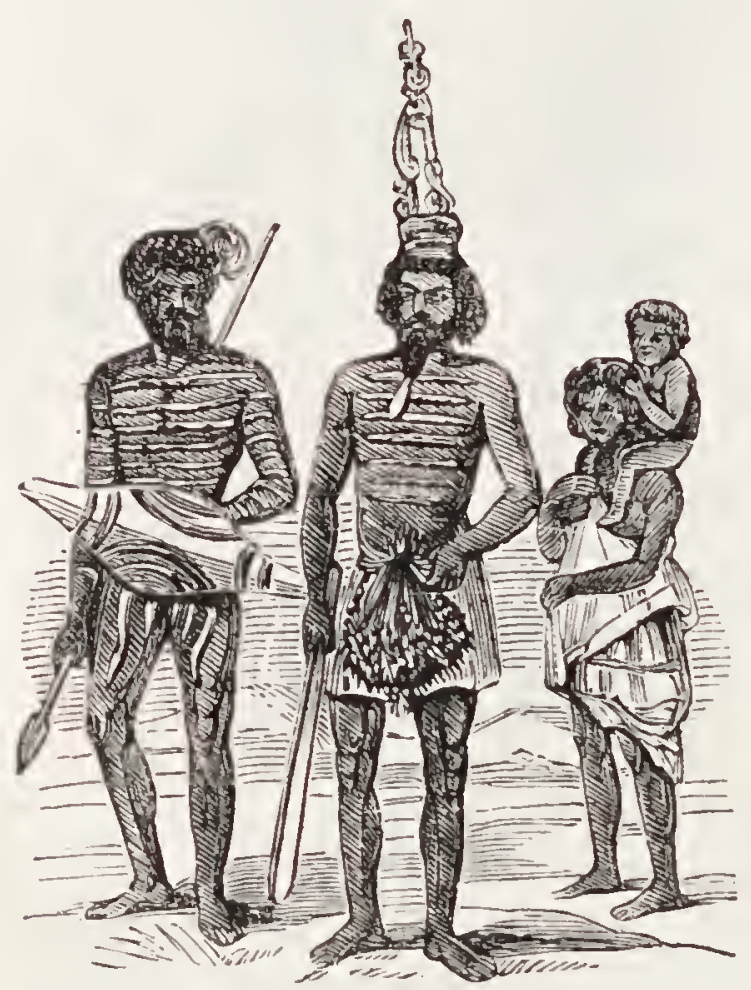

AUSTRALIAN ABORIGINES.

Pelagian tribes of any class. They occupy a very low position in the scale of human races. Their skin is lighter than that of the negro; their woolly hair grows in small tufts, each hair llaving a spiral twist. Their constructive powers are very limited; a lut of the rudest fashion, more like a kennel than a habitation; some nndressed skins of beasts for clothes; a spear, boomerang, and shield, constitute their arms; and if we add the workmanship of a fisli-hook to take their prey, we enumerate the extent of their wealth and constructive capability. Their' habits are unclean, and their morals of the lowest standard; treachery, cruelty, lying, and theft are their constant practice. Their food consists chiefly of wild animals, reptiles, fish, ants, and almost any kind of offal. The number of the aborigines is rapidly diminishing, and it is probable that in a few years they will be totally extinguished.

\section{What are the Principal Polynesian Races?}

They are the Tahitians, the Marquesas, the Sandwich Islanders, the New Zealanders, the Tongoese, the Samoan Islanders, Neru Caledonians, \&c. The Polynesian races 
"I am the living bread which came down from hearen: if any man eat of this bread, he shall live for ever: and the bread that I wiil give is my flesh, which I will give for the life of the world."-JoHn $v$.

display considerable variety among themselves, both as to physical and moral characteristics. The Tahitians are considered the best type of the whole Polynesian race. The men are tall, strong, well-limbed, and finely shaped. The women of the superior rank are also in general above the European middle stature, but those of the inferior class are below it, and some of them very small. Their natural complexion is that kind of clear olive or brunette which many people in Europe prefer to the fairest white and red. This refers to females of the better class, who are sheltered from the wind and sun; they have no tint in their cheeks which we distinguish by the name of colour. Their hair in general is black, but it is occasionally brown, red, or flaxen.*

1063. The majority of the Polynesian Islands present the phenomenon of an imperfect and recent civilization,

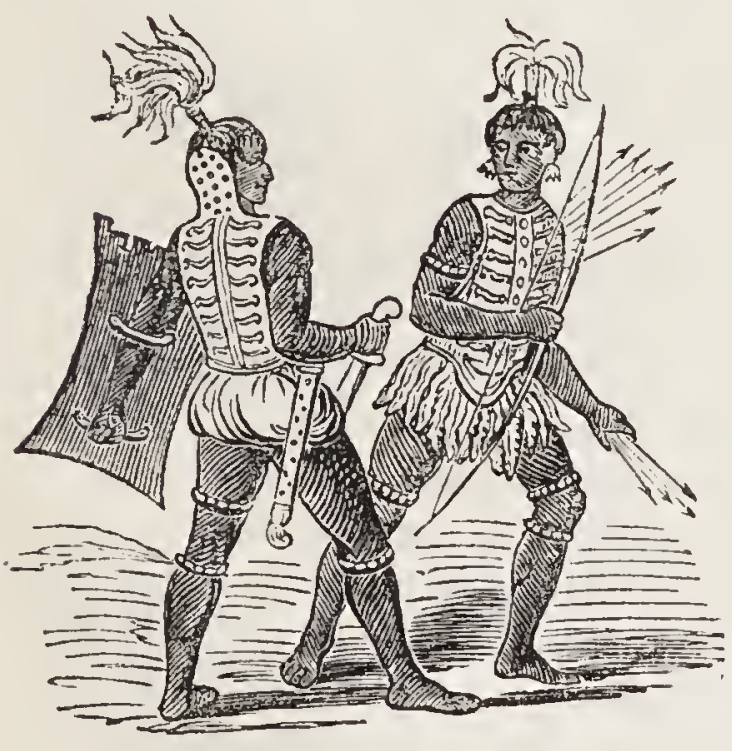

OMBAY WARRIORS. engrafted upon a state of comparative barbarism. All the tribes that have come under the in. fluences of civilization have readily adopted the Christian religion. The capital of the Sandwich Islands, Honolu, can boast of its theatres, hotels, and ball-rooms, as well as churches and schools, and the richer natives have the houses and dress of Europeans; but the people generally are 
"Verily, verily, I say unto you, The hour is coming, and now is, when the dead shall hear the voice of the Sun of God: and they that liear shall live." -Jour v.

stated to live and clothe themselves much as they did before the white man came to reside among them. In islands which have not been much frequented by Europeans, they exhibit, in various degrees, the characteristics of savage people, but are generally tractable, and capable of receiving good impressions from acts of kindness and confidence.

1064. The practices of immolation which prevail in certain barbarous and semi-barbarous tribes are of a very extraordinary charaeter. Sometimes these saerifiees are made in deferenee to religion or superstitious customs; in others from obedience to social laws, and more rarely from trifling causes of personal degradation. Two instanees are reeorded by an Englishman, John Jaekson, who for some years resided with a tribe of Feejeean Islanders, by whom he lrad been made eaptive. of eael of these oeeurrences he was an eye-wituess.

1065. The other story told by Jaekson is as follows:- "I saw 3 tall young man, about twenty years of age. He appeared to be ailing, but not at all emaciated. He was rolling up the mat he had been sleeping upon, evidently preparing to go away somewhere. I addressed him, and asked lim where he was going, when he immediately told me he was going to be buried. I observed that he was not dead yet, but he said he should soon be dead when he was put underground. I asked him why he was going to be buried? He said it was three days sinee he liad eaten anything, and eonsequently was getting rery thin, and that if he lived any longer lie would be much thinner, and then the women would eall him a 'lila' (skeleton), and laugh at him. I told him he was a fool to throw his life away for fear of being laughed at, and asked him who or what his private god was, knowing it would be no use talking to him about God, whom he had never lieard of. He said his god was a shark, and that if he were cast away in a canoe, and obliged to swim, the sharks would not bite him. I asked him if he believed the shark, his god, had any porver to act orer him? He said yes. Well, then, said I, why do you not live a little longer, and trust to your god to give you an appetite?

1066. "Finding that lie could not give me satisfaetory answers, and being determined to get buried, to avoid the jeers of the ladies, whieh 
"Love ye your enemies, and do good, and lend, hoping for nothing again, and your reward shall be great, and ye shall be the children of the Highest : for He is kind unto the unthankful and to the evil."-Luke vi.

to a Feejeean are intolerable, he told me that I knew nothing about it, and that I must not compare him to a white man, who was generally insensible to all shame, and did not care how much he was laughed at. I called him a fool, and said the best thing he could do was to get buried out of the way, because I knew that most of them work by rules of contrary; but it was all to no purpose.

1067. "By this time all his relations had gathered round the door. His father had a kind of wooden spade to dig the grave with, his. mother a new suit of tapa, his sister some vermilion, and a whale's tooth, as an introduction to the great god of Rage-Rage. He arose, took up lis bed and walked, not for life, but for leath, his father, mother, and sister following after, with several other distant relations, whom I accompanied. I noticed that they. seemed to follow him in something the same way that they follow a corpse to the grave in Europe; but, instead of lamenting, they were, if not rejoicing, acting and chatting. in a very unconcerned way.

1068. "At last we reached a place where several graves could be seen, and a spot was soon selected by the man who was to be buried. The old man, his father, began digging the grave, while lis mother assisted in putting on a new tapa, and his sister besmeared him with vermilion and lamp-black, so as to send him decent into the invisible world, he (the victim) delivering messages that were to be taken by his sister to people then absent. His father then announced to him and the rest that the grave was completed, and asked him in rather a surly tone whether he was not ready by this time. The mother then nosed him, and so did the sister. He said, 'Before I die, I should like a drink of water.' His father made a surly remark, and said, as he ran to fetch it in a leaf doubled up, 'You have been a considerable trouble during your life, and it appears that you are going to trouble us equally at your death.' 'The father returned with the water, which the son drank off, and then looked up into a tree covered with tough vines, saying he should prefer being strangled with a vine to being smotlered in the grave. His father becanic excossively angry, and, spreading the mat at the bottom of the grave, told the son to die, 'faka tamata' (like a man), when lie stepped into the grave, which was not more than four feet, and lay down on his back with the whale's tooth in his hands, which were clasped across his body.

1069. "The spare sides of the mat were lapped over him, so as to 
"Blessed are ye, when men sluall hate you, and when they shall separate you from thcir company, and shall reproach you, and cast out your name as evil, for the Son of man's sake."-Luke vi.

prevent the earth from getting to his body, and then about a foot of earth was shovelled in upon him as quickly as possible. His father stamped it immediately down solid, and called out in a loud roice, 'Sa tiko, sa tiko" (You are stopping there, you are stopping there), meaning 'Good bye, good bye.' The son answered with a very audible grunt and then about two feet more earth was shovelled in, and stamped upon as before by the father', and 'Sa tiko' called out again, which was answered by another grunt, but much fainter.

1070. The grave was then completely filled up, when, for curiosity sake, I myself said, 'Sa tiko', but no answel' was given, although I fancied, or really did see the earth crack a little on the top of the grave. The father and mother then turned back to back on the middle of the grave, and, haring dropped some kind of leaves from their hands, walked away in opposite directions towards a running stream of water hard by, where they and all the rest washed themselves, and made me wash myself, and then we retired to the town, where there was a feast prepared.

1071. "As soon as the feast was over (it being then dark), began the dance and uproar which are always carried on either at uatural or violent deaths. All classes then give themselves up to excess, especially at unnatural deaths of this sort, and create all manner of uproar, by means of large bamboos, trumpet-shells, \&c., which will contribute to the general noise. This uproar is considered requisite to drive the spirit away, and deter him from desiring to dwell in or hover about his late residence. The uproar is always held in the late habitation of the deceased, the reason being that, as no one knows for a certainty what reception he will receive in the invisible world, if it is not according to his expectations he will most likely repent of his bargain, and wish to come back: for this reason, they make a great noise to frighten him away, and dismantle his former habitation of everything that is attractive, and clothe it with everything that to their illeas seems repulsive." **

* Jackson's Narratire of Two Years' Residence in the Feejeean Islands. 
"If thy brother shall trespass against thee, go and tell him his fault between thee and him aione: if he shall hear thee, thou hast gained thy brother."-MATTHEw xviii.

\section{THE EARLY BRITISH TRIBES.}

\section{What were the Celtic Nations?}

They may be regarded as amongst the very early migrators that left the high lands of Central Asia, and moved in tribes not only towards the west, but penetrated to the extremity of India.

1073. The southern tribes, having in their most early communion with Indo-Arab neighbours, acquired the lore of Western Asia, proceeded by sea, carrying the traditions and philosophy of the East to the coasts of Great Britain, destined to be first set up as indigenous; later, to accept numerous grafts from the same quarter, brought by private traders; and, finally, to prepare the West to accept the tidings of the Gospel without the resolute opposition which Greek and Roman civilization so long opposed to Christianity.

1074. The Celtic race is still distinctly marked in Cornwall and Wales by a more spare make, black curly hair, very dark eyes, and brown complexion, frequently set off with bright red lips. It is a spirited race, gifted with the highest imaginative power, serious, thoughtful, religious, obstinate, attached to its own nationalities, and, though in many cases proved to have been a sea-faring people, nowhere really fond of a sea life.*

1075. Their chief divisions, as they appeared in the progress of history, were the Celts of Gaul, comprising the

* Lieutenant Smith's "Natural History of the Human Species." 
"Verily I say unto you, That many prophets and righteous men have desired to see those things which ye see, and have not seen them; and to hear those things which ye hear, and have not heard them."-Matrinew xiii.

proper Celta, and the Belga ; British Celts, divided into the Cambrians and the Picts; the Gaels, divided into Scotch Gaels, Irish Gaels, and Manxmen, or Gaelic Celts of the Isle of Man. They constituted the ancient tribes of Ireland, Scotland, England, Gaul (north of the Loire, and west of the Rhine), Helvetia, and the Agri Decumates, the Cimbri, and Teutones. There still exist two stronglymarked types:-The Silurian, eyes and hair black; complexion dark, with a ruddy tinge; chiefly found in South Wales. 'The Hibernian, eyes grey; hair yellowish red, or' sandy; complexion light. The probable movement of population was to Ireland from the nearest part of Scotland, to Scotland from England, to England from the parts about Calais and Dunkirk.*

1076. At the time of the invasion of Britain by Julius Casar, the country was divided into settlements occupied by different tribes, of which those on the southern coast, opposite Gaul, were the most advanced towards civilization, on account of their intercourse with the people of Gaul. The conquests of Cresar, however, penetrated the interior of the country only to a very limited extent. It was not until the governorship of Agricola, some 140 years after the invasion by Crsar, that the whole of the tribes occupying the interior, and a portion of the north of the island, were subdued. Even then the Caledonians, the Picts, and Scots, continued their hostility, not only to the Roman authority, but to the British people on their borders. In the interval between the invasion by Cresar and the further conquest of Britain by Agricola, new tribes were frequently discovered which were before unknown, and battles were constantly waged to bring these new tribes into subjection.

1077. A very great portion of the island was then covered with roods fens, and marshes; the assemblages of rude houses, whiclı constituted the towns, were invariably centered in forests, trees being felled to clear the ground for a settlement, the trunks thereof being used as barriers against the incursions of enemies, and further strengthened by ditches 
"The stork in the heaven knoweth her appointed times; and the turtle and the crarie and the swallow observe the time of their coming; but my people know not the judgment of the Lord."-JereuraH viii.

dug around them. The approaches to those towns were little nore than trackways through the forests. Some of the woods were of immense cxtent, and covered the present areas of entire counties. Cresar could make no impression upon the native tribes until he harl felled trees and made road-ways, by which he might pursue the Britons into their strongholds.

1078. Bogs and marshes also presented great obstacles to the progress of the Romans into the interior. Severus, who held his court at York, resolved to enter Caledonia and subdue the northern barbarians. The county of Durham and the country lying to the north were still an impassable wilderness; every league that the Roman army advanced gave them an incalculable amount of labour in cutting down forests, draining morasses, constructing roads, and bridging rivers. It is stated that in this expedition Severus lost 50,000 men, though he fouglit no battle, nor saw any large body of enemies.**

1079. What were the Caledonians?

Anciently, the name of Caledonia comprised all Scotland, and after a time merely that portion of the land north of Antoninus's wall, or the estuaries of the Forth and Clyde; but, as the native South Britons advanced before the conquering Romans, the Caledonians, or people of Caledonia, migrated further north and west, pressing to the extreme limits of the land, flooding the Western Isles, and from thence emigrating into Ireland.

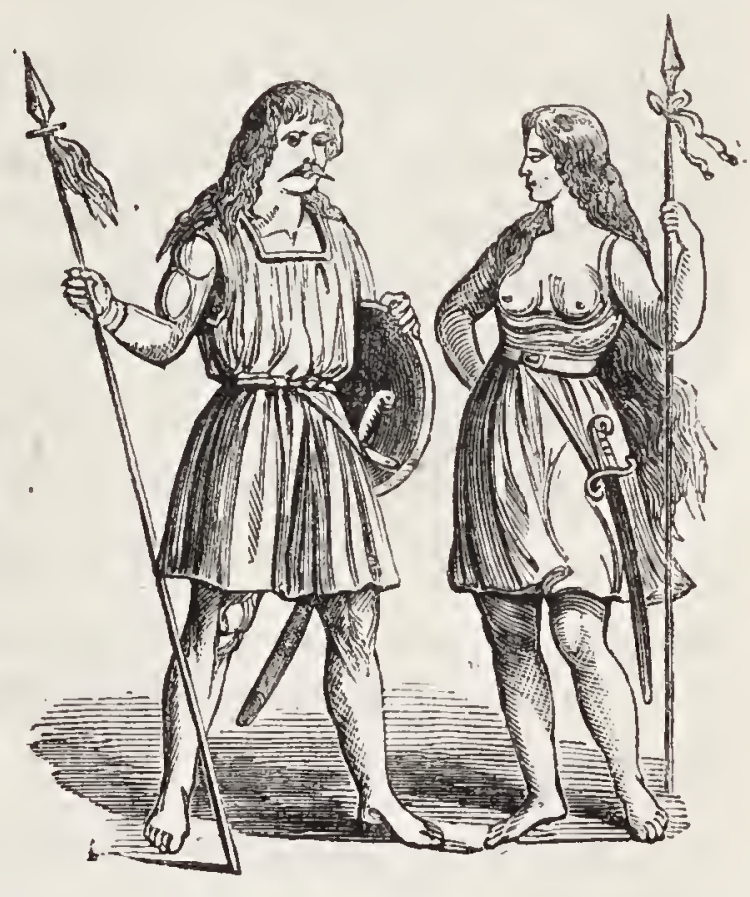

CALEDONIANS.

1080. The country the Caledonians possessed they called

* Philp's "History of Progress in Great Britain." 
"Thou hast made of a city an heap; of a defenced city a ruin: a palace of strangers to be no city; it shall never be built."-IsalaH xxr.

Caeldoch, or a district of the Gael, from which, by tho transposition of a letter and the softening of the pronun. ciation, we obtain the word Caledonia. 'This part of the island was so little known to the Romans, and so little did they care, after the battle of the Grampians, to extend their knowledge, that they called all the parts morth of the furthest wall Britannia barbara, or barbarous Britain.

1081. The clothing of the ancient Britons consisted most commonly of a loose mantle or plaid. This was a piece of cloth, of square form, sufficiently large to cover the body, both behind and before. It was fastened upon the breast, or on one shoulder, by a clasp; or, for want of that, with a bone or sharp-pointed piece of wood. As this garment succeeded the mantles made of skins of some of the larges animals, which had formerly been worn, it was made to imitate those skins in shape. But these garments, when they were at first introduced, were only used by persons of rank and wealth, and by them only in the winter season, when they went abroad.

\section{What were the Brigantes?}

They were a powerful British tribe who peopled the districts now comprising Lancashire, Yorkshire, Cumberland, and Durham; and probably derived their name from their piratical or brigand-like character'. 'They committed such outrages upon their neighbours that Antoninus Pius took away the greater part of their territory.

1083. The Parisi held a settlement adjoining to the Brigantes, and are supposed to have been a division of the tribe. They occupied the south-easter'n angle of Yorkshire.

1084. Northumberland was occupied by the Ottadani, a people depending upor, or confederated with, the Brigantes, in the same manner as the Parisi. Their name was probably derived from the situation occupied by them; it 
" Trust ye in the Lord for ever ; for in the Lord Jehovah is everlasting strength : for He bringeth down them that dwell on high; the lofty city, He layeth it low, even to the ground; He bringeth it even to the dust."-IsAIAII xxvi.

means beyond, or above, and was intended to indicate their situation above the Tyne.

1085. The system of warfare of the Britons was as follows:-They rode about all parts of the battle casting their darts, and oftentimes, with the terrible noise of their horses, and the rattling of their chariotwheels, they amazed the enemy and broke his ranks; driving in among their enemies in heavy waggons, they would spring out, and fight on foot. In the meanwhile, the waggoners withdrew themselves from the battle, and set themselves in such order that, should the battle be lost, the defeated Britons might have easy access to them, and thus escape. The women appear to have borne arms with the men, and many of that sex became renowned for great courage. But, besides the use of arms, the British women had another employment in the field. When Paulinus Suetonius attacked the Druids in the isle of Mona, the British army stood on the shore, thick of men and munition, and women running up and down among them, like

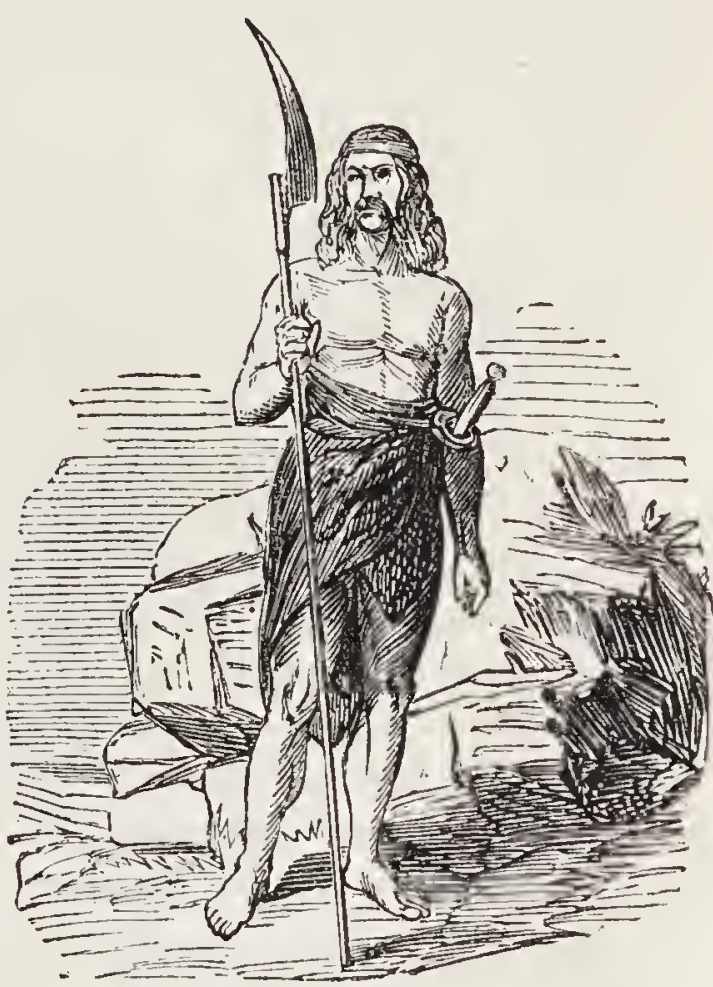

PICT. Furies, carrying burning fire-brands, in strange attire, and with their hair hanging about their shoulders. The strangeness of the sight so amazed the Romans that they stood still, till Paulinus appealed to them not to be daunted by an army of women and wizards.

\section{What were the Picts?}

It is scarcely possible to separate the Picts from the Scots and Caledonians. 'They occupied the northern borders of Scotland, and were a people peculiarly ferocious. Some historians derive these people from the ancient 
"The fathers shall eat the sons in the mirlst of thee, and the sons shall eat their fathers; and I will execute judgments in thee, and the whole remnant of thee I will scatter into all the winds."-EZEKIEL v.

Germans, others from the Pictones of Gaul, while Bede says that "the Picts came, as they report, from Scythia, in a few long ships to Ireland," and, after in vain soliciting a settlement among the people whom they found there, at their advice came over to Britain, and established themselves. Their name is otherwise said to have been derived from the habit of painting their bodies, which they adhered to after most of the other families of Britain had abandoned that custom.

1087. The history of the Britons, for a period of nearly five hundred years after the first Roman invasion, is little more tlian a continuous story of bloodshed and miscry. Invaded from the south by a powerful and disciplined foe; overwhelmed on the north by barbaric tribes, bursting in from a barren country, like hungry wolves, to feed upon their prey; themselves occupying every interval of time and opportunity with intestine strife and sanguinary struggles, which wasted their own strength, - no wonder that "grievous famine increased; that they" abandoned their towns and fortifications, and took to flight from a ruthless enemy, by whom they were rent in pieces like lambs in the hands of bloody butchers, or in the jaws of savage beasts; no wonder that the poor distressed people forebore not to rob each other of the little sustenance they possessed, and so increased their hostile oppressions by domestic vexations, until, sinking under despair, they petitioned the Emperor Honorius for protection, saying,-"The barlorians beat us back to the sea; the sea again drives us back upon the barbarians: thus, between two linds of deatl, we are either slaughtered or diowned."*

\section{What were the Iceni?}

The Iceni were the tribes who occupied the present areas of Suffolk, Norfolk, Cambridge, and Huntingdon. About the year 61 a revolt was commenced by this tribe, which nearly proved destructive to the Roman supremacy. It was in this revolt that the British Queen Boadicea displayed extraordinary valour. 
"Behold, the days come, saith the Lord, that the plowman shall overtake the reaper, and the treader of grasses him that soweth the seed; and the mountains shall drop sweet wine, and all the hills shall melt."-Aros ix.

\section{What were the Cantii?}

They were a powerful tribe that occupied the present sirea of Kient. It was within the settlement of this people that Cessar effected a landing upon two occasions, and with the Cantii his first battles must have been mainly fought.

1090. The Cantii had four chiefs, or kings, named respectively Cyngetorex; Carvilius, Taximagulus, and Senogax. There is little doubt that before the invasion by the Romans the whole space of country from Deptford to Lambeth was a swampy marsli, a great part of which was constantly overflowed by the tide, and quite uninhabitable. This marsh, with the channel of the Thames at its extremity, might be looked upon by the Cantii and the Trinobantes as a barrier between them. The Romans drained as much of the land as suited their purpose, erected a station, and made roads to it; but, on their further conquests, they removed to the north side of the river, where London now stands, after which, neither of the above tribes claiming the drained district, it became part of the country of the Regni.

\section{What were the Trinobantes?}

They were a numerous and powerful tribe occupying the area of Middlesex and Essex. The Trinobantes were the first people who submitted to the Romans, which they did on account of the oppressions of Cassibelanus and the Catieuchlani. They were, however, long regarded with hatred by the contemporary Britons for having been the first to surrender. At a later period the Trinobantes, Catieuchlanii, and Dobunii (tribes that occupied Buckinghamshire, Bedfordshire, Huntingdonshire, and Oxfordshire), were united under the government of Cunobeline, a grandson of the British King Lud.

1092. When we contemplate the vast city of London, with its two million and a lalf of inhabitants, and think of the wonder's of social, political, and scientific triumphs that emanated therefrom, it becomes curious to reflect that this, the greatest and richest city in the world, was founded by the Britons, in all probability many years before the 
"Eye hath not seen, nor ear heard, neither have entered into the heart of man, the things which God hath prepared for them that love him."-I. Conistr. ii.

Romans set foot upon our soil; and that it must have been in their time a mere town, or series of straggling houses, scattered along the south bank of the Thames. Camden, speaking of the origin of the name of London, says, "For myself, as Cæsar and Strabo expressly say that the Britons give the names of cities or towns to woods and groves fortified by trees which they had cut down, and I am informed that groves in the British language are called Lhwn, I am almost inclined to think that London had its name from thence, as the city in the grove."

\section{What were the Belgce?}

'They were a race of people who originally "were the most remote of old Gaul, as well in point of civilization, as in locality." A very early account of Somersetshire describes it as "a vast wilderness covered with brambles and briers, with thick woods extending every way, and with high mountains and amazing valleys." To the north of Salisbury Plain, in Wiltshire, lies Stonehenge, one of the most interesting relics of Druidical antiquity. Many conjectures respecting the massive stones of Stonehenge have been indulged in. There remains, however, no doubt that it formed one of the chief temples of Druidical worship, and was probably the seat of their great assize. Skulls of cattle sacrificed by the Druids have been dug up in the immediate neighbourhood.

1094. Stonehenge was in all probability founded four or five hundred years prior to the landing of Julius Cesar. It is believed to have been deroted to the worship of the moon. 'There was a stone temple at Abury, which was the seat of the arch-Druid of the Belge. There is also a similar temple in Somersetshire. Around Stonehenge are barrows, or burial-places of the Britons, which rise like waves upon the green plain, so numerous that "one may count fifty at one 
“ He hath appointed a day, in which he will judge the world in rirhteousness by that man whom he hath orlainci; whereof he hath givell assurance unto all inen, in that He hath raised him from the dead."-Acrs xrii.

time, in the evening, when the sloping rays of the sun shine on the ground beyond them."

1095. The Druids were the priests or ministers of religion, lawgivers, and teaehers among the ancient Gauls, Britons, and Germans, and were the most distingnished order among these primitive people. The Druids affected a knowledge of astrology, geometry, natural philosophy, polities, and all that was known in their early age of geography. They were the interpreters of religion to the people, and the judges of all affairs, eivil and politieal, and their decree regarded with sueh esteem, that whoever had the impiety to question their judgment, or dispnte their verdict, was deelared impious and excommunicated.

1096. They believed in the immortality of the soul, and the doctrine of transmigration of souls; and there seems to be little donbt that they were closely allied in their belief to the Greek philosonlhers and the Persian MIagi. They were divided into three orders, the Bards, Vates, and Druids proper'; or the poets, the priests, and the naturalists, or teaehers and lawgivers. They wore long white garments and a white surplice while offieiating, carried a wand in their hands, and wore a kind of ornament round the neek, enchased in gold, called the "Druid's egg;" their finger's and arms were eorered with braeelets, and they wore ehaplets of oak-leaves upon their heads. Their hair was eut

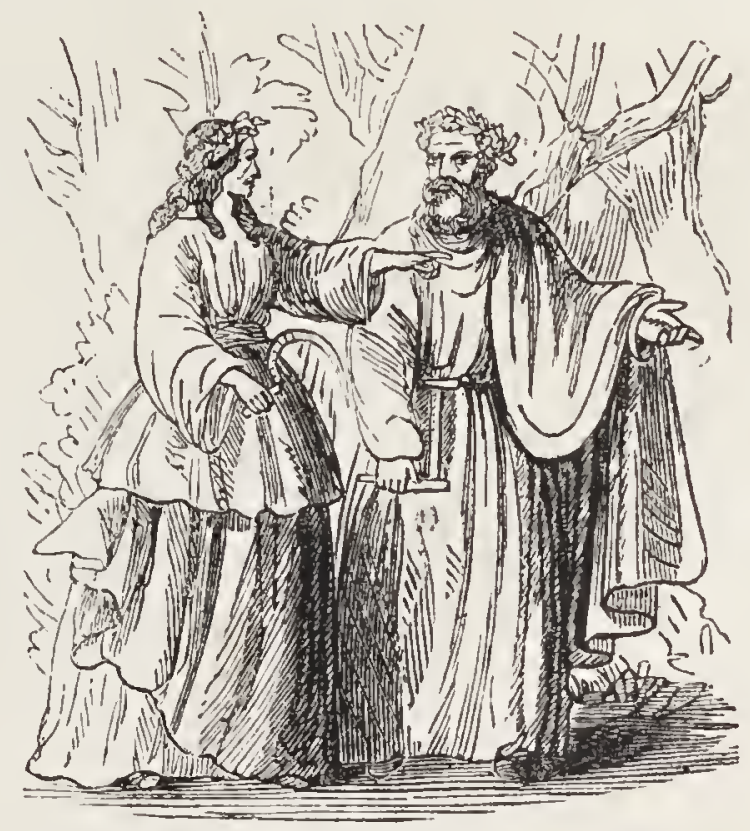

ARCH-DEUID AND PRIESTESS. close, but the beard was allowed to fall full, long, and majestie. Eaeh nation had a chief or areh-Druid, who was invested with supreme pontifical and civil authority.

1097. The Druids had the sole edueation of the people; and such was the jealousy of their dogmas being properly known, that all 
"And as we have borne the image of the eartliy, we sliall also bear the image of the heavenly. Now this I say, bretlren, that flesli and blood cannot inherit the kingdom of heaven; neither doth corruption inherit incorruption :"

their annals, laws, ereeds, and traditions were thrown into mystic verse, and eommitted to memory, not being allowed to be written.

1098. Their chief drug and sovereign remedy mas the mistlctoe, whieh was sought for with great solemnity, and, when found, hailed with.great homage. Next in importance as a medicine were the sarine, mallow, and vervain, each being gathered with magic spells, religious sites, and at eertain pliases of the moon. Like the Greek oraele and the Roman augur, the Druid gave his opinion in an oraeular manner, forming that opinion from the flight of birds, or any unusual appearance in the earth or heaven.

1099. The ordinary punislment inflieted by them was that of exeommunieation, whielı was carried ont with such rigour that it was pollution for any one to touch or speak to the interdieted eulprit. The Druids worshipped a Supreme Being under the name of Hesus, and their sacred symbol was an oak. Their elief residence in Britain was in the Isle of "Mona," or Anglesea, and it was in this island that the Romans, under Suetonius Paulinus, finding it impossible to subdue the Britons as longe as the priesthood existed and eneouraged them to revolt and heroism, attacked tliem with an overwhelming foree, and, though he encountered a desperate resistance from both men and romen, finally suceeded.

1100. What were the Regni?

They were tribes that occupied the areas of Surrey and Sussex. The spot at present known as Holwood Hill, in Surrey, is said to have been the seat of the capital of the tribe. The "Devil's Dike," near Brighton, was a British earthwork, probably constructed as a retreat for the distressed Britons.

\section{What were the Silures?}

They were tribes who occupied those parts which the Welsh called Dehenbarth, or the south part, now divided into the counties of IIereford, Monmouth, Glamorgan, Brecknock, and Radnor. Their king was Caractacus. "The Silures were a tribe distinctly marked from the other' British people, supposed to have been originally Hibernians. 
"Behold, I show you a mystery; we shall not all sleep, but we shall all be changed, in a moment, in the twiukling of an eye, at the last trump: for tlie trumpet shall sound, and the dead shall be raised incorruptible, and we sliall be changed." 1 COR. $\mathrm{XV}$.

Their complexions were ruddy, and their hair dark and

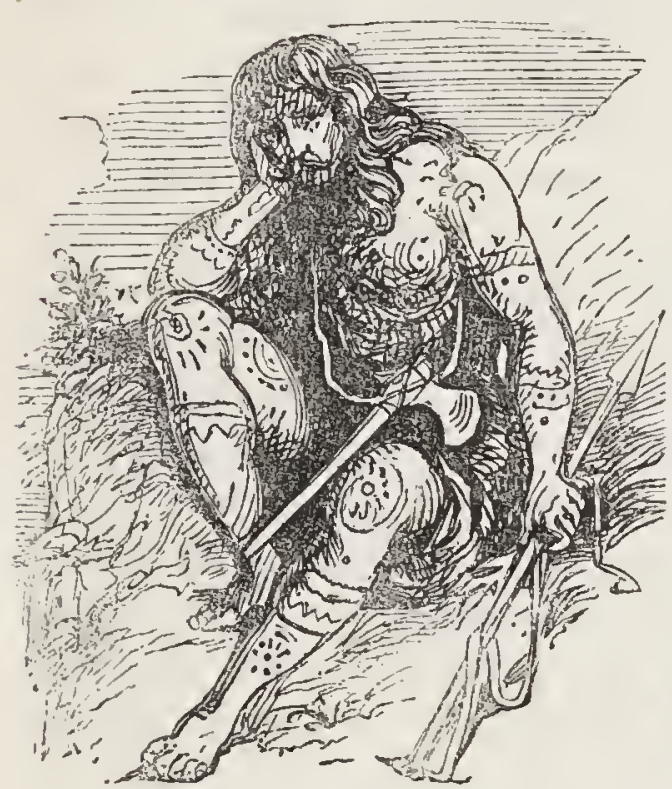

SILURIAN BRITON. curled; they were warlike, impatient of slavery, of great intrepidity, and exhibited a stubbornness uninfluenced alike by clemency or severity. 1102. When the Romans invaded their territory, the Silurians withstood so harassing a war, and inflieted such heavy losses upon their invaders, that Ostorius, the Roman general, died worn out witl grief and diffeulties; and Veranius, who subsequently attaeked the Silures, did so in vain. Caraetacus was, however, defeated and made eaptive. Deing severely pressed, he retired into the dominions of the Ordoviccs, whose territory included a portion of Shropshire, and his last great battle was fought upon a hill, now ealled Caer-Caradoc, twolve miles from Ludlow. Caraetaeus fortified the hill with a rampart of stones, and held it obstinatcly against the Romans until the latter effeeted breaches in the rude rampart, remains of which may still be seen, and drove the Silures in disorder to the mountains. Caractaeus fled for protection to the territory of the Brigantcs; but the Silures were not reduced until the time of Vespasian, when Julius Frontinus conquered them, and placed garrisons of the legionary troops among them.

1103. There were other tribes in various parts of Britain, such as the Danmonii, in the districts of Devon and Cornwall; the Durotrige, in Dorsetshire; the Attrebatti, in Berkshire; the Caticuchlani, in Buckinghamshire, Bedfordshire, and Huntingdonshire; the Doburi, in Gloueestershire; the Dimcte, in Pembrokeshire, Carmarthenshire, and Cardiganshire, \&e. \&e. Cairn Boseawen, in Cornwall, was the seat of the ehicf Druid of the Danmonii: the stones and Druidieal altars remain to this day. In Madern parish there was a holed stone used by the Druids for the purpose of drawing ehildren through, for the cure of diseases.

1104. According to Lieut. Smith, the movements of the Caucasian 
"And now, brethren, I commend you to God, and to the word of His grace, which is able to build you up, and to gire you an inheritance among all them which ato sanctified."-Ac'r's xx.

tribes, their probable migration down the Oxus, and passage of the Oural Momtains, and thenee, by Russia, Poland, the Baltie, Seandi. navia, and Denmark, in to Friesland and Belgium, arc chiefly confirmed by the so-called Celtic mode of ereeting monumcuts, altars, and tombs, witl huge stones, on thc surfacc of the carth, or hidden in eairns and barrows. The early Cclts must have been seamen on more than one occasion, having traversed great portions of the South Seas, and left the evidcree of their toils on the coasts of China, as well as Ancriea. 'i'hat these massive structures are not the chaneerrork of unallied nations. is plain from the faet that, among nearly one hundred and fifty eromleelis, logring stones, masses of unhewn roek, eleared aray to eonstitutethem into eolossal idols, circlcs of stones, single stones, mysterious cares ror worship or initiation, se., we find that they are plaeed morc or less in certain territorial regions, where they form groups or lines, learling from one to anotlicl. Thus, in partienlar, those bearing the eliaracter of cromleehs pass down the west sidc of the Indus to the sca; then divide castward, following the coast to the Coimbatoor, and further on to China and the islands of the Paeifie; whilc the other linc forms two branehes, one of which follows the monntain chain to the Caspian, the other by the HGlmmnd, through the desert of Iran, to Persepolis, and up the 'Tigris, till it meets the first on the highlands of Armenia, where they beeome direetly referable to Cyelopean and otlicr CeltoTimnic tribes, and pass from botl eoasts of Asia Minor along the two shorcs of the Meditcrinean, np the west eoast of Spain, and by the Alps and Cevennes down the Loire to the sea, wherc both unite again, and then, slirting the ocean towards the north, cross orer into Britain.

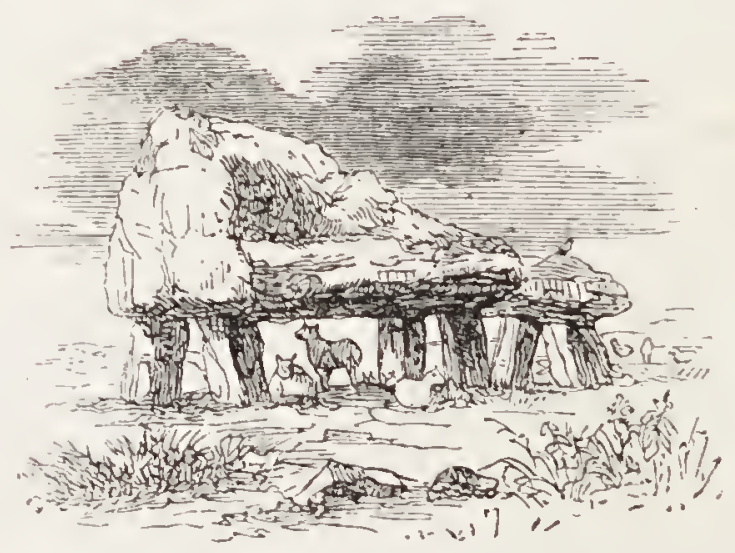




\section{GLOS SARY.}

ACOTyLEDor, a plant bearing seeds without lobes.

ACRIFolium, a plant with prickly leaves.

ACrogex, a plant growing only at the top.

AGGlomerate, to gather as into a ball.

ALG is, sea weeds, eellular aquatic plants.

AlLuvius, matter transported by runining water.

Amponites, an extinct and numerous genus of the order of

Molluses, allied to the modern Cephalopoda, which inliabited eurverl and cliambered shells.

Arorphous, irregular in figure or in shape.

ArorphozoA, the least organized animals; sponges, kc.

AMYGDAlord, one of the forms of trap-rocks, in whieh agates and simple minerals appear to be scattered like almoncls in a cake. AxAlogue, a body that resembles another body, of whieh it is aecordingly the analogue.

Axiryous, eontaining no water.

ANTEDILUVIAN, befole the flood.

ANTENNa, horns or feelers with which the heads of inseets are furnished.

Antrracite, eoal consisting almost wholly of carbon.

AfChipelago, a colleetion of islands.

ARENACEOUS, strata eomposed of grains like sand.

Argillaceous, eonsisting partly of elay.

Articulated, liaving joints.

ATolls, eoral islands of eircular form, consisting of a ring of coral surrounding a eentral lagoon.

ATOM, an elementary constituent of matter ineapable of dirision.

A URIFERous, produeing gold.

Azorc, the lowest strata, devoid of traees of life.

BAsAlt, a roek of igneous origin, in whieh prismatie strueture is very general, prisms sometimes jointed.

BAsis, a hollow trougl on the earth's surfaee, formed by the older roeks; sometimes used synonymously with "formations" to express 
the deposits lying in a eertain eavity or depression of the lower roeks; the bef from whieh water gathers into a lake or river.

Brisanous, furnished with two hands.

Brtuner, mineral piteh.

BouldERs, a term applied to large rounded blocks of stone lying on the surface or embedded in loose soil, and whieh have been transported from a distance.

Brackisir, moderately salt.

Brancins, the gills of fishes.

Breccra, mineral fragments joined.

Carrozorc, the upper division of strata holding recent forms of animal life.

C.licareors Rock, limestone, enleareous spar, erystallised carbonate of lime.

Caloric, the prineiple of heat.

CANDESCENCE, whiteness from great heat.

Carbovacrous, relating to earbon, eharcoal, or coal.

Chrboniferous, yielding eon.

Carsirorous, feeding on flesh.

Celiudose, vegetable tissue of eells.

Cetaceous, of the whale kind.

CinALK, a soft white limestone.

Cuert, a flinty stone found in many limestones.

Cirloride or Sodrum, rock salt.

Cinorite, a mineral often formed in thin plates like miea, and of a greenish lure.

Clinange, a fissile strueture, not coincident with original lamination; an example of metamorphism.

Coleor'ters, an order of insects whieh have four iwings, the upper pair being hard, and forming a slield; beetles.

Concretse, to unite in one mass.

Confluext, flowing or uniting together.

Confonaribe, strata whieh are parallel to one another in rarious. positions.

Covaniers, speeies whieh belong to the same genus.

Coxglomerate, eollected into a ball or mass.

Coniferous, bearing fruit like the cones of the pine.

CORALLACEOUS, resembling coral.

Crustaceous, shelly, or crusty.

Cryptoganic, a name applied to a class of plants, such as ferns, mosses, seaweed, and fungi, in which the organs of reproduction are coneealed. 
CRIstal, a mineral having regular gcometrical forms.

Cristalline, not purely crystal, but like.

CUPIFERous, yielding copper.

DEBACLE, a breaking out or ovcr, a deluge.

DECIDUous, shedding the leaves in autumn.

DENUDATror, the process by which flowing water uncorcrs rocks.

Desrceate, to deprive of moisture.

DETrites, a mass formed by the wcaring away of rocks.

Urie, a mass of igncous rock often found traversing other rocks, and sometimes projecting from them, so as to resemble a wall.

Drufrum, a deposit caused by a flow of water, or a deluge.

Drp, rhen a strata does not lie horizontally, but is inclined, it is suid to dip, and the angle it makes with the horizon is called the angle of dip or inclination.

DIPTERA, an order of insects comprising those which have only two wings.

DoLERITE, an igneous rock, composed of felspar and angitc.

Dolomrte, a crystallized rock containing carbonate of lime and carbonate of magnesia.

DUNE, a hill of sand.

EArtil's CRUst, such superficial parts of the earth as are accessible to man.

ECHINI, sea melins.

EFfution, a flowing out.

Erriria, the wing-cascs of beetles.

Expogexs, plants whose growth or incrcase takes placc in the interior of the stem.

Endosmose, absorption through membrancs.

EOCENe, the lowest great division of the tcrtiary strata in which the dawn of recent life appears.

Equilateral, having the sides equal.

Erratrc, wandering, moving:

EscarpuENT, the abrupt face of a lidge of high land.

Estuarres, inlets of the land which arc entered by rivers and the tides of the sea.

Exforiate, to come off in leaves or scales.

Exogers, plants or trees whose increase in growth is on the outer surface of the trunk.

Exотіс, of or from a foreign land.

Exuvi玉, cast-off slins, shells, \&c., of animals. 
FAUlit, a fissurc on one side of which the rocks have been displaced, with reference to the otlicr side.

FaUna, animals now or formerly natives of any area of land or sen.

Fetspar, a gronp of minerals in crystallization, in which silica is combined with various bases.

Felspar, a simple mineral which, next to quartz, constitutes the chief inaterial of rocks.

FeLspatric, belonging to felspar.

Ferrugrnous, like or containing iron rust or oxide of iron.

Filicifoum, resembling ferns.

Floculent, like locks of wool.

Fonmatrox, a group of rocks associated by position, by succession of time, and by organic and mineral identities.

Fossin, a petrified organic body.

Gasteropods, a dirision of the Testacea, in which, as in the limpet, the foot is attaclied to the body.

GaUlt, a provincial name for a series of beds of clay and marl, the geological position of which is between the $\mathrm{U}_{\mathrm{p} p \mathrm{p}}$ and Lower Grcensand.

Grerss, a name applied to the oldest granitic strata.

Granines, the order of plants to whieh grasses belong.

Grante, grain-stone composed of distinct quartz, felspar, and mica; sometimes the mica fails, or is partially replaced by hornblende; the rock then passes to sycnite.

GREExtore, an igneous rock composed of felspar and hornblende. GREGARIOUs, living in flocks or lierds.

Grit, a provincial name for a soft sandstone.

Grisux, a mineral composed of lime and sulphuric acid, called also sulphate of lime.

HOWNGLNDE, a simple mineral of a dark green or black colour, which enter's largely into the composition of several Trap rocks.

HrPOGExe, a term used as a substitute for "primary," to indicate formation or transformation from below, and applied to grinite, gneiss, Sc.. including both plutonic and metamorphic locks.

ICTIYOLOG $X$, the natural history of fishes.

In Neous, fiery, produced by fire.

INCANDESCENT, having a more intense degree of lieat than that which is known as red; a state of white heat.

INDIGENOUS, native to a eominty. 
INFUSORIA, minute animal organisms.

INsECtrvorous, living on insects.

INSPISSATE, to thicken by evaporation.

INvertebrated ANimals, those which are destitute of a backbone.

IRRUPTION, a breaking or bursting in.

Isotinermat, having the same mean temperature.

Jurassic, the limestones belonging to the Oolitic group constitute the clief part of the mountains of Jura, between France and Switzerland, and hence geologists of the Continent lave given the name to the group.

KAOLIN, Clina clay, from decomposed felspar.

Kimmenidge Cray, a thick bed of clay, part of the Oolitic group, so called because fund well developed at himmeridge.

LACUstrine, produced by or pertaining to the waters of lakes.

LAMETriferous, liaving very thin plates.

LEUCITE, a claracteristic mineral in certain lavas, unusually of a white colour.

Lras, a provincial name for an argillaceons limestone, characterised by peculiar fossils, and forming a peculiar group of strata, interposed between the Oolite and New Red Sandstone.

Ligneous, woody, or like wool.

LIGNITE, wood converted into a kind of coal.

Lruestone, indurated carbonate of lime, often of organic origin.

IrrTorat, belonging to the shore.

LoAx, clay and sand combined.

LUCIFEROUs, giving or producing light.

Mackesian Limestone, an extensive series of beds, the geological position of which is immediately above the Coral Measures, so called because the limestone contains Magnesia.

MAMMAL, an animal which suckles its young.

Mamaliprous, containing remains of Mammals.

MARL, the term is variously employed; in Norfolk soft chalk is called marl; in Worcestershire the red marl contains very little calcarcous matter; properly an argillaceous stratum with much calcareous matter in it.

Marsupinta, a division of Mammalia with external pouches in which the young are developed and nursed.

Matrix, the place in which a mineral or shell is cmberded in a rock. 
MEDUS T, a genus of marine radiated animals without shells.

Meiocene, the middle tertiaries, holding a less proportion of reeent fossiliferous species than the pleiocene.

Mesotype, a zeolitie mineral frequent in eavities of basalt and lava.

MEsozorc, the great division of the strata holding the middle forms of life.

MICA, a genus of minerals mostly remarkable for the thin brilliant elastic plates into which it is divisible.

Mrveral, inorganic matter.

Mrocens, a dirision of tertiary stratn intervening between the Eoeene and the Plioeene formations, so ealled beeause a minority of its fossil sliells are referable to liring species.

Moldusca, soft animals, a great division of the Invertebrata.

Monare, a Swiss term for the débris of rocks brought into valleys by glaciers.

MUscilelkalk, a limestone of the Upper New Red Sandstone group, meaning shells and limestone.

Neptunias, stratified deposits from water, in eontradistinetion to plutonie.

NoDUte, a mass colleeted around some eentral point or nucleus.

Norial Groups, eertain groups of rocks taken as a standard.

Onsidiax, a glassy volcanic product.

Olivixe, a mineral eomposed of siliea, with magnesia and other bases, frequent in igneous rocks.

Oolite, limestone formed of spherieal or eilipsoidal masses like small eggrs, collected around portions of organic matter.

Orgavisus (fossils), remains of animals or plants.

Oxrgex, one of the constituent parts of the atmosphere which enters also largely into the eomposition of water and solid substanees.

PACirydermata, an order of thiek-skinned animals, including the elephant, rhinocerous, mastodon, scc., whose remains are perfeetly found in tertiary strata.

PAL.jontologr, zoology and botany applied to the aneient form of life.

PALAOzOIC, the lowest of three grand dirisions of strata, inelnding the most ancient forms of life.

Pegmatrle, binary granite eontaining only quartz and felspar. Feldaian, found in the deep sea, distinet from littoral and estrary. 
Peroxme, the full degree of oxidation.

Prastrc Cray, one of the beds of the Eocene Tertiary period, so called becanse it is capable of being monlded into pottery.

Pliocene, the upper tertiaries, containing the larger proportion of plants and animals.

Prutonic Rocks, igneous products of the internal earth.

PoRPIIRY, an igneons rock with detached crystals, mostly of felspar

Precrprtates, deposits occasioned by chemical decomposition, matter separated from solution.

Primary or Primitre Rocrs werc meant to include the earlicst of all, but the term is now seldom uscd.

Protoxide, the first degree of oxidation.

Protozorc, the strata containing the earliest forms of life, the supposed first series of animals and plants.

PUMrCE STONE, volcanic matter expanded into a spongy or frotly state.

Prrites, iron, copper, and other metals combined with sulphur, found usually in yellow shining crystals like brass, in both stratified and unstratified rocks.

CoArtz, crystallised silica, rock crystal.

RoCK SALT, muriate of sodil, found in large solid masses chiefly in New Red Sandstone formation.

SAlts, combinations of acids and bases.

SANDSTONE, any stone which is composed of sandy particles.

Scurst, fossil rocks; laminated rocks, but distinct from slate.

SCORIX, rolcanic cinders.

SECONDARY, the second or middle great group of strata, mesozoic strata.

SEDIMEXTARY Rochs, those which liave been formed by theil materials having been thrown down from a state of suspension in water.

SELENTte, crystallized sulphate of lime.

SERPENTrE, a beautiful rock composed of some magnesian mineral spotted like a serpent.

SHale, laminated argillaceous strata.

SiringLe, loose pebbles waslied by the sea.

Silex, the name of ors of the pule earths, flint.

Srurca, the most frequert constituent of minerals and rocks; a compound of siliciam and oxygen.

Srlt, fine sediment from zivers. 
Slate, a fissile argillaceous rock, whose lamination is not due to deposition, as in shale, but is the effect of metamorphism called cleavage.

StAlActite, earthy matter separated from solution in water, and consolidated while descending, so as to be attached to the rock above.

Stalagmite, the same matter that forms stalactite, but, having fallen, forms rising points or pillars.

STrAta, rocks successively deposited from water, the several beds or layers of thin rocks.

SYENITE, an igneous crystallized rock composed of quartz, felspar, and hornblende.

TALc, a soft, flexible, magnesian mineral, otherwise resembling mica.

TArus, loose detritus, accumulated by falling from the face of rocks and precipices.

Tertals, the third or upper grand division of strata, cainozoic.

Testacea, Molluscous animals haring a shelly covering.

Traxsitiox, the passage from one condition or group to another.

Trar. Any plutonic rock witl the exception of granite, is often described as of the trap series.

Travertix, a white concretionary limestone composed of glassy felspar.

UNCONFORMABL, strata laiel on one another or against one another, having differences in their dip.

Vertebrated Aximals, all those furnished with a backbone. Volcaric, implying the action of fire at or near the surface.

WACRE, an eartly variety of plutenic rocks, bearing to basalt nearly the same relation which volcanic bears to the more crystallized and solid kinds of roleanic rocks.

WARP, the deposit of mudly water's.

Zoormyres, corals, sponges, and other aquatic animals of allied forms.

FIXIs. 





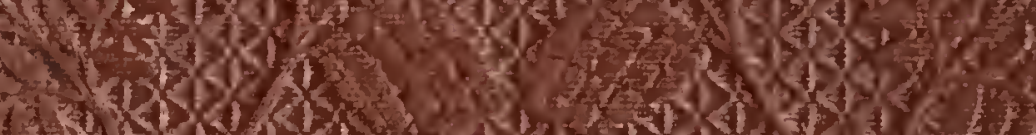

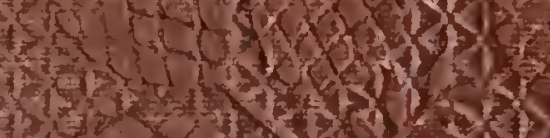

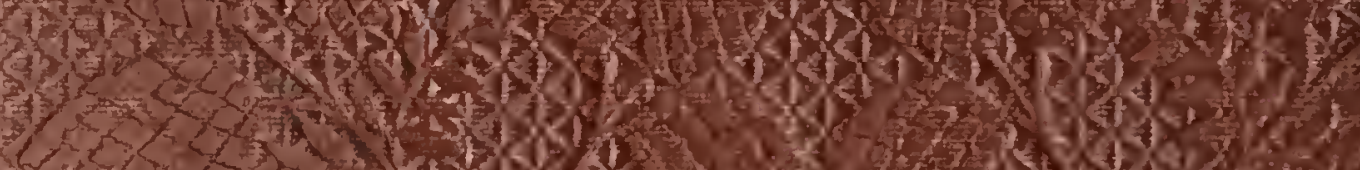

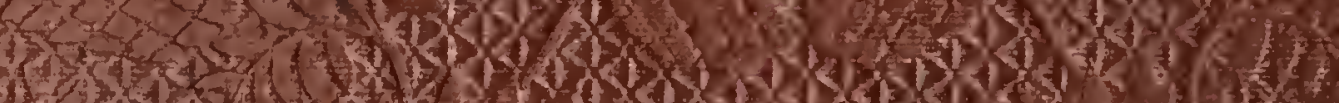

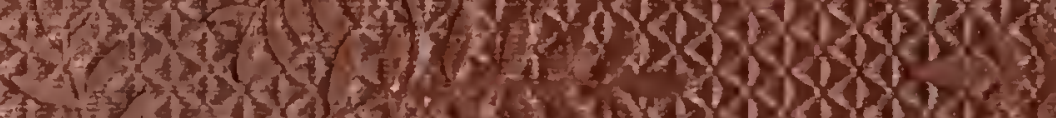

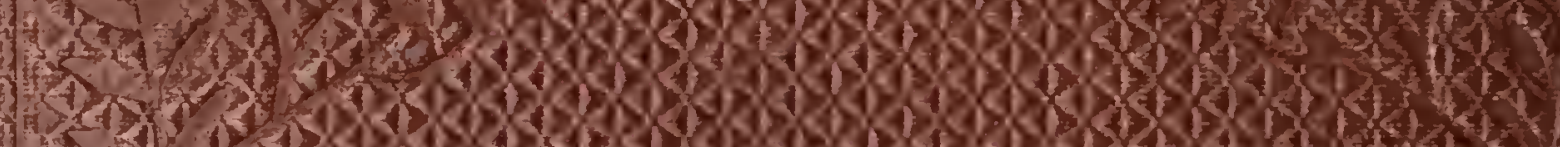

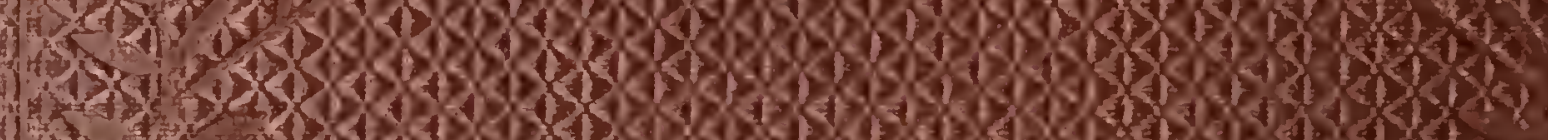

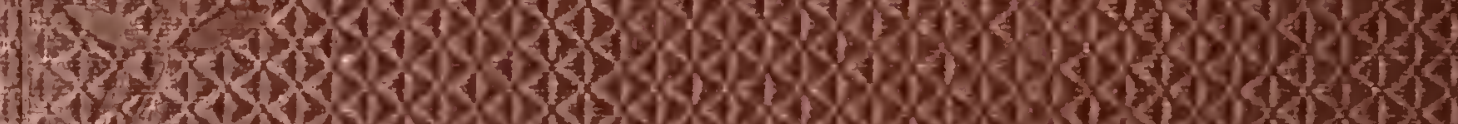

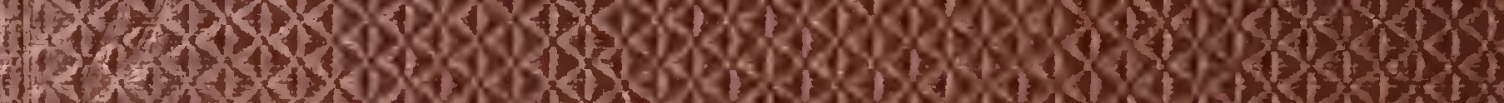

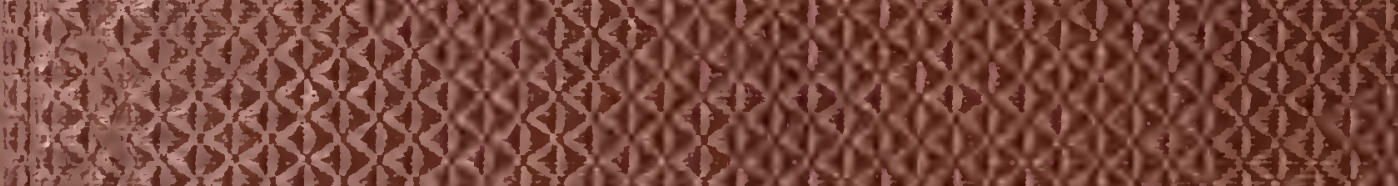

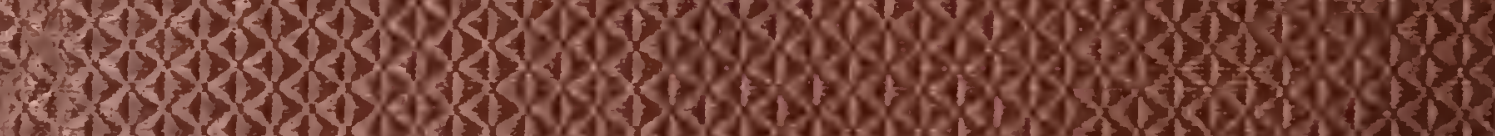

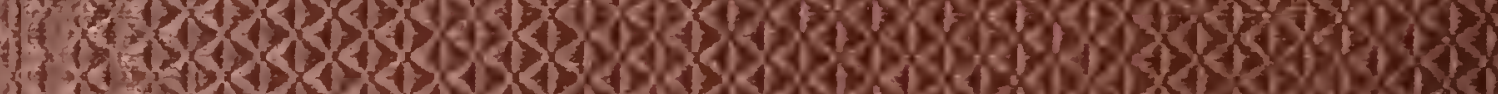

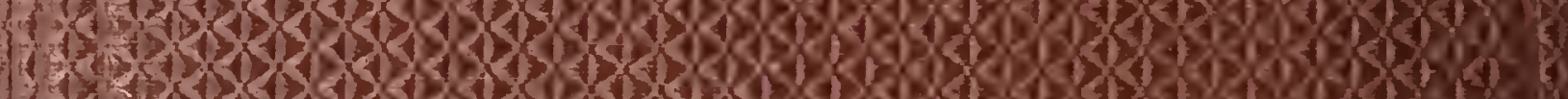

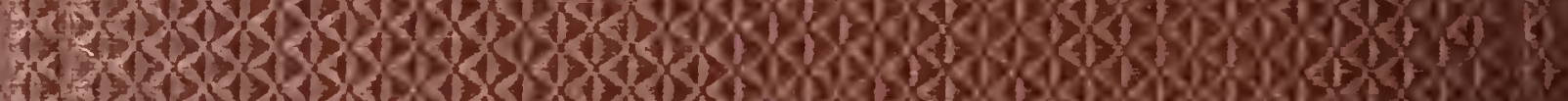

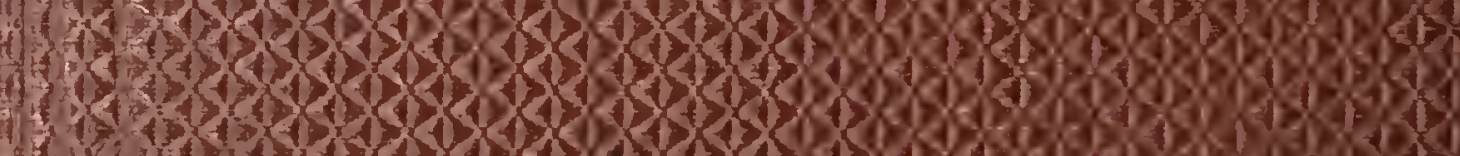

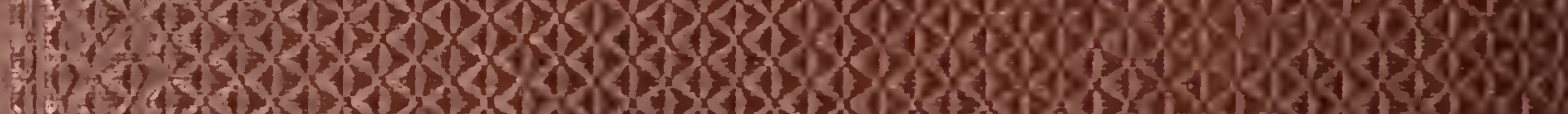

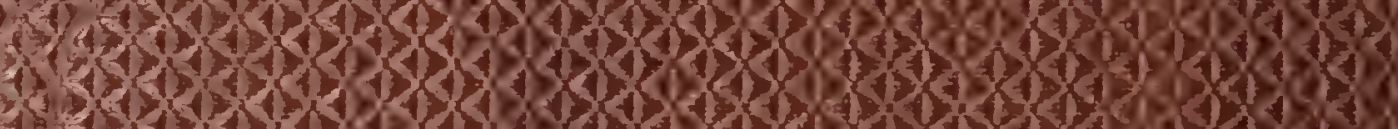

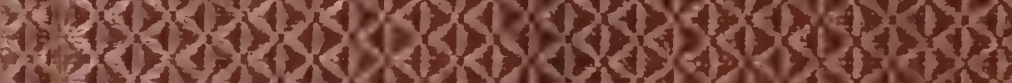

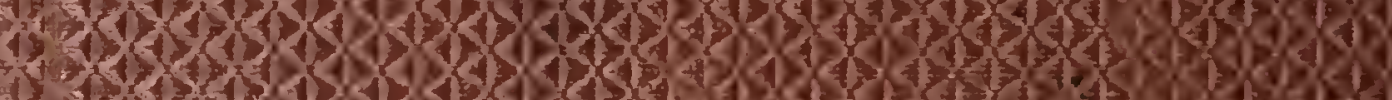

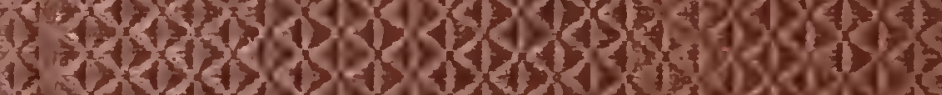

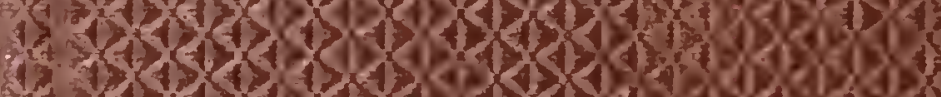

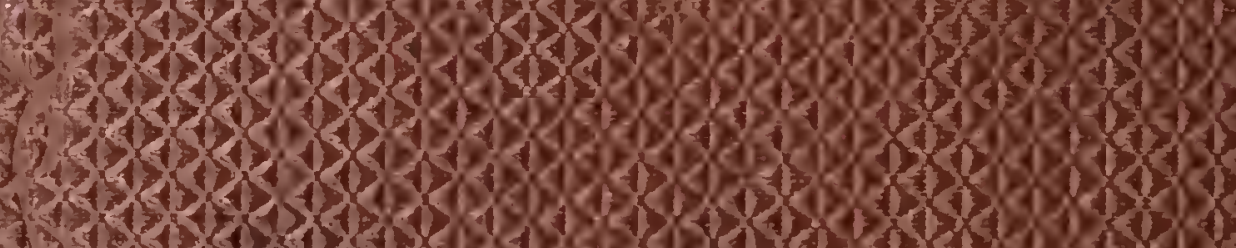

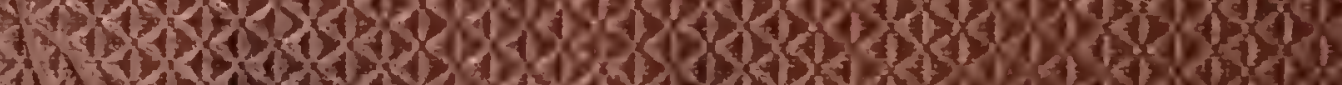

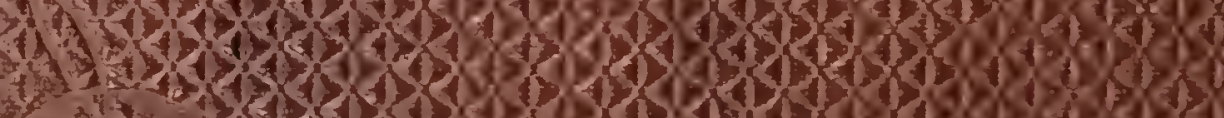

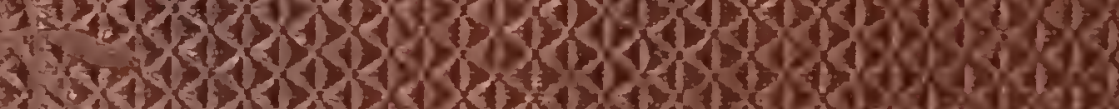

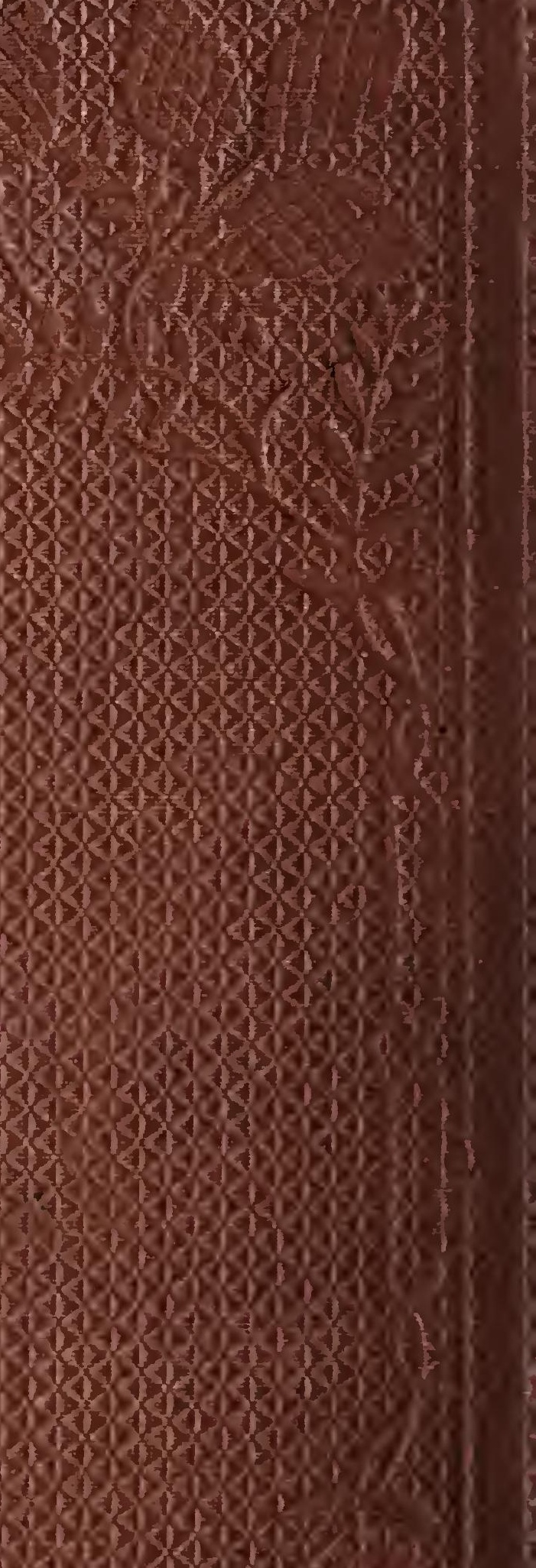

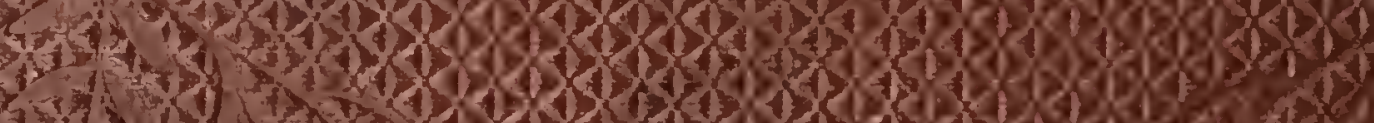

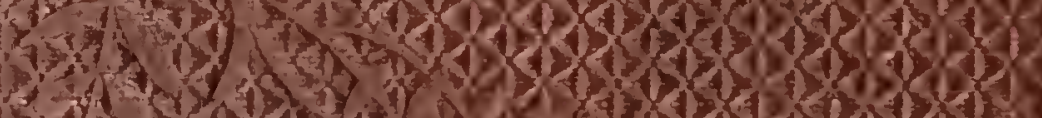

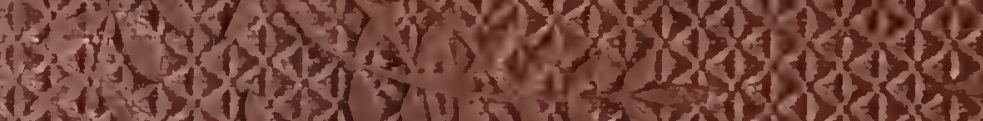

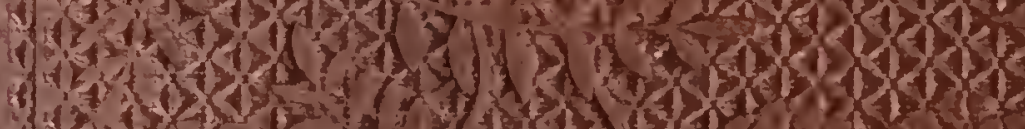

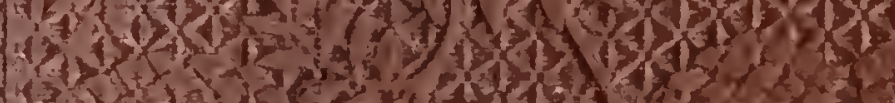

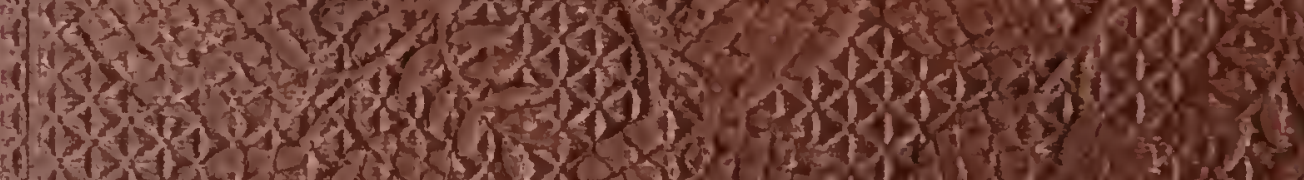

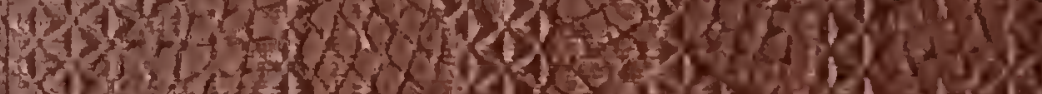

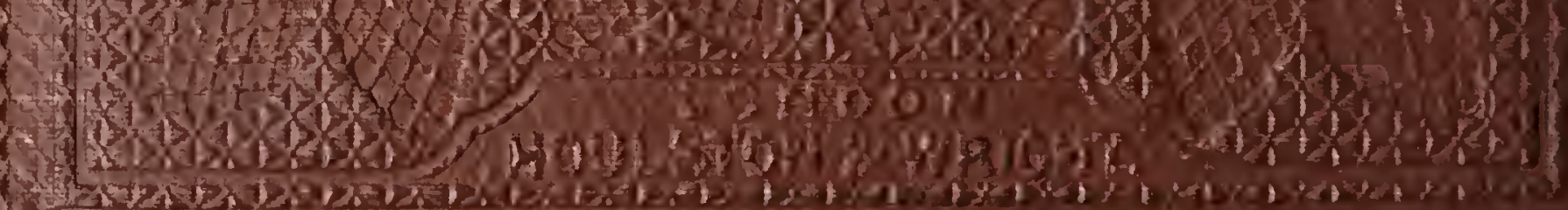

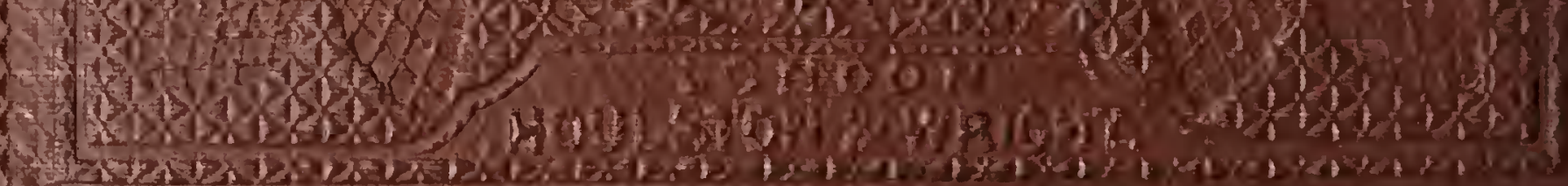

